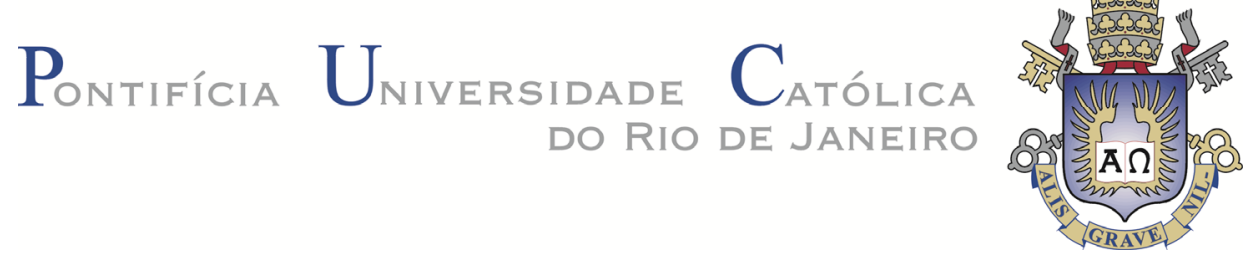

Miriam Rosanna Escalaya Advincula

Avaliação do Efeito de Aumento de Poropressão nas Características de Resistência de Três Solos Tropicais

Tese apresentada como requisito parcial para obtenção do Título de Doutor pelo Programa de PósGraduação em Engenharia Civil do Departamento de Engenharia Civil da PUC-Rio.

Orientador: Prof. Tácio Mauro Pereira de Campos 
Miriam Rosanna Escalaya Advincula

\section{Avaliação do Efeito de Aumento de Poropressão nas Características de Resistência de Três Solos Tropicais}

Tese apresentada como requisito parcial para obtenção do Título de Doutor pelo Programa de PósGraduação em Engenharia Civil do Departamento de Engenharia Civil do Centro Técnico Científico da PUC-Rio. Aprovada pela Comissão Examinadora abaixo assinada.

Prof. Tácio Mauro Pereira de Campos

Orientador

Departamento de Engenharia Civil - PUC-Rio

Prof ${ }^{a}$. Michéle Dal Toé Casagrande Departamento de Engenharia Civil - PUC-Rio

Prof. Fernando Antônio Medeiros Marinho Universidade de São Paulo

Prof. Luiz Antonio Bressani Universidade Federal do Rio Grande do Sul

Prof. Sérgio Tibana Universidade Estadual do Norte Fluminense

Prof. Márcio da Silveira Carvalho Coordenador Setorial do Centro Técnico Científico - PUC-Rio

Rio de Janeiro, 19 de fevereiro de 2016 
Todos os direitos reservados. É proibida a reprodução total ou parcial do trabalho sem autorização da universidade, da autora e do orientador.

\section{Miriam Rosanna Escalaya Advincula}

Graduou-se em Engenharia Civil na Universidad Nacional San Luis Gonzaga de Ica (Perú). Obteve o título de Mestre em Ciências, área de concentração Engenharia Geotécnica, pela Universidad Nacional de Ingenieria (Perú). Principais áreas de interesse e linhas de pesquisa: Mecânica dos Solos, Geotecnia Experimental e Geotecnia Ambiental.

Ficha Catalográfica

\section{Escalaya Advincula, Miriam Rosanna}

Avaliação do efeito de aumento de poropressão nas características de resistência de três solos tropicais / Miriam Rosanna Escalaya Advincula; orientador: Tácio Mauro Pereira de Campos. - 2016.

278 f. : il. (color).; $30 \mathrm{~cm}$

Tese (doutorado) - Pontifícia Universidade Católica do Rio de Janeiro, Departamento de Engenharia Civil, 2016.

Inclui bibliografia

1. Engenharia civil - Teses. 2. Aumento de poropressão. 3. Solos tropicais. 4. Características de resistência; 5. Ensaio triaxial. I. Campos, Tácio Mauro Pereira de. II. Pontifícia Universidade Católica do Rio de Janeiro. Departamento de Engenharia Civil. III. Título. 


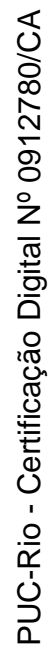

À memoria de meu adorado e inesquecível pai. 


\section{Agradecimentos}

A Deus, por ter me dado esta grande oportunidade e mais que tudo, ter me dado forças para não desistir dos meus objetivos nos momentos mais difíceis e por ter colocado no meu caminho pessoas maravilhosas, as quais não posso deixar de agradecer:

Aos meus pais, Alejandro (in memorian) e Elena, e aos meus irmãos pelo apoio e incentivo sempre constantes ao longo de minha vida.

Ao professor Tácio pelos ensinamentos e valiosa orientação.

Ao professor Gusmão pela atenção dispensada e ajuda com os instrumentos eletrônicos.

Ao amigo e professor Franklin Antunes, pelos conhecimentos transmitidos, inesgotável paciência e constante apoio na caraterização dos solos.

Aos membros da banca, pela participação e contribuições.

A todos os professores do DEC/PUC-Rio que contribuíram na minha formação. Em especial ao professor Alberto Sayão, pela amizade e incentivo que sempre me deu desde o inicio dos meus estudos de doutorado.

Aos funcionários do laboratório de Geotecnia da DEC/PUC: Mónica, Edson, Amaury, Josué, Deivid, Rogério, Alex e Carlos, pelos conhecimentos transmitidos, ajuda prestada, e a amizade no dia a dia que será sempre lembrada com muito carinho. 
Aos professores Jorge Alva Hurtado e Marco Hernandez Aguilar pelo incentivo na realização do meu curso do doutorado e por terem despertado em mim o gosto pela Geotecnia.

Aos companheiros de jornada, queridos amigos: Mariana, Roberta, Gricel, Manuella, Guillermo, Ingrid, Ivânia, Jeferson, Julio, Mario, Rafael B., Thaís, Thiago e Victor, pela amizade, colaboração e convivência especial durante minha permanência no Laboratório de Geotecnia.

A todos os colegas e amigos da PUC-Rio, pelo companheirismo e amizade construída ao longo desses anos, e que ajudaram de certa forma no desenvolvimento desta tese. Em especial a Ronald, Perlita, Lidia, Carlos L., Hugo, Gary, German, Bianca, Carlos A., Carlos B., Cesar, Daniel, Eliot, Elvis, Evelin, Jorge, Liset, Lizardo, Luis Fernando, Maria, Martha, Nilda, Rafael L. e Tania.

A Gustavo H. e Gloria A., pela amizade e ajuda prestada.

Aos funcionários do DEC/PUC- Rio, pela disponibilidade e atenção, em especial a Rita e Fátima.

Ao CNPq e à PUC-Rio pelo apoio financeiro concedido. 


\section{Resumo}

Escalaya Advincula, Miriam Rosanna; Campos, Tácio Mauro Pereira de. Avaliação do efeito de aumento de poropressão nas características de resistência de três solos tropicais. Rio de Janeiro, 2016. 278p. Tese de Doutorado - Departamento de Engenharia Civil, Pontifícia Universidade Católica do Rio de Janeiro.

O aumento da poropressão é um dos mais significativos fatores desencadeantes da ruptura de taludes em muitas regiões do mundo, principalmente em climas tropicais, onde os solos residuais e coluvionares são abundantes. A fim de compreender e analisar o mecanismo e as condições que conduzem a tais rupturas, nesta tese se apresenta um estudo do comportamento de solos submetidos a ensaios triaxiais de aumento de poropressão, que simulam a elevação do nível piezométrico em encostas. Os ensaios foram realizados em amostras indeformadas de dois solos coluvionares e um solo residual jovem, obtidos de diferentes encostas no Rio de Janeiro. Adicionalmente, foram realizados ensaios de cisalhamento direto com plano cortado e superfície polida, e ensaios triaxiais convencionais drenados e não drenados, com a finalidade de obter a resistência residual e a linha de estado crítico dos solos, bem como ilustrar as diferenças de comportamento sob diferentes trajetórias de tensão. Para monitorar as deformações locais das amostras e obter uma medida apropriada das poropressões foram utilizados instrumentos eletrônicos de medição interna e um minitransdutor de pressão na meia altura dos corpos de prova. Os resultados mostraram que sob o efeito de poropressão cada solo apresentou um comportamento distinto, o que se atribui principalmente ao grau de intemperismo e às suas diferentes características estruturais. Observou-se, ainda, que as trajetórias de tensão seguidas nos ensaios têm uma influência significativa nas características de resistência a grandes deformações dos solos.

\section{Palavras-chave}

Aumento de poropressão; solos tropicais; características de resistência; ensaio triaxial. 


\section{Abstract}

Escalaya Advincula, Miriam Rosanna; Campos, Tácio Mauro Pereira de (Advisor). Evaluation of the effect of pore-pressure increase on the strength characteristics of three tropical soils. Rio de Janeiro, 2016. 278p. DSc. Thesis - Departamento de Engenharia Civil, Pontifícia Universidade Católica do Rio de Janeiro.

Pore-pressure increase is one of the most significant triggering factors for slope failures in many regions around the world, mainly in tropical climates, where residual and colluvium soils are abundant. In order to analyze and understand the mechanisms and conditions leading to such failures, this thesis presents a study of the soils behavior under triaxial tests of pore-pressure increase, that mimic the elevation of piezometric level in slopes. The tests were performed on soil samples of two colluvial and one young residual soils from different slopes in Rio de Janeiro. Additionally, direct shear tests with cut plane and polished surface, and conventional undrained and drained triaxial testing were carried out to obtain the residual shear strength and the critical state line of soils, and illustrate the behavior differences under different stress paths. Internal instrumentation and a miniature pore-pressure transducer at the mid-height of the specimens were used to monitoring local deformations of the specimens and get appropriate porepressure measures. The results showed that under the effect of pore-pressure increase each soil showed different behavior. It is attributed mainly to the degree of weathering and their differing structural features. It was also observed that the stress path followed in the tests have a significant influence on the strength characteristics of the large strain state of soils.

\section{Keywords}

Pore pressure increase; tropical soils; strength characteristics; triaxial test. 


\section{Sumário}

1. Introdução 31

2. Revisão bibliográfica 34

2.1 Movimentos gravitacionais de massa em encostas $\quad 34$

2.1.1 Classificação dos movimentos de massa 34

2.1.2 Fatores condicionantes da instabilidade de encostas 39

2.1.3 Efeito da água sobre a estabilidade de encostas 42

2.2 Mecanismos de ruptura de encostas por aumento de poropressão 46

2.2.1 Tensões in situ de um solo superficial de encosta 46

2.2.2 Iniciação da ruptura: Trajetória de tensões no campo 48

2.2.3 Simulação em laboratório dos mecanismos de ruptura de encostas induzidos por precipitações $\quad 50$

2.2.4 Estudos anteriores e aplicações do ensaio de aumento de poropressão 52

2.3 Principais características dos movimentos de massa do tipo fluxo induzido por chuvas $\quad 70$

$\begin{array}{ll}\text { 2.3.1 Estágio de ruptura } & 70\end{array}$

$\begin{array}{ll}\text { 2.3.2 Estágio de pós-ruptura } & 71\end{array}$

2.4 Estado crítico, estado permanente e parâmetro de estado 72

3. Características dos locais estudados e amostragem 76

3.1 Campus Avançado da PUC - Tinguá 76

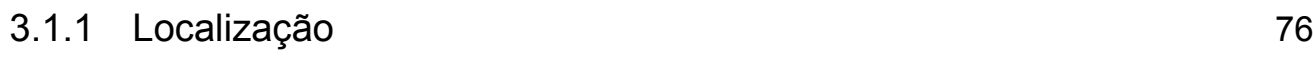

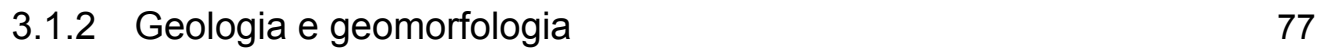

$\begin{array}{lll}3.1 .3 & \text { Aspectos climáticos } & 78\end{array}$

$\begin{array}{lll}3.1 .4 & \text { Características do local estudado } & 78\end{array}$

$\begin{array}{ll}3.2 \text { Duque de Caxias } & 79\end{array}$

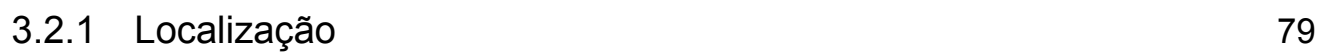

$\begin{array}{ll}3.2 .2 \text { Geologia e geomorfologia } & 79\end{array}$

3.2.3 Aspectos climáticos $\quad 80$

3.2.4 Características do local estudado $\quad 80$

3.3 Campo Experimental II PUC-Rio $\quad 81$

3.3.1 Localização $\quad 81$

3.3.2 Geologia e geomorfologia $\quad 81$

3.3.3 Aspectos climáticos $\quad 82$

3.3.4 Características do local estudado 82

$\begin{array}{ll}3.4 \text { Amostragens } & 83\end{array}$

4. Caracterização dos solos $\quad 86$

4.1 Caracterização física $\quad 86$

4.1.1 Análise granulométrica $\quad 86$

4.1.2 Limites de Atterberg $\quad 89$

4.1.3 Massa específica dos grãos 90 
4.1.4 Índices físicos 90

4.1.5 Análises de resultados da caraterização física 91

$\begin{array}{ll}4.2 \text { Caracterização química } & 91\end{array}$

4.2.1 Análise química $\quad 92$

4.2.2 Perda ao fogo 92

4.2.3 $\mathrm{pH}\left(\mathrm{em} \mathrm{H}_{2} \mathrm{O}\right.$ e em KCl) 93

4.2.4 Análises de resultados da caraterização química 94

4.3 Caracterização mineralógica 95

4.3.1 Fração areia 95

4.3.1.1 Fração retida na peneira $\mathrm{n}^{\circ} 40$

4.3.1.2 Fração passante a peneira $\mathrm{n}^{\circ} 40$ e retida na peneira $\mathrm{n}^{\circ} 200 \quad 96$

$\begin{array}{lll}\text { 4.3.2 } & \text { Fração silte e argila } & 97\end{array}$

4.3.3 Análise de resultados da caraterização mineralógica 100

4.4 Caracterização microestrutural 101

$\begin{array}{ll}\text { 4.5 Características da porosidade } & 106\end{array}$

4.6 Considerações finais sobre a caracterização dos solos estudados 109

5. Equipamentos e técnicas experimentais 112

$\begin{array}{ll}5.1 \text { Considerações gerais } & 112\end{array}$

5.2 Ensaio triaxial de aumento de poropressão 113

5.2.1 Equipamentos, sistemas de controle e instrumentação 116

5.2.1.1 Prensa triaxial 116

5.2.1.2 Sistema de controle de pressão 116

$\begin{array}{ll}5.2 .1 .3 \text { Instrumentos convencionais } & 120\end{array}$

5.2.1.4 Instrumentação Interna 123

5.2.1.5 Sistema de aquisição de dados 127

$\begin{array}{ll}5.2 .2 \text { Metodologia empregada } & 128\end{array}$

5.2.2.1 Operações pré-ensaios 128

5.2.2.2 Moldagem dos corpos de prova 131

5.2.2.3 Procedimento de ensaio 132

5.2.2.4 Algumas considerações do ensaio 141

5.3 Ensaios triaxiais drenados e não drenados convencionais 142

5.3.1 Ensaios triaxiais CIU e CID 142

5.3.1.1 Equipamento utilizado $\quad 142$

5.3.1.2 Metodologia empregada 143

5.3.2 Ensaios triaxiais CKU 144

5.4 Ensaio de cisalhamento direto com plano cortado e superfície polida 145

$\begin{array}{lll}5.4 .1 & 145\end{array}$

$\begin{array}{lll}5.4 .2 & \text { Metodologia empregada } & 147\end{array}$

5.4.2.1 Moldagem dos corpos de prova 147

5.4.2.2 Procedimento de ensaio 148

6. Apresentação e avaliação dos resultados: Ensaios de cisalhamento direto com plano cortado e superfície polida, e triaxiais convencionais 150

6.1 Ensaios de cisalhamento direto com plano cortado e superfície polida 150 
6.1.1 Solo do Campus Avançado da PUC em Tinguá 150

6.1.2 Solo do Campo Experimental II PUC-Rio 154

6.1.3 Solo de Duque de Caxias 159

6.1.4 Comparação entre os valores de resistência máxima e residual dos solos estudados 163

6.2 Ensaios triaxiais convencionais drenados e não drenados 166

6.2.1 Ensaios triaxiais nos solos coluvionares 166

6.2.1.1 Solo do Campo Experimental II PUC-Rio 176

6.2.1.2 Solo do Campus Avançado da PUC em Tinguá 176

6.2.2 Ensaios triaxiais no solo residual jovem de Duque de Caxias 188

6.3 Considerações finais dos ensaios triaxiais convencionais e de cisalhamento direto com plano cortado e superfície polida 196

7. Apresentação e avaliação dos resultados: Ensaios triaxiais com aumento de poropressão

7.1 Solo do Campo Experimental II PUC-Rio 198

7.2 Solo do Campus Avançado da PUC em Tinguá 212

7.3 Solo de Duque de Caxias 222

8. Discussão final dos resultados 233

8.1 Solo do Campo Experimental II PUC-Rio 233

8.2 Solo do Campus Avançado da PUC em Tinguá 238

8.3 Solo de Duque de Caxias 243

9. Conclusões e sugestões para trabalhos futuros 248

9.1 Conclusões 248

9.2 Sugestões para trabalhos futuros 252

$\begin{array}{ll}\text { Referências bibliográficas } & 254\end{array}$

APÊNDICES

Apêndice A: Calibração dos instrumentos eletrônicos de medição

Apêndice B: Fotografias dos corpos de prova ao final dos ensaios de aumento de poropressão 


\section{Lista de Figuras}

Figura 2.1 - Caraterização geotécnica dos movimentos de massa, (a) Estágios do movimento, (b) Tipos de materiais, (c) Tipos de movimentos, (d) Folha de caraterização (adaptado de Leroueil et al., 1996)

Figura 2.2 - Diagrama esquemático da resposta hidrológica da encosta a chuvas intensas. As setas indicam a direção do fluxo da água (adaptado de Leroueil, 2001)

Figura 2.3 - Interpretação esquemática das condições de tensões, (a) Forças em um talude infinito no campo, (b) Tensões para um corpo de prova em um ensaio de compressão triaxial (adaptado de Anderson, 1992)

Figura 2.4 - (a) Diagrama esquemático mostrando um elemento do solo em uma encosta sujeito à infiltração de precipitações, (b) Correspondente trajetória de tensões no campo (adaptado de Farooq et al., 2004)

Figura 2.5 - Trajetória de tensões seguida no campo e em ensaios triaxiais (adaptado de Brand, 1981)

Figura 2.6 - Resultados de ensaios de aumento de poropressão, (a) na areia Monterey, (b) no solo coluvionar argiloso (adaptado de Andersom e Riemer, 1995)

Figura 2.7 - Trajetória de tensões de amostras no ensaio de aumento de poropressão, realizados no nível de tensões in situ, (a) s' vs $\mathrm{t}$, (b) e vs s' (adaptado de Anderson e Sitar, 1995)

Figura 2.8 - Resultado típico de ensaio CKU, note-se que a resistência pico é atingida com uma deformação muito baixa, além, a poropressão aumenta e a resistência diminui com a deformação contínua (adaptado de Anderson e Sitar, 1995)

Figura 2.9 - Envoltórias de ruptura e trajetórias de tensão do ensaio de aumento de poropressão (CSD) realizado em um solo residual (adaptado de Zhu e Anderson, 1998)

Figura 2.10 - Resultado de ensaio de aumento de poropressão em um solo arenoso, (a) Envoltórias de ruptura e trajetórias de tensão, (b) Relação e vs p' e linha de estado permanente estimada (adaptado de Orense et al., 2004)

Figura 2.11 - Ilustração esquemática da trajetória de tensões seguida por 
materiais sem coesão durante o ensaio de aumento de poropressão (adaptado de Petley et al., 2005b)

Figura 2.12 - Ilustração esquemática da trajetória de tensões seguida por materiais com coesão durante o ensaio de aumento de poropressão (adaptado de Petley et al., 2005b)

Figura 2.13 - Padrões de deformação observados em ensaios de aumento de poropressão e a sua relação com os padrões de comportamento de movimentos de massa (adaptado de Carey, 2011)

Figura 2.14 - Definição do parâmetro de estado $\psi$ e do parâmetro de estado modificado $\bar{\psi}$ (adaptado de Chu et al., 2003)

Figura 2.15 - Trajetória de tensão seguida em um ensaio APP (esquemático). Em (a) Y pode estar acima ou abaixo da linha de estado critico, dependendo do solo considerado (adaptado de Leroueil e Hight, 2003).

Figura 3.1 - Plano de localização do Campus Avançado da PUC - Tinguá (Google Earth, 2014)

Figura 3.2 - Vista da base da encosta onde se realizou a amostragem do solo no Campus Avançado da PUC - Tinguá

Figura 3.3 - Plano de localização da área estudada em Duque de Caxias (Google Earth, 2014)

Figura.3.4 - Vista da encosta onde se realizou a amostragem do solo em Duque de Caxias

Figura 3.5 - Localização do Campo Experimental II da PUC-Rio

Figura 3.6 - Vista da encosta onde se realizou a amostragem no Campo Experimental II da PUC-Rio

Figura 3.7 - Amostras indeformadas retiradas do talude de (a) Tinguá e (b) Duque de Caxias

Figura 3.8 - Amostragem no Campo Experimental II - PUC, (a) Amostragem de mini blocos inalterados, (b) Preparação de corpos de prova em campo para execução de ensaio de cisalhamento direto

Figura 4.1 - Curvas granulométricas dos ensaios realizados com e sem defloculante, (a) Solo de Tinguá, (b) Solo da PUC, (c) Solo de Duque de Caxias

Figura 4.2 - Ensaio de sedimentação com hexametafosfato de sódio e água, após 24h. (a) Solo de Tinguá, (b) Solo da PUC, (c) Solo de Duque de Caxias. Observa-se que nos estados de sedimentação sem 
defloculante (bureta à direita em cada figura) as amostras apresentam-se floculadas

Figura 4.3 - Frações de areia dos solos. (a) e (d) Tinguá, (b) e (e) PUC, (c) e (f) Duque de Caxias. Qt = quartzo, Agr = agregados argilo-ferruginosos, Il = ilmenita, $\mathrm{Bia}=$ biotita alterada, $\mathrm{CMn}=$ concreções de manganês

Figura 4.4 - Difratograma do solo de Tinguá. Ct=caulinita, Gb=gibbsita, Qt=quartzo

Figura 4.5 - Difratograma do solo da PUC. Ct=caulinita, Gt=goethita, Qt=quartzo

Figura 4.6 - Difratograma do solo de Duque de Caxias. Ct=caulinita, Mb=biotita, Gt=goethita (Carvalho, 2012)

Figura 4.7 - Termograma do solo coluvionar de Tinguá (Galindo, 2013) 99

Figura 4.8 - Termograma do solo coluvionar da PUC (Galindo, 2013)

Figura 4.9 - Termograma do solo residual jovem de Duque de Caxias (Carvalho, 2012)

Figura 4.10 - Imagens obtidas no MEV convencional do solo Duque de Caxias em diferentes ampliações e análise EDS para pontos específicos (Carvalho, 2012)

Figura 4.11 - Imagens obtidas no MEV convencional do solo coluvionar de Tinguá em diferentes ampliações e análise EDS para pontos específicos 104 Figura 4.12 - Imagens obtidas no MEV de baixo vácuo do solo coluvionar de Tinguá em diferentes ampliações e análise EDS para pontos específicos

Figura 4.13 - Imagens obtidas no MEV convencional do solo coluvionar da PUC em diferentes ampliações e análise EDS para pontos específicos

Figura 4.14 - Imagens obtidas no MEV de baixo vácuo do solo coluvionar da PUC em diferentes ampliações e análise EDS para pontos específicos 105 Figura 4.15 - Distribuição acumulativa dos diâmetros dos poros dos solos 107 Figura 4.16 - Curvas de distribuição incremental dos diâmetros dos poros dos solos Duque de Caxias, Tinguá e PUC, com a classificação dos poros segundo a IUPAC

Figura 5.1 - Arranjo esquemático do equipamento utilizado nos ensaios de aumento de poropressão

Figura 5.2 - (a) Vista geral dos equipamentos usados nos ensaios de aumento de poropressão, (b) Detalhe da câmara triaxial com instrumentação interna 
Figura 5.3 - (a) Controlador de pressão e volume GDS, (b) Esquema de funcionamento do controlador

Figura 5.4 - Dispositivo para aplicação de tensão controlada (adaptado de Andrade,1988)

Figura 5.5 - Componentes internos do dispositivo de aplicação de tensão controlada

Figura 5.6 - (a) Medidor de variação de volume tipo Imperial College, (b) Esquema do medidor de variação volumétrica (adaptado de De Campos, 1985)

Figura 5.7 - (a) Eletronível tipo Imperial College, (b) Detalhes do eletronível, (c) Vista em planta (modificado de Kuwano et al., 2000)

Figura 5.8 - (a) Transdutor de deslocamento radial tipo Imperial College, (b) Detalhes de medidor de deformação radial, (c) Esquema elétrico de LVDT

Figura 5.9 - (a) Minitransdutor de poropressão PDCR81, (b) Detalhes do minitransdutor (adaptado de Muraleetharan e Granger, 1999)

Figura 5.10 - Sistema de aquisição de dados: Datalogger ALMEMO®28909

Figura 5.11 - Câmara de acrílico utilizada na saturação e calibração do minitransdutor de poropressão

Figura 5.12 - Preparação de membrana de látex para execução de ensaios Figura 5.13 - (a) Equipamentos usados na moldagem dos corpos de prova, (b) Moldagem de corpos de prova do solo de Duque de Caxias, (c) Moldagem de corpos de prova de solos da PUC e Tinguá

Figura 5.14 - (a) Diagrama de configuração de um corpo de prova no ensaio triaxial com a instalação do minitransdutor de poropressão, (b) Detalhes do minitransdutor de poropressão colocado sobre o corpo de prova (adaptado de Hight, 1982)

Figura 5.15 - Sequência da montagem do corpo de prova para realização de ensaio triaxial

Figura 5.16 - Esquema de funcionamento do equipamento no momento da percolação

Figura 5.17 - Trajetórias de tensão seguidas na etapa de adensamento anisotrópico (adaptado de Baldi et al., 1988)

Figura 5.18 - Esquema de funcionamento do equipamento na etapa de aumento de poropressão 
Figura 5.19 - Sistema de aquisição de dados QuantumX. (a) Software CatmanEasy, (b) Amplificador universal MX840A

Figura 5.20 - Prensa de cisalhamento direto pertencente ao Laboratório de Geotecnia e Meio Ambiente da PUC-Rio

Figura 5.21 - (a) Moldagem de corpo de prova do solo de Duque de Caxias para realização de ensaio de cisalhamento direto com plano cortado e superfície polida, (b) Corpo de prova pronto para ensaio

Figura 5.22 - Principais passos seguidos para a obtenção de resistência residual mediante o ensaio de cisalhamento direto com plano cortado e superfície polida

Figura 6.1 - Resultados do ensaio de cisalhamento direto com plano cortado e superfície polida no solo coluvionar de Tinguá, (a) Fase para obtenção de resistência máxima, (b) Fase de reversão para obtenção de resistência residual

Figura 6.2 - Envoltórias de resistência de pico para o solo coluvionar de Tinguá: (a) linear, (b) bilinear e (c) curva

Figura 6.3 - Envoltórias de resistência residual para o solo coluvionar de Tinguá: (a) linear, (b) bilinear, e (c) curva

Figura 6.4 - Resultados do ensaio de cisalhamento direto com plano cortado e superfície polida no solo coluvionar da PUC, (a) Fase para obtenção de resistência máxima, (b) Fase de reversão para obtenção de resistência residual

Figura 6.5 - Envoltórias de resistência pico para o solo coluvionar da PUC:

(a) linear, (b) bilinear, (c) curva, (d) curva e linear

Figura 6.6 - Envoltórias de resistência residual para o solo da PUC: (a) linear, (b) bilinear, (c) curva

Figura 6.7 - Resultados do ensaio de cisalhamento direto com plano cortado e superfície polida para obtenção de resistência residual em amostras amolgadas do solo da PUC

Figura 6.8 - Envoltória de resistência residual para amostras amolgadas do solo da PUC

Figura 6.9 - Resultados do ensaio de cisalhamento direto com plano cortado e superfície polida no solo residual jovem de Duque de Caxias, (a) Fase para obtenção de resistência máxima, (b) Fase de reversão para obtenção de resistência residual

Figura 6.10 - Envoltórias de resistência pico para o solo de Duque de 
Caxias: (a) linear, (b) bilinear, (c) curva, (d) curva e linear

Figura 6.11 - Envoltórias de resistência residual para o solo de Duque de Caxias (a) linear, (b) bilinear, (c) curva

Figura 6.12 - Envoltória de resistência ao cisalhamento máxima e residual para: (a) Solo coluvionar de Tinguá, (b) Solo coluvionar da PUC, (c) Solo residual de Duque de Caxias

Figura 6.13 - Resultado dos ensaios triaxiais CID do solo coluvionar da PUC

Figura 6.14 - Curvas tensão desviadora normalizada vs deformação axial dos ensaios CID do solo coluvionar da PUC

Figura 6.15 - Resultado dos ensaios triaxiais CIU do solo coluvionar da PUC

Figura 6.16 - Curvas tensão - deformação normalizadas dos ensaios CIU no solo coluvionar da PUC, (a) Tensão desviadora normalizada por $\sigma^{\prime}$ v vs deformação axial, (b) Poropressão normalizada por $\sigma_{c}^{\prime}$ vs deformação axial

Figura 6.17 - Curvas de razão das tensões principais efetivas vs deformação axial dos ensaios CIU do solo coluvionar da PUC

Figura 6.18 - Linha de estado crítico no plano $p_{c}^{\prime}$ vs $q_{c}$ para o solo coluvionar da PUC, (a) Ajuste linear, passando pela origem, (b) Ajuste curvo, (c) Superposição dos resultados dos ensaios CIU realizados por Hurtado (2010)

Figura 6.19 - Linha de estado crítico no plano, (a) e vs $\mathrm{p}_{\mathrm{c}}$, (b) $v$ vs $\mathrm{p}_{\mathrm{c}}^{\prime}$ do solo coluvionar da PUC

Figura 6.20 - Envoltória e parâmetros de resistência de Mohr-Coulomb na condição pico para os ensaios drenados e não drenados do solo coluvionar da PUC

Figura 6.21 - Trajetórias de tensão, envoltória de resistência de pico e linha de estado crítico, obtidas dos ensaios CID e CIU do solo coluvionar da PUC

Figura 6.22 - Trajetórias de tensão, envoltória de resistência de pico e linha de estado crítico, obtidas dos ensaios CID e CIU do solo coluvionar da PUC no presente estudo, junto às trajetórias de tensão obtidas por Hurtado (2010)

Figura 6.23 - Variação dos parâmetros de deformabilidade com a tensão confinante para o solo coluvionar da PUC, (a) Variação do módulo de Young E, (b) Variação do coeficiente de Poisson 
Figura 6.24 - Resultado dos ensaios triaxiais CID do solo coluvionar de Tinguá

Figura 6.25 - Curvas tensão desviadora normalizada por $\sigma_{C}^{\prime}$ vs deformação axial dos ensaios CID do solo coluvionar de Tinguá

Figura 6.26 - Resultado dos ensaios triaxiais CIU do solo coluvionar de Tinguá

Figura 6.27 - Curvas tensão-deformação normalizadas do ensaio CIU do solo coluvionar de Tinguá, (a) Tensão desviadora normalizada por $\sigma_{c}^{\prime}$ vs deformação axial, (b) Poropressão normalizada por $\sigma_{c}^{\prime} v s$ deformação axial Figura 6.28 - Resultado dos ensaios triaxiais CKU do solo coluvionar de Tinguá

Figura 6.29 - Curvas tensão-deformação do ensaio CKU, obtida com o medidores de deformação interna (eletroníveis) e externa (LSCDT) - solo coluvionar de Tinguá

Figura 6.30 - Curvas tensão-deformação em escala ampliada onde as deformações foram obtidas com eletroníveis e LSCDT - solo coluvionar de Tinguá: (a) CKU 75, (b) CKU 150, (c) CKU 300

Figura 6.31 - Curvas normalizadas do ensaio CKU do solo coluvionar de Tinguá, (a) Tensão desviadora normalizada por $\sigma^{\prime}$ vs deformação axial, (b) Poropressão normalizada por $\sigma_{c}^{\prime}$ vs deformação axial

Figura 6.32 - Curvas de razão das tensões principais efetivas vs deformação axial dos ensaios, (a) CIU e (b) CKU do solo coluvionar de Tinguá

Figura 6.33 - Linha de estado crítico do solo coluvionar de Tinguá no plano $\mathrm{p}_{\mathrm{c}}{ }_{\mathrm{c}}$ vs $\mathrm{q}_{\mathrm{c}},(\mathrm{a})$ Ajuste linear passando pela origem, (b) Ajuste curvo

Figura 6.34 - Linha de estado crítico do solo coluvionar de Tinguá no plano: (a) e vs $\mathrm{p}_{\mathrm{c}}{ }_{\mathrm{c}},(\mathrm{b}) v$ vs $\mathrm{p}_{\mathrm{c}}$

Figura 6.35 - Envoltória e parâmetros de resistência de Mohr-Coulomb na condição de pico para os ensaios drenados e não drenados do solo coluvionar de Tinguá

Figura 6.36 - Trajetórias de tensão, envoltória de resistência de pico e linha de estado crítico do solo coluvionar de Tinguá, obtidas dos ensaios CID, CIU e CKU.

Figura 6.37 - Variação dos parâmetros de deformabilidade com a tensão confinante para o solo coluvionar de Tinguá, (a) Variação do módulo de Young E, (b) Variação do coeficiente de Poisson 
Figura 6.38 - Variação do módulo de deformação $E_{i}$ e $E_{50}$ em função da tensão confinante, utilizando medidor de deformação axial interno (eletroníveis) e externo (LSCDT) nos ensaios CKU do solo coluvionar de Tinguá

Figura 6.39 - Curvas $\sigma_{\mathrm{d}}$ vs $\varepsilon_{\mathrm{a}}$ e $\Delta \mathrm{u}$ vs $\varepsilon_{\mathrm{a}}$ dos ensaios CIU do solo residual jovem de Duque de Caxias (Carvalho, 2012)

Figura 6.40 - Curvas $\sigma_{\mathrm{d}} / \sigma_{3}{ }_{3}$ vs $\varepsilon_{\mathrm{a}}$ dos ensaios CIU do solo residual jovem de Duque de Caxias (Carvalho, 2012)

Figura 6.41 - Trajetórias de tensões dos ensaios CIU do solo residual jovem de Duque de Caxias (Carvalho, 2012)

Figura 6.42 - Curvas $\sigma_{1}{ }_{1} / \sigma_{3}{ }_{3}$ vs $\varepsilon_{\mathrm{a}}$ dos ensaios CIU do solo residual jovem de Duque de Caxias (Carvalho, 2012)

Figura 6.43 - Envoltórias de resistência de ruptura dos ensaios realizados por Carvalho (2012), no solo residual jovem de Duque de Caxias

Figura 6.44 - Variação do módulo de Young secante correspondente a $50 \%$ da máxima tensão desviadora para o solo residual jovem de Duque de Caxias

Figura 6.45 - Estimativa das linhas de estado crítico do solo residual jovem de Duque de Caxias (Carvalho, 2012)

Figura 6.46 - Curva de plastificação correspondente à região de plastificação da estrutura por cisalhamento no solo residual de Duque de Caxias (Carvalho, 2012)

Figura 7.1 - Resultados dos ensaios APP no solo coluvionar da PUC: (a) Trajetórias de tensão vs tensão média efetiva, (b) Deformação axial vs tensão média efetiva, (c) Deformação volumétrica vs tensão média efetiva

Figura 7.2 - Desenho esquemático do ponto de plastificação e mudança de volume em um ensaio de aumento de poropressão (adaptado de Junaideen et al., 2010)

Figura 7.3 - Comparação entre as curvas de deformação axial obtidas com a instrumentação interna (eletroníveis) e instrumentação externa (LSCDT) nos ensaios APP do solo coluvionar da PUC

Figura 7.4 - Exemplo de curva $\varepsilon_{a}$ vs tempo utilizada no cálculo da velocidade de deformação axial após inicio da ruptura (ensaio PUC300)

Figura 7.5 - Comparação entre as curvas de deformação volumétrica obtidas com a instrumentação interna (eletroníveis e transdutor de deslocamento radial) e o medidor de variação de volume tipo Imperial 
College (MVV) nos ensaios APP do solo coluvionar da PUC

Figura 7.6 - Relação entre a deformação volumétrica e a deformação de cisalhamento nos ensaios APP do solo coluvionar da PUC

Figura 7.7 - Trajetórias de tensão dos ensaios APP do solo coluvionar da PUC no espaço e vs p'. (a) p' em escala aritmética, (b) p' em escala logarítmica

Figura 7.8 - Variação ao longo do tempo da poropressão no meio e base do corpo de prova, da deformação axial e da deformação volumétrica dos ensaios : (a) PUC50 e (b) PUC75

Figura 7.9 - Trajetórias de tensão dos ensaios APP do solo coluvionar da PUC, junto à linha de estado crítico e envoltória correspondente ao inicio da deformação rápida

Figura 7.10 - Detalhe das trajetórias de tensão dos ensaios APP de menor tensão confinante inicial do solo coluvionar da PUC, junto à linha de estado crítico e envoltória correspondente ao inicio de deformação rápida

Figura 7.11 - Resultados dos ensaios APP no solo coluvionar de Tinguá:

(a) Trajetórias de tensão vs tensão média efetiva, (b) Deformação axial vs tensão média efetiva, (c) Deformação volumétrica vs tensão média efetiva

Figura 7.12 - Relação entre a deformação volumétrica e a deformação de cisalhamento nos ensaios APP do solo coluvionar de Tinguá

Figura 7.13 - Trajetória de tensões dos ensaios APP do solo coluvionar de Tinguá no espaço e vs p', (a) p' em escala aritmética, (b) p' em escala logarítmica

Figura 7.14 - Comparação entre as curvas obtidas no adensamento anisotrópico ao longo da linha $\mathrm{Kc}$ e o adensamento anisotrópico simplificado (adensamento isotrópico + carregamento axial drenado)

Figura 7.15 - Variação ao longo do tempo da poropressão no meio e base do corpo de prova, da deformação axial e da deformação volumétrica dos ensaios : (a) TIN100, (b) TIN150, (c) TIN220, (d) TIN300

Figura 7.16 - Trajetórias de tensão dos ensaios APP do solo coluvionar de Tinguá, junto à linha de estado crítico e envoltória APP

Figura 7.17 - Detalhe das trajetórias de tensão dos ensaios APP de menor tensão confinante no solo coluvionar de Tinguá, junto à linha de estado crítico e envoltória APP

Figura 7.18 - Resultados dos ensaios APP no solo de Duque de Caxias, (a) Trajetórias de tensão vs tensão média efetiva, (b) e (c) Deformação 
axial e deformação volumétrica vs tensão média efetiva dos ensaios que romperam

Figura 7.19 - Trajetórias de tensão dos ensaios APP no espaço e vs p', (a) Trajetórias com p' em escala aritmética, (b) Trajetórias com p' em escala logarítmica

Figura 7.20 - Variação, ao longo do tempo, da poropressão, deformação axial e da deformação volumétrica dos ensaios: (a) DC220, (b) DC300, (c) DC300II

Figura 7.21 - Resultado do carregamento axial não drenado realizado em amostras que não romperam durante o ensaio APP, (a) Curva tensão desviadora vs deformação axial, (b) Variação da poropressão vs deformação axial

Figura 7.22 - Trajetórias de tensão do carregamento axial não drenado em amostras que não romperam durante o ensaio APP

Figura 7.23 - Trajetórias de tensão dos ensaios APP e de carregamento axial não drenado do solo de Duque de Caxias, junto à linha de estado crítico e envoltória APP

Figura 8.1 - Trajetórias de tensão no espaço e vs p' e linhas de estado crítico obtidas nos ensaios de aumento poropressão e ensaios triaxiais convencionais no solo coluvionar da PUC

Figura 8.2 - Relação entre o parâmetro de estado modificado, $\bar{\psi}$, e a relação de tensões efetivas no escoamento, $\eta$, nos ensaios de aumento de poropressão do solo coluvionar da PUC

Figura 8.3 - Envoltórias obtidas a partir dos diferentes tipos de ensaios realizados no solo coluvionar da PUC

Figura 8.4 - Trajetórias de tensão no espaço e vs p' e linhas de estado crítico obtidas no ensaio APP e ensaios triaxiais convencionais do solo coluvionar de Tinguá

Figura 8.5 - Relação entre o parâmetro de estado modificado, $\bar{\psi}$, e a relação de tensões efetivas no escoamento, $\eta$, nos ensaios APP do solo coluvionar de Tinguá

Figura 8.6 - Envoltórias obtidas a partir dos diferentes tipos de ensaios realizados no solo coluvionar de Tinguá

Figura 8.7 - Trajetórias de tensão dos ensaios APP do solo residual jovem de Duque de Caxias, junto à linha de estado crítico, envoltórias de resistência de pico e residual, curva de plastificação e envoltória APP 
Figura 8.8 - Comparação no plano p' vs q da linha de estado crítico determinada nos ensaios APP com a linha estabelecida por Carvalho (2012) no solo residual jovem de Duque de Caxias

Figura 8.9 - Relação entre o parâmetro de estado modificado, $\bar{\psi}$, e a relação de tensões efetivas no escoamento, $\eta=q / p$ ', nos ensaios APP do solo residual jovem de Duque de Caxias

Figura 8.10 - Trajetórias de tensão no espaço e vs p' e linhas de estado crítico obtidas no ensaio APP e ensaios triaxiais CIU realizados por Carvalho (2012), no solo residual jovem de Duque de Caxias 


\section{Lista de Tabelas}

Tabela 2.1 - Classificação de movimentos de massa (modificado de Hutchinson, 1988)

Tabela 2.2 - Características dos principais grupos de processos de instabilização (Augusto Filho, 1992)

Tabela 2.3 - Inventário de causas de movimentos de massa (Cruden e Varnes, 1996)

Tabela 2.4 - Principais fatores agravantes ou acionantes - estágio de préruptura (Leroueil, 2004)

Tabela 2.5 - Processos de ativação e reativação de colúvios (Lacerda, 2004)

Tabela 2.6 - Resumo de principais caraterísticas dos ensaios de aumento de poropressão encontrados na literatura

Tabela 4.1 - Resultados dos ensaios de granulometria dos solos estudados

Tabela 4.2 - Resultados dos ensaios de limites de consistência

Tabela 4.3 - Resultados dos ensaios massa específica dos grãos

Tabela 4.4 - Índices físicos médios obtidos por correlação

Tabela 4.5 - Composição química dos solos

Tabela 4.6 - Determinação da perda ao fogo dos três solos

Tabela 4.7 - $\mathrm{pH}$ dos solos estudados

Tabela 4.8 - Porosidade por injeção de mercúrio dos solos

Tabela 4.9 - Distribuição de poros em porcentagem segundo IUPAC

Tabela 5.1 - Programa de ensaios executados

Tabela 5.2 - Resumo das principais caraterísticas da instrumentação de laboratório usada

Tabela 6.1 - Índices físicos no inicio, após o adensamento e no final do ensaio dos corpos de prova do solo coluvionar de Tinguá usados no ensaio de cisalhamento direto

Tabela 6.2 - Resumo dos resultados obtidos a partir dos ensaios de cisalhamento direto com plano cortado e superfície polida nos corpos de prova do solo coluvionar de Tinguá

Tabela 6.3 - Índices físicos no inicio, após o adensamento e no final do ensaio dos corpos de prova do solo coluvionar da PUC usados no ensaio de cisalhamento direto 
Tabela 6.4 - Resumo dos resultados obtidos a partir dos ensaios de cisalhamento direto com plano cortado e superfície polida nos corpos de prova do solo coluvionar da PUC

Tabela 6.5 - Índices físicos no inicio, após o adensamento e no final do ensaio dos corpos de prova do solo residual jovem de Duque de Caxias usados no ensaio de cisalhamento direto

Tabela 6.6 - Resumo dos resultados obtidos a partir dos ensaios de cisalhamento direto com plano cortado e superfície polida nos corpos de prova do solo de Duque de Caxias

Tabela 6.7 - Índices físicos no inicio, após o adensamento e no final do ensaio dos corpos de prova do solo coluvionar da PUC usados nos ensaios triaxiais

Tabela 6.8 - Parâmetros de deformabilidade E e $v$ obtidos nos ensaios triaxiais do solo coluvionar da PUC

Tabela 6.9 - Índices físicos no inicio, após o adensamento e no final do ensaio dos corpos de prova do solo coluvionar de Tinguá usados nos ensaios triaxiais

Tabela 6.10 - Parâmetros de deformabilidade E e $v$ obtidos nos ensaios triaxiais do solo coluvionar de Tinguá

Tabela 6.11 - Dados dos corpos de prova do solo residual jovem de Duque de Caxias usados em ensaios triaxiais CIU realizados por Carvalho (2012)

Tabela 6.12 - Módulo de deformabilidade $E_{50}$ obtidos nos ensaios triaxiais do solo residual de Duque de Caxias (Carvalho, 2012)

Tabela 7.1 - Índices físicos no inicio, após o adensamento e no final dos ensaios APP, dos corpos de prova do solo coluvionar da PUC

Tabela 7.2 - Parâmetros de estado, $\psi$, e parâmetros de estado modificado, $\bar{\psi}$, obtidos das trajetórias de tensão no espaço e vs p' dos ensaios APP do solo coluvionar da PUC

Tabela 7.3 - Índices físicos no inicio, após o adensamento e no final do ensaio APP dos corpos de prova do solo coluvionar de Tinguá

Tabela 7.4 - Parâmetros de estado, $\psi$, e parâmetros de estado modificado, $\bar{\psi}$, obtidos das trajetórias de tensão no espaço e vs p' dos ensaios APP do solo coluvionar de Tinguá

Tabela 7.5 - Índices físicos no inicio, após o adensamento e no final dos ensaios APP, dos corpos de prova do solo residual jovem de Duque de Caxias 
Tabela 7.6 - Parâmetros de estado, $\psi$, e parâmetros de estado modificado, $\bar{\psi}$, obtidos das trajetórias de tensão no espaço e vs p' dos ensaios APP do solo residual jovem Duque de Caxias 


\section{Lista de símbolos e abreviações}

$\begin{array}{ll}\% & \text { porcentagem } \\ \circ & \text { grau } \\ \text { “ } & \text { polegada } \\ \text { a' } & \text { intercepto “coesivo" no diagrama s vs t' } \\ \text { atm } & \text { atmosfera }\end{array}$

ABNT Associação Brasileira de Normas Técnicas

AC corrente alternada

Agr agregados argilo-ferruginosos

APP Aumento de poropressão

ASTM American Society for Testing and Materials

ATD Análise Térmica Diferencial

B parâmetro de Skempton

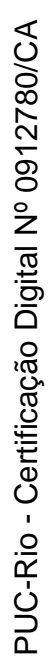

Bia

biotita alterada

c' intercepto coesivo

$\mathrm{c}_{\mathrm{r}}^{\prime} \quad$ intercepto coesivo residual

$\mathrm{cm} \quad$ centímetro

C celsius

CD

ensaio triaxial drenado

CID

adensado isotropicamente drenado

CIU

adensado isotropicamente não drenado

CKU

adensado anisotropicamente não drenado

$\mathrm{CMn}$

concreções de manganês

CNPS

Centro Nacional de Pesquisa de Solos

CPP

Ensaio de ciclagem de poropressão

CS

Constant Shear Test

CSD

Constant Shear Drained Test

CSU

Constant Shear Undrained Test

Ct

caulinita

CU

ensaio triaxial não drenado

dh deslocamento horizontal

dv

deslocamento vertical

DC

corrente contínua

DEQM Departamento de Engenharia Química e Materiais

DL

Dead Load Test

DRX

Difração de Raios-x

e

índice de vazios 


\begin{tabular}{|c|c|}
\hline $\mathrm{e}_{\mathrm{o}}$ & índice de vazios inicial \\
\hline$e_{\text {adens }}$ & índice de vazios após o adensamento \\
\hline$e_{f}$ & índice de vazios final \\
\hline$e_{s s}$ & índice de vazios no estado permanente ou crítico \\
\hline$e_{y}$ & índice de vazios no ponto de escoamento \\
\hline$E_{i}$ & módulo de Young tangente inicial \\
\hline$E_{50}$ & módulo secante correspondente a $50 \%$ da tensão de ruptura \\
\hline EDS & Energy Dispersive Spectrometry \\
\hline EMBRAPA & Empresa Brasileira de Pesquisas Agrárias \\
\hline FD & fluência drenada \\
\hline FND & fluência não drenada \\
\hline g & grama \\
\hline $\mathrm{Gb}$ & gibbsita \\
\hline GCO & Geotechnical Control Office \\
\hline GEO & Geotechnical Engineering Office \\
\hline Gs & peso específico real dos grãos \\
\hline Gt & goethita \\
\hline $\mathrm{hr}$ & hora \\
\hline HIST & Erro de histerese \\
\hline Ia & índice de atividade \\
\hline Il & ilmenita \\
\hline IP & índice de plasticidade \\
\hline IUPAC & União Internacional da Química Pura e Aplicada \\
\hline $\mathrm{K}_{\mathrm{o}}$ & coeficiente de empuxo em repouso \\
\hline $\mathrm{K}_{\mathrm{c}}$ & relação de tensões principais $\left(\mathrm{K}_{\mathrm{c}}=\sigma_{1}{ }_{1} / \sigma_{3}^{\prime}\right)$ \\
\hline $\mathrm{K}_{\mathrm{cf}}$ & relação de tensões principais na ruptura \\
\hline $\mathrm{K}_{\mathrm{f}}$ & envoltória de ruptura \\
\hline $\mathrm{kg}$ & quilograma \\
\hline $\mathrm{km}$ & quilômetro \\
\hline $\mathrm{kN}$ & quilonewton \\
\hline $\mathrm{kPa}$ & quilopascal \\
\hline $\ln$ & logaritmo neperiano \\
\hline $\log$ & logaritmo \\
\hline LEC & linha de estado crítico \\
\hline LL & limite de liquidez \\
\hline LP & limite de plasticidade \\
\hline LSCDT & Linear Strain Conversion Displacement Transducer \\
\hline LVTD & Linearly Variable Differential Transformer \\
\hline $\mathrm{m}$ & metro \\
\hline $\mathrm{mA}$ & miliampere \\
\hline
\end{tabular}




\begin{tabular}{|c|c|c|}
\hline & $\min$ & minuto \\
\hline & $\mathrm{mm}$ & milímetro \\
\hline & $\mathrm{mV}$ & milivolt \\
\hline & M & inclinação da linha do estado crítico no plano p'-q \\
\hline & $\mathrm{Mb}$ & biotita \\
\hline & MEV & Microscopia Eletrônica de Varredura \\
\hline & MVV & Medidor de Variação de Volume \\
\hline & Mpa & megapascal \\
\hline & $\mathrm{n}$ & porosidade \\
\hline & $n^{\circ}$ & número \\
\hline & $\mathrm{N}$ & newton \\
\hline & NBR & norma brasileira \\
\hline & NL & Erro de não linearidade \\
\hline & $p^{\prime}$ & tenso efetiva média $\left(\sigma^{\prime}{ }_{1}+2 \sigma^{\prime}\right) / 3$ \\
\hline & $p_{c}^{\prime}$ & tenso efetiva média na condição de estado critico \\
\hline & $\mathrm{pH}$ & potencial de hidrogenização \\
\hline & psi & libra força por polegada quadrada \\
\hline ญे & $\mathrm{Pa}$ & pascal \\
\hline$\stackrel{\infty}{N}$ & PPR & Porepressure Reinflation Test \\
\hline Б্ & PUC & Pontifícia Universidade Católica \\
\hline$\frac{\sum_{0}^{\prime}}{\sigma}$ & PVC & policloreto de vinila \\
\hline 䓂 & q & $\sigma_{d}=\sigma_{1}^{\prime}-\sigma_{3}^{\prime}$ \\
\hline 茜 & $q_{c}$ & $\sigma^{\prime}{ }_{1}-\sigma^{\prime}{ }_{3}$ na condição de estado crítico \\
\hline ల్ల & Qt & quartzo \\
\hline 苞 & $\mathrm{R}^{2}$ & coeficiente de correlação \\
\hline$\frac{\mathrm{o}}{\mathrm{n}}$ & s & segundo \\
\hline 它 & $\mathrm{s}^{\prime}$ & $\left(\sigma_{1}^{\prime}+\sigma_{3}^{\prime}\right) / 2$ \\
\hline & $S$ & grau de saturação \\
\hline & SAD & sistema de aquisição de dados \\
\hline & SSL & Steady State Line \\
\hline & SUCS & Sistema Unificado de Classificação de Solos \\
\hline & $\mathrm{t}$ & tempo \\
\hline & $\mathrm{t}$ & $\left(\sigma_{1}^{\prime}-\sigma_{3}^{\prime}\right) / 2$ \\
\hline & $\tan$ & tangente \\
\hline & $\mathrm{T}$ & temperatura \\
\hline & $\mathrm{u}$ & poropressão \\
\hline & $\mu \mathrm{m}$ & micro metro \\
\hline & UFRJ & Universidade Federal do Rio de Janeiro \\
\hline & UK & Reino Unido \\
\hline & V & volt \\
\hline
\end{tabular}




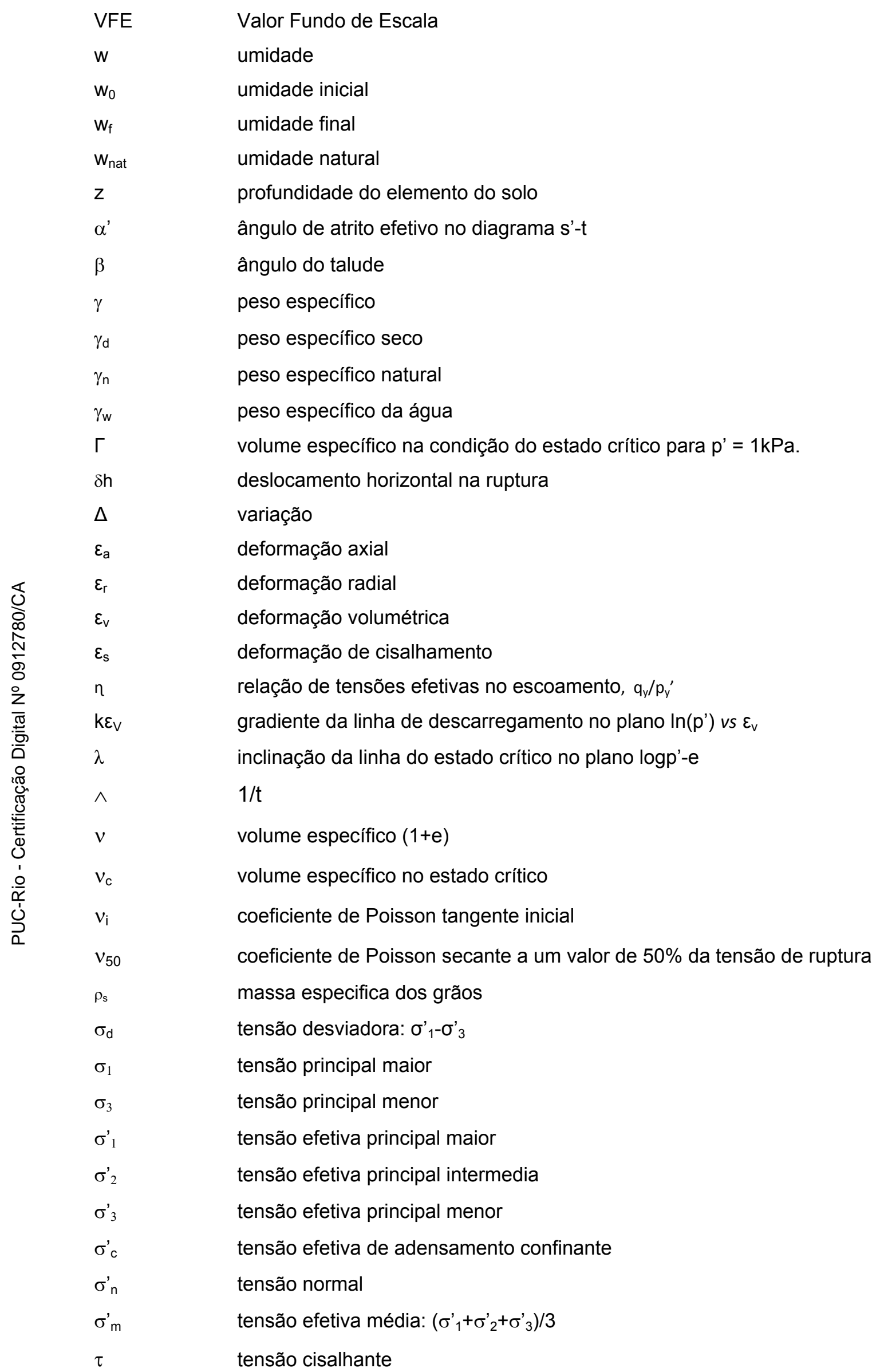




$\begin{array}{ll}\phi^{\prime} & \text { ângulo de atrito efetivo } \\ \phi_{\mathrm{c}}^{\prime} & \text { ângulo de atrito no estado crítico } \\ \phi_{\mathrm{r}}^{\prime} & \text { ângulo de atrito residual } \\ \phi_{\mathrm{fi}}^{\prime} & \text { ângulo de atrito efetivo da linha de início de ruptura } \\ \phi_{\mathrm{ss}}^{\prime} & \text { ângulo efetivo da linha de estado permanente } \\ \varnothing & \text { diâmetro } \\ \psi & \text { parâmetro de estado } \\ \bar{\psi} & \text { parâmetro de estado modificado } \\ \omega & \text { ângulo de inclinação da tensão principal em relação ao plano horizontal }\end{array}$




\section{1 \\ Introdução}

É geralmente reconhecido, que um rápido aumento da poropressão é um fator causal importante na maioria dos movimentos gravitacionais de massa. $O$ aumento das poropressões em taludes pode ocorrer por infiltração das chuvas, vazamento subterrâneo de tubulações de serviços públicos, desenvolvimento de condições de artesianismo ou entrada de águas subterrâneas de áreas adjacentes. Em muitas partes do mundo, tal aumento de poropressão ocorre principalmente durante ou após chuvas, daí esses tipos de rupturas são chamados comumente de ruptura de taludes induzida por chuvas.

As rupturas de taludes induzidas por chuvas são muito comuns em regiões com climas tropicais ou subtropicais, tais como: Hong Kong, Taiwan, Cingapura, Japão e Brasil. Estas rupturas podem ocorrer em encostas (taludes naturais) compostas de diferentes materiais, incluindo solos residuais e depósitos coluviais. Taludes de aterros, cortes em encostas e corpos de barragens também podem ser propensos a este tipo de ruptura. A grande maioria destes movimentos de massa ocorre em profundidades rasas, normalmente menores que três metros. Ocasionalmente eles se transformam em movimentos rápidos de fluxos de detritos que podem percorrer uma grande distância, aumentando o potencial de dano.

Quando uma encosta é submetida ao aumento da poropressão devido à infiltração ou subida do lençol freático, as tensões totais e de cisalhamento permanecem essencialmente constantes, porém a tensão efetiva média diminui. Este comportamento corresponde a uma especifica trajetória de tensão, oposta às trajetórias típicas reproduzidas em ensaios de laboratório convencionais onde a tensão de cisalhamento é aumentada.

Embora a importância da diferença entre ambas trajetórias de tensão tenha sido reconhecida, os estudos do comportamento do solo durante o aumento da poropressão têm sido limitados, principalmente em solos característicos de climas tropicais. Nesses estudos, as mudanças de tensão decorrentes do aumento da pressão da água nos poros são simuladas em 
ensaios triaxiais especiais que são geralmente chamados de "Ensaios de aumento de poropressão" ou "Ensaios de cisalhamento constante".

Dentro deste contexto, e admitindo a necessidade de uma maior compreensão do comportamento do solo antes e durante o estágio de ruptura devido ao aumento da poropressão, desenvolveu-se, neste trabalho, um programa experimental de laboratório, visando conhecer como o aumento da poropressão afeta as características de resistência de dois solos coluvionares e um solo residual jovem ou saprolítico, oriundos de três encostas de Rio de Janeiro.

Para alcançar este objetivo um equipamento triaxial convencional foi adaptado para a execução de ensaios de aumento de poropressão, permitindo caracterizar o comportamento dos três solos, simulando a trajetória de tensão a que esses solos seriam submetidos durante a elevação do nível piezométrico.

A avaliação da relação entre o incremento da poropressão e o comportamento de deformação dos corpos de prova, foi efetuada utilizando-se instrumentação interna. Além disso, utilizou-se um minitransdutor de pressão a meia altura das amostras que permitiu acompanhar a variação da poropressão durante o ensaio.

Adicionalmente, foram executados ensaios triaxiais convencionais e de cisalhamento direto com plano cortado e superfície polida, com o intuito de determinar relações tensão-deformação e, em particular, envoltórias que caracterizam o estado crítico, de pico e residual dos solos estudados, além de comparar seu comportamento nas diferentes trajetórias de tensão.

Para o melhor entendimento deste trabalho, o mesmo é apresentado em nove capítulos, incluindo esta introdução, sendo descritos a seguir, resumidamente, o conteúdo de cada um deles.

O Capítulo 2 abrange uma revisão bibliográfica sobre os temas relacionados ao objetivo da pesquisa, dando uma noção básica sobre as principais classificações e fatores condicionantes dos movimentos de massa, bem como a influência da água sobre a estabilidade de encostas e os mecanismos de ruptura pelo aumento de poropressão. Ainda, apresenta-se uma síntese da revisão das investigações já existentes, onde o ensaio de aumento de poropressão foi utilizado, que permitiu definir os critérios e a metodologia mais adequada a ser implementada na execução dos ensaios na presente pesquisa.

No Capítulo 3 são descritos os aspectos gerais dos locais de estudo, abrangendo aspectos geológicos, geomorfológicos e climáticos. 
No Capítulo 4 são apresentados os procedimentos experimentais para a realização dos ensaios de caraterização geotécnica dos solos, assim como os resultados obtidos, com a análise e interpretação dos mesmos.

O Capítulo 5 apresenta as técnicas experimentais dos ensaios de laboratório, executados a fim de identificar as características de resistência dos três solos estudados. Fornece-se detalhes acerca do ensaio de aumento de poropressão realizado neste trabalho, apresentando os aspectos relevantes, as adaptações feitas no equipamento triaxial convencional, a metodologia empregada na execução dos ensaios, como também pormenores da instrumentação usada na pesquisa. Além disso, descrevem-se as metodologias dos ensaios de cisalhamento direto com plano cortado e superfície polida para obtenção de resistência residual, e dos ensaios triaxiais drenados e não drenados convencionais.

No Capítulo 6 são apresentados e analisados os resultados dos ensaios de cisalhamento direto com plano cortado e superfície polida, e dos ensaios triaxiais convencionais executados.

No Capítulo 7 constam os resultados e a análise dos ensaios de aumento de poropressão realizados nos três solos estudados.

O Capítulo 8 envolve a discussão final dos resultados dos ensaios de aumento de poropressão, considerando os diferentes ensaios realizados nos solos.

No Capítulo 9 são apresentadas as principais conclusões e sugestões para futuros trabalhos.

No final da tese encontram-se as Referências Bibliográficas e os Apêndices onde são apresentadas informações adicionais deste trabalho. 


\section{2 \\ Revisão bibliográfica}

\section{1. \\ Movimentos gravitacionais de massa em encostas}

\subsection{1.}

Classificação dos movimentos de massa

Entende-se como movimento gravitacional de massa qualquer deslocamento de um determinado volume de solo. Em geral, a literatura trata os movimentos de massa como processos associados a problemas de instabilidade de encostas.

Existem diversas propostas de classificação de movimentos de massa, podendo-se citar as apresentadas por Terzaghi (1950), Varnes (1958, 1978), Sharpe (1938), Skempton e Hutchinson (1969), Augusto Filho (1992), Cruden e Varnes (1996), Sassa (1985), Hutchinson (1988), Vargas (1999), entre outros.

A metodologia proposta por Cruden e Varnes (1996), baseada em Varnes (1978), tornou-se uma das mais difundidas e utilizadas. Nesse trabalho, os autores apresentam uma classificação dos tipos de movimento de massa, levando em consideração o material envolvido, a velocidade do movimento, a umidade do solo comprometido na movimentação e se o movimento é reativado. Segundo essa proposta, qualquer movimento de massa pode ser classificado e descrito por dois termos, onde o primeiro indica o material: solo, rocha, ou detritos; e o segundo, o tipo de movimento: queda (fall), tombamento (topple) escorregamento (slide), espraiamento/expansão lateral (lateral spread), corrida ou fluxo (flow). No caso de múltiplos movimentos estes termos são repetidos quantas vezes forem necessárias.

Hutchinson (1988) propôs uma das classificações consideradas mais complexas e completas, com base na morfologia dos processos e materiais movimentados, com algumas considerações ao mecanismo, material e razão de movimentação. De acordo com essa proposta, podem-se dividir os movimentos de massa em: movimentos devidos ao alívio de tensões (rebound), rastejo (creep), deformações em cristas e encostas de montanhas (sagging), escorregamentos (landslides), movimentação/fluxo de detritos (debris flow), 
tombamento (toppling), quedas (falls) e movimentos complexos de encostas. A Tabela 2.1 apresenta a classificação detalhada de Hutchinson (1988).

Tabela 2.1 - Classificação de movimentos de massa (modificado de Hutchinson, 1988)

\begin{tabular}{|c|c|c|c|}
\hline Tipos & \multicolumn{3}{|c|}{ Subtipos } \\
\hline $\begin{array}{l}\text { Movimentos por } \\
\text { alivio de tensões } \\
\text { (Rebound) }\end{array}$ & \multicolumn{3}{|l|}{$\begin{array}{l}\text { - Artificiais } \\
\text { - Naturais }\end{array}$} \\
\hline \multirow{4}{*}{$\begin{array}{l}\text { Rastejo } \\
\text { (Creep) }\end{array}$} & - Superficial e sazonal & \multicolumn{2}{|c|}{$\begin{array}{l}\text { - Em solos e tálus (não associados a regimes glaciais) } \\
\text { - Associado com regimes glaciais }\end{array}$} \\
\hline & \multicolumn{3}{|l|}{ - Profundo e contínuo } \\
\hline & \multicolumn{3}{|l|}{ - Pré-ruptura } \\
\hline & \multicolumn{3}{|l|}{ - Pós-ruptura } \\
\hline \multirow{3}{*}{$\begin{array}{l}\text { Deformação em } \\
\text { crista e encostas de } \\
\text { montanhas } \\
\text { (Sagging of Montain } \\
\text { slopes) }\end{array}$} & - Em uma única face & \multirow{2}{*}{\multicolumn{2}{|c|}{\begin{tabular}{|l|l|} 
- Associado a deslizamentos rotacionais \\
- Associado a deslizamentos não circulares \\
- Associado a duplos deslizamentos rotacionais \\
- Associados a duplos deslizamentos não circulares
\end{tabular}}} \\
\hline & - Nas duas faces & & \\
\hline & \multicolumn{3}{|c|}{ - Associado com quedas múltiplas } \\
\hline \multirow{7}{*}{$\begin{array}{l}\text { Escorregamentos } \\
\text { (landslides) }\end{array}$} & - Ruptura confinada & $\begin{array}{l}\text { - Em encostas naturais } \\
\text { - Em taludes artificiais }\end{array}$ & \\
\hline & - Rotacional & $\begin{array}{l}\text { - Simples } \\
\text { - Sucessivos } \\
\text { - Múltiplos } \\
\end{array}$ & \\
\hline & - Composto & $\begin{array}{l}\text { - Retrogressivo } \\
\text { - Progressivo }\end{array}$ & \\
\hline & \multirow{4}{*}{ - Translacional } & \multicolumn{2}{|c|}{$\begin{array}{l}\text { - Muito raso e plano ao longo de toda a encosta } \\
\text { - Raso e plano } \\
\text { - Envolvendo turfas }\end{array}$} \\
\hline & & - Envolvendo rochas & \begin{tabular}{|l|} 
- Planar e em blocos \\
- Em degraus \\
- Em cunha \\
\end{tabular} \\
\hline & & - Envolvendo detritos & $\begin{array}{l}\text { - Em zona periglacial } \\
\text { - Em área não periglacial }\end{array}$ \\
\hline & & \multicolumn{2}{|l|}{ - Escoamento súbito } \\
\hline \multirow{7}{*}{$\begin{array}{l}\text { Movimentos de } \\
\text { detritos } \\
\text { (Debris movements } \\
\text { of flow - like form) }\end{array}$} & \multicolumn{3}{|c|}{ - Deslizamento de lama (não-periglacial) } \\
\hline & \multicolumn{3}{|c|}{ - Deslizamento de lama (periglacial) } \\
\hline & - Fluxo & \multicolumn{2}{|c|}{$\begin{array}{l}\text { - Em materiais fofos não coesivos } \\
\text { - Em siltes muito porosos, levemente cimentados } \\
\text { - Em rochas brandas muito porosas }\end{array}$} \\
\hline & \multirow{3}{*}{$\begin{array}{l}\text { - Fluxo de detritos } \\
\text { (rápidos e muito rápidos, } \\
\text { com alto teor de } \\
\text { umidade) }\end{array}$} & $\begin{array}{l}\text { - Em detritos de rochas } \\
\text { alteradas }\end{array}$ & $\begin{array}{l}\text { - Fluxo de detrito em encosta } \\
\text { - Fluxo de detritos canalizados } \\
\text { (lama e rocha) }\end{array}$ \\
\hline & & - Envolvendo turfas e loc & \\
\hline & & $\begin{array}{ll}\text { - Associado com } \\
\text { vulcões }\end{array}$ & $\begin{array}{l}\text { - Lava quente } \\
\text { - Lava fria }\end{array}$ \\
\hline & \multicolumn{3}{|c|}{ - Sturzstroms (fluxo extremamente rápido de detritos secos) } \\
\hline \multirow{3}{*}{$\begin{array}{l}\text { Tombamentos } \\
\text { (Topples) }\end{array}$} & \multirow{2}{*}{$\begin{array}{l}\text { - Tombamento delimitado } \\
\text { por descontinuidades } \\
\text { pré-existentes }\end{array}$} & \multicolumn{2}{|l|}{ - Simples } \\
\hline & & \multicolumn{2}{|l|}{ - Múltiplos } \\
\hline & \multicolumn{3}{|c|}{ - Tombamento pela ruptura por aumento de tensão } \\
\hline \multirow{2}{*}{$\begin{array}{l}\text { Quedas } \\
\text { (Falls) }\end{array}$} & \multicolumn{3}{|c|}{ - Primária: envolvendo material imediatamente desprendido (solos e rochas) } \\
\hline & \multicolumn{3}{|c|}{ - Secundária: envolvendo materiais fofos, anteriormente desprendidos (rochas) } \\
\hline \multirow{8}{*}{$\begin{array}{l}\text { Movimentos } \\
\text { complexos em } \\
\text { encostas } \\
\text { (Complex slope } \\
\text { movements) }\end{array}$} & - Arqueamento e abaulame & nto de vale & \\
\hline & $\begin{array}{l}\text { - Em blocos } \\
\text { - Falésias de argila abando }\end{array}$ & & \\
\hline & $\begin{array}{l}\text { - Deslizamentos } \\
\text { transformados em fluxo }\end{array}$ & $\begin{array}{l}\text { - Fluxo ou deslizamento } \\
\text { no pé de deslizamento }\end{array}$ & $\begin{array}{l}\text { de lama em material depositado } \\
\text { s anteriores }\end{array}$ \\
\hline & $\begin{array}{l}\text { de detritos ou } \\
\text { deslizamento de lama. }\end{array}$ & $\begin{array}{l}\text { - Deslizamentos rotacior } \\
\text { sensíveis }\end{array}$ & ais múltiplos em argilas \\
\hline & & - Queda de solo congela & \\
\hline & - Causados por erosão inte & & \\
\hline & - Deslizamentos multi-difer & enciados & \\
\hline & - Deslizamentos multi-estra & tificados & \\
\hline
\end{tabular}


Hungr et al. (2001) aprofundou a classificação dos movimentos de massa tipo fluxo tendo em conta a saturação do solo, referindo-se à classificação de Cruden e Varnes (1996).

A maioria das classificações tem aplicabilidade regional e baseia-se nas condições geológicas e climáticas locais. Existem algumas propostas para adequar a classificação dos movimentos de massa a ambientes tropicais, como é o caso do Brasil (Vargas, 1985; Costa Nunes, 1969). Augusto Filho (1992) reuniu, de forma sucinta, os principais tipos de movimentos de massa que ocorrem com maior frequência no Brasil, relativos à dinâmica de ambientes tropicais, baseando-se na classificação de Varnes (1978). Segundo o autor, os movimentos de massa podem ser classificados em quatro grupos fenomenológicos, como mostrado na Tabela 2.2.

Tabela 2.2 - Características dos principais grupos de processos de instabilização (Augusto Filho, 1992)

\begin{tabular}{|c|c|}
\hline Processos & Características do movimento, material e geometria \\
\hline $\begin{array}{l}\text { Rastejo ou } \\
\text { fluência } \\
\text { (creep) }\end{array}$ & $\begin{array}{l}\text { - Vários planos de deslocamento (internos) } \\
\text { - Velocidades muito baixas a baixas (cm/ano), diminuindo com a profundidade } \\
\text { - Movimentos constantes, sazonais ou intermitentes } \\
\text { - Solo, depósitos, rocha alterada/fraturada } \\
\text { - Geometria indefinida }\end{array}$ \\
\hline $\begin{array}{l}\text { Escorregamento } \\
\text { (slide) }\end{array}$ & $\begin{array}{l}\text { - Poucos planos de deslocamento (externos) } \\
\text { - Velocidade média }(\mathrm{m} / \mathrm{h}) \text { a alta }(\mathrm{m} / \mathrm{s}) \\
\text { - Pequenos a grandes volumes de material } \\
\text { - Geometria e materiais variáveis } \\
\text { - Planares - solos pouco espessos, solos e rochas com um plano de fraqueza } \\
\text { - Circulares - solos espessos, homogêneos e rochas muito fraturadas } \\
\text { - Em cunha - solos e rochas com dois planos de fraqueza }\end{array}$ \\
\hline $\begin{array}{l}\text { Queda } \\
\text { (fall) }\end{array}$ & $\begin{array}{l}\text { - Sem planos de deslocamento } \\
\text { - Movimentos tipo queda livre ou em plano inclinado } \\
\text { - Velocidades muito altas (vários } \mathrm{m} / \mathrm{s} \text { ) } \\
\text { - Material rochoso } \\
\text { - Pequenos a médios volumes } \\
\text { - Geometria variável: lascas, placas, blocos, etc. } \\
\text { - Rolamento de matacão } \\
\text { - Tombamento }\end{array}$ \\
\hline $\begin{array}{c}\text { Corrida } \\
\text { (flow) }\end{array}$ & $\begin{array}{l}\text { - Muitas superfícies de deslocamento (internas e externas à massa em } \\
\text { movimentação) } \\
\text { - Movimento semelhante ao de um líquido viscoso } \\
\text { - Desenvolvimento ao longo das drenagens } \\
\text { - Velocidades médias a altas } \\
\text { - Mobilização de solo, rocha, detritos e água } \\
\text { - Grandes volumes de material } \\
\text { - Extenso raio de alcance, mesmo em área planas }\end{array}$ \\
\hline
\end{tabular}

Em muitos casos são observadas combinações de mecanismos, configurando um evento complexo. Neste caso uma movimentação inicial, em uma certa categoria, pode ser seguida por outro tipo de movimento, e ainda outro. Para exemplificar, pode-se supor que um tombamento seja seguido por uma queda, cujo impacto, em uma encosta de solo, provoque uma corrida de detritos. 
Para ajudar na melhor compreensão e análise de movimentos de massa, e organizar o conhecimento sobre o comportamento dos taludes, Vaunat et al. (1994) e Leroueil et al. (1996) propuseram uma caracterização geotécnica de movimentos de massa, onde tanto os aspectos geomorfológicos como o comportamento mecânico dos solos e rochas são abordados.

$\mathrm{Na}$ caraterização geotécnica, os movimentos de massa são classificados de acordo com o tipo de material, o tipo de movimento e a fase de movimento (Figura 2.1). Os tipos de materiais são reunidos em 10 classes principais: rochas duras intactas, rochas duras fissuradas, rochas brandas, formações estruturalmente complexas, argilas rijas, argilas moles, siltes e areias finas e grossas, debris e materiais de granulação grossa, solos verdadeiramente colapsíveis (loess ...) e outros materiais não saturados (solos residuais ...).

Os tipos de movimentos são diferenciados de acordo com a classificação geomorfológica proposta por Cruden et al. (1994) e Cruden e Varnes (1996), isto é, quedas, tombamento, expansão lateral, escorregamento (translacional e rotacional) e escoamento (rastejo e corrida). Os movimentos são divididos em quatro estágios: pré-ruptura, ruptura, pós-ruptura e reativação. Esta classificação é esquematizada como uma matriz 3-D, mostrada na Figura 2.1. Cada elemento da matriz corresponde a um determinado padrão de resposta do talude e está associado com um conjunto de fatores de predisposição, acionantes (ou agravante) e reveladores.

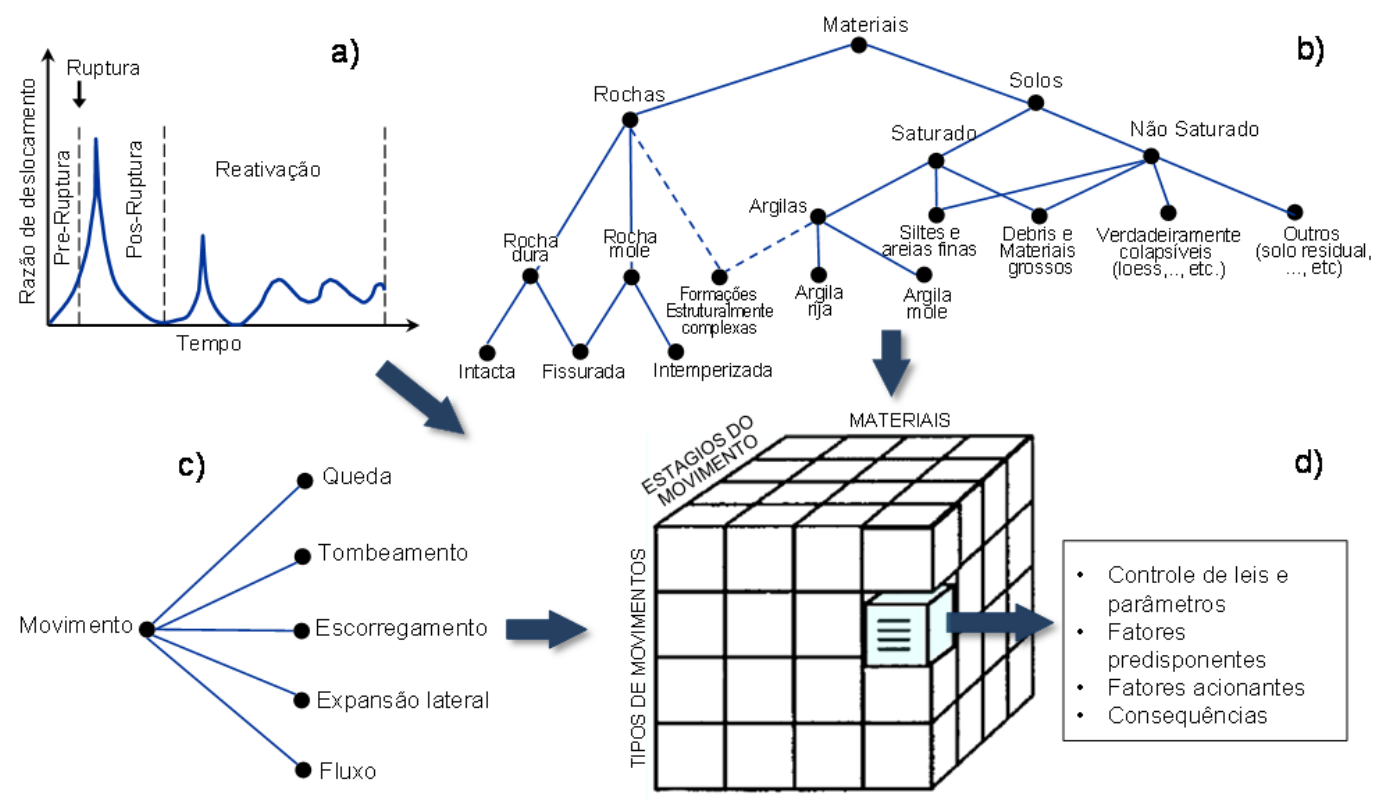

Figura 2.1 - Caraterização geotécnica dos movimentos de massa, (a) Estágios do movimento, (b) Tipos de materiais, (c) Tipos de movimentos, (d) Folha de caraterização (adaptado de Leroueil et al., 1996) 
Os diferentes estágios envolvidos na ocorrência de movimento de massa podem ser descritos como se segue:

a) Estágio pré-ruptura: inclui todo e qualquer processo de deformação que pode levar à ruptura, mesmo que esta nunca aconteça. Nesta fase, a massa de solo está essencialmente sobreadensada, intacta e contínua. Esse processo é determinado a relativamente pequenas razões de deslocamento, sendo controlado principalmente pelos fenômenos de ruptura progressiva e creep. Ao se aproximar à ruptura, a razão de deslocamento aumenta.

Como consequência, tem-se uma gradual formação e propagação da zona de cisalhamento na massa de solo. A duração do estágio depende das características do solo e do estado de tensões inicial, que pode ser extremamente variável. Como fatores agravantes para esses movimentos, podem-se ter condições temporárias que venham a ter efeito na velocidade dos mesmos, como, por exemplo, carregamento no topo do talude; condições que induzam variação de poropressão; erosão no pé do talude, etc.

b) Estágio de ruptura: é caracterizado pela formação de uma zona ou superfície contínua de cisalhamento na massa do solo. Embora o processo de ruptura seja geralmente complexo e resultante de uma combinação de vários fatores, é geralmente caracterizado pela envoltória de tensões efetivas cisalhantes. A ruptura é influenciada pelos efeitos da velocidade de deformação, ruptura progressiva e descontinuidades.

c) Estágio pós-ruptura: este inclui a movimentação da massa de solo ou rocha, desde a sua ruptura até o término de sua movimentação. Este estágio é caracterizado pelo aumento da razão de deslocamento logo após a ruptura, seguido da diminuição progressiva da velocidade. O comportamento do material deslizante durante este estágio depende principalmente da redistribuição da energia potencial requerida na ruptura, que se divide em energia de fricção, energia de desagregação e energia cinética. A duração do estágio é extremamente variável com as características mecânicas dos materiais envolvidos e com as características geométricas da encosta.

d) Estágio de reativação: caracteriza-se pelo deslizamento da massa de solo ao longo de uma ou mais superfícies de ruptura pré-existentes. Este estágio é controlado pelo comportamento de atrito de solo após grandes deslocamentos (ângulo de atrito residual). A reativação pode ser ocasional ou contínua, com variações sazonais de velocidade de movimento.

Para cada elemento relevante da matriz de caracterização proposta por Leroueil et al. (1996), devem ser identificados: 
1. As leis e os parâmetros que controlam o fenômeno; poderiam ser os parâmetros de resistência nos estágios de ruptura e reativação.

2. Os fatores predisponentes, os quais fornecem informações a respeito da situação atual e determina a resposta do talude após a ocorrência de um fator acionante (Tabela 2.3 - grupos 1 a 4 ).

3. Os fatores acionantes, os quais conduzem à ruptura ou os fatores agravantes que produzem uma modificação significativa nas condições da estabilidade ou na velocidade do movimento. Eles podem ser temporários (por exemplo, chuvas fortes ou rebaixamento rápido) ou progressivos (por exemplo, erosão ou intemperismo), (ver Tabela 2.1). (Tabela 2.3 - grupos 2 a 4);

4. Os fatores revelantes, os quais fornecem a evidência antes e/ou depois do movimento no talude, mas geralmente não participam do processo (por exemplo, presença de fissuras).

5. As possíveis, diretas ou indiretas, consequências do movimento.

\subsection{2. \\ Fatores condicionantes da instabilidade de encostas}

Os processos envolvidos em movimentos de massa compreendem uma série de eventos, muitas vezes de caráter cíclico, provocados por vários fatores associados à geologia, geomorfologia e hidrogeologia da área e à ação antrópica. Na maioria dos processos de instabilização de encostas e taludes atuam, concomitantemente, mais de um fator condicionante. Apesar dessa complexidade de eventos, é possível tentar estabelecer um conjunto de condicionantes que atuam de forma direta e imediata na deflagração desses processos de instabilização. Vários autores discutem estas relações, dentre os quais destacam-se os trabalhos de Terzaghi (1950), Cruden e Varnes (1996), Augusto Filho e Virgili (1998) e Leroueil (2004).

De acordo com Terzagui (1950) as causas dos movimentos de massa podem ser divididas em externas e internas. As causas externas são aquelas que provocam aumento nas tensões cisalhantes ao longo da superfície potencial de ruptura, enquanto que as causas internas provocam a diminuição da resistência ao cisalhamento do solo.

Dentre as causas externas destacam-se, a sobrecarga na parte superior do talude, escavação no pé, o efeito de vibrações, movimentos tectônicos, entre outros. Como causas internas pode-se citar, o efeito da oscilação térmica, a 
perda de resistência pela ação do intemperismo e a elevação da poropressão na superfície potencial de deslizamento.

Cruden e Varnes (1996) apresentaram os principais fatores condicionantes e as características que contribuem para os movimentos de massa, sumarizados na Tabela 2.3, divididos em quatro grupos: causas geológicas, morfológicas, físicas e antrópicas.

Tabela 2.3 - Inventário de causas de movimentos de massa (Cruden e Varnes, 1996)

\begin{tabular}{l|l}
\hline 1. Causas geológicas & 3. Causas físicas \\
- Materiais fracos & - Chuvas intensas \\
- Materiais sensíveis & - Derretimento rápido de neve \\
- Materiais desgastados (intemperizados) & - Precipitação excepcional prolongada \\
- Materiais cisalhados & - Rebaixamento rápido (de inundações e marés) \\
- Materiais fissurados & - Terremoto \\
- Massa com descontinuidade orientada & - Erupção vulcânica \\
adversamente (estratificação, xistosidade, & - Descongelamento \\
etc.) & - Intemperismo/desgaste devido ao \\
- Estrutura com descontinuidade orientada & congelamento e descongelamento \\
adversamente (falha, contato, sem & - Intemperismo/desgaste devido à contração-e \\
conformidade) & expansão \\
- Contraste na permeabilidade & \\
- Contraste na rigidez (duro, material denso & \\
sobre material plástico) & \\
\hline 2. Causas morfológicas & 4. Causas humanas \\
- Subpressão tectônica ou vulcânica & - Escavação de talude ou do seu pé \\
- Reação glacial & - Carregamento de talude ou de sua crista \\
- Erosão fluvial de pé de talude & - Rebaixamento (de reservatórios) \\
- Erosão de onda de pé de talude & - Desmatamento \\
- Erosão glacial de pé de talude & - Irrigação \\
- Erosão de margens laterais & - Mineração \\
- Erosão subterrânea (dissolução, "piping”) & - Vibração artificial \\
- Deposição de carga no talude ou na sua crista & - Vazamentos de águas servidas ou de \\
- Remoção da vegetação (por fogo na floresta, & abastecimento \\
seca) & \\
\hline & \\
\hline
\end{tabular}

Augusto Filho e Virgili (1998) avaliaram os fatores condicionantes dos escorregamentos e os processos associados descritos na literatura e resumiram os principais fatores condicionantes para movimentos de massa nas encostas brasileiras da seguinte forma:

- Características climáticas, com destaque para o regime pluviométrico;

- Características e distribuição dos materiais que compõem o substrato das encostas e taludes, abrangendo solos, rochas, depósitos e estruturas geológicas (xistosidade, fraturas, etc.);

- Características geomorfológicas, com destaque para a inclinação, amplitude e forma do perfil das encostas (retilíneo, convexo e côncavo); 
- Regime das águas de superfície e sub-superfície;

- Características do uso e ocupação, incluindo cobertura vegetal e as diferentes formas de intervenção antrópica das encostas, como cortes, aterros, concentração de água pluvial e servida, etc.

Leroueil (2004) apresenta uma lista dos principais fatores agravantes ou acionantes de movimentos de massa terrestres e submarinos, no estágio de préruptura, os quais são divididos em três grupos na Tabela 2.4 : (a) os que aumentam as solicitações, (b) os que diminuem a resistência, (c) os que possivelmente aumentam as solicitações e diminuem a resistência.

Tabela 2.4 - Principais fatores agravantes ou acionantes - estágio de pré-ruptura (Leroueil, 2004)

\begin{tabular}{|c|c|c|}
\hline & Terrestres & submarinos \\
\hline \multicolumn{3}{|l|}{ Aumento das solicitações } \\
\hline Erosão e escavação no pé & $x$ & $x$ \\
\hline Sobrecarga na crista, sedimentação (e possível sobreadensamento) & $x$ & $x$ \\
\hline Rebaixamento rápido do nível de água adjacente a taludes & $x$ & \\
\hline Terremoto & $x$ & $x$ \\
\hline Atividade vulcânica & $x$ & $x$ \\
\hline Queda de rocha & $x$ & $x$ \\
\hline \multicolumn{3}{|l|}{ Diminuição da resistência } \\
\hline $\begin{array}{l}\text { Infiltração devido a chuva, derretimento de neve, irrigação, vazamento de } \\
\text { águas servidas } \\
\text { Intemperismo }\end{array}$ & $\mathrm{x}$ & \\
\hline Mudanças físico-químicas & $x$ & \\
\hline Cravação de estacas & $x$ & $x$ \\
\hline Fadiga devido a carregamento cíclico e creep & $x$ & $x$ \\
\hline Descongelamento de solos congelados & $\mathrm{x}$ & \\
\hline \multicolumn{3}{|l|}{ Possível aumento das solicitações e decréscimo na resistência } \\
\hline Vibrações e terremotos que podem gerar excesso de poropressão & $x$ & $x$ \\
\hline Balanço de árvores devido a rajadas de ventos & $x$ & \\
\hline Ondas de tormenta e mudanças no nível do mar & & $\mathrm{x}$ \\
\hline
\end{tabular}

Por outro lado, Lacerda (2004) relata os principais processos de ativação e reativação em solos coluvionares, dividindo-os em duas classes: (a) interferência humana e (b) causas naturais (Tabela 2.5).

Analisando os fatores condicionantes propostos, percebe-se que a água possui papel fundamental na maioria dos movimentos de massa, seja por meio do incremento dos esforços solicitantes (aumento do peso específico do solo devido à elevação da sua umidade, desenvolvimento de pressões hidrostáticas em fraturas da rocha e aumento das poropressões devido à percolação) ou pela sua participação na redução dos parâmetros de resistência do solo (redução ou 
eliminação da "coesão aparente" dos solos inicialmente no estado não saturado). Dessa forma, a ação da água determina e caracteriza os diferentes processos de mobilização e, nesse sentido, a compreensão da sua forma de atuação em cada caso é fundamental para o entendimento e a previsão do comportamento dos taludes.

Tabela 2.5 - Processos de ativação e reativação de colúvios (Lacerda, 2004)

\begin{tabular}{l|l}
\hline Interferência humana & - Aumento de carregamento no topo \\
\hline \multirow{4}{*}{ Causas naturais } & - Cortes no pé \\
\hline & - Elevação do nível de água \\
& - Artesianismo \\
& Injeção de água do aquífero através de veios permeáveis e \\
& zonas intemperizadas da rocha matriz \\
& Aumento do carregamento local no meio do talude devido ao \\
& acúmulo do colúvio (Isto pode causar uma iniciação de \\
& escorregamento em solo residual sob o colúvio solto. \\
& Dependendo da velocidade de aumento de carga, o movimento \\
& pode iniciar um fluxo de detritos) \\
& Carregamento súbito por queda de rochas
\end{tabular}

\subsection{3. \\ Efeito da água sobre a estabilidade de encostas}

Inúmeros fatores atuam no desencadeamento de movimentos de massa, conforme abordado no item anterior. Entretanto a água é o principal agente condicionante de processos de instabilização de encostas em climas tropicais. Ela atua desde o processo de formação dos solos através do intemperismo até a diminuição de resistência devido ao aumento de poropressão positiva ou por redução da sucção.

Geralmente, as características das chuvas influenciam tanto a ocorrência quanto o tipo das rupturas de taludes. Em regiões tropicais, o clima quente e o alto índice de pluviosidade favorecem a formação de perfis com camadas espessas de solo, proporcionando um aumento indireto da probabilidade de movimentos de massa.

A instabilização pode se dar por infiltração (chuva, lançamento de águas servidas, ruptura de tubulações, etc.) ou pela subida do nível freático e consequente redução de sucção. A água pode ser tanto agente preparatório para o escorregamento, como deflagrador desse processo.

Numerosos estudos têm examinado a causa de ruptura de taludes em regiões tropicais e concluído que a infiltração de água de chuva é o mais proeminente/importante fator acionante na instabilidade de taludes. Dentre estes 
se podem citar: Barata (1969), Costa Nunes (1969), Wolle (1988) e Lacerda (1997). Alguns casos foram detalhadamente estudados em laboratório e campo.

Wolle (1988) associa os tipos de movimentos translacionais observados na parte intermediária das encostas da Serra de Mar a mecanismos que dependem das condições de como se dá o fluxo de água no talude.

O primeiro mecanismo consiste na elevação do nível freático nas encostas que apresentam nível freático permanente ou sazonal (apenas na estação mais chuvosa). Nesses casos, os escorregamentos ocorrem com formação de rede de fluxo paralela ao talude, ou seja, há elevação de pressões de água positiva nos poros do solo devido à infiltração da água da chuva. Porém, esse nível freático pode ser perene; nos períodos de estiagem, o solo permanece não saturado.

O perfil geotécnico desses casos, em geral, é semelhante. São solos coluvionares ou residuais sobrepostos à rocha impermeável (ou solo residual com permeabilidade muito menor que a do solo superficial), cujo nível freático se eleva a partir do contato solo-rocha (ou solo menos permeável). Os escorregamentos também ocorrem no contato solo-rocha. Os casos estudados que exemplificam esse mecanismo são os escorregamentos de Monte Serrat e Morro da Caneleira (Vargas, 1999), Cactáreo-RJ (Andrade et al., 1992), LagoaRJ (Gerscovich et al., 2006), São Mateus-SP (Franch e Futai, 2009), entre outros.

O segundo mecanismo refere-se ao caso em que o nível freático se encontra abaixo da superfície de ruptura do escorregamento, não podendo ser explicado o deslizamento pelo aparecimento de poropressões positivas.

Neste caso a rocha subjacente é intensamente fraturada, de forma que a permeabilidade do material mais profundo não permite a formação de uma rede de fluxo paralela à superfície do talude, o fluxo nesses casos é essencialmente vertical. Dessa forma, não podem ocorrer poropressões devido à percolação. Assim a ruptura desses taludes ocorre devido à eliminação, ou mesmo à redução da sucção, pela infiltração das águas de chuvas, que provoca a perda da "coesão aparente" do solo. A ruptura ocorre quando a frente de umedecimento atinge uma profundidade crítica, na qual os parâmetros de resistência não mais garantem a estabilidade do talude.

O autor destaca que esses deslizamentos são bastante rasos, envolvendo apenas o horizonte de solo superficial (em torno de $1 \mathrm{~m}$ de espessura) ou no máximo atingindo o solo saprolítico (com 2 a $4 \mathrm{~m}$ ). Alguns casos brasileiros que ocorreram sob esse mecanismo são os escorregamentos de Morro do Querosene-RJ (Souza, 1995), Vista Chinesa-RJ (Duarte et al., 2005), Espinhaço 
da Gata, Recife-PE (Coutinho e Severo, 2009), Serra do Mar-SP (Wolle e Carvalho, 1989), entre outros.

O terceiro mecanismo foi proposto por Costa Nunes (1969), citado por Wolle (1988), segundo o qual a ruptura se deve a uma intensa erosão, resultante do grande escoamento superficial, causado por chuvas de excepcional intensidade, que provocam a liquefação dos horizontes superficiais.

Com relação aos escorregamentos rotacionais profundos que ocorrem na parte superior das encostas, Wolle (1988) menciona que esses não podem ser explicados apenas pela redução da sucção devido à saturação ou pela ação erosiva de agentes externos. Necessita-se admitir o estabelecimento de redes de fluxo que gerem poropressões bastante elevadas.

Segundo Futai (2012) as ocorrências de desastres no Brasil estão concentradas na Serra do Mar, cuja característica geológica pode definir o mecanismo de instabilização. Nos casos em que existem permeabilidades crescentes com a profundidade, os escorregamentos podem ocorrer na condição não saturada ou no máximo com anulação da sucção (Serra do Mar no trecho paulista). No caso em que a rocha é impermeável ou mesmo permeável, podese formar um nível freático, o escorregamento está associado à elevação desse nível, conforme identificado por Vargas (1999) e Andrade et al. (1992). Se fosse suficientemente íngreme, uma encosta poderia escorregar em condições não saturadas, mesmo sendo a rocha impermeável.

Os casos de desastres naturais misturam vários tipos de deslizamentos; por isso, não é possível generalizar os mecanismos. Porém, é possível dizer que alguns escorregamentos e fontes de materiais que geram as corridas de lama ou mesmo as corridas de detritos (debris flow) são provocados pela infiltração em condições especiais. Infiltrações decorrentes de chuvas prolongadas podem saturar o solo e, inclusive, gerar pressões de água positiva rapidamente, cujo escorregamento resultante pode ser um tipo de mecanismo detonador de corridas.

Segundo Leroueil et al. (2001), o processo de infiltração em encostas não saturadas é bastante complexo por estar relacionado às condições iniciais, no que diz respeito ao perfil do grau de saturação e poropressões, os quais são dependentes das condições hidrológicas antecedentes. A condutividade hidráulica relaciona-se diretamente com o grau de saturação e a sucção matricial, tornando complexa a análise do processo de infiltração em meio não saturado, comum na maioria das encostas. 
Observações realizadas por Leroueil (2001) a partir de Lacerda (1989), Johnson e Sitar (1990), e Montgomery et al. (1997) mostram que o desenvolvimento de poropressões em encostas e a iniciação de corridas de detritos (debris flow) pode não resultar apenas de infiltrações verticais da água de chuva, que se infiltra diretamente na superfície do talude e se propaga em profundidade através de padrões de fluxo de água subterrânea relacionados à configuração estratigráfica da encosta, mas também de fluxos de água em camadas de solos mais permeáveis e afloramentos de água (springs) nascentes das fraturas do maciço rochoso encontrado em profundidade (Anderson e Sitar, 1995; Anderson et al., 1997; Lacerda, 2004). O fluxo interno no talude também pode ser influenciado por buracos de animais e furos de raízes.

A resposta hidrológica de um deslizamento provocado por intensas precipitações pode ser esquematizada como mostrada na Figura 2.2.

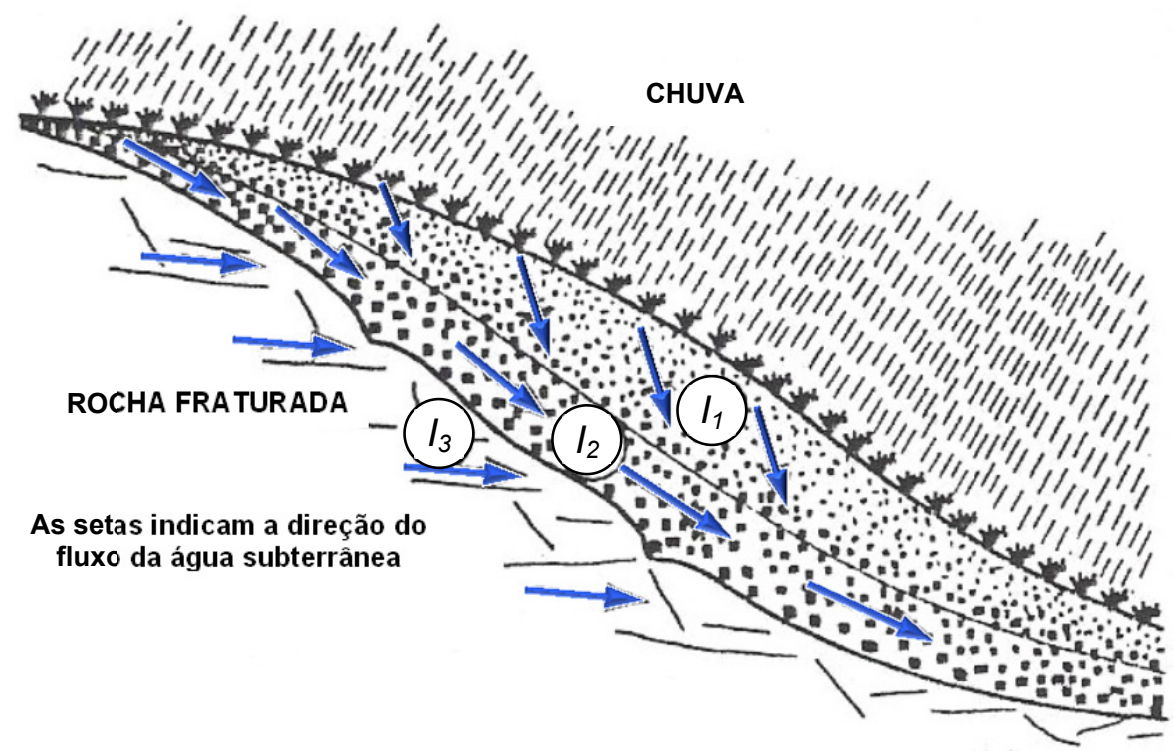

Figura 2.2 - Diagrama esquemático da resposta hidrológica da encosta a chuvas intensas. As setas indicam a direção do fluxo da água (adaptado de Leroueil, 2001)

De acordo com Santos (1996) o fluxo de água pode ser afetado por fatores geológicos, tais como: presença de intrusões magmáticas, sistema de estratificação das rochas sedimentares, dobramentos e foliações das rochas metamórficas, descontinuidades estruturais (falhas, fraturas, etc.) e presença de unidades anisotrópicas no maciço.

O nível piezométrico oscila sazonalmente nas estações do ano, variando de acordo com o regime de chuvas local. Segundo Lacerda (1989), esta oscilação do nível piezométrico pode causar rupturas por fadiga, devido às 
variações cíclicas da poropressão. Segundo Santos (1996), o aumento de poropressão até próximo ao valor que ocasionaria a ruptura acarreta aumento da taxa de deformação por creep ou ruptura por acúmulo de deformação na ciclagem da poropressão.

Em relação ao processo de instabilidade de encostas com solos coluvionares, podem ser reconhecidos dois cenários de acordo com a morfologia do talude. As encostas com solos coluvionares com inclinação elevada (maiores que $30^{\circ}$ ), em geral, não têm nível freático elevado, o solo coluvionar fica sobreposto a um solo residual menos permeável ou sobre uma rocha impermeável, por conseguinte, podem estar sujeitos a escorregamentos translacionais, como indicado anteriormente.

Os depósitos com baixa declividade apresentam comportamento diferente. Quando instáveis, essas massas coluvionares saturadas se movem na forma de rastejo ou em escorregamento ativo lento e contínuo. De acordo com Barata (1969), o principal mecanismo de instabilização de taludes em solos coluvionares é provocado pelos movimentos de rastejo. A elevada permeabilidade da massa coluvionar permite sua saturação facilmente por infiltração da água das chuvas, provocando movimentos lentos. À medida que o movimento se processa, abre-se uma fenda na parte superior do depósito até o contato com o solo residual, facilitando ainda mais a infiltração de água. $O$ movimento, geralmente contínuo, sofre aceleração no período chuvoso. A ocorrência de chuvas de intensidade elevada pode levar o solo coluvionar à ruptura.

\section{2 .}

\section{Mecanismos de ruptura de encostas por aumento de poropressão}

\subsection{1.}

\section{Tensões in situ de um solo superficial de encosta}

As tensões in situ podem ser avaliadas considerando um elemento de solo em uma encosta, localizado na base do manto superficial e sobre uma eventual superfície de ruptura, como mostrado na Figura 2.3. Este elemento do solo está sujeito a tensões induzidas pela gravidade que dependem do ângulo de inclinação da encosta e da densidade do solo sobrejacente; além disso, quando a água está presente, a percolação influencia nas deformações. Para fins de análise, o talude é considerado infinitamente longo, de modo que as tensões em um ponto podem ser avaliadas sem considerar a pressão ativa e passiva do solo 
acima e abaixo. Assim, a tensão efetiva principal menor, $\sigma_{3}^{\prime}$, e a tensão efetiva principal maior, $\sigma_{1}{ }_{1}$, atuam no plano do talude, como mostrado na Figura 2.3.

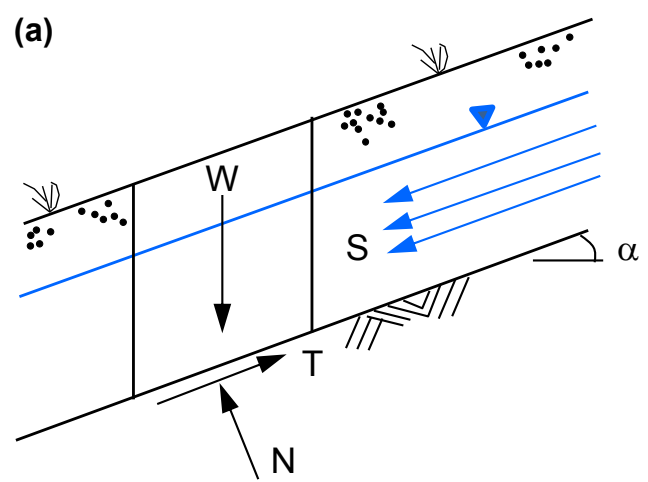

$W=$ peso

$S=$ força de percolação

$\mathrm{T}=$ força de cisalhamento

$\mathrm{N}=$ força normal

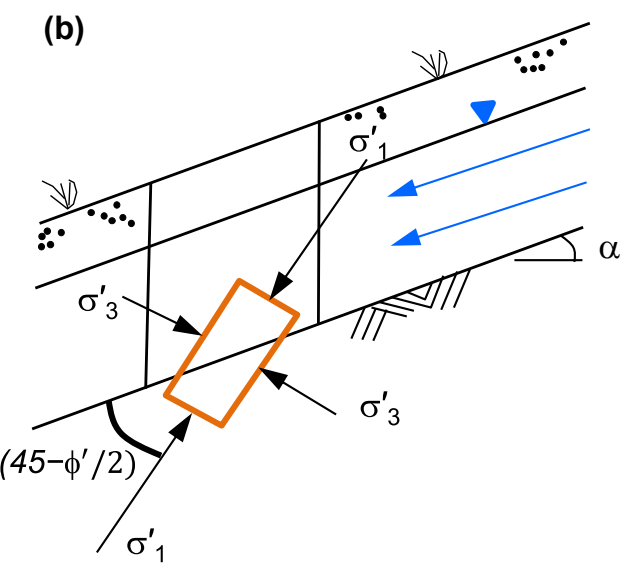

$\sigma_{1}^{\prime}=$ tensão principal maior

$\sigma_{3}^{\prime}=$ tensão principal menor

$\phi^{\prime}=$ ângulo de atrito efetivo

Figura 2.3 - Interpretação esquemática das condições de tensões, (a) Forças em um talude infinito no campo, (b) Tensões para um corpo de prova em um ensaio de compressão triaxial (adaptado de Anderson, 1992)

O talude é também considerado longo e planar no sentido transversal, de modo que existe uma condição de deformação plana, e não existe deformação na direção da tensão efetiva principal intermedia, $\sigma_{2}^{\prime}$, (direção transversal ao talude). Assim, a tensão in situ $\sigma_{2}^{\prime}$ é na ordem de $\mathrm{K}_{0} \sigma_{1}{ }_{1}$ (onde $\mathrm{K}_{\mathrm{o}}$ é igual ao coeficiente de empuxo em repouso) e se aproxima a $\sigma_{3}{ }_{3}$ quando o ângulo do talude é reduzido a zero. Em contraste, o valor de $\sigma_{2}$ do corpo de prova no ensaio de compressão triaxial é sempre igual a $\sigma_{3}^{\prime}$. Portanto, a anisotropia de tensões em um ensaio triaxial adensado com uma dada relação de tensões $\mathrm{K}_{\mathrm{c}}=\sigma_{1}{ }_{1} / \sigma^{\prime}{ }_{3}$, é realmente um pouco maior que a anisotropia in-situ, e a tensão efetiva média, $\sigma_{m}^{\prime}=\left(\sigma_{1}{ }_{1}+\sigma_{2}^{\prime}+\sigma_{3}^{\prime}\right) / 3$, é algo menor no ensaio de compressão triaxial do que seria para os valores in-situ de $\sigma_{1}^{\prime}$ e $\sigma_{3}^{\prime}$. 
Em um talude, assumido completamente seco (ou hidrostaticamente submerso), infinito e planar, a orientação das tensões principais pode ser determinada adotando hipóteses relacionadas à direção das deformações (Vaughan e Kwan, 1984; Kramer, 1988) e a rotação das tensões (Lowe, 1967). Assumindo que não existe deformação linear em planos paralelos à superfície do talude, Vaughan e Kwan (1984) inferiram as seguintes equações para o cálculo de tensões principais iniciais.

$$
\begin{aligned}
& \sigma_{1}^{\prime}=\gamma z \cos ^{2} \beta(1-\tan \beta \cot 2 \omega+\tan \beta p \operatorname{cosec} 2 \omega) \\
& \sigma_{3}^{\prime}=\gamma z \cos ^{2} \beta(1-\tan \beta \cot 2 \omega-\tan \beta p \operatorname{cosec} 2 \omega)
\end{aligned}
$$

Onde $\gamma=$ densidade do solo, $z=$ profundidade do elemento de solo, $\beta=$ ângulo do talude e $\omega$ = ângulo de inclinação da tensão principal em relação ao plano horizontal.

É fácil compreender que a suposição é razoável para um talude comprido, constituído por um material rígido em uma profundidade relativamente rasa, visto que o material rígido vai impor a condição de deformação zero paralela ao talude no material sobrejacente, mais flexível. Tal situação é uma aproximação aceitável para um talude de solo residual, sustentado por uma rocha dura não intemperizada. No entanto, esta análise leva a uma relação de tensões principais $\left(\mathrm{K}_{\mathrm{c}}=\sigma^{\prime}{ }_{1} / \sigma^{\prime}{ }_{3}\right)$ irrealisticamente alta para encostas íngremes.

Em contraste, Lowe (1967) simplesmente assumiu que as orientações das tensões principais iniciais são aproximadamente as mesmas que na ruptura, e isso é provavelmente verdade para encostas íngremes que existem naturalmente em um estado próximo à ruptura. Tomando essa premissa em consideração e negligenciando a percolação e os efeitos capilares, Anderson e Sitar (1995) determinaram que, em princípio, a razão de tensões in situ $\mathrm{K}_{c}$ é aproximadamente igual a um décimo do ângulo de inclinação do talude. Assim, considerando que o talude do local varia de $37^{\circ}$ a $55^{\circ}$, a proporção de tensões principais seria na faixa de 3,7 a 5,5 .

\subsection{2.}

\section{Iniciação da ruptura: Trajetória de tensões no campo}

Rupturas de taludes causadas pela infiltração de águas de chuva ocorrem frequentemente em encostas que são marginalmente estáveis e compostas de diferentes tipos de solos, como solos coluvionares e residuais, com uma ampla gama de gradação (Anderson e Sitar, 1995; Tsukamoto et al., 1998). Tais 
rupturas de encostas ocorrem tipicamente em profundidades rasas, geralmente inferiores a 3 metros (Lumb, 1975; Brand et al., 1984; Lin e Kung, 2000).

O mecanismo que leva à ruptura de taludes induzida por precipitações pluviométricas pode ser resumido, em termos gerais, como segue. Quando a água da chuva se infiltra em um perfil do solo, que está inicialmente em um estado não saturado, ocorre uma diminuição da pressão negativa de poros (ou sucção matricial). Isto provoca uma diminuição da tensão efetiva normal que atua ao longo do potencial plano de ruptura, que por sua vez diminui a resistência ao cisalhamento a um ponto onde o equilíbrio já não pode ser sustentado na encosta. Desconsiderando o aumento do peso específico do solo causado pela infiltração da chuva, o processo que leva à ruptura ocorre essencialmente sob tensões totais constantes e aumento da poropressão.

Considerando o elemento de solo mostrado na Figura 2.4 (a) sobre um potencial plano de ruptura em uma encosta submetida à infiltração da água de chuva, a Figura 2.4 (b) ilustra os círculos de Mohr que representam as correspondentes condições de tensões de campo e a trajetória seguida por tal elemento de solo.

Quando o elemento de solo está no estado não saturado tem poropressão negativa (sucção do solo), tal como é representado pelo círculo de Mohr A. Com a infiltração da água de chuva no perfil do solo, a sucção do solo diminui à medida em que o elemento de solo se torna saturado pela elevação do nível piezométrico. O círculo de Mohr A migra da direita para a esquerda, como mostrado pelo círculo $B$. No entanto, a diminuição da sucção através da infiltração da água da chuva, por si só não pode conduzir à ruptura. A geração de poropressão positiva pode ser necessária para que a ruptura aconteça (Johnson e Sitar, 1990; Sitar et al., 1992; Eckersley, 1990), como representado pelo círculo $\mathrm{C}$.

Isto implica que, no momento da ruptura, o elemento do solo ao longo do potencial plano de ruptura está quase saturado e qualquer aumento no peso unitário do solo devido à saturação é insignificante. Em outras palavras, a trajetória de tensão de campo seguida por um elemento de solo durante a precipitação é caracterizada por um aumento de poropressão na condição de tensão de cisalhamento, $\tau$, quase constante, como representado pela linha horizontal na Figura 2.4 (b).

Observa-se que a magnitude da tensão de cisalhamento durante a resposta hidrológica do solo durante a precipitação pode mudar dependendo da direção do fluxo de percolação, e a trajetória de tensões de campo pode se 
desviar da horizontal. No entanto, esse desvio pode ser considerado relativamente pequeno e a natureza exata do fluxo de percolação desconhecida (Anderson e Sitar, 1995). Portanto, a trajetória de tensões horizontal pode ser considerada uma suposição razoável para a resposta hidrológica do solo devido a precipitações pluviométricas.

A trajetória de tensões no campo causa um aumento em $\mathrm{K}_{\mathrm{c}} \mathrm{e}$, em algum valor crítico, quando $\mathrm{K}_{\mathrm{c}}=\mathrm{K}_{\mathrm{f}}$, começa a deformação cisalhante. Este ponto é o início da ruptura, e ele é atingido por uma mudança de tensões causada pela resposta hidrológica à chuva.

(a)

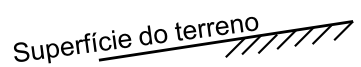

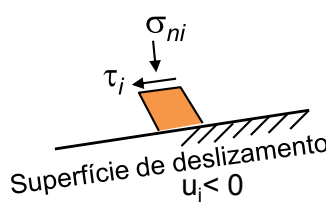

A
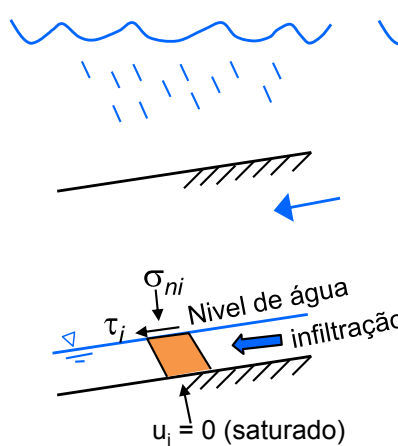

B
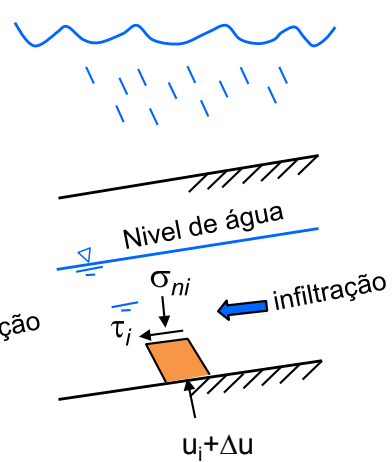

C

(b)

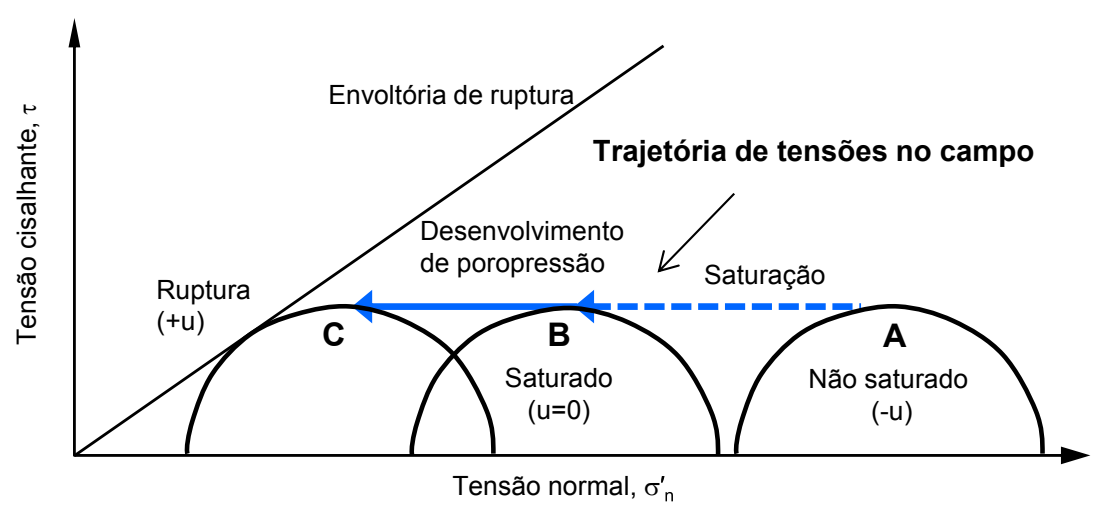

Figura 2.4 - (a) Diagrama esquemático mostrando um elemento do solo em uma encosta sujeita à infiltração de precipitações, (b) Correspondente trajetória de tensões no campo (adaptado de Farooq et al., 2004)

\subsection{3.}

\section{Simulação em laboratório dos mecanismos de ruptura de encostas induzidos por precipitações}

As investigações convencionais dos mecanismos e comportamento de movimentos de massa são baseadas, em grande parte, em ensaios convencionais de mecânica dos solos, com o fim de estabelecer as 
características de resistência na superfície de cisalhamento. Estes ensaios convencionais são os ensaios triaxial drenado, triaxial não drenado e cisalhamento direto, e são usados para estabelecer os parâmetros c' e $\phi^{\prime}$, requeridos na análise de estabilidade de taludes. Embora estes métodos podem ser adequados para estabelecer a estabilidade existente de uma encosta e para a concepção de medidas de remediação, a sua capacidade de permitir a interpretação dos mecanismos de ruptura é limitada, e está fortemente baseada na retroanálise dos parâmetros de resistência do talude. Isso muitas vezes pode levar a modelos de deslizamento de terra inexatos, que podem não ser adequados para avaliar com precisão o potencial de perigo do deslizamento.

A grande fraqueza desses métodos é que o desenvolvimento da superfície de cisalhamento nos ensaios geotécnicos convencionais se inicia com o aumento da tensão desviadora a uma taxa de deslocamento constante, até a ruptura, enquanto que a maioria das rupturas dos movimentos de massa ocorre como resultado do aumento da poropressão dentro da encosta, que levam a uma redução na tensão efetiva média com tensão desviadora aproximadamente constante, tal como descrito no item 2.2.2.

Procedimentos de ensaios de laboratório que simulam o processo de ruptura causado por incrementos de poropressão foram inicialmente descritos por Bishop e Henkel (1962) e mais tarde evoluíram com Brand (1981), que conceituou o mecanismo de deslizamentos desencadeados por chuvas, representado pela trajetória de tensões do campo (Figura 2.5).

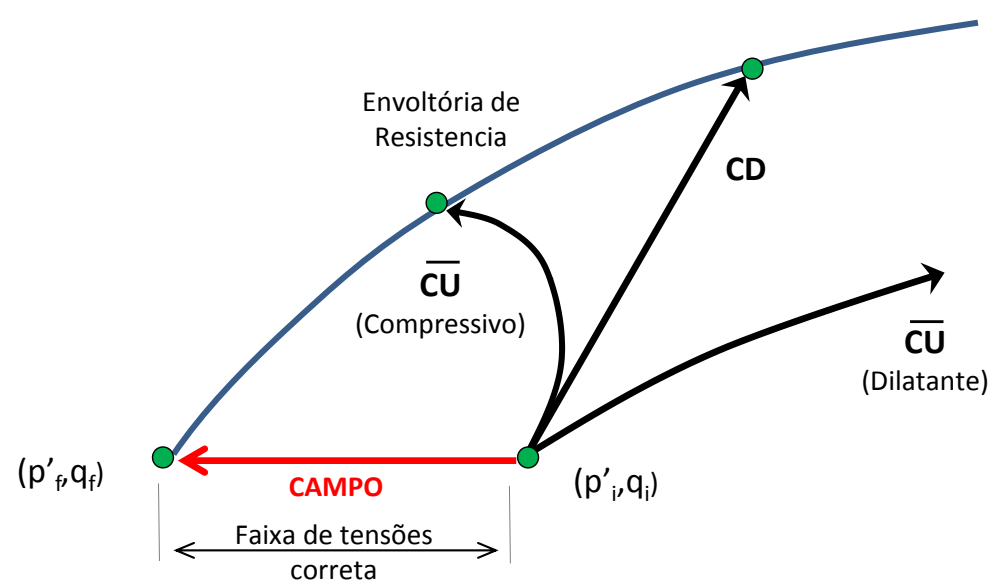

Figura 2.5 - Trajetória de tensões seguida no campo e em ensaios triaxiais (adaptado de Brand, 1981)

A Figura 2.5 ilustra a diferença entre as trajetórias de tensão normalmente seguidas nos ensaios triaxiais convencionais, adensado não drenado (CU) e adensado drenado (CD), e a trajetória que reflete a condição de campo durante 
chuvas. Na figura, o estado de tensões inicial do ensaio é representado por $\left(p_{\mathrm{i}}^{\prime}\right.$, $\left.q_{i}\right)$ onde $p^{\prime}=\left(\sigma_{1}^{\prime}+2 \sigma_{3}^{\prime}\right) / 3$ é a tensão efetiva média e $q=\left(\sigma^{\prime}{ }_{1}-\sigma^{\prime}{ }_{3}\right)$ é a tensão desviadora. $O$ incremento da poropressão diminui a tensão efetiva média de ( $p_{i}^{\prime}$, $\left.q_{i}\right)$ a $\left(p_{f}^{\prime}, q_{f}\right)$, enquanto as tensões totais normais, $\sigma_{1}$ e $\sigma_{3}$, permanecem constantes. Assume-se que a ruptura ocorre em $\left(p_{f}^{\prime}, q_{f}\right)$, quando se atinge a envoltória de ruptura.

A trajetória de tensão de campo seguida por um elemento de solo, tal como descrito acima, pode ser simulada no laboratório por meio de ensaios triaxiais drenados de tensão de cisalhamento constante, sendo a ruptura atingida por aumento de poropressão; para isso dois tipos de procedimentos são geralmente usados (Brand, 1981; Brenner et al., 1985; Atkinson e Farrar, 1985; Anderson e Sitar, 1994): (1) diminuindo a pressão da câmara gradualmente, enquanto a poropressão e a tensão desviadora permanecem inalteradas, (2) incrementando gradualmente a poropressão dentro do corpo de prova enquanto a pressão na câmara e a tensão desviadora são mantidas constantes. Note-se que, mesmo quando há uma mudança na contrapressão ou na poropressão, este ensaio é ainda considerado como um ensaio "drenado", dado que o volume da amostra está mudando. Anderson e Sitar (1994) verificaram que os dois diferentes procedimentos de ensaios proporcionam resultados semelhantes.

Embora ambos procedimentos produzam a mesma trajetória de tensões, somente o segundo modela o mecanismo de ruptura corretamente. Assim, o segundo procedimento, em que a pressão de poros é aumentada gradualmente enquanto $\sigma_{3}$ e $\sigma_{1}$ são mantidas constantes, foi utilizado neste estudo.

\subsection{4. \\ Estudos anteriores e aplicações do ensaio de aumento de poropressão}

Ao longo dos anos, o ensaio de aumento de poropressão tem sido conhecido por diferentes nomes. Dentre estes, destacam-se: "Ensaio de carga morta constante" (Constant dead load test - DL) (GCO, 1982; Brenner et al., 1985; GEO, 1994; Chen et al., 2000, 2004), "Ensaio drenado de cisalhamento constante" (Constant shear drained - CSD) (Anderson e Sitar, 1995; Anderson e Riemer, 1995; Santos et al., 1996; Zhu e Anderson, 1998; Chu et al., 2003; Springman et al., 2003; Farooq et al., 2004; Lourenço et al., 2006), "Ensaio de trajetória de tensão desviadora constante" (Constant deviatoric stress path CQD) (Dai et al., 1999) "Pore pressure reinflation test (PPR)" (Petley et al. 
2005b) e "Ensaio de cisalhamento constante" (Constant shear test - CS) (Junaidden, 2005; Junaidden et al., 2010).

$\mathrm{Na}$ literatura é possível encontrar descritos os diversos critérios seguidos na execução do ensaio de aumento de poropressão. Entretanto, a concepção não difere muito da proposta por Brand (1981). Estes ensaios tem sido executados em diferentes materiais, usando-se amostras inalteradas e amolgadas sob condições saturadas e não saturadas.

Os primeiros estudos com ensaios triaxiais de aumento de poropressão foram reportados por Brenner et al. (1985) e Atkinson e Farrar (1985). Porém, apenas um número limitado de ensaios em amostras reconstituídas foi realizado nesses estudos.

Brenner et al. (1985) realizaram ensaios de laboratório em amostras compactadas de um solo residual de Hong-Kong, nas condições saturada e não saturada, simulando a trajetória de tensão da ruptura de um talude induzida pela chuva, seguindo a técnica proposta por Brand (1981). Nos ensaios realizados em amostras saturadas, os parâmetros de resistência obtidos foram diferentes daqueles obtidos através de ensaios de compressão triaxial convencionais, observando-se em todas as amostras a dilatação durante a ruptura. No caso do solo não saturado, os autores observaram que as amostras exibiram dilatação ou contração, dependendo de sua condição inicial.

Atkinson e Farrar (1985) realizaram quatro ensaios de aumento de poropressão em amostras compactadas de argila de um aterro escorregado no Reino Unido, usando tensões baixas. Adicionalmente, realizaram ensaios CID no mesmo solo, para tensões altas. Nos ensaios realizados com pequenas tensões efetivas, a envoltória de ruptura obtida foi marcadamente curva e a resistência do solo foi significativamente menor do que a inferida a partir dos resultados de ensaios convencionais CID, que foram realizados com tensões efetivas maiores (assumindo uma envoltória de ruptura linear). Os autores concluíram que os ensaios triaxiais convencionais, realizados com tensões confinantes baixas, poderiam sobrestimar a resistência quando submetidos a trajetórias de tensão que simulam o comportamento do solo no campo durante precipitações.

Bressani e Vaughan (1989) apresentaram resultados de ensaios triaxiais drenados convencionais, comparados com ensaios drenados com trajetória horizontal, realizados em um solo artificialmente cimentado. Bressani e Vaughan concluíram que para materiais fracamente cimentados a resistência observada em tensões efetivas baixas é dependente das trajetórias de tensão. 
Esta conclusão foi baseada nos dados de seus próprios ensaios e nos ensaios obtidos pela Agência de Controle Geotécnico de Hong Kong (GCO, 1982) em um granito intemperizado. Os dados obtidos pela Agência de Controle Geotécnico mostraram que as relações de tensões principais na ruptura, $\mathrm{K}_{\mathrm{cf}}=\sigma_{1}{ }_{1} / \sigma_{3}^{\prime}$, das amostras no ensaio de aumento de poropressão foram superiores às das amostras no ensaio CIU e CID do mesmo solo. Bressani e Vaughan atribuíram isto a um maior intercepto coesivo obtido no ensaio de aumento de poropressão, e indicaram que os ensaios CIU e CID destruíram a cimentação (bonding) do solo; podendo estes últimos subestimar a resistência de um material com cimentação, submetido à trajetória de tensões no campo durante precipitações (Anderson, 1992).

Sasitharan et al. (1993) reportaram os resultados de dois ensaios de aumento de poropressão em areias muito fofas de Ottawa, para sustentar seus conceitos de limites de estado (state boundary). O limite do estado é considerado na representação de uma superfície no espaço p'-q- $v$ que define o fator acionante do colapso ou liquefação estática para areias fofas. Vaid e Eliadorani (1998) realizaram este mesmo tipo de ensaio em areia do rio Fraser, no Canadá, e identificaram um domínio no espaço de tensões em que se desenvolve a instabilidade das areias.

Anderson e Riemer (1995) realizaram ensaios de aumento de poropressão para avaliação do potencial de colapso de solos em taludes, quando submetidos ao incremento transiente das poropressões durante chuvas. Foram estudados dois tipos de solos, uma areia fina bem graduada e um solo coluvionar argiloso.

A Figura 2.6 apresenta os resultados obtidos nos ensaios. Os resultados mostram que o comportamento compressivo só foi observado para o caso das areias preparadas em um estado extremamente fofo (colapsaram). As amostras inalteradas do solo coluvionar apresentaram comportamento dilatante, mesmo estando todas, exceto uma, em um estado bem acima da linha do estado permanente ou crítico, e que os ensaios de compressão triaxial não drenados em amostras desse mesmo solo mostraram tendência de compressão. De acordo com os autores, isso evidencia que o conhecimento da trajetória de tensões é fundamental na previsão do potencial de colapso e, portanto, do potencial de liquefação de solos fofos saturados. 

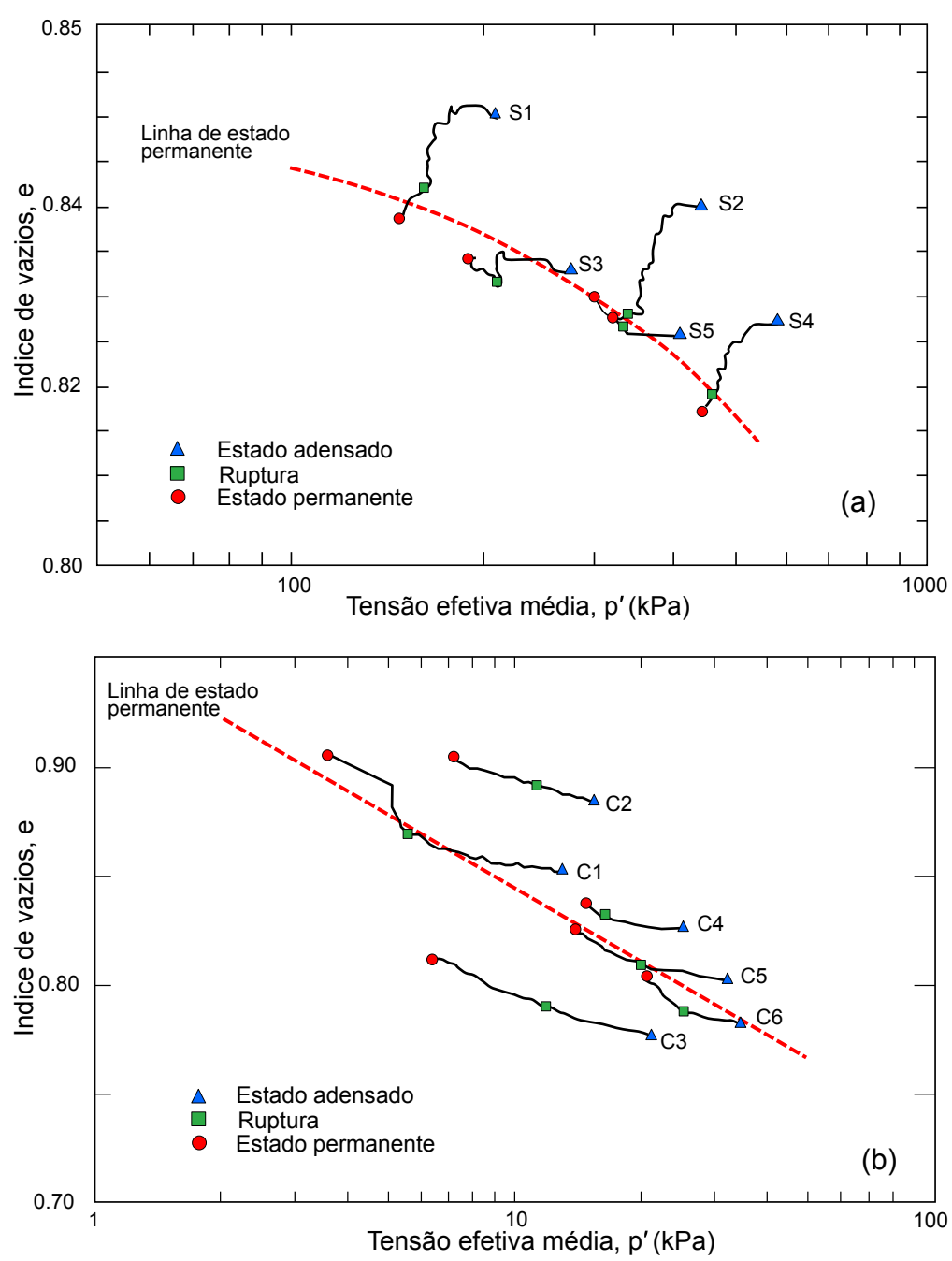

Figura 2.6 - Resultados de ensaios de aumento de poropressão, (a) na areia Monterey, (b) no solo coluvionar argiloso (adaptado de Andersom e Riemer, 1995)

Anderson e Sitar (1995) realizaram um estudo detalhado em amostras inalteradas de solo coluvionar de uma área susceptível a corridas de detritos no parque regional de Briones, Califórnia. Os autores realizaram ensaios de aumento de poropressão a partir de adensamento anisotrópico, aos que denominaram ensaios triaxiais drenados de cisalhamento constante (CSD), além de ensaios triaxiais convencionais adensados anisotropicamente não drenados (CKU). A maioria dos ensaios CSD foi executada com tensões próximas das condições in situ, obtendo-se os resultados apresentados na Figura 2.7 (a) s' vs $t$ e (b) e vs s'.

Os resultados obtidos mostraram que nenhum dos corpos de prova testados no ensaio CSD apresentou comportamento de colapso, embora a maioria deles se encontrasse acima da linha de estado permanente (steady state) ou de estado crítico, no plano e vs s'. De acordo com os conceitos de estado crítico, estes corpos de prova deveriam ter exibido comportamento de 
contração, porém todos eles exibiram comportamento dilatante durante todo o ensaio, independentemente de suas posições no plano e vs s'.

Este fenômeno foi atribuído à trajetória de tensões adotada e à estrutura cimentante do solo. Adicionalmente, os autores reportaram que as trajetórias de tensão continuaram além do ponto de escoamento (definido como o ponto onde uma deformação axial significativa se inicia) dirigindo-se depois para abaixo da envoltória. No final de cada ensaio, assumiu-se que o solo se encontrava no estado crítico. A envoltória obtida para todos os ensaios CSD realizados foi não linear e inclinada em baixas tensões confinantes (não mostrada na Figura 2.7). Para baixas tensões não foi encontrada muita diferença entre os parâmetros obtidos da envoltória formada com os pontos onde se inicia a deformação rápida e da envoltória de grandes deformações ou estado crítico (Figura 2.7 a).
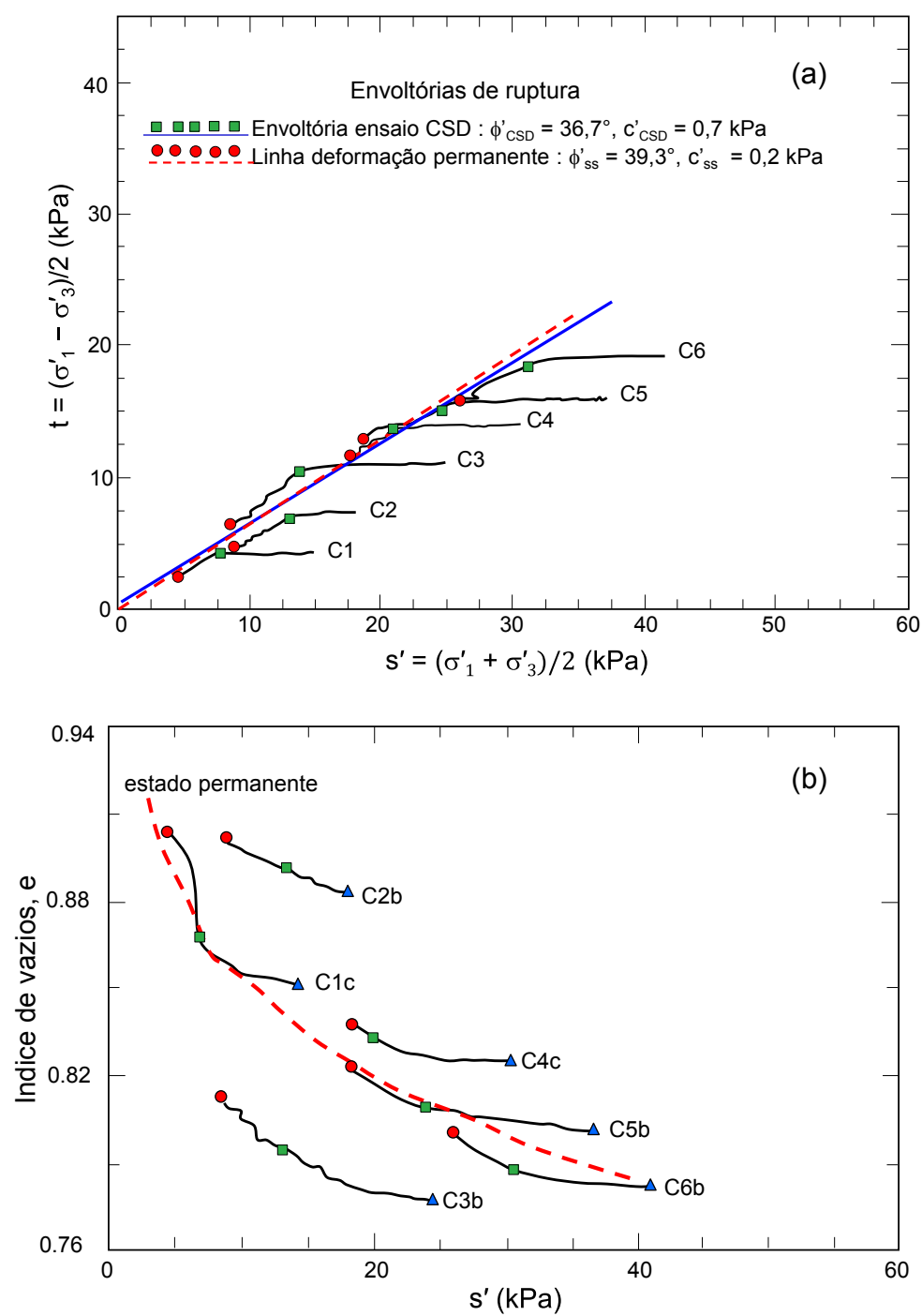

Figura 2.7 - Trajetória de tensões de amostras no ensaio de aumento de poropressão, realizados no nível de tensões in situ, (a) s' vs t, (b) e vs s' (adaptado de Anderson e Sitar, 1995) 
Em contraste, os corpos de prova ensaiados de forma não drenada no ensaio CKU exibiram um tipo de comportamento que, segundo os autores, poderia levar o solo de um talude à mobilização de um fluxo de detritos: com um pequeno incremento da tensão de cisalhamento, o solo desenvolveu sua resistência pico em uma deformação axial muito baixa (menor do que 0,5\%). Em seguida o incremento da deformação provocou um aumento na poropressão, que, por sua vez, provocou uma diminuição na resistência, como observado na Figura 2.8. A tendência de mudança de volume contrativa, induzida pela deformação, leva à continua perda de resistência e pode levar a uma ruptura tipo fluxo.

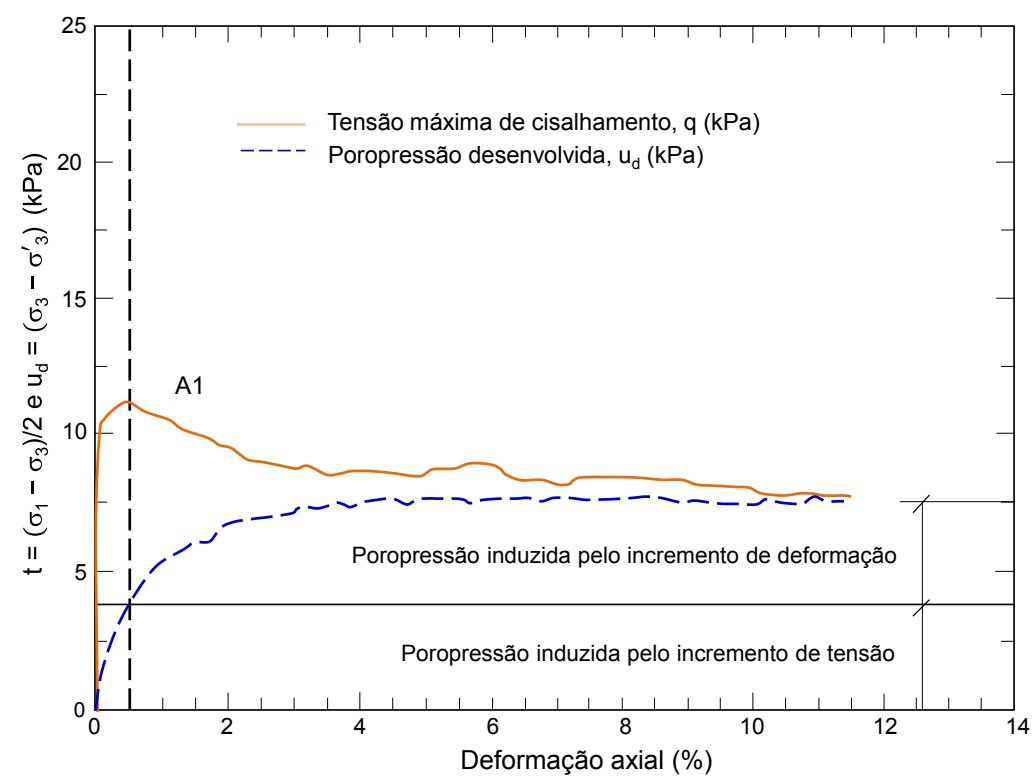

Figura 2.8 - Resultado típico de ensaio CKU, note-se que a resistência pico é atingida com uma deformação muito baixa, além, a poropressão aumenta e a resistência diminui com a deformação contínua (adaptado de Anderson e Sitar, 1995)

Baseados na observação de que o ensaio CSD conduz à dilatação durante o cisalhamento, enquanto que o ensaio CKU conduz ao comportamento de contração, Anderson e Sitar (1995) propuseram que em um talude - embora as tensões in situ inicialmente mudem de forma drenada (ao longo de uma trajetória de cisalhamento constante) devido a um aumento das poropressões - é a carga compressiva não drenada (aumento da tensão de cisalhamento) a que provoca a geração de poropressão e a perda de resistência necessária para a mobilização de fluxo de detritos. Os autores sugeriram que o aumento da tensão de cisalhamento necessário para causar tal ruptura não drenada é pequeno. Além disso, a transferência de tensões perto da base das trincas de tração, formadas quando a ruptura é iniciada, ou a transferência de tensões a partir de uma região 
do talude que atingiu a ruptura para outra que não a atingiu, poderiam ser suficientes para provocar a mobilização de uma ruptura não drenada.

Anderson e Sitar (1995) concluíram que a ruptura por fluxo causada pela infiltração de água de chuva é um processo de duas fases; a ruptura no solo é iniciada sob condições drenadas seguida de deformações não drenadas, se a tendência de alteração de volume do solo for de contração. Os autores referiramse a este processo como iniciação drenada e mobilização não drenada.

Posteriormente, Santos et al. (1996) estudaram o efeito da elevação da poropressão e de suas variações cíclicas sobre o comportamento do solo residual da encosta de Soberbo, Alto de Boa Vista, Rio de Janeiro. Para isto, realizaram ensaios com carga constante em amostras inalteradas, sendo a ruptura atingida por aumento de poropressão (APP). Os autores realizaram também ensaios modificados de aumento de poropressão onde antes de atingida a ruptura, foram introduzidas etapas de fluência não drenada (Ensaio FND) e fluência drenada (Ensaios FD).

Adicionalmente, foram realizados ensaios com variação cíclica de poropressão (Ensaios CPP), onde a poropressão variou entre valores máximos e mínimos, inferiores àqueles necessários para provocar a ruptura. Nos ensaios, a tensão confinante era aplicada utilizando-se um sistema de pressão composto de potes de mercúrio. Para aplicação de tensão de desvio foi usada uma prensa com tensão controlada por meio de um pendural onde eram colocados pesos. Os incrementos de poropressão foram aplicados através da elevação do pote de mercúrio ligado à base da amostra (Santos, 1996; Santos et al., 2004).

Os resultados mostraram que a ruptura por acréscimo de poropressão ocorre com pequenas deformações axiais e é essencialmente dilatante, independentemente do fato de que nos ensaios convencionais, o solo apresente comportamento compressivo. Os parâmetros de resistência obtidos a partir dos ensaios de aumento de poropressão foram idênticos àqueles obtidos em ensaios de compressão triaxial convencional CID e CIU.

Os autores consideraram que o escoamento (mudança de comportamento elástico para plástico) observado nos ensaios de aumento de poropressão devese à quebra da estrutura do solo herdada da rocha de origem e é possível conseguir o mesmo efeito (quebra da estrutura) durante o processo de ciclagem de poropressão, se o estado de tensão durante as variações cíclicas estiver abaixo da superfície de escoamento plástico. Com relação aos ensaios de fluência, verificou-se que a condição drenada é a mais crítica para a ruptura por creep. 
Similar comportamento dilatante foi reportado por Dai et al. (1999) em um solo coluvionar de Hong Kong.

Por outro lado, Zhu e Anderson (1998) usaram o ensaio de aumento de poropressão (denominado pelos autores ensaios triaxiais drenados de cisalhamento constante - CSD) para estudar o comportamento de amostras inalteradas de um talude de solo residual de Honolulu, Havaí; típico de locais sujeitos a deslizamentos de terra induzidos por precipitações. Adicionalmente, realizaram ensaios triaxiais não drenados adensados anisotropicamente (CKU) com a finalidade de comparar os parâmetros de resistência determinados através das diferentes trajetórias de tensão.

Dois tipos diferentes de resultados foram alcançados no ensaio CSD, mostrados na Figura 2.9. Algumas das amostras ensaiadas com tensões efetivas muito baixas não romperam, embora $\sigma_{3}^{\prime}$ tenha sido reduzida a zero. Segundo os autores isto aconteceu devido a certa resistência não confinada das amostras, que foi atribuída à estrutura cimentante do solo ou ao reforço de raízes. Para as amostras que romperam, a trajetória de tensões foi horizontal, passando através da envoltória de estado crítico ou permanente (steady state) até alcançar uma envoltória claramente definida, onde a ruptura acontece. Em seguida, a tensão desviadora caiu enquanto a amostra se deformou rapidamente, atingindo a envoltória de grandes deformações, devido à quebra de ligações e ao fato que o solo já não podia suportar a tensão de cisalhamento aplicada. Por outro lado, a resistência obtida com os ensaios de aumento de poropressão foi encontrada ser maior que a resistência a grandes deformações (large strain strength) do ensaio CKU.

Zhu e Anderson (1998) também relataram que algumas amostras com elevado índice de vazios dilataram, enquanto que algumas amostras com baixo índice de vazios contraíram, atribuindo esse comportamento aos componentes e à estrutura do solo residual. Os autores afirmaram que as trajetórias de tensão têm grande influência na resistência ao cisalhamento do solo. Os valores dos parâmetros de resistência c'e $\phi$ ' variaram consideravelmente para as diferentes trajetórias de tensão dos ensaios. O ângulo de atrito para ensaios CSD foi aproximadamente $7^{\circ}$ menor do que para os ensaios CKU, mas com uma coesão efetiva maior quando o solo seguiu a trajetória CSD. No estado de grandes deformações, os parâmetros de resistência obtidos nos ensaios CSD foram todos maiores do que no ensaio CKU. Uma vez que a força de atrito é menor a baixa profundidade, a coesão pode desempenhar um papel significativo no controle da estabilidade de taludes rasos. Em virtude disso, os parâmetros do 
ensaio CKU serão mais conservadores do que os parâmetros CSD nas análises de estabilidade de deslizamentos rasos provocados pelas chuvas.

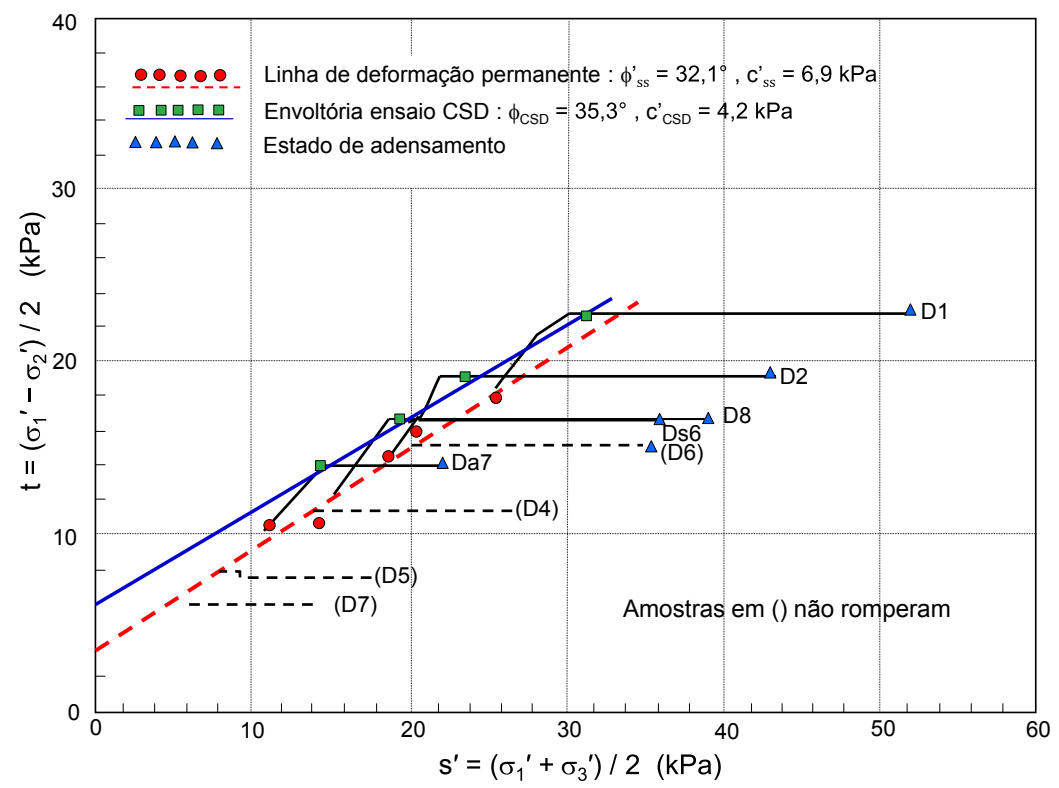

Figura 2.9 - Envoltórias de ruptura e trajetórias de tensão do ensaio de aumento de poropressão (CSD) realizado em um solo residual (adaptado de Zhu e Anderson, 1998)

A capacidade das amostras de solo residual de manter uma tensão de cisalhamento acima do sugerido pela linha de estado permanente (steady state line) foi atribuída à estrutura cimentante do material. Assim, os autores concluíram que, desde que a resistência da cimentação é metaestável ou não confiável, os parâmetros de resistência obtidos nos ensaios CSD, que reproduzem a trajetória de tensões de campo durante chuvas, devem ser empregados na análise do início do deslizamento induzido por precipitações. Já, as análises de pós-ruptura ou mobilização do talude devem ser conduzidas com parâmetros de resistência obtidos do estado de grandes deformações no ensaio CSD.

Martins (2001) apresentou resultados de dois ensaios triaxiais em amostras de um solo residual de arenito Botucatu (sitio da Vila Scharlau, RS, Brasil) os quais foram submetidos a trajetórias de tensão efetivas de descarregamento por aumento de poropressão. Estas trajetórias foram impostas por um equipamento triaxial servo-controlado, sob condições drenadas. As trajetórias dos ensaios demostraram que para baixos níveis de tensões efetivas o solo é capaz de ultrapassar a envoltória de resistência ao cisalhamento a grandes deformações, devido à presença de cimentação. Além disso, a envoltória de ruptura obtida apresentou uma redução da componente coesiva, em comparação à obtida com ensaios convencionais (Martins et al., 2001). 
Orense et al. (2004) realizaram uma série de ensaios em amostras de taludes arenosos escorregados do Japão. Os ensaios reproduziram a condição de campo, em que a tensão desviadora permaneceu constante, enquanto que a poropressão foi aumentada. Algum tempo após o inicio do ensaio, a deformação axial se incrementou gradualmente e sofreu posteriormente um rápido incremento, levando o corpo de prova à ruptura. Tal transição nas taxas de deformação foi definida pelos autores como o ponto de inicio de ruptura. Este estudo mostrou que para estes materiais não coesivos pode ser definida uma "linha de iniciação de ruptura". Na Figura 2.10 mostra-se a linha de iniciação de ruptura, além da linha de estado permanente ou crítico, definida assumindo que no final de cada ensaio o solo se encontrava em estado crítico. Adicionalmente, realizaram ensaios triaxiais convencionais drenados e não drenados para ilustrar a diferença da resposta do solo sob diferentes trajetórias de tensão.
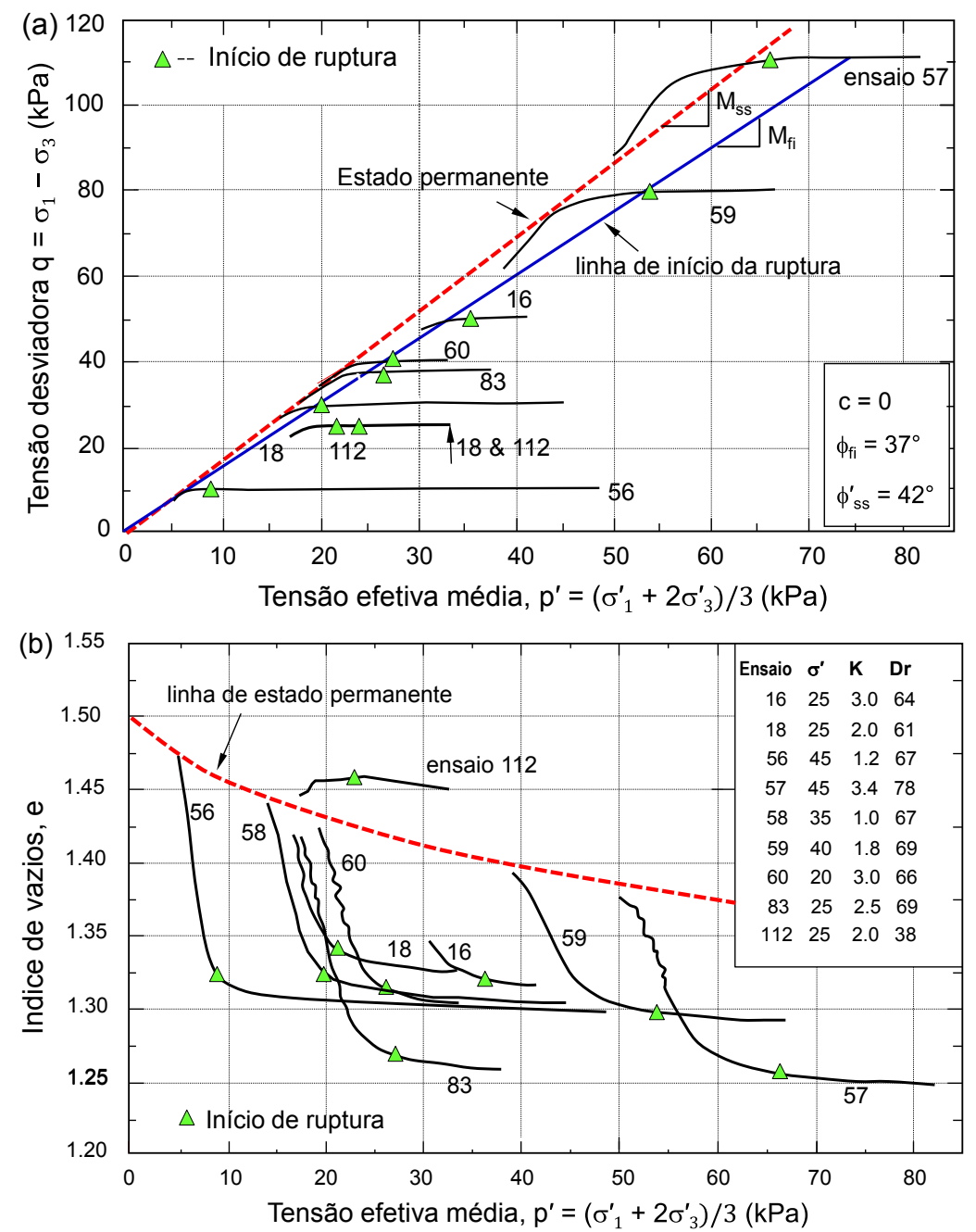

Figura 2.10 - Resultado de ensaio de aumento de poropressão em um solo arenoso, (a) Envoltórias de ruptura e trajetórias de tensão, (b) Relação e vs p' e linha de estado permanente estimada (adaptado de Orense et al., 2004) 
A relação entre a linha de estado crítico ou de estado permanente e a linha de iniciação de ruptura foi amplamente definida para estes materiais arenosos como sendo:

$$
\tan \phi_{\mathrm{fi}}^{\prime}=0,73-0,83 \phi_{\mathrm{ss}}^{\prime}
$$

Onde $\phi_{\mathrm{fi}}^{\prime}$ é o ângulo efetivo da linha de início de ruptura; $\phi_{\text {ss }}^{\prime}$ é o ângulo efetivo da linha de estado permanente. Os parâmetros de resistência no estado permanente de cada solo estudado foram encontrados quase únicos, mesmo que as trajetórias de tensão foram diferentes.

Orense et al. (2004) sugeriram que em um sistema real a linha de inicio de ruptura é mais significativa do que a do estado permanente, representando o ponto na trajetória de tensões de aumento de poropressão quando a ruptura do talude vai ser iniciada. Os autores concluíram que, para analisar a instabilidade de encostas originada pelas chuvas, a utilização de parâmetros de resistência associados ao início da ruptura no ensaio de aumento de poropressão pode ser mais apropriada do que a utilização de parâmetros obtidos em ensaios triaxiais convencionais.

Futai et al. (2004), visando a investigação da envoltória de ruptura para baixos níveis de tensão, realizaram três ensaios de poropressão em amostras inalteradas de um solo saprolítico de gnaisse, de uma área perto da cidade de Ouro Preto, no estado de Minas Gerais, Brasil. Os solos ensaiados romperam em $\sigma_{3}{ }_{3}=0$, definindo a linha de ruptura por desconfinamento. Após a ruptura, a tensão desviadora diminuiu até a linha de estado crítico. Durante a diminuição da tensão efetiva média, o solo experimentou expansão contínua.

Petley et al. (2005b) definiram dois tipos diferentes de comportamento dos solos no ensaio de aumento de poropressão, baseados em resultados oriundos da literatura. As Figuras 2.11 e 2.12 resumem o comportamento típico para solos, que os autores denominaram com coesão e sem coesão.

Segundo Petley et al. (2005b), o conjunto de resultados analisado sugere que o mecanismo de ruptura para materiais com coesão derivada de forças interpartículas difere daqueles sem coesão. Isto permite que o material atinja uma resistência de pico maior. Porém, após o desenvolvimento completo da ruptura, um rápido enfraquecimento ocorre em direção à linha de estado permanente.

Transferindo estes conceitos para o sistema de movimentos de massa, devem-se esperar caraterísticas de movimento diferentes no início da ruptura em materiais com coesão, em comparação com os movimentos que ocorrem em 
materiais sem coesão. No primeiro caso, presume-se que a ruptura acontecerá quando a superfície de ruptura (cisalhamento) esteja totalmente desenvolvida neste ponto, o enfraquecimento dos materiais a um estado inferior vai deixar uma grande força desequilibrada que poderia causar uma rápida aceleração. No outro caso, dado que não existe um processo de perda de resistência rápido no desenvolvimento de um movimento de massa em materiais sem coesão, podese esperar que a taxa de aceleração seja menor e menos dramática. Neste caso, deveria haver uma forte correlação entre a taxa de movimento e o nível do lençol freático, uma vez que este último controla eficazmente a magnitude da tensão de cisalhamento.

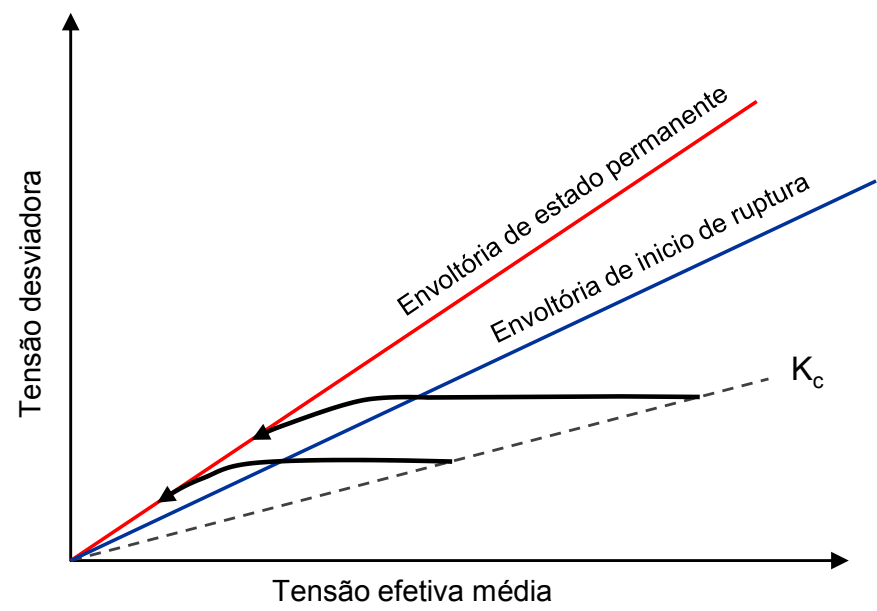

Figura 2.11 - Ilustração esquemática da trajetória de tensões seguida por materiais sem coesão durante o ensaio de aumento de poropressão (adaptado de Petley et al., 2005b)

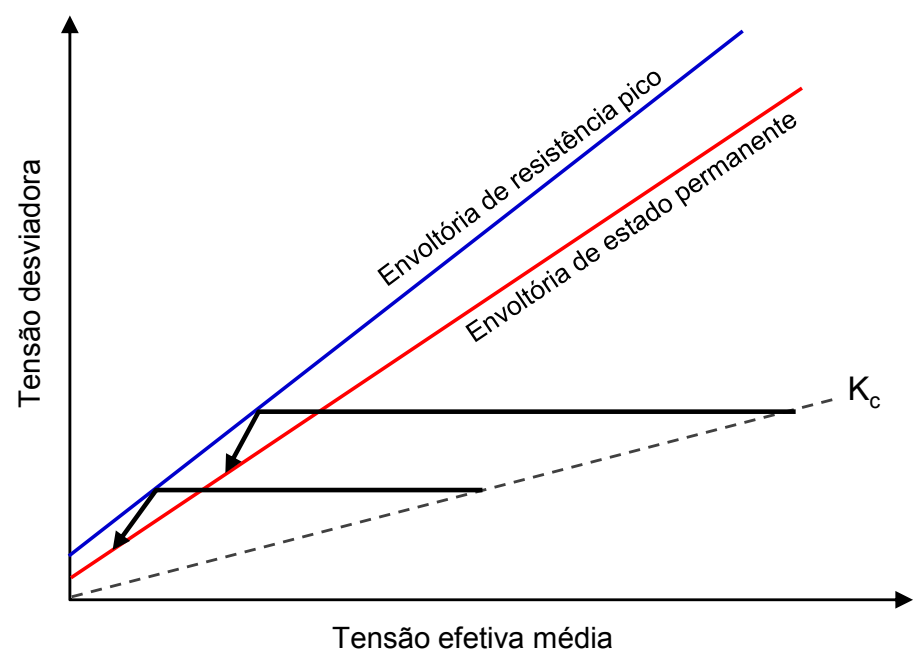

Figura 2.12 - Ilustração esquemática da trajetória de tensões seguida por materiais com coesão durante o ensaio de aumento de poropressão (adaptado de Petley et al., 2005b) 
Outros pesquisadores têm considerado uma série de taxas de aumento de poropressão em diferentes tipos de solos, a fim de determinar o seu comportamento na ruptura (Petley et al., 2005a; Petley e Allison, 2006; Ng e Petley, 2009; Carey, 2011). Nos ensaios de aumento de poropressão, denominado por esses autores como Pore pressure Reinflation Test (PPR), as amostras foram inicialmente adensadas isotropicamente a uma predeterminada tensão efetiva média e posteriormente submetidas a um período de cisalhamento convencional drenado ou não drenado até certa tensão efetiva. $A$ tensão desviadora, então, foi mantida constante e a ruptura foi iniciada pelo aumento de poropressão na amostra.

Os resultados desses ensaios, realizados ao longo de uma gama de materiais, ilustraram dois padrões distintos de deformação na ruptura quando plotados no espaço $\wedge-t$, uma tendência "linear" negativa e outra "assintótica" (Figura 2.13), onde $\wedge$ é o inverso da velocidade e t é o tempo (Saito, 1965). O comportamento linear, em todas as circunstâncias, relaciona-se com a ruptura frágil e o desenvolvimento de uma superfície singular de cisalhamento, enquanto que a tendência assintótica é associada a uma deformação plástica ou dúctil nas amostras onde não pode ocorrer a ruptura frágil (Petley et al., 2005a).

O primeiro comportamento foi relacionado pelos autores ao mecanismo dominante de movimentos de massa que acontecem pela primeira vez, caracterizados por movimentos rápidos, catastróficos; enquanto o segundo foi relacionado a uma ruptura contínua, plástica como um rastejo, dentro de materiais dúcteis ou à reativação de movimentos de massa em uma superfície de cisalhamento existente (Petley et al., 2002).

Vários estudos têm sido realizados para avaliar o comportamento instável da areia por meio do ensaio de aumento de poropressão (e.g. Tsukamoto,1998; Chu et al., 2003, 2012; Farooq, 2004; Lourenco, et al., 2011). Chu et al. (2003) realizaram ensaios de aumento de poropressão em areia solta e densa, e propuseram o uso de um parâmetro de estado modificado e a linha de estado crítico para avaliar as condições de instabilidade de taludes de solos granulares contrativos e dilatantes, sob diferentes níveis de tensão. 


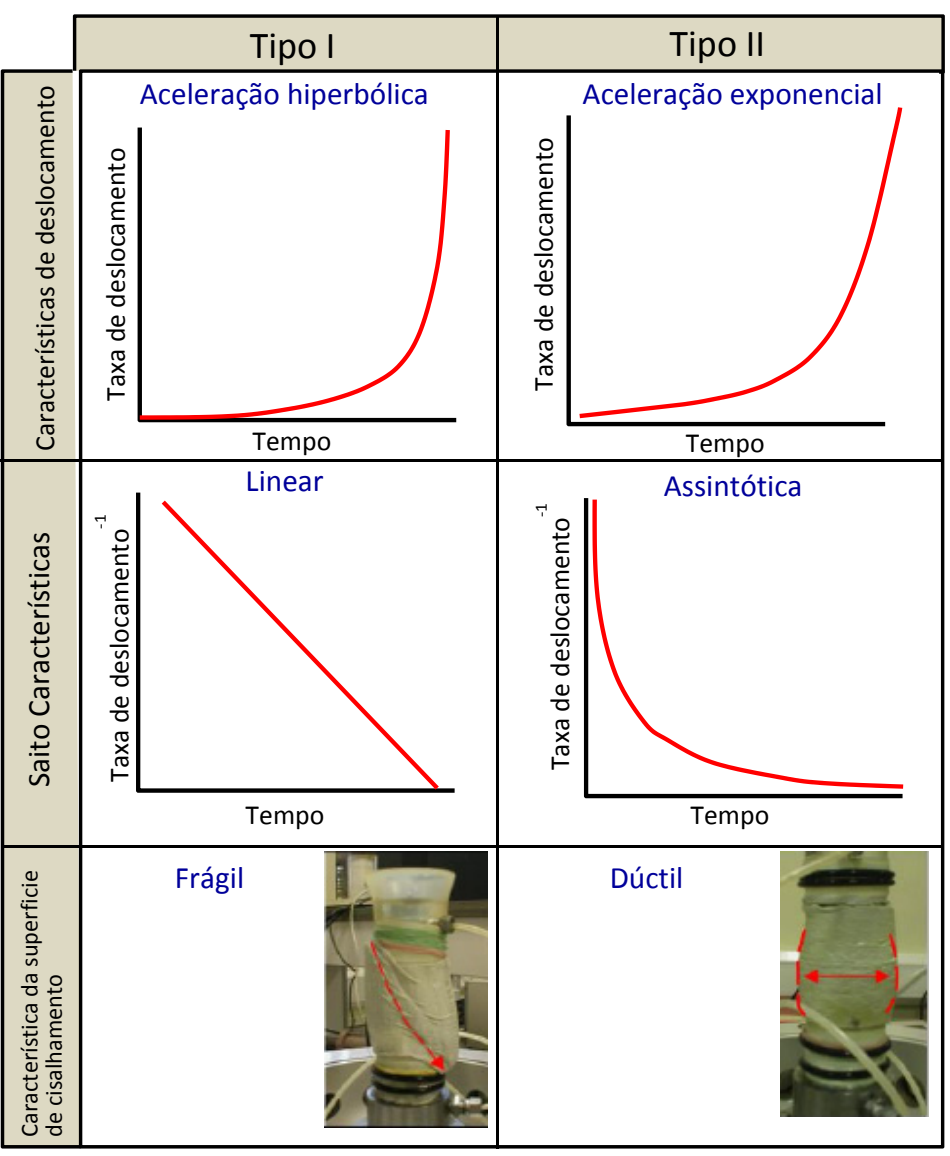

Figura 2.13 - Padrões de deformação observados em ensaios de aumento de poropressão e a sua relação com os padrões de comportamento de movimentos de massa (adaptado de Carey, 2011)

Sprigman et al. (2003), Farooq et al. (2004) e Chen et al. (2004) realizaram os ensaios de aumento de poropressão em amostras inicialmente não saturadas, infiltrando água dentro dos corpos de prova a uma taxa constante.

Junaideen (2005) investigou o comportamento de amostras compactadas de dois solos residuais em ensaios de aumento de poropressão que denominou "Ensaio de cisalhamento constante" (Constant shear test - CS). Dos resultados obtidos, o autor concluiu que os solos com um parâmetro de estado positivo $(\psi>0)$ no escoamento apresentam comportamento contráctil; entretanto, os solos com um parâmetro de estado negativo $(\psi<0)$ no escoamento exibem comportamento dilatante. O conceito do parâmetro de estado, $\psi$, e sua determinação são dados em detalhe no item 2.4. Segundo o autor, os parâmetros de resistência obtidos a partir de ensaios CS são muito semelhantes àqueles usados convencionalmente na prática. Ao longo da trajetória do ensaio de aumento de poropressão, um solo "fofo" pode colapsar e liquefazer, enquanto um solo "denso" exibe um comportamento pós-escoamento que parece ser controlado pelas condições de drenagem. 
Slongo (2008) realizou três ensaios de aumento de poropressão em um solo residual de biotita gnaisse proveniente do Parque Nacional Dois Irmãos no Alto Leblon, RJ, Brasil, além de ensaios triaxiais com trajetória s' constante e triaxiais convencionais CID e CIU. Os ensaios de aumento de poropressão apresentaram uma envoltória deslocada para cima na ordem de $10 \mathrm{kPa}$, com base na envoltória única obtida para os outros ensaios, evidenciando um aparente aumento do intercepto coesivo, com o ângulo de atrito permanecendo aproximadamente constante. $\mathrm{O}$ autor atribuiu o fato a um erro experimental oriundo de uma medição de poropressão não representativa nos ensaios durante o aumento de poropressão, sugerindo a execução de ensaios com medição de poropressão na parte média do corpo de prova.

Silveira (2008) realizou um ensaio de aumento de poropressão, ao que denominou CSD em uma amostra de solo remoldada, proveniente de uma área de ocorrência de dezenas de movimentos de massa e corridas de detritos, próxima da cidade de São Vendelino, Rio Grande do Sul, Brasil. Este ensaio foi realizado com o objetivo de comparar com os resultados de um ensaio hollow cylinder.

A Tabela 2.6 apresenta, de maneira resumida, as principais caraterísticas dos ensaios desenvolvidos pelos autores supracitados, os critérios utilizados em cada uma das etapas dos ensaios bem como as principais caraterísticas associadas a cada um dos solos estudados.

A partir destes estudos, observa-se que são poucos os ensaios triaxiais de aumento de poropressão realizados em amostras indeformadas em áreas tropicais. Além disso, constatou-se que no Brasil foram desenvolvidos uma quantidade mínima de ensaios deste tipo.

Ainda, a maioria dos ensaios foi realizada sem o controle do comportamento das deformações, mediante o uso de instrumentos de medição interna, além da falta de monitoramento no mesmo corpo de prova da taxa de variação de poropressão, como forma de garantir uma avaliação adequada de tensões efetivas.

Sendo assim, esta revisão das pesquisas existentes confirma a necessidade de estudos mais detalhados do comportamento mecânico dos solos de origem tropical sujeitos a incrementos de poropressão, com uma análise minuciosa dos mecanismos que levam à iniciação e propagação das deformações de cisalhamento e eventualmente possíveis movimentos de massa rápidos. 
PUC-Rio - Certificação Digital № 0912780/CA

Tabela 2.6 - Resumo de principais caraterísticas dos ensaios de aumento de poropressão encontrados na literatura

\begin{tabular}{|c|c|c|c|c|c|c|c|}
\hline \multirow{2}{*}{ Referência } & \multirow{2}{*}{ Denominação de ensaio } & \multirow{2}{*}{ Solo estudado } & \multirow{2}{*}{ Localização } & \multirow{2}{*}{ Amostra } & \multicolumn{3}{|c|}{ Características do ensaio } \\
\hline & & & & & Saturação & Procedimentos prévios a simulação de trajetória & Simulação da trajetória de campo \\
\hline GCO,1982 & $\begin{array}{l}\text { Ensaio de carga morta - DL } \\
\text { (Dead Load Test) }\end{array}$ & $\begin{array}{l}\text { Solo coluvionar proveniente da } \\
\text { decomposição de rocha } \\
\text { vulcânica e granito }\end{array}$ & $\begin{array}{l}\text { Mid Levels, Hong } \\
\text { Kong }\end{array}$ & Inalterada & SIM & $\begin{array}{l}\text { Adensamento anisotrópico até pressões de } 50 \text { a } 137 \\
\mathrm{KPa}\end{array}$ & $\begin{array}{l}\text { Aumento de poropressão com taxa controlada para } \\
\text { que diferença de poropressão entre os dois } \\
\text { extremos no c.p não seja maior a } 2 \mathrm{kPa}\end{array}$ \\
\hline \multirow{2}{*}{ Brenner et al., 1985} & \multirow{2}{*}{$\begin{array}{l}\text { Ensaio de carga morta - DL } \\
\text { (Dead Load Test) }\end{array}$} & \multirow{2}{*}{$\begin{array}{l}\text { Solo coluvionar derivado de } \\
\text { solo residual vulcânico (18\% } \\
\text { areia, } 47 \% \text { silte, } 35 \% \text { argila) }\end{array} \mid$} & \multirow{2}{*}{ Tai Po, Hong Kong } & \multirow{2}{*}{ Alterada } & SIM & $\begin{array}{l}\text { Adensamento Isotrópico até pressões de } 100,200 \mathrm{e} \\
400 \mathrm{kPa} \text {, após cisalhamento drenado até } \mathrm{q}=160 \mathrm{kPa}\end{array}$ & $\begin{array}{l}\text { Redução de tensão confinante ou aumento de } \\
\text { contrapressão com incrementos e decréscimos de } \\
20 \mathrm{kPa}\end{array}$ \\
\hline & & & & & NÃO & $\begin{array}{l}\text { Adensamento Isotrópico até pressões de } 10,30 \text { e } \\
60 \mathrm{kPa} \text {, posteriormente cisalhamento drenado até q } \\
=73-204 \mathrm{kPa}\end{array}$ & $\begin{array}{l}\text { Incremento de poropressão (diminuição de sução } \\
\text { de } 10 \mathrm{kPa} \text { ) }\end{array}$ \\
\hline $\begin{array}{l}\text { Atkinson e Farrar, } \\
1985\end{array}$ & & $\begin{array}{l}\text { Argila de Londres (do aterro } \\
\text { Denham) }\end{array}$ & $\begin{array}{l}\text { Denham, Bucks, } \\
\text { UK }\end{array}$ & Alterada & SIM & Não indica & Aumento de poropressão de $1 \mathrm{kPa} / \mathrm{hr}$ \\
\hline $\begin{array}{l}\text { Bressani e Vaughan; } \\
\quad 1989\end{array}$ & & $\begin{array}{l}\text { Solo artificial (para simular } \\
\text { propriedades de solo residual). } \\
\text { Areia com caulim }\end{array}$ & & Alterada & SIM & $\begin{array}{l}\text { Adensamento Isotrópico, após incremento de tensão } \\
\text { desviadora }\end{array}$ & $\begin{array}{l}\text { Aumento de poropressão (taxa de aumento não } \\
\text { indicada) }\end{array}$ \\
\hline $\begin{array}{l}\text { Sasitharan et al., } \\
1993\end{array}$ & \begin{tabular}{|l|} 
Ensaio de trajetória de tensão \\
desviadora constante drenado \\
(Constant deviator stress \\
drained stress path)
\end{tabular} & Areia & Ottawa, Illinois & Alterada & SIM & $\begin{array}{l}\text { Adensamento Isotrópico tensão efetiva media de } 350 \\
\mathrm{kPa} \text {, após cisalhamento drenado até tensão } \\
\text { desviadora desejada }\end{array}$ & $\begin{array}{l}\text { Aumento de poropressão (taxa de aumento não } \\
\text { indicada) }\end{array}$ \\
\hline \multirow[t]{2}{*}{ GCO,1994 } & \multirow[t]{2}{*}{$\begin{array}{l}\text { Ensaio de carga morta - DL } \\
\text { (Dead Load Test) }\end{array}$} & \multirow[t]{2}{*}{$\begin{array}{l}\text { Rocha vulcânica decomposta } \\
\text { (18\% pedregulho, } 42 \% \text { areia, } \\
40 \% \text { silte e argila) }\end{array}$} & \multirow[t]{2}{*}{$\begin{array}{l}\text { Kwun Lung Lau, } \\
\text { Kennedy, Hong } \\
\text { Kong }\end{array}$} & \multirow[t]{2}{*}{ Inalterada } & \multirow[t]{2}{*}{ SIM } & \multirow[t]{2}{*}{ Adensamento anisotrópico até $p^{\prime}=60-100 \mathrm{kPa}$} & $\begin{array}{l}\text { Injeção controlada de água com taxa controlada } \\
\text { para que diferencia de poropressão no c.p não seja } \\
\text { maior a } 1 \mathrm{kPa}\end{array}$ \\
\hline & & & & & & & Aumento de poropressão a $2 \mathrm{kPa} / \mathrm{hr}$ \\
\hline \multirow{2}{*}{$\begin{array}{l}\text { Anderson e Riemer; } \\
\quad 1995\end{array}$} & \multirow{2}{*}{$\begin{array}{l}\text { Ensaio Drenado de } \\
\text { Cisalhamento Constante - } \\
\text { CSD (Constant Shear Drained } \\
\text { Test) }\end{array}$} & $\begin{array}{c}\text { Areia uniformemente graduada } \\
\text { (Monterei \#0) }\end{array}$ & Areia de praia & Alterada & \multirow{2}{*}{ SIM } & \multirow{2}{*}{$\begin{array}{l}\text { Adensamento anisotrópico pela linha } \mathrm{K}_{\mathrm{c}}=2.5 \text { até } \\
\text { tensão efetiva media de } 13 \text { a } 35 \mathrm{kPa}\end{array}$} & $\begin{array}{l}\text { Redução de tensão confinante, no inicio a } 4 \\
\mathrm{kPa} / \mathrm{min} \text {, perto de ruptura a } 1 \mathrm{kPa} / \mathrm{min}\end{array}$ \\
\hline & & $\begin{array}{l}\text { Solo coluvionar argiloso }(5 \% \\
\text { areia, } 55-70 \% \text { silte, } 25-40 \% \\
\text { argila) }\end{array}$ & \begin{tabular}{|c|} 
Parque Regional de \\
Briones, \\
Berkeley,California \\
\end{tabular} & Inalterada & & & $\begin{array}{l}\text { Redução de tensão confinante e aumento de } \\
\text { contrapressão a } 0,67 \mathrm{kPa} / \mathrm{hr}\end{array}$ \\
\hline $\begin{array}{l}\text { Anderson e Sitar; } \\
\quad 1995\end{array}$ & $\begin{array}{|ll|}\text { Ensaio Drenado de } \\
\text { Cisalhamento Constante } & - \\
\text { CSD (Constant } & \text { Shear Drained } \\
\text { Test) } & \end{array}$ & $\begin{array}{l}\text { Solo coluvionar argiloso }(5 \% \\
\text { areia, } 55-70 \% \text { silte, } 25-40 \% \\
\text { argila) }\end{array}$ & $\begin{array}{c}\text { Parque Regional de } \\
\text { Briones, } \\
\text { Berkeley,California }\end{array}$ & Inalterada & SIM & $\begin{array}{l}\text { Adensamento anisotrópico pela linha } \mathrm{K}_{\mathrm{c}}=2.4-2.8 \text { até } \\
\text { tensão efetiva media de } 15 \text { a } 72 \mathrm{kPa}, 215 \mathrm{kPa}\end{array}$ & $\begin{array}{l}\text { Redução de tensão confinante e aumento de } \\
\text { contrapressão a } 0,67 \mathrm{kPa} / \mathrm{hr}\end{array}$ \\
\hline $\begin{array}{l}\text { Santos et al., } \\
1996,2004\end{array}$ & $\begin{array}{l}\text { Aumento de poropressão } \\
\text { (APP) }\end{array}$ & $\begin{array}{l}\text { Solo residual (saprolítico) de } \\
\text { rocha gnáissica (quartzo- } \\
\text { diorito). Areia siltosa }\end{array}$ & $\begin{array}{l}\text { Encosta Soberbo, } \\
\text { Alto de Boa vista, } \\
\text { RJ-Brasil }\end{array}$ & Inalterada & SIM & $\begin{array}{l}\text { Adensamento isotrópico até tensão efetiva media de } \\
50,100,200 \text { e } 600 \mathrm{kPa} \text {, após cisalhamento não } \\
\text { drenado até } 50 \text { a } 60 \% \text { da resistência obtida em } \\
\text { ensaios drenados }\end{array}$ & $\begin{array}{l}\text { Aumento de poropressão (taxa não indicada) } \\
\text { (Fizeram-se também ensaios com ciclagem de poro } \\
\text { pressão, aumento de poropressão com fluência } \\
\text { drenada e não drenada antes de atingir a ruptura) }\end{array}$ \\
\hline
\end{tabular}


PUC-Rio - Certificação Digital № 0912780/CA

Tabela 2.6 - Resumo de principais caraterísticas dos ensaios de aumento de poropressão encontrados na literatura (continuação)

\begin{tabular}{|c|c|c|c|c|c|c|c|}
\hline \multirow{2}{*}{ Referência } & \multirow{2}{*}{ Denominação de ensaio } & \multirow{2}{*}{ Solo estudado } & \multirow{2}{*}{ Localização } & \multirow{2}{*}{ Amostra } & \multicolumn{3}{|c|}{ Características do ensaio } \\
\hline & & & & & Saturação & Procedimentos prévios a simulação de trajetória & Simulação da trajetória de campo \\
\hline $\begin{array}{l}\text { Zhun e Anderson, } \\
1998\end{array}$ & $\begin{array}{l}\text { Ensaio Drenado de } \\
\text { Cisalhamento Constante - } \\
\text { CSD (Constant Shear Drained } \\
\text { Test) }\end{array}$ & $\begin{array}{l}\text { Solo residual (silte de alta } \\
\text { plasticidade ou areia siltosa) } \\
\text { (25-35\% silte e argila; } 65-75 \% \\
\text { areia) - basalto intemperizado }\end{array}$ & Honolulu, Havaí & Inalterada & SIM & $\begin{array}{l}\text { Adensamento anisotrópico pela linha } K_{c}=2.5 \text { até } \\
\text { tensão confinante efetiva de } 15 \text { a } 52 \mathrm{kPa}\end{array}$ & Redução de tensão de confinamento a $1 \mathrm{kPa} / \mathrm{hr}$ \\
\hline $\begin{array}{l}\text { Tsukamoto et } \\
\text { al.,1998 }\end{array}$ & $\mid \begin{array}{lrr}\text { Ensaio } \quad \text { Drenado r } & \text { de } \\
\text { Cisalhamento Constante- CSD } \\
\text { (Constant Shear Drained Test) }\end{array}$ & Areia & $\begin{array}{l}\text { Omigawa, Chiba, } \\
\text { Japão }\end{array}$ & Alterada & SIM & $\begin{array}{l}\text { Adensamento isotrópico até tensão efetiva media de } \\
50 \mathrm{kPa} \text {, após cisalhamento drenado até linha } \mathrm{K}_{\mathrm{c}}\end{array}$ & $\begin{array}{l}\text { Redução de tensão de confinamento (taxa de } \\
\text { redução não indicada) }\end{array}$ \\
\hline Dai et al., 1999 & $\begin{array}{l}\text { Ensaio de trajetória de tensão } \\
\text { desviadora constante - CQD } \\
\text { (Constant deviatoric stress } \\
\text { path tests) }\end{array}$ & $\begin{array}{l}\text { Solo coluvionar. Silte argiloso } \\
\text { ou areia argilo-siltosa }\end{array}$ & $\begin{array}{l}\text { Ilha Lantau, Hong } \\
\text { Kong }\end{array}$ & Inalterada & SIM & $\begin{array}{l}\text { Adensamento anisotrópico pela linha } K_{c}=3.6 \text { até } \\
p^{\prime}<60 \mathrm{kPa}\end{array}$ & Aumento de poropressão a 0,9 kPa/hr \\
\hline Martins, F.B.; 2001 & & $\begin{array}{l}\text { Solo residual de arenito de } \\
\text { Botucatu (areia } 68 \% \text {, silte } \\
27 \% \text {, argila } 5 \% \text { - LL }=21 \% \text {; NP) }\end{array}$ & Vila Scharlau, RGS & Inalterada & SIM & $\begin{array}{l}\text { Adensamento isotrópico ate tensão efetiva media de } \\
150 \mathrm{kPa} \text { e } 200 \mathrm{kPa} \text {, após aplicação de tensão } \\
\text { desviadora na condição s' cte ou carregamento axial }\end{array}$ & Aumento de poropressão (taxa não indicada) \\
\hline $\begin{array}{l}\text { Springman et al., } \\
2003\end{array}$ & $\begin{array}{|ll|}\text { Ensaio } & \text { Drenado de } \\
\text { Cisalhamento } & \text { Constante } \\
\text { CSD (Constant } & \text { Shear Drained } \\
\text { Test) } & \\
\end{array}$ & Morena & $\begin{array}{l}\text { Gruben, Canton } \\
\text { Wallis, Suíça }\end{array}$ & Alterada & NÃO & $\begin{array}{l}\text { Adensamento isotrópico até tensão efetiva media de } \\
25,40,75 \mathrm{kPa} \text {, após cisalhamento drenado até linha } \\
\mathrm{KC}=2,5\end{array}$ & Aumento de poropressão a $0,5 \mathrm{kPa} / \mathrm{hr}$ \\
\hline Chu et al., 2003 & $\begin{array}{|ll|}\text { Ensaio } \quad \text { Drenado de } \\
\text { Cisalhamento } & \text { Constante } \\
\text { CSD (Constant } & \text { Shear Drained } \\
\text { Test) } & \\
\end{array}$ & Areia marina dragada & Cingapura & Alterada & SIM & $\begin{array}{l}\text { Adensamento isotrópico até tensão efetiva media de } \\
150 \mathrm{kPa} \text {, após cisalhamento drenado até } \mathrm{q}=150 \\
\mathrm{kPa}(\mathrm{em} \text { areia fofa) }, 303,343 \mathrm{kPa} \text { (em areia densa) }\end{array}$ & Redução de tensão de confinamento a 1 kPa/min \\
\hline \multirow{3}{*}{ Orense et al., 2004} & \multirow{3}{*}{\begin{tabular}{|l|} 
Ensaio Drenado de \\
Cisalhamento Constante - \\
CSD (Constant Shear Drained \\
Test) \\
\end{tabular}} & $\begin{array}{l}\text { Areia com pedregulho( } 29,35 \% \\
\text { pedregulho; } 62,55 \% \text { areia; } \\
8,10 \% \text { fino) }\end{array}$ & \multirow[t]{2}{*}{$\begin{array}{l}\text { Kumanodaira, } \\
\text { Gunma, Japão }\end{array}$} & \multirow{3}{*}{ Alterada } & \multirow{3}{*}{ SIM } & \multirow{3}{*}{$\begin{array}{l}\text { Adensamento isotrópico até valor predeterminado, } \\
\text { após adensamento anisotrópico até } \mathrm{Kc}=1,2 \text { a } 3,4 \text {. } \\
\text { Tensão efetiva media de } 25 \text { a } 85 \mathrm{kPa}\end{array}$} & \multirow{3}{*}{$\begin{array}{l}\text { Aumento de poropressão a } 0,003 \mathrm{kPa} / \mathrm{seg} \text { e } \\
0,0015 \mathrm{kPa} / \mathrm{seg}\end{array}$} \\
\hline & & \begin{tabular}{|l|} 
Areia siltosa ( $9,5 \%$ pedregulho; \\
$46,83 \%$ areia; $43,67 \%$ fino)
\end{tabular} & & & & & \\
\hline & & $\begin{array}{l}\text { Areia }(0,5 \% \text { pedregulho; } 90,1 \% \\
\text { areia; } 9,4 \% \text { fino) }\end{array}$ & $\begin{array}{l}\text { Omigawa, Chiba, } \\
\text { Japão }\end{array}$ & & & & \\
\hline Farooq et al., 2004 & $\begin{array}{|lrr|}\text { Ensaio } & \text { triaxial } & \text { drenado de } \\
\text { tensão } & \text { de } & \text { cisalhamento } \\
\text { constante } & \text { (Constant } & \text { Shear } \\
\text { Stress Drained Triaxial Test) }\end{array}$ & Areia & $\begin{array}{l}\text { Omigawa, Chiba, } \\
\text { Japan }\end{array}$ & Alterada & NÃO & $\begin{array}{l}\text { Adensamento isotrópico até valor predeterminado, } \\
\text { após cisalhamento drenado até } \mathrm{Kc}=2 \text { a } 3,8 \text {. Ensaio } \\
\text { com tensões efetivas de confinamento de } 20-50 \mathrm{kPa}\end{array}$ & $\begin{array}{l}\text { Infiltração de água desde base. Topo foi ventilado } \\
\text { para a atmosfera. }\end{array}$ \\
\hline
\end{tabular}


PUC-Rio - Certificação Digital № 0912780/CA

Tabela 2.6 - Resumo de principais caraterísticas dos ensaios de aumento de poropressão encontrados na literatura (continuação)

\begin{tabular}{|c|c|c|c|c|c|c|c|}
\hline \multirow{2}{*}{ Referência } & \multirow{2}{*}{ Denominação de ensaio } & \multirow{2}{*}{ Solo estudado } & \multirow{2}{*}{ Localização } & \multirow{2}{*}{ Amostra } & \multicolumn{3}{|c|}{ Características do ensaio } \\
\hline & & & & & Saturação & Procedimentos prévios a simulação de trajetória & Simulação da trajetória de campo \\
\hline Futai et al., 2004 & Aumento de Poropressão & Saprolítico de gnaisse & $\begin{array}{c}\text { Ouro Preto, Minas } \\
\text { Gerais, Brasil }\end{array}$ & Inalterada & SIM & $\begin{array}{l}\text { Adensamento Isotrópico até tensão confinante media } \\
\text { de } 75 \mathrm{kPa} \text {, após cisalhamento drenado até } \mathrm{q}=25,35 \\
\text { e } 68 \mathrm{kPa}\end{array}$ & $\begin{array}{l}\text { Aumento de poropressão (taxa de aumento não } \\
\text { indicada) }\end{array}$ \\
\hline \multirow{2}{*}{ Petley et al., 2005a } & \multirow{2}{*}{$\begin{array}{l}\text { Porepressure Reinflation Test } \\
\text { (PPR) }\end{array}$} & Argila (Gault Clay) & $\begin{array}{c}\text { Selborne, } \\
\text { Hampshire, UK }\end{array}$ & Inalterada & \multirow{2}{*}{ SIM } & \multirow{2}{*}{$\begin{array}{l}\text { Adensamento isotrópico até tensão efetiva media de } \\
200 \mathrm{kPa} \text {, após cisalhamento não drenado até } 80 \% \\
\text { da resistência pico }\end{array}$} & Aumento de poropressão a $10 \mathrm{kPa} / \mathrm{dia} ; 1 \mathrm{kPa} / \mathrm{min}$ \\
\hline & & $\begin{array}{l}\text { Depósito de arenito (molasse) } \\
\text { altamente fraturado }\end{array}$ & Tessina, Itália & Inalterada & & & Aumento de poropressão a 10; $15 \mathrm{kPa} / \mathrm{hr}$ \\
\hline Petley et al., 2005b & $\begin{array}{l}\text { Porepressure Reinflation Test } \\
\text { (PPR) }\end{array}$ & $\begin{array}{l}\text { Areia siltosa }(66,4 \% \text { areia; } \\
28,3 \% \text { silte; } 5,3 \text { argila })\end{array}$ & $\begin{array}{c}\text { Black vem, Dorset, } \\
\text { UK }\end{array}$ & $\begin{array}{l}\text { Inalterada } \\
\text { / Alterada }\end{array}$ & SIM & $\begin{array}{l}\text { Adensamento isotrópico até tensão efetiva media de } \\
100 \mathrm{kPa} \text {, após cisalhamento drenado até tensão } \\
\text { desviadora de } 105 \mathrm{kPa}\end{array}$ & Aumento de poropressão a $10 \mathrm{kPa} / \mathrm{hr}$ \\
\hline \multirow{2}{*}{ Junaidden, S.M; 2005} & \multirow{2}{*}{ 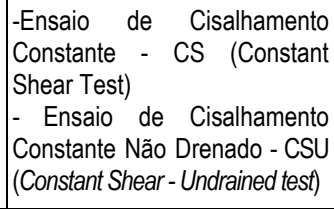 } & \multirow{2}{*}{$\begin{array}{l}\text { Solo residual granítico (35\% } \\
\text { pedregulho, } 51-55 \% \text { areia, } 8- \\
14 \% \text { silte, } 1-2 \% \text { argila). Solo } \\
\text { arenoso }\end{array}$} & $\begin{array}{l}\text { Beacon Hill, Hong } \\
\text { Kong }\end{array}$ & \multirow{2}{*}{ Alterada } & \multirow{2}{*}{ SIM } & $\begin{array}{l}\text { Adensamento isotrópico até tensão efetiva media de } \\
27 \text { a } 127 \mathrm{kPa} \text {, após cisalhamento drenado até } \mathrm{Kc}= \\
1.6 \text { a } 1.8 ; 2.1 \text { a } 2.9 \text { (42 a } 154 \mathrm{kPa})\end{array}$ & Aumento de poropressão de 4 a $30 \mathrm{kPa} / \mathrm{hr}$ \\
\hline & & & $\begin{array}{l}\text { Shau Kei Wan, } \\
\text { Hong Kong }\end{array}$ & & & $\begin{array}{l}\text { Adensamento isotrópico até tensão efetiva media de } \\
27 \text { a } 127 \mathrm{kPa} \text {, após cisalhamento drenado até } \mathrm{Kc}= \\
1.7(42 \text { a } 125 \mathrm{kPa})\end{array}$ & Aumento de poropressão de $10 \mathrm{kPa} / \mathrm{hr}$ \\
\hline \multirow[t]{2}{*}{ Ng, K.Y ; 2007} & \multirow{2}{*}{$\begin{array}{l}\text { Pore pressure Reinflation Test } \\
\text { (PPR) }\end{array}$} & \begin{tabular}{|l|} 
Tufo e lava riolitica intemperizada \\
(1,3\% pedregulho; $13,7 \%$ areia; \\
$60,3 \%$ silte; $24,7 \%$ argila)
\end{tabular} & $\begin{array}{c}\text { Tung Chung, Isla } \\
\text { Lantau, Hong Kong }\end{array}$ & \multirow[t]{2}{*}{ Inalterada } & \multirow[t]{2}{*}{ SIM } & \multirow{2}{*}{$\begin{array}{l}\text { Adensamento Isotrópico até tensão efetiva media de } \\
200 \mathrm{kPa} \text {, após cisalhamento drenado até q=100kPa } \\
\text { (25\% da max resistência), 200,300 kPa }\end{array}$} & \multirow{2}{*}{$\begin{array}{l}\text { e - Aumento de poropressão de } 0,5-100 \mathrm{kPa} / \mathrm{hr} \\
\text { a - Aumentos de poropressão escalonados cada hora } \\
\text { de } 5-50 \mathrm{kPa} \\
\text { - Aumentos de poropressão } 54-77 \mathrm{ln} \mathrm{kPa} / \mathrm{hr}\end{array}$} \\
\hline & & $\begin{array}{|lc|}\text { Tufo } & \text { cristalino intemperizado } \\
(8,9 \% & \text { pedregulho; } 17,1 \% \text { areia; } \\
48,6 \% \text { silte, } 25,5 \% \text { argila }) \\
\end{array}$ & $\begin{array}{c}\text { Pui O, Isla Lantau, } \\
\text { Hong Kong }\end{array}$ & & & & \\
\hline Slongo, G. R; 2008 & Aumento de Poropressão & $\begin{array}{l}\text { Solo residual de biotita de } \\
\text { gnaisse }(52 \% \text { areia, } 35 \% \text { silte, } \\
14 \% \text { argila }- \text { LL } 39,2 \% ; \mid I P 11,2 \%)\end{array}$ & $\begin{array}{l}\text { Parque Nacional } \\
\text { Dois Irmãos, Alto } \\
\quad \text { Leblon, RJ }\end{array}$ & Inalterada & SIM & $\begin{array}{l}\text { Adensamento isotrópico até tensão efetiva media de } \\
125 \text { e } 220 \mathrm{kPa} \text {, após aplicação de tensão desviadora } \\
\text { na condição s' constante até } 30,60 \text { e } 75 \mathrm{kPa}\end{array}$ & $\begin{array}{l}\text { Aumento de poropressão (taxa de aumento não } \\
\text { indicada) }\end{array}$ \\
\hline Silveira, R.M.; 2008 & CSD & $\begin{array}{l}\text { Solo coluvionar (1\% pedregulho, } \\
\text { 18\%areia, 47\% silte, 34\% argila - } \\
\text { LL 55\%; IP 19\%) }\end{array}$ & $\begin{array}{c}\text { São Vendelino, Rio } \\
\text { Grande do Sul }\end{array}$ & Alterada & SIM & $\begin{array}{l}\text { Adensamento isotrópico até tensão efetiva media de } \\
30 \mathrm{kPa} \text {, após cisalhamento drenado até } 24 \mathrm{kPa}\end{array}$ & $\begin{array}{l}\text { Aumento de poropressão (taxa de aumento não } \\
\text { indicada) }\end{array}$ \\
\hline Carey, J.M; 2011 & $\begin{array}{l}\text { Pore pressure Reinflation Test } \\
\text { (PPR) }\end{array}$ & $\begin{array}{l}\text { Solo argiloso (Gault Clay; } 44- \\
47 \% \text { areia, } 39-48 \% \text { silte, } 6- \\
14 \% \text { argila) }\end{array}$ & $\begin{array}{l}\text { Ventnor } \\
\text { Undercliff,Isla de } \\
\text { Wight, UK }\end{array}$ & \begin{tabular}{|l|} 
Inalterada \\
|Alterada
\end{tabular} & SIM & $\begin{array}{l}\text { Adensamento Isotrópico até tensão confinante media } \\
\text { de } 250-550 \mathrm{kPa} \text {, após cisalhamento drenado até } \\
q=400 \text { a } 500 \mathrm{kPa}\end{array}$ & $\begin{array}{l}\text { Aumento de poropressão de } 5-18 \quad \mathrm{kPa} / \mathrm{hr} \\
\text { Realizou-se } 1 \text { ensaio a } 10 \mathrm{kPa} / \mathrm{hr} \text { (cada } 24 \mathrm{horas}) \\
\text { por } 524 \text { dias }\end{array}$ \\
\hline Lourenço et al., 2011 & $\begin{array}{l}\text { Ensaio Drenado de } \\
\text { Cisalhamento Constante } \\
\text { Modificado (Modified CSD test) }\end{array}$ & Areia & $\begin{array}{l}\text { Toyoura, Tottori, } \\
\text { Japão }\end{array}$ & Alterada & SIM & $\begin{array}{l}\text { Adensamento isotrópico até tensão efetiva media de } \\
50 \mathrm{kPa} \text {, após cisalhamento drenado até } \mathrm{Kc}=2,0 \text { a } 3,3\end{array}$ & $\begin{array}{l}\text { Aumento de poropressão por um extremo } \\
\text { permitindo drenar pelo outro a } 0,84-1,08 \mathrm{kPa} / \mathrm{min}\end{array}$ \\
\hline Chu et al., 2012 & $\begin{array}{l}\text { Ensaio Drenado de } \\
\text { Cisalhamento Constante - CSD } \\
\text { (Constant Shear Drained Test) }\end{array}$ & Areia marina dragada & Changi, Cingapura & Alterada & SIM & $\begin{array}{l}\text { Adensamento isotrópico até tensão efetiva media de } \\
150 \mathrm{kPa} \text {, após cisalhamento drenado até } q / p^{\prime}=0,81\end{array}$ & $\begin{array}{l}\text { Redução de tensão de confinamento a 0,1; } 1 ; 3 \text { e } 5 \\
\mathrm{kPa} / \mathrm{min}\end{array}$ \\
\hline
\end{tabular}




\section{3. \\ Principais características dos movimentos de massa do tipo fluxo induzido por chuvas}

Os movimentos de massa induzidos por chuvas, do tipo fluxo (Hungr et al., 2001), muitas vezes representam uma ameaça significativa para as populações e estruturas, sendo caracterizados por percorrer longas distâncias (centenas de metros) e pelas altas velocidades (na ordem de metros/segundo).

Estes movimentos de massa podem ser desencadeados em muitos contextos geoambientais e geralmente envolvem depósitos de solos superficiais de variada classificação e origem. Em áreas de encostas com coberturas superficiais semelhantes e características de precipitação uniformes, tais movimentos de massa podem ocorrer ao mesmo tempo (como registrado em áreas de até dezenas de $\mathrm{km}^{2}$ ).

Exemplos significativos são aqueles que envolvem depósitos piroclásticos na América Central (Capra et al., 2003), Nova Zelândia (Ekanayake e Phillips, 2002) e na Itália (Cascini, 2004); solos intemperizados em Hong Kong (Take et al., 2004) e Japão (Wang et al., 2002); assim como depósitos coluvionares no Brasil (Lacerda, 2004) e Hong Kong (Fuchu et al., 1999).

Os movimentos de massa do tipo fluxo podem ser considerados fenômenos complexos de instabilidade de encostas, uma vez que apresentam diferentes características cinemáticas durante os estágios de ruptura, pósruptura e propagação (Fell et al., 2000; Hungr et al., 2001; Leroueil, 2004).

Os estágios de ruptura e pós-ruptura ocorrem dentro das chamadas áreas de origem dos movimentos de massa. $O$ estágio de ruptura se caracteriza pela formação de uma superfície contínua de cisalhamento através de toda a massa de solo (Leroueil, 2004). O estágio pós-ruptura é representado pela geração rápida de grandes deformações plásticas e a consequente aceleração repentina da massa rompida de solo (Hungr, 2003). O estágio de propagação inclui o movimento da massa rompida de solo, a partir das áreas de origem do movimento para as áreas de deposição, onde a massa rompida para.

\subsection{1.}

\section{Estágio de ruptura}

O início da ruptura de movimentos de massa superficiais induzidos por precipitações está estritamente relacionado com o aumento da poropressão e à consequente redução das tensões efetivas médias (Anderson e Sitar, 1995; 
Alonso et al., 1995; Iverson et al., 1997). De acordo com Leroueil (2001), o estágio de ruptura dos movimentos de massa superficiais do tipo fluxo em encostas, induzidos pelas chuvas, é geralmente um processo drenado, isto é, não há variações de poropressões induzidas pela mudança do volume do solo. Pode ser assumido que o processo se desenvolve sob tensões normais totais constantes (Anderson e Sitar, 1995), a trajetória de tensões in situ geral pode ser descrita por uma trajetória de tensões de cisalhamento constante associada a um aumento da razão entre a tensão desviadora, q, e a tensão efetiva média, p'.

$\mathrm{O}$ incremento de poropressão é frequentemente associado à chuva que se infiltra diretamente na superfície do talude e às caraterísticas hidrogeológicas da rocha subjacente, que podem impor condições de contorno hidráulicas severas na parte inferior dos depósitos superficiais (Figura 2.2). Exemplos típicos disso são a elevação do lençol freático no maciço rochoso (Montgomery et al., 1997; Leroueil, 2004; Lacerda et.al., 1997) e/ou presença de afloramentos de água (springs) do maciço rochoso (Anderson e Sitar, 1995; Anderson et al., 1997; Lacerda, 2004).

\subsection{2.}

\section{Estágio de pós-ruptura}

$\mathrm{Na}$ literatura, a aceleração da massa rompida durante o estágio de pósruptura é atribuída a diferentes causas. No entanto, a maioria das pesquisas identifica como principal causa o desenvolvimento de condições não drenadas, totais ou parciais, capazes de produzir poropressões elevadas durante o cisalhamento.

Particularmente, referindo-se a diferentes tipos de estágios de pós-ruptura, Cascini et al. (2010) descreveram a existência de três principais classes de fenômenos: escorregamentos (slides), flowslide e transformação do escorregamento para fluxo (slide to flow).

Escorregamento (slide) é uma ruptura de talude que ocorre sob condições drenadas. Em contraste, um flowslide acontece quando se desenvolvem condições parciais ou totalmente não drenadas. Este é o caso típico do solo saturado fofo sob cisalhamento (e.g. liquefação estática); flowslides estão associados ao aumento de poropressões. Por outro lado, a transição de escorregamento para um fluxo (slide to flow) é causada por rupturas locais que produzem uma variação na geometria da encosta. Este mecanismo está associado ao excesso de poropressão transiente localizado, que não está associado a condições não drenadas, mas é gerado por variações locais das 
condições de contorno hidráulicas, na parte inferior do depósito de solo superficial.

Cascini et al. (2010) afirmaram que, não obstante as diferenças anteriores, para todas as tipologias de movimentos de massa, a eventual aceleração súbita da massa rompida (estágio de pós-ruptura) é uma consequência ao invés de uma causa do processo de instabilidade de um talude, como demonstrado experimentalmente por Eckersley (1990) e Chu et al. (2003).

\section{4 .}

\section{Estado crítico, estado permanente e parâmetro de estado}

De acordo com Roscoe et al. (1958), o estado crítico pode ser definido como a condição de uma amostra em que grandes distorções cisalhantes ocorrem sem variação de tensão efetiva nem de volume específico.

Poulos (1981) definiu o estado de deformação permanente (steady state of deformation) como o estado em que uma massa de partículas está deformando continuamente com velocidade constante, sem variar de volume, sob tensões cisalhante e confinante efetiva constantes. Ainda, enfatizou que no estado de deformação permanente as deformações ocorrem com velocidade constante, e que, somente após a quebra e orientação de partículas, esta condição se estabelece de fato. A contribuição de Castro e associados foi significativa para a compreensão do estado de deformação permanente (Castro 1969, Castro et al., 1982).

Embora as duas definições pareçam muito similares, exceto, possivelmente, pela referência feita a uma velocidade constante de deformação no caso do estado permanente, diversos autores tem discutido se as linhas de estado crítico e de estado permanente são as mesmas ou não (Casagrande, 1975; Poulos, 1981; Sladen et al., 1985; Alarcon-Guzman et al., 1988; Been et al., 1991). De acordo com Been et al. (1991), "as diferenças parecem residir nos métodos de obtenção. Os pesquisadores do estado crítico, em geral se basearam em ensaios triaxiais de deformação controlada sob solicitação drenada, realizados em amostras dilatantes, para determinar o estado crítico. $\mathrm{O}$ estado permanente é obtido em ensaios de tensão controlada sob solicitação não drenada, geralmente em amostras fofas (contrativas)". Considerando que os conceitos apresentados são equivalentes, Poorooshasb e Consoli (1991) sugerem o uso do termo "estado último" para definir o comportamento de solos arenosos. 
Been et al. (1991) realizaram um extenso programa de ensaios de compressão triaxial monotônicos drenados e não drenados em areia (areia de Erksak) e encontraram as linhas de estado crítico e de estado permanente coincidentes e independentes das trajetórias de tensão. Os autores acreditaram que os estados crítico e permanente são idênticos. Em um diagrama e-log p', a linha correspondente ao estado crítico (LEC) ou linha de estado permanente (Steady State Line - SSL) é frequentemente caracterizada por sua inclinação $\lambda$ (Figura 2.14).

Been e Jefferies (1985) propuseram o parâmetro de estado $\psi$ para caracterizar o comportamento de areias, onde $\psi$ é definido em um diagrama e vs log p' (Figura 2.14) como a diferença entre o índice de vazios de interesse $e_{o}(e m$ um ponto tal como I) e o índice de vazios na linha de estado permanente (ou LEC) $e_{L E C(I)}$ sob a mesma tensão efetiva média, $\psi=e_{o}-e_{s s}$.

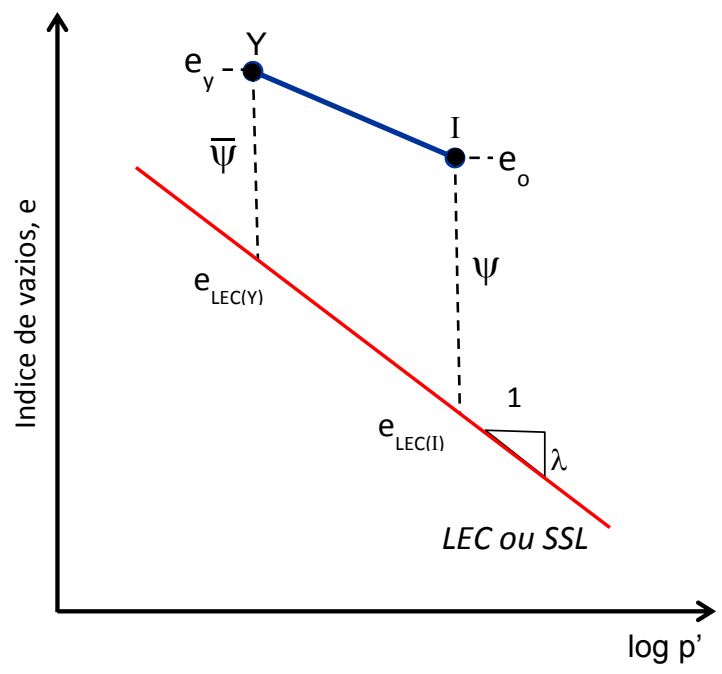

$$
\begin{aligned}
& \psi=\mathrm{e}_{\mathrm{o}}-\mathrm{e}_{\operatorname{LEC}(\mathrm{I})} \\
& \bar{\psi}=\mathrm{e}_{\mathrm{y}}-\mathrm{e}_{\operatorname{LEC}(\mathrm{Y})}
\end{aligned}
$$

$\Psi$ = parâmetro de estado

$\Psi$ = parâmetro de estado modificado

$\mathrm{e}_{\mathrm{o}}=$ índice de vazios no ponto inicial

$e_{y}=$ índice de vazios no ponto de escoamento

$\mathrm{e}_{\text {LEC }}=$ índice de vazios no estado crítico sob a mesma tensão média efetiva

Figura 2.14 - Definição do parâmetro de estado $\psi$ e do parâmetro de estado modificado $\bar{\psi}$ (adaptado de Chu et al., 2003)

O parâmetro de estado $\psi$ definido na Figura 2.14 tem sido utilizado para avaliar o comportamento dos solos. Elementos de solo com condições de estado abaixo da LEC $(\psi<0)$ são associados a um comportamento dilatante em ensaios não drenados, enquanto elementos de solo com condições de estado acima da LEC $(\psi>0)$ são associados a um comportamento contráctil. Se $\psi$ é grande o suficiente, pode ocorrer alguma deformação por amolecimento (strain softening) durante o carregamento não drenado.

O parâmetro de estado também tem sido usado para interpretar ensaios in situ e prever corrida de detritos. Lee et al. (1988), sugeriram a avaliação do 
potencial de fluxo de detritos considerando a posição do índice de vazios e a condição da tensão efetiva iniciais (I na Figura 2.14) em relação à LEC do solo. A partir de observações de campo e de ensaios de laboratório realizados a solos provenientes de locais propensos ao desenvolvimento de fluxos de detritos, eles encontraram uma associação entre os estados iniciais encontrados acima da linha de estado crítico e a ocorrência de fluxo de detritos, enquanto, os estados iniciais próximos ou abaixo da linha de estado crítico correspondem a movimentos lentos e rupturas não-desintegradoras.

No entanto, de acordo com Leroueil e Hight (2003), $\psi$ tem sido definido a partir de ensaios não drenados frequentemente realizados após adensamento isotrópico e é, consequentemente, associado a um determinado tipo de ensaio. Ele pode não se aplicar a outros tipos de ensaio, tais como os ensaios de aumento de poropressão. Isto pode ser ilustrado por resultados de ensaios de aumento de poropressão realizados por Anderson e Sitar (1995) e Anderson e Riemer (1995) em um solo coluvionar argiloso da California, e por Santos et al. (1996) em um solo residual do Rio de Janeiro, onde a dilatância foi observada, em vez da contração esperada (vide item 2.2.4).

Leroueil (2001) indicou que o comportamento de instabilidade de um solo ao longo de uma trajetória de tensão de cisalhamento constante pode ser esquematicamente descrita usando a linha de estado crítico (LEC) mostrada na Figura 2.14. Leroueil enfatizou o fato que no contexto das encostas, a possibilidade de liquefação não é controlada pela posição relativa das condições de tensão iniciais, ponto I, em relação à LEC, ou parâmetro de estado $\psi$, como sugerido por Lee et al. (1988) mas sim pela posição relativa do ponto no escoamento $Y$ (Figura 2.14) com respeito à LEC, o parâmetro de estado $\bar{\psi}$. Para evitar divergência de conceitos, Chu et al. (2003) chamou a $\bar{\psi}$ de "parâmetro de estado modificado".

Leroueil (2001) explicou esse comportamento da seguinte forma (ver Figura esquemática 2.15). Se as condições iniciais de tensão estão no ponto I, nas Figuras 2.15 (a) e (b), e se a tensão efetiva média é diminuída, acontece primeiro uma alteração de volume do solo, geralmente expansão, e o escoamento (yielding) é atingido em um ponto, como por exemplo $Y$. Este último ponto pode estar na linha de estado crítico (LEC) ou de deformação permanente, como mostrado na Figura 2.15 (a), ou acima, no caso de solos densos ou microestruturados, ou abaixo, na superfície de colapso no caso de areias fofas. 

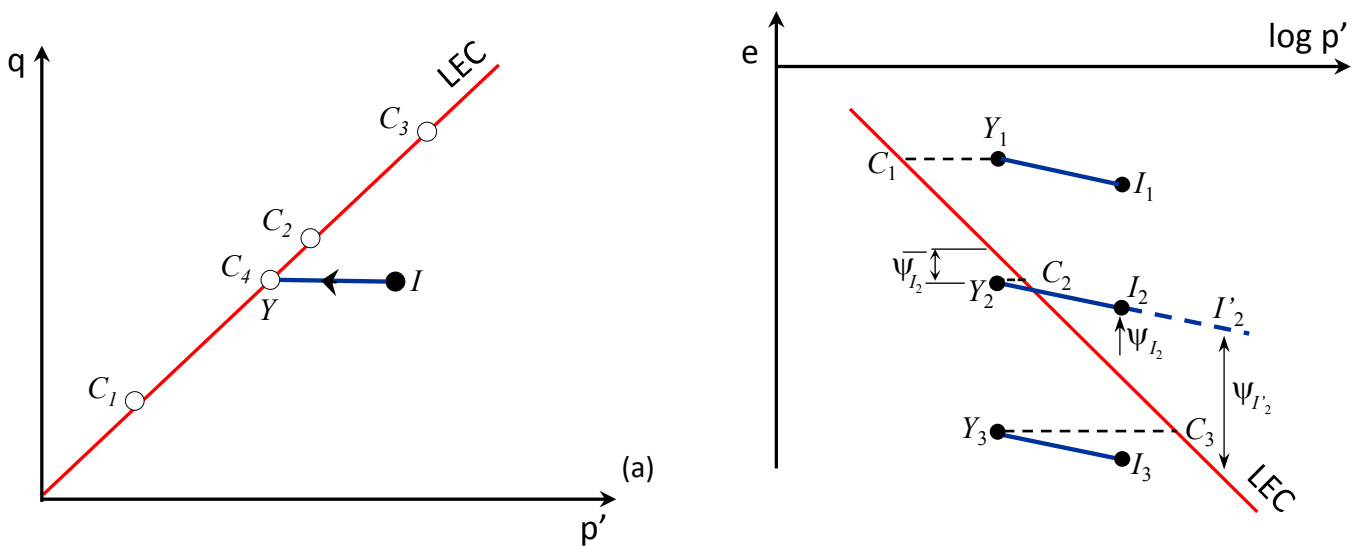

(b)

Figura 2.15 - Trajetória de tensão seguida em um ensaio APP (esquemático). Em (a) Y pode estar acima ou abaixo da linha de estado crítico, dependendo do solo considerado (adaptado de Leroueil e Hight, 2003).

Se as condições iniciais estão no ponto $I_{1}$, bem acima da LEC, o solo no escoamento, $Y_{1}$, está acima da LEC (Figura 2.15b); para condições de pósruptura não drenadas, a resistência última, em $\mathrm{C}_{1}$ é menor do que a tensão de cisalhamento aplicada inicialmente, e o escoamento é seguido pelo colapso não drenado e o fluxo da massa do solo. Tal condição corresponde a areia de Monterey (Figura 2.6 a). Se as condições iniciais estiverem no ponto $\mathrm{I}_{3}$, abaixo da LEC, o escoamento iniciará em $Y_{3}$ (Figura 2.15b). O estado último em condições não drenadas, $C_{3}$, corresponde então a uma resistência maior do que a tensão de cisalhamento no escoamento e, portanto, é estabilizante.

Para o caso intermediário com condições iniciais de tensão, $\mathrm{I}_{2}$, acima da LEC e escoamento, $Y_{2}$, abaixo (Figura 2.15b), o solo seria dilatante com uma tendência para expandir em direção à LEC.

Segundo Leroueil e Hight (2003), o solo coluvionar estudado por Anderson e Sitar (1995) e Anderson e Riemer (1995), bem como o solo residual ensaiado por Santos et al. (1996) parecem corresponder ao caso 2, com comportamento contráctil em ensaios não drenados $\mathrm{CKU}$, e comportamento dilatante em ensaios drenados de aumento de poropressão. Nesses ensaios, o potencial para a instabilidade do solo, portanto, é controlado pelo parâmetro de estado modificado no escoamento, $\bar{\psi}_{\mathrm{I} 2}$ (Figura $2.15 \mathrm{~b}$ ), e não pelo parâmetro de estado $\psi_{\mathrm{I} 2}$ associado com condições de estado inicial (após o adensamento). 


\section{3 \\ Características dos locais estudados e amostragem}

Para a realização da presente tese foram escolhidos três solos característicos de ambientes tropicais: dois coluvionares ou coluviais, e um residual jovem ou saprolítico, provenientes de encostas localizadas em diferentes áreas do Estado de Rio de Janeiro. A escolha destes solos deve-se ao fato de já terem sido estudados por outros pesquisadores, estando à disposição informações bastante úteis para esta pesquisa, além da facilidade de acesso às áreas.

O primeiro solo estudado é um solo coluvionar localizado no Campus Avançado da PUC-Rio em Tinguá, no município de Nova Iguaçu, RJ. Nessa região foram registrados alguns movimentos de massa, o que levou a realização de diversas pesquisas na área, como a de De Campos (2012), Galindo (2013) e Menacho (2014), além de outras investigações que estão sendo desenvolvidas em paralelo à deste trabalho.

O segundo solo estudado corresponde a um perfil de solo residual jovem ou saprolítico, proveniente de uma rocha migmatítica, no município de Duque de Caxias, RJ. Este solo foi amplamente estudado por Carvalho (2012), que constatou a presença de agentes cimentantes na sua composição.

O terceiro é um solo coluvionar, localizado na encosta do campus principal da PUC-Rio, RJ. Este solo tem sido objeto de diversas teses e dissertações (e.g. Marinho, 1986; Lins, 1991; Daylac, 1994; Beneveli, 2002; Duarte, 2004; Soares, 2005; Hurtado, 2010; Galindo, 2013). Estes pesquisadores utilizaram esse solo para realizar ensaios especiais e testar equipamentos desenvolvidos na PUC-Rio.

\section{1.}

\section{Campus Avançado da PUC - Tinguá}

\subsection{1.}

\section{Localização}

O Campus Avançado da PUC-Rio está localizado no bairro de Tinguá, no entorno da Reserva Biológica do Tinguá, na área correspondente ao município de Nova Iguaçu, no Estado do Rio de Janeiro, conforme indicado na Figura 3.1. 


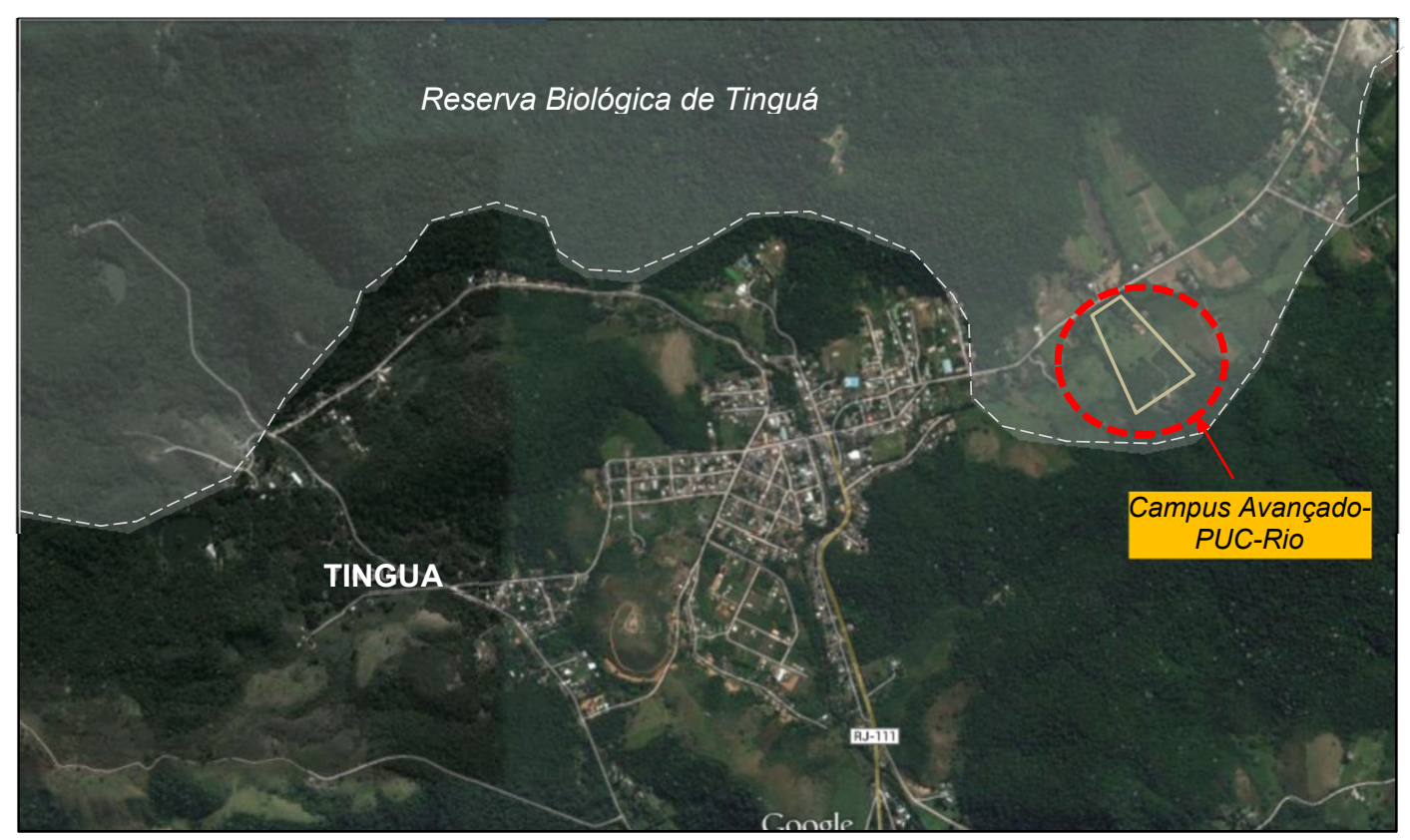

Figura 3.1 - Plano de localização do Campus Avançado da PUC-Tinguá (Google Earth, 2014)

\subsection{2.}

\section{Geologia e geomorfologia}

Conforme De Campos (2012), quatro unidades litológicas principais podem ser observadas na região do Maciço de Tinguá, a saber: o Biotita Gnaisse (Migmatito) e o Granito Foliado (Granito Gnaisse) da Unidade Rio Negro, o Leucognaisse do Batólito Serra dos Órgãos, e as alcalinas do Maciço Alcalino de Tinguá. Foi possível observar que quase a totalidade dos afloramentos são de rochas gnáissicas.

A área estudada pertence ao Batólito da Serra dos Órgãos, sendo caracterizada por leucognaisses. De um modo geral, esta unidade litológica é constituída por minerais com granulação média a fina, sendo constituídos essencialmente por quartzo, feldspato e biotita com textura granular.

Geomorfologicamente, a região caracteriza-se pela presença de um grande número de colinas com cristas vertentes e convexas, que tendem a ser em maior número à medida que se aproximam do maciço do Tinguá e dos contrafortes da Serra do Mar (Araújo, 2008).

A Reserva Biológica do Tinguá está formada por cinco bacias hidrográficas, e é caracterizada por depósitos de grandes espessuras de tálus e colúvios nos talvegues, e por solos residuais pouco espessos ou inexistentes nas partes mais altas. 


\subsection{3.}

\section{Aspectos climáticos}

O clima da região do Tinguá, segundo a classificação de Köppen, é do tipo Cwb, correspondente ao Clima Tropical de Altitude, possuindo verões amenos e chuvas típicas da estação, ou seja, de grande intensidade, porém com baixa duração, sendo pouco pronunciada nos pontos mais altos na estação seca.

A temperatura média anual de toda a região varia entre $13^{\circ} \mathrm{C}$ e $23^{\circ} \mathrm{C}$, com uma pluviosidade média entre $1500 \mathrm{~mm}$ e $2600 \mathrm{~mm}$, distribuída de forma heterogênea entre as estações. O verão e a primavera são as estações mais chuvosas em detrimento do inverno e outono, que por sua vez, possuem as menores médias de precipitação (De Campos, 2012).

\subsection{4. \\ Características do local estudado}

Os taludes das encostas da região onde se encontra a área de estudo apresentam declividades médias de $25^{\circ}$, com presença de vegetação graminóide. O solo coluvionar é de tonalidade avermelhada com presença de pequenos grãos de quartzo e com fragmentos de rochas pegmatíticas quartzofeldspáticas brancas. A Figura 3.2 mostra a área específica estudada.

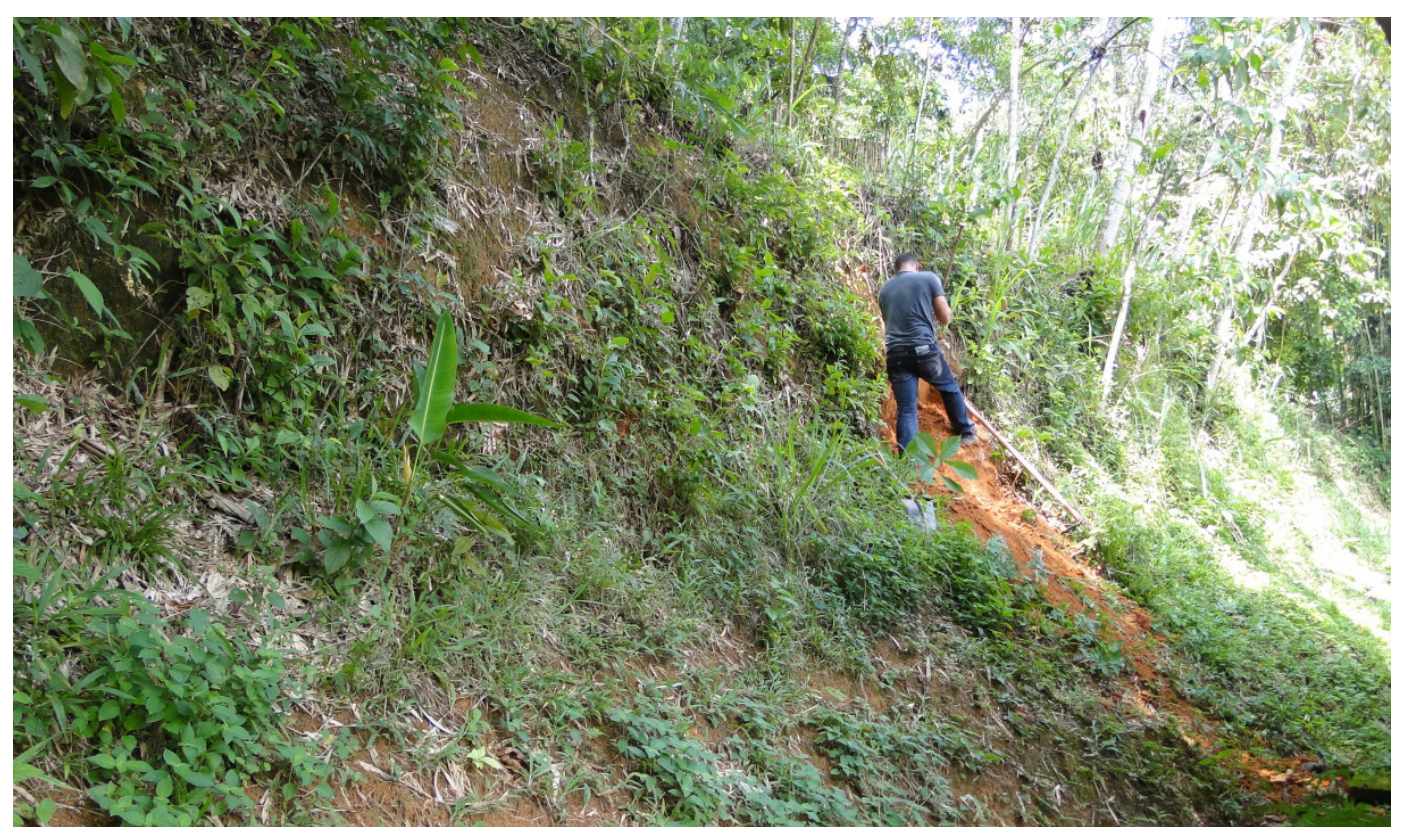

Figura 3.2 - Vista da base da encosta onde se realizou a amostragem do solo no Campus Avançado da PUC - Tinguá 


\section{2. \\ Duque de Caxias}

\subsection{1.}

Localização

A área de estudo está situada no município de Duque de Caxias-RJ, na rua vicinal Boa Vista, na altura do km 13 da Rodovia Washington Luiz, tal como mostrado na Figura 3.3, onde se indicam pontos de fácil identificação para auxilio na sua localização.

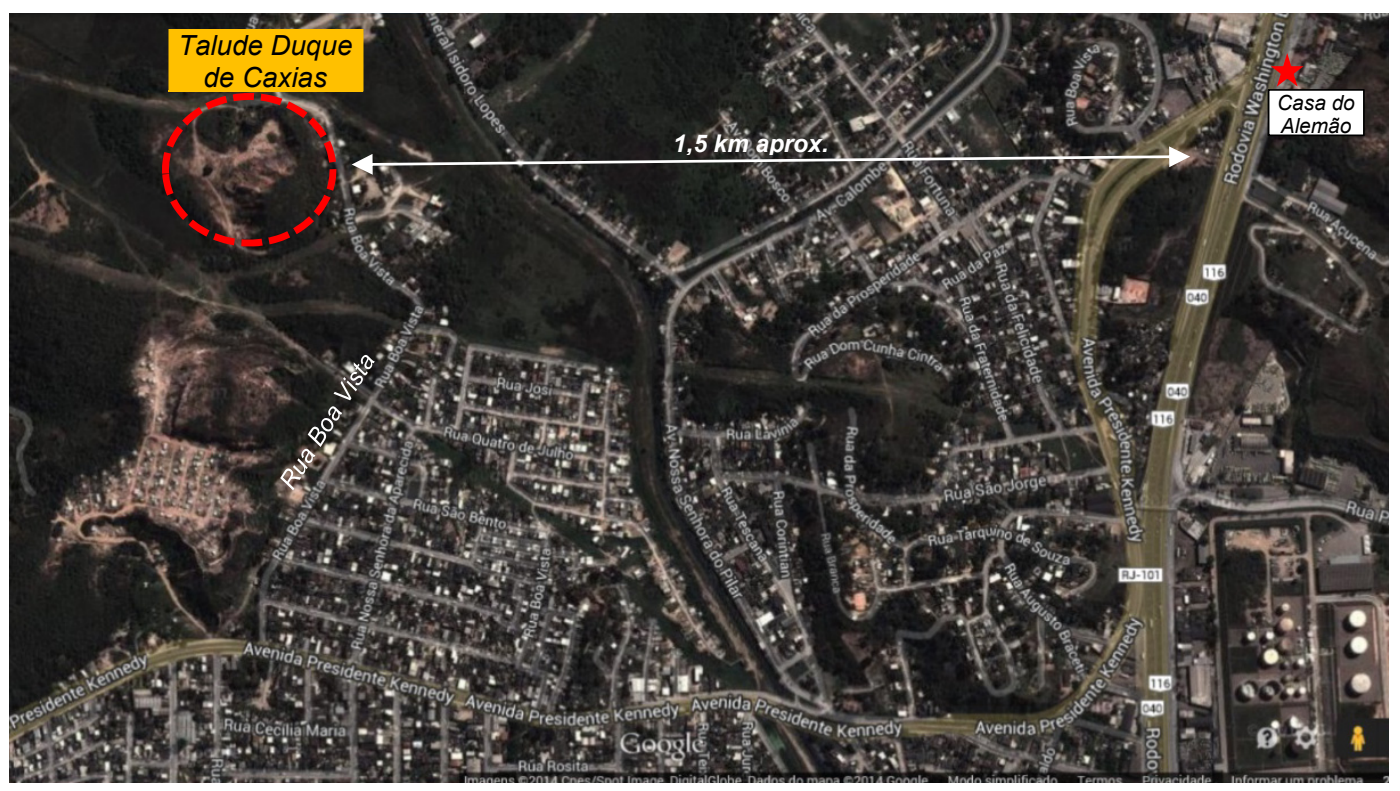

Figura 3.3 - Plano de localização da área estudada em Duque de Caxias (Google Earth, 2014)

\subsection{2.}

\section{Geologia e geomorfologia}

A área está inserida no Batólito Serra dos Órgãos. Esta formação está constituída por Ortognaisses cuja composição varia de granítica a granodiorítica, tendo o metamorfismo modificado a estrutura das rochas, mas não sua composição mineralógica essencial (Polivanov, 1998). Os mesmos são compostos basicamente por microclina amendoada, quartzo grosseiro, plagioclásio e hornblenda (Penha et al., 1981). As encaixantes dos batólitos são rochas migmatizadas atribuídas à unidade Rio Negro. Numerosos enclaves máficos e restos das rochas encaixantes podem ser encontrados em seu interior. Corpos tabulares de leucognaisse também ocorrem associados ao granitoide (Heilbron et al., 1995). 


\subsection{3.}

\section{Aspectos climáticos}

Segundo a classificação de Köppen, esta área apresenta clima quente e úmido, com estação chuvosa no verão e seca no inverno, com os verões mais quentes do que no litoral.

\subsection{4.}

\section{Características do local estudado}

O perfil de solo presente na área é resultado de processos intempéricos de um migmatito extremamente fraturado. Observa-se a presença de duas feições distintas, dispostas de forma aleatória: a leucocrática (constituída por quartzo-kfeldspato e pobre em minerais máficos), e a melanocrática (rica em minerais máficos, principalmente biotita). Estas feições formam um maciço heterogêneo, não sendo possível no campo perceber a evolução da alteração no sentido vertical, uma vez que a resistência dos minerais ao intemperismo em cada feição é diferente (Antunes, 2015). Contudo é possível identificar solos residuais provenientes destas feições. Observa-se sistemas de fraturas sub-horizontais e sub-verticais com diversos mergulhos nas duas feições.

$\mathrm{Na}$ presente tese optou-se por trabalhar com o solo residual jovem ou saprolítico proveniente da feição melanocrática, o qual possui um alto teor de finos e presença marcante de minerais máficos. $\mathrm{Na}$ área de estudo o talude apresenta declividade elevada, sem presença de vegetação, conforme observado na Figura 3.4.

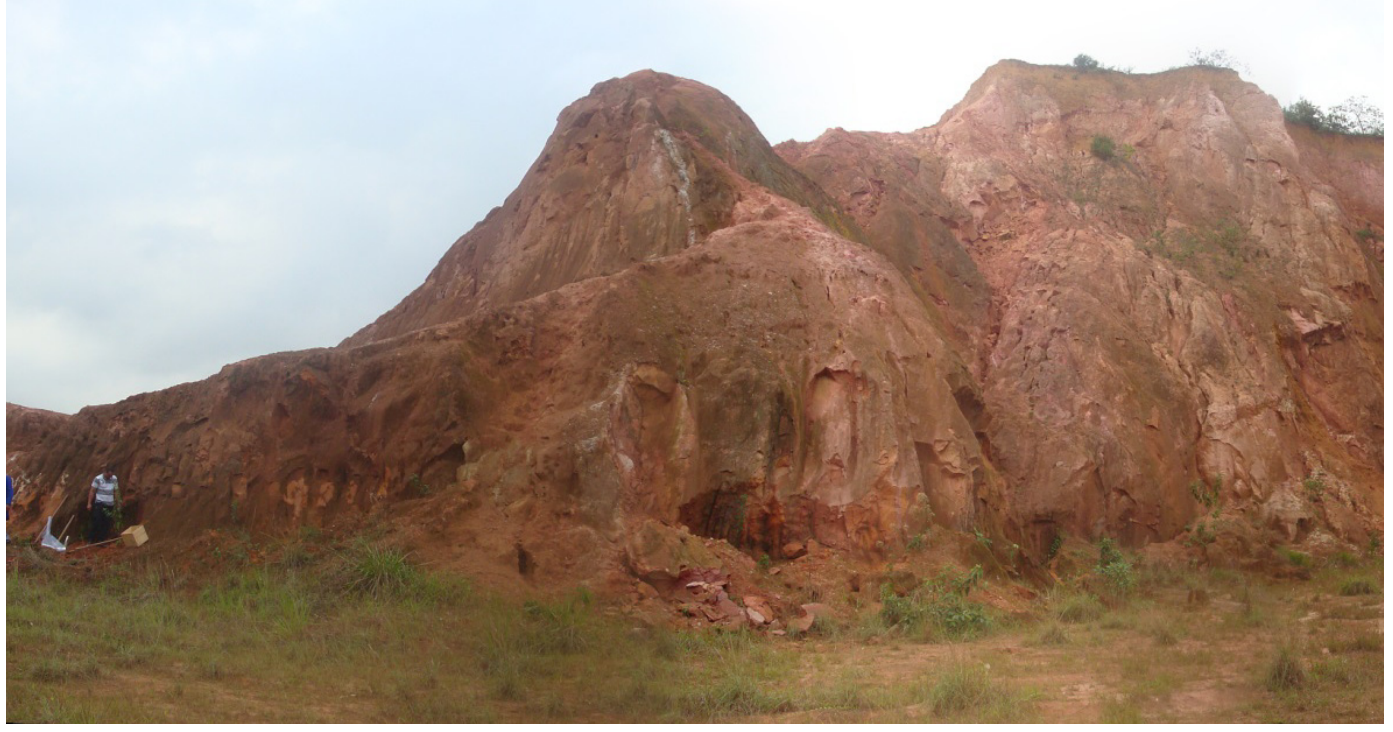

Figura 3.4 - Vista da encosta onde se realizou a amostragem do solo em Duque de Caxias 
Através da análise tátil-visual, detectou-se que o solo é rico em biotita alterada, possui grande teor de areia fina e contém uma grande concentração de ferro, o que the garante uma maior resistência à desagregação por erosão. $O$ solo possui coloração variada em tons, roxo, vermelho e amarelo em diversas zonas, com concreções pretas, e apresenta brilho caraterístico de um solo micáceo, o que foi comprovado nas análises mineralógicas, que serão apresentadas posteriormente.

\section{3.}

\section{Campo Experimental II PUC-Rio}

\subsection{1.}

\section{Localização}

O Campo Experimental II situa-se no interior do Campus da Gávea da Pontifícia Universidade Católica do Rio de Janeiro, na encosta localizada ao lado da autoestrada Lagoa-Barra, conforme mostrado na Figura 3.5.

\subsection{2. \\ Geologia e geomorfologia}

O Campo Experimental II da PUC-Rio está inserido no maciço da Tijuca, que se caracteriza por apresentar biotita-plagioclásio-gnaisses, microclinagnaisses, leptinitos/granitos e granodioritos (Brito, 1981).

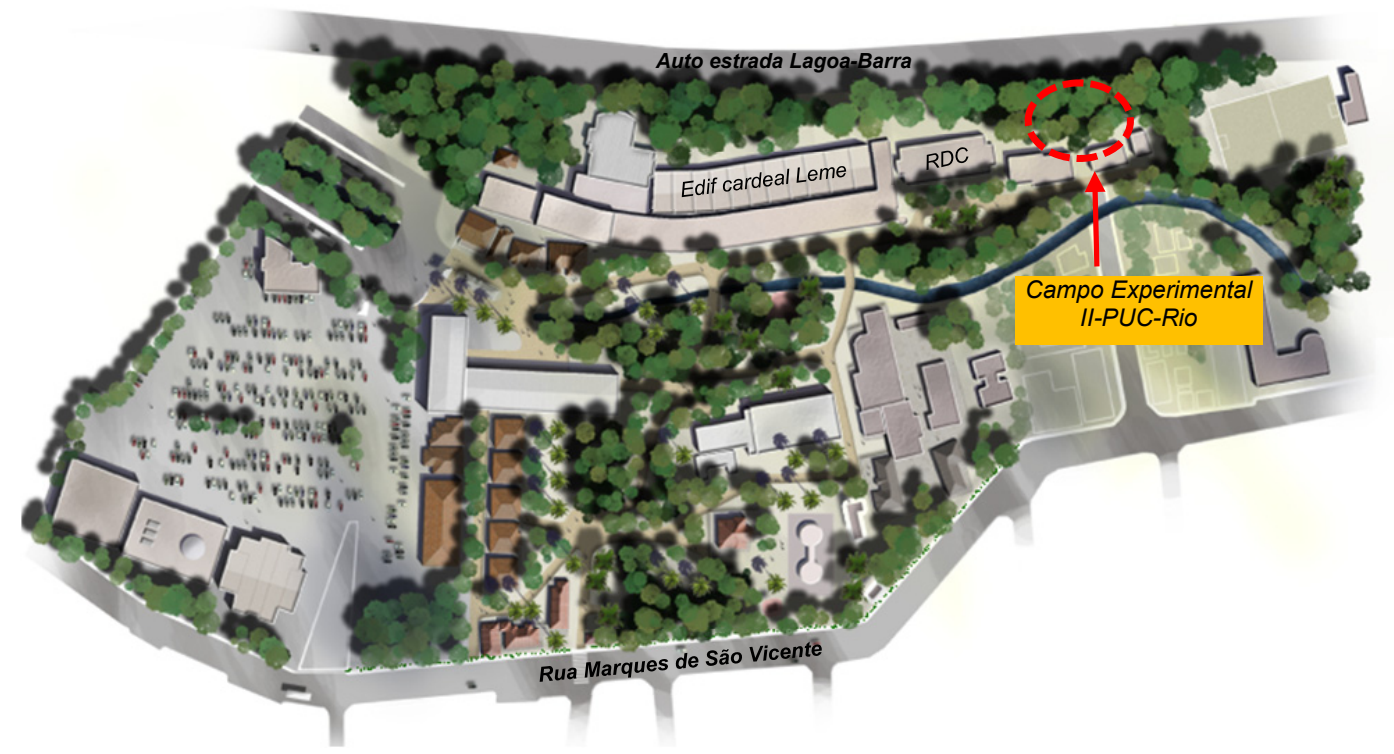

Figura 3.5 - Localização do Campo Experimental II da PUC-Rio 
Segundo Sertã (1986) o embasamento local é constituído por um gnaisse cataclástico (rocha alterada de alto grau de metamorfismo) do tipo granadabiotita-plagioclásio-gnaisse, com textura granulolepidoblástica, referido ao PréCambriano de idade não determinada. Tal tipo de gnaisse é constituído, principalmente por quartzo, feldspato e biotita, tendo como minerais acessórios a muscovita e a granada.

Brito (1981) destaca que a geomorfologia do município de Rio de Janeiro caracteriza-se pela presença de morros que se elevam bruscamente, quase sem a transição da planície. A feição abrupta e declividade elevada apresentada na encosta da PUC-Rio ratificam as referidas características.

\subsection{3.}

\section{Aspectos climáticos}

Segundo Brito (1981) a região em estudo pertence a uma Zona Megatérmica com clima tropical úmido chuvoso, dentro da variedade Af da Classificação Climática de Köppen, tendo no mês mais seco precipitação superior a $60 \mathrm{~mm}$ e no mês mais frio temperatura superior a $18^{\circ} \mathrm{C}$. A pluviosidade média da região gira em torno de 1.800 a $2.000 \mathrm{~mm}$ anuais.

A análise climática da região indica condições para o desenvolvimento de solos profundos, bem desenvolvidos, com tendência acentuada para acidez e com um processo de intemperismo bem caracterizado.

\subsection{4.}

\section{Características do local estudado}

No Campo Experimental II não existem afloramentos rochosos, o manto do solo é muito desenvolvido.

A área da encosta estudada apresenta declividade inferior a $25^{\circ}$, com presença de vegetação arbustiva, como mostrado na Figura 3.6. No local constatou-se a presença de um solo coluvionar ou coluvial de tonalidade vermelho amarelo, com aspecto macroscópico aparentemente homogêneo, apresentando alguns pequenos grãos de quartzo e foram encontradas raízes no local. Constitui-se basicamente por argilominerais (caulinita principalmente), quartzo e óxidos de ferro e alumínio, como produtos do intemperismo dos minerais primários da biotita gnaisse (Soares, 2005). 


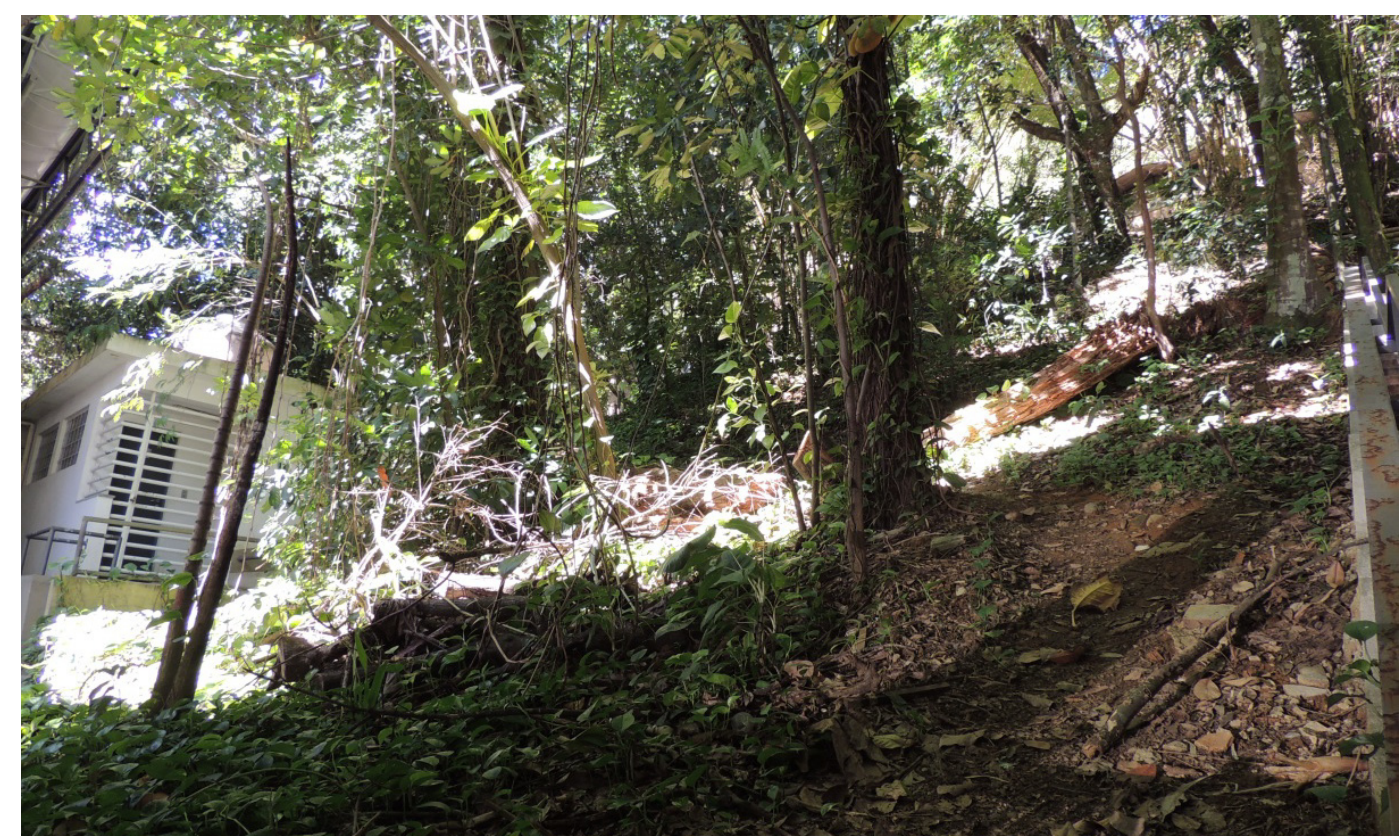

Figura 3.6 - Vista da encosta onde se realizou a amostragem no Campo Experimental II da PUC-Rio

\section{4.}

\section{Amostragens}

A amostragem foi feita o mais sub-superficial possível, porém evitou-se a presença de raízes. Foram retiradas amostras tanto indeformadas como amolgadas das três áreas estudadas.

Os solos de Duque de Caxias e Tinguá foram amostrados na forma de blocos indeformados, com dimensões aproximadas de $25 \times 25 \times 25 \mathrm{~cm}$, extraídos da parte superficial do talude, após descarte dos primeiros centímetros contaminados. Os blocos indeformados foram talhados manualmente, com auxilio de pá de corte, picareta e facas. Foram recolhidas também amostras amolgadas do mesmo local onde se encontravam os blocos, destinadas para realização dos ensaios de caracterização.

No total foram coletados dois blocos de amostras indeformadas em cada um dos locais, em diferentes oportunidades. Os blocos indeformados retirados do Campus Avançado do Tinguá e Duque de Caxias são mostrados na Figura 3.7. Os taludes de retirada dos blocos e os pontos de coleta podem ser visualizados nas Figuras 3.2 e 3.4 .

No caso do Campo Experimental II da PUC, devido à presença de grande quantidade de raízes, os solos foram amostrados na forma de mini blocos indeformados e corpos de prova em anéis metálicos, extraídos de locais em que a camada de matriz de solo coluvionar apresentava baixa concentração de 
raízes e pedras, possibilitando amostragens sem quebras ou amolgamento, retirados de profundidades aproximadas entre $20 \mathrm{~cm}$ e $50 \mathrm{~cm}$, tendo-se o cuidado de remover a camada superficial de solo orgânico e as camadas de solo que apresentavam raízes. A quantidade de amostras indeformadas extraídas do Campo Experimental II consistiu na mesma quantidade de ensaios que foram realizados em laboratório.
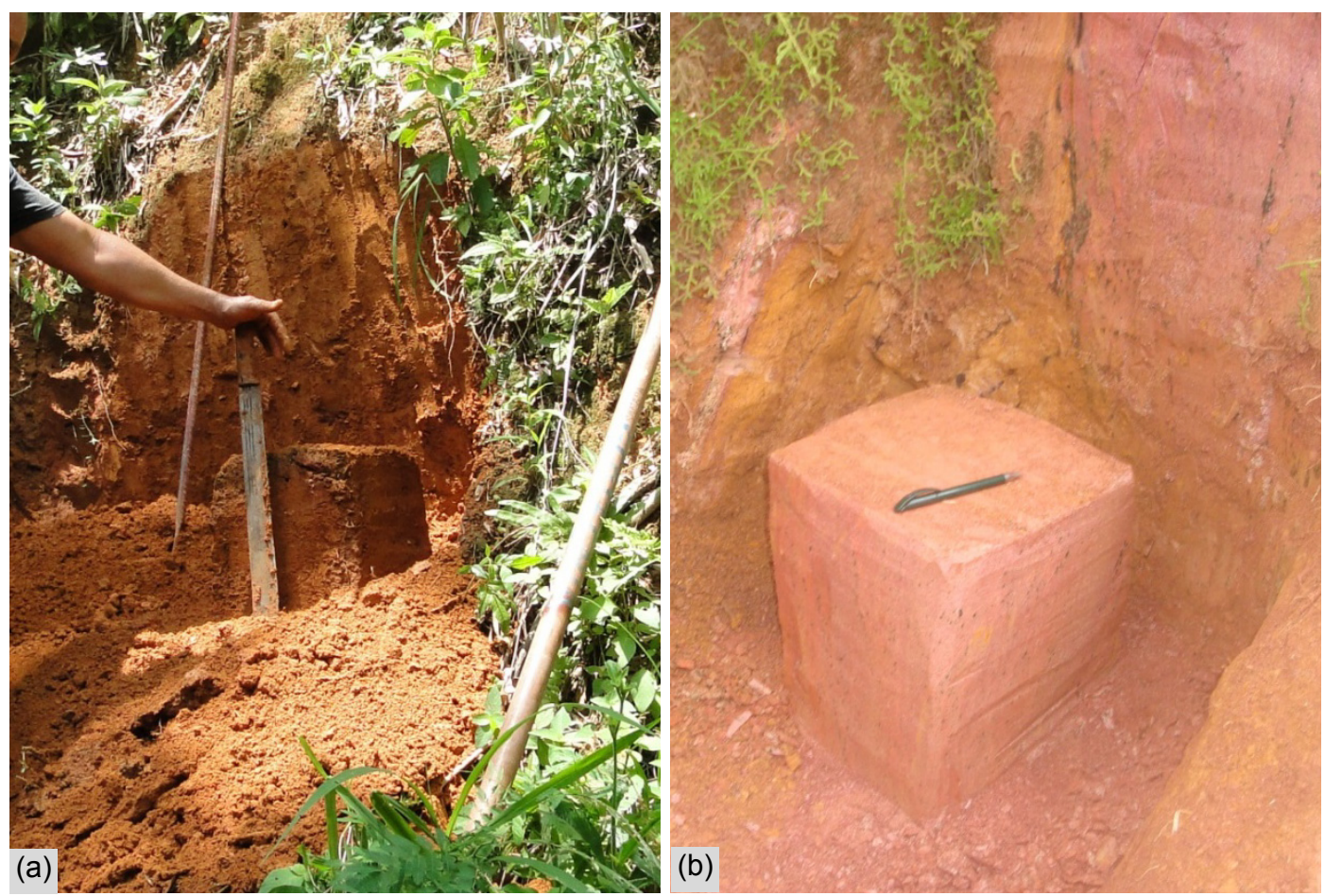

Figura 3.7 - Amostras indeformadas retiradas do talude de (a) Tinguá e (b) Duque de Caxias

No caso dos corpos de prova dos ensaios de cisalhamento direto, a amostragem foi realizada de acordo com a seguinte descrição: cada anel metálico de borda cortante de dimensões $10 \times 10 \times 2 \mathrm{~cm}$ foi untado com vaselina em pasta, com o objetivo de minimizar o atrito solo/molde. $O$ anel foi cuidadosamente cravado contra o bloco indeformado de solo, previamente esculpido, e ao mesmo tempo a amostra era aparada com o auxílio de um estilete, removendo os excessos laterais. As amostras foram retiradas com excesso de altura, para posterior regularização e moldagem em laboratório.

Para a realização de ensaios triaxiais em laboratório, foram amostrados mini blocos indeformados, com dimensões aproximadas de $15 \times 10 \times 10 \mathrm{~cm}$. Optou-se por retirar blocos destas dimensões, devido à grande dificuldade encontrada em se amostrar blocos de maiores dimensões sem a presença de raízes. A Figura 3.6 mostra a área de coleta das amostras indeformadas para a 
realização dos ensaios triaxiais e a Figura 3.8 mostra os mini blocos e a extração dos corpos de prova para o ensaio de cisalhamento direto.

Também foram recolhidas amostras amolgadas neste mesmo local, as quais serviram para realização dos ensaios de caracterização.
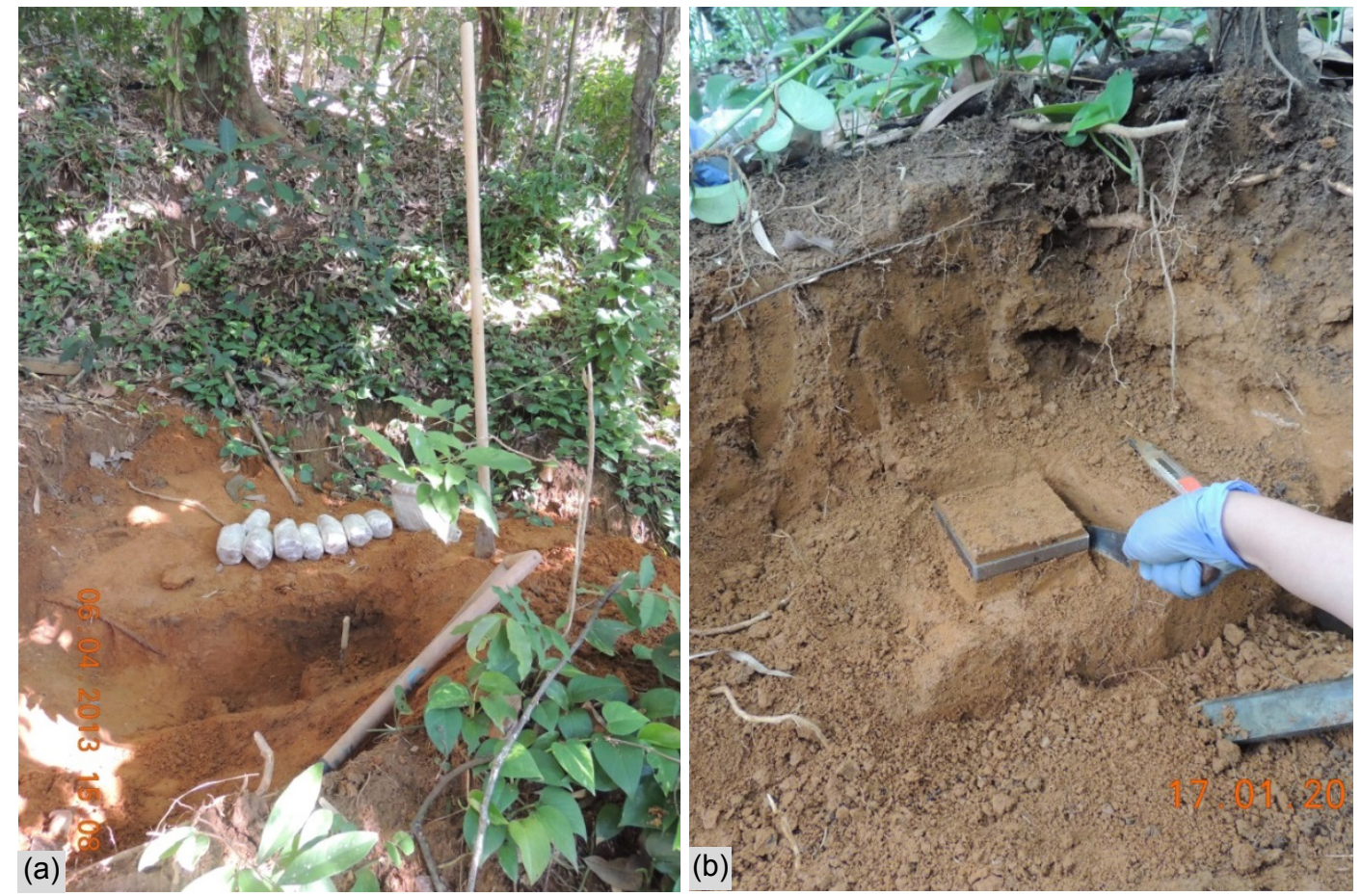

Figura 3.8 - Amostragem no Campo Experimental II - PUC, (a) Amostragem de mini blocos inalterados, (b) Preparação de corpos de prova em campo para execução de ensaio de cisalhamento direto

De maneira geral, após as amostras indeformadas terem sido extraídas das encostas, eram envolvidas em filme plástico de PVC, filme de alumínio e fita de embalagem, e acondicionadas no interior de caixas de madeira, com a intenção de proteger as amostras quanto à perda de teor de umidade de campo, além de minimizar os efeitos de trepidação ou a possibilidade de danos durante o transporte até o laboratório. As amostras amolgadas foram armazenadas em sacos plásticos hermeticamente fechados para manter suas condições de umidade de campo. No laboratório os blocos foram parafinados e armazenados na câmara úmida, juntamente com as amostras amolgadas. 


\section{4 \\ Caracterização dos solos}

No presente capítulo são descritos os procedimentos experimentais para a realização dos ensaios de caracterização geotécnica dos solos, assim como os resultados obtidos, com a análise e interpretação dos dados.

Com a finalidade de efetuar uma melhor caracterização, foram incorporados alguns resultados alcançados em outras pesquisas.

Para facilitar a identificação dos solos coluviais ou coluvionares do Campus Avançado da PUC-Rio em Tinguá e do Campo Experimental II da PUCRio, ambos vão ser identificados respectivamente como "Solo de Tinguá" e "Solo da PUC".

\section{1. \\ Caracterização física}

Para a determinação das propriedades índice básicas das amostras de solo estudadas, foram realizados ensaios de caracterização física. Tal caracterização foi feita no Laboratório de Geotecnia e Meio Ambiente da PUC Rio, utilizando amostras amolgadas e indeformadas. As amostras amolgadas foram preparadas de acordo com o procedimento de secagem prévia, conforme a NBR 6457/86, seguindo as demais recomendações da Associação Brasileira de Normas Técnicas (ABNT).

A partir das amostras indeformadas utilizadas em outros ensaios, foram obtidas outras propriedades índices, como: peso específico natural $\left(\gamma_{\text {nat }}\right)$, peso específico seco $\left(\gamma_{d}\right)$, índice de vazios (e), porosidade (n) e grau de saturação (S).

\subsection{1.}

\section{Análise granulométrica}

A análise granulométrica foi realizada conforme a NBR 7181/1984, pela combinação de ensaios de sedimentação e peneiramento, com apenas algumas adaptações.

O ensaio de sedimentação foi realizado de acordo com a metodologia utilizada no Laboratório de Geotecnia e Meio Ambiente da PUC-Rio, com o 
material passante na peneira de $0,42 \mathrm{~mm}\left(\mathrm{n}^{\circ} 40\right)$, e não na peneira de $2 \mathrm{~mm}\left(\mathrm{n}^{\circ}\right.$ 10) conforme recomendado pela Norma. Além disso, para fins de comparação, optou-se por realizar ensaios com e sem o uso do agente defloculante para a dispersão das partículas, não previsto nas normas.

Das análises granulométricas, foram obtidas as porcentagens das frações de solo para cada amostra, como pode ser visto na Tabela 4.1 e nas curvas granulométricas dos três solos, apresentadas na Figura 4.1. A porcentagem da fração fina, correspondente ao material que passa na peneira ${ }^{\circ}$ 200, abrange as frações silte e argila. A Figura 4.1 apresenta as curvas granulométricas onde os ensaios de sedimentação foram feitos com o defloculante hexametafosfato de sódio e sem defloculante, respectivamente. A partir desta figura, é possível observar que os resultados apresentam grandes diferenças, especialmente no caso dos solos coluvionares ou coluviais.

Os ensaios onde a sedimentação foi realizada sem o uso do defloculante tiveram como objetivo verificar o grau de floculação das partículas de argila. Tal estado é evidenciado na Figura 4.2, onde se pode observar que nos ensaios feitos sem defloculante todos os solos se sedimentaram por completo em um período menor que 30 minutos, mostrando o caráter floculado dos mesmos.

Nas curvas granulométricas obtidas com o uso de defloculante, verificouse que a amostra correspondente ao solo da PUC apresenta uma porcentagem de argila em torno a $59 \%$. Na amostra do solo de Tinguá, o valor é em torno a $51 \%$. Na amostra do solo residual jovem de Duque de Caxias observa-se uma menor quantidade, em torno de $9,2 \%$.

Tabela 4.1 - Resultados dos ensaios de granulometria dos solos estudados

\begin{tabular}{|c|c|c|c|c|c|c|c|c|}
\hline \multicolumn{9}{|c|}{ Solos Coluvionares } \\
\hline \multirow{2}{*}{ Amostra } & \multicolumn{4}{|c|}{ com defloculante (\%) } & \multicolumn{4}{|c|}{ sem defloculante (\%) } \\
\hline & pedregulho & areia & silte & argila & pedregulho & areia & silte & argila \\
\hline Tinguá & 0,9 & 34,7 & 12,6 & 51,8 & 0,9 & 57,8 & 39,8 & 1,5 \\
\hline PUC & 1,1 & 30,6 & 8,5 & 59,8 & 1,1 & 51,9 & 45,0 & 2,0 \\
\hline \multicolumn{9}{|c|}{ Solo Residual } \\
\hline \multirow{2}{*}{ Amostra } & \multicolumn{4}{|c|}{ com defloculante (\%) } & \multicolumn{4}{|c|}{ sem defloculante (\%) } \\
\hline & pedregulho & areia & silte & argila & pedregulho & areia & silte & argila \\
\hline $\begin{array}{c}\text { Duque } \\
\text { de Caxias }\end{array}$ & 0 & 50,7 & 40,1 & 9,2 & 0 & 52,1 & 47,5 & 0,4 \\
\hline
\end{tabular}



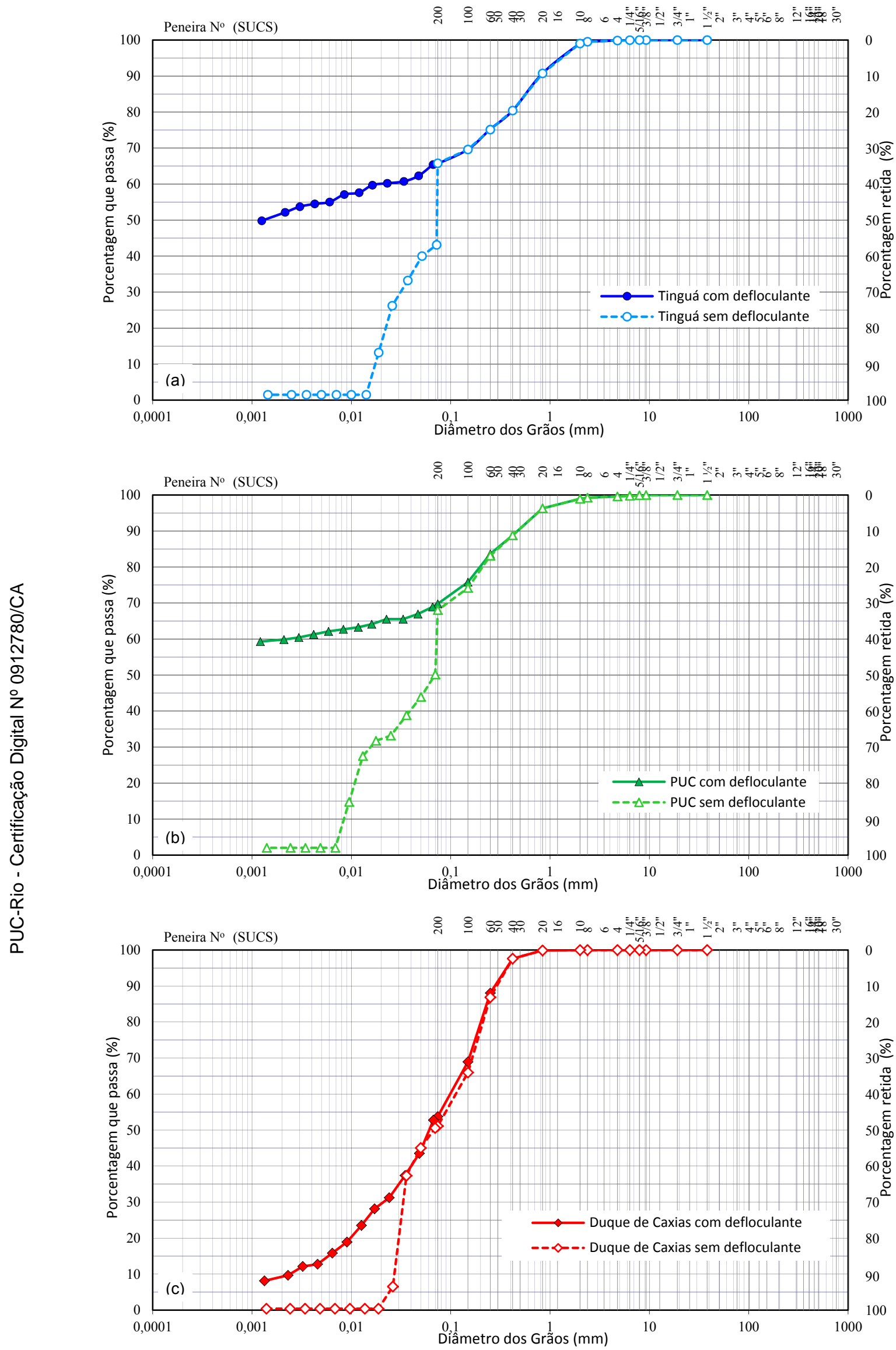

Figura 4.1 - Curvas granulométricas dos ensaios realizados com e sem defloculante, (a) Solo de Tinguá, (b) Solo da PUC, (c) Solo de Duque de Caxias 

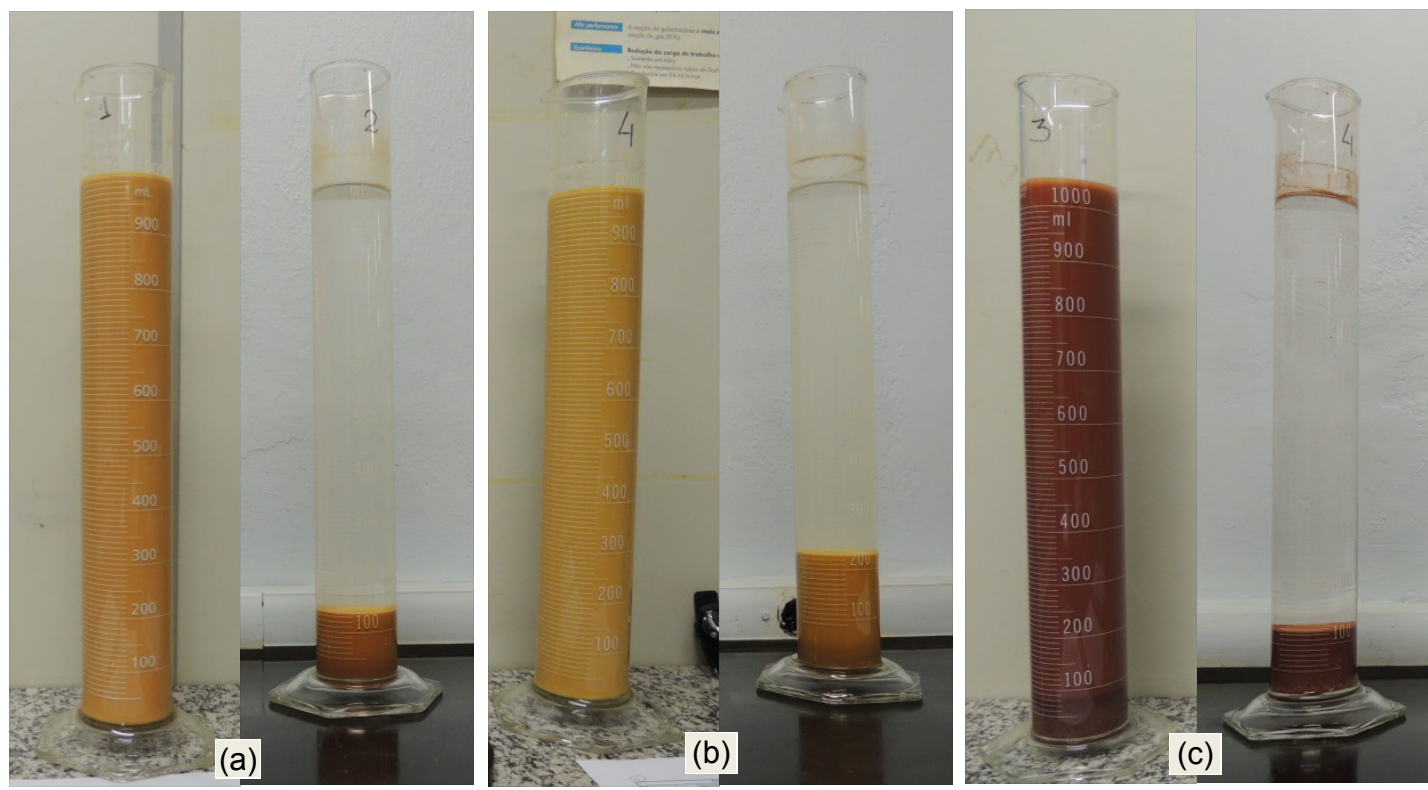

Figura 4.2 - Ensaios de sedimentação com hexametafosfato de sódio e água, após $24 \mathrm{hr}$. (a) Solo de Tinguá, (b) Solo da PUC, (c) Solo de Duque de Caxias. Observa-se que nos ensaios de sedimentação sem defloculante (bureta à direita em cada figura) as amostras apresentam-se floculadas

\subsection{2.}

\section{Limites de Atterberg}

Os ensaios de limite de liquidez e de plasticidade foram realizados segundo as normas NBR 6459/84b e a NBR 7180/1984, respectivamente. Os ensaios foram realizados com amostras secas ao ar, destorroadas e peneiradas na peneira $\mathrm{n}^{\circ} 4$ (abertura $0,42 \mathrm{~mm}$ ). Os resultados obtidos estão apresentados na Tabela 4.2.

Tabela 4.2 - Resultados dos ensaios de limites de consistência

\begin{tabular}{c|c|c|c|c}
\hline Amostra & $\begin{array}{c}\mathrm{LL} \\
(\%)\end{array}$ & $\begin{array}{c}\mathrm{LP} \\
(\%)\end{array}$ & $\begin{array}{c}\text { IP } \\
(\%)\end{array}$ & Ia \\
\hline Tinguá & 73,1 & 43,0 & 30,1 & 0,58 \\
PUC & 61,3 & 33,1 & 28,2 & 0,47 \\
\hline
\end{tabular}

* O solo de Duque de Caxias não apresentou limites de consistência

Com os valores obtidos dos limites de liquidez (LL,\%) e plasticidade (LP,\%), além dos dados da análise granulométrica, foi determinado o índice de plasticidade (IP, \%) através da diferença: IP $=\mathrm{LL}-\mathrm{LP}$.

De acordo com a proposta de Skempton, o Índice de atividade (Ia), correspondente à fração argila é calculado por:

$$
I a=\frac{I P}{\%<2 \mu m}
$$


Onde, segundo sua atividade, as argilas são classificadas como: inativa (Ia $<0,75)$, atividade normal $(0,75<$ Ia $<1,25)$ e ativa $($ Ia $>1,25)$.

\subsection{3.}

\section{Massa específica dos grãos}

O ensaio para a determinação da massa especifica dos grãos foi realizado segundo a NBR 6508/1984, com secagem ao ar prévia do material, seguida de destorroamento e passagem na peneira $n^{\circ} 40$ (abertura 0,42 mm).

O valor da massa específica dos grãos é obtido através da média de quatro determinações sob as mesmas condições. Os resultados obtidos para os três solos são mostrados na Tabela 4.3.

Tabela 4.3 - Resultados dos ensaios massa específica dos grãos

\begin{tabular}{c|cc}
\hline \multicolumn{3}{c}{ Solos Coluvionares } \\
\hline Amostra & $\rho_{\mathrm{s}}\left(\mathrm{g} / \mathrm{cm}^{3}\right)$ \\
\hline Tinguá & 2,676 \\
PUC & 2,739 \\
\hline & & \\
\hline Amostra & Solo Residual \\
\hline Duque de Caxias & $\rho_{\mathrm{s}}\left(\mathrm{g} / \mathrm{cm}^{3}\right)$ \\
\hline
\end{tabular}

\subsection{4.}

\section{Índices físicos}

Por correlação, foram determinados os índices físicos calculados com dados provenientes de corpos de prova usados nos ensaios de cisalhamento direto e triaxial. A Tabela 4.4 apresenta os valores médios dos índices do solo em seu estado natural.

Tabela 4.4 - Índices físicos médios obtidos por correlação

\begin{tabular}{c|c|c|c|c|c}
\hline \multicolumn{7}{c}{ Solos Coluvionares } \\
\hline Amostra & $\begin{array}{c}\gamma_{\mathrm{n}} \\
\left(\mathrm{kN} / \mathrm{m}^{3}\right)\end{array}$ & $\begin{array}{c}\gamma_{\mathrm{d}} \\
\left(\mathrm{kN} / \mathrm{m}^{3}\right)\end{array}$ & índice de vazios & $\begin{array}{c}\text { porosidade } \\
(\%)\end{array}$ & $\begin{array}{c}\text { grau de saturação } \\
(\%)\end{array}$ \\
\hline Tinguá & 17,07 & 13,62 & 0,95 & 48,61 & 68,29 \\
PUC & 17,63 & 14,17 & 0,94 & 48,27 & 71,87 \\
\hline \multicolumn{7}{c}{ Solo Residual } \\
\hline Amostra & $\begin{array}{c}\gamma_{\mathrm{n}} \\
\left(\mathrm{kN} / \mathrm{m}^{3}\right)\end{array}$ & $\begin{array}{c}\gamma_{\mathrm{d}} \\
\left(\mathrm{kN} / \mathrm{m}^{3}\right)\end{array}$ & índice de vazios & $\begin{array}{c}\text { porosidade } \\
(\%)\end{array}$ & $\begin{array}{c}\text { grau de saturação } \\
(\%)\end{array}$ \\
\hline Cuque de & 16,37 & 12,18 & 1,37 & 57,65 & 72,93 \\
\hline
\end{tabular}




\subsection{5.}

\section{Análise de resultados da caracterização física}

Analisando-se os resultados da caracterização física dos três solos observa-se que:

Nas análises granulométricas, a comparação estabelecida entre os resultados dos ensaios realizados com e sem o uso de defloculante indicaram, principalmente para os solos coluvionares, elevado nível de agregação. O que permite inferir que os agregados de argila encontram-se no estado natural, compondo as frações de silte e areia, na forma de microagregados arenosiltosos.

O solo residual de Duque de Caxias apresenta valores de densidade relativa dos grãos em torno de 2,88, o que pode estar relacionado com porcentagens elevados de minerais máficos na composição da sua rocha de origem. Os solos pertencentes à PUC e Tinguá possuem valores entre 2,6 e 2,7, indicando provavelmente que são provenientes de áreas de rochas com elevado teor de materiais félsicos (quartzo, feldspato).

Os solos coluvionares apresentam índices físicos semelhantes.

De acordo com o índice de atividade (Ia) proposto por Skempton, as frações de argila dos solos coluvionares são inativas.

O solo residual jovem de Duque de Caxias não apresentou limites de consistência, possivelmente por seu baixo teor de argila e a sua fração de silte e areia fina, constituída essencialmente por mica intemperizada. Este solo foi classificado através do Sistema Unificado de Classificação dos Solos (SUCS) como areia siltosa. Sendo os solos coluvionares de Tinguá e PUC classificados como siltes de alta plasticidade, considerando a fração fina (silte e argila) dispersa.

\section{2.}

\section{Caracterização química}

A caracterização química dos solos foi executada a fim de se determinar os elementos químicos que os compõem e tentar compará-los com seu respetivo grau de alteração. Foram realizadas também determinações de $\mathrm{pH}$ e perda ao fogo. 


\subsection{1.}

\section{Análise química}

Os resultados destas análises são provenientes tanto de minerais primários como de minerais secundários. Foram determinadas por fluorescência de raios $X$ em amostras passantes na peneira $n^{\circ} 200$, fundidas em tetraborato de lítio, e analisadas no Laboratório de Fluorescência e Difração de Raios-X do Departamento de Geologia da UFRJ. Estes resultados foram extraídos da dissertação de mestrado de Manuella Galindo (Galindo, 2013) e da tese de doutorado de Taíse Carvalho (Carvalho, 2012), apresentados a seguir na Tabela 4.5 .

Através desta análise foram obtidos os teores de alumina $\left(\mathrm{Al}_{2} \mathrm{O}_{3}\right)$, sílica $\left(\mathrm{SiO}_{2}\right)$, potássio $\left(\mathrm{K}_{2} \mathrm{O}\right)$, óxido de titânio $\left(\mathrm{TiO}_{2}\right)$, ferro $\left(\mathrm{Fe}_{2} \mathrm{O}_{3}\right)$, manganês $(\mathrm{MnO})$, dentre outros elementos presentes nos solos.

Tabela 4.5 - Composição química dos solos

\begin{tabular}{c|c|c|c|c|c|c|c|c}
\hline \multicolumn{10}{c}{ Solos Coluvionares * } \\
\hline \multirow{2}{*}{ Amostra } & \multicolumn{7}{c}{ Constituintes em porcentagens } \\
\cline { 2 - 9 } & $\mathrm{Al}_{2} \mathrm{O}_{3}$ & $\mathrm{SiO}_{2}$ & $\mathrm{P}_{2} \mathrm{O}_{5}$ & $\mathrm{~K}_{2} \mathrm{O}$ & $\mathrm{TiO}_{2}$ & $\mathrm{Fe}_{2} \mathrm{O}_{3}$ & $\mathrm{ZrO}_{2}$ & $\mathrm{Traços}$ \\
\hline \multirow{2}{*}{ Tinguá } & 40,92 & 33,41 & 0,15 & 0,28 & 1,01 & 6,72 & 0,01 & $\mathrm{Ca}, \mathrm{Cr}, \mathrm{Mn}$ \\
PUC & 32,83 & 42,59 & 0,10 & 0,15 & 1,10 & 7,73 & 0,01 & $\mathrm{Ca}, \mathrm{Cr}, \mathrm{Mn}$ \\
\hline \multicolumn{10}{c}{ Solo Residual ** } \\
\hline \multirow{2}{*}{$\begin{array}{c}\text { Amostra } \\
\text { Duque de } \\
\text { Caxias }\end{array}$} & 26,04 & 39,98 & 0,29 & 4,18 & 0,35 & 18,16 & $\mathrm{Mg}, \mathrm{S}, \mathrm{K}, \mathrm{Ca}, \mathrm{Zr}, \mathrm{Nb}$ \\
\hline
\end{tabular}

Fonte : * Galindo (2013) , ** Carvalho (2012)

\subsection{2.}

\section{Perda ao fogo}

O ensaio de perda ao fogo consiste na determinação da perda de massa do solo durante a queima em mufla a $600^{\circ} \mathrm{C}$, durante 6 horas.

A metodologia consiste em secar uma pequena quantidade de solo em um recipiente de porcelana (cadinho) na estufa a temperatura de $105-110^{\circ} \mathrm{C}$, até constância de massa. Em seguida, o solo seco é levado à mufla a temperatura de $600^{\circ} \mathrm{C}$ por 6 horas até obtenção da constância de massa. A quantificação é feita pela diferença de massa antes e após o aquecimento na mufla. Essa perda de massa é chamada perda ao fogo. 
O índice de perda ao fogo dos três solos estudados foi obtido no Laboratório de Geotecnia e Meio Ambiente da PUC-Rio. Os resultados dos ensaios estão apresentados na Tabela 4.6.

Tabela 4.6 - Determinação da perda ao fogo dos três solos

\begin{tabular}{c|c}
\hline \multicolumn{2}{c}{ Solos Coluvionares } \\
\hline Amostra & Perda ao fogo a $600^{\circ}(\%)$ \\
\hline Tinguá & 12,61 \\
PUC & 9,36 \\
\hline & Solo Residual \\
\hline Amostra & Perda ao fogo a $600^{\circ}(\%)$ \\
\hline Duque de Caxias & 12,02 \\
\hline
\end{tabular}

Deve-se considerar que a perda ao fogo não está somente relacionada com os porcentuais da fração argila, mas também com a presença de oxihidróxido de ferro e alumínio (goethita e gibbsita), além de compostos amorfos de ferro e alumínio presentes na massa de solo.

\subsection{3. $\mathrm{pH}\left(\mathrm{em} \mathrm{H}_{2} \mathrm{O}\right.$ e em KCl)}

A determinação do $\mathrm{pH}$ (potencial hidrogeniônico) fornece a acidez ou alcalinidade do solo e a solubilidade de alguns elementos. $\mathrm{O} \mathrm{pH}$ foi determinado na suspensão dos solos tanto em água destilada quanto em solução aquosa saturada de $\mathrm{KCl}$ (proporção 1:2,5), mediante o uso do pHmetro. O ensaio para a determinação do $\mathrm{pH}$ foi realizado no Laboratório de Geotecnia e Meio Ambiente da PUC-Rio conforme o Manual de Métodos de Análises de Solos (CNPS/EMBRAPA, 1997).

A metodologia consiste em: misturar a suspenção 1:2,5 com um bastão de vidro, deixar em repouso por um período mínimo de uma hora. Calibrar o pHmetro com soluções tampão. Após a calibração, limpar o eletrodo com água destilada e deixa-lo na solução de estocagem. Depois de transcorrida uma hora, misturar novamente a suspensão com o bastão e mergulhar o eletrodo na suspensão. Fazer a leitura de $\mathrm{pH}$.

$\mathrm{O} \mathrm{pH}$ determinado em cloreto de potássio $(\mathrm{KCl})$ apresenta valores mais baixos que os determinados em $\mathrm{H}_{2} \mathrm{O}$, salvo no caso de solos extremamente intemperizados. De acordo com Agnelli e Albiero (1997), pode-se verificar através do $\mathrm{pH}$ se o solo possui capacidade de retenção de ânions ou cátions. 
Valores negativos de $\Delta \mathrm{pH}\left(\mathrm{pH}_{\mathrm{KCl}}-\mathrm{pH}_{\mathrm{H} 2 \mathrm{O}}\right)$ indicam retenção de cátions, e valores positivos sugerem retenção de ânions.

A Tabela 4.7 apresenta os valores obtidos através desses ensaios.

Tabela 4.7 - $\mathrm{pH}$ dos solos estudados

\begin{tabular}{c|c|c|c}
\hline \multicolumn{4}{c}{ Solos Coluvionares } \\
\hline \multirow{2}{*}{ Amostra } & \multicolumn{3}{c}{$\mathrm{pH}$} \\
\cline { 2 - 4 } & água & $\mathrm{KCl}$ & $\Delta \mathrm{pH}^{*}$ \\
\hline Tinguá & 5,1 & 4,5 & $-0,6$ \\
PUC & 4,1 & 4,0 & $-0,1$ \\
\hline \multicolumn{4}{|c}{ Solo Residual } \\
\hline \multirow{2}{*}{ Amostra } & água & $\mathrm{pH}$ & $\Delta \mathrm{pH}^{*}$ \\
\cline { 2 - 4 } & 4,5 & 4,2 & $-0,3$ \\
\hline${ }^{*} \Delta \mathrm{pH}=\mathrm{pH}_{\mathrm{KCl}}-\mathrm{pH}_{\text {água }}$ &
\end{tabular}

Os valores obtidos para $\mathrm{pH}$ em água mostram que os solos estudados são ácidos $(\mathrm{pH}<7)$.

\subsection{4. \\ Análises de resultados da caracterização química}

Os resultados da caracterização química mostram que:

Os solos coluvionares de Tinguá e PUC apresentam diferenças significativas quanto os valores de alumina $\left(\mathrm{Al}_{2} \mathrm{O}_{3}\right)$ e sílica $\left(\mathrm{SiO}_{2}\right)$. Os valores de alumina maiores no solo de Tinguá devem estar correlacionados com a presença de gibbsita na fração argila. No caso da sílica, o solo PUC apresenta um valor maior, possivelmente em função de seu maior teor de fração argila. Ressalta-se que tanto os valores de alumina como de sílica são provenientes da composição química dos argilominerais, de minerais resistentes ao intemperismo como o quartzo, além da possível presença de compostos amorfos de alumina e sílica. Observa-se um ligeiro aumento do teor de ferro no solo PUC, o que pode ser relacionado com a composição mineralógica da possível rocha de origem.

O solo residual jovem de Duque de Caxias apresenta um teor elevado de ferro, que está vinculado à composição mineralógica da rocha de origem e à formação do mineral secundário goethita, como produto do processo de intemperismo dos minerais máficos presentes na rocha matriz. Ressalta-se que o óxido de ferro pode atuar como substancia cimentante nas partículas que compõem o solo, principalmente nas partículas finas. 
O valor maior de perda ao fogo do solo de Tinguá pode estar relacionado à presença de gibbsita na fração argila.

Os valores de $\mathrm{pH}$ em torno de 5 são correlacionados com solos muito intemperizados, como indica a ausência de álcalis (cálcio, magnésio, sódio e potássio) na sua composição química.

\section{3.}

\section{Caracterização mineralógica}

O estudo da mineralogia das diversas frações do solo contribui significativamente como indicador de seu grau de alteração, abrangendo os componentes da fração areia, silte e argila. O objetivo principal é identificar os componentes minerais de cada fração do solo.

\subsection{1. Fração areia}

Além de identificar os componentes, bem como descrever as formas dos grãos, tentou-se fazer uma estimativa dos minerais predominantes nesta fração.

As análises nas frações areia foram feitas no Laboratório de Geotecnia e Meio Ambiente da PUC-Rio, utilizando-se a lupa binocular marca Tecnival. Foram executadas no material retido na peneira $n^{\circ} 40$, passante na peneira $n^{\circ}$ 40 e retido na peneira $n^{\circ} 200$. Os componentes minerais destas frações, descritos a seguir, podem ser vistos na Figura 4.3.

\subsubsection{1. \\ Fração retida na peneira $n^{\circ} 40$}

No solo de Tinguá, esta fração está constituída, essencialmente, por grãos de quartzo hialinos, subarredondados e subangulosos, não rugosos, e por agregados argilo-ferruginosos de cor marrom avermelhado, conforme observado na Figura 4.3 (a). Também são observados traços de minerais opacos (magnetita), feldspatos e biotita alterada.

A amostra de areia do solo da PUC, como mostra a Figura 4.3 (b), está constituída essencialmente por grãos de quartzo hialino e traços de minerais opacos (ilmenita, magnetita e óxido de manganês). Os grãos de quartzo se apresentam não rugosos, subarredondados e arredondados.

A amostra de Duque de Caxias é constituída por partículas de mica biotita de forma laminar, mostrando sinais de visível alteração, definidos pela mudança de cor e brilho (os grãos vão ficando dourados e depois completamente 
descorados). Ocorrem também concreções de óxido de ferro e manganês, além de alguns grãos de quartzo, como pode ser observado na Figura 4.3 (c).

Material retido na peneira $n^{\circ} 40$
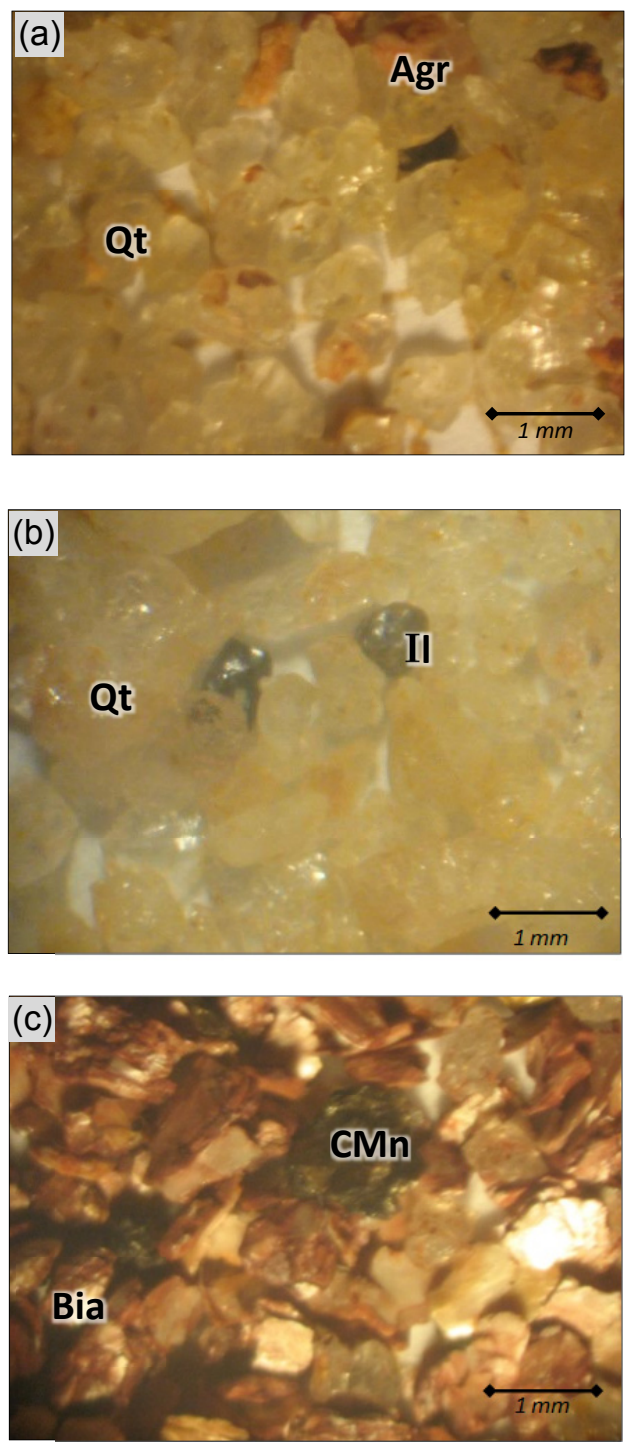

Material passante na peneira $n^{\circ} 40 \mathrm{e}$ retido na peneira $n^{\circ} \mathbf{2 0 0}$

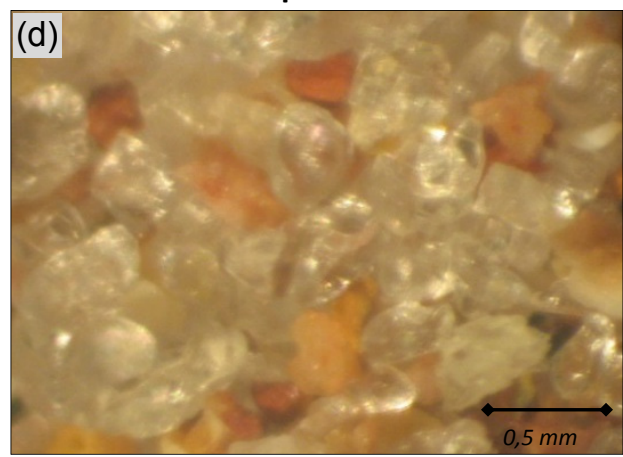

(e)
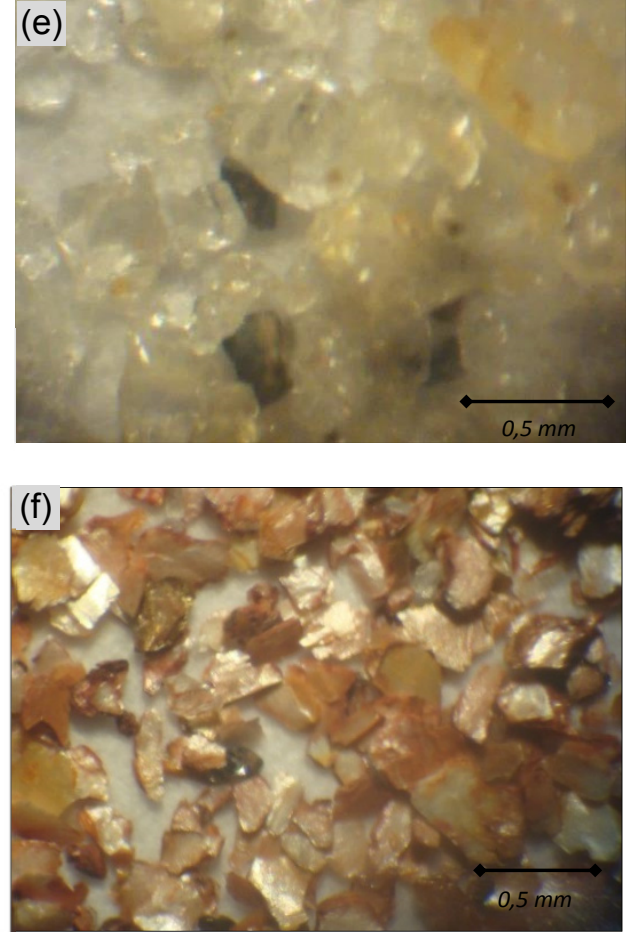

Figura 4.3 - Frações de areia dos solos. (a) e (d) Tinguá, (b) e (e) PUC, (c) e (f) Duque de Caxias. $\mathrm{Qt}=$ quartzo, $\mathrm{Agr}=$ agregados argilo-ferruginosos, $\mathrm{Il}=$ ilmenita, $\mathrm{Bia}=$ biotita alterada, $\mathrm{CMn}=$ concreções de manganês

\subsubsection{2.}

\section{Fração passante na peneira $n^{\circ} 40$ e retida na peneira $n^{\circ} 200$}

A fração de areia fina do solo de Tinguá tem a mesma composição que a fração grosseira, mas os grãos de quartzo se apresentam um pouco mais arredondados e a percentagem de agregados argilo-ferruginosos é maior (Figura $4.3 \mathrm{~d})$. 
$\mathrm{Na}$ amostra do solo da PUC, mostrada na Figura 4.3 (e), observa-se o quartzo hialino subarredondado e arredondado, igual ao da fração mais grossa, mas, com maior porcentagem de ilmenita (óxido de ferro e titânio).

No solo Duque de Caxias esta fração possui a mesma composição que a retida na peneira $n^{\circ} 40$; porém, a biotita tem um maior grau de alteração, conforme mostra a Figura 4.3 (f).

\subsection{2.}

\section{Fração silte e argila}

A identificação dos componentes minerais das frações silte e argila foi executada através de Difração de Raios-X (DRX) e Análise Térmica Diferencial (ATD), nos Laboratórios de Difratometria de Raio-X e Análise Térmica Diferencial do Departamento de Engenharia Química e Materiais da PUC-Rio (DEQM). As descrições destes métodos podem ser vistas em detalhe em Santos (1975).

Para as análises de Difração de Raios-X utilizou-se um Difratômetro Siemens, modelo D5000. A velocidade de varredura foi de $0,02 \% \mathrm{~min}$. As leituras dos difratogramas foram executadas abrangendo ângulos $2 \theta$ de 2 a $30^{\circ}$.

Para as amostras de Tinguá e PUC, a análise foi executada nas frações passantes nas peneiras $n^{\circ} 200$ (silte e argila) e $n^{\circ} 400$ (argila), pelo método do pó. A preparação das amostras foi feita por peneiramento. No caso do solo de Duque de Caxias, os resultados das análises de difração de raios-X foram retirados de Carvalho (2012). As análises foram feitas no material passante na peneira $n^{\circ} 40$, utilizando-se o método do pó. Para caracterizar separadamente as frações silte e argila, foram feitas lâminas orientadas pelo método de gotejamento com material passante na peneira $n^{\circ} 200$.

Os difratogramas das diferentes amostras são apresentados nas Figuras 4.4 a 4.6 .

No caso do solo coluvionar de Tinguá, tanto no material passante na peneira $n^{\circ} 200$ quanto no material passante na peneira $n^{\circ} 400$, observa-se a presença de caulinita, gibbsita (hidróxido de alumínio) e quartzo. Com predominância da gibbsita, principalmente na fração argila, o que pode refletir o elevado grau de intemperismo deste solo.

Os resultados do solo coluvionar da PUC mostram a presença de caulinita, goethita (hidróxido de ferro) e quartzo, tanto no material passante na peneira $\mathrm{n}^{\circ}$ 200 como na peneira $n^{\circ} 400$. 
Os difratogramas dos solos provenientes do solo Duque de Caxias indicam a presença de caulinita e goethita nas duas frações analisadas, e biotita apenas na fração passante na peneira $n^{\circ} 40$. Os difragtogramas mostram a predominância de caulinita bem cristalizada. Fica evidente a evolução do intemperismo, com a biotita como mineral índice, evoluindo para caulinita, além de uma maior quantidade de goethita na fração passante na peneira $n^{\circ} 200$, produto do intemperismo.

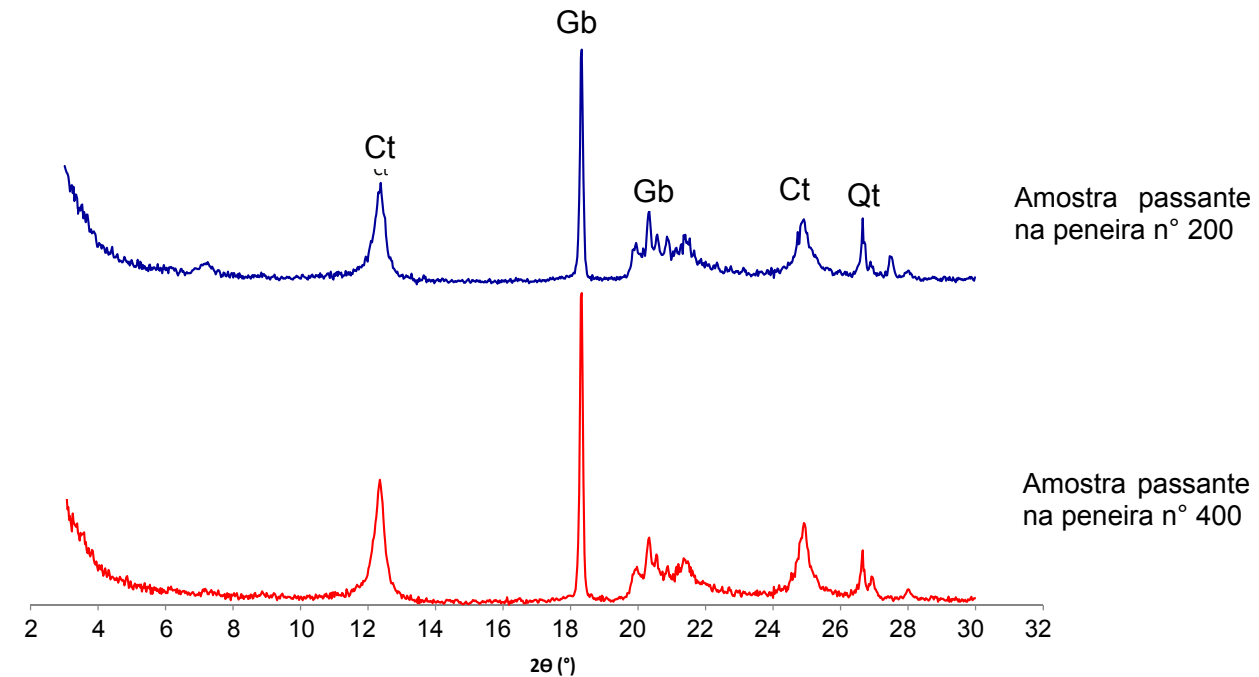

Figura 4.4 - Difratogramas do solo de Tinguá. Ct=caulinita, Gb=gibbsita, Qt=quartzo

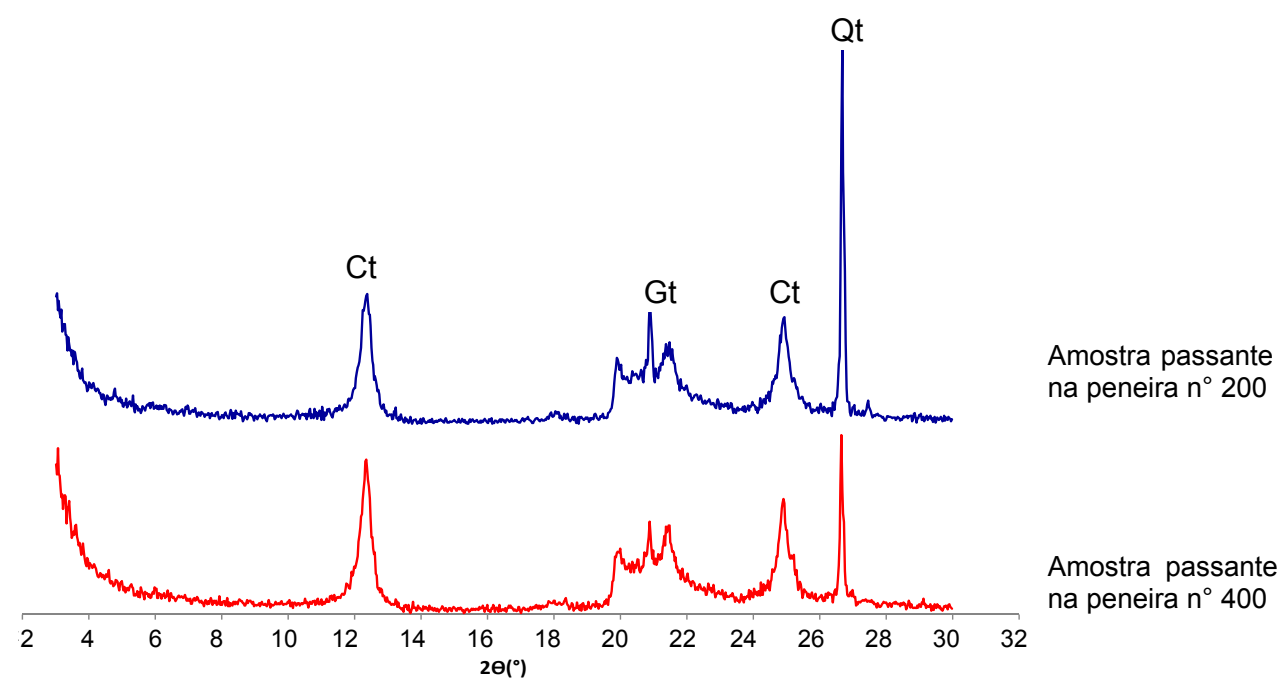

Figura 4.5 - Difratogramas do solo da PUC. Ct=caulinita, Gt=goethita, Qt=quartzo 


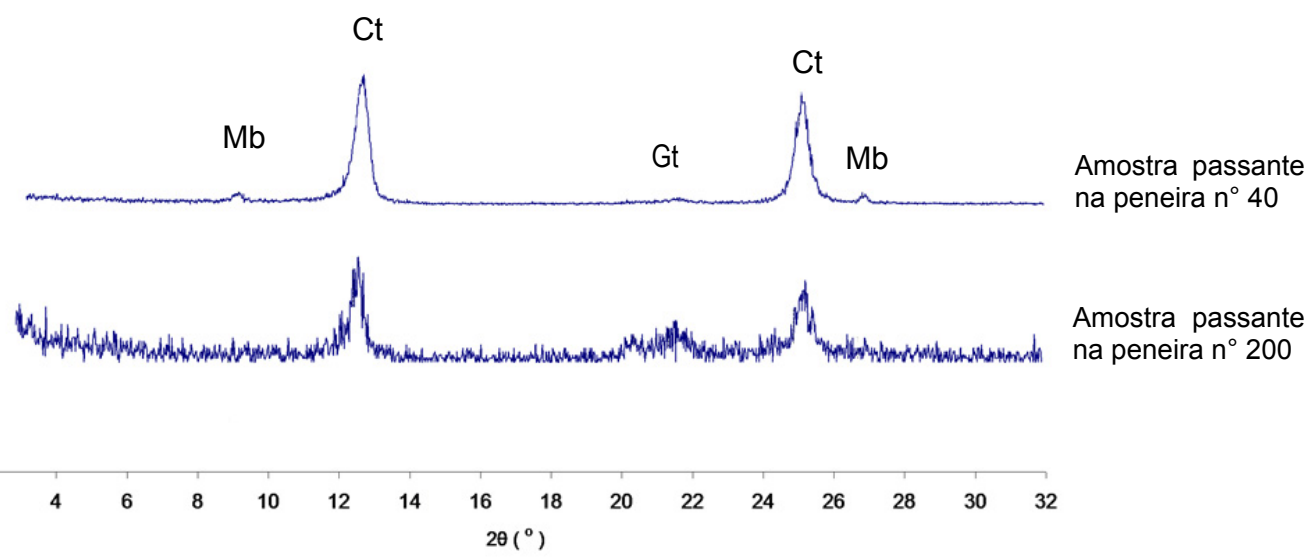

Figura 4.6 - Difratogramas do solo de Duque de Caxias. Ct=caulinita, Mb=biotita, $\mathrm{Gt}=$ goethita (Carvalho, 2012)

As Análises Térmica Diferencial foram executadas nas frações silte e argila, com o auxílio de um equipamento do fabricante Perkin Elmer e do sistema de aquisição de dados Pyris. Estas fazem parte da dissertação de mestrado de Manuella Galindo (Galindo, 2013) e da tese de doutorado de Taise Carvalho (Carvalho, 2012). As amostras foram aquecidas até $1050^{\circ} \mathrm{C}$, com aumento de $15^{\circ} \mathrm{C}$ por minuto.

As Figuras 4.7 a 4.9 mostram os termogramas das respectivas amostras. Nestas figuras observa-se que a caulinita é comum aos solos coluvionares de Tinguá e PUC, e ao residual jovem de Duque de Caxias, destacando-se a presença de gibbsita apenas no solo coluvionar de Tinguá, concordante com o difratograma da Figura 4.4.

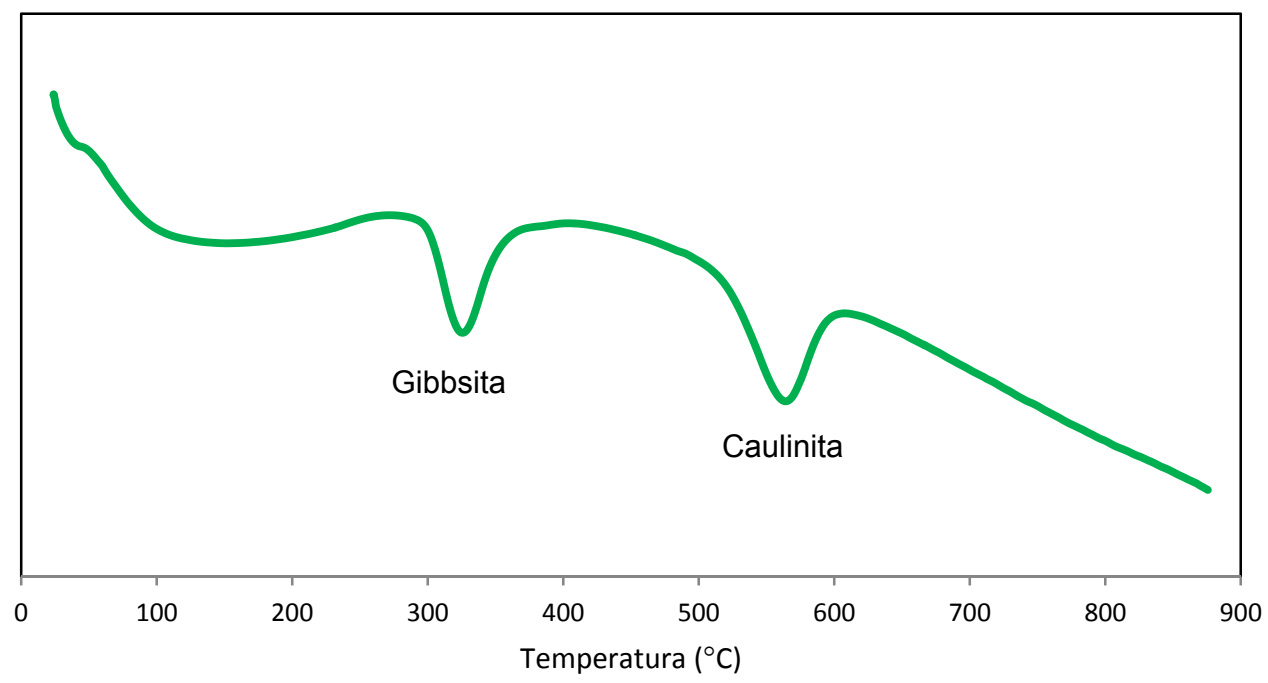

Figura 4.7 - Termograma do solo coluvionar de Tinguá (Galindo, 2013) 


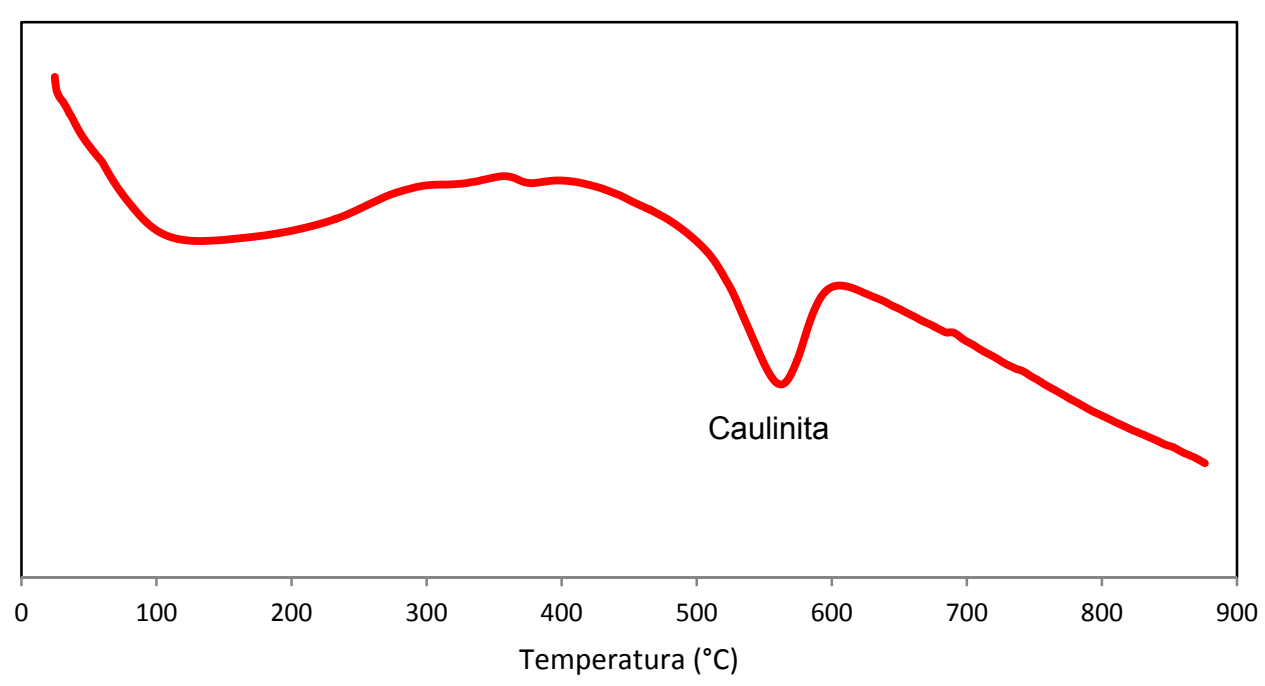

Figura 4.8 - Termograma do solo coluvionar da PUC (Galindo, 2013)

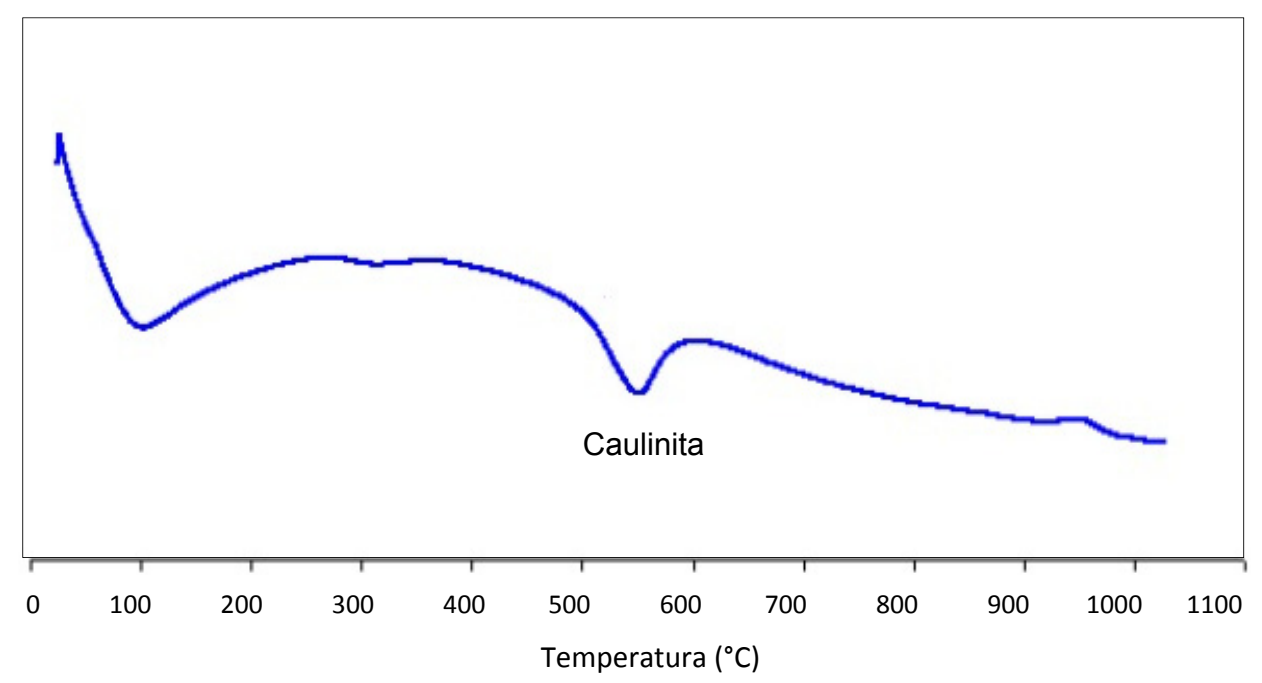

Figura 4.9 - Termograma do solo residual jovem de Duque de Caxias (Carvalho, 2012)

\subsection{3.}

\section{Análise de resultados da caracterização mineralógica}

Os solos coluvionares ou coluviais de Tinguá e PUC apresentaram nas frações areia grossa e fina, basicamente grãos de quartzo e traços de mica e minerais opacos. Os grãos de quartzo apresentaram características semelhantes em ambas as amostras; porém, na fração retida na peneira $n^{\circ} 40$ do solo da PUC, os grãos de quartzo são mais arredondados.

Nas análises realizadas mediante DRX e ATD constatou-se que a fração fina (silte e argila) do solo coluvionar da PUC é constituída principalmente por caulinita, enquanto que o solo de Tinguá, por caulinita e gibbsita, praticamente nas mesmas porcentagens, indicando que a fração fina deste solo é mais intemperizada que a do anterior. 
No solo residual de Duque de Caxias observou-se na fração areia, mediante a lupa binocular, apenas quartzo e mica biotita com diferentes graus de alteração, como minerais essenciais da rocha de origem. Mediante o DRX e ATD detectou-se caulinita, goethita (óxido de ferro) e biotita na fração passante na peneira $n^{\circ} 40$, não sendo observada a biotita no material passante na peneira $\mathrm{n}^{\circ} 200$.

A ausência de feldspatos indica que este solo, embora seja solo residual jovem ou saprolítico, já se encontra em um nível de alteração bastante elevado.

\section{4. \\ Caracterização microestrutural}

A microestrutura do solo é o fator que melhor explica o seu comportamento mecânico no laboratório. Mostra o arranjo dos grãos que os compõem, bem como a possível presença de substancias cimentantes.

As características microestruturais dos solos foram obtidas através da microscopia eletrônica de varredura (MEV), na qual o solo pode ser fotografado com ampliação de centenas a milhares de vezes. O princípio de funcionamento do MEV consiste na incidência de um feixe de elétrons de alta energia na superfície da amostra, onde ocorre uma interação e parte do feixe é refletido e coletado pelo detector. A grande vantagem desta técnica é o alto poder de penetração do feixe de elétrons e a possibilidade da amostra ser examinada em três dimensões. Este procedimento permite observar o arranjo das partículas, cimentações, forma e distribuição de vazios, e até mesmo identificar alguns minerais. A técnica da microscopia eletrônica de varredura (MEV) acoplada ao analisador de energia dispersiva (EDS - Energy Dispersive Spectrometry) contribui significativamente na identificação da constituição química do mineral, pois permite a sua análise detalhada, assim como de suas alterações.

$\mathrm{Na}$ presente pesquisa, os ensaios MEV foram realizados utilizando a técnica convencional, submetendo as amostras a alto vácuo, e a técnica alternativa de baixo vácuo que permitiu a visualização de amostras com umidade natural, sem metalização e sem perda do contraste natural vindo da interação feixe amostra.

Para a realização do ensaio convencional, pequenos torrões de cada amostra de solo com dimensões aproximadas de $0,5 \times 0,5 \times 0,5 \mathrm{~cm}$ foram secos em estufa à temperatura de aproximadamente $70^{\circ} \mathrm{C}$. Em seguida as amostras foram encaminhadas ao laboratório de Microscopia Eletrônica do Departamento de Engenharia Química e Materiais da PUC-Rio (DEQM) onde foram submetidas 
a alto vácuo e a deposição de um fino filme de ouro por bombeamento iônico, com o objetivo de garantir a condutividade elétrica da superfície, necessária para a formação da imagem. Posteriormente, as amostras foram colocadas no interior da câmara do microscópio eletrônico marca JEOL JSM-6510LV, e então foram selecionadas algumas imagens com as feições microestruturais de interesse, em diferentes escalas de aumento, e armazenadas de forma digital. Já para a realização dos ensaios MEV de baixo vácuo foram utilizados pequenos torrões dos solos na umidade natura. No presente estudo foram realizados aumentos de 20 a 1000 vezes como mostram as Fotos 4.10 a 4.14.

A porosidade do solo pode ser visualizada no MEV, porém sua distribuição ou quantificação é difícil de ser obtida pelas fotografias.

Nas Figuras 4.10 a 4.14 são apresentadas algumas imagens e gráficos resultantes da microscopia eletrônica de varredura realizada nos três solos estudados. No caso do solo residual jovem de Duque de Caxias, os resultados das análises foram retirados de Carvalho (2012), quem realizou o MEV convencional. Cada amostra analisada foi interpretada desde pequenos aumentos, enfocando características gerais, a aumentos mais detalhados, a fim de melhor definir as características estruturais e os aspectos de porosidade. Foi utilizada a microanálise por dispersão de energia EDS para definir a composição química qualitativa e semi-quantitativa de alguns pontos selecionados de interesse, a fim de confirmar sua composição química.

A Figura 4.10 é formada por duas imagens do solo residual jovem de Duque de Caxias em diferentes escalas (aumentos de 100 e 1000 vezes). Observa-se na Figura 4.10 (a) a presença de biotita alterada, iniciando sua alteração pelas bordas. Observa-se também a presença de macroporos entre pacotes desse mineral. A organização espacial mostra o aspecto estruturado do solo. Agentes cimentantes foram identificados entre pacotes. Na Figura 4.10 (b) fica evidente a presença de vazios intra-grãos, entre os placóides de biotita em processo de alteração, com material precipitado, tanto sobre os pacotes como entre os mesmos, composto basicamente por silício, alumínio e ferro (segundo análises EDS dos pontos 1 e 2), sendo o último elemento em grande concentração. Tanto os óxidos de ferro como os de manganês são provenientes do processo de intemperismo da mica biotita. Quando esses óxidos ocorrem entre grãos, podem atuar como cimento. O silício e o alumínio são constituintes básicos da mica biotita e da caulinita, podendo ainda estar em estado amorfo. 
$\mathrm{Na}$ mesma figura se apresenta a análise EDS dos pontos 1 e 2 de interesse. O elemento ouro presente nos EDS está relacionado com a preparação da amostra.
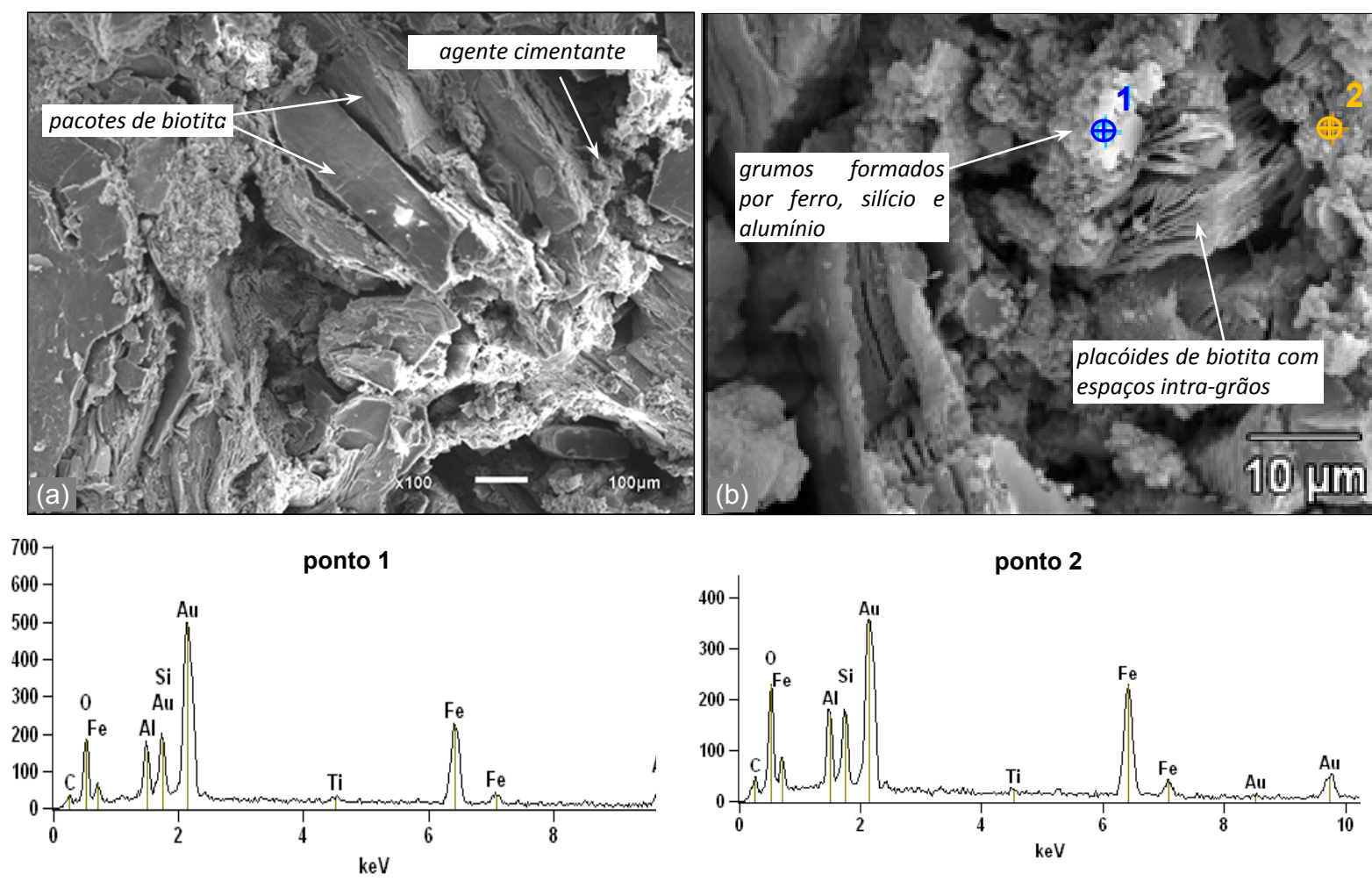

Figura 4.10 - Imagens obtidas no MEV convencional do solo Duque de Caxias em diferentes ampliações e análise EDS para pontos específicos (Carvalho, 2012)

As Figuras 4.11 a 4.14 apresentam as imagens obtidas para diferentes ampliações (de 20 a 1000 vezes) no MEV convencional e de baixo vácuo dos solos coluvionares de Tinguá e PUC. Estes solos apresentam características semelhantes, mostrando a formação de microagregados ligados por algum cimento ou por contato entre eles, dando origem a uma distribuição bimodal de poros. Em geral, os microporos caracterizam a estrutura interior dos microagregados e os macroporos constituem os vazios entre microagregados. Observa-se uma estrutura mais porosa na amostra pertencente ao solo de Tinguá.

$\mathrm{Na}$ análise química (EDS), a porcentagem de alumínio maior no solo de Tinguá estaria correlacionada à presença de gibbsita. No caso do solo da PUC a quantidade de silício e alumínio confirma que o argilomineral existente no solo é a caulinita. Neste solo observou-se uma maior quantidade de ferro, especialmente nas análises realizadas com o MEV de baixo vácuo. Note-se que 
as análises EDS são pontuais, não significando que as porcentagens indicadas nas figuras represetam a análise química total do solo.
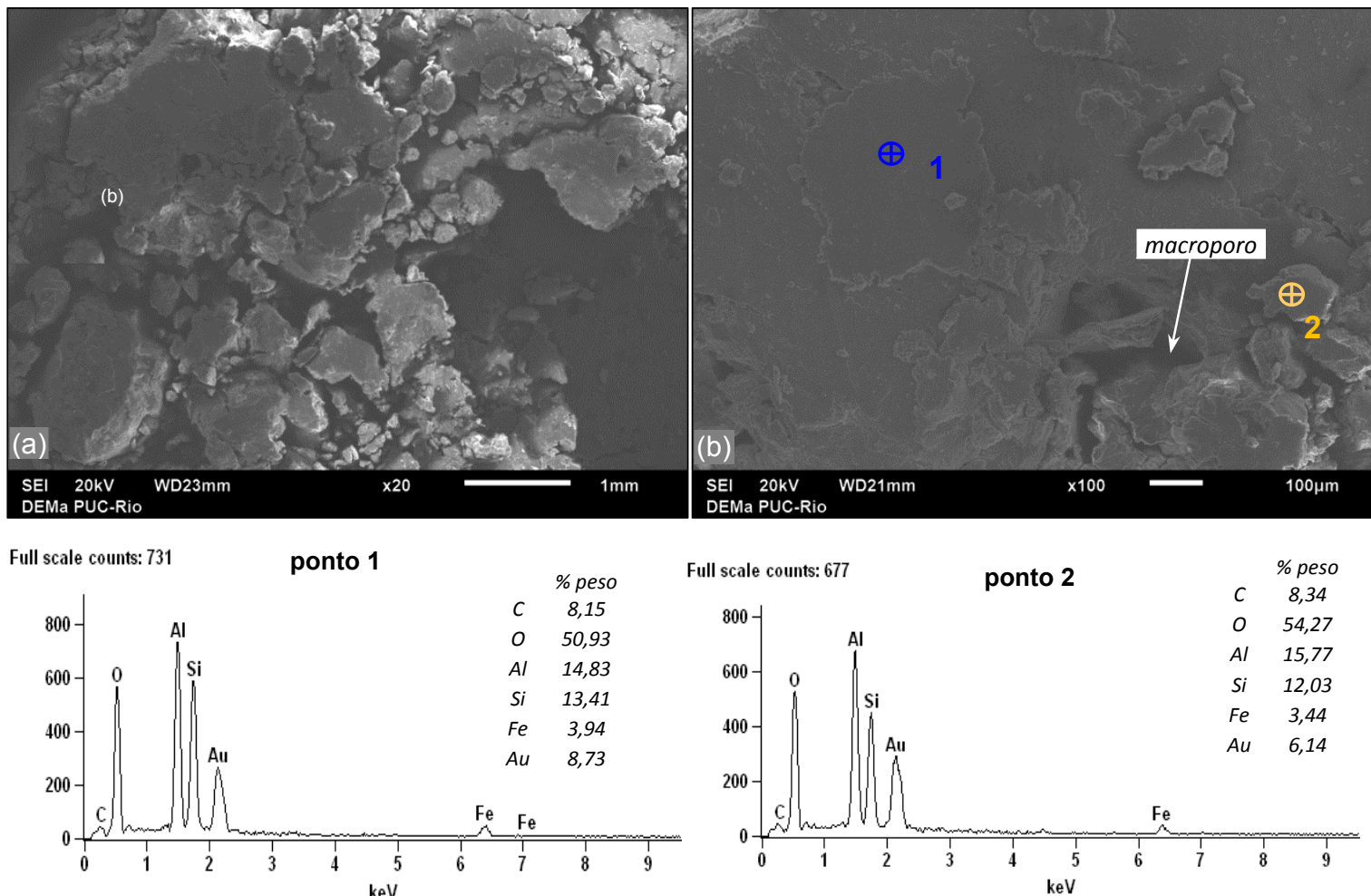

Figura 4.11 - Imagens obtidas no MEV convencional do solo coluvionar de Tinguá em diferentes ampliações e análise EDS para pontos específicos
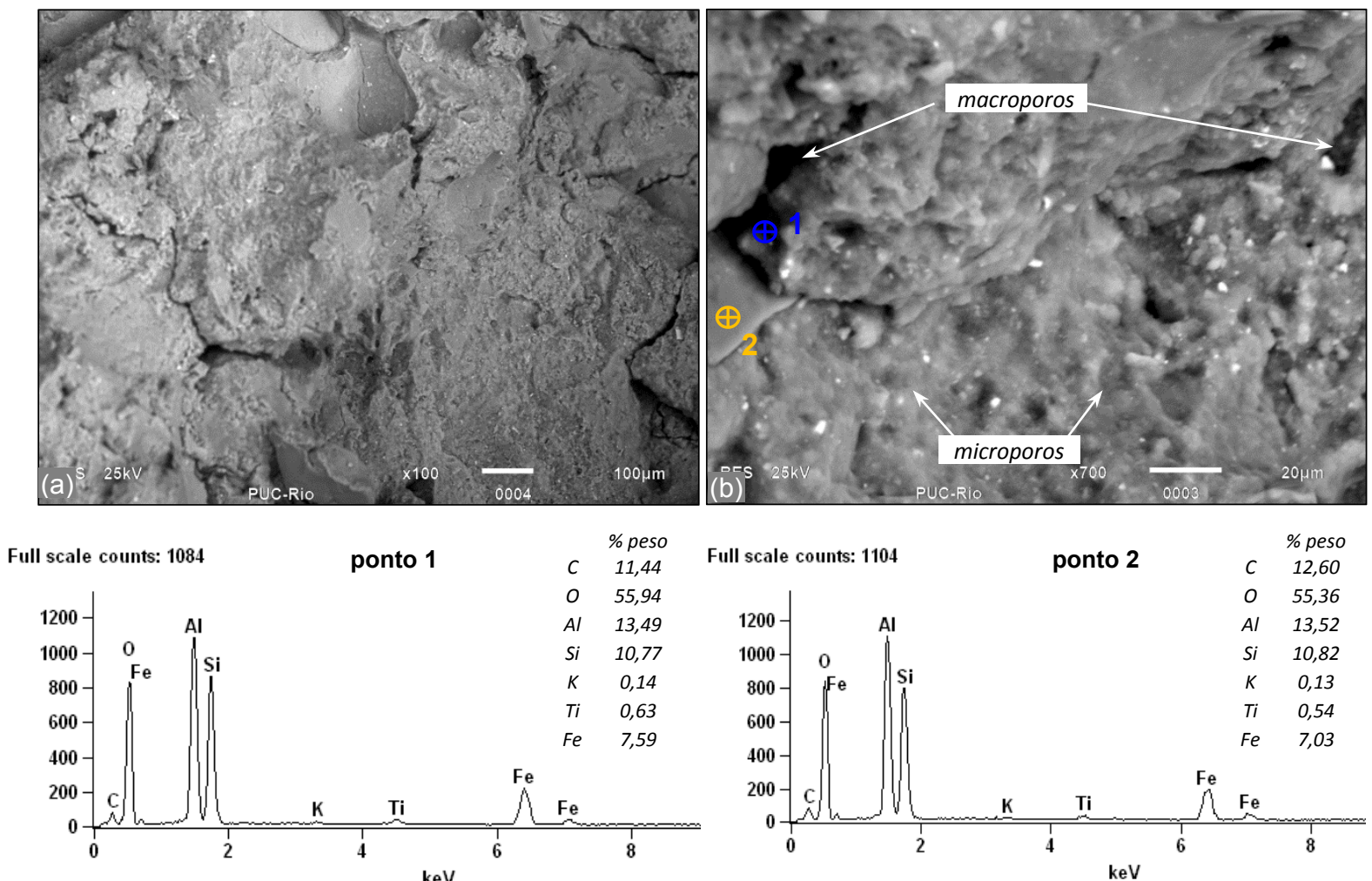

Figura 4.12 - Imagens obtidas no MEV de baixo vácuo do solo de Tinguá em diferentes ampliações e análise EDS para pontos específicos 

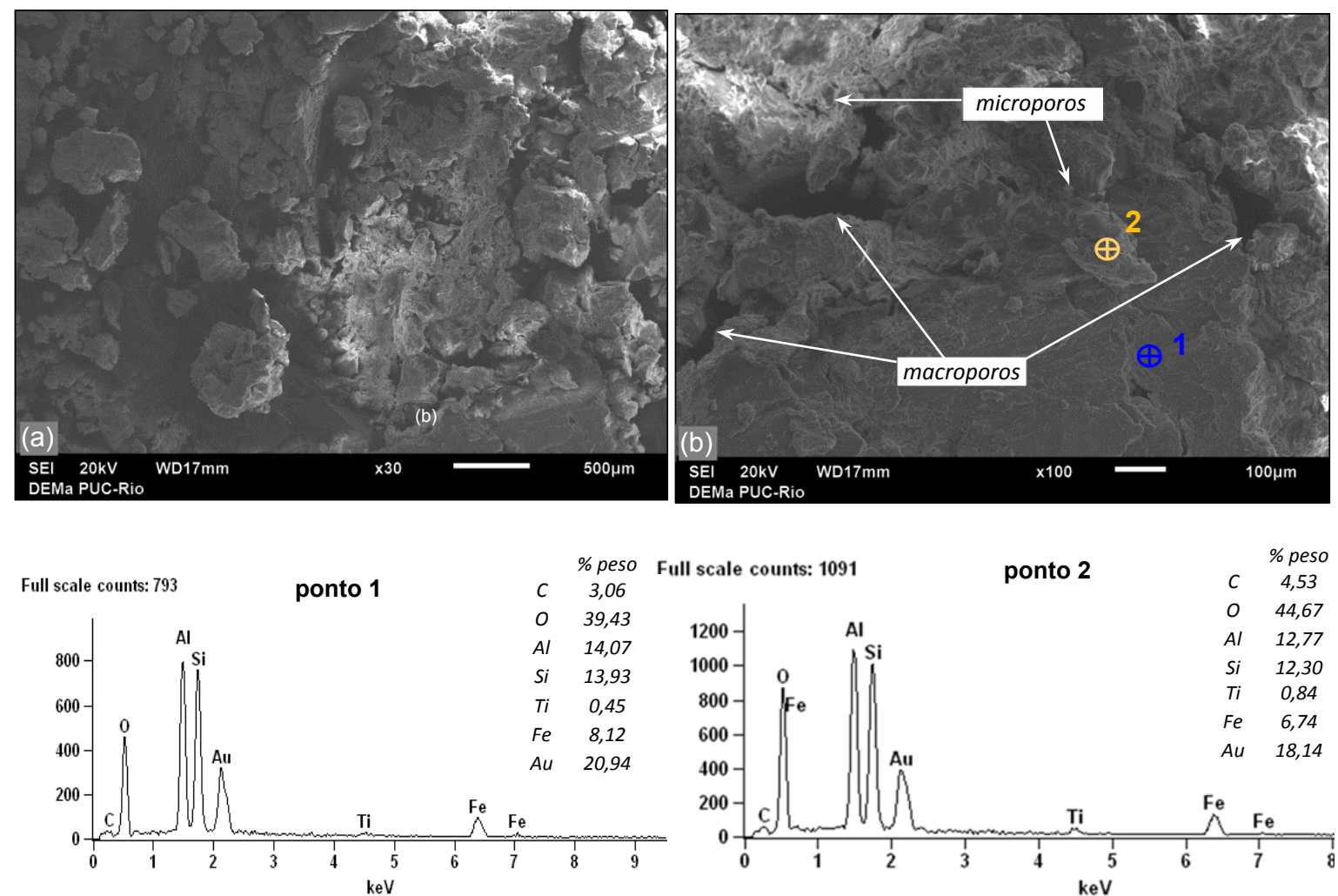

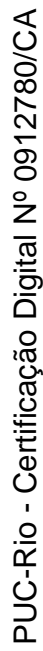

Figura 4.13 - Imagens obtidas no MEV convencional do solo coluvionar da PUC em diferentes ampliações e análise EDS para pontos específicos
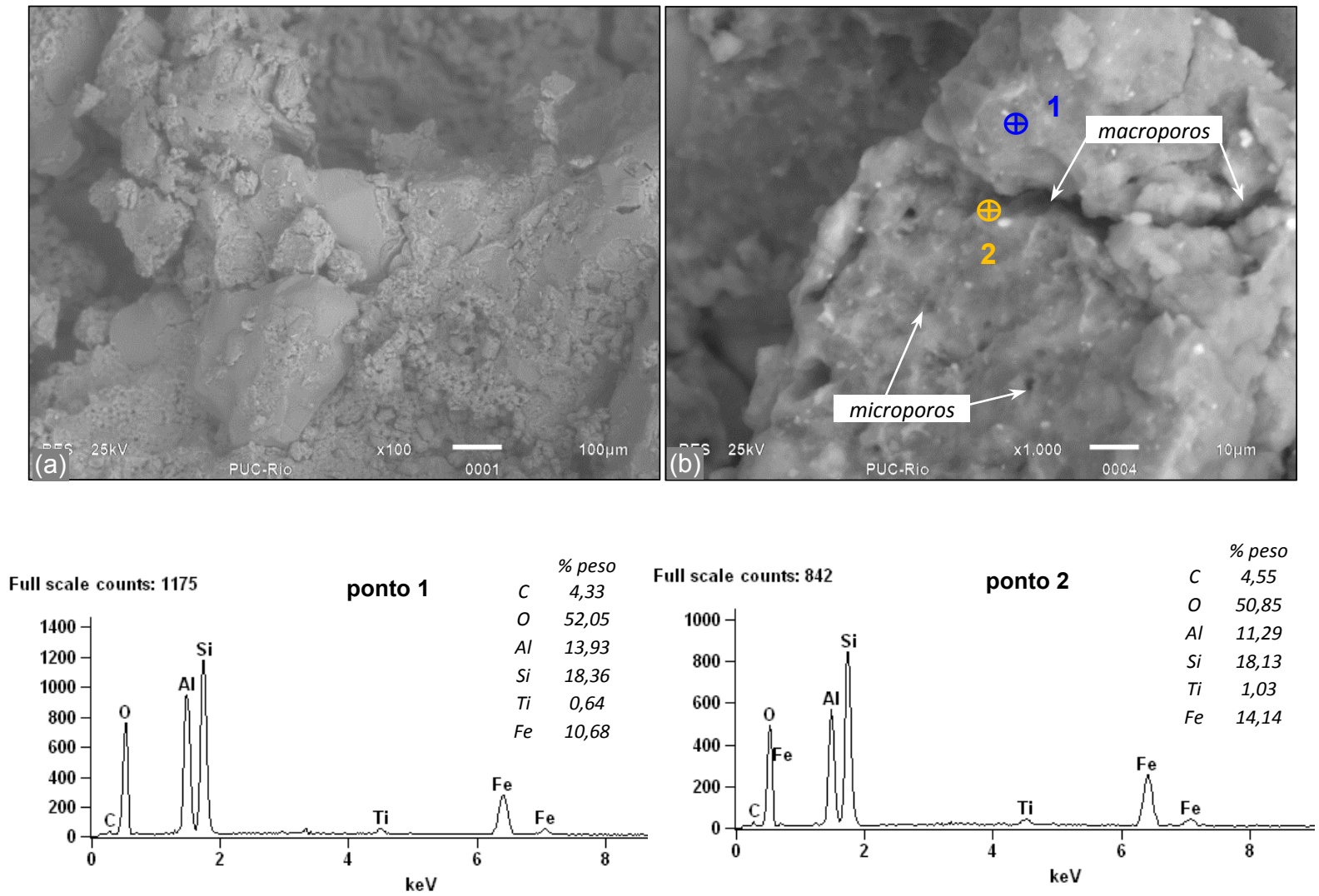

Figura 4.14 - Imagens obtidas no MEV de baixo vácuo do solo coluvionar da PUC em diferentes ampliações e análise EDS para pontos específicos 


\section{5. \\ Características da porosidade}

Para determinar o tamanho, quantidade e distribuição dos espaços porosos dos solos estudados foram realizados ensaios de porosimetria por intrusão de mercúrio. A técnica se baseia no fato de que o mercúrio se comporta como um fluído não-molhante em relação à maior parte das substâncias. Por consequência, não penetra espontaneamente em pequenos poros destes materiais a menos que se aplique uma pressão sobre ele. $\mathrm{O}$ volume de mercúrio que penetra nos poros é definido diretamente como uma função da pressão aplicada, com auxilio da equação de Washburn que supõe os poros de forma cilíndrica.

Neste ensaio, a amostra de solo, previamente seca ao ar, é submetida à injeção de mercúrio sob pressão. Inicialmente a amostra de solo é colocada em um recipiente, designado de penetrômetro, o qual é preenchido por mercúrio. Em seguida, aplica-se o vácuo para que o mercúrio possa penetrar nos poros do solo sem a interferência da água e do ar. Para cada estágio de pressão aplicada, mede-se o volume de mercúrio que penetra nos poros da amostra. $\mathrm{O}$ ensaio começa com a intrusão nos poros de maior diâmetro, a baixas pressões, estendendo-se a intrusão para os poros de menor diâmetro, à medida que as pressões vão sendo elevadas.

Através do registro da redução do nível de mercúrio no capilar, juntamente com a pressão aplicada, se obtém a curva porosimétrica que apresenta o volume dos poros do material, que foi penetrado pelo mercúrio, a uma determinada pressão. Basicamente o ensaio de porosimetria ao mercúrio fornece duas curvas: a curva de volume acumulado e um histograma de frequência contínuo dos diversos diâmetros de poros constituintes da estrutura do solo. Com a primeira é possível obter, para um determinado diâmetro de poro, as porcentagens, em relação ao volume de vazios total da amostra, dos poros de diâmetro maior ou menor do que o considerado. Já a segunda curva, $\mathrm{dv} / \mathrm{d}(\log \mathrm{d}) \mathrm{x}$ diâmetro de poros, fornece os intervalos de diâmetros de poros que aparecem com mais frequência na estrutura do solo.

Todos os ensaios de injeção de mercúrio foram realizados no Laboratório da Fundação de Apoio à Física e à Química da Universidade de São Carlos. O equipamento utilizado foi o Micromeritics Poresizer 9320, que investiga poros de diâmetro a partir de $0,7 \mathrm{~mm}$ a uma pressão aplicada de aproximadamente $0,0017 \mathrm{MPa}(0,17 \mathrm{~atm})$, até poros de $0,000006 \mathrm{~mm}$ ou 60 Angström de diâmetro 
a uma pressão aplicada de $212 \mathrm{MPa}$ (2000 atm). No caso do solo de Duque de Caxias, os resultados do ensaio foram retirados de Carvalho (2012).

A Figura 4.15 apresenta a distribuição acumulativa dos diâmetros dos poros para os solos estudados, onde se mostra que os solos coluvionares da PUC e Tinguá apresentam dois patamares na curva de distribuição acumulativa dos diâmetros dos poros, enquanto o solo residual jovem de Duque de Caxias apresenta curva em forma de "S".

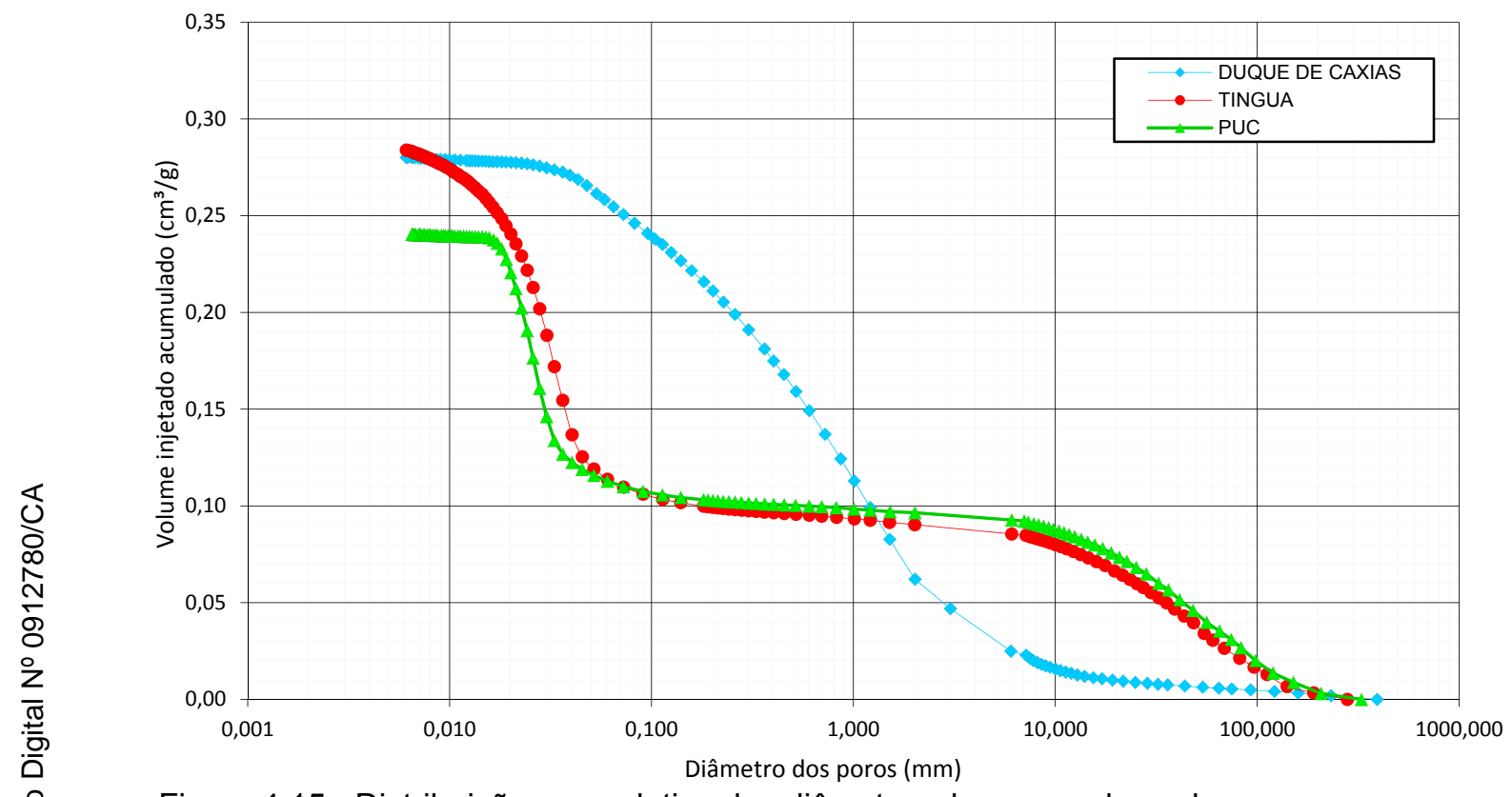

Figura 4.15 - Distribuição acumulativa dos diâmetros dos poros dos solos

A Tabela 4.8 apresenta os valores de porosidade total obtidos para os três solos estudados nos ensaios de porosimetria. A porosidade total é obtida multiplicando-se o volume total injetado na amostra por grama de solo pelo peso específico seco do solo (obtido nesse ensaio). De acordo com esses valores a amostra do solo de Tinguá indica uma porosidade maior que as outras amostras.

Tabela 4.8 - Porosidade por injeção de mercúrio dos solos

\begin{tabular}{c|cc}
\hline \multicolumn{2}{c}{ Solos Coluvionares } \\
\hline Amostra & \multicolumn{1}{c}{ Porosidade por injeção de mercúrio (\%) } \\
\hline Tinguá & 45,31 \\
PUC & 36,22 \\
\hline Amostra & Porosidade por injeção de mercúrio (\%) \\
\hline Duque de Caxias & 38,24 \\
\hline
\end{tabular}


Na Figura 4.16 tem-se a distribuição incremental dos diâmetros dos poros nos três solos, onde se mostram as faixas de microporos, mesoporos e macroporos referidas à classificação dos espaços porais pelo sistema da IUPAC - União Internacional de Química Pura e Aplicada (1982).

De acordo com esta classificação, o solo de Duque de Caxias possui uma maior concentração de macroporos, enquanto nos demais ocorre a predominância de microporos.

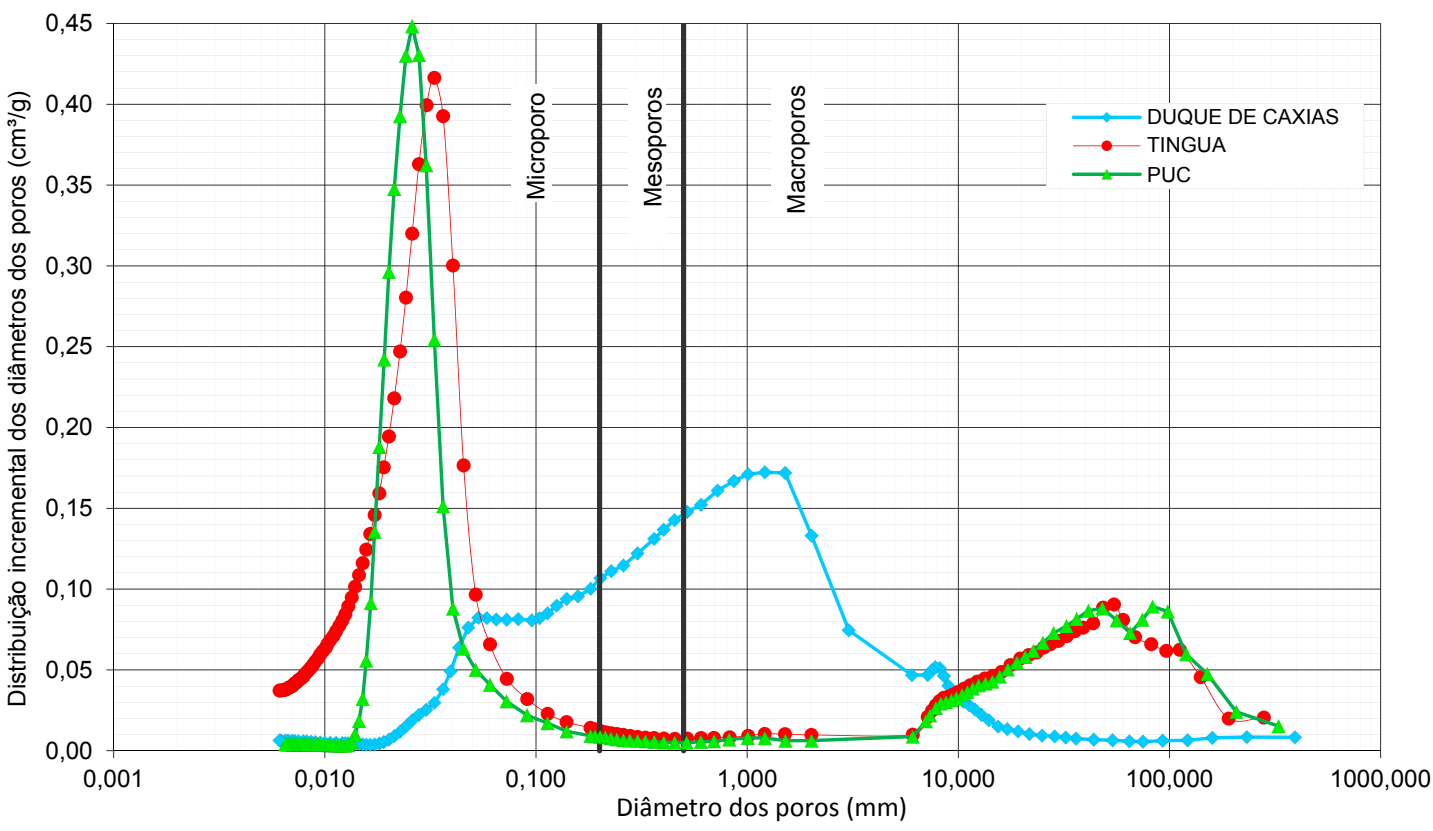

Figura 4.16 - Curvas de distribuição incremental dos diâmetros dos poros dos solos Duque de Caxias, Tinguá e PUC, com a classificação dos poros segundo a IUPAC

Analisando a Figura 4.16, pode-se notar que a distribuição do diâmetro dos poros para o solo Duque de Caxias indica somente um pico, referindo-se a um diâmetro representativo especifico, isto é, a curva representa uma forma unimodal. O mesmo não ocorre com as amostras dos solos Tinguá e PUC, onde a distribuição do diâmetro dos poros se dá na forma bimodal, ou seja, existe uma concentração de poros em dois diâmetros muito distintos.

A partir dos resultados mostrados na Figura 4.16 é possível obter a porcentagem volumétrica de microporos, mesoporos e macroporos presentes nos solos estudados conforme Tabela 4.9.

Camapum de Carvalho (2004) afirma que nos solos pouco intemperizados, a agregação entre as partículas é pequena. A estrutura é influenciada pela estrutura da rocha mãe e a distribuição de poros é relativamente homogênea (mono-modal). Nestes solos, o nível de herança da rocha mãe depende do grau de alteração sofrido. Já nos solos lateríticos, principalmente os profundamente intemperizados, a agregação é importante. A estrutura independe da origem 
(residual ou transportado) e é geralmente marcada por porosidade elevada que se distribui entre os agregados e no interior dos mesmos, conferindo ao solo uma distribuição de poros bi-modal. De acordo com esta afirmação os solos coluvionares da PUC e Tinguá apresentam o formato caraterístico de solos intemperizados, contendo poros entre partículas e poros entre agregados de partículas, tal como observado nas análises MEV.

Tabela 4.9 - Distribuição de poros em porcentagem segundo IUPAC

\begin{tabular}{c|c|c|c}
\hline \multicolumn{4}{c}{ Solos Coluvionares } \\
\hline Amostra & $\begin{array}{c}\text { Microporos (\%) } \\
\varnothing<0,2 \mu \mathrm{m}\end{array}$ & $\begin{array}{c}\text { Mesoporos (\%) } \\
0,2 \mu \mathrm{m} \phi<0,5 \mu \mathrm{m}\end{array}$ & $\begin{array}{c}\text { Macroporos (\%) } \\
\varnothing>0,5 \mu \mathrm{m}\end{array}$ \\
\hline Tinguá & 65,02 & 1,27 & 33,71 \\
PUC & 57,24 & 1,04 & 41,72 \\
\hline \multicolumn{4}{|c}{ Solo Residual } \\
\hline Amostra & Microporos (\%) & Mesoporos (\%) & $\begin{array}{c}\text { Macroporos (\%) } \\
\varnothing>0,5 \mu \mathrm{m}\end{array}$ \\
\hline Duque de Caxias & $\varnothing<0,2 \mu \mathrm{m}$ & $0,2 \mu \mathrm{m} \varnothing<0,5 \mu \mathrm{m}$ & 53,30 \\
\hline
\end{tabular}

4.6.

Considerações finais sobre a caracterização dos solos estudados

Neste capítulo foram apresentadas e discutidas as características dos solos coluvionares e residual jovem estudados. Observa-se que tentar estabelecer uma classificação rigorosa e única, como a SUCS, não é adequado, já que não reflete as características destes solos. Tendo em vista a natureza dos solos, foram considerados os aspetos físicos, químicos, mineralógicos e microestruturais.

Nas análises granulométricas, a comparação estabelecida entre os resultados dos ensaios realizados com e sem uso de defloculante, revelaram, principalmente para os solos coluvionares, que há floculação de argilas, as que se encontram na forma de microagregados areno-siltosos no estado natural do solo.

Os solos coluvionares possuem valores de densidade relativa dos grãos entre 2,6 e 2,7 indicando que são provenientes, provavelmente, de áreas de rochas quartzo-feldspáticas. O solo residual jovem apresenta um valor em torno de 2,88 que pode estar ligado aos minerais máficos, principalmente à biotita, na composição da sua rocha de origem.

Os resultados obtidos para os limites de consistência e índices de plasticidade indicaram valores de $L L=73,1 \%, L P=43 \%, I P=30,1 \%$ para o solo coluvionar de Tinguá e de $L L=61,3 \%, L P=33,1 \%, I P=28,1 \%$ para o solo 
coluvionar da PUC. O índice de atividade encontrado para o solo de Tinguá foi de 0,58 , e para o solo da PUC foi de 0,47 sendo a fração argila de ambos os solos classificada como inativa. O solo residual jovem de Duque de Caxias não apresentou limites de consistência, possivelmente por seu baixo teor de argila e a sua fração de silte e areia fina, constituída essencialmente por mica interperizada. Este solo foi classificado pela SUCS como areia siltosa. Sendo os solos coluvionares de Tinguá e PUC classificados como siltes de alta plasticidade, considerando a fração fina (silte e argila) dispersa.

Os solos coluvionares apresentam índices físicos semelhantes.

O estudo da mineralogia dos solos foi dividido em duas partes: Análise da fração areia mediante o uso da lupa binocular, e análise da fração silte e argila mediante os ensaios DRX e ATD. Os solos coluvionares apresentaram na fração areia grossa e fina, basicamente grãos de quartzo e traços de mica e minerais opacos. A fração fina do solo coluvionar da PUC é constituída principalmente por caulinita e goethita (óxido de ferro), enquanto que a do solo coluvionar de Tinguá, por caulinita e gibbsita, praticamente nas mesmas proporções, indicando que a fração fina deste solo é mais intemperizada que a do anterior. No solo residual jovem de Duque de Caxias observou-se na fração areia, principalmente mica biotita com diferentes graus de alteração. Na fração passante na peneira $\mathrm{n}^{\circ}$ 40 encontrou-se caulinita, goethita e biotita, não sendo observada a biotita no material passante na peneira $\mathrm{n}^{\circ} 200$.

Os resultados das análises químicas foram coerentes com os resultados mineralógicos, pois a composição química obtida faz parte da composição dos minerais e argilominerais identificados. Destaca-se o teor de óxido de ferro do solo coluvionar da PUC, ligeiramente mais elevado em comparação com o solo coluvionar de Tinguá, que pode estar relacionado com a composição mineralógica da provável rocha de origem. No solo residual jovem de Duque de Caxias identificou-se um teor elevado de ferro, vinculado à rocha de origem ou área fonte e à formação do mineral secundário goethita. Estes teores de óxido de ferro também foram constatados em pontos específicos da amostra no MEV por meio das análises EDS. Através das análises químicas se identificaram os três solos como ácidos ( $\mathrm{pH}$ em torno de 5) e muito intemperizados devido à lixiviação intensa dos álcalis (cálcio, magnésio, sódio e potássio).

A presença de gibbsita no solo de Tinguá, em principio, deveria fazer com que os índices de plasticidade e de atividade deste solo fossem menores do que do solo da PUC, o que não acontece. Possivelmente, este fato decorre devido à maior proporção de óxido de ferro nas amostras da PUC, que tenderia a diminuir 
sua atividade e plasticidade. O alto valor de densidade relativa dos grãos do solo da PUC $(G s=2,738)$ é, também, um indicativo da presença de óxido de ferro no solo, que se encontraria envolvendo as partículas do argilomineral caulinita.

De acordo com Antunes et al. (2015) ambos solos são considerados lateríticos, sendo que o solo de Tinguá está em estado mais avançado de laterização. Um solo pode ser indicado como laterítico pela composição mineralógica da fração argila ou pela relação molecular de sílica-alumínio $\left(\mathrm{Ki}=\mathrm{SiO}_{2} / \mathrm{Al}_{2} \mathrm{O}_{3}\right)$ computada a partir dos resultados obtidos em ensaios químicos de Ataque Sulfúrico (Antunes et al., 1982). No caso do solo coluvionar de Tinguá considerou-se a mineralogia da fração argila para classificar o solo como laterítico; no solo da PUC, além da mineralogia, considerou-se o valor de $\mathrm{Ki}$ inferior a $2(\mathrm{Ki}=1,49)$ obtido por Duarte $(2004)$, um dos parâmetros químicos dos solos lateríticos, considerados na ciência do solo (EMBRAPA, 2013).

Ambos os solos coluvionares estão marcados pela distribuição de poros bimodal dividida predominantemente em macro e microporos. Os microporos se situam no interior dos agregados e os macroporos entre eles. Observando-se no solo de Tinguá uma estrutura mais porosa que pode estar correlaciona com à composição mineralógica da fração fina, pela presença de gibbsita. O solo residual jovem de Duque de Caxias apresenta uma distribuição de poros unimodal, com um diâmetro de poros representativo específico.

Os processos de laterização conferem à estrutura aberta dos solos coluvionares a formação de microagregados que podem se ligar a outros por contato entre eles ou por algum cimento, que embora fraco, pode conferir ao solo efeitos de um pseudo sobreadensamento.

No solo Duque de Caxias encontrou-se principalmente biotita intemperizada com presença de concreções de manganês (óxi-hidróxido de ferro precipitado), sendo o ferro liberado depositado nos vazios do solo. O oxihidróxido de ferro juntamente com o material fino (silte e argila - principalmente a goethita) atuam como cimento. A presença de agentes cimentantes no solo foi observada tanto na lupa binocular como nos resultados de microscopia eletrônica de varredura (MEV) deste solo. O papel da goethita como agente cimentante é ressaltado por Collins (1985) que afirma que este argilomineral pode contribuir com o aumento da resistência ao cisalhamento do solo em termos de coesão aparente. A ausência de feldspatos indica que este solo, embora seja residual jovem ou saprolítico, já se encontra em um nível de alteração bastante elevado. 


\section{5 \\ Equipamentos e técnicas experimentais}

\section{1 \\ Considerações gerais}

Este capítulo apresenta as técnicas experimentais dos ensaios de laboratório, executados a fim de identificar as características de resistência dos três solos estudados, bem como os equipamentos utilizados para a realização dos mesmos. O programa experimental da presente tese compreende, além da caraterização geotécnica dos solos exposta no capítulo anterior, a execução de três séries distintas de ensaios.

A primeira série envolve a execução de ensaios triaxiais de aumento de poropressão, de modo a simular a trajetória de tensões seguida no campo por um elemento de solo localizado ao longo de uma superfície potencial de ruptura, em um talude sujeito a precipitações pluviométricas de alta intensidade. Os ensaios foram realizados em corpos de prova indeformados dos três solos estudados, que foram adensados anisotropicamente com relações de tensões $\mathrm{K}_{\mathrm{c}}$ de 2,0 e $2,5\left(\mathrm{~K}_{\mathrm{c}}=\sigma^{\prime}{ }_{1} / \sigma^{\prime}{ }_{3}\right)$ até tensões efetivas de $25,50,75,100,150,220$ e 300 $\mathrm{kPa}$.

A segunda série compreende a execução de ensaios triaxiais convencionais com adensamento isotrópico drenados (CID) e não drenados (CIU), assim como triaxiais convencionais com adensamento anisotrópico não drenados (CKU), seguindo a trajetória de tensões de compressão axial, com velocidade de deslocamento constante. Os ensaios foram realizados em corpos de prova indeformados submetidos a tensões efetivas de confinamento de 25 , 75, 150 e $300 \mathrm{kPa}$. Os ensaios CID e CIU foram executados somente em amostras dos solos coluvionares da PUC e Tinguá. Visto que o solo de Duque de Caxias foi estudado em bastante detalhe, por Carvalho (2012), não se realizaram estes tipos de ensaios nesse solo. Os ensaios CKU foram realizados somente em amostras do solo coluvionar de Tinguá, com a finalidade de auxiliar a determinação das envoltórias e avaliar o comportamento não drenado do solo sob tal forma de adensamento. 
A terceira série de ensaios é composta por ensaios de cisalhamento direto com plano cortado e superfície polida, para obtenção da resistência residual. Estes ensaios foram realizados nos três solos estudados, utilizando-se tensões normais iniciais de adensamento de 25, 50, 75, 100, 150 e $200 \mathrm{kPa}$.

A segunda e terceira série de ensaios foram realizadas com a finalidade de determinar as relações tensão-deformação e as envoltórias que caracterizam o estado crítico, de pico e residual dos três solos estudados, comparando o comportamento destes nas diferentes trajetórias de tensão.

$\mathrm{Na}$ Tabela 5.1 é mostrado o programa de ensaios executados em cada solo.

Tabela 5.1 : Programa de ensaios executados

\begin{tabular}{c|c|c|c|c|c}
\hline \multirow{2}{*}{ Solo } & \multicolumn{5}{|c}{ Número de Ensaios } \\
\cline { 2 - 6 } & $\begin{array}{c}\text { Aumento de } \\
\text { poropressão }\end{array}$ & $\begin{array}{c}\text { Triaxial } \\
\text { CIU }\end{array}$ & $\begin{array}{c}\text { Triaxial } \\
\text { CID }\end{array}$ & $\begin{array}{c}\text { Triaxial } \\
\text { CKU }\end{array}$ & $\begin{array}{c}\text { Cisalh. Direto com } \\
\text { plano cortado e } \\
\text { superfície polida }\end{array}$ \\
\hline PUC & 8 & 3 & 3 & - & $9^{*}$ \\
\hline Tinguá & 8 & 4 & 4 & 3 & 6 \\
\hline $\begin{array}{c}\text { Duque de } \\
\text { Caxias }\end{array}$ & 12 & - & - & - & 6 \\
\hline *3 dos ensaios foram realizados em amostras amolgadas
\end{tabular}

\section{2}

\section{Ensaio triaxial de aumento de poropressão}

O ensaio triaxial de aumento de poropressão consiste, inicialmente, em reproduzir as condições de tensões existentes no campo, $K_{c}=\sigma_{1}{ }_{1} / \sigma_{3}{ }_{3}$. Em seguida, as tensões totais são mantidas constantes e se aumenta sucessivamente a poropressão até a ruptura; simulando assim a elevação do nível piezométrico, e consequentemente o aumento da poropressão, durante o período de chuvas intensas.

Para a execução dos ensaios e simulação da trajetória de tensão pretendida, foi adaptada uma prensa triaxial convencional, a fim de permitir o controle independente da tensão axial, da pressão na câmara e da poropressão no corpo de prova. Em virtude disso, foi acoplado ao sistema um dispositivo que permitia o controle das tensões axiais aplicadas, além de um controlador de pressão GDS, utilizado para o incremento da poropressão a uma taxa especificada. As Figuras 5.1 e 5.2 mostram o esquema dos equipamentos utilizados, assim como uma vista geral deles. 


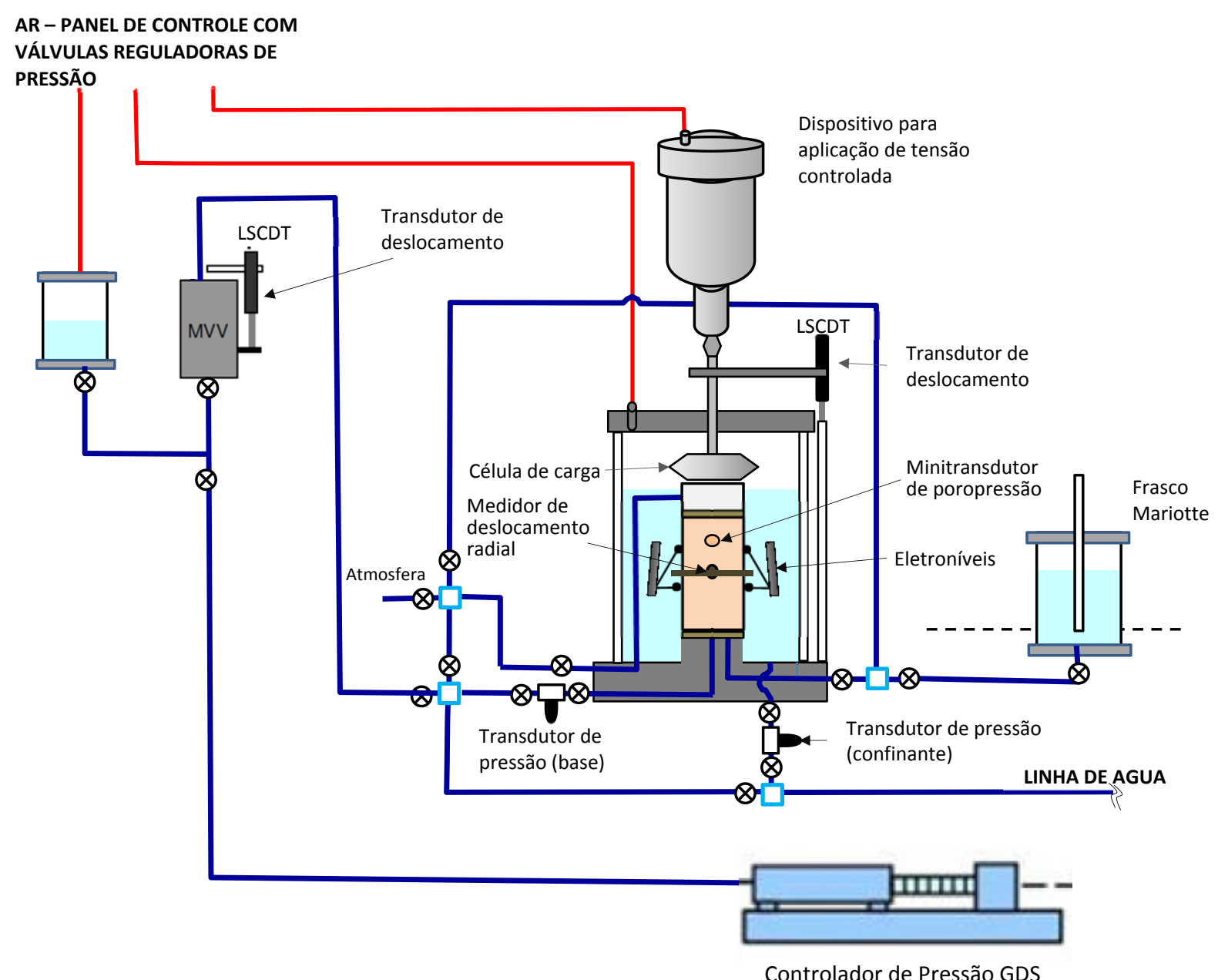

Figura 5.1 - Arranjo esquemático do equipamento utilizado nos ensaios de aumento de poropressão 

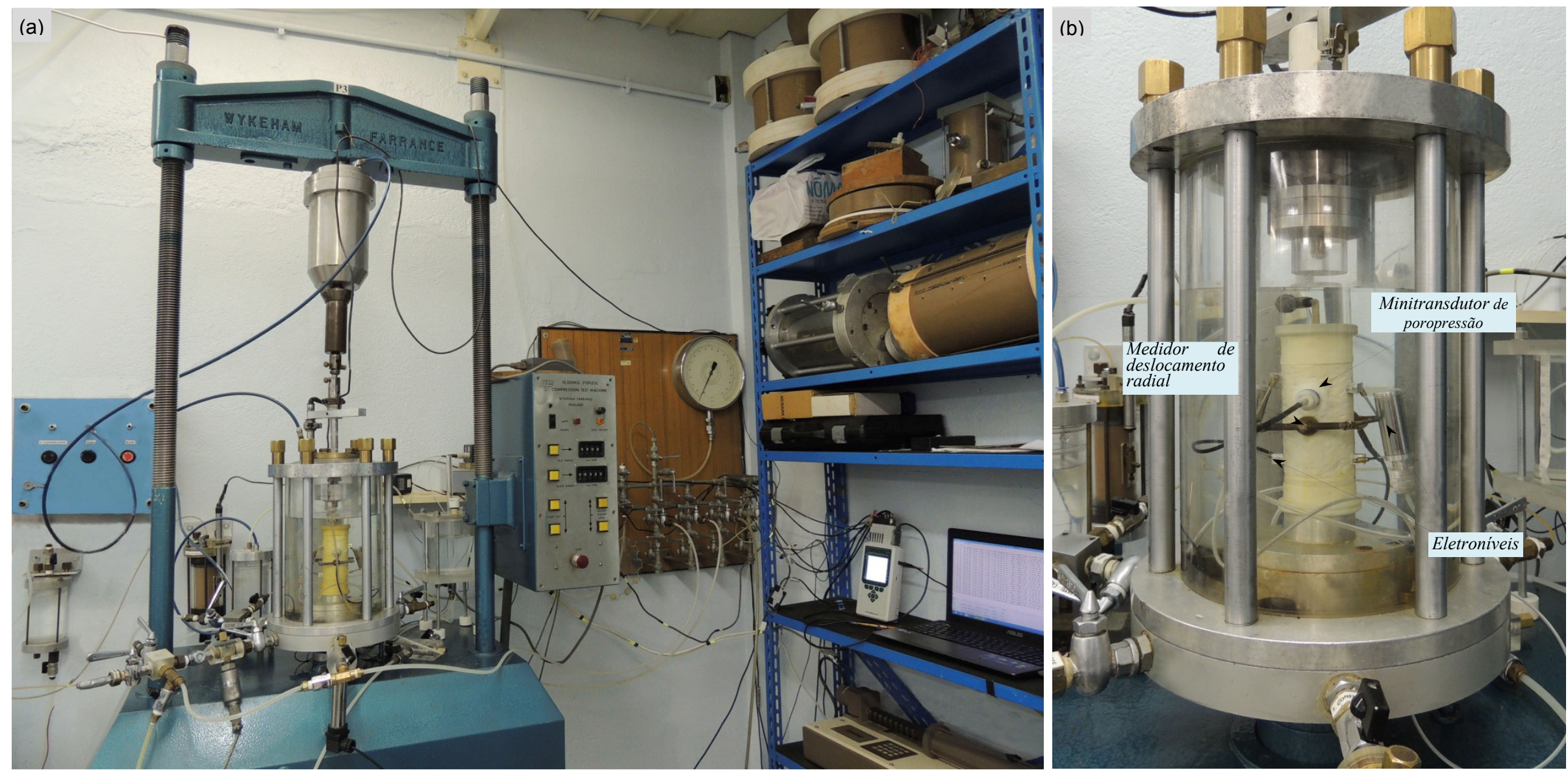

Figura 5.2 - (a) Vista geral dos equipamentos usados nos ensaios de aumento de poropressão, (b) Detalhe da câmara triaxial com instrumentação interna 
O desenvolvimento das deformações da amostra, originado pela redução da tensão efetiva média, foi monitorado ao longo do tempo mediante a utilização de instrumentação interna. Da mesma forma, as poropressões foram medidas na parte inferior e a meia altura do corpo de prova com a finalidade de avaliar a uniformidade da distribuição da tensão efetiva, que somente foi alcançada após a escolha de uma apropriada taxa de incremento de poropressão.

Para o controle adequado das leituras dos instrumentos de medição, foi adaptado um novo sistema de aquisição de dados.

Neste item são apresentados os detalhes relacionados aos equipamentos e a instrumentação empregada, assim como, a metodologia e a seleção de critérios para execução dos ensaios de aumento de poropressão

\subsection{1}

\section{Equipamentos, sistema de controle e instrumentação}

\subsubsection{1}

\section{Prensa triaxial}

Os ensaios triaxiais com aumento de poropressão foram executados em uma prensa triaxial Wykeham Farrance modelo WF10073, com capacidade de 10000 kg, cujo painel de controle lateral permite a seleção da taxa de deslocamento constante, que pode variar de 0,0005 a $50 \mathrm{~mm} / \mathrm{min}$.

A câmara triaxial empregada é da mesma fabricação, Modelo WF11521, para corpos de prova de 4" (101,6 mm) de diâmetro, com pedestal adaptado para amostras de 1,5" e corpo de acrílico que suporta pressão confinante máxima de $700 \mathrm{kPa}$. As dimensões da câmara permitem a utilização de instrumentação interna nos corpos de prova, possibilitando a saída dos fios dos instrumentos por meio de furos existentes no pedestal. Através da base, são realizados o enchimento da câmara, as medidas de poropressão e da tensão confinante. Na tampa superior existem dois furos, um central pelo qual passa a haste da célula de carga e o outro mais periférico para despressurização e controle da pressão de confinamento.

\subsubsection{2}

\section{Sistema de controle de pressão}

O controle de pressão nos ensaios foi realizado de duas maneiras diferentes: mediante um sistema de ar comprimido e mediante um controlador de pressão e volume tipo GDS. 
$\mathrm{Na}$ aplicação da pressão confinante e da contrapressão, utilizou-se um sistema de ar comprimido controlado por um painel de válvulas reguladoras de pressão (ver Figura 5.1), ligadas à rede de ar comprimido do laboratório que fornece uma pressão máxima na linha de $1000 \mathrm{kPa}$. O controle é realizado manualmente pelo operador da prensa. Este processo consiste na regulagem da pressão via leituras fornecidas pelo transdutor de pressão. O sistema possui três válvulas Watson Smith, que trabalham na faixa de 10 - $820 \mathrm{kPa}$, sendo que uma das válvulas serve para aplicação da pressão de ar no topo da câmara triaxial, que confere a pressão confinante, outra para aplicação da contrapressão e, a última, possibilitou a aplicação da pressão de ar no dispositivo de controle da tensão vertical no corpo de prova.

Para a aplicação da pressão confinante na câmara, a mesma foi preenchida com água até uma determinada altura. Neste trabalho se adotou como referência a metade da altura do cabeçote do corpo de prova. $\mathrm{O}$ ar comprimido, ao preencher o restante da câmara, transmite a pressão diretamente à água de confinamento e ao corpo de prova submerso. O uso da câmara triaxial como uma interface ar-água, permitiu que a pressão da câmara se mantivesse constante, mesmo durante as rupturas súbitas, que eram esperadas durante os ensaios de tensão controlada constante. $O$ ar da câmara evitaria qualquer mudança de pressão devida ao deslocamento do pistão no interior dela.

No caso da contrapressão, o ar comprimido era aplicado em uma interface e esta, por sua vez, ao medidor de variação de volume (MVV), que transmitia a pressão para o corpo de prova.

A aplicação da pressão, durante a fase de aumento de poropressão, foi realizada por meio de um controlador de pressão e volume tipo GDS, cujo alcance de pressão varia de 0 a $2000 \mathrm{kPa}$. Maiores detalhes das características deste equipamento e da maneira de transmissão da pressão ao interior do corpo de prova são dados no item a seguir.

\section{a) Controlador de pressão e volume GDS}

O GDS é um controlador de pressão e volume de água. No seu interior, um pistão move-se introduzindo a pressão diretamente no fluido. Este equipamento também possibilita a medida da quantidade de fluido que entra ou sai do mesmo para manutenção da pressão.

O GDS, pertencente ao laboratório de Geotecnia da PUC-Rio, atinge capacidades em pressão e volume de $2 \mathrm{MPa}$ e $200 \mathrm{~cm}^{3}$, respectivamente, com 
uma resolução de medidas de $1 \mathrm{kPa}$ e $1 \mathrm{~cm}^{3}$. Este equipamento foi utilizado na fase de aumento de poropressão, incrementando as pressões com uma velocidade constante. As variações de pressão e de volume foram controladas em tempo real, através de uma interface visual no próprio equipamento.

A pressão do GDS foi aplicada ao corpo de prova através do MVV, o que permitiu realizar uma medição contínua do volume de entrada ou de saída de água, necessário para manter o incremento da poropressão em uma velocidade controlada (verificando o volume de água injetada, indicada no GDS). Detalhes sobre a operação do medidor de variação de volume são dados mais adiante.

O controlador de pressão GDS foi programado através de seu próprio painel de controle. Para qualquer mudança na poropressão, resultante da deformação do solo, o GDS responde para manter a taxa de incremento especificada. Se a amostra tende a se contrair, este se move para trás, permitindo que a água drene para fora da amostra. Já, se a amostra tende a dilatar, este se move para frente, permitindo que a água drene para dentro da amostra.

$\mathrm{Na}$ Figura 5.3 pode-se observar o controlador GDS, bem como a sua disposição esquemática.

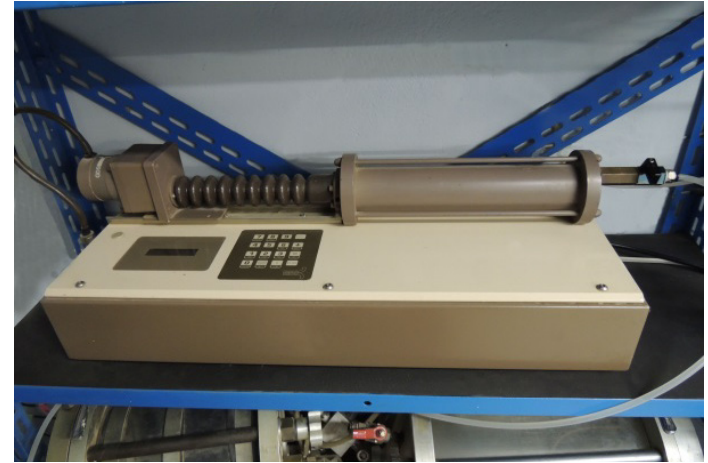

(a)

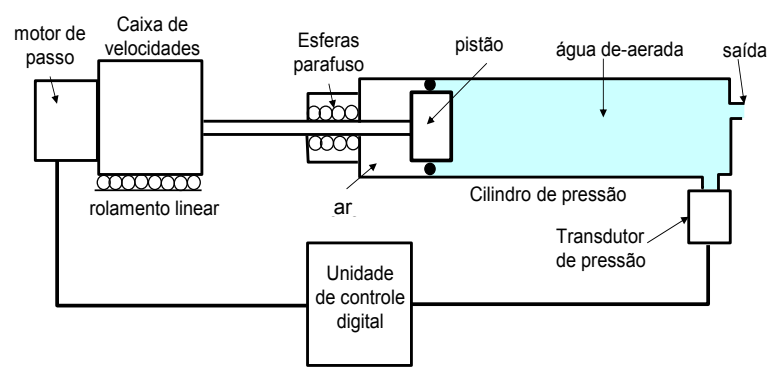

(b)

Figura 5.3 - (a) Controlador de pressão e volume GDS, (b) Esquema de funcionamento do controlador

\section{b) Dispositivo para aplicação de tensão controlada}

Para os ensaios triaxiais com aumento de poropressão, tornou-se necessária a utilização de uma prensa triaxial que permitisse o controle das tensões aplicadas. Por esse motivo, optou-se por utilizar um dispositivo desenvolvido por Andrade (1988) que, acoplado à prensa convencional de deformação controlada, permite o controle das tensões aplicadas e a simulação das trajetórias de tensão pretendidas. 
O equipamento, conforme mostrado nas Figuras 5.4 e 5.5, é composto por uma câmara superior, limitada por um diafragma tipo "Bellofram", onde é aplicada a pressão por ar comprimido. O "Bellofram" é solidarizado a um pistão vazado de PVC e a um eixo retificado de aço, por intermédio de um parafuso central.

Uma mola de comprimento livre, equivalente à altura do aparelho, e com constante elástica elevada, é colocada sob o pistão de PVC com a finalidade de manter o mesmo próximo à tampa do aparelho, na ausência de ar comprimido, e forçar a utilização de pressões de ar compatíveis com a sensibilidade das válvulas de controle.

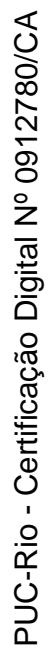

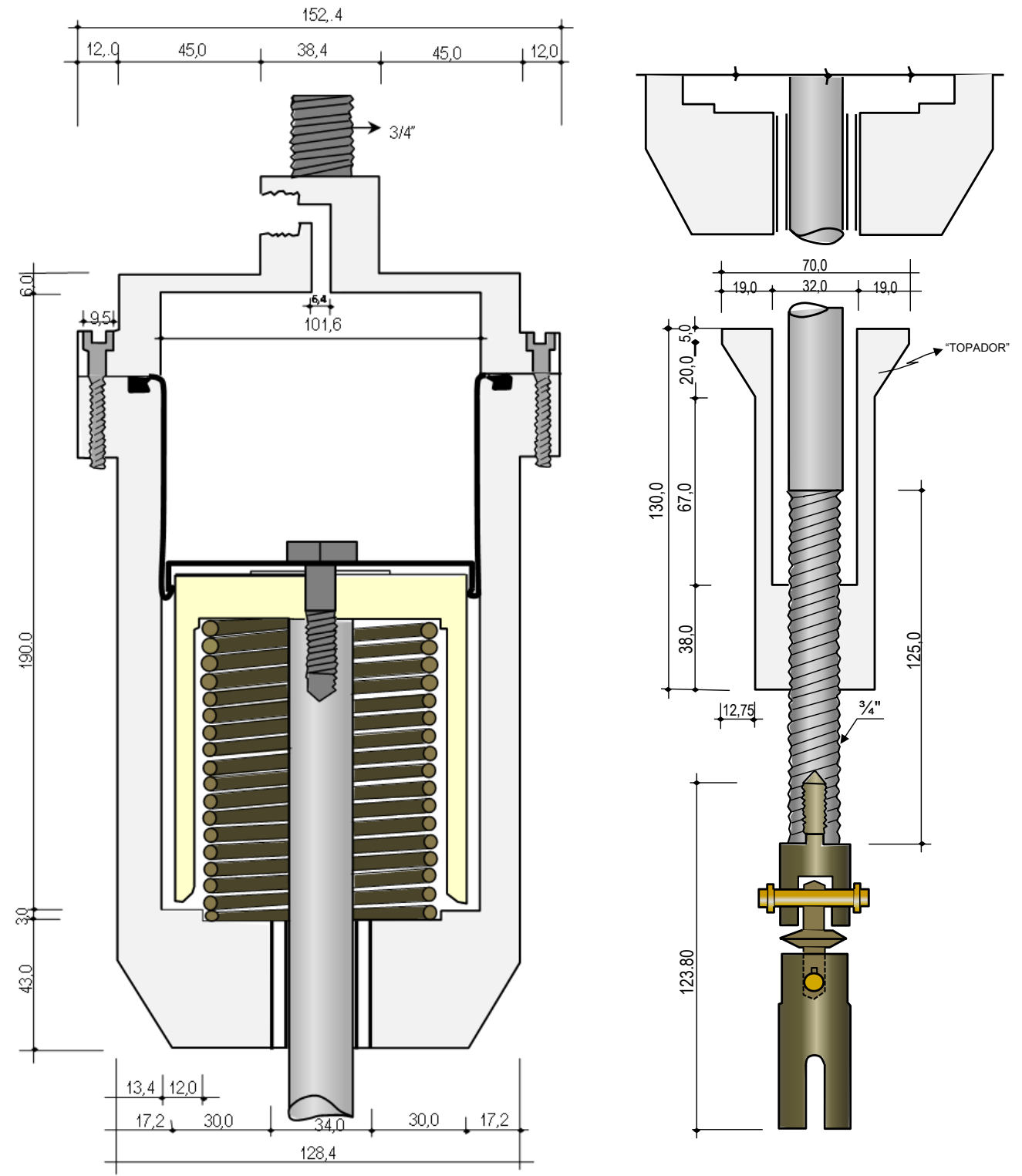

Figura 5.4- Dispositivo para aplicação de tensão controlada (adaptado de Andrade,1988) 


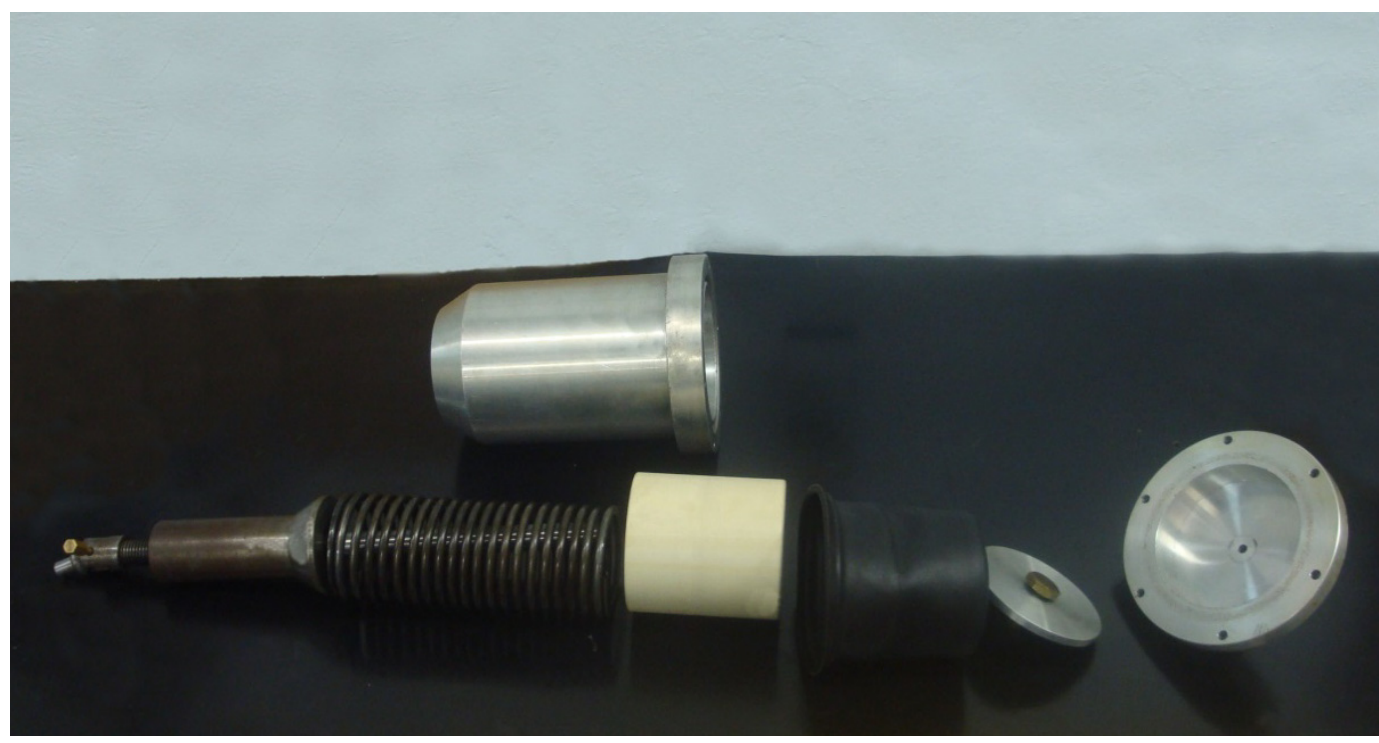

Figura 5.5 - Componentes internos do dispositivo de aplicação de tensão controlada

O eixo retificado possui um "topador" de localização regulável, que permite também a realização de ensaios de deformação controlada, para qualquer curso. Esse eixo é ligado à célula de carga por meio de uma rótula de aço.

Por tanto, com o embolo pôde-se controlar de forma independente a tensão desviadora aplicada ao corpo de prova. Devido à possibilidade de existência de atrito entre a haste da célula de carga e a câmara triaxial, o controle do incremento de tensão efetiva aplicada, foi efetuado pelas respostas fornecidas pela célula de carga, exigindo uma manipulação bastante cautelosa das válvulas reguladoras de pressão.

\subsubsection{3}

\section{Instrumentos convencionais}

A instrumentação convencional utilizada consistiu de transdutores de carga, pressão, deslocamento e variação de volume.

\section{a) Célula de carga}

A medição da força aplicada foi feita através de células de carga, instaladas no interior da câmara triaxial. Neste trabalho, foram utilizadas duas células de carga: uma célula de $5 \mathrm{kN}$ de capacidade máxima, da marca ELE Internacional Ltda., e posteriormente, devido a um defeito da primeira, uma célula de $1 \mathrm{kN}$ de capacidade máxima, do fabricante Controls. Esta nova célula de carga foi considerada adequada devido aos baixos níveis de tensões dos ensaios. 


\section{b) Transdutores de pressão da câmara triaxial}

De forma a mensurar as pressões aplicadas, utilizaram-se dois transdutores, instalados na base da câmara triaxial.

As medidas da poropressão na base do corpo de prova foram efetuadas com um transdutor de pressão, marca Schaevitz, de 1034 kPa (150 psi) de capacidade máxima. Para a medida de pressão da câmara triaxial, utilizou-se um transdutor amplificado com saída em corrente (transmissor de pressão) de 1034 $\mathrm{kPa}$ (150 psi) de capacidade máxima, do fabricante MGI. Este último foi alimentado por uma fonte externa de 19 VDC, conforme instrução do fabricante.

\section{c) Transdutores de deslocamento}

O deslocamento axial foi monitorado com um transdutor de deslocamento resistivo, tipo LSCDT (Linear Strain Conversion Displacement Transducer) de 25,4 $\mathrm{mm}$ de faixa de deslocamento, do fabricante Wykeham Farrance. Este LSCDT foi instalado do lado externo da câmara, preso à haste da célula de carga, com o objetivo de medir o deslocamento relativo da câmara triaxial.

O deslocamento axial local do corpo de prova foi medido por dois transdutores do tipo eletronível, que são descritos com maior detalhe no item 5.2.1.4.

\section{d) Medidor de variação de volume (MVV)}

A variação volumétrica foi medida com um transdutor de variação de volume do tipo Imperial College, fabricado na PUC-Rio (De Campos, 1985) que consiste de duas câmaras, limitadas por diafragmas tipo "Bellofram" que são fixados a um cilindro maciço de PVC. A câmara inferior comumente é conectada diretamente ao sistema de aplicação de contrapressão, enquanto que a superior é ligada ao sistema de drenagem do corpo de prova. Com a entrada ou saída de água do corpo de prova, ocorre a movimentação do diafragma.

Seu funcionamento consiste na aplicação de pressão na câmara inferior formada pela borracha "Bellofram", a qual empurra o cilindro de PVC para cima, transmitindo esta pressão para a câmara superior e, consequentemente, para a amostra. Caso a amostra varie de volume, a água irá entrar ou sair do medidor de variação volumétrica. Todo e qualquer movimento do cilindro de PVC é medido através de um transdutor de deslocamento, que indicará este movimento através de uma variação elétrica. Assim, através da calibração feita, que relaciona a variação de leitura do transdutor de deslocamento com uma variação volumétrica, se pode obter a variação de volume da amostra. 
A capacidade máxima do medidor de variação de volume é dada pela dimensão do "Bellofram". O MVV utilizado na presente pesquisa tem uma capacidade máxima de $100 \mathrm{~cm}^{3}$, com resolução de $0,01 \mathrm{~cm}^{3}$, e utiliza para seu funcionamento um transdutor resistivo de deslocamento, similar ao que foi utilizado para medição do deslocamento axial, porém com faixa de deslocamento de $50 \mathrm{~mm}$.

Neste trabalho, o MVV foi adaptado para permitir a medição da variação de volume do corpo de prova no momento do aumento de poropressão. Para isso, as duas câmaras do MVV trabalharam saturadas. A câmara inferior foi conectada a uma interface arlágua e ao controlador de pressão GDS.

A interface ar/água permite a aplicação da pressão a partir do sistema de ar, e a transmite ao corpo de prova durante as fases de saturação e adensamento. Já, durante a fase de aumento de poropressão, fecha-se a válvula que conecta o MVV com a interface ar/água e o GDS inicia, mediante esta câmara inferior, o incremento de poropressão a velocidade constante. A posição do MVV no sistema pode ser visualizada na Figura 5.1.

A Figura 5.6 mostra o MVV e um esquema de seu funcionamento.

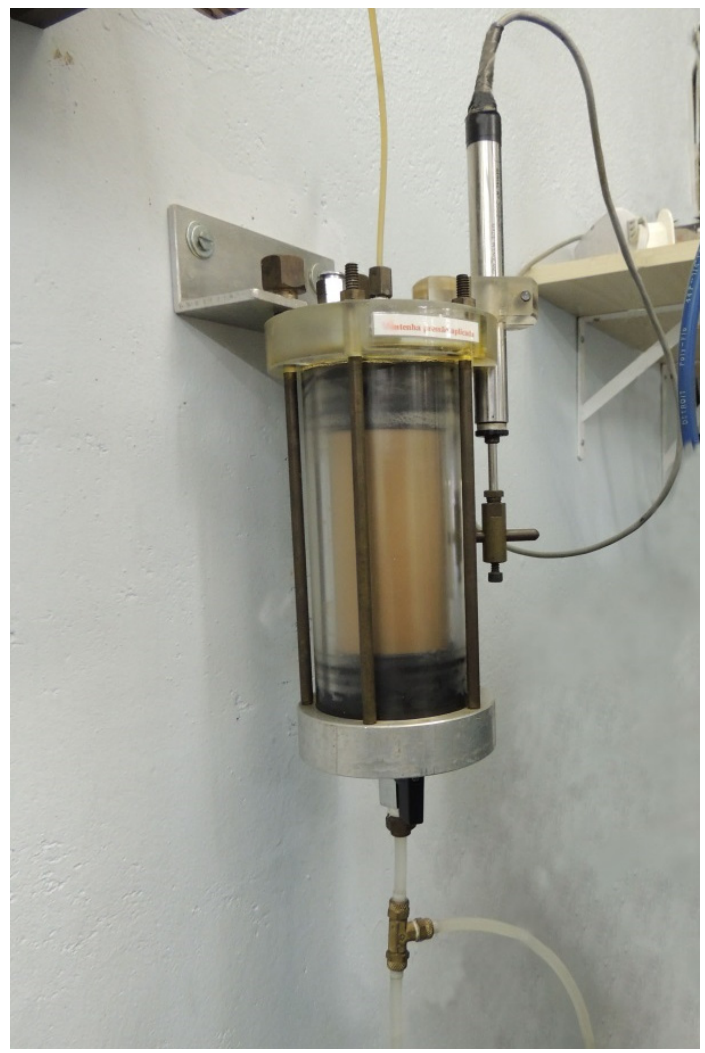

(a)

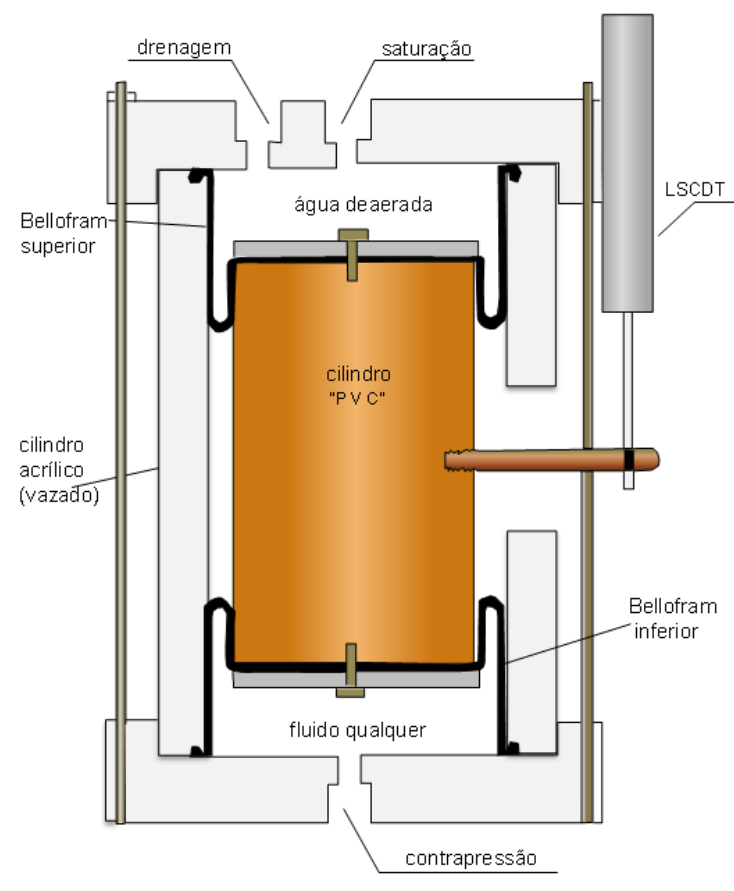

(b)

Figura 5.6 - (a) Medidor de variação de volume tipo Imperial College, (b) Esquema do medidor de variação volumétrica (adaptado de De Campos, 1985) 


\subsubsection{4 Instrumentação Interna}

Com a finalidade de obtenção de dados, relativos a deformações e pressões, que sejam isentos ou menos afetados por erros inerentes às condições de contorno da amostra (De Campos e Marinho, 1986), utilizou-se instrumentação interna, que consistiu dos seguintes transdutores: um minitransdutor de poropressão, um medidor de deslocamento radial e dois medidores de deslocamento axial (eletroníveis).

\section{a) Medidor de deslocamento axial (eletronível)}

Os deslocamentos locais axiais do corpo de prova foram medidos por dois eletroníveis tipo Imperial College desenvolvidos na PUC-Rio (Marinho, 1986; Slongo, 2008).

O eletronível consiste de uma cápsula de vidro vedada, que contém três eletrodos verticais coplanares, parcialmente imersos em um líquido eletrolítico. A cápsula, ao sofrer uma inclinação, provoca uma variação de tensão entre os eletrodos, decorrente da variação de volume do líquido entre os mesmos. Assim, ao se induzir uma variação angular do nível eletrolítico, obtém-se uma variação de tensão elétrica. Esta variação angular é conseguida através do deslocamento vertical da amostra.

O eletronível está protegido da água e da pressão por um tubo de aço inoxidável, que é vedado nas extremidades através de "o-rings" e um selante, como está indicado em detalhe na Figura 5.7, e montado na parte inferior de um sistema de braços móveis. O deslocamento relativo entre as duas sapatas instaladas nos braços móveis, as quais são coladas à membrana através de um adesivo de ação rápida para superfícies flexíveis (a base de cianocrilato), é que permite a inclinação do eletronível. Medidas diretas de deslocamentos são obtidas a partir de calibrações adequadas do instrumento.

Para evitar a decomposição do fluido eletrolítico, o eletronível é excitado com corrente alternada (Symes, 1983). Interfaces, constituídas por circuitos de oscilação, retificação e filtragem, são necessárias para permitir que sua leitura seja feita por sistemas usuais de aquisição de dados, os quais trabalham com corrente contínua.

Considerando a amostra homogênea, a deformação axial principal é dada pela média aritmética dos eletroníveis, e a parcela de inclinação é dada pela 
diferença das deformações dos mesmos (Burland e Symes, 1982; Symes e Burland, 1984; Jardine et al., 1984).

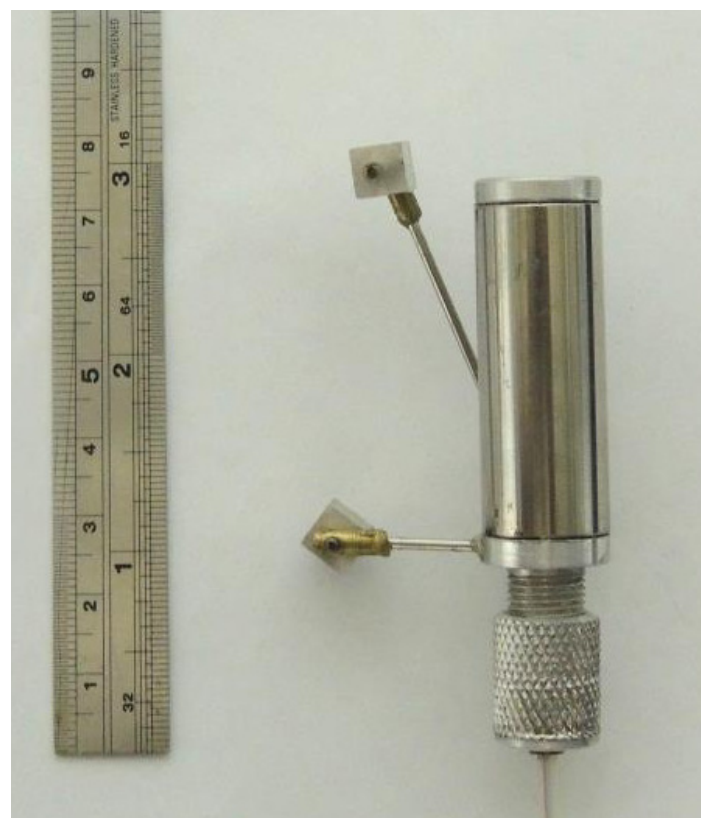

(a)

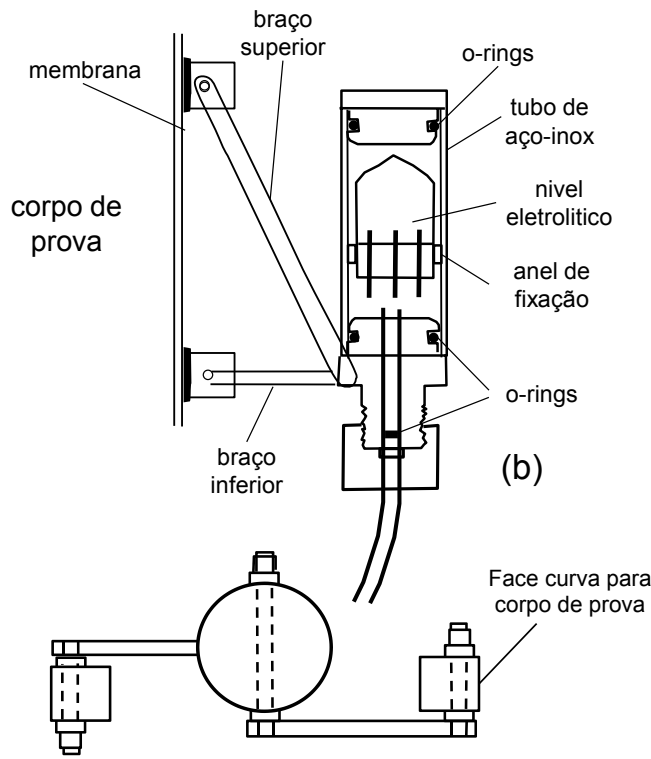

(c)

Figura 5.7 - (a) Eletronível tipo Imperial College, (b) Detalhes do eletronível, (c) Vista em planta (modificado de Kuwano et al., 2000)

\section{b) Medidor de deslocamento radial}

A variação radial do corpo de prova foi monitorada através de um transdutor submersível LVDT (Linear Variable Differential Transformer), adaptado pelo Imperial College, cuja faixa de trabalho linear é de $\pm 7 \mathrm{~mm}$.

O LVDT é constituído por três bobinas (uma primária e duas secundárias) e um núcleo cilíndrico de material ferromagnético, conforme mostrado na Figura 5.8. O núcleo cilíndrico move-se solidariamente com o corpo de prova, alterando o acoplamento magnético entre a bobina primária e as bobinas secundárias, causando assim uma alteração na tensão de saída (alternada). Usando circuitos condicionadores de excitação e leitura, o sinal de saída é convertido em corrente contínua, cujo valor é diretamente proporcional ao deslocamento do núcleo.

O LVDT é suportado por uma estrutura retangular de aço inoxidável de peso leve, a fim de minimizar os efeitos adversos sobre a amostra (ver Figura 5.8 a). A estrutura metálica e o núcleo cilíndrico do LVDT são colados em contato com a amostra, sobre a membrana, em torno da meia altura do corpo de prova. 


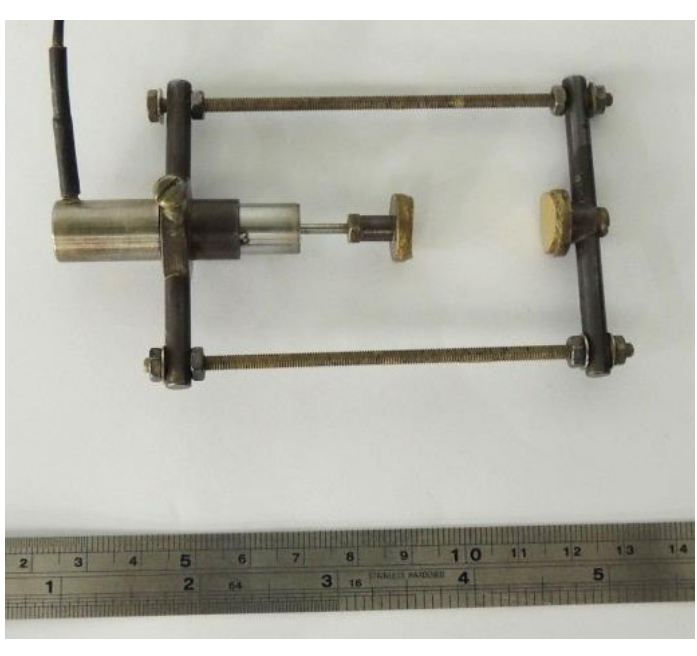

(a)
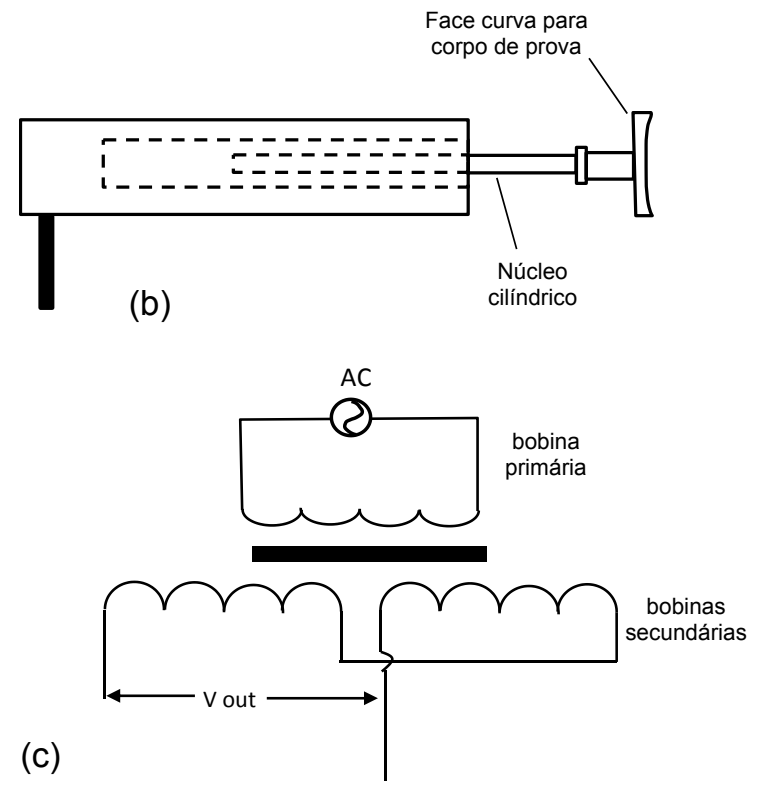

Figura 5.8 - (a) Transdutor de deslocamento radial tipo Imperial College, (b) Detalhes de medidor de deformação radial, (c) Esquema elétrico de LVDT

\section{c) Minitransdutor de poropressão}

Para medir a poropressão a meia altura do corpo de prova foi utilizado um minitransdutor, modelo PDCR-81 da marca Druck, com capacidade de 200 psi (1379 kPa).

Este dispositivo consiste de um diafragma de silicone de $0,09 \mathrm{~mm}$ de espessura, instrumentado com strain gages, suportado em um cilindro de vidro interno e protegido por uma pedra porosa. A deformação do diafragma provoca uma mudança na resistência dos strain gages. Essa variação de resistência é convertida em uma variação de tensão (voltagem), a qual é equivalente à pressão que atua no diafragma.

O pequeno tamanho do PDCR-81 permite que ele seja colocado em contato direto com a amostra sem causar o mínimo de interferência. O pequeno tamanho também conduz a um tempo de resposta rápido uma vez que o volume do líquido ao ser comprimido ou descomprimido, para uma dada mudança, é menor. Este tempo de resposta rápida permite que o PDCR-81 seja o melhor instrumento utilizado para monitorar em tempo real as mudanças de poropressão durante um ensaio (Muraleetharan et al., 1999).

Na Figura 5.9 é apresentado o minitransdutor de poropressão e um diagrama esquemático dele.

O uso do minitransdutor, para a medição da poropressão desenvolvida na região central do corpo de prova, permite eliminar quaisquer dúvidas relativas a efeitos de extremidade. 


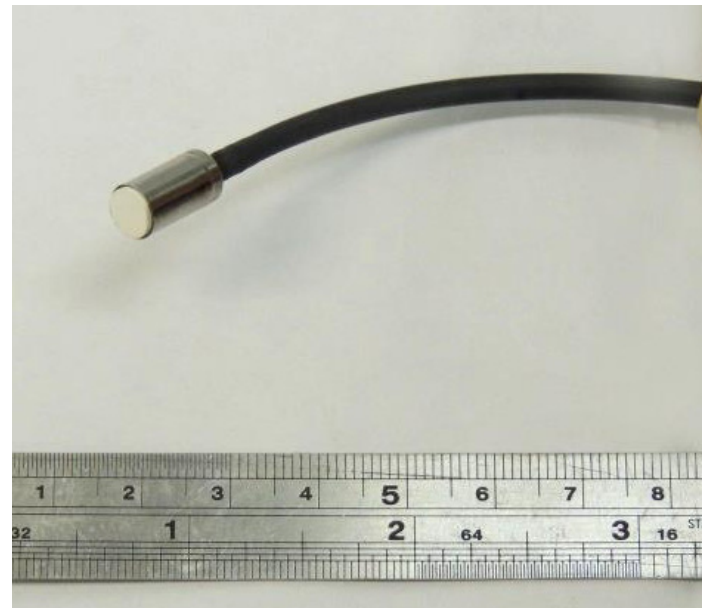

(a)

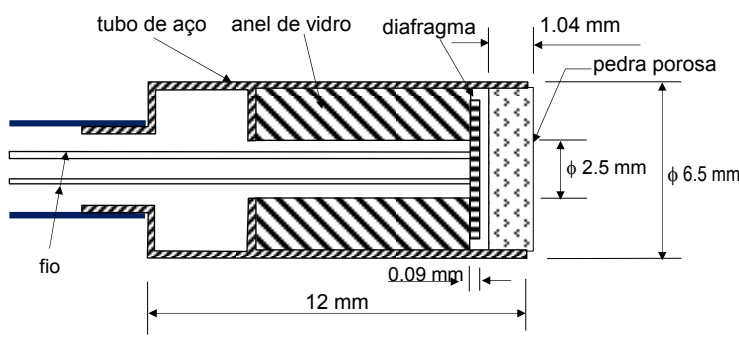

(b)

Figura 5.9 - (a) Minitransdutor de poropressão PDCR81, (b) Detalhes do minitransdutor (adaptado de Muraleetharan e Granger, 1999)

Embora, os ensaios foram realizados em condições drenadas, o monitoramento das alterações localizadas de poropressão foi considerado importante, por causa do possível desenvolvimento de condições não drenadas dentro do corpo de prova.

A capacidade de cada instrumento e a resolução dos mesmos no sistema são mostradas na Tabela 5.1. As caraterísticas principais de cada um dos instrumentos elétricos utilizados são apresentadas no Apêndice $A$, junto com as suas calibrações.

Tabela 5.2 - Resumo das principais caraterísticas da instrumentação de laboratório usada

\begin{tabular}{c|c|c|c}
\hline Instrumento & Tipo de medida & Capacidade & Resolução \\
\hline Célula de carga & força desviadora & $5 \mathrm{kN}$ & $0,6 \mathrm{~N}^{*}$ \\
\hline Célula de carga & força desviadora & $1 \mathrm{kN}$ & $0,2 \mathrm{~N}^{* *}$ \\
\hline $\begin{array}{c}\text { Transdutor de } \\
\text { deslocamento }\end{array}$ & deslocamento axial (externo) & $25 \mathrm{~mm}$ & $0,01 \mathrm{~mm}$ \\
\hline $\begin{array}{c}\text { Medidor de variação de } \\
\text { volume }\end{array}$ & variação de volume & $100 \mathrm{~cm}^{3}$ & $0,01 \mathrm{~cm}^{3}$ \\
\hline $\begin{array}{c}\text { Transdutor de pressão } \\
\text { pressão base }\end{array}$ & $1034 \mathrm{kPa}$ & $0,5 \mathrm{kPa}$ \\
\hline $\begin{array}{c}\text { Transmissor de pressão } \\
\text { pressão confinante }\end{array}$ & $1034 \mathrm{kPa}$ & $0,5 \mathrm{kPa}$ \\
\hline $\begin{array}{c}\text { Minitransdutor de } \\
\text { pressão }\end{array}$ & $\begin{array}{c}\text { pressão a meia altura do corpo } \\
\text { de prova }\end{array}$ & $1379 \mathrm{kPa}$ & $0,2 \mathrm{kPa}$ \\
\hline $\begin{array}{c}\text { Eletroniveis } \\
\text { interna) }\end{array}$ & $\begin{array}{c}\text { deslocamento axial (medida } \\
\text { interna) }\end{array}$ & $10 \mathrm{~mm}$ & $0,006 \mathrm{~mm}$ \\
\hline $\begin{array}{c}\text { Medidor de } \\
\text { deslocamento radial }\end{array}$ & $\begin{array}{c}\text { deslocamento radial (medida } \\
\pm 7 \mathrm{~mm}\end{array}$ & $0,005 \mathrm{~mm}$ \\
\hline
\end{tabular}

Nota: As células de carga propiciaram no ensaio uma resolução da ordem de $0,5 \mathrm{kPa}^{*}$ e de $0,2 \mathrm{kPa}^{* *}$, na medida da tensão desviadora 


\subsubsection{5 \\ Sistema de aquisição de dados}

As leituras de todos os instrumentos de medição foram registradas por um sistema de aquisição de dados (SAD), que foi adaptado ao sistema com a colaboração do professor Luiz Gusmão, do departamento de Eng. Elétrica da PUC-Rio.

A aquisição de dados foi efetuada por um Datalogger ALMEMOß 2890-9, fabricado por AHLBORN, que opera com conversor A/D Delta-Sigma de 24 bits e dispõe de 9 canais de entrada para conectores pré-programados para cada tipo de medidas (ver na Tabela A.1 do apêndice A), mais 32 canais adicionais para sondas multifuncionais ou programação de processos. A comunicação externa com o computador é realizada por meio de saída USB 2.0, sendo utilizado o software AMR-CONTROL V5. Na Figura 5.10 é apresentado o sistema de aquisição de dados usado.

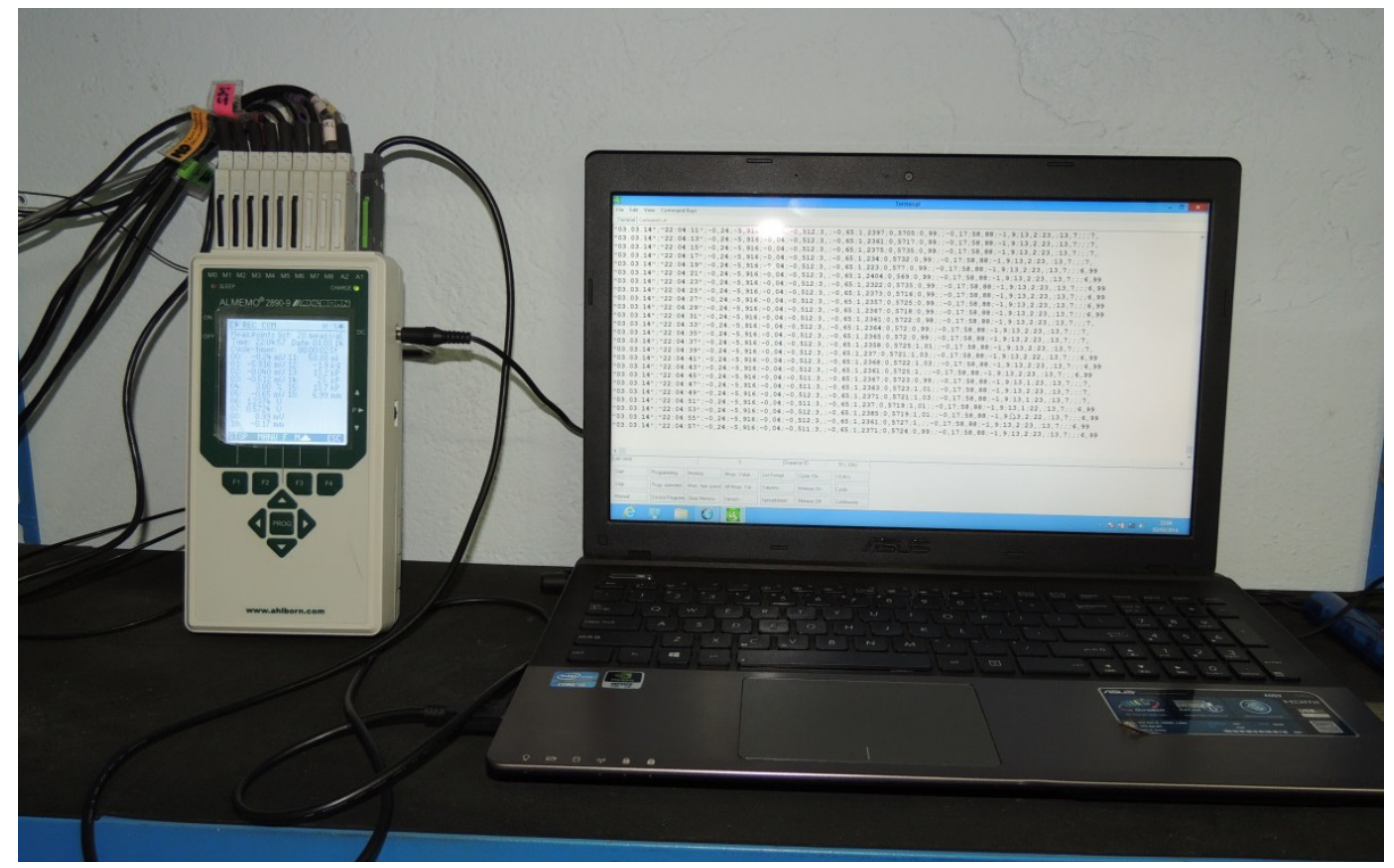

Figura 5.10 - Sistema de aquisição de dados: Datalogger ALMEMO ${ }^{\circledR} 2890-9$

A alimentação é feita por bateria recarregável $6 \mathrm{NMH}$, adaptador $\mathrm{AC}$ para 12 VDC. O aparelho é capaz de alimentar sensores com até 12VDC (máximo $100 \mathrm{~mA}$ ) para uso com bateria recarregável ou adaptador principal.

Os dados capturados no computador foram manipulados através dos programas Excel e Grapher, onde com o auxílio das equações de calibração dos 
instrumentos, as leituras foram transformadas de VDC para unidades de engenharia.

O sistema de aquisição de dados permitiu o monitoramento contínuo das grandezas, necessárias para o acompanhamento dos ensaios, armazenando dados por períodos de tempo constantes e predefinidos, com uma resolução de $\pm 0,01 \%$.

\section{2 .2}

\section{Metodologia empregada}

\subsubsection{1}

\section{Operações pré-ensaios}

\section{a) Calibração dos instrumentos}

A calibração dos instrumentos de medição utilizados nos ensaios foi a fase inicial da etapa de ensaios. Quando se trabalha com instrumentos elétricos são necessárias cuidadosas calibrações destes instrumentos, na medida do possível nas condições em que eles irão ser usados, procurando calibrá-los utilizando dispositivos ou arranjos que simulem, da forma mais aproximada possível, o comportamento dos mesmos durante o ensaio.

No apêndice A são apresentados os detalhes da calibração dos instrumentos utilizados, além das curvas de calibração obtidas.

\section{b) Verificação de estanqueidade do conjunto}

É de fundamental importância realizar uma minuciosa verificação de existência de pontos de vazamentos.

Primeiramente, verificou-se que não existiam vazamentos detectáveis a olho nu, aplicando pressões com valores suficientemente altos em toda a tubulação. A presença de vazamentos pequenos, não visíveis a olho nu, foi detectada aplicando-se altas pressões (até $700 \mathrm{kPa}$ ) e verificando sua estabilidade através do transdutor.

Estas operações se realizaram isolando pequenos trechos de testes, facilitando assim, a determinação de suas localizações.

\section{c) Saturação das tubulações, pedras porosas e minitransdutor de poropressão}

Antes do início de cada ensaio, foi realizada a saturação de toda a tubulação de água do sistema. Este processo consistiu em percolar água, 
aplicando pressão, para a retirada de qualquer bolha de ar que pudesse estar presente nas linhas.

As pedras porosas foram previamente saturadas e mantidas em água destilada até a montagem do ensaio. Ao final de todos os ensaios elas foram levadas a um equipamento de ultrassom e mantidas "vibrando" por 30 minutos, para retirar eventuais obstruções de seus poros.

Para saturar a pedra porosa do minitransdutor, este foi imerso em água deaerada por cerca de 48 horas, e logo submetido a ciclos de aumento e diminuição de pressão, até uma pressão máxima de $800 \mathrm{kPa}$. O incremento da pressão de água possibilitaria a dissolução do ar preso no espaço entre o sensor e a pedra porosa, e as pressões decrescentes ajudariam ao ar dissolvido fluir para fora. Este último procedimento foi realizado após a colocação do minitransdutor em uma câmara especial de acrílico, confeccionada por Hurtado (2010) para permitir a saturação e posterior calibração do transdutor. Na Figura 5.11 é mostrada a câmara de acrílico utilizada.

Depois de realizada a saturação das linhas de drenagem, foram feitas as leituras de referência dos transdutores. Elas representam o zero dos instrumentos.

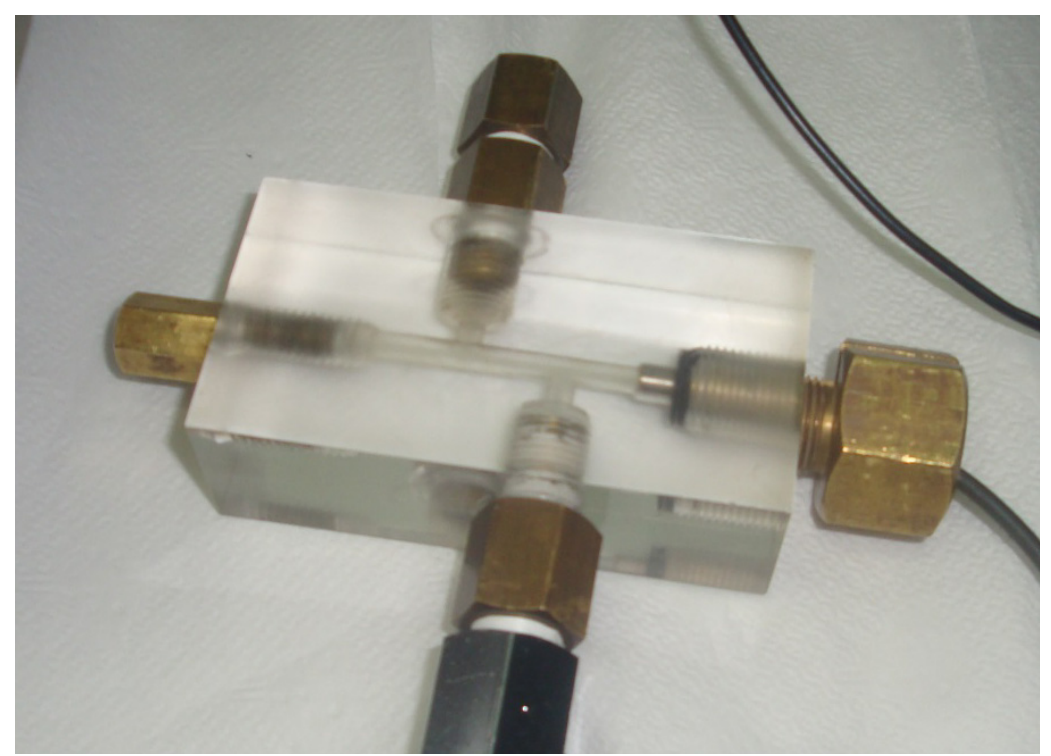

Figura 5.11 - Câmara de acrílico utilizada na saturação e calibração do minitransdutor de poropressão

\section{d) Preparação da membrana}

Antes da montagem de cada ensaio, a membrana de látex foi preparada para permitir a passagem do minitransdutor de poropressão. 
Depois da verificação da ausência de furos na membrana, foi cortado um orifício na região central com ajuda de um vazador manual, onde se encaixou um bico de borracha de diâmetros externo e interno iguais a 0,98 cm e 0,62 cm, respectivamente. O bico de borracha funcionou como peça para encaixe do elemento de medição.

Pelo menos três camadas de látex líquido foram então colocadas em todo o bico de borracha, formando uma extensão contínua da membrana de látex. A membrana, geralmente, era preparada um dia antes da montagem da amostra.

Para que fosse possível a aplicação de vácuo, quando no posicionamento da membrana ao redor do corpo de prova, foram fabricados expansores de membrana especiais com orifícios e tampões removíveis, para acomodar o bico de borracha.

A Figura 5.12 mostra os materiais empregados na preparação da membrana e os expansores de membrana usados, com orifícios em posições diferentes.
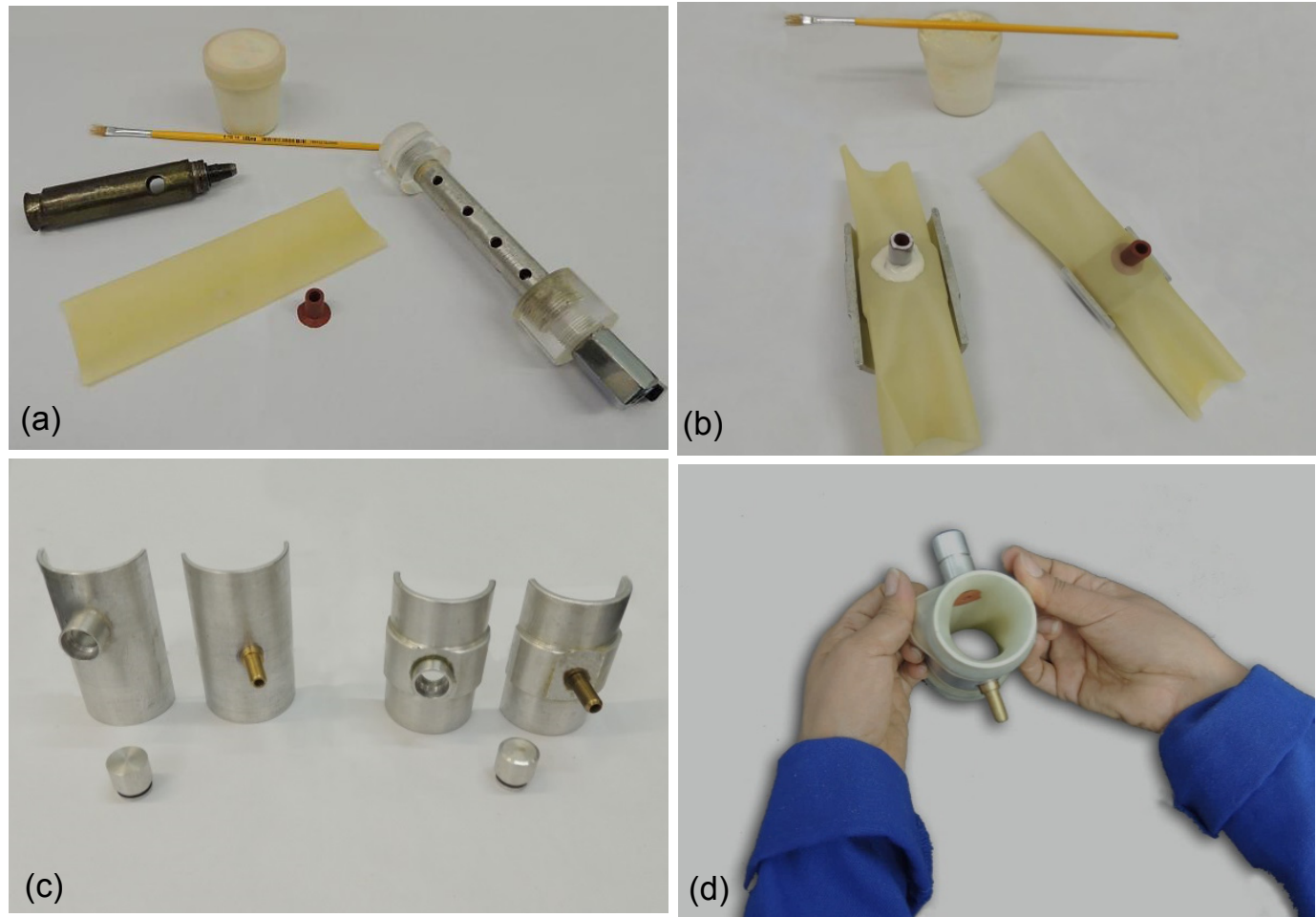

Figura 5.12 - Preparação de membrana de látex para execução de ensaios 
5.2.2.2

Moldagem dos corpos de prova

Os corpos de prova, para os ensaios triaxiais, foram obtidos por talhagem dos blocos indeformados, que foram fracionados em blocos menores, com dimensões aproximadas de $15 \mathrm{~cm} \times 5 \mathrm{~cm} \times 5 \mathrm{~cm}$.

No caso do solo de Duque de Caxias, os mini blocos oriundos do fracionamento do bloco maior, após o nivelamento do topo e da base, eram cuidadosamente instalados sobre um torno manual, específico para a moldagem de corpos de prova cilíndricos, com 1,5" de diâmetro (vide Figura 5.13 b). Com o auxilio de uma faca afiada, aliada ao leve giro do corpo de prova, foi feito o desbaste lateral grosseiro da amostra, sempre a partir do topo e da base. Com uma régua fez-se o acabamento fino, sempre em movimentos verticais.

Após a moldagem do cilindro de solo, este corpo de prova era disposto em um berço metálico com 3" de comprimento, onde suas faces transversais eram desbastadas, tornando-as paralelas entre si, resultando em amostras com dimensões similares. Cuidados para se evitar qualquer perturbação no corpo de prova e perda de umidade foram rotineiramente tomados.

A elaboração dos corpos de prova dos solos da PUC e de Tinguá, foi feita através da cravação nos mini blocos de um moldador cilíndrico bipartido de alumínio. Com a finalidade de se cravar o moldador verticalmente e sem movimentos laterais, utilizou-se um extrator de amostras ao qual se ajustou o molde citado.

O moldador, que possui uma ponta biselada, foi suavemente encostado no mini bloco, previamente confinado com papel filme e fita adesiva. Com ajuda de um estilete e uma faca, o solo era desbastado em toda sua área lateral, para que a cravação se desse com um mínimo de perturbação possível, como mostrado na Figura 5.13 (c). No interior do molde se passou uma camada de vaselina para reduzir o atrito. Através do sistema de cravação, o molde era empurrado para baixo penetrando no mini bloco, que já estava parcialmente talhado. Todo o processo foi feito da forma mais lenta possível.

Após a total cravação do molde, o anel biselado foi removido, e o topo e a base da amostra foram aplainados. Posteriormente o molde foi retirado no sentido da cravação, de modo a não induzir outras perturbações ao corpo de prova.

Cabe ressaltar que no solo coluvionar de Tinguá, vários dos corpos de prova foram "perdidos" durante a operação de moldagem. Isso ocorreu devido à 
presença de concreções e "regiões" mais fragilizadas, quebradiças, vazios e raízes.

A Figura 5.13 apresenta o detalhe dos equipamentos utilizados no processo de moldagem dos corpos de prova.

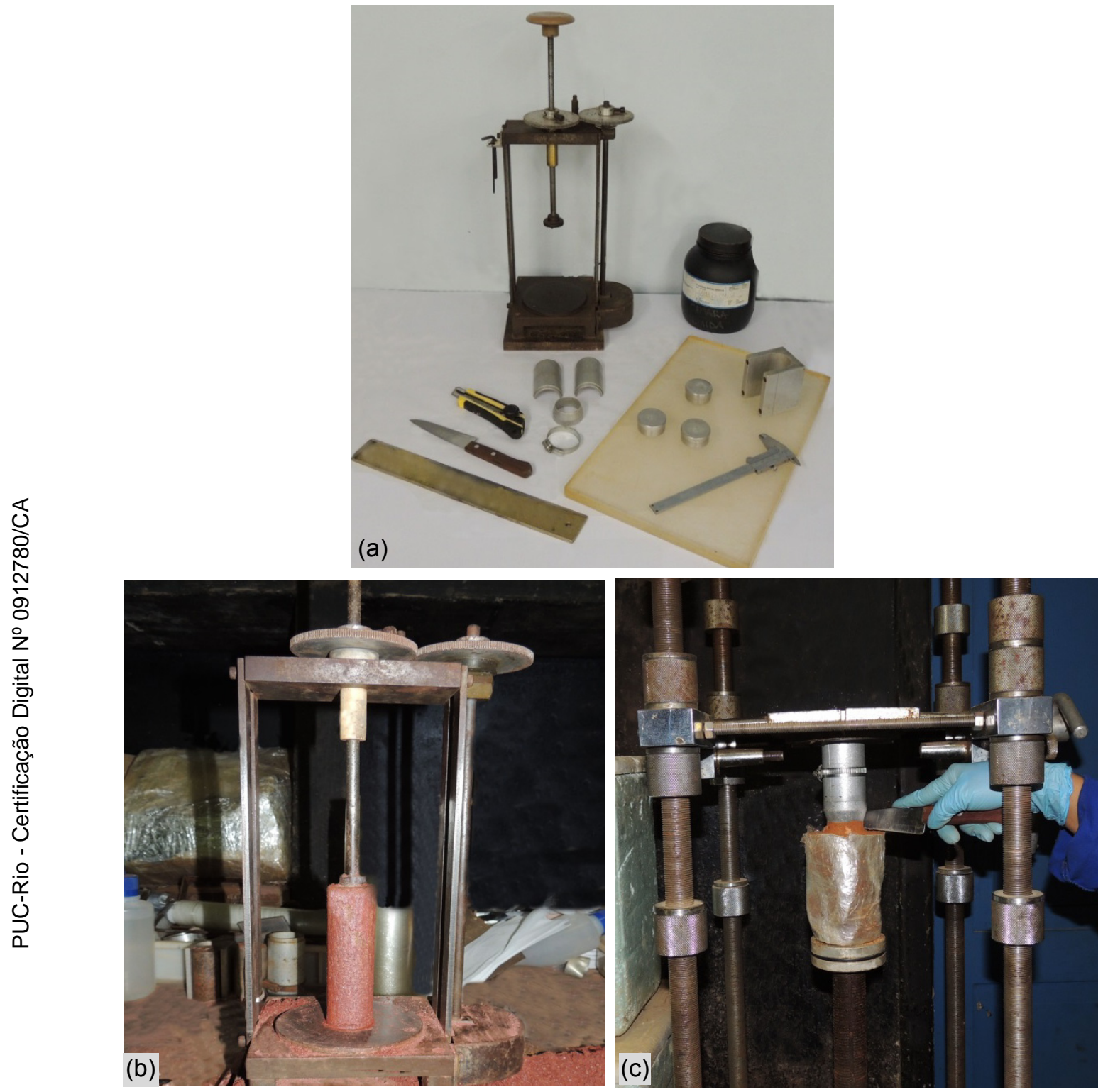

Figura 5.13 - (a) Equipamentos usados na moldagem dos corpos de prova, (b) Moldagem de corpos de prova do solo residual jovem de Duque de Caxias, (c) Moldagem de corpos de prova de solos coluvionares da PUC e Tinguá

\subsubsection{3}

\section{Procedimento de ensaio}

\section{a) Montagem do corpo de prova}

Após a moldagem, posicionou-se o corpo de prova indeformado no pedestal da câmara triaxial, sobre um papel filtro apoiado em uma pedra porosa 
convencional. O corpo de prova foi imediatamente coberto pela membrana, com ajuda do expansor especial. Colocou-se o papel filtro e a pedra porosa de topo, além do "top cap", e se isolou a amostra através de anéis de vedação (o-rings). Durante a montagem do corpo de prova, dedicou-se especial atenção ao seu nivelamento.

Terminada a montagem do corpo de prova, a membrana foi preparada para a colagem dos sensores. Para isso, foram feitas marcas com ajuda de um molde nos lugares onde se colocaria a instrumentação interna, posicionando os eletroníveis em pontos diametralmente opostos e sobre a região central da amostra. A distância entre os eixos das sapatas de cada eletronível foi utilizada para o cálculo da deformação axial, que corresponde aos deslocamentos verticais relativos ocorridos em cerca de $2 / 3$ da altura do corpo de prova. A marcação para o posicionamento do suporte do medidor de deformação radial foi locada no centro do corpo de prova, em um lugar que admitia o movimento do instrumento sem colisão com os eletroníveis e o minitransdutor.

Em seguida, o minitransdutor de poropressão foi instalado, introduzindo o elemento de medição dentro da peça de borracha, de forma que a ponta porosa do minitransdutor ficasse totalmente em contato com o corpo de prova. Para garantir o contato do minitransdutor com o corpo de prova, foi colocada uma fina camada de caulim na pedra porosa antes da instalação. Segundo De Campos (1984), o tempo de resposta do transdutor não é afetado devido à alta permeabilidade deste tipo de argila. Após a inserção do minitransdutor na peça de borracha, dois anéis de vedação (colocados previamente no cabo flexível do minitransdutor) foram fixados sobre o conjunto, com a ajuda de um pequeno expansor. Posteriormente, colocaram-se duas camadas de látex líquido para garantir a estanqueidade do conjunto. O fio do minitransdutor foi fixado de modo a minimizar a tração na amostra.

Nos primeiros ensaios realizados, o minitransdutor foi colocado na meia altura do corpo de prova, já em uma segunda fase o minitransdutor foi deslocado ligeiramente em direção ao topo, com a finalidade de permitir a colocação do transdutor de deslocamento radial. A Figura 5.14 mostra uma vista em corte do corpo de prova com o minitransdutor de poropressão e os detalhes de sua colocação na membrana.

Após o revestimento de látex líquido ter secado, a colagem dos medidores de deslocamento axial e radial foi feita cuidadosamente, utilizando-se um adesivo de secagem rápida, buscando o alinhamento em relação às marcas feitas na membrana (verticalidade dos medidores de deformação axial e 
horizontalidade do medidor de deformação radial). Vale ressaltar que nesta etapa foi garantido que a tubulação de drenagem e os fios dos instrumentos não iriam atrapalhar o funcionamento dos eletroníveis, impedindo a rotação dos mesmos. Isto foi verificado antes da montagem do ensaio.

Em seguida, a haste da célula de carga foi lubrificada, para diminuir o atrito no momento da transmissão da força axial ao corpo de prova.

O restante da montagem seguiu a rotina convencional sugerida por Head (1998).

$\mathrm{Na}$ Figura 5.15 se mostram os principais passos seguidos para a montagem do corpo de prova.

(a)

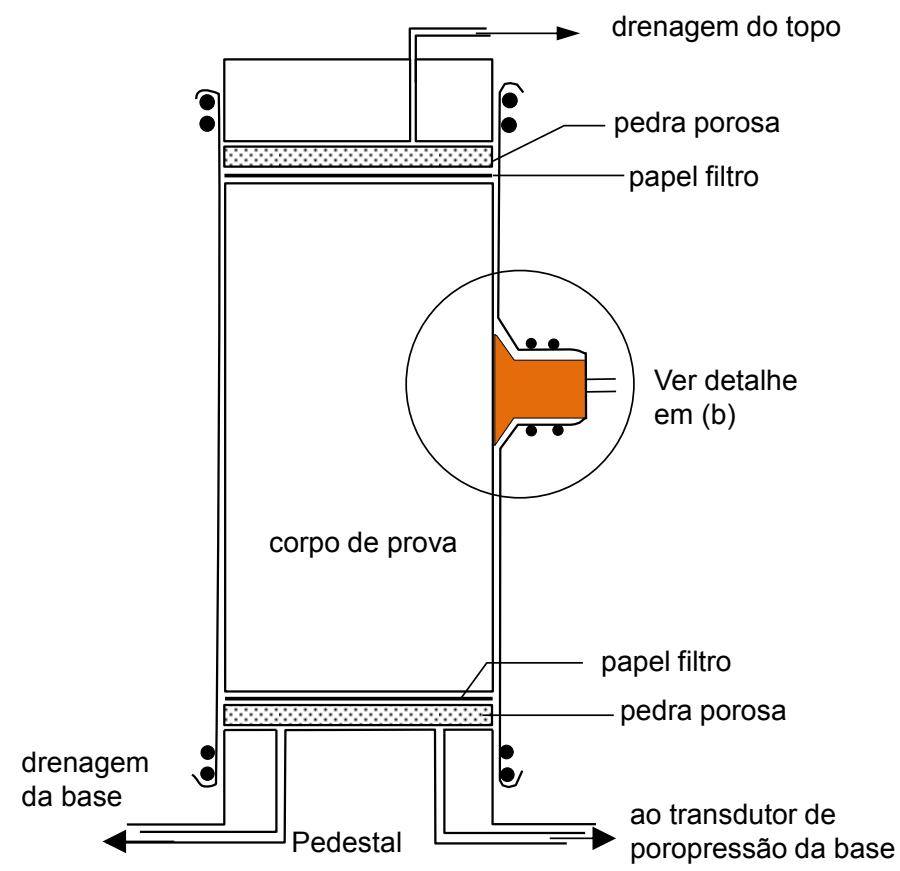

(b)

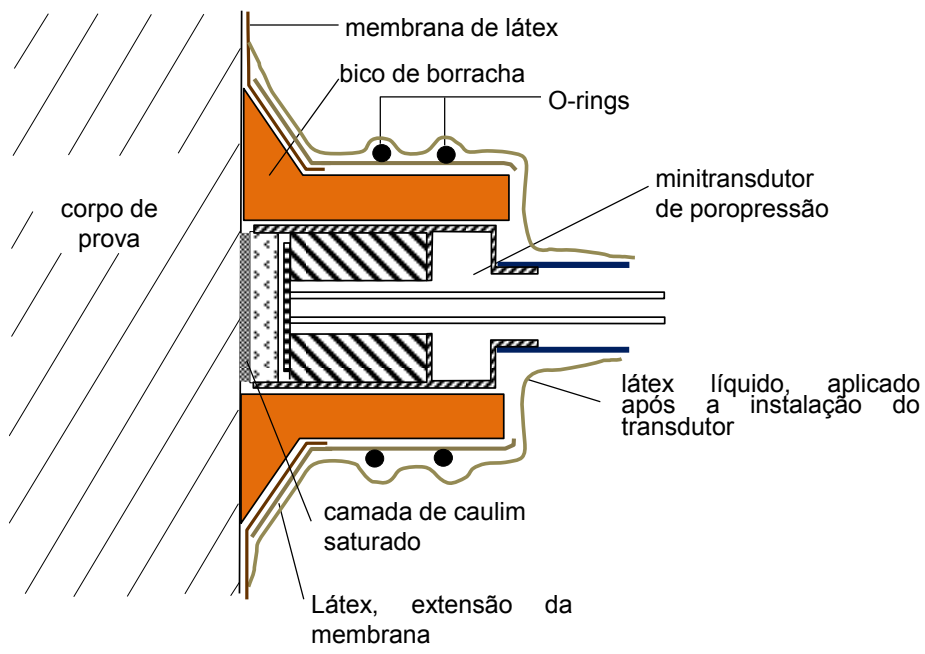

Figura 5.14 - (a) Diagrama de configuração de um corpo de prova no ensaio triaxial com a instalação do minitransdutor de poropressão, (b) Detalhes do minitransdutor de poropressão colocado sobre o corpo de prova (adaptado de Hight, 1982) 

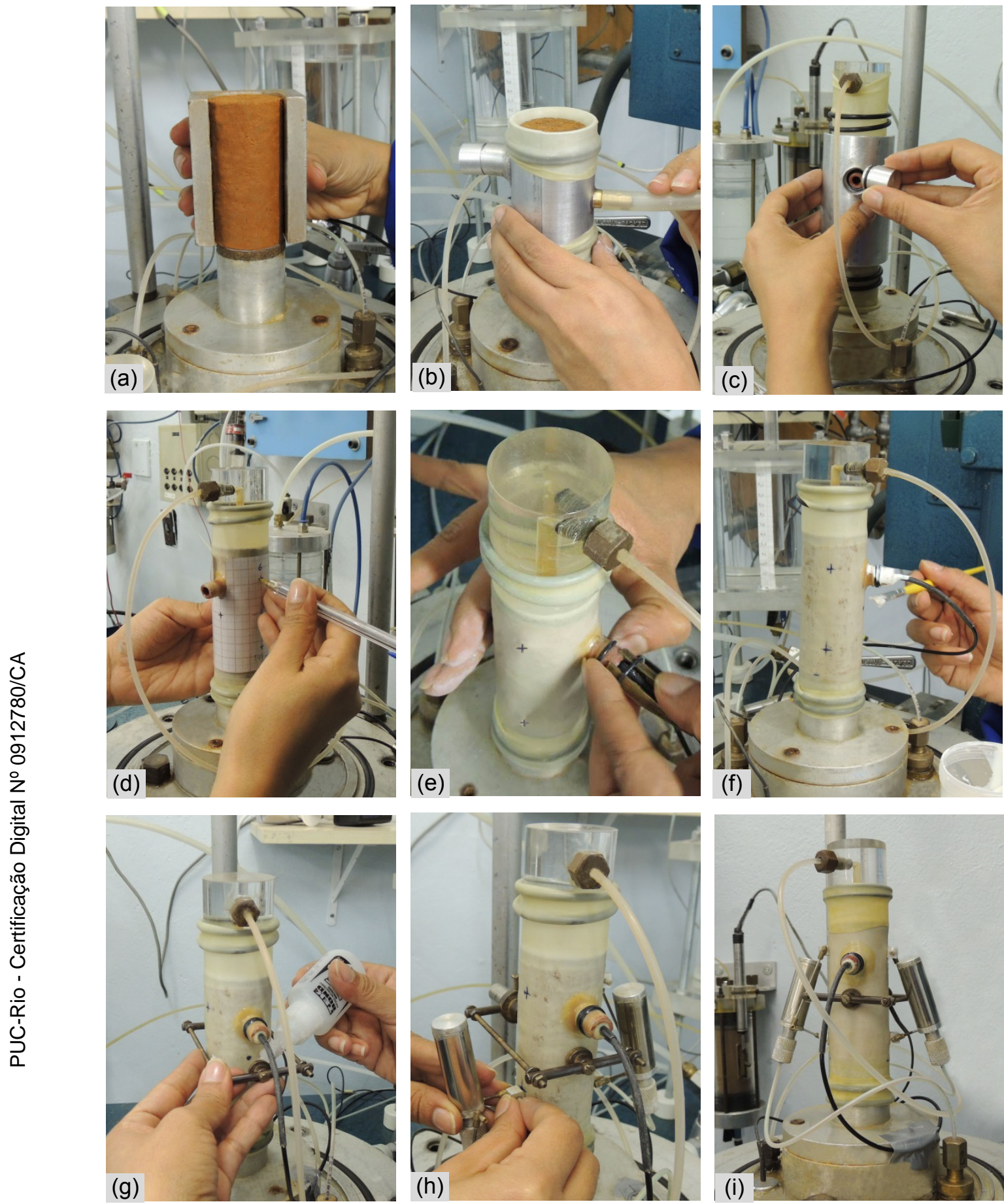

(a) Posicionamento do corpo de prova no pedestal

(f) Colocação de látex liquido sobre o bico de borracha

(b) Colocação da membrana

(c) Retirada do expansor

(g) Colocação do transdutor de deslocamento radial

(d) Preparação da membrana para colagem

(h) Colocação dos eletroníveis dos sensores

(i) Corpo de prova com instrumentação

(e) Instalação do minitransdutor de poropressão

Figura 5.15 - Sequência da montagem do corpo de prova para realização de ensaio triaxial 


\section{b) Saturação}

A saturação constou de duas etapas: a percolação de água na amostra e a aplicação de incrementos de pressão confinante e contrapressão, alternadamente.

Percolação de água: A percolação é a primeira fase da saturação, e tem início logo após a preparação da amostra. A finalidade deste processo é preencher os vazios da amostra com água, e desta forma expulsar o ar existente entre as partículas. Esta etapa precede a da saturação por contrapressão, pois, ao aplicar este procedimento, aumenta-se o grau de saturação do corpo de prova, diminuindo assim a magnitude da tensão efetiva, a ser gerada devido ao aumento da tensão confinante na fase seguinte.

A percolação foi realizada da base para o topo do corpo de prova, de forma a facilitar a expulsão do ar, como pode ser observado na Figura 5.16. O fluxo de água foi desencadeado devido a uma sucção de $10 \mathrm{kPa}$, gerada através da coluna de água formada pela linha ligada ao topo do corpo de prova. Com esta finalidade, um frasco Mariotte foi ligado a uma das duas linhas de drenagem da base, impondo-se uma carga igual à pressão atmosférica, enquanto que a tubulação que sai do topo do corpo de prova foi ligada a um béquer graduado, para medição do volume de água que passou pelo corpo de prova.

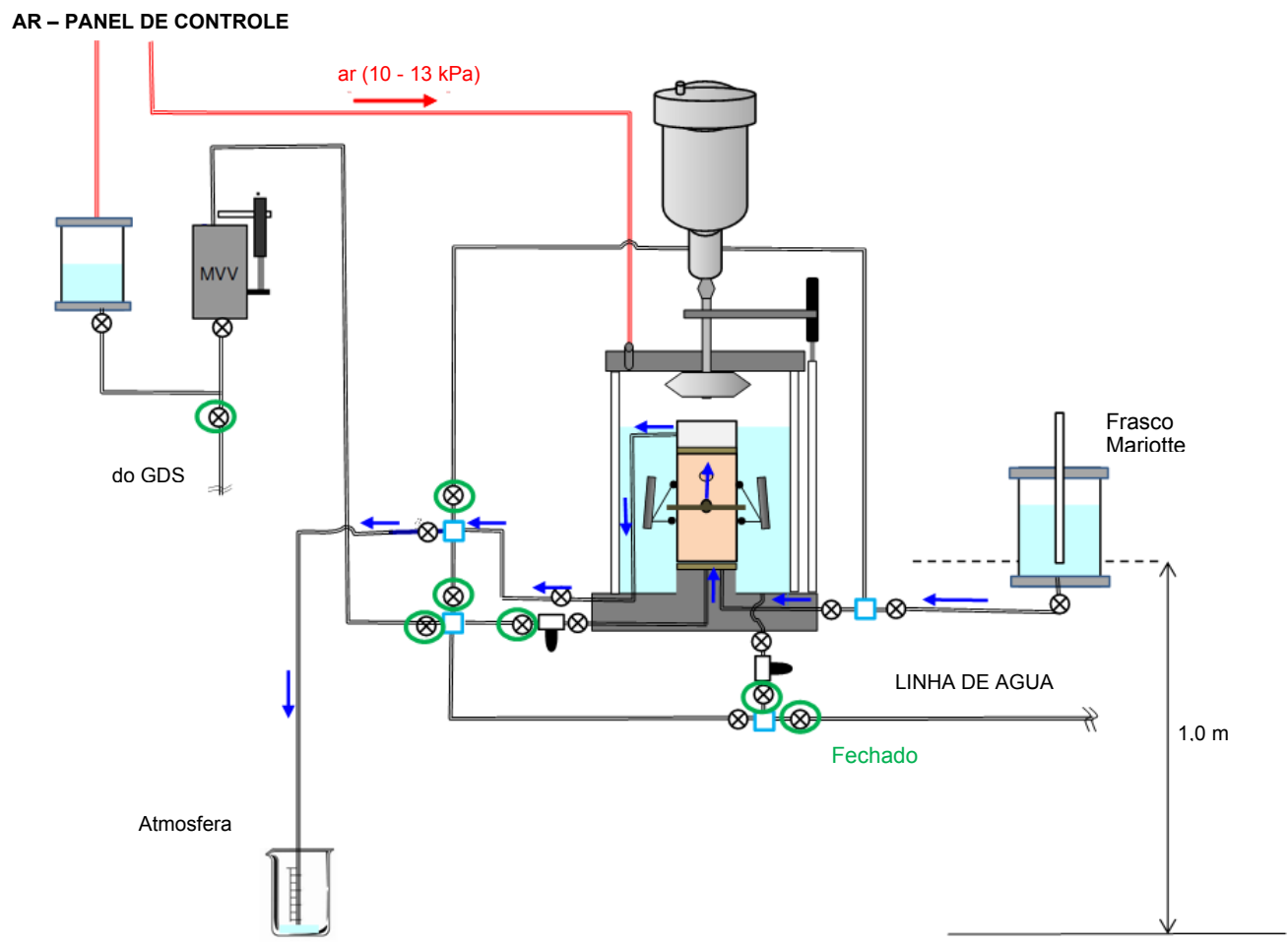

Figura 5.16 - Esquema de funcionamento do equipamento no momento da percolação 
Aplicou-se uma tensão confinante entre 10 e $13 \mathrm{kPa}$ para evitar fluxo de água entre a membrana e o corpo de prova. A percolação foi mantida até que o volume percolado fosse equivalente ao dobro do volume de vazios.

Com a finalidade de manter a linha saturada, e consequentemente o valor desejado de sucção, em intervalos regulares de tempo circulava-se água proveniente da linha de água do reservatório, fechando previamente as válvulas do corpo de prova.

Aplicação de Contrapressão : Esta fase tem a finalidade de promover a completa saturação do corpo de prova, através da dissolução do ar na água.

O aumento de contrapressão foi realizado em etapas, sendo o primeiro ajuste executado para uma tensão confinante de $20 \mathrm{kPa}$, seguido por acréscimos de $25 \mathrm{kPa}$ nas primeiras etapas de saturação, até atingir um valor do parâmetro $B\left(B=\Delta u / \Delta \sigma_{c}\right)$ igual a 0,75 ; e subsequentes acréscimos de $50 \mathrm{kPa}$. Após o aumento não drenado da tensão confinante, a contrapressão foi ajustada de modo que se tenha uma diferença entre tensões de $10 \mathrm{kPa}$ em cada estágio. Tanto as drenagens do topo, quanto da base, mantiveram-se ligadas ao medidor de variação de volume.

O critério adotado para determinar o tempo de aplicação de cada incremento de contrapressão, foi a estabilização do MVV. Após a curva volume de água versus tempo tender para uma assíntota horizontal, o corpo de prova ainda ficava cerca de 30 minutos submetido às tensões de cada estágio para equalização das pressões, minimizando assim a magnitude das tensões efetivas geradas, principalmente no centro do corpo de prova, ao ser aplicado um novo acréscimo de tensão confinante (Carvalho, 2012). Ao final de cada estágio, determinou-se o parâmetro de poropressão $B$, considerando-se o solo saturado para $B \geq 0,98$. $A$ saturação foi atingida, de forma geral, para tensões confinantes de no máximo $400 \mathrm{kPa}$. Depois de atingidas as pressões máximas, deixou-se estabilizar o sistema durante aproximadamente 12 horas com a finalidade de garantir o equilíbrio das pressões e a saturação completa.

\section{c) Adensamento anisotrópico}

Atingida a saturação, iniciava-se a fase de adensamento anisotrópico correspondente ao nível de tensão estabelecido no programa de ensaio.

Durante a fase inicial de adensamento anisotrópico, a tensão desviadora foi aumentada em pequenos incrementos, com a finalidade de transferir o estado de tensão isotrópica para um ponto na linha $\mathrm{K}_{\mathrm{c}}\left(\mathrm{K}_{\mathrm{c}}=\sigma^{\prime}{ }_{1} / \sigma^{\prime}{ }_{3}\right)$. Este nível de $\mathrm{K}_{\mathrm{c}}$ 
representa o estado de campo do elemento de solo, ao longo do plano potencial de ruptura em uma encosta. Os incrementos da tensão desviadora foram aplicados através do embolo para aplicação de tensão controlada, mediante a manipulação das válvulas de controle do sistema de ar comprimido, mantendo a tensão de câmara constante e as linhas de drenagem do topo e da base abertas.

Os corpos de prova foram, em seguida, adensados anisotropicamente ao longo da linha $\mathrm{K}_{\mathrm{c}}$, até a tensão de adensamento desejada, mediante a aplicação, em pequenos estágios, de combinações apropriadas de tensão confinante e axial. Em cada estágio, com as linhas de drenagem do corpo de prova fechadas, aumentava-se inicialmente a tensão confinante, o que provocava alterações na leitura da célula de carga, como resposta do comportamento do corpo de prova. Depois de estabilizada a leitura da célula de carga, aplicava-se o incremento previsto da tensão desviadora, e em seguida, abriam-se as válvulas do topo e da base, para dar início ao adensamento.

A velocidade de adensamento e o final de cada estágio foram controlados pela estabilização da variação volumétrica e pela combinação de medidas de poropressão na base e no meio do corpo de prova, as quais foram extremamente valiosas, permitindo determinar quando foram atingidas as condições uniformes dentro deste. A variação de altura do corpo de prova, durante o adensamento, foi acompanhada ao longo de toda a etapa mediante os eletroníveis.

A trajetória ACB na Figura 5.17 mostra a trajetória seguida na fase de adensamento anisotrópico, anteriormente descrita.

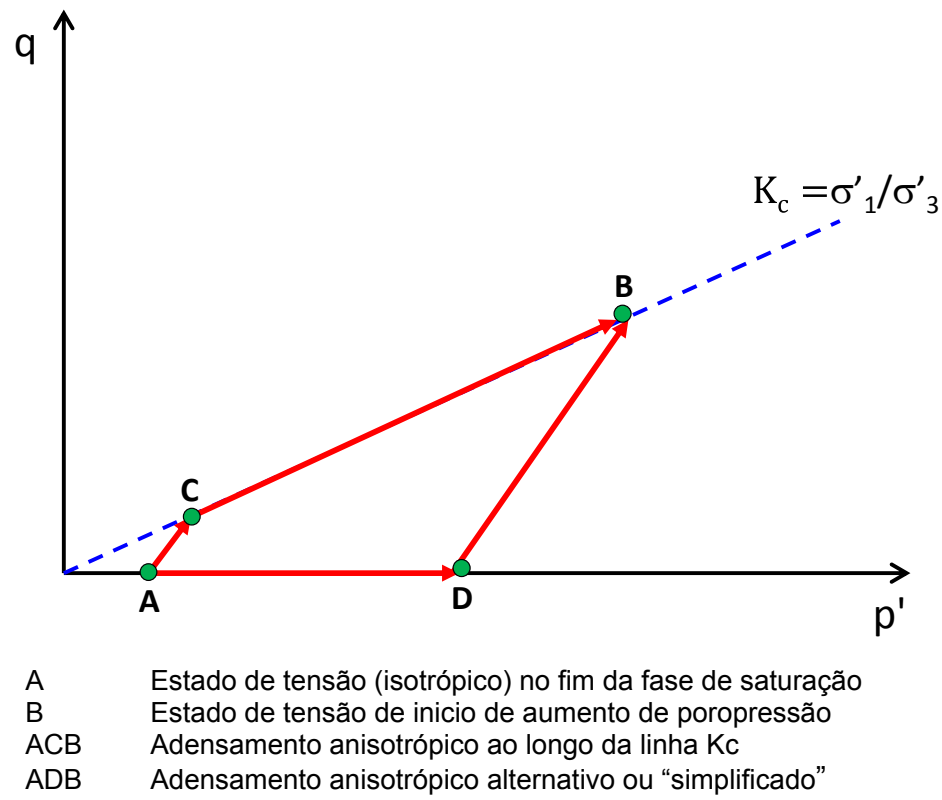

Figura 5.17 - Trajetórias de tensão seguidas na etapa de adensamento anisotrópico (adaptado de Baldi et al., 1988) 
Devido à ruptura de algumas amostras do solo coluvionar, no momento de realizar o adensamento anisotrópico seguindo a trajetória $A C B$, optou-se pela realização de um procedimento alternativo ou "método simplificado". Neste caso, partiu-se do estado (isotrópico) de tensão efetiva do final da fase de saturação (ponto A), e aplicou-se um incremento de tensão, por meio de um aumento da pressão na água da câmara, de modo a perfazer um estado de tensão isotrópico no ponto D, Figura 5.17. Em seguida, por meio da ação do embolo, aplicou-se a tensão desviadora em pequenos estágios de tensão controlada, sob condições drenadas, de modo que a tensão efetiva vertical atingisse o ponto $B$ (trajetória ADB na figura). O final de cada estágio também foi determinado pela estabilização da variação volumétrica e das medidas de poropressão.

Considerando que a declividade dos taludes dos locais onde foram extraídos os solos varia entre $20^{\circ}$ e $55^{\circ}$, a relação das tensões principais no campo $\left(\mathrm{K}_{\mathrm{c}}=\sigma_{1}{ }_{1} / \sigma_{3}^{\prime}\right)$ seria em torno de 2,0 a 5,5 , segundo o critério de Anderson e Sitar (1995) exposto no item 2.2.1. Porém, ciente de que as amostras poderiam se romper, caso fosse utilizado um coeficiente de tensão mais elevado durante a fase de adensamento, os corpos de prova do solo de Duque de Caxias e Tinguá foram adensados ao longo da linha $\mathrm{K}_{\mathrm{c}}=2,5$; enquanto que os corpos de prova do Campo Experimental da PUC foram adensados ao longo da linha $\mathrm{K}_{\mathrm{c}}=2,0$.

Alguns ensaios realizados com corpos de prova do solo de Tinguá e PUC foram adensados anisotropicamente mediante o método simplificado, uma vez que vários corpos de prova sofreram ruptura ao tentar ser adensados ao longo da linha $\mathrm{K}_{\mathrm{c}}$, para tensões efetivas maiores que $150 \mathrm{kPa}$.

As tensões efetivas de adensamento utilizadas para a execução dos ensaios foram de 25, 50, 75, 100, 150, 220 e $300 \mathrm{kPa}$. Embora, as tensões de confinamento in situ sejam baixas, foram realizados ensaios com tensões efetivas de confinamento maiores, com a finalidade de avaliar se o comportamento do solo depende da pressão de confinamento neste tipo de ensaio.

\section{d) Aumento de poropressão}

Uma vez que o nível de tensão desejado foi alcançado, o corpo de prova foi submetido a uma trajetória de tensão de cisalhamento constante, através do aumento de sua poropressão.

A contrapressão foi aplicada pelo controlador de pressão e volume (GDS) através das linhas de drenagem do topo e da base do corpo de prova, à velocidade de $1 \mathrm{kPa} / \mathrm{hr}$ nos solos coluvionares da PUC e Tinguá, e de $2 \mathrm{kPa} / \mathrm{hr}$ 
no solo residual jovem de Duque de Caxias. Estas velocidades foram selecionadas de modo a assegurar o equilíbrio das poropressões dentro do corpo de prova durante os ensaios, o que foi monitorado continuamente mediante a medida da poropressão a meia altura e na base do corpo de prova. A escolha das velocidades foi realizada depois de se executar vários testes com diferentes taxas de aumento de poropressão.

A Figura 5.18 mostra um esquema de funcionamento dos equipamentos na fase de adensamento anisotrópico.

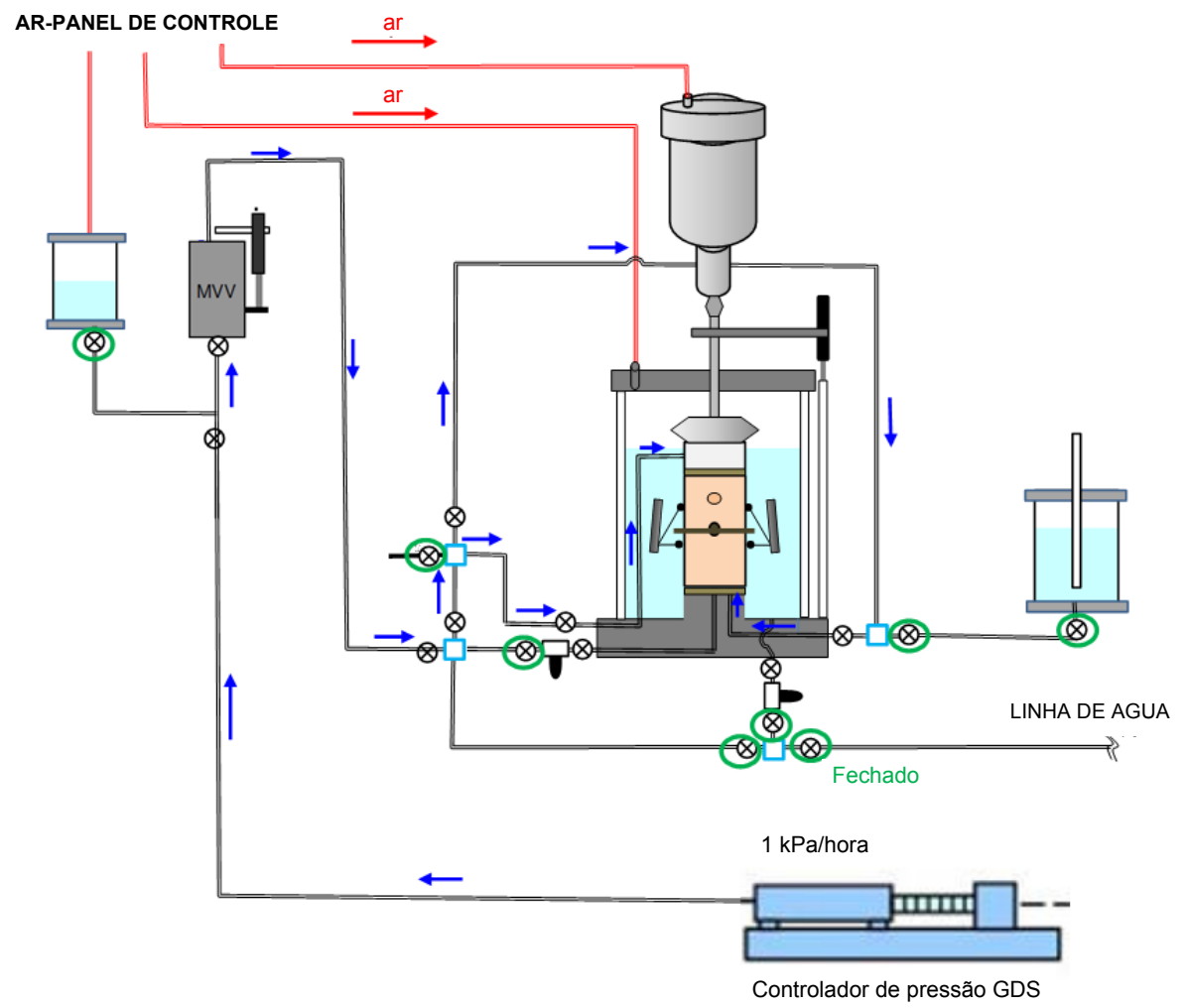

Figura 5.18 - Esquema de funcionamento dos equipamentos na etapa de aumento de poropressão

Esta fase finalizava quando $\sigma_{3}{ }_{3}$ aproximava-se a zero ou quando a amostra apresentava uma grande deformação súbita.

No caso em que o corpo de prova não rompia ao atingir $\sigma_{3}^{\prime} \approx 2 \mathrm{kPa}$, o ensaio de aumento de poropressão era concluído e procedia-se ao carregamento axial por deformação controlada, ajustando o "topador" do dispositivo de aplicação de tensão controlada e fechando as válvulas de drenagem do corpo de prova. Este valor de tensão efetiva foi escolhido a fim de evitar a percolação de agua entre a amostra e a membrana impermeável que a envolve, a possível danificação da amostra e o consequente comprometimento do ensaio. 
Ao fim do ensaio o corpo de prova era cuidadosamente retirado para a determinação da umidade final, e o zero de todos os transdutores era verificado.

\subsubsection{4}

\section{Algumas considerações do ensaio}

Durante o período de desenvolvimento dos ensaios, várias dificuldades foram enfrentadas. Entre estas, destacam-se efeitos devidos a variações de temperatura, problemas de instabilidade eletroeletrônicos e complicações ao tentar manter a tensão desviadora constante.

A variação brusca da temperatura pode afetar sensivelmente os instrumentos elétricos de medição. Sendo os ensaios de longa duração, é bastante provável que tais variações possam acontecer, principalmente nos meses mais frios ou quentes do ano. Por isso, é importante que os ensaios sejam acompanhados com registros contínuos de temperatura na área de trabalho. Estas medições servem como base de critério, para avaliar se uma mudança brusca na resposta de um instrumento pode ser devido a efeitos de temperatura.

Por essa razão, durante todo o ensaio realizou-se um monitoramento da temperatura mediante dois dispositivos diferentes. O primeiro foi colocado próximo da prensa triaxial e realizava registros da temperatura durante 0 transcurso do ensaio, com uma resolução de $1^{\circ} \mathrm{C}$. O segundo permitia visualizar a temperatura do ambiente, possibilitando perceber qualquer mudança no funcionamento do ar condicionado que pudesse alterar o desenvolvimento do ensaio, especialmente na fase de aumento de poropressão.

Foi observado que o funcionamento do GDS era afetado com as mudanças bruscas da temperatura, provavelmente causado pela expansão das tubulações, originando eventuais variações na taxa de aumento de poropressão. Ainda, o GDS teve que ser ligado com várias horas de antecedência do início da fase de aumento de poropressão, para que se conseguissem valores de pressão iniciais constantes.

Alguns ensaios foram total ou parcialmente perdidos devido à ocorrência de falhas de energia, problemas associados à instrumentação ou ao compressor do laboratório. 


\section{3 \\ Ensaios triaxiais drenados e não drenados convencionais}

Foram realizados sete ensaios triaxiais adensados isotropicamente drenados (CID) e sete ensaios triaxiais adensados isotropicamente não drenados (CIU), seguindo a trajetória de tensões convencionais, com velocidade de deslocamento constante. Estes ensaios foram realizados em corpos de prova indeformados provenientes dos solos coluvionares da PUC e de Tinguá, a partir da aplicação de tensões efetivas de confinamento de 75, 150 e 300 kPa no solo da PUC; e de 25, 75, 150 e 300 kPa no solo de Tinguá.

Adicionalmente, foram realizados três ensaios triaxiais adensados anisotropicamente não drenados (CKU) no solo coluvionar de Tinguá. As tensões confinantes utilizadas foram da ordem de 75, 150 e $300 \mathrm{kPa}$.

\subsection{1}

\section{Ensaios triaxiais CIU e CID}

\subsubsection{1}

\section{Equipamento utilizado}

Os ensaios triaxiais convencionais foram executados no Laboratório de Geotecnia e Meio Ambiente do DEC da PUC-Rio. Nos ensaios triaxiais adensados isotropicamente foram utilizadas duas prensas fabricadas pela empresa Wykeham-Farrance Eng Ltd (modelo WF10071), de velocidade de deslocamento controlada. Estas prensas, com 10 toneladas-força de capacidade máxima, são dotadas de motor elétrico associado a um sistema de engrenagens, que permite a adoção de diferentes velocidades de cisalhamento. Sobre elas são montadas câmaras triaxiais, também de fabricação inglesa, Wykeham Farrance Ltd.

Os instrumentos de medição acoplados ao equipamento foram todos de acionamento elétrico. A tensão confinante na câmara e a contrapressão aplicada na amostra foram medidas por transdutores da marca Schaevitz, com capacidade máxima igual a 150 psi (aproximadamente 1034 kPa). O deslocamento axial do corpo de prova, por sua vez, foi monitorado por instrumentos tipo LSCDT de 25,4 mm de taxa de deslocamento, do fabricante Wykeham Farrance. Com relação à variação volumétrica sofrida pelo corpo de prova, esta foi registrada por transdutores de variação de volume tipo Bellofram, projetados e construídos na PUC-Rio (De Campos, 1985) que estão instalados entre os sistemas de aplicação de contrapressão e de drenagem da amostra. A 
medição da carga axial foi realizada por células de carga internas com capacidade de $5 \mathrm{kN}$, da marca ELE International Ltd, que medem diretamente os acréscimos de força axial, dispensando as correções devidas ao atrito de sua haste com o topo da câmara.

Todos os ensaios foram realizados com o auxílio do sistema de aquisição de dados QuantumX da marca HBM, com amplificador universal MX840A, composto por 3 módulos sincronizados de 8 canais cada. O programa utilizado para a aquisição dos sinais foi o CatmanEasy da HBM. A Figura 5.19 mostra o sistema de aquisição de dados usado nestes ensaios.
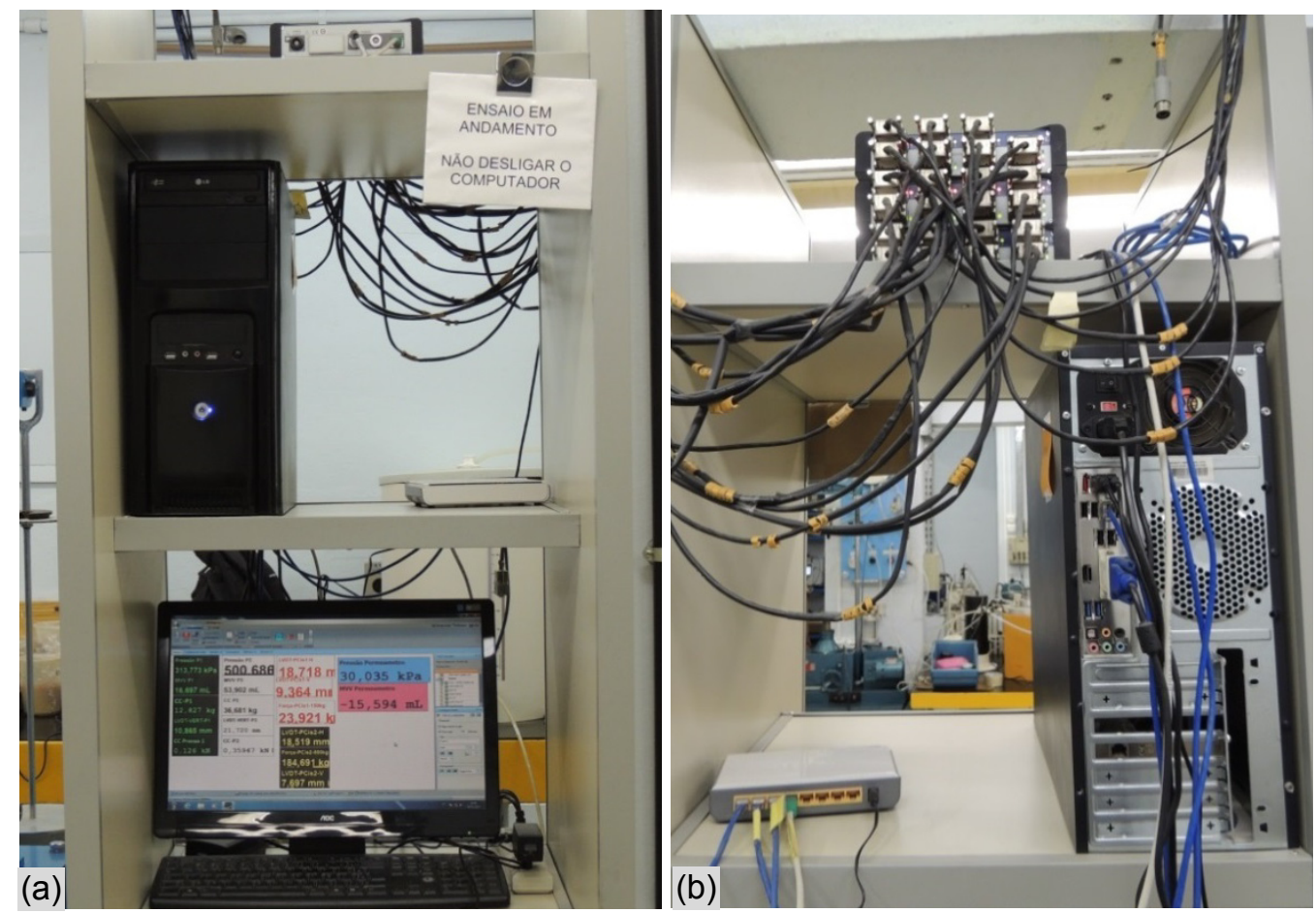

Figura 5.19 - Sistema de aquisição de dados QuantumX. (a) Software CatmanEasy, (b) Amplificador universal MX840A

\subsubsection{2 \\ Metodologia empregada}

A confecção dos corpos de prova, verificação de estanqueidade do conjunto, assim como a saturação das linhas e pedras porosas, seguiram o mesmo procedimento adotado para o ensaio de aumento de poropressão.

Após a operação de moldagem, os corpos de prova foram instalados no interior das câmaras triaxiais, cuidadosamente envolvidos por membranas flexíveis e impermeáveis, e posteriormente levados à saturação. Para isto, as amostras foram submetidas a um estagio de fluxo ascendente e a sucessivos incrementos de tensão confinante e de contrapressão alternadamente, 
mantendo-se sempre a diferença de $10 \mathrm{kPa}$. Ao final de cada incremento, foi calculado o parâmetro de poropressão $B$, admitindo-se os corpos de prova saturados no caso de valores deste parâmetro acima de 0,98 . O período total de saturação foi de aproximadamente dois dias.

Após os procedimentos de saturação, os corpos de prova foram adensados isotropicamente sob diferentes níveis de tensão, de acordo com a programação preestabelecida. $O$ adensamento isotrópico foi realizado aumentando-se a tensão confinante em condições não drenadas, até que a diferença desta com a contrapressão atingisse a tensão efetiva desejada. Em seguida, as drenagens do topo e da base foram abertas, permitindo o adensamento da amostra. A análise da evolução da curva "variação de volume versus raiz quadrada do tempo" permitia identificar o término do adensamento primário.

As medidas para correção de altura e volume dos corpos de prova foram realizadas, possibilitando o cálculo dos novos índices físicos.

Após o adensamento, procedeu-se ao cisalhamento sob uma velocidade constante de deslocamento axial. Tal velocidade foi estabelecida de acordo com Head (1998). No caso de ensaios não drenados, a compressão axial imposta deve ser suficientemente lenta de forma a permitir a equalização dos excessos de poropressão gerados ao longo da altura do corpo de prova. No caso de ensaios drenados, a compressão axial imposta deve ser suficientemente lenta de forma a permitir a total drenagem da água do corpo de prova, sem geração de excesso de poropressão. Assim, para ambos solos utilizou-se a velocidade de $0,033 \mathrm{~mm} / \mathrm{min}$, nas condições drenadas e não drenadas.

No caso dos ensaios CID, as válvulas de drenagem foram mantidas abertas para permitir a drenagem, enquanto, nos ensaios $\mathrm{CIU}$, foram fechadas, a fim de manter as condições não drenadas dentro do corpo de prova. A compressão axial normalmente foi continuada até atingir $20 \%$ da deformação axial. Ao final dos ensaios, determinou-se o teor de umidade de cada corpo de prova.

\subsection{2}

\section{Ensaios triaxiais CKU}

Os ensaios triaxiais adensados anisotropicamente foram realizados na mesma prensa usada para ensaios de aumento de poropressão, que permitia o controle das tensões aplicadas na fase de adensamento anisotrópico. Além 
disso, possibilitou o uso dos eletroníveis para o controle da deformação axial dos corpos de prova durante todo o ensaio. Os procedimentos adotados nos ensaios $\mathrm{CKU}$, até o estágio de adensamento, são semelhantes aos indicados no item 5.2.2.

Nesses ensaios, os corpos de prova foram adensados com relações $K_{c}$ de 2,5. Depois de atingida a tensão efetiva desejada, foram em seguida submetidos a carga de compressão não drenada em um modo de deformação controlada.

\section{4 \\ Ensaios de cisalhamento direto com plano cortado e superfície polida}

O ensaio de cisalhamento direto com plano cortado e superfície polida foi realizado nos três solos estudados, com a finalidade de obtenção da resistência ao cisalhamento na condição residual, através da utilização da prensa de cisalhamento direto convencional.

O método consiste em cortar o corpo de prova, com um fio de aço fino, ao longo do plano horizontal, dado pela interface das metades da caixa de cisalhamento, e polir as superfícies que tornarão a ser colocadas em contato, de modo a facilitar a formação da superfície de ruptura na condição residual.

Os ensaios foram executados na condição inundada em amostras indeformadas adensadas, obtendo-se inicialmente a tensão cisalhante de pico ou máxima. Encerrado o primeiro ciclo, utilizou-se o método de precorte e polimento do plano de cisalhamento, e, em seguida, submeteu-se o corpo de prova a um ciclo de cisalhamento, até a obtenção de uma condição tida como residual.

O cisalhamento direto com plano cortado e superfície polida pode ser entendido como uma extensão do ensaio de cisalhamento convencional.

\subsection{1}

\section{Equipamento utilizado}

Nos ensaios, foram utilizadas duas prensas de cisalhamento direto fabricadas pela empresa Wykeram-Ferrance, modelo 25210, pertencentes ao Laboratório de Geotecnia e Meio Ambiente da PUC-Rio. A Figura 5.20 mostra uma das prensas. 


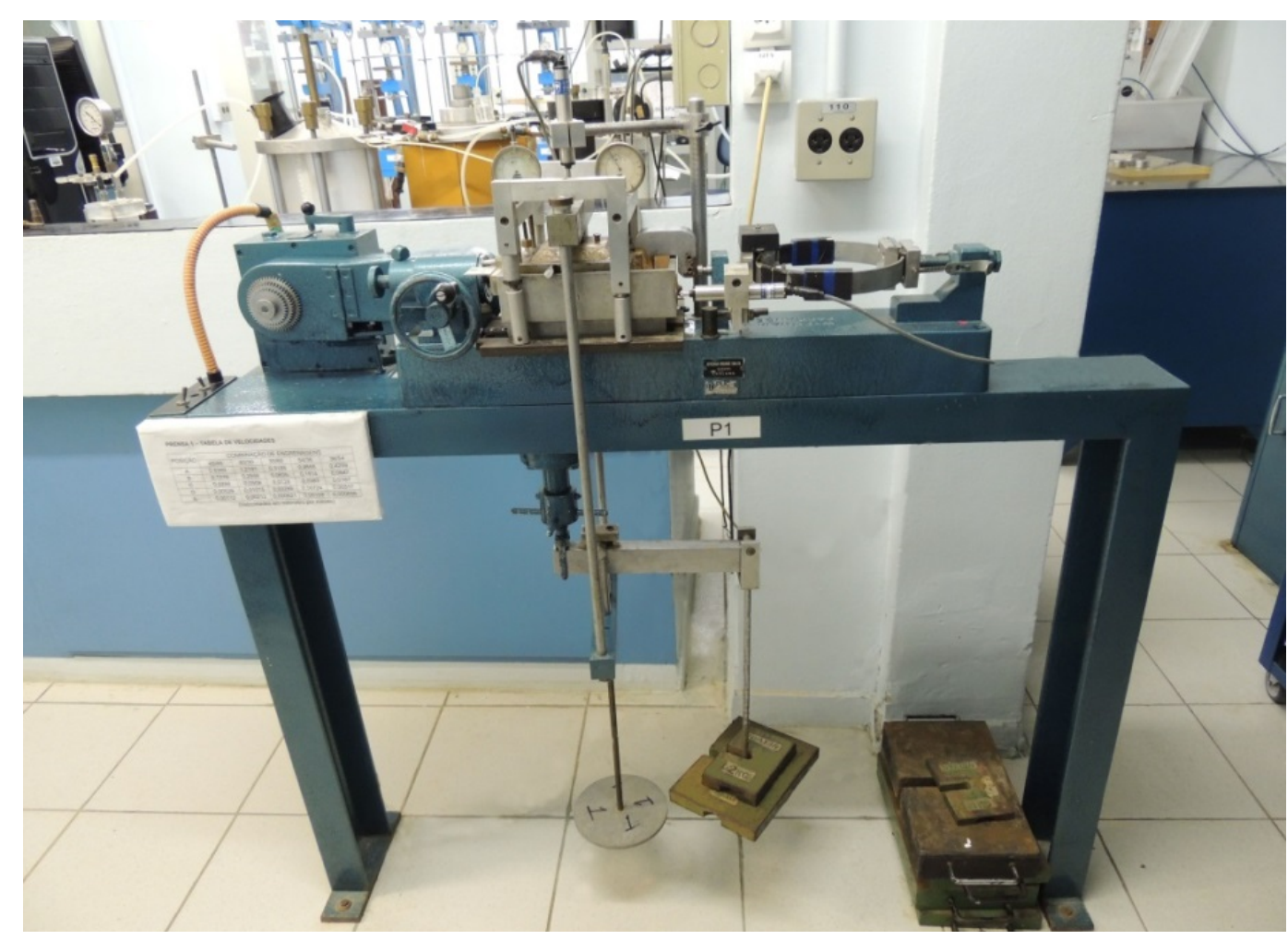

Figura 5.20 - Prensa de cisalhamento direto pertencente ao Laboratório de Geotecnia e Meio Ambiente da PUC-Rio

Cada prensa utilizada no programa experimental é provida de um motor elétrico associado a um jogo de engrenagens, capazes de impor ao conjunto diferentes velocidades de deslocamento constantes. Estas possuem um sistema individual tipo pendural, com braço de alavanca para a aplicação de carga vertical.

As grandezas físicas, nestes equipamentos, foram medidas por meio de um anel de carga instrumentado, desenvolvido na PUC-Rio, para a medida da força horizontal, e transdutores de deslocamento tipo LSCDT para a medida do deslocamento vertical do corpo de prova, assim como o deslocamento horizontal da caixa de cisalhamento.

Todos os instrumentos acima estão ligados ao mesmo sistema de aquisição de dados usado nos ensaios triaxiais convencionais (Figura 5.19). 


\subsubsection{Metodologia empregada}

\subsubsection{1 \\ Moldagem dos corpos de prova}

A moldagem dos corpos de prova se deu através de moldes metálicos de seção quadrada de $10 \times 10 \mathrm{~cm}$ e altura $2 \mathrm{~cm}$, os quais foram inicialmente limpos, medidos, lubrificados com vaselina e pesados.

No caso do solo de Tinguá e Duque de Caxias os corpos de prova foram moldados no laboratório diretamente nos blocos indeformados; no caso do solo da PUC a moldagem se realizou no campo, devido à grande quantidade de raízes, conforme especificado no item 3.4.

O molde era posicionado sobre uma superfície plana no bloco, com a borda biselada em contato com o solo, e cuidadosamente cravado alguns milímetros. O solo em volta era então removido com uma faca. Para facilitar a cravação e manter o avanço vertical do anel foi utilizada uma régua. A amostra era separada do bloco e rasada em ambos lados com a régua.

A presença esporádica de concreções, em especial nos solos de Tinguá, foi problemática, pois as mesmas por vezes se constituiam um obstáculo à inserção do anel metálico de moldagem, causando a perda dos corpos de prova.

Do solo excedente da moldagem foram recolhidas três cápsulas com material para determinação do teor de umidade. Para cada corpo de prova, foram medidos o peso, o volume e o teor de umidade, visando à determinação dos índices físicos.

A Figura 5.21 apresenta o processo de moldagem dos corpos de prova.
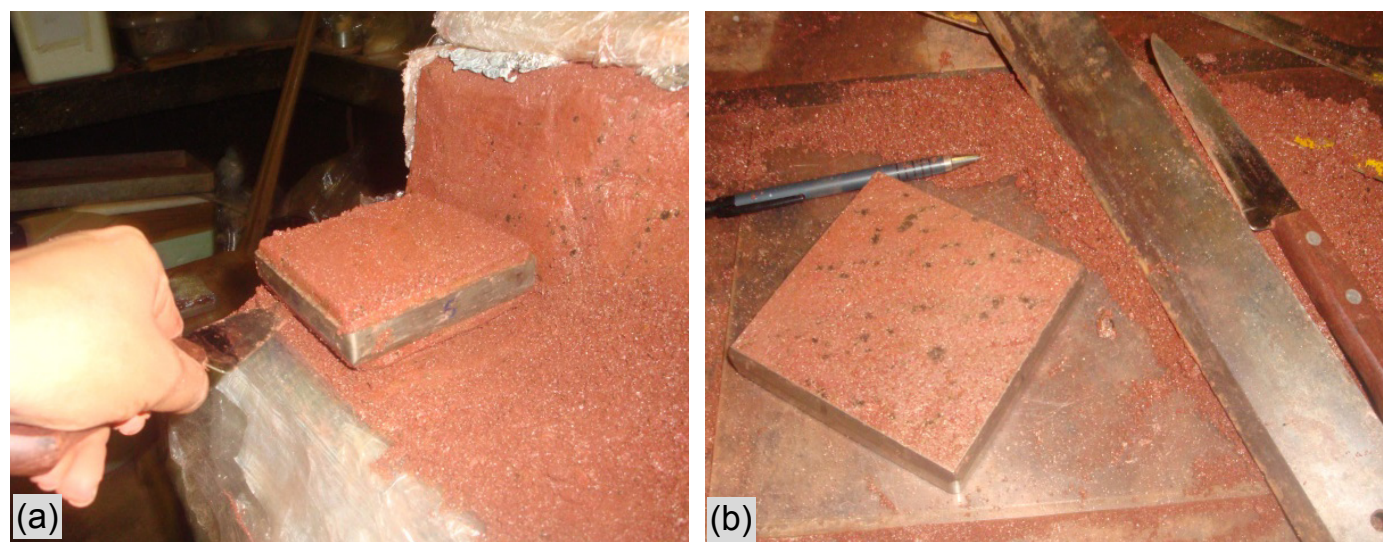

Figura 5.21 - (a) Moldagem de corpo de prova do solo de Duque de Caxias para realização de ensaio de cisalhamento direto com plano cortado e superfície polida, (b) Corpo de prova pronto para ensaio 


\subsubsection{2}

\section{Procedimento de ensaio}

Primeiramente, foi realizado o ensaio de cisalhamento direto convencional para determinação da resistência de pico, sob velocidade de deformação constante. O corpo de prova foi instalado na caixa de cisalhamento, a tensão normal foi aplicada e o interior do suporte da caixa inundado. As amostras foram adensadas para carregamentos de 25, 50, 75, 100, 150 e $200 \mathrm{kPa}$ durante 24 horas.

Após o período de adensamento, as duas partes da caixa bipartida foram separadas de 0,5 $\mathrm{mm}$ através de um dispositivo implementado na PUC-Rio, composto por um suporte com quatro parafusos espaçadores, com a finalidade de evitar o atrito entre ambas partes da caixa durante todo o ensaio. A distância estre as metades foi medida através de extensômetros colocados no suporte.

$\mathrm{Em}$ todos os ensaios, procurou-se cisalhar o corpo de prova até o deslocamento máximo permitido pelo carro guia da prensa de cisalhamento. (15 $\mathrm{mm})$. O cisalhamento se deu com uma velocidade constante de $0,128 \mathrm{~mm} / \mathrm{min}$ para os solos de Tinguá e Duque de Caxias, e de $0,082 \mathrm{~mm} / \mathrm{min}$ para o solo da PUC, menores do que aquelas calculadas pelo critério de Gibson e Henkel (1954), com o intuito de garantir a condição de cisalhamento drenado.

Após completar o primeiro cisalhamento, procedeu-se ao sifonamento do excesso da água da caixa de cisalhamento, ao alivio da tensão normal e à retirada da caixa de cisalhamento do carro guia. Posteriormente, foi realizado o corte com um fino fio de aço entre as metades da caixa, no sentido de cisalhamento, e realizou-se a separação das caixas. Com ajuda de um acrílico, ligeiramente umedecido, procedeu-se ao alisamento das superfícies, tomando cuidado para garantir que a direção do alisamento coincida com a direção do cisalhamento que a amostra experimentaria no equipamento de cisalhamento direto.

Uma vez que ambas as metades foram polidas, uniu-se as mesmas novamente e o ensaio foi reiniciado, recolocando a caixa de cisalhamento no carro guia, a tensão normal e a água de inundação. Realizou-se um novo ciclo de cisalhamento, com a amostra adensada por mais 24 horas. Depois de encerrado o ensaio, o teor de umidade final da amostra foi obtido.

A Figura 5.22 mostra os principais passos seguidos para a obtenção da resistência residual mediante o ensaio de cisalhamento direto, com plano cortado e superfície polida. 

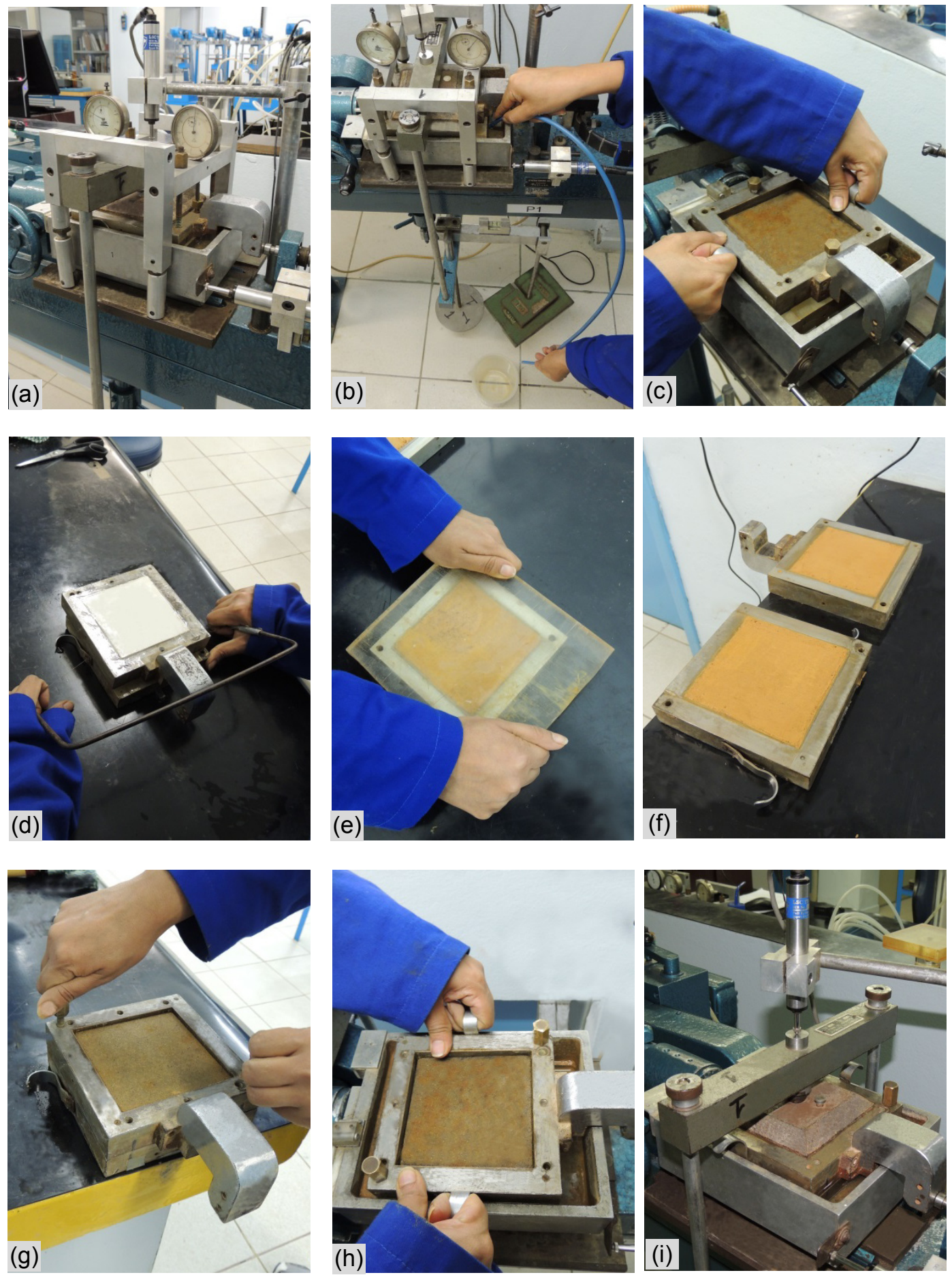

(a) Realização de ensaio cisalhamento

(e) Alisamento da superfície com acrílico direto convencional

(f) Ambas as superfícies polidas

(b) Sifonamento do excesso da água

(c) Retirada da caixa de cisalhamento do

(g) União das duas metades da caixa carro guia

(h) Recolocação de caixa no carro guia

(d) Corte com fino fio de aço no sentido do (i) Início de novo ciclo de cisalhamento com adensamento por 24 horas

Figura 5.22 - Principais passos seguidos para a obtenção de resistência residual mediante o ensaio de cisalhamento direto com plano cortado e superfície polida 
6

Apresentação e avaliação dos resultados: Ensaios de cisalhamento direto com plano cortado e superfície polida, e triaxiais convencionais

Este capítulo apresenta os resultados dos ensaios de cisalhamento direto com plano cortado e superfície polida, e dos triaxiais convencionais, os quais são analisados brevemente à medida que são mostrados.

\section{1.}

Ensaios de cisalhamento direto com plano cortado e superfície polida

Como alternativa para medição da resistência residual, foram realizados ensaios de cisalhamento direto pela técnica de plano cortado e superfície polida, em amostras submersas dos três solos estudados, utilizando-se tensões normais iniciais de adensamento de 25, 50, 75, 100, 150 e 200 kPa.

\subsection{1.}

\section{Solo do Campus Avançado da PUC em Tinguá}

A Tabela 6.1 detalha os índices físicos dos corpos de prova do solo coluvionar de Tinguá no início, após o adensamento da fase onde se obteve a resistência pico ou máxima, e no final do ensaio.

Tabela 6.1 - Índices físicos no início, após o adensamento e no final do ensaio dos corpos de prova do solo coluvionar de Tinguá usados no ensaio de cisalhamento direto

\begin{tabular}{|c|c|c|c|c|c|c|c|c|c|}
\hline \multirow{2}{*}{ Ensaio } & \multirow{2}{*}{$\begin{array}{c}\sigma_{n}^{\prime} \\
(\mathrm{kPa})\end{array}$} & \multicolumn{6}{|c|}{ Índices físicos iniciais } & \multirow{2}{*}{$\begin{array}{c}\text { Após } \\
\text { adensamento } \\
\mathrm{e}_{\text {adens }} \\
\end{array}$} & \multirow{2}{*}{$\begin{array}{c}\text { Finais } \\
w_{f} \\
(\%)\end{array}$} \\
\hline & & $\begin{array}{l}w_{o} \\
(\%)\end{array}$ & $\begin{array}{c}\gamma_{\mathrm{n}} \\
\mathrm{kN} / \mathrm{m}^{3}\end{array}$ & $\begin{array}{c}\gamma_{\mathrm{d}} \\
\mathrm{kN} / \mathrm{m}^{3}\end{array}$ & $e_{o}$ & $\begin{array}{c}n \\
(\%)\end{array}$ & $\begin{array}{c}\mathrm{S} \\
(\%)\end{array}$ & & \\
\hline TING25 & 26,8 & 24,70 & 16,33 & 13,10 & 1,043 & 51,06 & 63,36 & 1,020 & 41,08 \\
\hline TING50 & 50,7 & 24,37 & 17,20 & 13,83 & 0,935 & 48,33 & 69,73 & 0,861 & 35,37 \\
\hline TING75 & 74,3 & 23,44 & 17,14 & 13,89 & 0,927 & 48,10 & 67,66 & 0,871 & 35,08 \\
\hline TING100 & 103,3 & 25,12 & 17,24 & 13,78 & 0,942 & 48,52 & 71,32 & 0,823 & 32,36 \\
\hline TING150 & 151,6 & 25,46 & 16,98 & 13,53 & 0,978 & 49,43 & 69,69 & 0,836 & 33,12 \\
\hline TING200 & 203,6 & 23,57 & 16,53 & 13,38 & 1,000 & 50,01 & 63,04 & 0,735 & 32,06 \\
\hline
\end{tabular}


Na Figura 6.1 apresentam-se curvas que relacionam a tensão cisalhante $(\tau)$, o deslocamento vertical $(\mathrm{dv})$ e a razão tensão cisalhante/tensão normal $\left(\tau / \sigma_{n}\right)$, com o deslocamento $(\mathrm{dh})$ dos ensaios de cisalhamento, tanto na fase de obtenção da resistência máxima, quanto na fase de reversão para obtenção da resistência residual. Deslocamentos positivos descrevem compressão do corpo de prova.
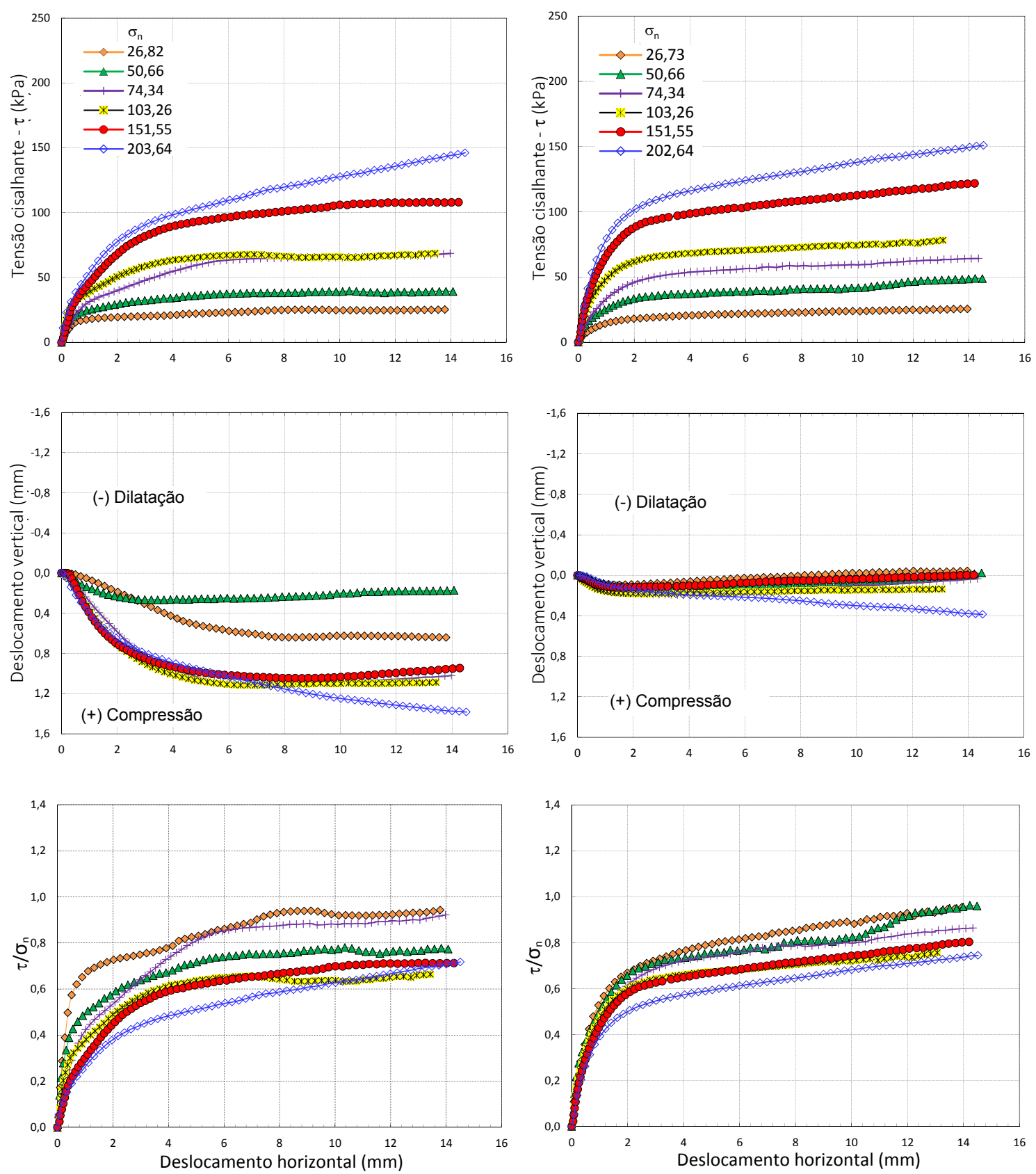

(a)

(b)

Figura 6.1 - Resultados do ensaio de cisalhamento direto com plano cortado e superfície polida no solo coluvionar de Tinguá, (a) Fase para obtenção de resistência máxima, (b) Fase de reversão para obtenção de resistência residual

Conforme mostra a Figura 6.1, as curvas $\tau$ vs dh não apresentam pico de resistência para as tensões normais investigadas. Observa-se mobilização da 
tensão cisalhante máxima para valores elevados de deslocamento horizontal (6,2 a 10,6 mm) no caso da primeira fase do ensaio, na obtenção da resistência pico; e de valores menores (3,4 a 4,4 mm) no caso da obtenção da resistência residual. Para todos os ensaios foi assumido que o solo havia rompido quando a curva $\tau$ vs dh atingiu uma inclinação constante ou nula, conforme o critério proposto por De Campos e Carrillo (1995). A Tabela 6.2 apresenta os dados na ruptura da fase de obtenção da resistência de pico e residual.

Tabela 6.2 - Resumo dos resultados obtidos a partir dos ensaios de cisalhamento direto com plano cortado e superfície polida nos corpos de prova do solo coluvionar de Tinguá

\begin{tabular}{c|c|c|c|c|c|c|c}
\hline \multirow{2}{*}{ Ensaio } & \multirow{2}{*}{$\begin{array}{c}\sigma_{n}^{\prime} \\
(\mathrm{kPa})\end{array}$} & \multicolumn{3}{|c|}{ Dados na ruptura pico } & \multicolumn{3}{c}{ Dados na ruptura residual } \\
\cline { 3 - 8 } & $\delta_{\mathrm{h}}$ & $\begin{array}{c}\tau \\
(\mathrm{kPa})\end{array}$ & $\begin{array}{c}\sigma_{\mathrm{n}}^{\prime} \\
(\mathrm{kPa})\end{array}$ & $\begin{array}{c}\delta_{\mathrm{h}} \\
(\mathrm{mm})\end{array}$ & $\begin{array}{c}\tau \\
(\mathrm{kPa})\end{array}$ & $\begin{array}{c}\sigma_{n}^{\prime} \\
(\mathrm{kPa})\end{array}$ \\
\hline TING25 & 26,8 & 8,8 & 25,2 & 29,4 & 4,0 & 20,5 & 27,9 \\
\hline TING50 & 50,7 & 10,4 & 39,6 & 56,5 & 3,7 & 36,9 & 52,6 \\
\hline TING75 & 74,3 & 6,2 & 63,8 & 79,2 & 4,2 & 54,1 & 77,6 \\
\hline TING100 & 103,3 & 6,7 & 67,7 & 110,6 & 3,4 & 67,2 & 106,9 \\
\hline TING150 & 151,6 & 10,6 & 106,9 & 169,2 & 3,6 & 97,2 & 157,2 \\
\hline TING200 & 203,6 & 8,0 & 119,7 & 221,2 & 4,4 & 118,4 & 212,9 \\
\hline
\end{tabular}

As curvas dv vs dh da Figura 6.1(a) indicam que o solo coluvionar de Tinguá apresentou comportamento de compressão para todas as tensões normais utilizadas.

Na Figura 6.1(b) observa-se que nas reversões não se obteve nenhuma queda significativa da tensão cisalhante máxima, para cada tensão normal aplicada. A fase residual aparentemente foi plenamente alcançada, desde que as curvas de variação volumétrica se estabilizaram. Com exceção do ensaio realizado com tensão normal de $202 \mathrm{kPa}$, as amostras praticamente não apresentaram deslocamento vertical na fase de reversão para obtenção da resistência residual.

As curvas $\tau / \sigma_{\mathrm{n}}$ vs $\mathrm{dh}$ tendem a se agrupar em uma faixa relativamente estreita, indicando uma relativa homogeneidade no comportamento cisalhante deste solo coluvionar.

Nas Figuras 6.2 e 6.3 os resultados dos ensaios estão representados como pontos em um diagrama $\tau$ vs $\sigma_{\mathrm{n}}$. As envoltórias foram analisadas, por correlações lineares, bi-lineares e curvas. As envoltórias Mohr Coulomb lineares e bi-lineares apresentaram coeficiente de correlação superior a 0,95. Entretanto, nota-se uma ligeira tendência de curvatura dos pontos, principalmente para tensões baixas. Por esse motivo, julgou-se oportuno determinar, também, a envoltória curva, segundo a equação: 


$$
\tau=\mathrm{A} \sigma^{\mathrm{b}}
$$

As equações que relacionam a tensão cisalhante e a tensão normal são mostradas em cada um dos gráficos. Para as relações lineares e bilineares são mostrados os respectivos parâmetros de resistência. Percebe-se a grande variabilidade destes, para os diferentes intervalos de tensões normais adotados, com ângulos de atrito variando de 26 a $37^{\circ}$ e coesão de 0 a $23 \mathrm{kPa}$.

Observa-se que as correlações curvas são satisfatórias para os casos de obtenção de resistência máxima e residual. Também, percebe-se que não houve variação de comportamento significativa em ambos casos.
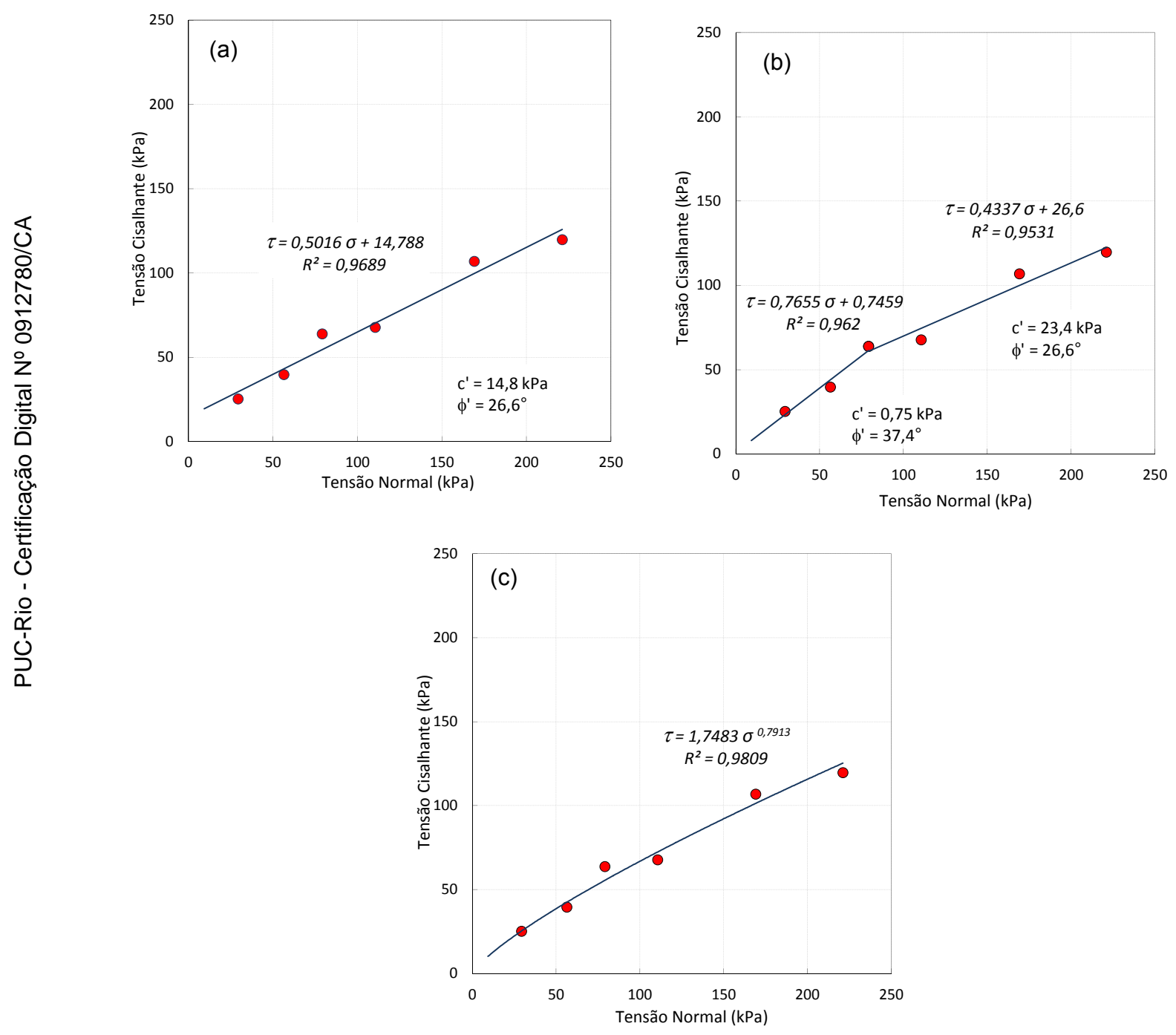

Figura 6.2 - Envoltórias de resistência de pico para o solo coluvionar de Tinguá: (a) linear, (b) bilinear e (c) curva 

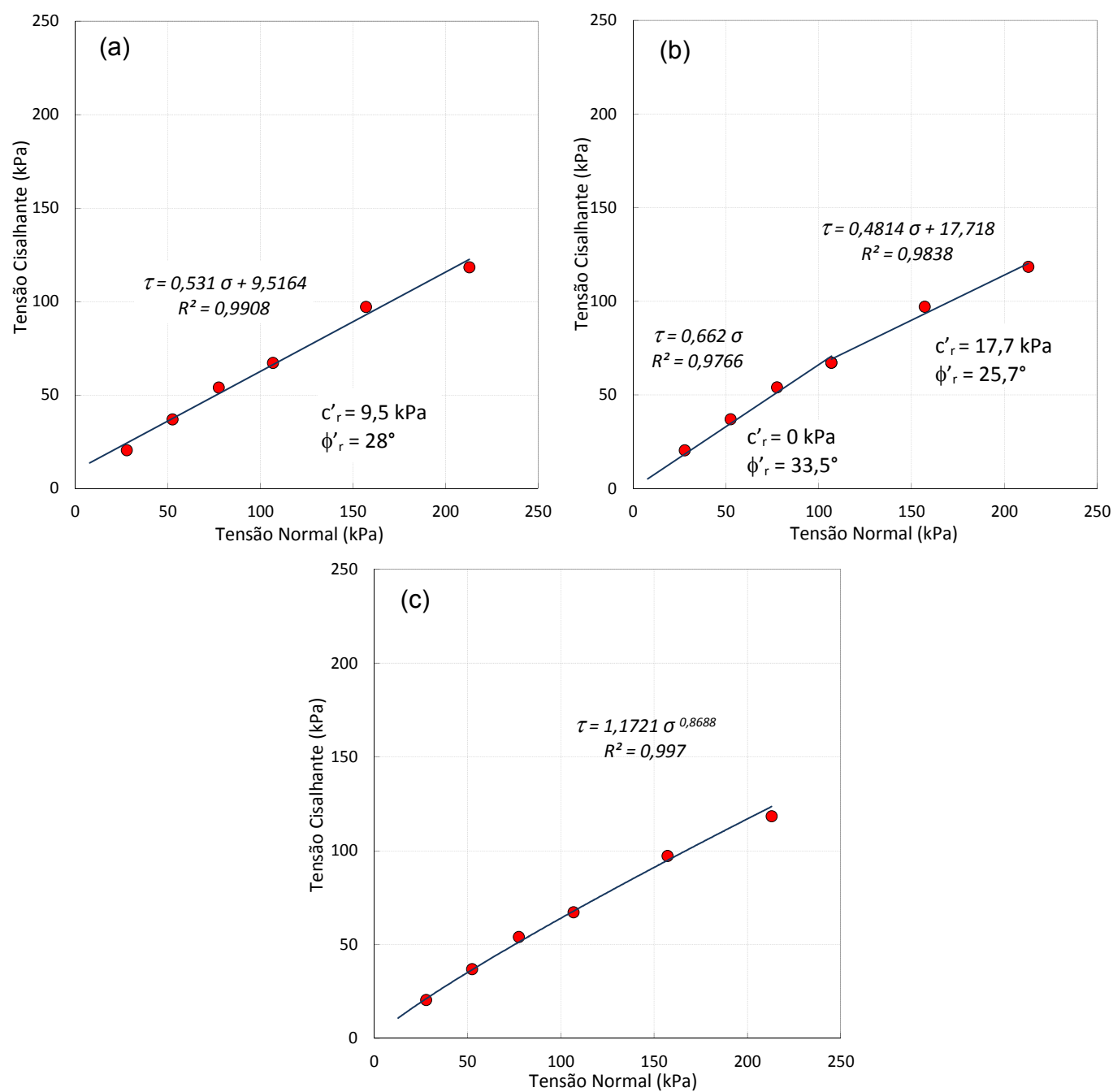

Figura 6.3 - Envoltórias de resistência residual para o solo coluvionar de Tinguá: (a) linear, (b) bilinear, e (c) curva

\section{1 .2}

\section{Solo do Campo Experimental II PUC-Rio}

Os índices físicos, correspondentes aos seis corpos de prova do solo coluvionar da PUC, estão apresentados na Tabela 6.3.

Tabela 6.3 - Índices físicos no início, após o adensamento e no final do ensaio dos corpos de prova do solo coluvionar da PUC usados no ensaio de cisalhamento direto

\begin{tabular}{|c|c|c|c|c|c|c|c|c|c|}
\hline \multirow[b]{2}{*}{ Ensaio } & \multirow{2}{*}{$\begin{array}{c}\sigma_{n}^{\prime} \\
(\mathrm{kPa})\end{array}$} & \multicolumn{6}{|c|}{ Índices físicos iniciais } & \multirow{2}{*}{$\begin{array}{c}\text { Após o } \\
\text { adensamento } \\
\mathrm{e}_{\text {adens }} \\
\end{array}$} & \multirow{2}{*}{$\begin{array}{r}\text { Finais } \\
w_{f} \\
(\%)\end{array}$} \\
\hline & & $\begin{array}{l}w_{o} \\
(\%)\end{array}$ & $\begin{array}{c}\gamma_{\mathrm{n}} \\
\mathrm{kN} / \mathrm{m}^{3}\end{array}$ & $\begin{array}{c}\gamma_{\mathrm{d}} \\
\mathrm{kN} / \mathrm{m}^{3}\end{array}$ & $e_{o}$ & $\begin{array}{c}n \\
(\%)\end{array}$ & $\begin{array}{c}S \\
(\%)\end{array}$ & & \\
\hline PUC25 & 26,8 & 25,36 & 17,08 & 13,63 & 1,010 & 50,25 & 68,77 & 0,986 & 34,86 \\
\hline PUC50 & 50,6 & 25,44 & 17,03 & 13,58 & 1,017 & 50,43 & 68,49 & 0,930 & 32,30 \\
\hline PUC75 & 74,3 & 25,86 & 17,37 & 13,80 & 0,985 & 49,61 & 71,94 & 0,871 & 33,40 \\
\hline PUC100 & 102,5 & 24,77 & 17,06 & 13,67 & 1,003 & 50,08 & 67,64 & 0,783 & 29,45 \\
\hline PUC150 & 150,3 & 24,63 & 17,24 & 13,84 & 0,980 & 49,49 & 68,88 & 0,752 & 31,23 \\
\hline PUC200 & 206,9 & 23,88 & 17,26 & 13,93 & 0,966 & 49,13 & 67,71 & 0,644 & 30,79 \\
\hline
\end{tabular}


Os resultados dos ensaios são apresentados na Figura 6.4. Como no solo coluvionar de Tinguá, as curvas $\tau$ vs dh mostram a inexistência de pico para todos os níveis de tensões normais aplicados.
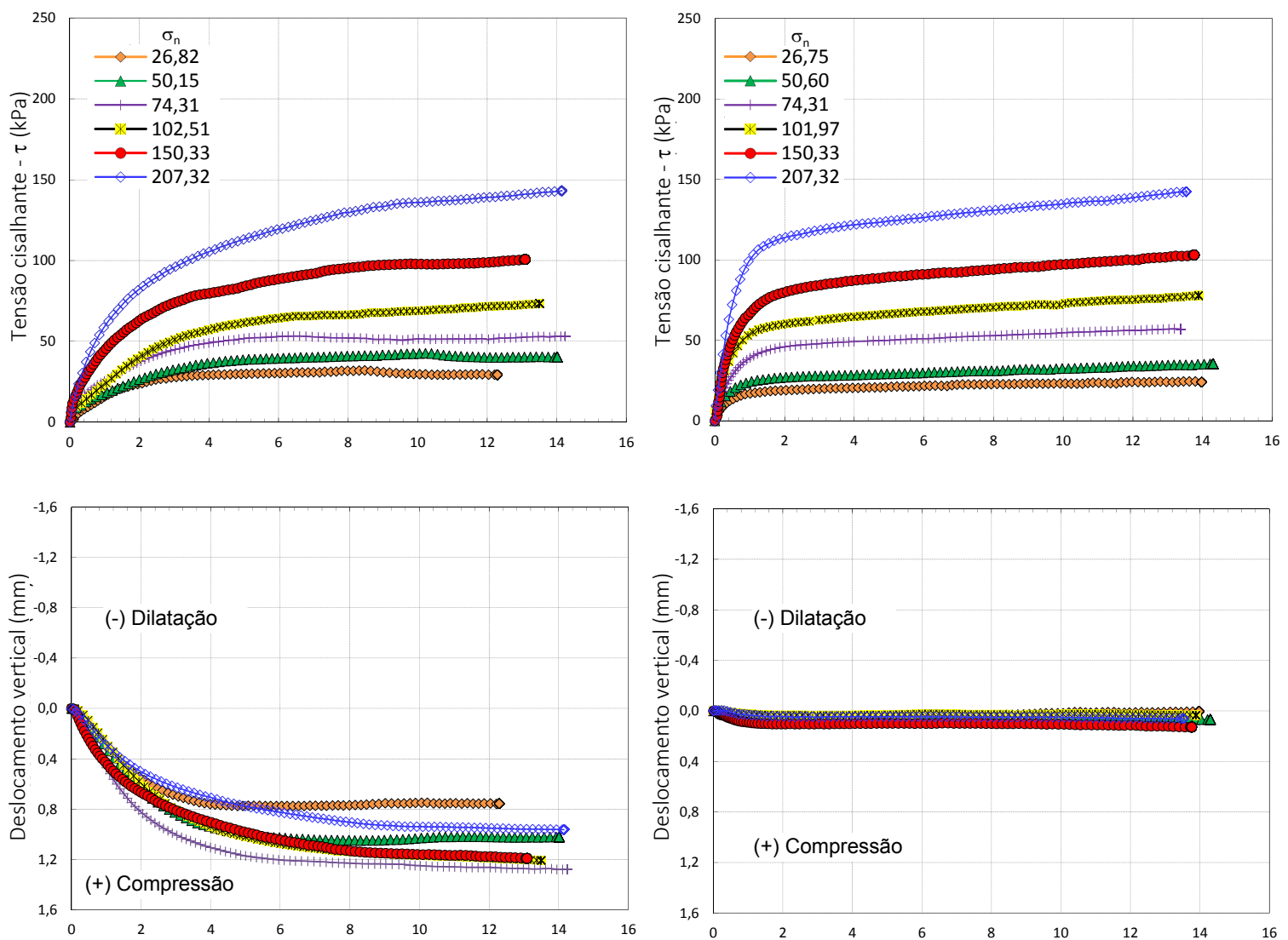

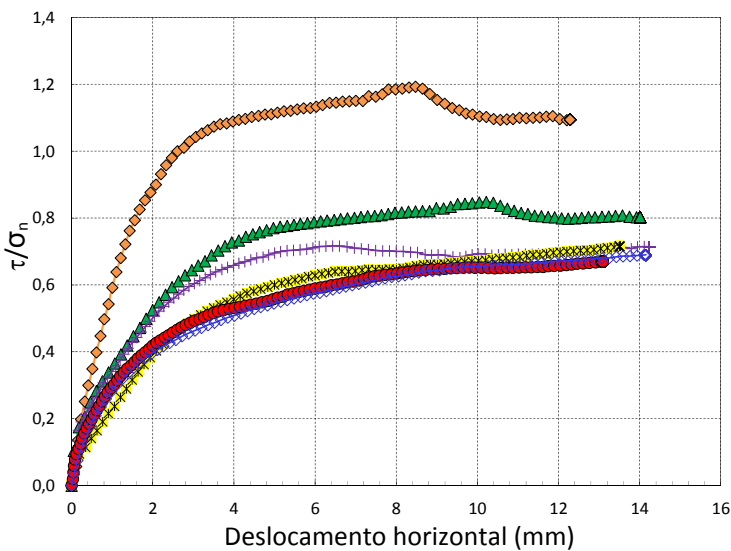

(a)

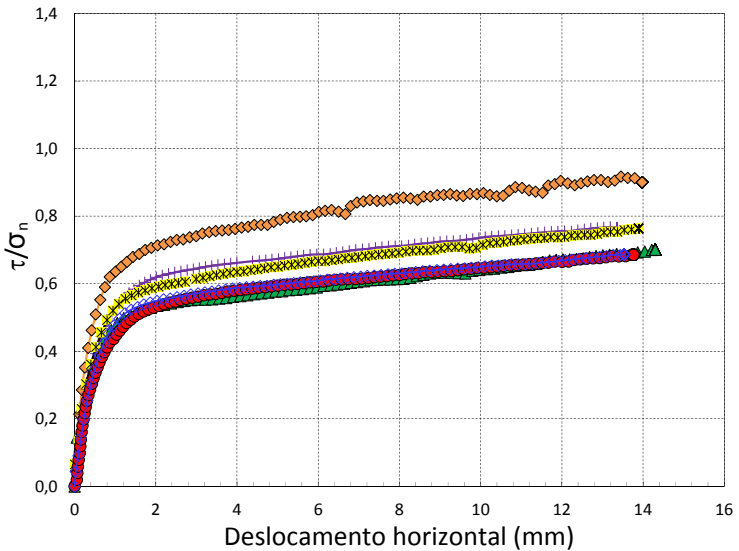

(b)

Figura 6.4 - Resultados do ensaio de cisalhamento direto com plano cortado e superfície polida no solo coluvionar da PUC, (a) Fase para obtenção de resistência máxima, (b) Fase de reversão para obtenção de resistência residual

$\mathrm{Na}$ maioria dos corpos de prova, as tensões máximas ocorreram com grandes deslocamentos horizontais no caso da obtenção da resistência pico, e com deslocamentos menores (2,4 a 3,9 mm) no caso de obtenção da resistência residual. Os dados de tensão cisalhante e normal na ruptura, das fases de 
obtenção de resistência pico e residual, são mostrados na Tabela 6.4.

Tabela 6.4 - Resumo dos resultados obtidos a partir dos ensaios de cisalhamento direto com plano cortado e superfície polida nos corpos de prova do solo coluvionar da PUC

\begin{tabular}{c|c|c|c|c|c|c|c}
\hline \multirow{2}{*}{ Ensaio } & \multirow{2}{*}{$\begin{array}{c}\sigma_{n}^{\prime} \\
(\mathrm{kPa})\end{array}$} & \multicolumn{3}{|c|}{ Dados na ruptura pico } & \multicolumn{3}{c}{ Dados na ruptura residual } \\
\cline { 3 - 8 } & $\begin{array}{c}\delta_{\mathrm{h}} \\
(\mathrm{mm})\end{array}$ & $\begin{array}{c}\tau \\
(\mathrm{kPa})\end{array}$ & $\begin{array}{c}\sigma_{n}^{\prime} \\
(\mathrm{kPa})\end{array}$ & $\begin{array}{c}\delta_{\mathrm{h}} \\
(\mathrm{mm})\end{array}$ & $\begin{array}{c}\tau \\
(\mathrm{kPa})\end{array}$ & $\begin{array}{c}\sigma_{n}^{\prime} \\
(\mathrm{kPa})\end{array}$ \\
\hline PUC25 & 26,8 & 8,5 & 32,0 & 29,3 & 3,5 & 20,3 & 27,8 \\
\hline PUC50 & 50,6 & 10,3 & 42,6 & 56,3 & 2,4 & 27,5 & 51,8 \\
\hline PUC75 & 74,3 & 6,5 & 53,3 & 79,4 & 3,1 & 48,1 & 76,7 \\
\hline PUC100 & 102,5 & 6,1 & 64,7 & 109,1 & 3,2 & 63,4 & 105,9 \\
\hline PUC150 & 150,3 & 8,8 & 97,0 & 164,6 & 3,9 & 87,0 & 156,4 \\
\hline PUC200 & 206,9 & 9,4 & 134,8 & 228,4 & 3,3 & 119,5 & 214,1 \\
\hline
\end{tabular}

Nas curvas dv vs dh (Figura 6.4a), o comportamento predominante foi de compressão.

As curvas $\tau / \sigma_{n}$ vs dh tendem a agrupar-se em uma faixa relativamente estreita, apesar de se observar o afastamento das curvas correspondentes às tensões menores, originado provavelmente, por algum tipo de cimentação nas amostras.

Os valores de $\tau$ e $\sigma_{n}$ na ruptura dos corpos de prova estão sumarizados nas envoltórias apresentadas nas Figuras 6.5 e 6.6. Nestas, mostram-se as envoltórias de resistência avaliadas por correlações lineares, bilineares e curvas, assim como a variabilidade dos parâmetros de resistência, nos diferentes intervalos de tensões normais adotados.

Como pode ser observado através das figuras referidas e na Tabela 6.4, os valores de $\tau_{\max }$, medidos na condição pico e residual, não são significativamente diferentes.

Fica evidente, pelas envoltórias de resistência máxima mostradas na Figura 6.5, que o solo apresenta boa aproximação com a envoltória curva próxima à origem (Figura 6.5d), existindo uma distinção entre o comportamento a altas $(>100 \mathrm{kPa}$ ) e a baixas tensões (até $100 \mathrm{kPa}$ ). Esta envoltória exibe uma característica marcante dos solos tropicais, cuja tendência é ser curva para baixas tensões. 

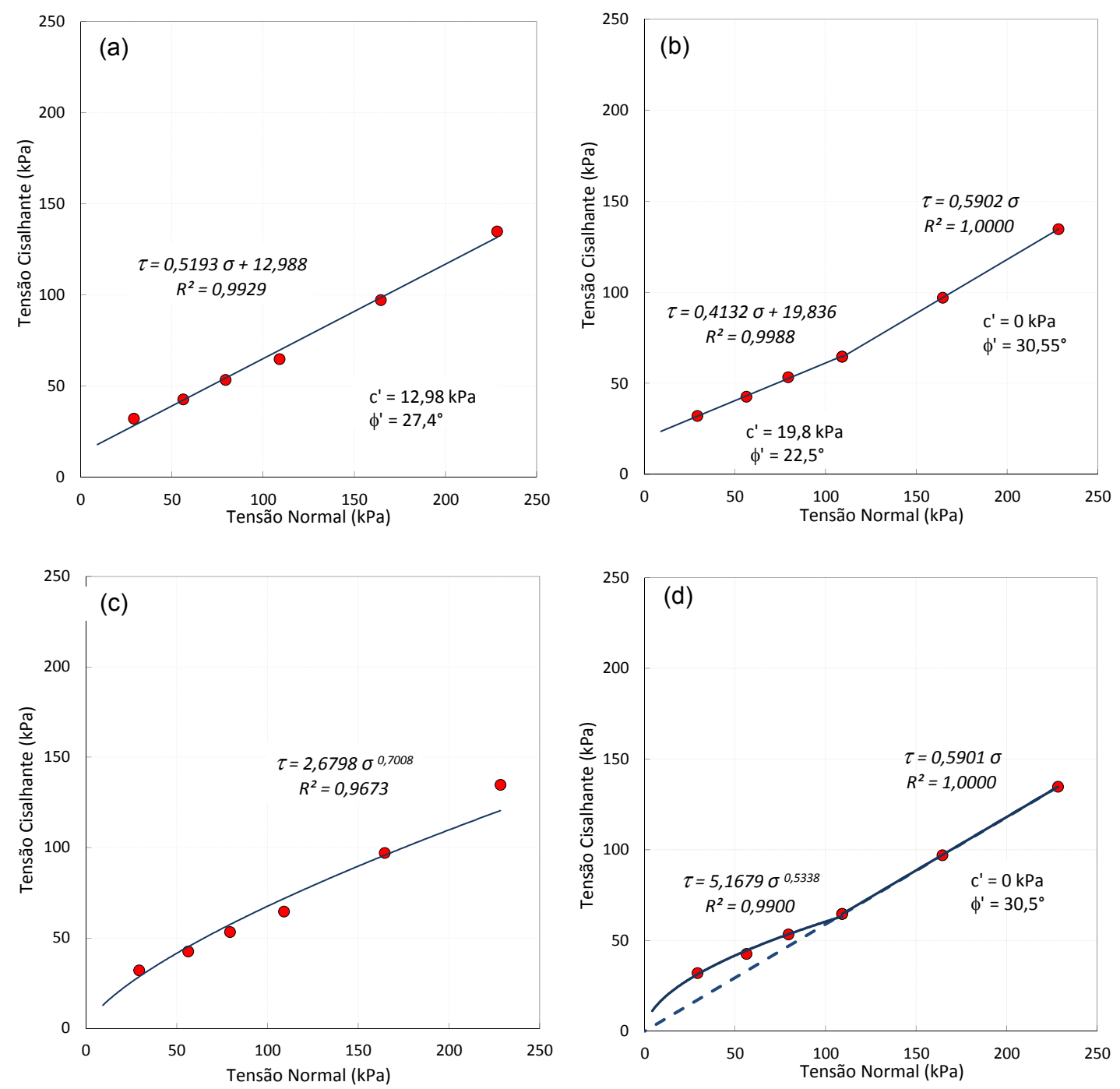

Figura 6.5 - Envoltórias de resistência pico para o solo coluvionar da PUC: (a) linear, (b) bilinear, (c) curva, (d) curva e linear
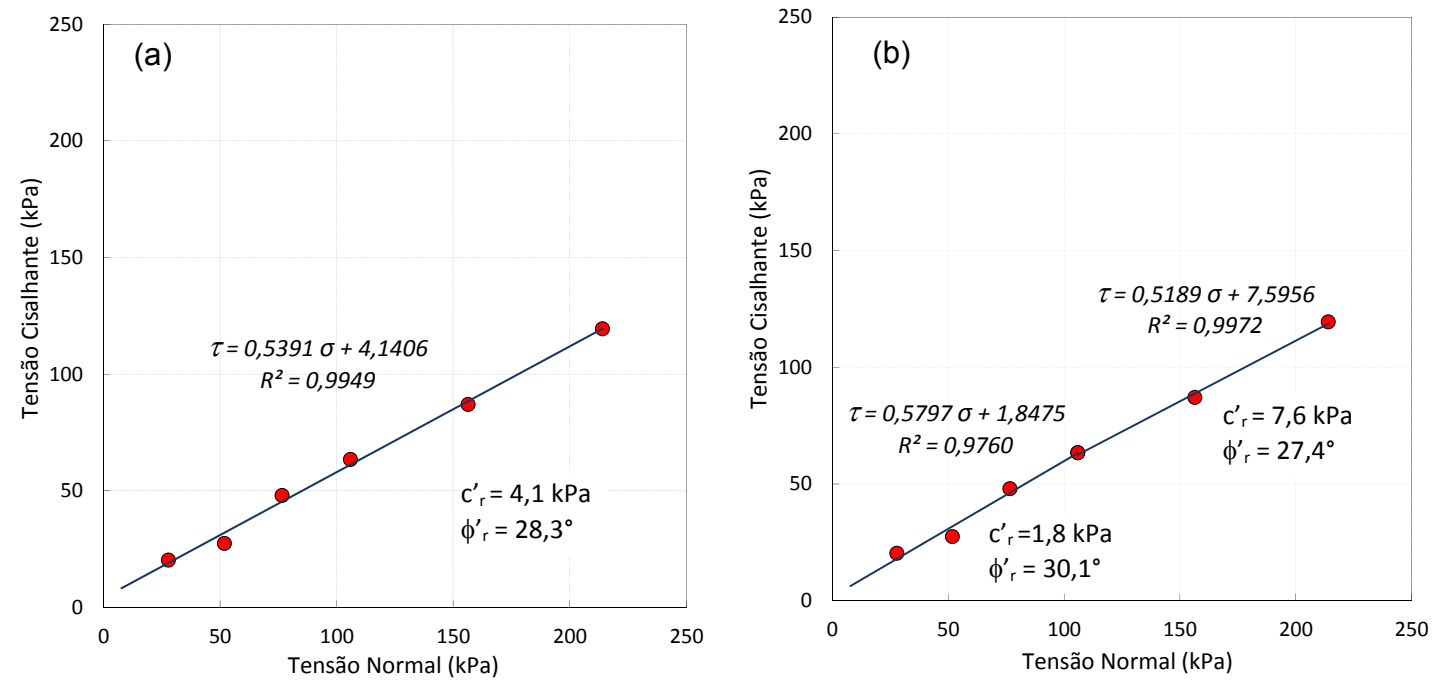

Figura 6.6 - Envoltórias de resistência residual para o solo da PUC: (a) linear, (b) bilinear 


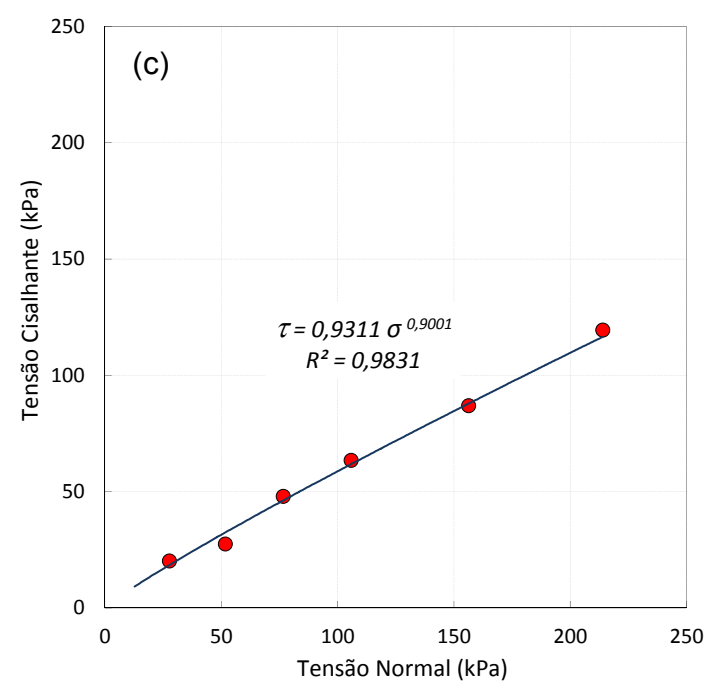

Figura 6.6 - (..continuação) Envoltórias de resistência residual para o solo da PUC: (c) curva

Com o intuito de avaliar a influência da presença de solo floculado (grumos) na resistência residual dos solos coluvionares, foram realizados ensaios de cisalhamento direto em amostras amolgadas do solo coluvionar da PUC, na condição inundada, com tensões normais de 25, 100 e $200 \mathrm{kPa}$.

As amostras foram remoldadas com o índice de vazios de campo, com a prévia formação de uma lama e desagregação dos grumos de solo com a mão. Os resultados da fase de reversão para obtenção de resistência residual são apresentados nas Figuras 6.7 e 6.8 .

As curvas $\tau$ vs dh da Figura 6.7 obtidas com as amostras amolgadas, em todos os níveis de tensões normais aplicados, apresentam o mesmo comportamento das curvas obtidas com as amostras inalteradas.

Na Figura 6.8, pode-se observar que na condição remoldada, a envoltória de resistência residual do solo coluvionar atingiu um bom ajuste na reta $c_{r}^{\prime}=0$, confirmando a desestruturação do material.

O resultado sugere que, o valor de coesão maior que zero obtido na aproximação linear da envoltória de resistência residual ou a tendência de curvatura na mesma, nos ensaios com as amostras inalteradas de ambos solos coluvionares, pode ser atribuído a uma leve estruturação ou cimentação do solo causada pela formação de microagregados. 

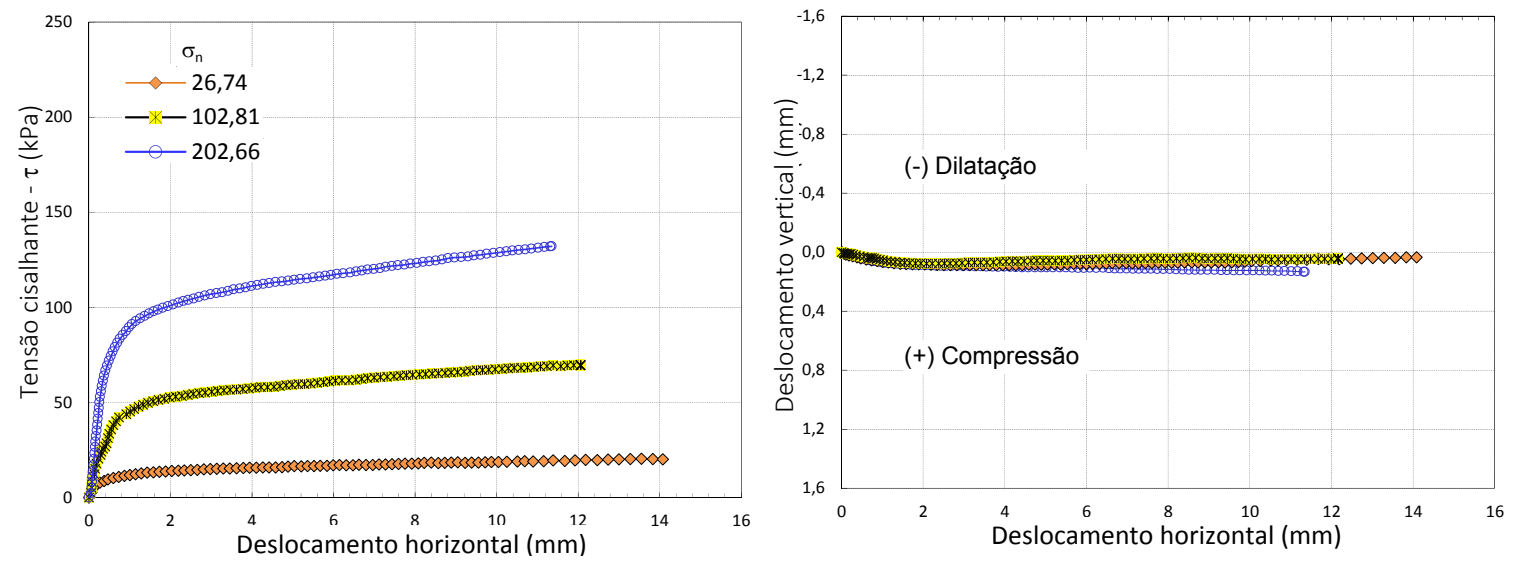

Figura 6.7- Resultados do ensaio de cisalhamento direto com plano cortado e superfície polida para obtenção de resistência residual em amostras amolgadas do solo da PUC

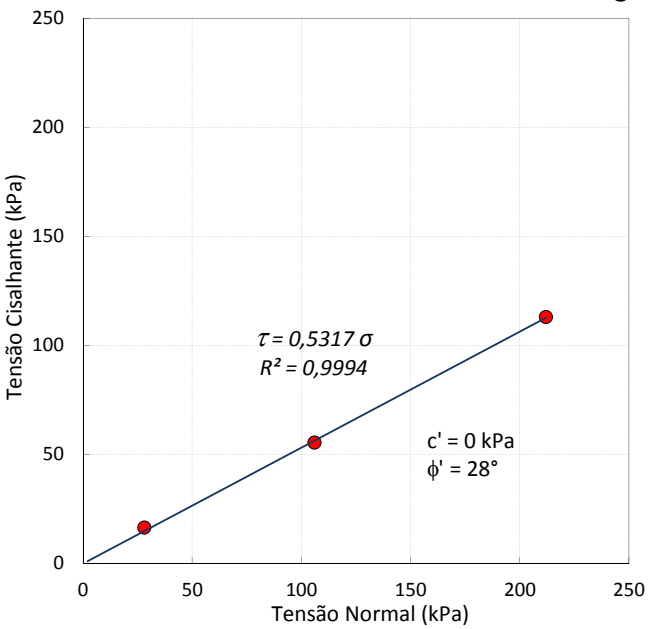

Figura 6.8 - Envoltória de resistência residual para amostras amolgadas do solo da PUC

\subsection{3.}

Solo de Duque de Caxias

A Tabela 6.5 apresenta os índices físicos dos corpos de prova correspondentes ao solo residual jovem de Duque de Caxias, no início, após o adensamento da fase onde se obteve a resistência pico ou máxima, e no final do ensaio.

Tabela 6.5 - Índices físicos no início, após o adensamento e no final do ensaio dos corpos de prova do solo residual jovem de Duque de Caxias usados no ensaio de cisalhamento direto

\begin{tabular}{|c|c|c|c|c|c|c|c|c|c|}
\hline \multirow{2}{*}{ Ensaio } & \multirow{2}{*}{$\begin{array}{c}\sigma_{n}^{\prime} \\
(\mathrm{kPa})\end{array}$} & \multicolumn{6}{|c|}{ Índices físicos iniciais } & \multirow{2}{*}{\begin{tabular}{|c|c|}
$\begin{array}{c}\text { Após o } \\
\text { adensamento }\end{array}$ \\
$\mathrm{e}_{\text {adens }}$ \\
\end{tabular}} & \multirow{2}{*}{$\begin{array}{c}\text { Finais } \\
\begin{array}{c}w_{f} \\
(\%)\end{array}\end{array}$} \\
\hline & & $\begin{array}{l}\mathrm{w}_{o} \\
(\%)\end{array}$ & $\begin{array}{c}\gamma_{\mathrm{n}} \\
\mathrm{kN} / \mathrm{m}^{2}\end{array}$ & $\begin{array}{c}\gamma_{\mathrm{d}} \\
\mathrm{kN} / \mathrm{m}^{2}\end{array}$ & $e_{o}$ & $\begin{array}{c}n \\
(\%)\end{array}$ & $\begin{array}{c}\mathrm{S} \\
(\%)\end{array}$ & & \\
\hline $\mathrm{DC} 25$ & 26,8 & 34,59 & 16,85 & 12,52 & 1,297 & 56,47 & 76,68 & 1,045 & 54,47 \\
\hline DC50 & 50,1 & 35,81 & 16,98 & 12,50 & 1,300 & 56,52 & 79,21 & 1,275 & 48,01 \\
\hline DC75 & 74,4 & 35,52 & 17,11 & 12,63 & 1,278 & 56,10 & 79,95 & 1,232 & 47,73 \\
\hline DC100 & 102,1 & 35,44 & 17,16 & 12,67 & 1,269 & 55,93 & 80,30 & 1,198 & 48,88 \\
\hline DC150 & 150,5 & 35,51 & 16,89 & 12,47 & 1,307 & 56,65 & 78,13 & 1,227 & 48,93 \\
\hline DC200 & 201,2 & 36,05 & 17,23 & 12,67 & 1,270 & 55,95 & 81,62 & 1,183 & 47,33 \\
\hline
\end{tabular}


As curvas $\tau$ vs dh, dh vs $d v$, e, $\tau / \sigma_{n} v s$ dh, para obtenção da resistência máxima e resistência residual das amostras do solo residual jovem de Duque de Caxias, estão mostradas na Figura 6.9.
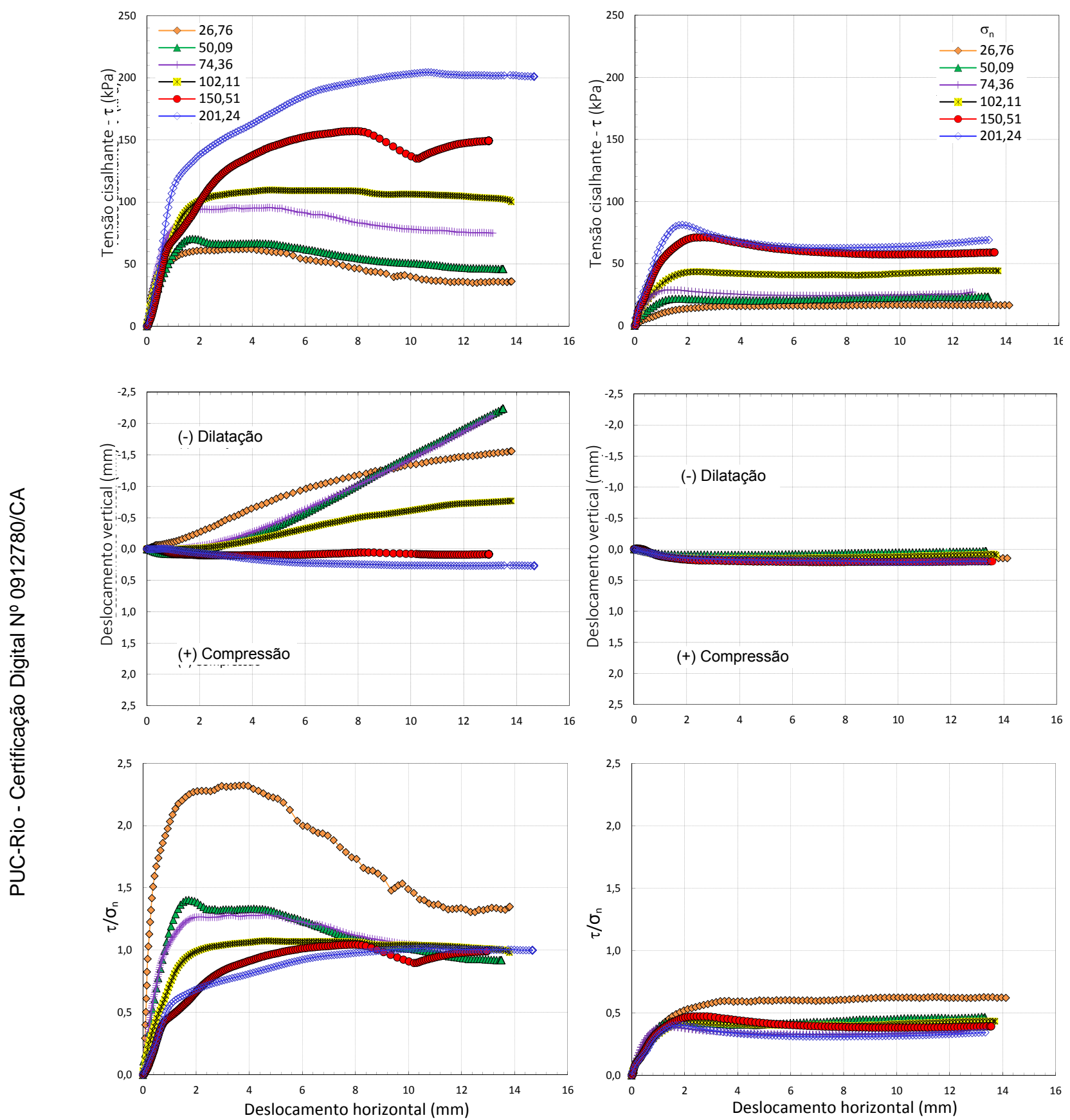

(a)

(b)

Figura 6.9 - Resultados do ensaio de cisalhamento direto com plano cortado e superfície polida no solo residual jovem de Duque de Caxias, (a) Fase para obtenção de resistência máxima, (b) Fase de reversão para obtenção de resistência residual

As curvas $\tau$ vs dh da fase de obtenção de resistência máxima, na Figura 6.9(a), mostram a presença de picos pouco pronunciados, ou até mesmo inexistentes. Para os ensaios com picos pouco pronunciados, foi assumido que $o$ 
solo havia rompido quando a curva atingiu o pico de resistência; enquanto que para os que não apresentaram pico, admitiu-se que o solo havia rompido quando a curva atingiu uma inclinação constante. Para baixas tensões verticais, os corpos de prova alcançaram o valor máximo de resistência ao cisalhamento a partir de 2 a $4 \mathrm{~mm}$ aproximadamente. Para as tensões verticais mais altas, a resistência máxima de cisalhamento atingiu-se somente após aproximadamente $8 \mathrm{~mm}$ de deslocamento horizontal. Os corpos de prova com carregamentos normais menores que $150 \mathrm{kPa}$ dilataram.

$\mathrm{Na}$ Tabela 6.6 são apresentados os dados na ruptura da tensão cisalhante e normal, da fase de obtenção da resistência de pico e residual.

Tabela 6.6 - Resumo dos resultados obtidos a partir dos ensaios de cisalhamento direto com plano cortado e superfície polida nos corpos de prova do solo de Duque de Caxias

\begin{tabular}{c|c|c|c|c|c|c|c}
\hline \multirow{2}{*}{ Ensaio } & \multirow{2}{*}{$\begin{array}{c}\sigma_{n}^{\prime} \\
(\mathrm{kPa})\end{array}$} & \multicolumn{3}{|c|}{ Dados na ruptura pico } & \multicolumn{3}{c}{ Dados na ruptura residual } \\
\cline { 3 - 8 } & $\begin{array}{c}\delta_{\mathrm{h}} \\
(\mathrm{mm})\end{array}$ & $\begin{array}{c}\tau \\
(\mathrm{kPa})\end{array}$ & $\begin{array}{c}\sigma_{n}^{\prime} \\
(\mathrm{kPa})\end{array}$ & $\begin{array}{c}\delta_{\mathrm{h}} \\
(\mathrm{mm})\end{array}$ & $\begin{array}{c}\tau \\
(\mathrm{kPa})\end{array}$ & $\begin{array}{c}\sigma_{n}^{\prime} \\
(\mathrm{kPa})\end{array}$ \\
\hline DC25 & 26,8 & 3,9 & 62,3 & 27,8 & 4,3 & 15,8 & 28,0 \\
\hline DC50 & 50,1 & 1,7 & 70,4 & 50,9 & 4,7 & 20,2 & 52,5 \\
\hline DC75 & 74,4 & 4,6 & 95,6 & 77,9 & 6,6 & 24,3 & 79,6 \\
\hline DC100 & 102,1 & 4,7 & 109,8 & 107,1 & 8,3 & 40,6 & 111,3 \\
\hline DC150 & 150,5 & 7,9 & 157,1 & 163,3 & 9,8 & 57,4 & 166,5 \\
\hline DC200 & 201,2 & 10,7 & 204,5 & 225,0 & 7,1 & 62,5 & 216,4 \\
\hline
\end{tabular}

Nas curvas $\tau$ vs dh da fase de reversão para obtenção da resistência residual, Figura 6.9 (b), pode-se observar que para as tensões verticais altas, o solo exibiu um pequeno pico da resistência ao cisalhamento, possivelmente devido a um efeito de "cicatrização" do plano de cisalhamento, após o adensamento, antes do cisalhamento ser reiniciado. Posteriormente, a resistência ao cisalhamento caiu para um valor praticamente constante, o que foi considerado como a resistência residual do solo.

Dos resultados obtidos, pode-se apreciar que o solo Duque de Caxias apresentou queda acentuada nos valores de resistência ao cisalhamento de pico para a residual.

$\mathrm{Na}$ Figura 6.9 (a) $\tau / \sigma_{\mathrm{n}}$ vs $\mathrm{dh}$, as curvas de menor tensão vertical apresentam-se mais afastadas das demais. Tal conduta pode indicar que nessas tensões o solo encontra-se abaixo da sua tensão de cedência ou plastificação (quebra de estrutura). 
Nas Figuras 6.10 e 6.11 são apresentados os diagramas de $\tau$ vs $\sigma_{\mathrm{n}}$, onde são analisadas as envoltórias de resistência máxima e residual, por correlações lineares, bilineares e curvas.

Observa-se que as correlações são satisfatórias para todos os casos, a exceção do ajuste mediante a envoltória curva única da resistência máxima (Figura 6.10c). No caso de obtenção de resistência máxima, a envoltória curva para baixas tensões, seguida pela envoltória linear para tensões maiores, seria uma boa aproximação que reflete o comportamento caraterístico de um solo tropical (vide Figura 6.10d).

O intercepto de coesão obtido é indício da existência de estruturação do solo, devido à cimentação observada nos ensaios de caracterização química e microestrutural do solo. Observa-se uma pequena variação dos parâmetros de resistência para as diversas envoltórias analisadas.
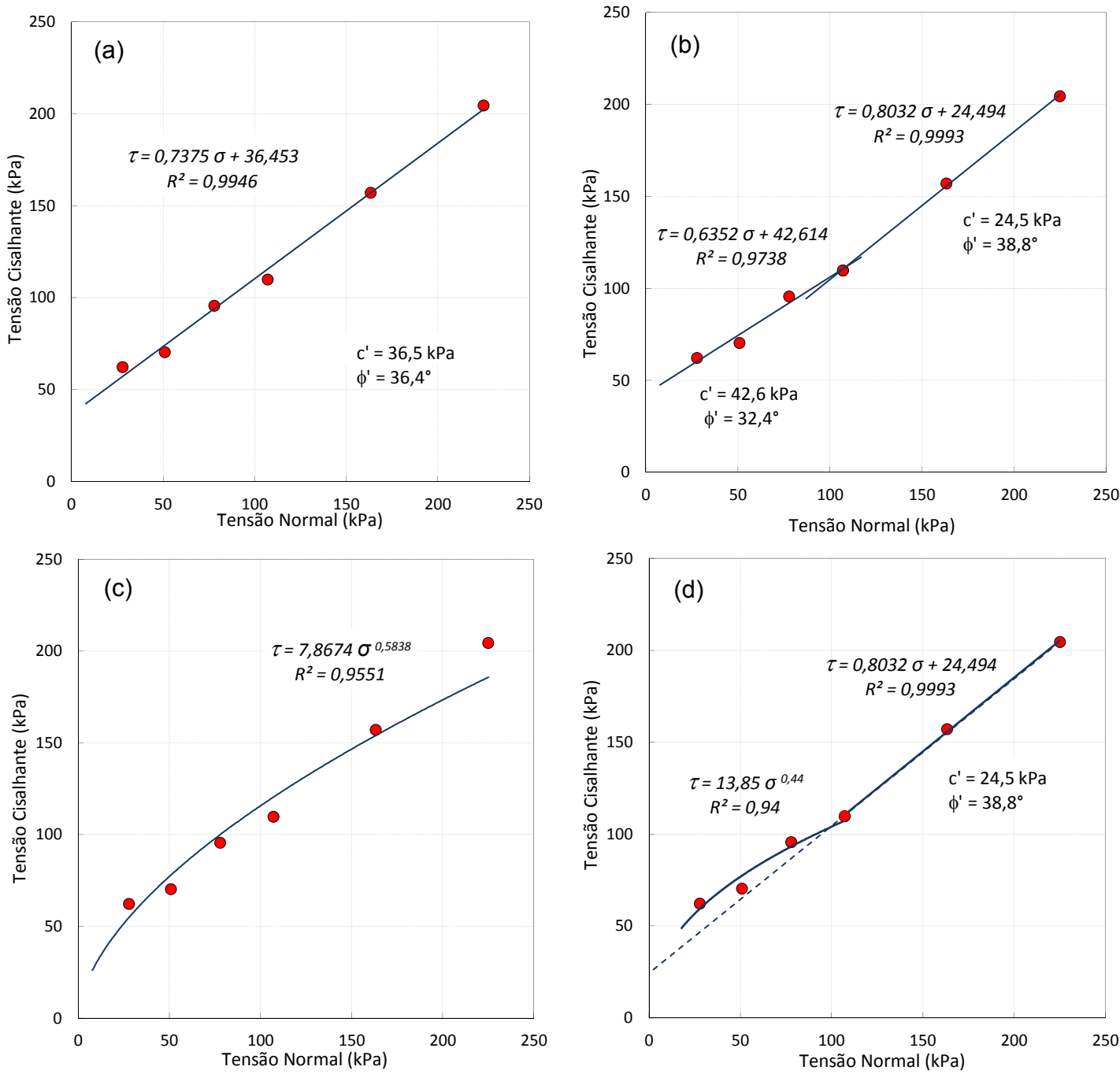

Figura 6.10 - Envoltórias de resistência de pico para o solo de Duque de Caxias: (a) linear, (b) bilinear, (c) curva, (d) curva e linear 

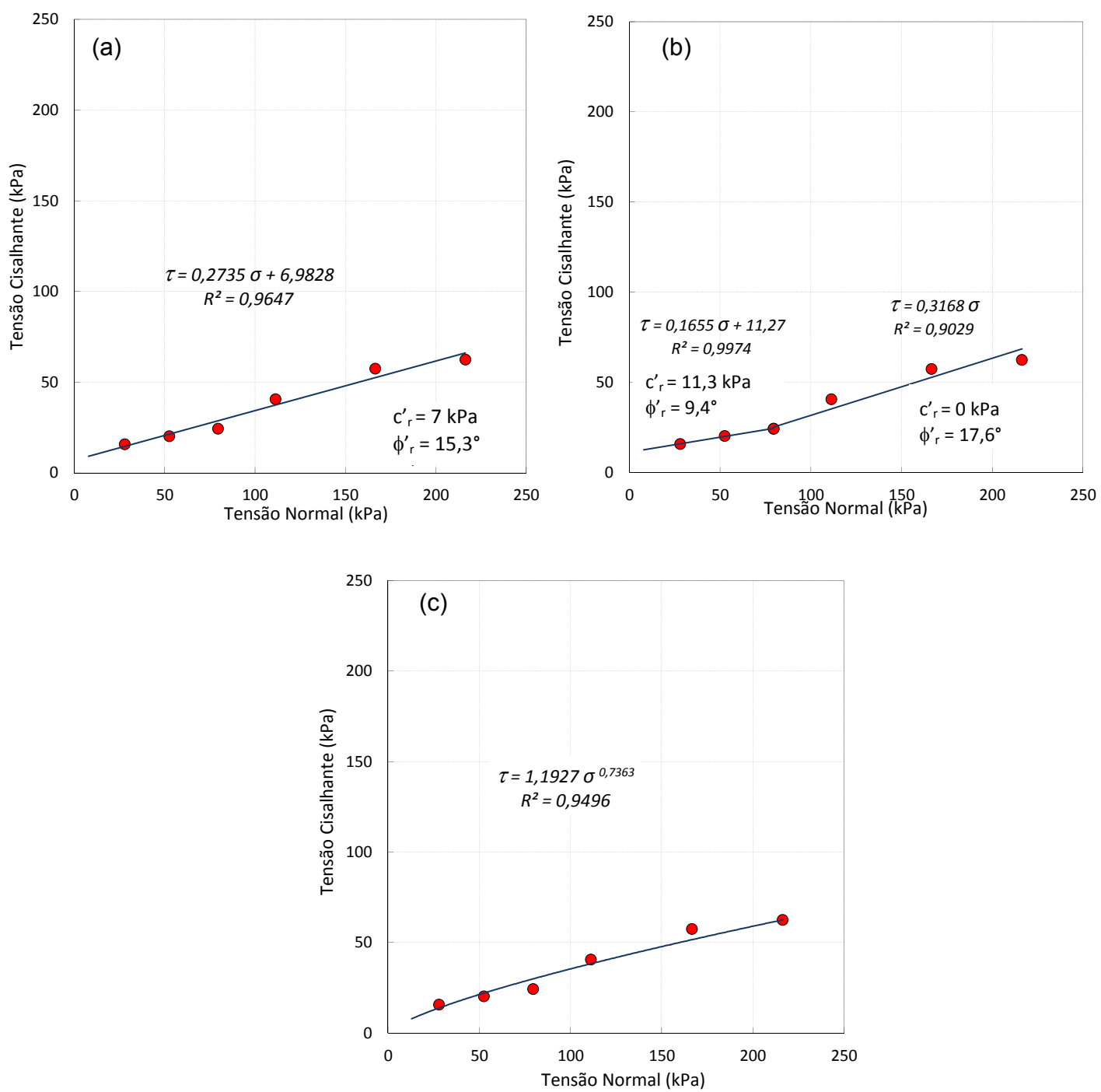

Figura 6.11 - Envoltórias de resistência residual para o solo de Duque de Caxias: (a) linear, (b) bilinear, (c) curva

\subsection{4.}

\section{Comparação entre os valores de resistência máxima e residual dos} solos estudados

Na Figura 6.12 plotaram-se em conjunto, para fins comparativos, os pontos de tensão cisalhante máxima e tensão cisalhante residual obtidos nos ensaios de cisalhamento direto com plano cortado e superfície polida dos três solos estudados. Com o intuito de visualizar a diferença foram traçadas duas retas para ajuste das envoltórias de resistência. A linha tracejada representa o ajuste dos pontos de tensão cisalhante residual, enquanto a linha cheia representa o ajuste dos pontos de tensão cisalhante máxima. 

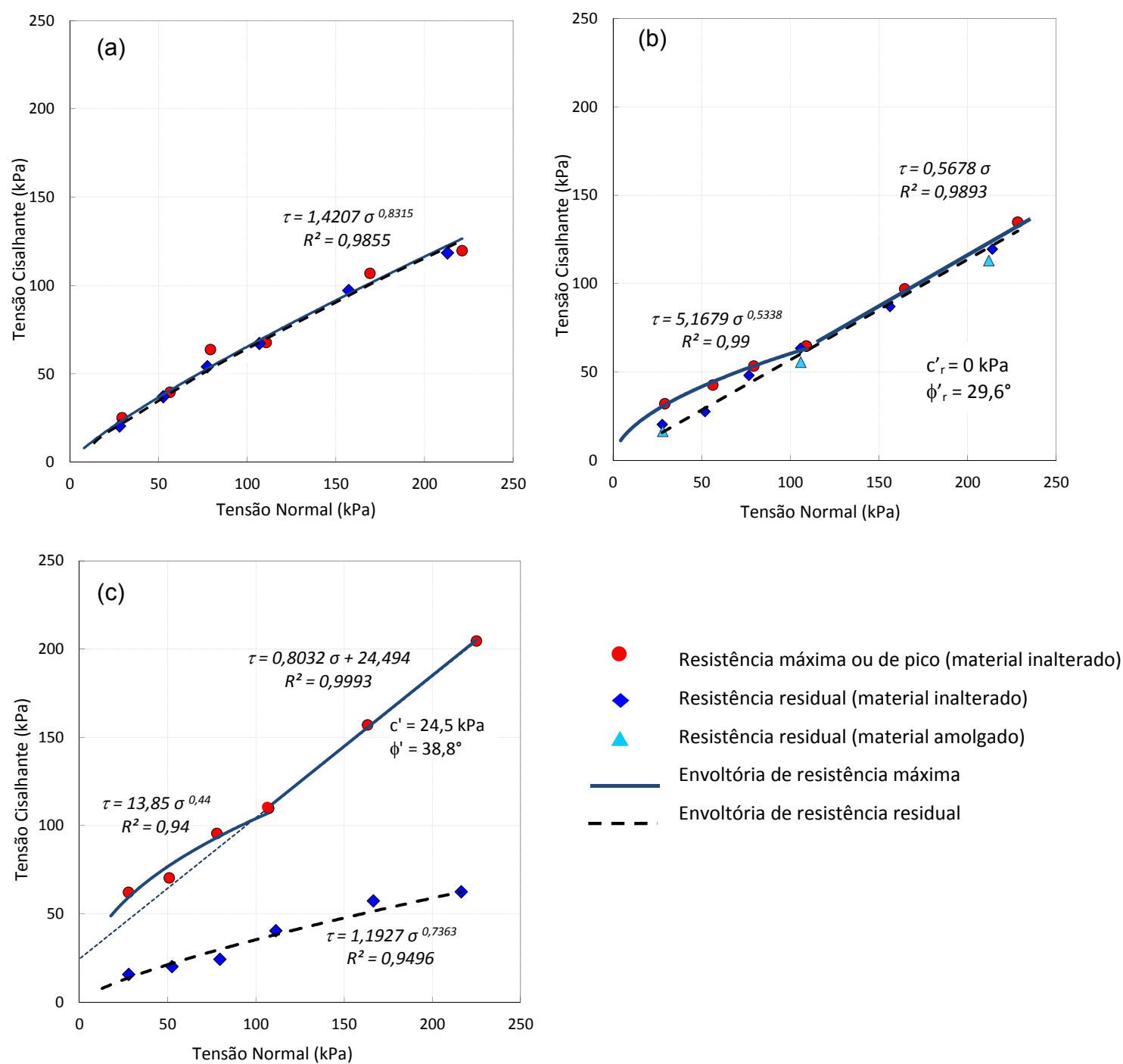

Figura 6.12 - Envoltória de resistência ao cisalhamento máxima e residual para: (a) Solo coluvionar de Tinguá, (b) Solo coluvionar da PUC, (c) Solo residual de Duque de Caxias

A análise conjunta dos ensaios nos solos coluvionares, explicitada pelas envoltórias de ruptura das Figuras 6.12(a) e (b), indica que os solos coluvionares ensaiados sob condições de inundação têm resistência ao cisalhamento bastante semelhante, embora com pequenas peculiaridades de comportamento.

Os solos coluvionares da PUC e Tinguá não apresentaram queda acentuada no valor de resistência até atingirem a condição residual. Este fenômeno poderia decorrer pela presença de alguma estrutura, resultante do processo de laterização, o que seria consistente com a presença do argilomineral caulinita em ambos os solos e de gibbsita no solo coluvionar de Tinguá. Esta estrutura origina por sua vez a tendência curva da envoltória.

Segundo Lacerda (2004) estes solos coluvionares apresentam elevados ângulos de atrito residuais, apesar do alto teor da fração argila, sendo este comportamento devido a sua estrutura ser de forma agregada. A coesão é 
praticamente nula, e o ângulo de atrito interno residual encontra-se na faixa de 28 a $32^{\circ}$, típico em solos derivados da alteração do granito e gnaisse (Lacerda, 2002).

Analisando a Figura 6.12 (a), observou-se que no solo coluvionar de Tinguá, uma envoltória curva única representa bem o comportamento do solo na condição de pico e residual.

A envoltória de resistência de pico do solo coluvionar da PUC, observada na Figura 6.12 (b), segue um aumento não linear da tensão cisalhante (região de influência da estrutura) e passa a acompanhar a envoltória linear convencional, variando com a tangente do ângulo de atrito efetivo. Inicialmente há uma contribuição da estrutura, a envoltória de pico está acima da envoltória residual e à medida que o processo de adensamento vai danificando a estrutura, a tangente decresce e converge para o ângulo de atrito residual. Neste conceito verifica-se como o solo se comporta com a variação do nível de adensamento promovido antes do processo de cisalhamento. O corpo de prova é adensado sob condições edométricas, portanto, há uma reestruturação neste processo, tanto maior quanto maior é a tensão normal imposta.

Observa-se um ajuste linear bastante satisfatório da envoltória de resistência residual aos pontos experimentais, tanto para os ensaios nas amostras indeformadas quanto nas remoldadas do solo coluvionar da PUC.

$\mathrm{Na}$ comparação dos comportamentos de pico e residual do solo residual jovem de Duque de Caxias (Figura 6.12c), pode-se observar que este solo apresentou queda acentuada nos valores de resistência ao cisalhamento de pico para residual. Como visto no item 4.3, este solo apresenta mica na sua composição, o que explicaria a causa do valor de ângulo de atrito residual mais baixo (Rigo et al., 2006).

$\mathrm{Na}$ envoltória de pico deste solo residual, pode-se verificar uma certa curvatura inicial no trecho entre as tensões normais de 25 e $100 \mathrm{kPa}$, evidenciando a cimentação presente no solo.

Verifica-se pelos gráficos que a envoltória curva é uma excelente opção para determinação da resistência ao cisalhamento dos solos coluvionares e residual.

Nos ensaios de cisalhamento direto realizados, observou-se que, em alguns casos, a envoltória de resistência residual é claramente curva; porém, para fins de comparações a ser feitas posteriormente, foram usados o valor de $\phi_{r}^{\prime}$ obtido por interpolação linear e intercepto coesivo nulo $\left(c_{r}^{\prime}=0\right)$. 


\section{2.}

\section{Ensaios triaxiais convencionais drenados e não drenados}

\subsection{1.}

\section{Ensaios triaxiais nos solos coluvionares}

Neste item são apresentados os resultados dos ensaios triaxiais drenados e não drenados realizados nos solos coluvionares estudados. Esta série de ensaios foi realizada com tensões efetivas de confinamento de 75, 150 e 300 kPa no solo da PUC; e de 25, 75, 150 e 300 no solo de Tinguá.

De uma maneira geral, a forma de ruptura dos corpos de prova foi do tipo plástica, isto é, de "embarrigamento". A correção de área foi aplicada a todos os valores de tensão desviadora medidos, utilizando a fórmula proposta por Bishop e Henkel (1962) para este tipo de ruptura. Não foram aplicadas correções de tensão devidas à influência da membrana de látex, uma vez que, dada à resistência ao cisalhamento do solo estudado, o valor a ser corrigido foi considerado desprezível.

Nos ensaios, a ruptura foi definida a partir do valor máximo da tensão desviadora $\left(\sigma_{d}\right)$, no caso que a curva tensão-deformação apresentou pico. Quando o solo se comportou de maneira strain-hardening, o critério de ruptura utilizado foi o proposto por De Campos e Carrillo (1995), baseado na inclinação da curva tensão-deformação. Nesses casos, a ruptura foi assumida quando a curva tensão-deformação passou a ter uma inclinação constante.

Além dos critérios acima mencionados, nos ensaios não drenados foi considerado o critério de ruptura da máxima razão entre as tensões principais efetivas $\left(\sigma^{\prime}{ }_{1} / \sigma^{\prime}{ }_{3 \max }\right)$.

\subsubsection{1.}

\section{Solo do Campo Experimental II PUC-Rio}

Neste item são apresentados e analisados os resultados de seis ensaios triaxiais adensados isotropicamente, drenados (CID) e não drenados (CIU), realizados no solo coluvionar do Campo Experimental II da PUC.

Os dados das amostras iniciais, tais como teor de umidade, peso específico, índices de vazios, porosidade, saturação, nível de tensão efetiva a que os mesmos foram submetidos ao final do adensamento, além do índice de vazios após adensamento e ao final do ensaio, são apresentados na Tabela 6.7. 
Tabela 6.7 - Índices físicos no início, após o adensamento e no final do ensaio, dos corpos de prova do solo coluvionar da PUC usados nos ensaios triaxiais

\begin{tabular}{c|c|c|c|c|c|c|c|c|c|c}
\hline & \multirow{6}{*}{ Ensaio } & \multicolumn{6}{|c|}{$\begin{array}{c}\sigma_{3}^{\prime} \\
(\mathrm{kPa})\end{array}$} & \multicolumn{6}{|c|}{$\begin{array}{c}\mathrm{w}_{\mathrm{o}} \\
(\%)\end{array}$} & $\begin{array}{c}\gamma_{\mathrm{n}} \\
\mathrm{kN} / \mathrm{m}^{3}\end{array}$ & $\begin{array}{c}\gamma_{\mathrm{d}} \\
\mathrm{kN} / \mathrm{m}^{3}\end{array}$ & $\mathrm{e}_{\mathrm{o}}$ & $\begin{array}{c}\mathrm{n} \\
(\%)\end{array}$ & $\begin{array}{c}\mathrm{S} \\
(\%)\end{array}$ & $\mathrm{e}_{\text {adens }}$ & $\mathrm{e}_{\mathrm{f}}$ & $\begin{array}{c}\mathrm{W}_{\mathrm{f}} \\
(\%)\end{array}$ \\
\hline PUC-CIU75 & 75 & 22,52 & 17,86 & 14,58 & 0,879 & 46,78 & 70,16 & 0,853 & 0,853 & 31,85 \\
\hline PUC-CIU150 & 150 & 23,34 & 18,05 & 14,63 & 0,872 & 46,58 & 73,31 & 0,764 & 0,764 & 29,77 \\
\hline PUC-CIU300 & 300 & 20,88 & 18,07 & 14,95 & 0,832 & 45,41 & 68,76 & 0,782 & 0,782 & 28,12 \\
\hline PUC-CID75 & 75 & 23,04 & 17,48 & 14,20 & 0,928 & 48,14 & 67,98 & 0,906 & 0,835 & 29,46 \\
\hline PUC-CID150 & 150 & 22,39 & 17,86 & 14,59 & 0,877 & 46,72 & 69,95 & 0,826 & 0,731 & 29,76 \\
\hline PUC-CID300 & 300 & 22,74 & 18,11 & 14,76 & 0,856 & 46,12 & 72,77 & 0,757 & 0,676 & 26,85 \\
\hline
\end{tabular}

\section{Comportamento Tensão-deformação}

Na Figura 6.13 apresentam-se em conjunto quatro gráficos obtidos para a série de ensaios drenados: (a) q vs $\varepsilon_{a}$, (b) p'vs q, (c) $\varepsilon_{v} v s \varepsilon_{a}$, (d) e vs p', onde p' = tensão efetiva média $\left(\left(\sigma_{1}^{\prime}+2 \sigma_{3}^{\prime}\right) / 3\right), q=$ tensão desviadora $\left(\sigma_{1}^{\prime}-\sigma_{3}^{\prime}\right), \varepsilon_{a}=$ deformação axial, $\varepsilon_{\mathrm{v}}=$ deformação volumétrica, $\mathrm{e}=$ índice de vazios .
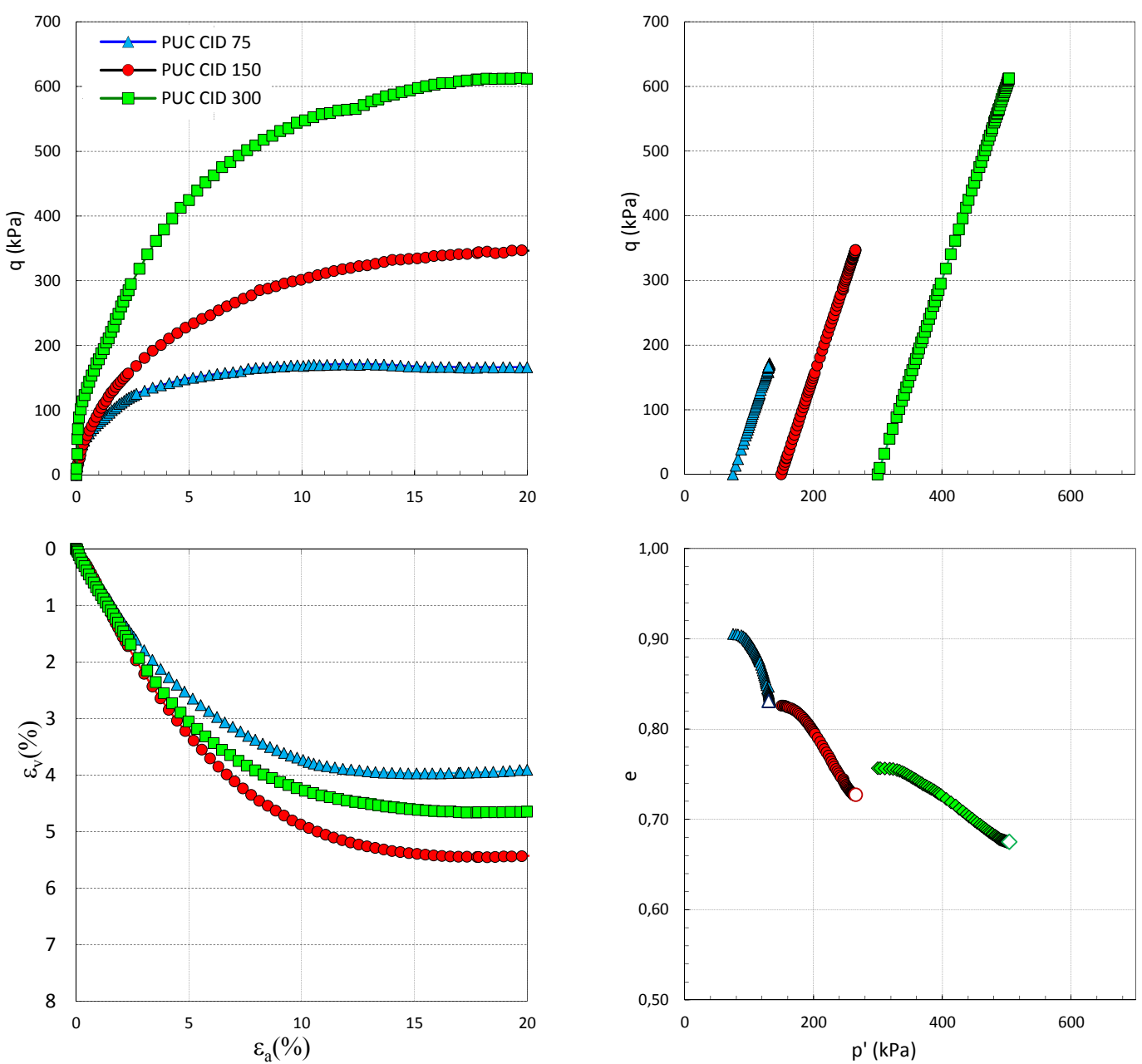

Figura 6.13 - Resultado dos ensaios triaxiais CID do solo coluvionar da PUC 
As curvas $q$ vs $\varepsilon_{a}$ dos ensaios drenados mostram amostras com ruptura dúctil, sem a ocorrência de um claro pico de resistência em todas as tensões efetivas utilizadas. Os resultados apresentaram um aumento de rigidez do solo consistente com o aumento da tensão efetiva de confinamento. As deformações volumétricas observadas foram de compressão em todos os ensaios, apresentando certa estabilização a partir de aproximadamente $15 \%$ da deformação axial.

Nas curvas de e vs p', nota-se que a variação do índice de vazios com p' durante a fase de cisalhamento mostra um comportamento similar para os corpos de prova ensaiados. Os primeiros pontos referem-se aos índices de vazios após a fase de adensamento isotrópico. Em cada uma das curvas encontram-se também apresentados o ponto final do ensaio, considerado como correspondente ao estado crítico de cada um deles (pontos vazados).

Já o comportamento normalizado, mostrado pela relação tensão desviadora/tensão confinante na Figura 6.14, indica uma relativa similaridade no comportamento ao cisalhamento para estas amostras do solo coluvionar da PUC.

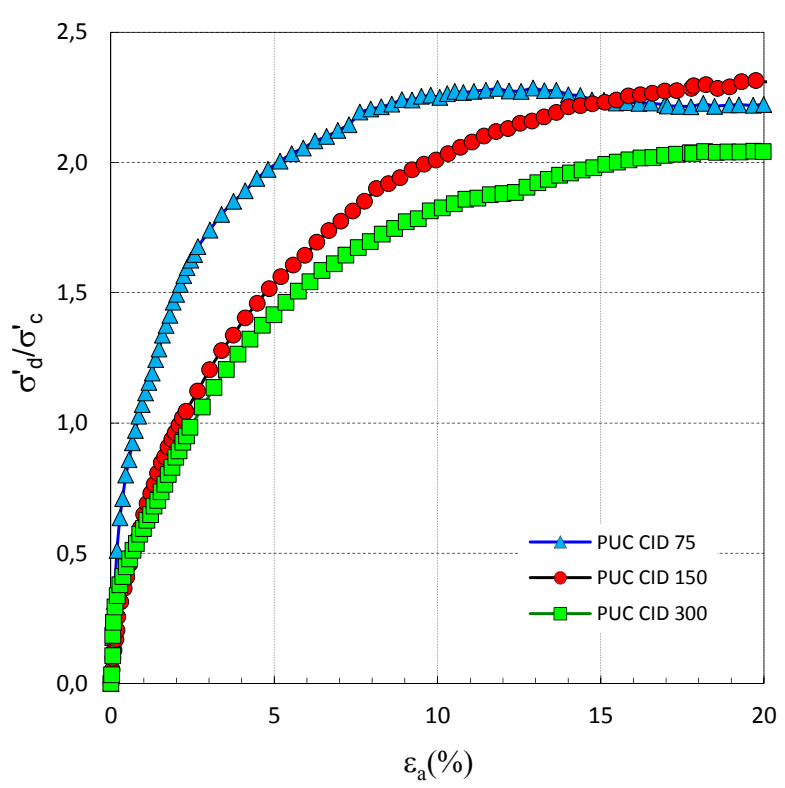

Figura 6.14 - Curvas tensão desviadora normalizada por $\sigma_{c}^{\prime}$ vs deformação axial dos ensaios CID do solo coluvionar da PUC

As curvas (a) q vs $\varepsilon_{a}$, (b) p' vs q, (c) $\Delta u$ vs $\varepsilon_{a}$, (d) e vs p' obtidas dos ensaios não drenados CIU, são mostradas na Figura 6.15.

O gráfico de q vs $\varepsilon_{\mathrm{a}}$ mostra um comportamento similar para todos os corpos de prova, com curvas que apresentam um crescimento rápido das tensões cisalhantes até cerca de 2-3 \% de deformação axial, quando denotam uma clara 
mudança de comportamento. A partir deste ponto, houve um crescimento lento, mas contínuo das tensões até o final do ensaio. As poropressões $(\Delta u)$ também crescem rapidamente até os mesmos níveis de deformações (2-3\%), apresentando pequenas reduções até o final dos ensaios. Essa diminuição é menor quanto mais baixo o nível de tensão efetiva de confinamento (Figura $6.15 c)$.

No gráfico p' vs q, Figura 6.15 (b), a trajetória de tensão do material adensado para a tensão efetiva de $75 \mathrm{kPa}$ segue uma direção quase vertical, inclinando-se para a direita, quando provavelmente atinge a envoltória de ruptura. Os corpos de prova adensados para as tensões de 150 e $300 \mathrm{kPa}$ apresentam uma trajetória direcionada para a esquerda desde o início da compressão, inclinando-se para a direita, também provavelmente, ao atingir a envoltória de ruptura.
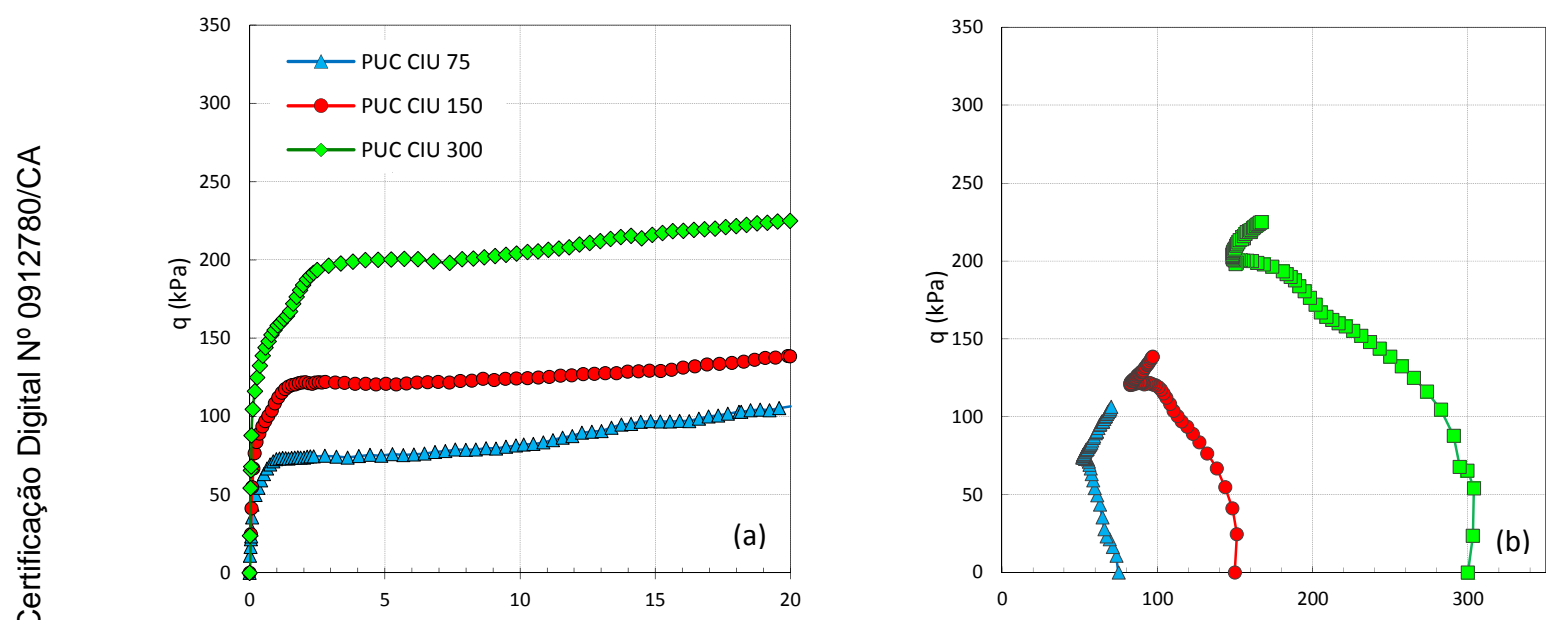

음
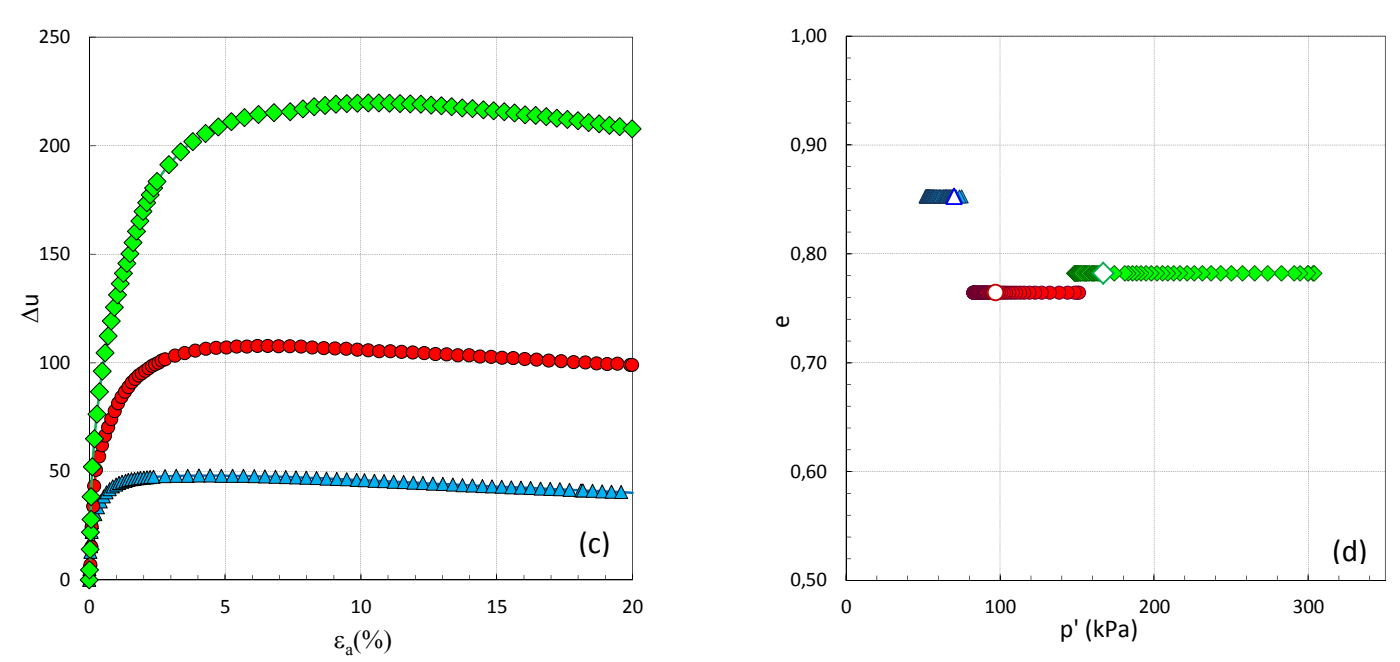

Figura 6.15 - Resultado dos ensaios triaxiais CIU do solo coluvionar da PUC

A Figura 6.15 (d) apresenta a variação dos índices de vazios e vs p' dos ensaios triaxiais CIU, desde a fase de adensamento isotrópico até o final de 
cisalhamento. Obviamente, na figura citada não se observa a variação de índice de vazios durante a fase de cisalhamento, verifica-se simplesmente a variação de p' e a posição do ponto correspondente ao estado crítico.

Em termos de curvas normalizadas, conforme observado na Figura 6.16, a amostra com menor tensão efetiva distancia-se das demais, possivelmente devido a uma leve estruturação ou cimentação causada pelos microagregados.
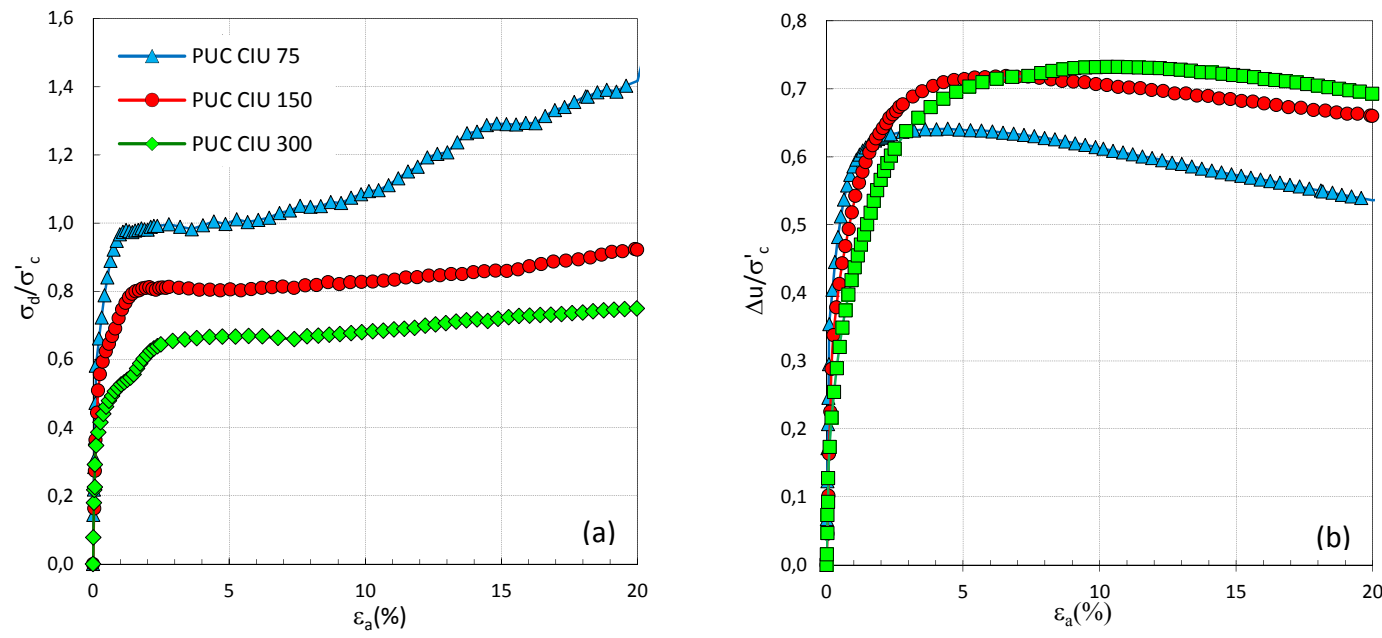

Figura 6.16 - Curvas tensão - deformação normalizadas dos ensaios CIU no solo coluvionar da PUC, (a) Tensão desviadora normalizada por $\sigma_{c}^{\prime}$ vs deformação axial, (b) Poropressão normalizada por $\sigma^{\prime}$ vs deformação axial

Na Figura 6.17 é apresentada a variação da razão entre as tensões principais efetivas e a deformação axial, empregadas para a determinação da envoltória de resistências dos ensaios $\mathrm{CIU}$, segundo o critério $\sigma^{\prime}{ }_{1} / \sigma^{\prime}{ }_{3 \max }$.

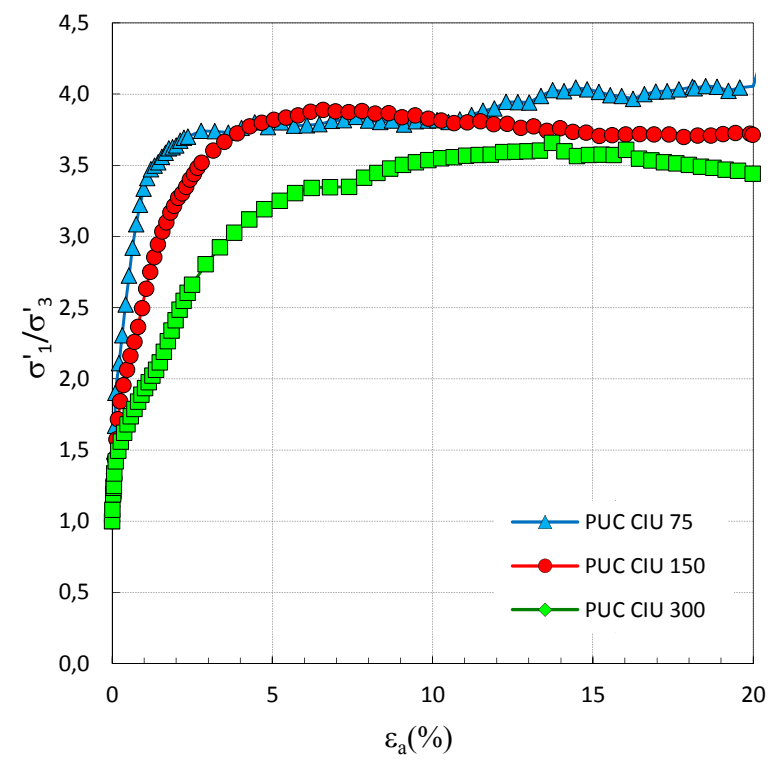

Figura 6.17 - Curvas de razão das tensões principais efetivas vs deformação axial dos ensaios CIU do solo coluvionar da PUC 


\section{Linha de Estado Crítico}

Quando uma amostra de solo, após ser adensada isotropicamente, é submetida ao cisalhamento em um equipamento triaxial, seu comportamento após grandes deformações, tanto em condições drenadas como não drenadas, tende à condição última, onde não mais ocorrem variações na tensão efetiva média, no volume específico do solo ou no índice de vazios. Essa condição é chamada de "estado crítico" e é alcançada em grandes deformações.

A linha que representa os pontos de estado crítico dos ensaios triaxiais drenados e não drenados é definida como linha de estado crítico - LEC.

Nas Figuras 6.18 e 6.19 apresenta-se a LEC obtida dos ensaios triaxiais drenados e não drenados, estimada a partir de tensões correspondentes à maior deformação axial atingida. As equações da LEC representadas nas figuras são:

$$
\mathrm{q}_{\mathrm{c}}=M \mathrm{p}_{\mathrm{c}}
$$

(representada na Figura 6.18 a), e

$$
v=\Gamma-\lambda \ln p_{c}^{\prime}
$$

(representada na Figura 6.19 b)

Nas equações 6.2 e 6.3 o índice c denota o estado crítico. M é a inclinação da LEC dada por q/p', $\lambda$ representa o gradiente da LEC, $v$ é o volume específico do solo $(v=1+e)$, $\Gamma$ é o volume específico para uma tensão efetiva de $1 \mathrm{kPa}$.

A linha de estado crítico relaciona-se com o critério de ruptura de MohrCoulomb, para compressão axial, pela equação:

$$
M=\frac{6 \operatorname{sen} \phi_{\mathrm{c}}^{\prime}}{3-\operatorname{sen} \phi_{\mathrm{c}}^{\prime}}
$$

onde $\phi_{c}^{\prime}$ é o ângulo de atrito interno no estado crítico.

A linha da Figura 6.18 foi traçada através do ajuste dos pontos finais dos ensaios, considerados próximos ao estado crítico, devido à tendência de estabilização do excesso de poropressão e da deformação volumétrica, ou da razão entre as tensões efetivas principais no caso dos ensaios que possuem um comportamento de ganho de resistência. Na Figura 6.18 (a), forçou-se a reta passar pela origem. Deste ajuste obteve-se $M=1,25$ o que corresponde a $\phi_{c}^{\prime}=$ $31,2^{\circ}$. Na Figura 6.18 (b) realizou-se um melhor ajuste dos pontos, onde se pode perceber a não linearidade da linha de estado crítico. Já, na Figura 6.18 (c) foram superpostos os resultados de ensaios triaxiais não drenados realizados por Hurtado (2010), corroborando a linha de estado crítico curva obtida para o solo coluvionar da PUC. 

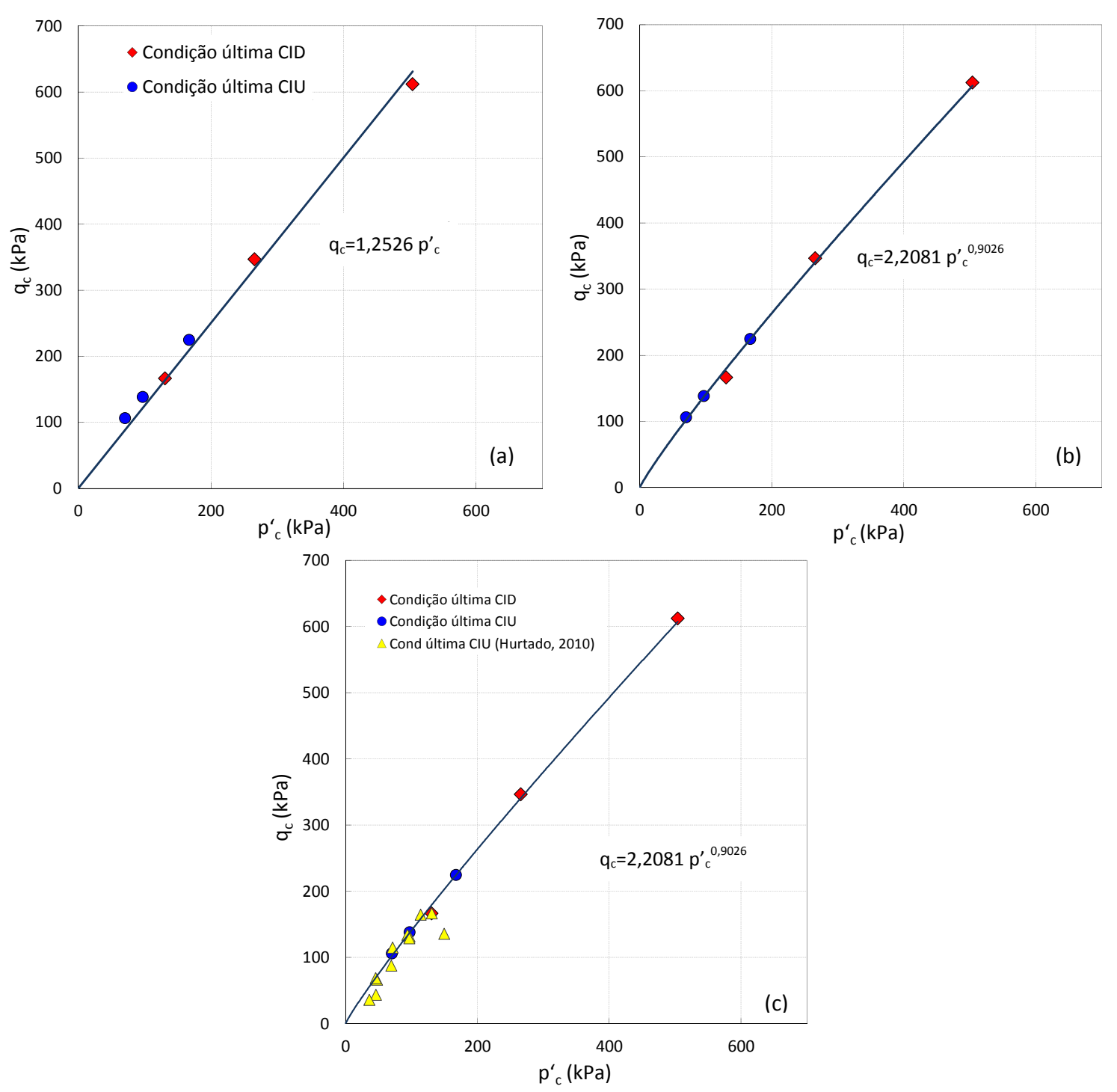

Figura 6.18 - Linha de estado crítico no plano $p_{c}^{\prime}$ vs $q_{c}$ para o solo coluvionar da PUC, (a) Ajuste linear, passando pela origem, (b) Ajuste curvo, (c) Superposição dos resultados dos ensaios CIU realizados por Hurtado (2010)

Na Figura 6.19 (a) apresenta-se uma linha aproximada do que poderia ser

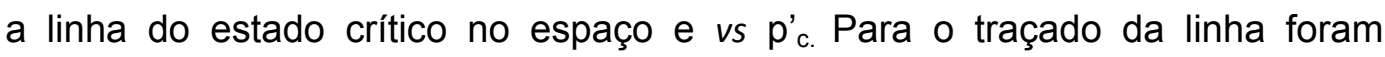
utilizados os valores últimos dos ensaios CIU e CID, mostrados como pontos vazados nas Figuras 6.13 (d) e 6.15 (d). Na Figura 6.19 (b) se observa a linha de estado crítico no plano $v$ vs $\mathrm{p}_{\mathrm{c}}$, , onde a tensão efetiva média, $\mathrm{p}_{\mathrm{c}}$, está representada em uma escala logarítmica. Observa-se dispersão dos dados quando representados neste espaço. Contudo, a linha ajustada aos pontos pode ser considerada próxima ao estado crítico.

Os parâmetros $\Gamma$ e $\lambda$ que definem a linha dos estados críticos são, respectivamente, 2,19 e 0,082 .

Deve-se perceber que a obtenção do estado crítico em ensaios triaxiais é muito difícil, uma vez que essa condição somente é obtida em grandes 
deformações. Deformações da ordem de $20 \%$ ou superiores são fortemente condicionadas pelos efeitos marginais, como a resistência da membrana, entre outros. Normalmente o ensaio termina por limitações do curso do pistão; do mesmo modo, com grandes deformações os efeitos de "embarrigamento" ou da formação de uma superfície de concentração de deformações cisalhantes no corpo de prova dificultam bastante a continuação do ensaio. Por conseguinte, não há garantia de que o estado estável seja atingido.

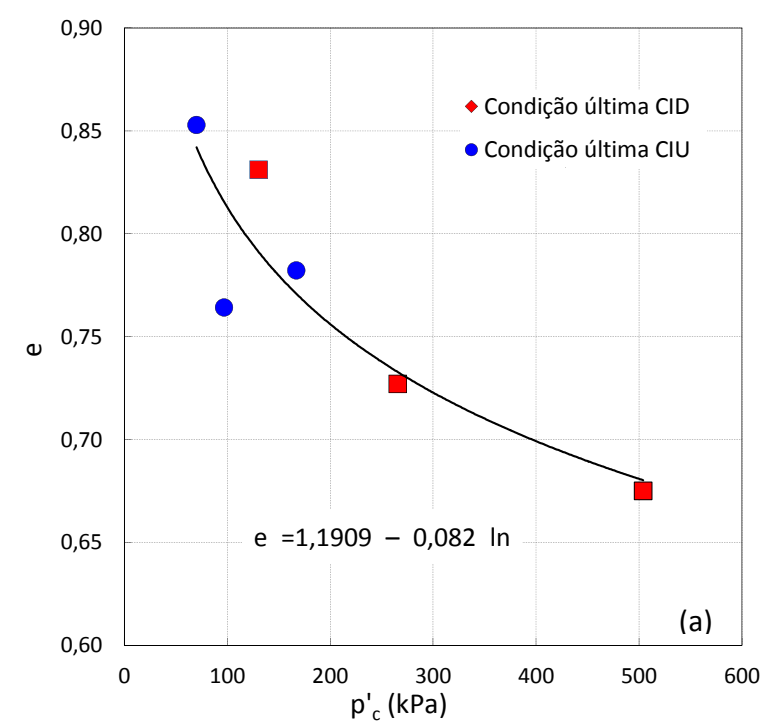

Figura 6.19 - Linha de estado crítico no plano, (a) e vs $\mathrm{p}_{\mathrm{c}}^{\prime}$, (b) $v$ vs $\mathrm{p}_{\mathrm{c}}^{\prime}$ do solo coluvionar da PUC

\section{Envoltórias e Parâmetros de Resistência}

Para determinação dos parâmetros de resistência ao cisalhamento, c' e $\phi$, foi traçada a envoltória de resistência ao cisalhamento no plano $s$ ' $v s t$, onde $s^{\prime}=\left(\sigma_{1}{ }_{1}+\sigma^{\prime}{ }_{3}\right) / 2$ e $t=\left(\sigma_{1}{ }_{1}-\sigma^{\prime}{ }_{3}\right) / 2$. A Figura 6.20 mostra a envoltória de resistência ao cisalhamento na ruptura, ajustada a partir dos dados obtidos com o critério proposto por De Campos e Carrillo (1995). Foram usados os pontos de ruptura dos ensaios drenados e não drenados.

$\mathrm{Na}$ figura são mostrados, também, os pontos conseguidos com o critério de ruptura da máxima razão entre as tensões principais efetivas $\left(\sigma_{1}^{\prime} / \sigma^{\prime}{ }_{3}\right)$ dos ensaios $\mathrm{ClU}$, que como pode ser visto, ajustam-se à envoltória traçada. Apresentam-se os parâmetros de resistência ao cisalhamento c' e $\phi^{\prime}$, calculados a partir dos valores de a' e $\alpha$ '.

A Figura 6.21 mostra as trajetórias de tensões efetivas no espaço p' vs q, juntamente com a envoltória de ruptura de resistência máxima ou de pico e a linha de estado crítico, obtidas a partir dos ensaios drenados e não drenados. Pode-se observar que a envoltória de resistência de pico e a linha de estado 
crítico é praticamente única; além de não linear, principalmente em baixas tensões. Na Figura 6.22 foram adicionadas à figura anterior as trajetórias de tensão obtidas por Hurtado (2010) em ensaios triaxiais CIU, realizados com diferentes velocidades de cisalhamento no solo coluvionar da PUC. Note-se o bom ajuste destas trajetórias à envoltória traçada.

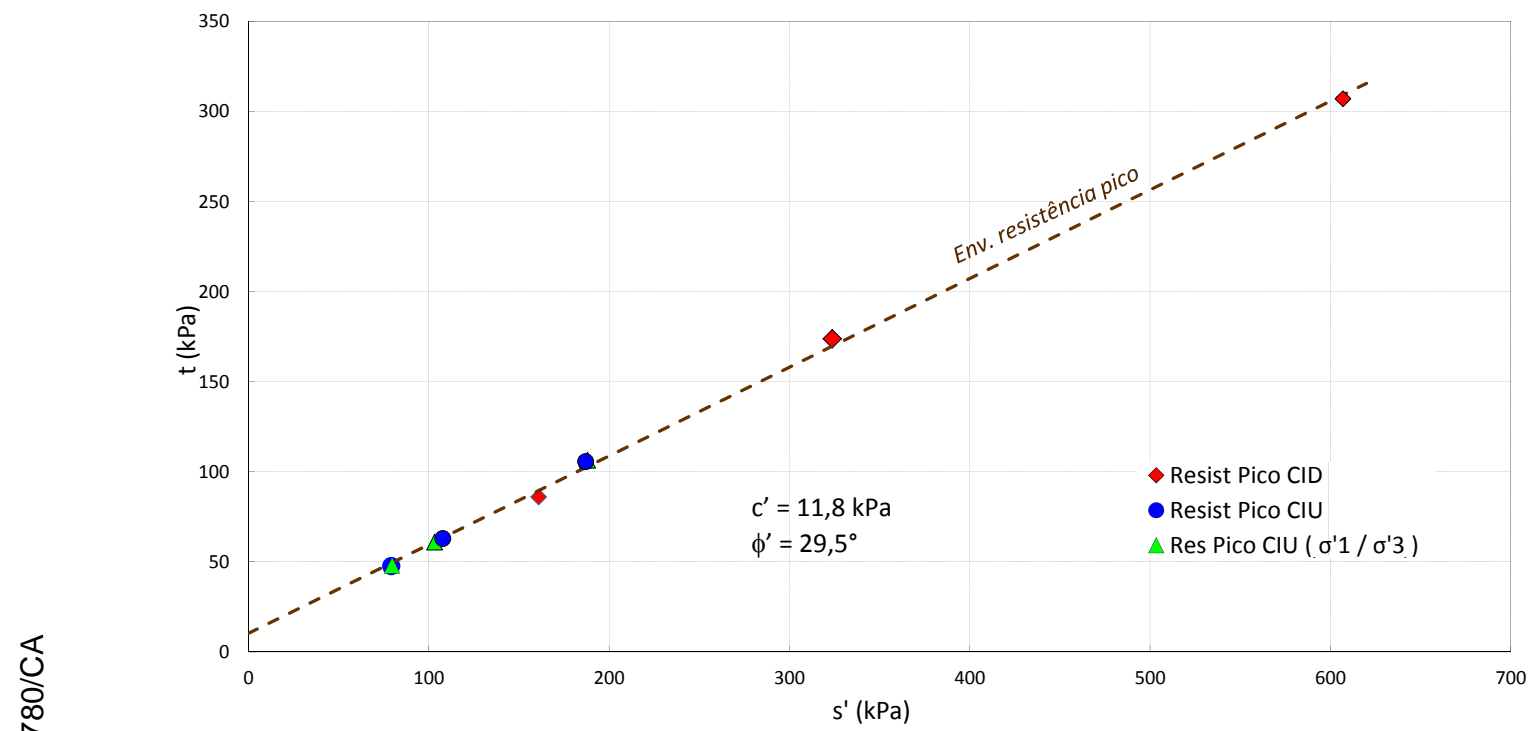

Figura 6.20 - Envoltória e parâmetros de resistência de Mohr-Coulomb na condição pico para os ensaios drenados e não drenados do solo coluvionar da PUC

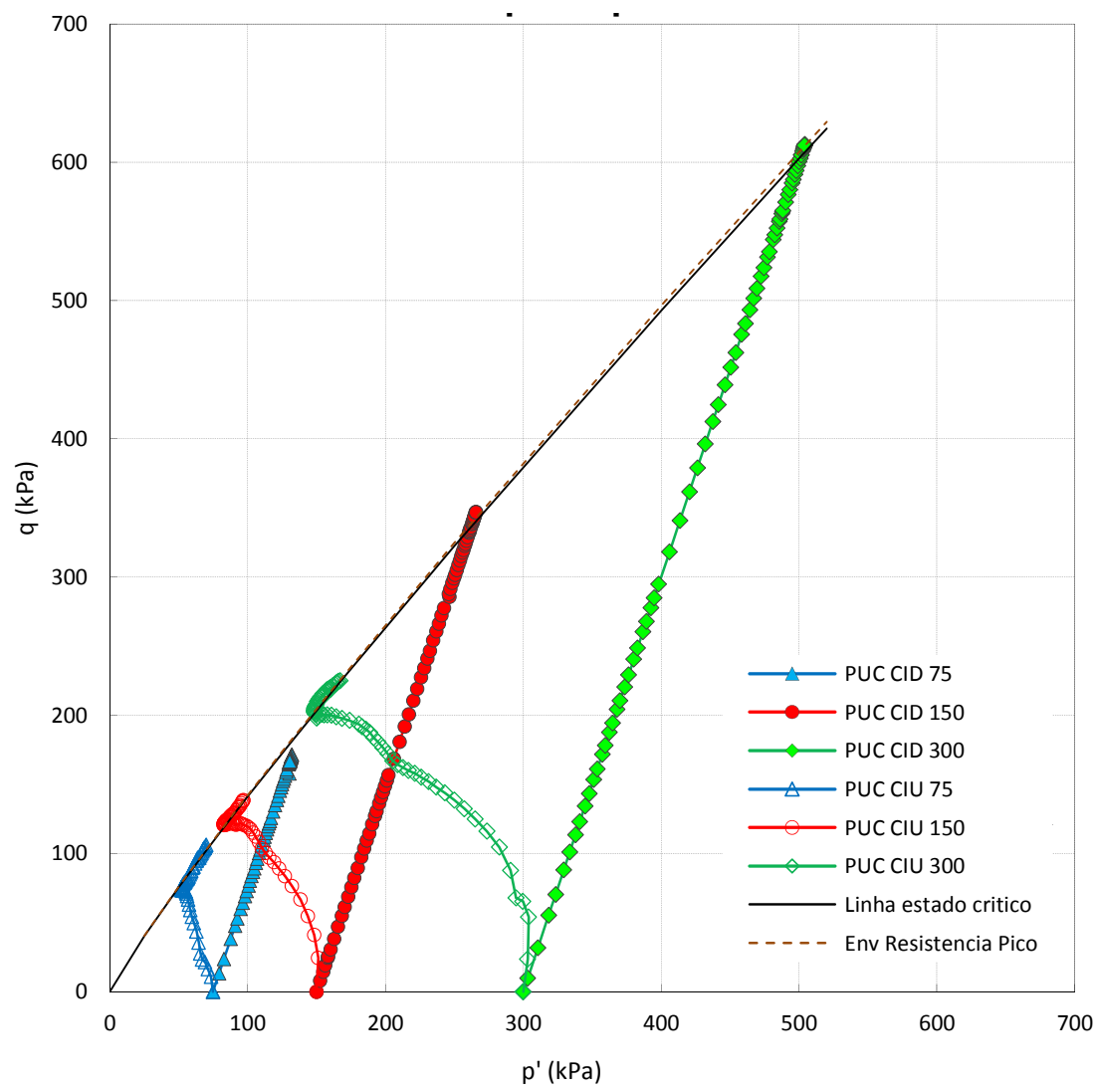

Figura 6.21 - Trajetórias de tensão, envoltória de resistência de pico e linha de estado crítico, obtidas dos ensaios CID e CIU do solo coluvionar da PUC 


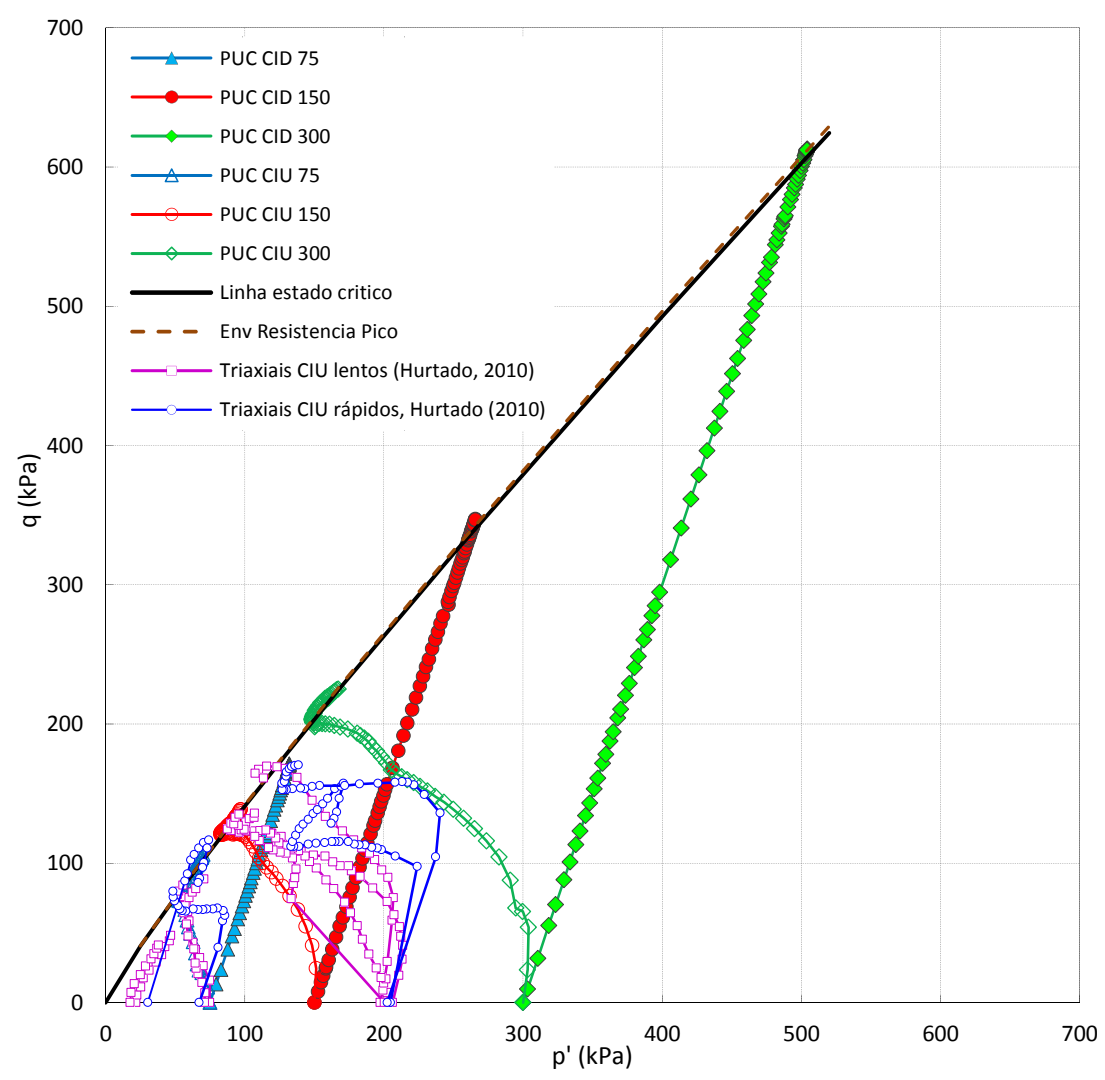

Figura 6.22 - Trajetórias de tensão, envoltória de resistência de pico e linha de estado crítico, obtidas dos ensaios CID e CIU do solo coluvionar da PUC no presente estudo, junto às trajetórias de tensão obtidas por Hurtado (2010)

\section{Parâmetros de Deformabilidade}

Através da análise das Figuras 6.13 e 6.15, foram determinados os módulos de Young tangente inicial $\left(E_{i}\right)$ e secante $\left(E_{50}\right)$, correspondente a um valor de $50 \%$ da tensão na ruptura para cada ensaio drenado e não drenado, assim como o coeficiente de Poisson tangente inicial $\left(v_{i}\right)$ e secante $\left(v_{50}\right)$ nos ensaios drenados. A Tabela 6.8 mostra os parâmetros de deformabilidade obtidos.

Tabela 6.8 - Parâmetros de deformabilidade $E$ e $v$ obtidos nos ensaios triaxiais do solo coluvionar da PUC

\begin{tabular}{c|c|c|c|c|c}
\hline Ensaio & $\begin{array}{c}\text { Tensão confinante } \\
\text { efetiva }(\mathrm{kPa})\end{array}$ & $\mathrm{E}_{\mathrm{i}}(\mathrm{MPa})$ & $v_{\mathrm{i}}$ & $\mathrm{E}_{50}(\mathrm{MPa})$ & $v_{50}$ \\
\hline PUC - CID75 & 75 & 37,27 & 0,35 & 7,65 & 0,19 \\
\hline PUC - CID150 & 150 & 33,61 & 0,22 & 6,19 & 0,13 \\
\hline PUC - CID300 & 300 & 94,74 & 0,08 & 13,28 & 0,15 \\
\hline PUC - CIU75 & 75 & 95,35 & - & 29,05 & - \\
\hline PUC - CIU150 & 150 & 94,74 & - & 52,33 & - \\
\hline PUC - CIU300 & 300 & 225,00 & - & 95,09 & - \\
\hline
\end{tabular}

A Figura 6.23 apresenta a variação dos parâmetros $E$ e $v$ com a tensão confinante. 

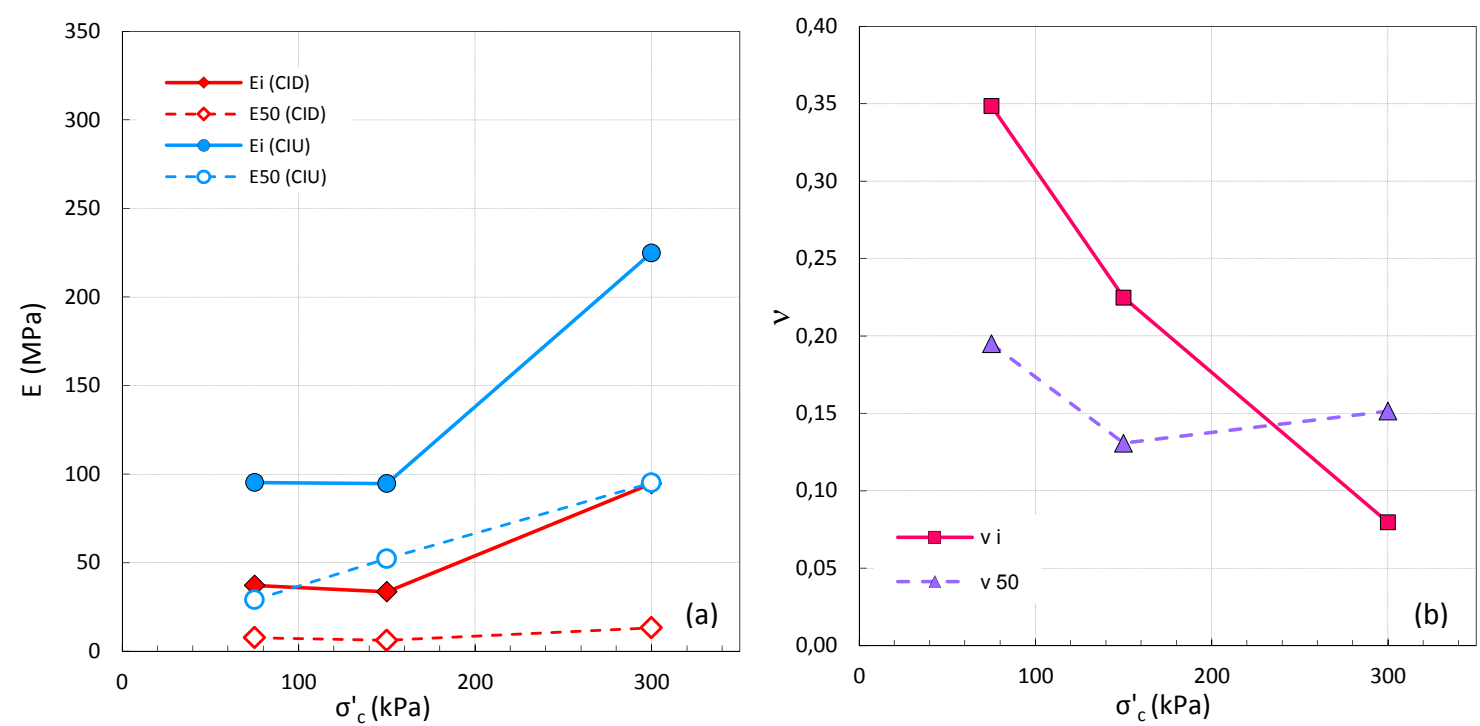

Figura 6.23 - Variação dos parâmetros de deformabilidade com a tensão confinante para o solo coluvionar da PUC, (a) Variação do módulo de Young E, (b) Variação do coeficiente de Poisson

Na Figura 6.23 (a) pode-se observar que ao se aumentar o nível de tensão confinante, o módulo de Young tende a aumentar. O aumento do módulo após um certo valor de $\sigma^{\prime}$ p pode estar associado a uma diminuição do índice de vazios e reestruturação do solo, após a quebra de ligações. Como esperado, $\mathrm{E}_{\mathrm{i}}$ é maior que $E_{50,}$ e a magnitude dos módulos de elasticidade obtidos nos ensaios triaxiais não drenados é maior que a obtida nos ensaios drenados. A Figura 6.23 (b) mostra a redução do coeficiente de Poisson com a tensão confinante, exceto no caso $v_{50}$ da amostra submetida à tensão confinante de $300 \mathrm{kPa}$. Foram obtidos valores de $v_{50}$ inferiores aos de $v_{\mathrm{i}}$ na maioria dos ensaios realizados.

\subsubsection{2.}

\section{Solo do Campus Avançado da PUC em Tinguá}

A apresentação dos resultados do solo coluvionar de Tinguá segue o mesmo padrão do solo da PUC. Além de oito ensaios CID e CIU, foram executados três ensaios triaxiais não drenados, adensados anisotropicamente $(\mathrm{CKU})$ com relações de tensões $\mathrm{K}_{\mathrm{c}}$ de $2,5\left(\mathrm{~K}_{\mathrm{c}}=\sigma_{1}{ }_{1} / \sigma_{3}{ }_{3}\right)$, com o intuito de auxiliar na determinação da resistência na condição última.

Os índices físicos dos corpos de prova empregados nos ensaios constam na Tabela 6.9. 
Tabela 6.9 - Índices físicos no início, após o adensamento e no final do ensaio dos corpos de prova do solo coluvionar de Tinguá usados nos ensaios triaxiais

\begin{tabular}{c|c|c|c|c|c|c|c|c|c|c}
\hline \multirow{2}{*}{ Ensaio } & \multirow{2}{*}{$\begin{array}{c}\sigma_{3}^{\prime} \\
(\mathrm{kPa})\end{array}$} & \multicolumn{6}{|c|}{ Índices físicos iniciais } & $\begin{array}{c}\text { Após } \\
\text { adensamento }\end{array}$ & \multicolumn{3}{c}{ Finais } \\
\cline { 5 - 12 } & & $\begin{array}{c}\gamma_{\mathrm{n}} \\
\mathrm{kN} / \mathrm{m}^{3}\end{array}$ & $\begin{array}{c}\gamma_{\mathrm{d}} \\
\mathrm{kN} / \mathrm{m}^{3}\end{array}$ & $\mathrm{e}_{\mathrm{o}}$ & $\begin{array}{c}\mathrm{n} \\
(\%)\end{array}$ & $\begin{array}{c}\mathrm{S} \\
(\%)\end{array}$ & $\mathrm{e}_{\text {adens }}$ & $\mathrm{e}_{\mathrm{f}}$ & $\begin{array}{c}\mathrm{W}_{\mathrm{f}} \\
(\%)\end{array}$ \\
\hline TIN-CIU25 & 25 & 27,01 & 17,61 & 13,87 & 0,930 & 48,18 & 77,76 & 0,923 & 0,923 & 34,77 \\
\hline TIN-CIU75 & 75 & 21,71 & 17,63 & 14,49 & 0,847 & 45,87 & 68,57 & 0,815 & 0,815 & 29,38 \\
\hline TIN-CIU150 & 150 & 19,46 & 17,66 & 14,78 & 0,810 & 44,76 & 64,27 & 0,736 & 0,736 & 30,82 \\
\hline TIN-CIU300 & 300 & 22,45 & 16,72 & 13,65 & 0,960 & 48,98 & 62,56 & 0,767 & 0,767 & 31,68 \\
\hline TIN-CID25 & 25 & 25,82 & 17,81 & 14,16 & 0,890 & 47,10 & 77,61 & 0,885 & 0,818 & 34,58 \\
\hline TIN-CID75 & 75 & 22,64 & 17,29 & 14,10 & 0,899 & 47,33 & 67,43 & 0,859 & 0,817 & 30,62 \\
\hline TIN-CID150 & 150 & 20,95 & 17,45 & 14,43 & 0,855 & 46,08 & 65,59 & 0,791 & 0,701 & 31,32 \\
\hline TIN-CID300 & 300 & 22,44 & 16,77 & 13,70 & 0,953 & 48,80 & 62,99 & 0,780 & 0,657 & 28,55 \\
\hline TIN-CKU75 & 75 & 23,55 & 17,08 & 13,83 & 0,936 & 48,34 & 67,37 & 0,905 & 0,905 & 34,60 \\
\hline TIN-CKU150 & 150 & 18,34 & 16,44 & 13,89 & 0,927 & 48,10 & 52,96 & 0,805 & 0,805 & 31,04 \\
\hline TIN-CKU300 & 300 & 20,96 & 17,74 & 14,67 & 0,824 & 45,19 & 68,04 & 0,677 & 0,677 & 30,99 \\
\hline
\end{tabular}

\section{Comportamento Tensão-deformação}

Os ensaios drenados forneceram os resultados apresentados nas Figuras

6.24 e 6.25. Na Figura 6.24 são mostradas as curvas (a) q vs $\varepsilon_{a}$, (b) p'vs q, (c) $\varepsilon_{v} v s$ $\varepsilon_{\mathrm{a}}$, (d) e vs p'. Na Figura 6.25 mostra-se o gráfico $\sigma_{\mathrm{d}} / \sigma_{\mathrm{c}}^{\prime} v s \varepsilon_{\mathrm{a}}$.

Na Figura 6.24 pode-se observar que a amostra com tensão confinante efetiva de $25 \mathrm{kPa}$ apresentou um pico de resistência pouco pronunciado para pequenas deformações; os outros ensaios alcançaram a ruptura a maiores deformações sem a formação de pico, e após tenderam a ficar estáveis. As deformações volumétricas observadas foram de compressão em todos os ensaios; porém, a amostra com tensão confinante de $25 \mathrm{kPa}$ apresentou uma leve expansão inicial, enquanto que no ensaio de $75 \mathrm{kPa}$ observou-se tendência dilatante a partir de aproximadamente $15 \%$ de deformação axial até o final do ensaio (deformação axial de $20 \%$ ).

Ao normalizar a tensão desviadora pela tensão efetiva de adensamento, tem-se que os maiores valores desta razão são alcançados nos ensaios executados com menor tensão efetiva (Figura 6.25), evidenciando-se a influência da cimentação causada pelos microagregados argilosos. 

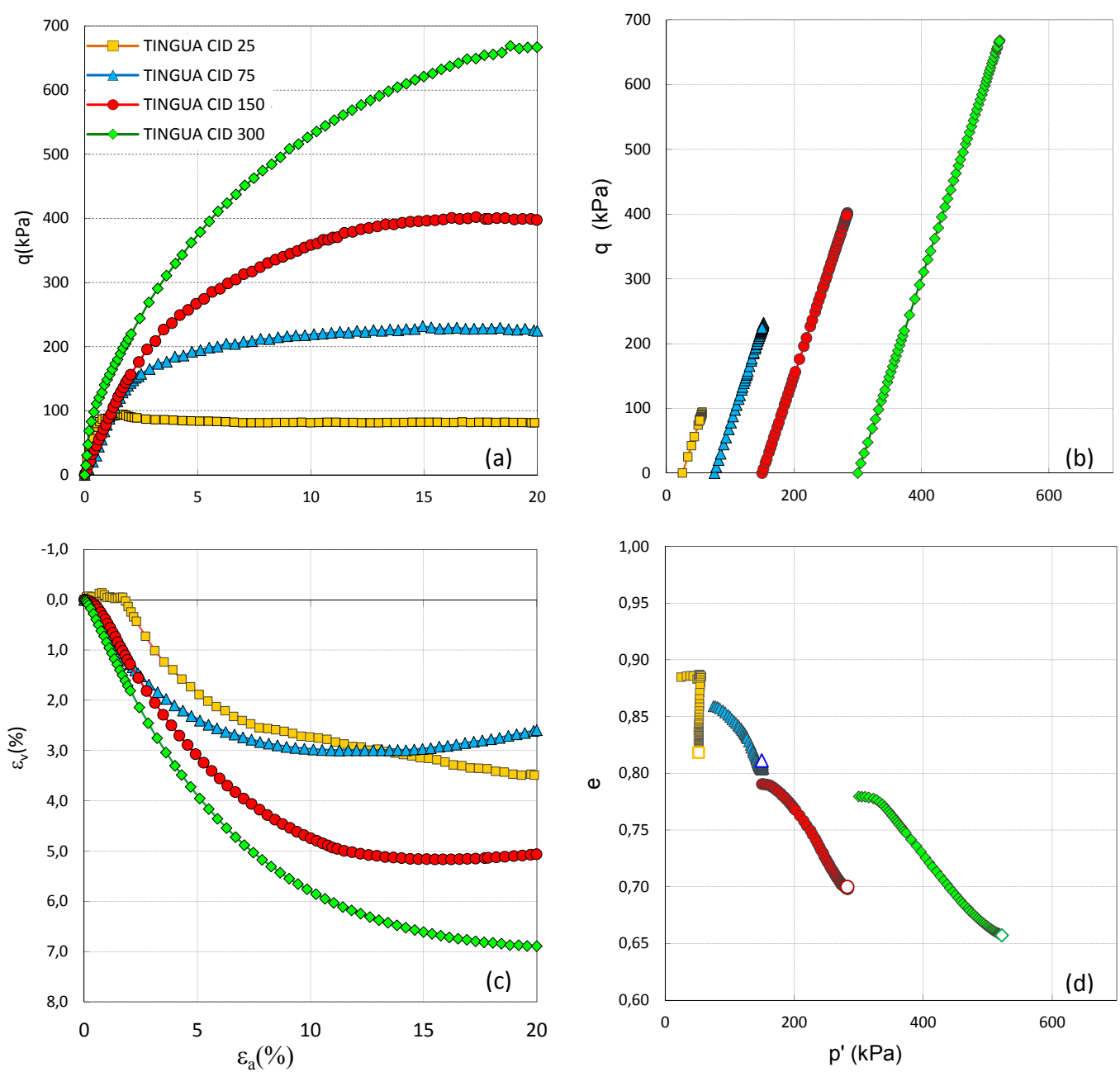

Figura 6.24 - Resultado dos ensaios triaxiais CID do solo coluvionar de Tinguá

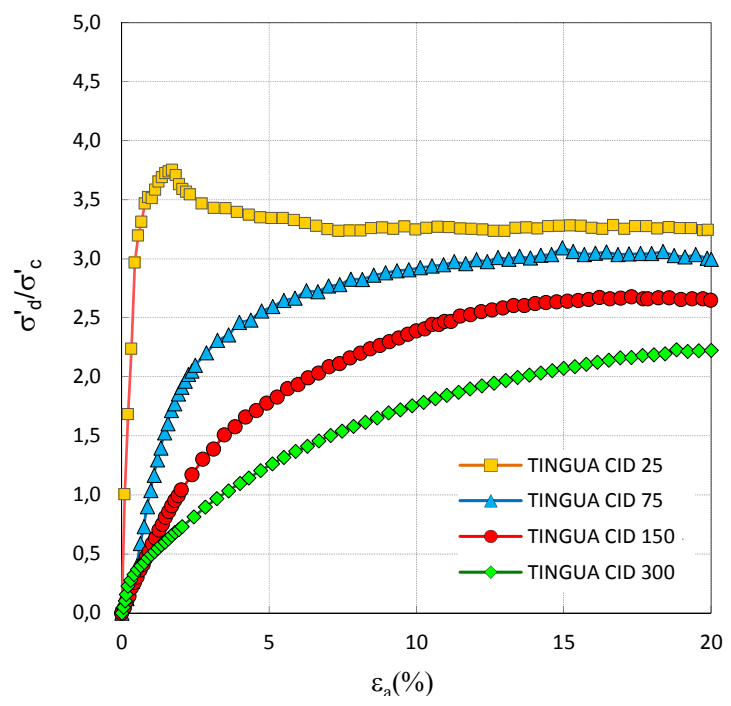

Figura 6.25 - Curvas tensão desviadora normalizada por $\sigma_{c}^{\prime}$ vs deformação axial dos ensaios CID do solo coluvionar de Tinguá

Os resultados dos ensaios CIU estão mostrados nas Figuras 6.26 e 6.27. 
No gráfico q vs $\varepsilon_{a}$ da Figura 6.26 (a) pode-se observar que o crescimento da tensão desviadora foi bastante rápido inicialmente; posteriormente se apresentou um comportamento lento, mas continuo, até o final dos ensaios.

Em relação às poropressões, as curvas $\Delta u$ vs $\varepsilon_{a}$ mostraram que, no ensaio com tensão confinante de $25 \mathrm{kPa}$ ocorreu um leve aumento da poropressão inicial, diminuindo em seguida com o aumento de deformações. Nos outros ensaios, as poropressões aumentaram até aproximadamente $4 \%$ da deformação axial, seguidas de uma diminuição gradativa. Este aumento foi compatível com a tensão de confinamento.

No gráfico da Figura 6.26 (b), a trajetória de tensão do corpo de prova adensado para a tensão efetiva de $25 \mathrm{kPa}$ tende para a direita, a de $75 \mathrm{kPa}$ segue uma direção praticamente vertical, para em seguida tender para a direita. Os outros corpos de prova apresentam trajetórias que tenderam para a esquerda desde o início do cisalhamento, inclinando-se logo para a direita, com tendência a tangenciarem uma mesma envoltória de resistência.
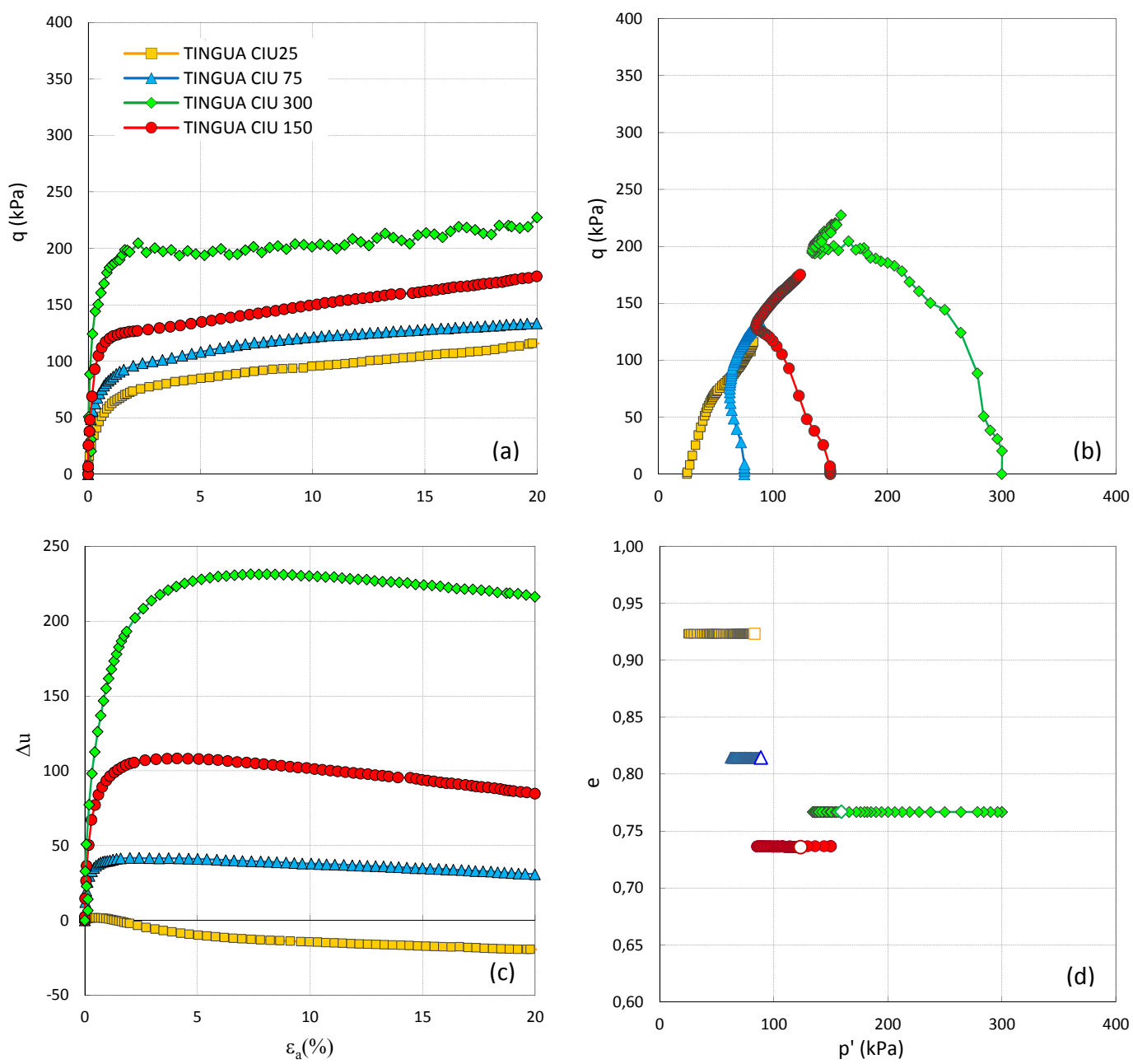

Figura 6.26 - Resultado dos ensaios triaxiais CIU do solo coluvionar de Tinguá 
Ao normalizar a tensão desviadora pela tensão efetiva de adensamento (Figura 6.27), a curva correspondente ao ensaio de menor tensão de adensamento apresentou-se afastada das outras, revelando o efeito da cimentação argilosa do solo nos níveis menores de tensão.
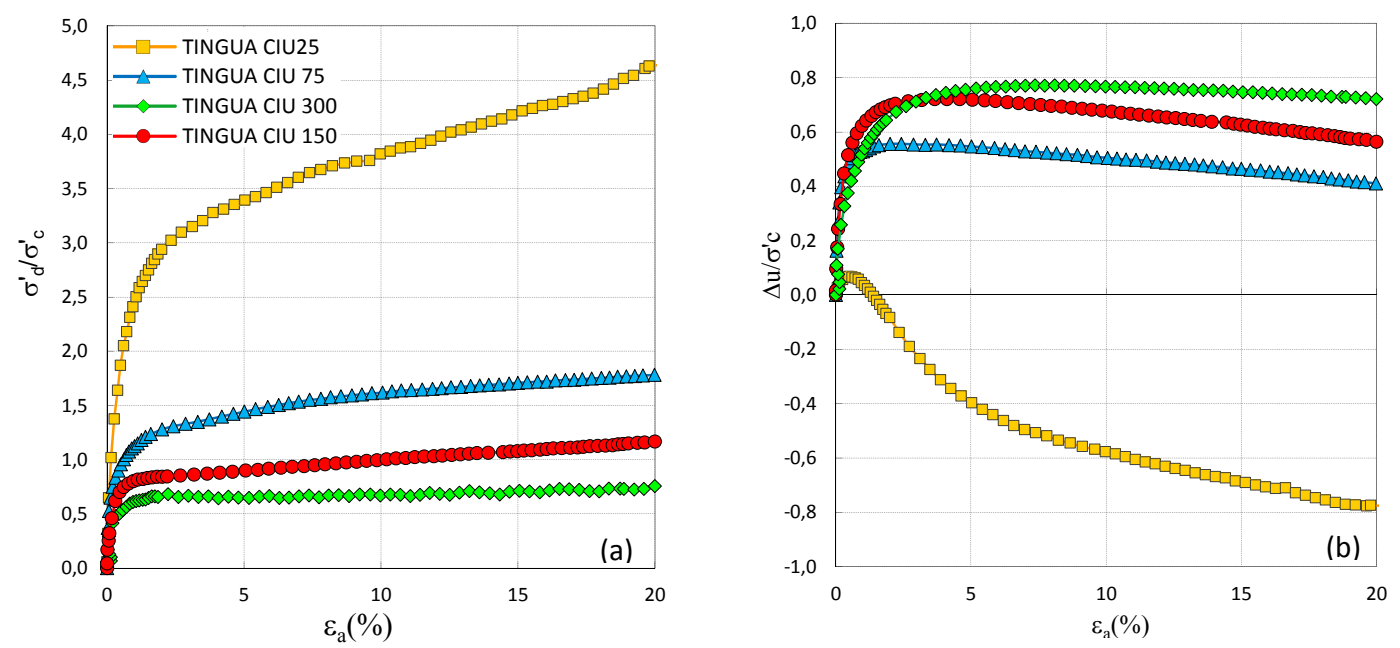

Figura 6.27 - Curvas tensão desviadora normalizada vs deformação do ensaio CIU do solo coluvionar de Tinguá, (a) Tensão desviadora normalizada por $\sigma_{c}^{\prime}$ vs deformação axial, (b) Poropressão normalizada por $\sigma_{c}^{\prime}$ vs deformação axial

A Figura 6.28 mostra os resultados dos ensaios triaxiais não drenados, com adensamento anisotrópico (CKU). Dentre os ensaios realizados na condição não drenada, somente os ensaios realizados com adensamento anisotrópico foram monitorados com o auxílio de medidores de deformação internos (eletroníveis), além da instrumentação convencional.

As curvas tensão-deformação mostradas na Figura 6.28 foram traçadas com os valores de deformação axial obtidos dos eletroníveis. A deformação obtida com estes instrumentos não apresentou grande diferença de valores quando comparada com a deformação determinada por instrumentos convencionais (LSCDT externo), conforme mostrado nas Figuras 6.29 e 6.30.

É evidente, a partir da Figura 6.28 (a), que os corpos de prova do ensaio CKU apresentaram resistência de pico em um nível muito baixo de deformação axial $(<1 \%)$, mostrando comportamento tipo strain-softening seguido por comportamento tipo strain-hardening. Por outro lado, o desenvolvimento da poropressão, mostrado na Figura 6.28 (c), começa em um ritmo acelerado até a tensão de pico, por causa do carregamento não drenado. Em seguida, a deformação após a tensão pico, causa um aumento das poropressões devido à tendência de mudança de volume compressiva do corpo de prova, o que gera a diminuição da resistência. Após alguma deformação, a dilatação do corpo de 
prova gera uma diminuição da poropressão e a amostra apresenta um ganho de resistência no final do ensaio.

As trajetórias de tensão mostram uma primeira inclinação para a direita, posteriormente se desviam para a esquerda e, em seguida, voltam para a direita, convergindo para a envoltória de grandes deformações.
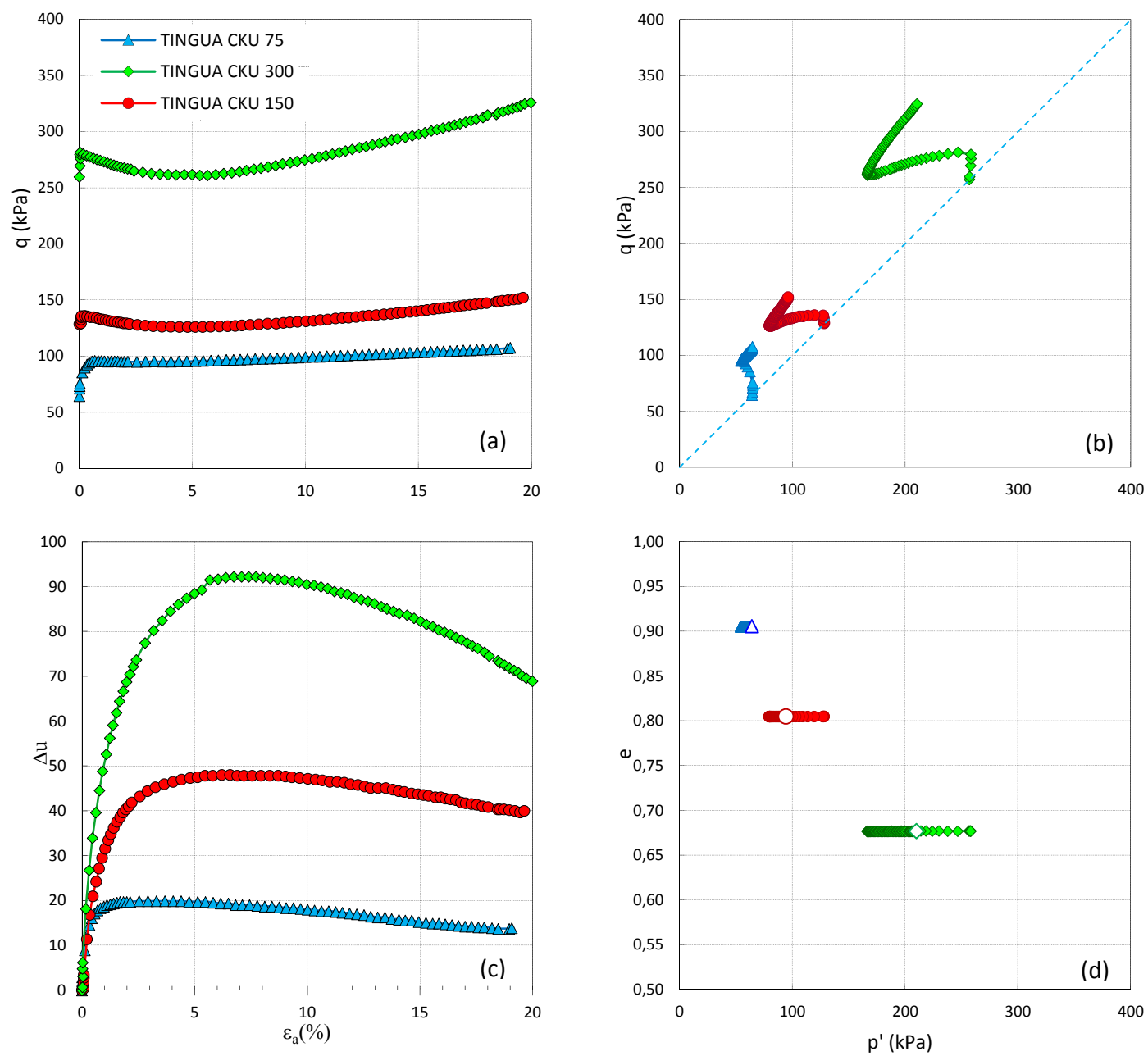

Figura 6.28 - Resultado dos ensaios triaxiais CKU do solo coluvionar de Tinguá

A Figura 6.29 apresenta as curvas tensão-deformação, mostradas na Figura 6.28(a), traçadas com os valores de deformação axial obtidos com os dois sistemas de medida de deformações (LSCDT e eletroníveis). Na Figura 6.30, encontram-se as mesmas curvas, porém em escala ampliada.

Pode-se apreciar que a deformação definida com os eletroníveis não apresentou grande diferença de valores quando comparada com a deformação determinada por instrumentos convencionais (LSCDT externo).

$\mathrm{Na}$ Figura 6.31 mostram-se as curvas tensão-deformação normalizadas, onde se pode apreciar que a curva correspondente ao ensaio de menor tensão efetiva distancia-se das demais, devido provavelmente à presença de algum tipo 
de estruturação. O ponto de ruptura dos corpos de prova admitido no valor de $\sigma_{\mathrm{dmax}}$ ou, pelo maior valor de $\sigma_{\mathrm{d}} / \sigma_{\mathrm{c}}^{\prime}$, mostra-se bem definido.

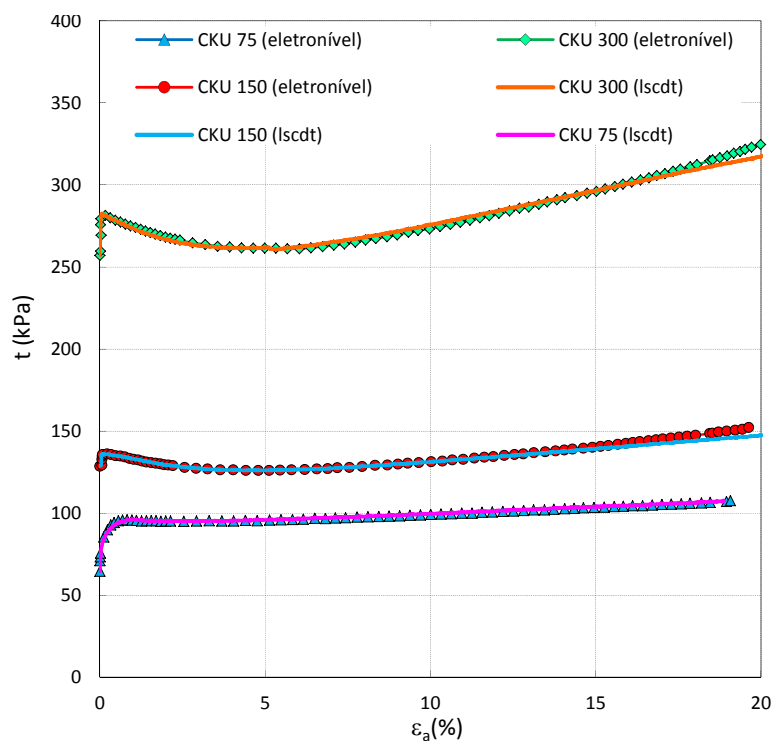

Figura 6.29 - Curvas tensão-deformação do ensaio CKU, obtida com os medidores de deformação interna (eletroníveis) e externa (LSCDT) - solo coluvionar de Tinguá
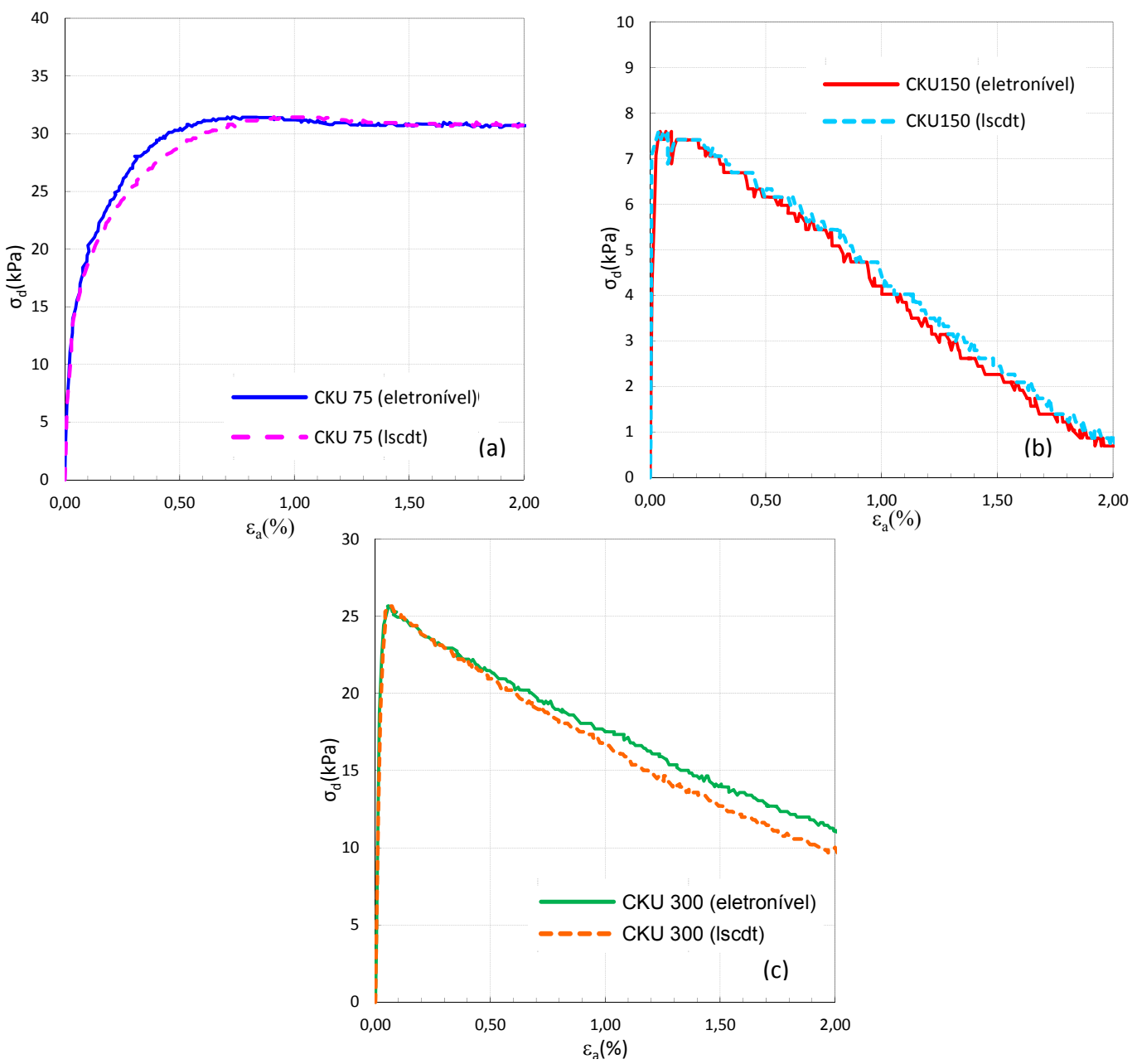

Figura 6.30 - Curvas tensão-deformação em escala ampliada onde as deformações foram obtidas com eletroníveis e LSCDT - solo coluvionar de Tinguá: (a) CKU 75, (b) CKU 150, (c) CKU 300 

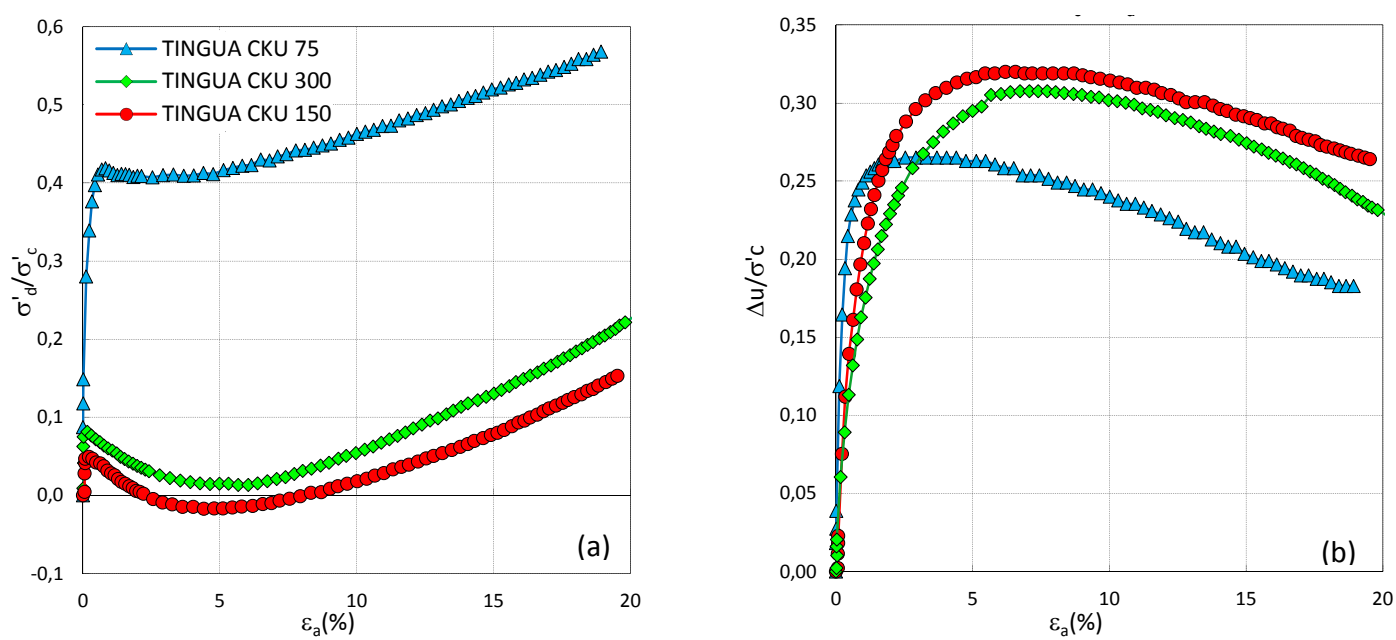

Figura 6.31 - Curvas normalizadas do ensaio CKU do solo coluvionar de Tinguá, (a) Tensão desviadora normalizada por $\sigma_{c}^{\prime}$ vs deformação axial, (b) Poropressão normalizada por $\sigma_{c}^{\prime}$ vs deformação axial

A variação da razão entre as tensões principais efetivas e a deformação axial, empregadas para a determinação da resistência máxima dos ensaios CIU e CKU, segundo o critério $\sigma_{1}^{\prime} / \sigma^{\prime}{ }_{3 \max }$, são apresentadas na Figura 6.32.
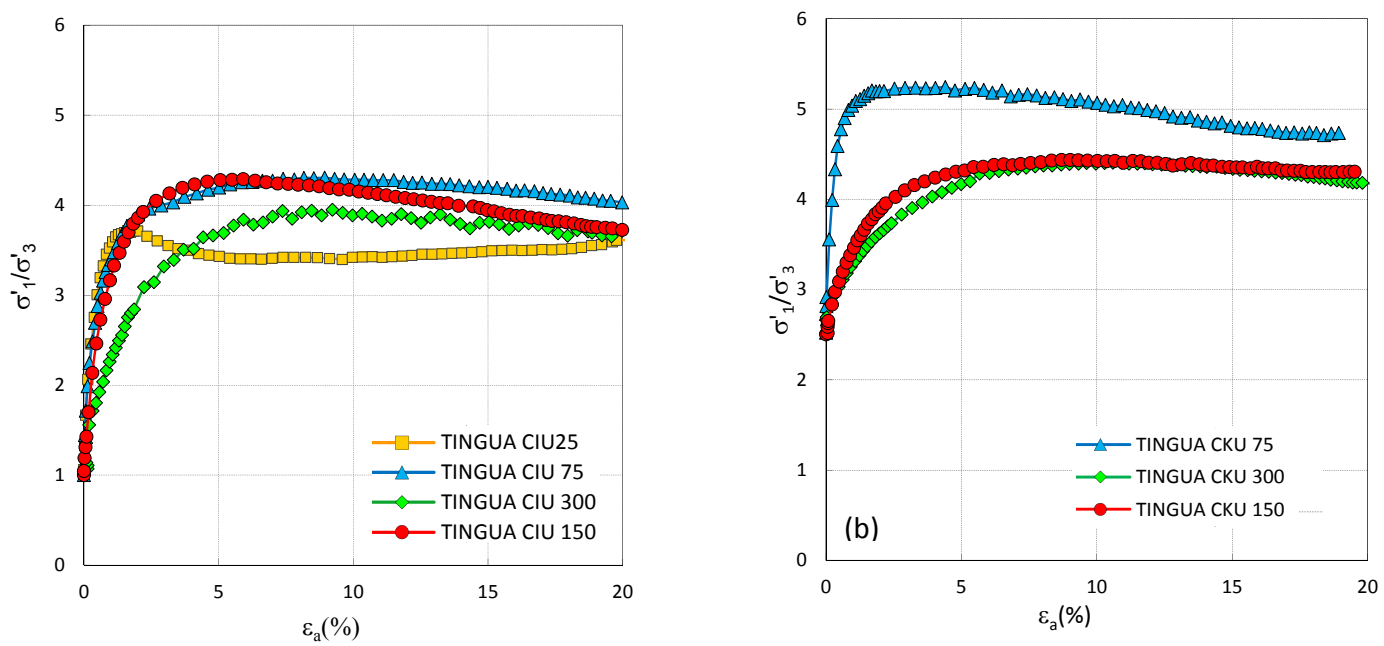

Figura 6.32 - Curvas de razão das tensões principais efetivas vs deformação axial dos ensaios, (a) CIU e (b) CKU do solo coluvionar de Tinguá

\section{Linha de Estado Crítico}

Para a determinação da linha do estado crítico, foram empregados os ensaios CID, CIU e CKU. Os pontos finais de cada ensaio foram admitidos próximos à condição de estado crítico, devido à tendência de estabilização da deformação volumétrica e a razão entre as tensões efetivas principais.

A Figura 6.33 apresenta a linha do estado crítico no espaço $p_{c}^{\prime}$ vs $q_{c}$, onde se pode apreciar o ajuste linear e curvo dos pontos. Note-se que o ajuste linear 
não é a melhor solução. $O$ valor médio do parâmetro $M$ obtido é de 1,36 , o que corresponde a $\phi_{c}^{\prime}=33,7^{\circ}$.
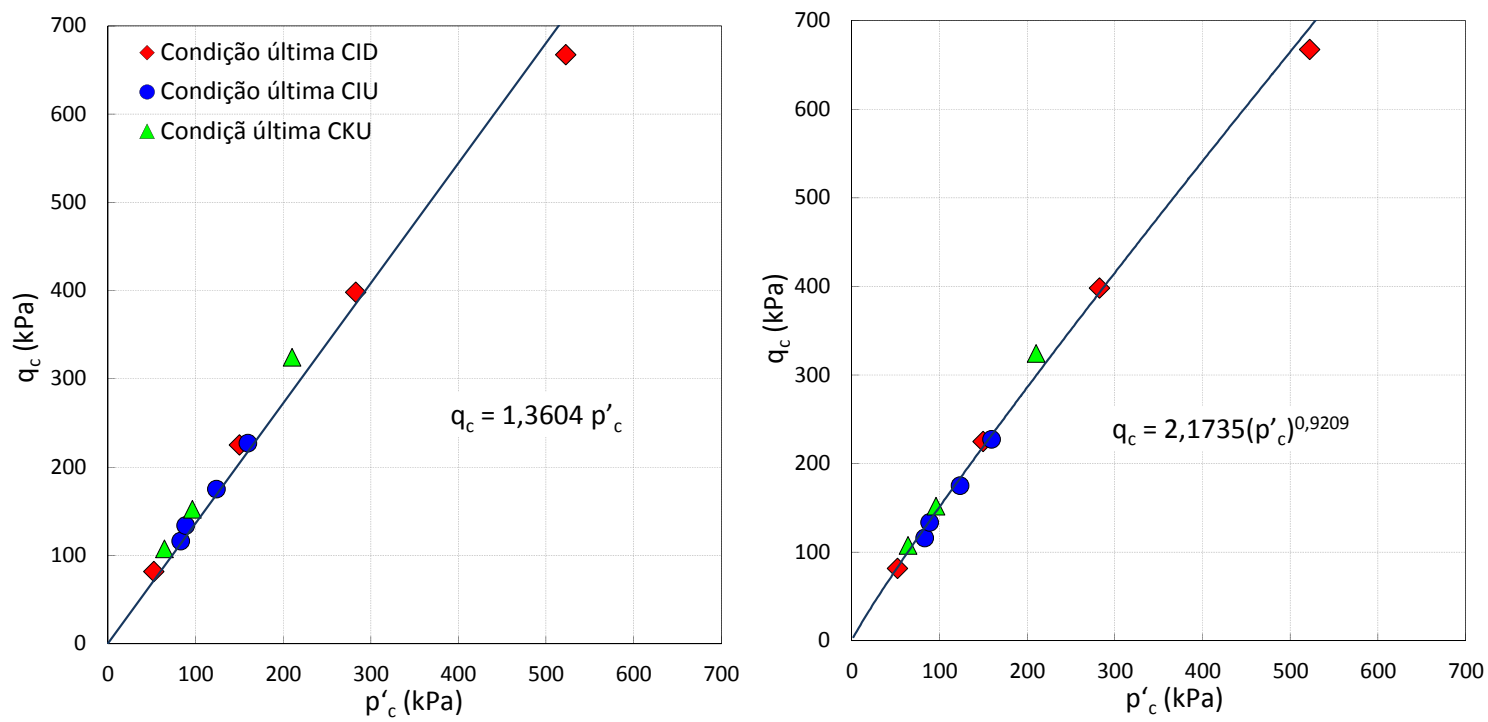

Figura 6.33 - Linha de estado crítico do solo coluvionar de Tinguá no plano $\mathrm{p}_{\mathrm{c}}^{\prime}$ vs $\mathrm{q}_{\mathrm{c}}$, (a) Ajuste linear passando pela origem, (b) Ajuste curvo

Os pontos correspondentes à condição mais próxima do estado crítico, no espaço e vs $\mathrm{p}_{\mathrm{c}}^{\prime} \mathrm{e} v$ vs $\mathrm{p}_{\mathrm{c}}^{\prime}$, estão mostrados na Figura 6.34. Os parâmetros $\Gamma$ e $\lambda$ que definem a LEC, obtidos através do ajuste de uma reta são, respetivamente 2,30 e 0,11 .
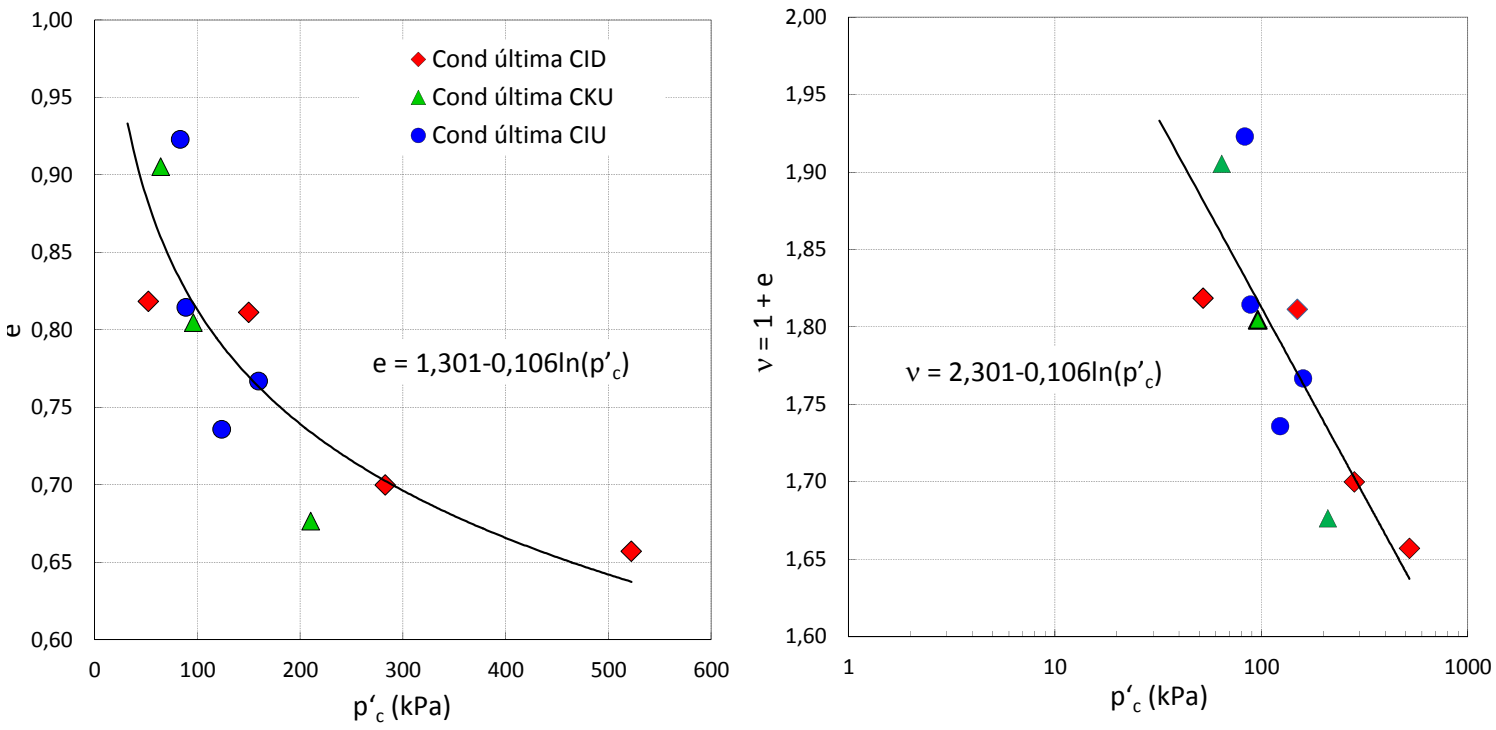

Figura 6.34 - Linha de estado crítico do solo coluvionar de Tinguá no plano: (a) e vs $\mathrm{p}_{\mathrm{c}}$, (b) $v v s \mathrm{p}_{\mathrm{c}}^{\prime}$ 


\section{Envoltórias e Parâmetros de Resistência}

A Figura 6.35 mostra a envoltória de resistência média no espaço s' vs t, considerando o critério de tensão desviadora máxima no caso que a curva tensão deformação apresentou pico, e o critério de De Campos e Carrillo (1995) quando o solo se comportou de maneira strain-hardening. Os pontos conseguidos com o critério de razão de tensões principais, dos ensaios não drenados, foram usados para conferir a envoltória traçada. São apresentados, também, os parâmetros de resistência ao cisalhamento c' e $\phi^{\prime}$, obtidos a partir dos valores de a' e $\alpha$ '.

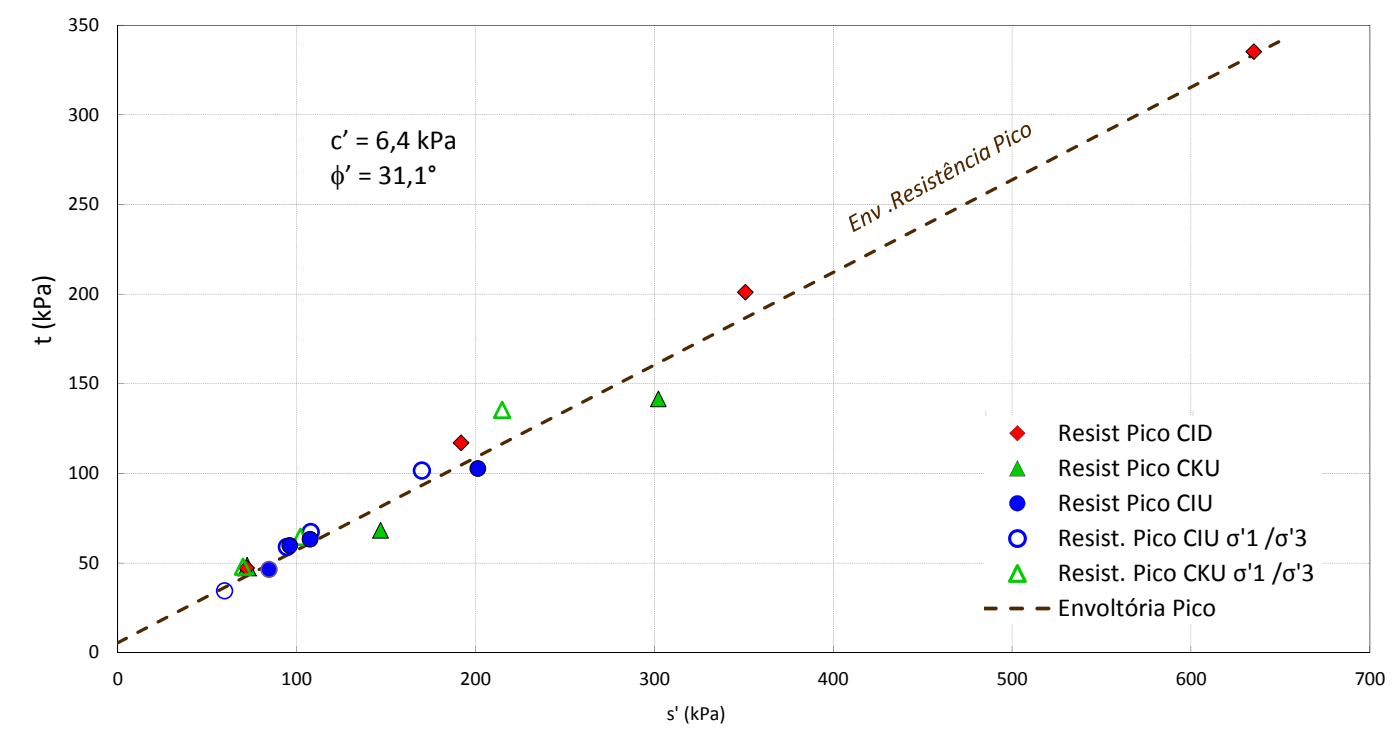

Figura 6.35 - Envoltória e parâmetros de resistência de Mohr-Coulomb na condição de pico para os ensaios drenados e não drenados do solo coluvionar de Tinguá

$\mathrm{Na}$ Figura 6.36 pode-se visualizar, no espaço p' vs q, a envoltória de resistência de pico ajustada entre os pontos máximos das trajetórias de tensões da série de ensaios triaxiais CID, CIU e CKU. Na mesma figura se observa a linha de estado crítico obtida na Figura 6.33 (b).

Note-se que, a envoltória de resistência de pico do solo coluvionar de Tinguá encontra-se baixo a linha do estado crítico, o que poderia ser um indício de se tratar de um solo metaestável ou susceptível ao fenômeno de liquefação. 


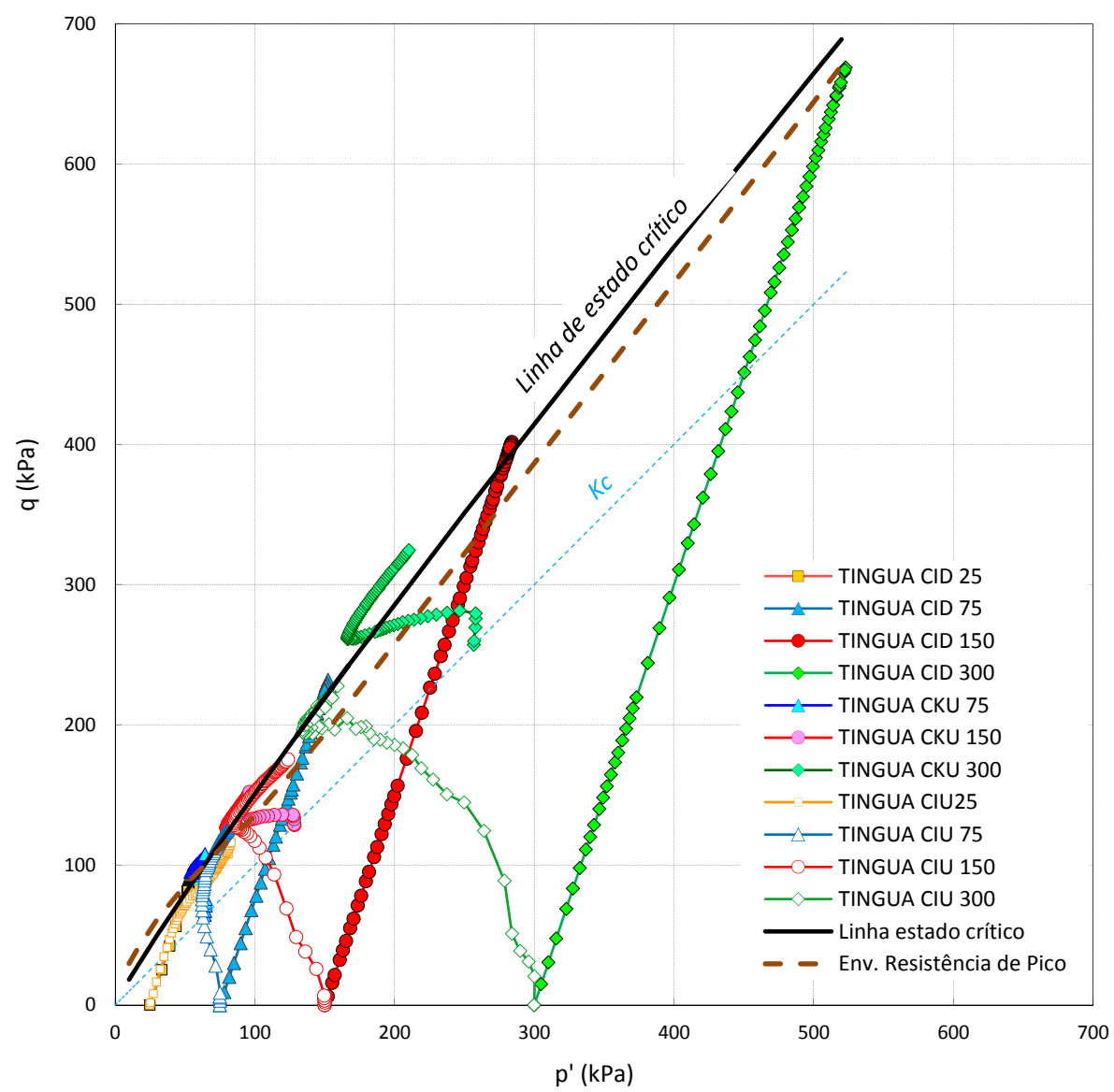

Figura 6.36 - Trajetórias de tensão, envoltória de resistência de pico e linha de estado crítico do solo coluvionar de Tinguá, obtidas dos ensaios CID, CIU e CKU.

\section{Parâmetros de Deformabilidade}

$\mathrm{Na}$ Tabela 6.10 se apresentam os módulos de Young tangente inicial $\left(E_{i}\right)$ e secante $\left(E_{50}\right)$ correspondente a um valor de $50 \%$ da tensão na ruptura, para os ensaios drenados e não drenados, assim como o coeficiente de Poisson tangente inicial $\left(v_{i}\right)$ e secante $\left(v_{50}\right)$ nos ensaios drenados. Para os ensaios CKU, foram obtidos os módulos de Young, utilizando o transdutor de deslocamento externo (LSCDT) e o medidor de deslocamento axial interno (eletronível).

Na Figura 6.37 se apresenta a variação dos parâmetros E e $v$ com a tensão confinante, nos ensaios CIU e CID. Na Figura 6.37 (a) pode-se observar que, na maioria dos casos, ao se aumentar o nível da tensão confinante, o módulo de Young tende a aumentar. No entanto, observou-se uma tendência de aumento dos módulos $E_{i}$ e $E_{50}$ nos ensaios TIN-CID25 e TIN-CIU25, além do módulo tangente inicial no ensaio TIN-CIU75.

É importante observar que a comparação foi considerada válida para ensaios com estado de tensões semelhantes no início de cisalhamento. Por tal motivo somente foram comparados os ensaios com adensamento isotrópico, CIU 
e CID. Isto porque os corpos de prova adensados anisotropicamente já estão submetidos a uma tensão cisalhante inicial.

A Figura 6.37 (b) mostra a redução do coeficiente de Poisson tangente inicial e secante com o aumento da tensão confinante nos ensaios CID.

Tabela 6.10 - Parâmetros de deformabilidade E e v obtidos nos ensaios triaxiais do solo coluvionar de Tinguá

\begin{tabular}{c|c|c|c|c|c}
\hline Ensaio & $\begin{array}{c}\text { Tensão confinante } \\
\text { efetiva }(\mathrm{kPa})\end{array}$ & $\mathrm{E}_{\mathrm{i}}(\mathrm{MPa})$ & $v_{\mathrm{i}}$ & $\mathrm{E}_{50}(\mathrm{MPa})$ & $v_{50}$ \\
\hline TIN - CID25 & 25 & 30,81 & 0,60 & 18,13 & 0,64 \\
\hline TIN - CID75 & 75 & 8,22 & 0,31 & 7,95 & 0,20 \\
\hline TIN - CID150 & 150 & 9,52 & 0,30 & 6,89 & 0,17 \\
\hline TIN - CID300 & 300 & 33,94 & 0,12 & 8,09 & 0,09 \\
\hline TIN - CIU25 & 25 & 100,12 & - & 9,45 & - \\
\hline TIN - CIU75 & 75 & 230,77 & - & 23,02 & - \\
\hline TIN - CIU150 & 150 & 214,29 & - & 42,56 & - \\
\hline TIN - CIU300 & 300 & 222,49 & - & 87,50 & - \\
\hline TIN - CKU75 & 75 & 71,43 & - & 33,48 & - \\
\hline TIN - CKU150 & 150 & 150,00 & - & 84,88 & - \\
\hline TIN - CKU300 & 300 & 111,11 & - & 99,52 & - \\
\hline TIN - CKU75* & 75 & 120,00 & - & 25,07 & - \\
\hline TIN - CKU150* & 150 & 88,89 & - & 53,05 & - \\
\hline TIN - CKU300* & 300 & 115,38 & - & 103,17 & - \\
\hline
\end{tabular}

*Deformação obtida com eletroníveis
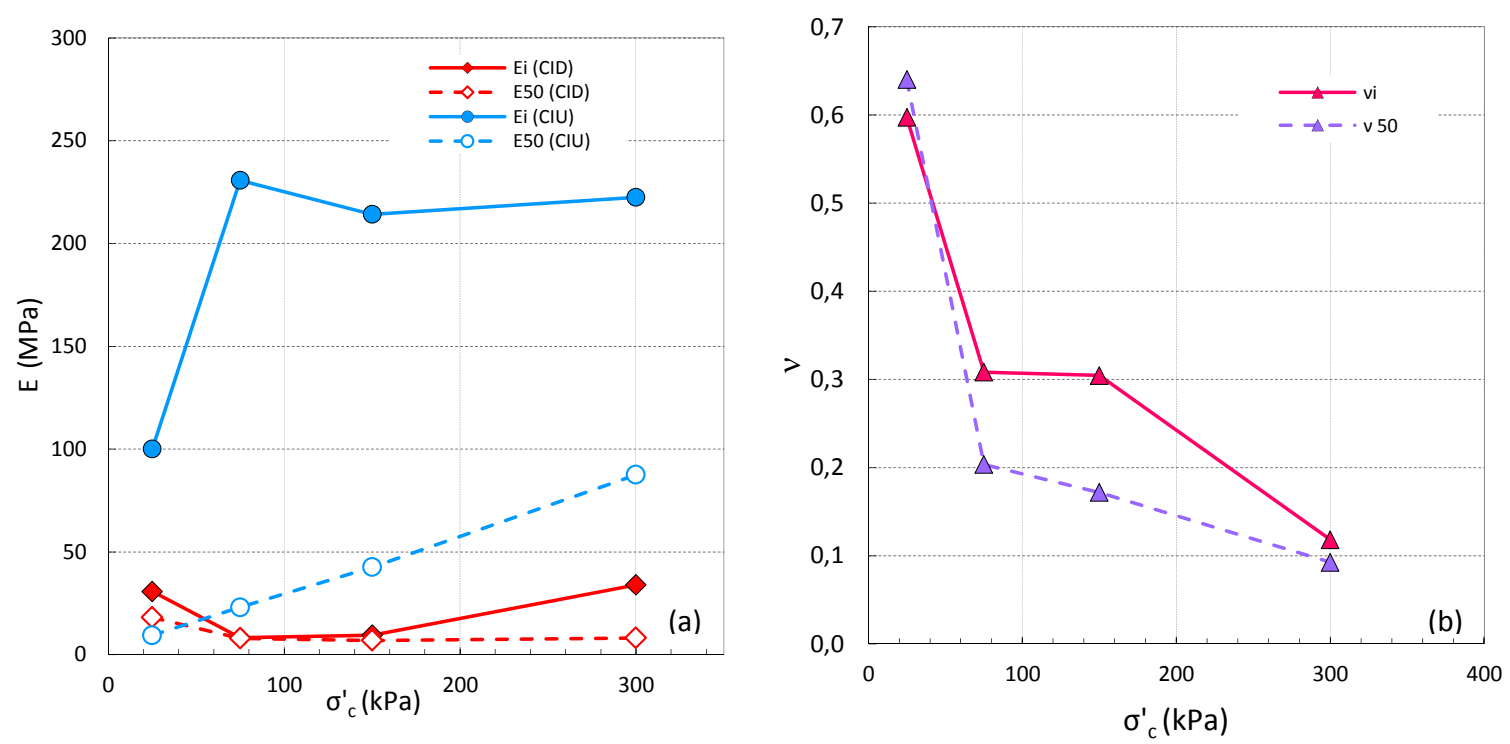

Figura 6.37 - Variação dos parâmetros de deformabilidade com a tensão confinante para o solo coluvionar de Tinguá, (a) Variação do módulo de Young E, (b) Variação do coeficiente de Poisson 
$A$ variação dos módulos $E_{i}$ e $E_{50}$, obtidos nos ensaios $C K U$, utilizando os eletroníveis e o LSCDT, é apresentada na Figura 6.38. A figura mostra que nas tensões de $\sigma_{\mathrm{C}}^{\prime}=75 \mathrm{kPa}$ e $300 \mathrm{kPa}$, os módulos iniciais obtidos com eletroníveis são maiores do que os obtidos com o LSCDT, já os módulos secantes obtidos com o LSCDT são maiores que os obtidos com os eletroníveis, na maioria das tensões. A diferença entre os módulos conseguidos com ambos os sistemas de medição é maior nas tensões de 75 e 150 kPa. Nas tensões maiores (300 kPa) esta diferença é mínima.

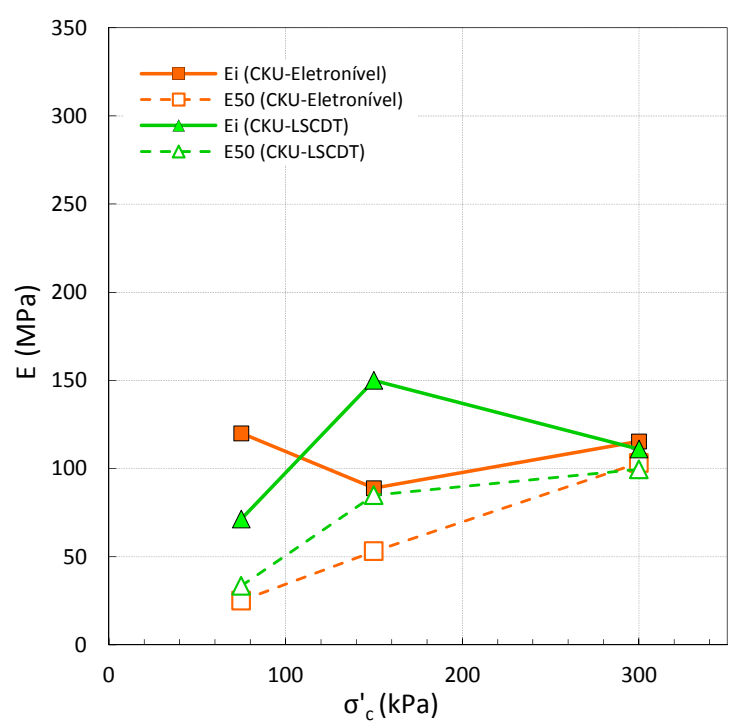

Figura 6.38 - Variação do módulo de deformação $E_{i}$ e $E_{50}$ em função da tensão confinante, utilizando medidor de deformação axial interno (eletroníveis) e externo (LSCDT) nos ensaios CKU do solo coluvionar de Tinguá

\subsection{2.}

\section{Ensaios triaxiais no solo residual jovem de Duque de Caxias}

O solo residual jovem de Duque de Caxias foi estudado em bastante detalhe por Carvalho (2012). Nesse trabalho, foram realizados ensaios para a caraterização, identificação e classificação dos solos, assim como ensaios para identificação das caraterísticas de compressibilidade e resistência. Com respeito aos ensaios de resistência, Carvalho (2012) realizou ensaios triaxiais CIU em amostras indeformadas, com o intuito de avaliar a influência dos processos de saturação tradicionalmente executados em solos residuais.

Os critérios de ruptura empregados para determinação da envoltória de resistência foram os critérios de máxima tensão desviadora e máxima razão entre as tensões efetivas principais.

$\mathrm{Na}$ Tabela 6.11 são mostrados ensaios realizados no referido trabalho. 
Tabela 6.11 - Dados dos corpos de prova do solo residual jovem de Duque de Caxias usados em ensaios triaxiais CIU realizados por Carvalho (2012)

\begin{tabular}{c|c|c|c|c|c|c|c|c|c}
\hline Ensaio & $\sigma_{C}^{\prime}$ & $\begin{array}{c}\mathrm{w}_{\mathrm{o}} \\
(\%)\end{array}$ & $\begin{array}{c}\mathrm{w}_{\mathrm{f}} \\
(\%)\end{array}$ & $\begin{array}{c}\gamma_{\mathrm{n}} \\
\left(\mathrm{kN} / \mathrm{m}^{3}\right)\end{array}$ & $\begin{array}{c}\gamma_{\mathrm{d}} \\
\left(\mathrm{kN} / \mathrm{m}^{3}\right)\end{array}$ & $\mathrm{e}_{\mathrm{o}}$ & $\mathrm{e}_{\text {adens }}$ & $\begin{array}{c}\mathrm{n} \\
(\%)\end{array}$ & $\mathrm{S}_{\mathrm{o}}(\%)$ \\
\hline DC-25 & 25 & 28,60 & 49,12 & 15,2 & 11,82 & 1,39 & 1,37 & 58,1 & 59,3 \\
\hline DC-75 & 75 & 33,42 & 47,74 & 15,84 & 11,87 & 1,38 & 1,36 & 58,0 & 69,8 \\
\hline DC-150 & 150 & 34,43 & 44,84 & 15,61 & 11,61 & 1,43 & 1,39 & 58,9 & 69,3 \\
\hline DC-300 & 300 & 29,6 & 61,8 & 15,37 & 11,86 & 1,38 & 1,29 & 58,0 & 61,8 \\
\hline DC-500 & 500 & 21,40 & 32,98 & 15,37 & 12,66 & 1,23 & 1,14 & 55,1 & 49,2 \\
\hline
\end{tabular}

\section{Comportamento Tensão - deformação}

As curvas $\sigma_{d} v s$ e e $\Delta u$ vs $\varepsilon_{a}$ dos ensaios $\mathrm{ClU}$ executados por Carvalho (2012) são apresentadas na Figura 6.39.
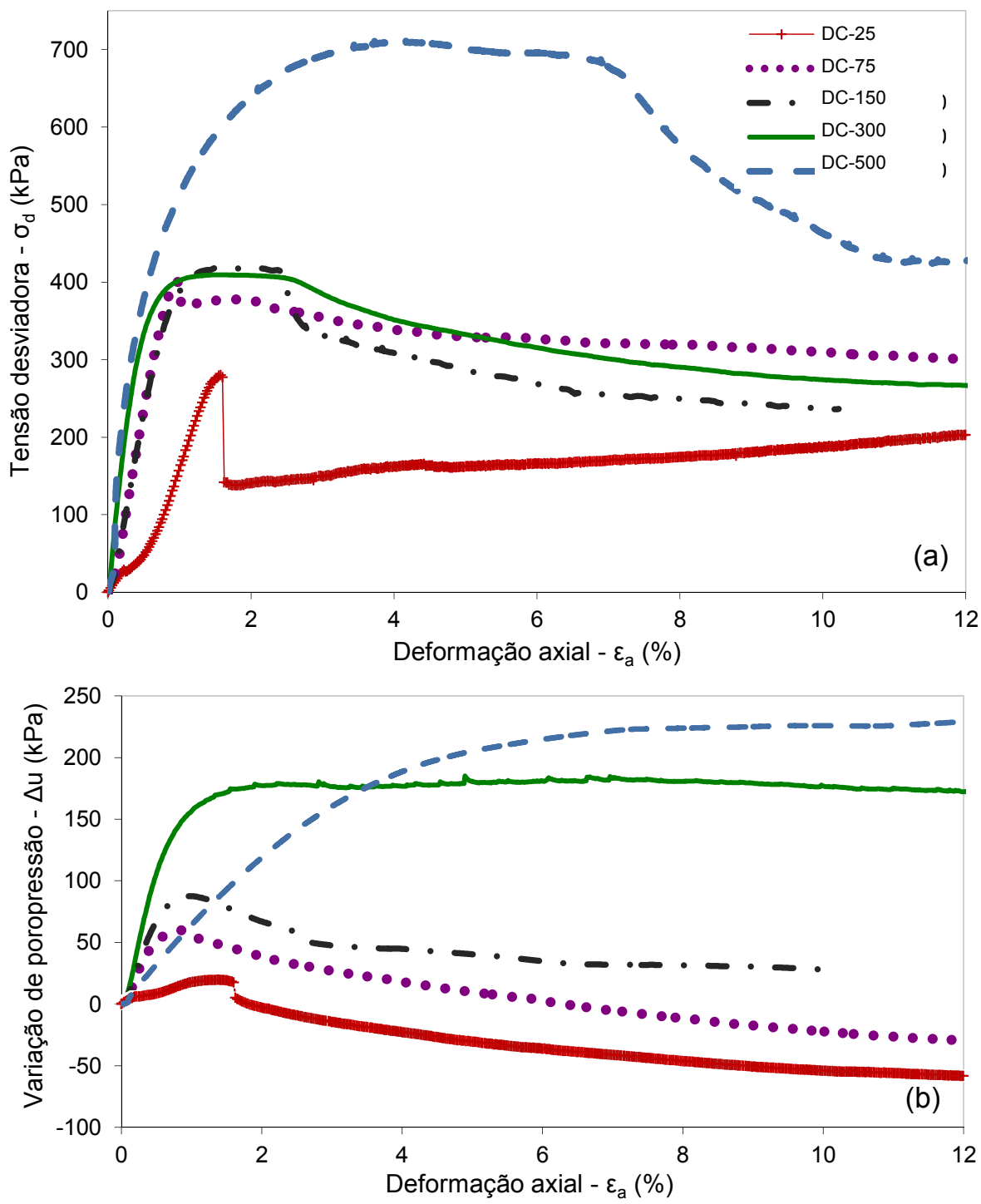

Figura 6.39 - Curvas $\sigma_{\mathrm{d}}$ vs $\varepsilon_{\mathrm{a}}$ e $\Delta \mathrm{u}$ vs $\varepsilon_{\mathrm{a}}$ dos ensaios CIU do solo residual jovem de Duque de Caxias (Carvalho, 2012) 
Carvalho (2012), ao estudar o comportamento tensão-deformação do solo Duque de Caxias através de ensaios CIU, observou que o comportamento desse solo está de acordo com o descrito por Leroueil e Vaughan (1990) para solos com estrutura cimentada. Para baixos níveis de tensão efetiva de adensamento (DC-25 e DC-75) um pico de resistência precede a máxima taxa de geração negativa de poropressão, que ocorre devido ao colapso da estrutura por cisalhamento. Nos ensaios DC-300 e DC-500 o solo apresenta comportamento strain-softening associado à geração positiva de poropressão, similar ao descrito por Leroueil e Vaughan (1990) para um nível intermediário de tensão efetiva de um solo com estrutura cimentada. Já no ensaio DC-150 se tem um comportamento strain-softening associado a um decréscimo de poropressão positiva. Este comportamento foi descrito por Carvalho como de transição entre o estabelecido por Leroueil e Vaughan (1990) para solos com estrutura cimentada quando submetidos a baixos níveis de tensão efetiva e para um intervalo intermediário.

Na Figura 6.40, ao normalizar a tensão desviadora pela tensão efetiva de adensamento, obteve-se que, os maiores valores desta razão foram alcançados no ensaio executado com menor tensão efetiva. Como a estrutura do solo é afetada com o aumento da tensão efetiva de adensamento, quando ocorre a completa desestruturação do solo devido à magnitude da tensão efetiva, as curvas normalizadas para tensões superiores a esta tendem a coincidir. Carvalho (2012) observou que o nível de tensão efetiva empregado nestes ensaios é inferior à tensão de cedência, por conseguinte, não se tem esta convergência de comportamento. A cedência (plastificação ou escoamento), nos solos residuais está associada à quebra da estrutura cimentada (Vaughan, 1985).

Carvalho adotou a tensão de $600 \mathrm{kPa}$, obtida no ensaio de adensamento odométrico, como a tensão de cedência para análise dos ensaios triaxiais, tendo em vista que as tensões alcançadas no adensamento isotrópico não foram suficientes para desencadear a plastificação da estrutura cimentado do solo. 

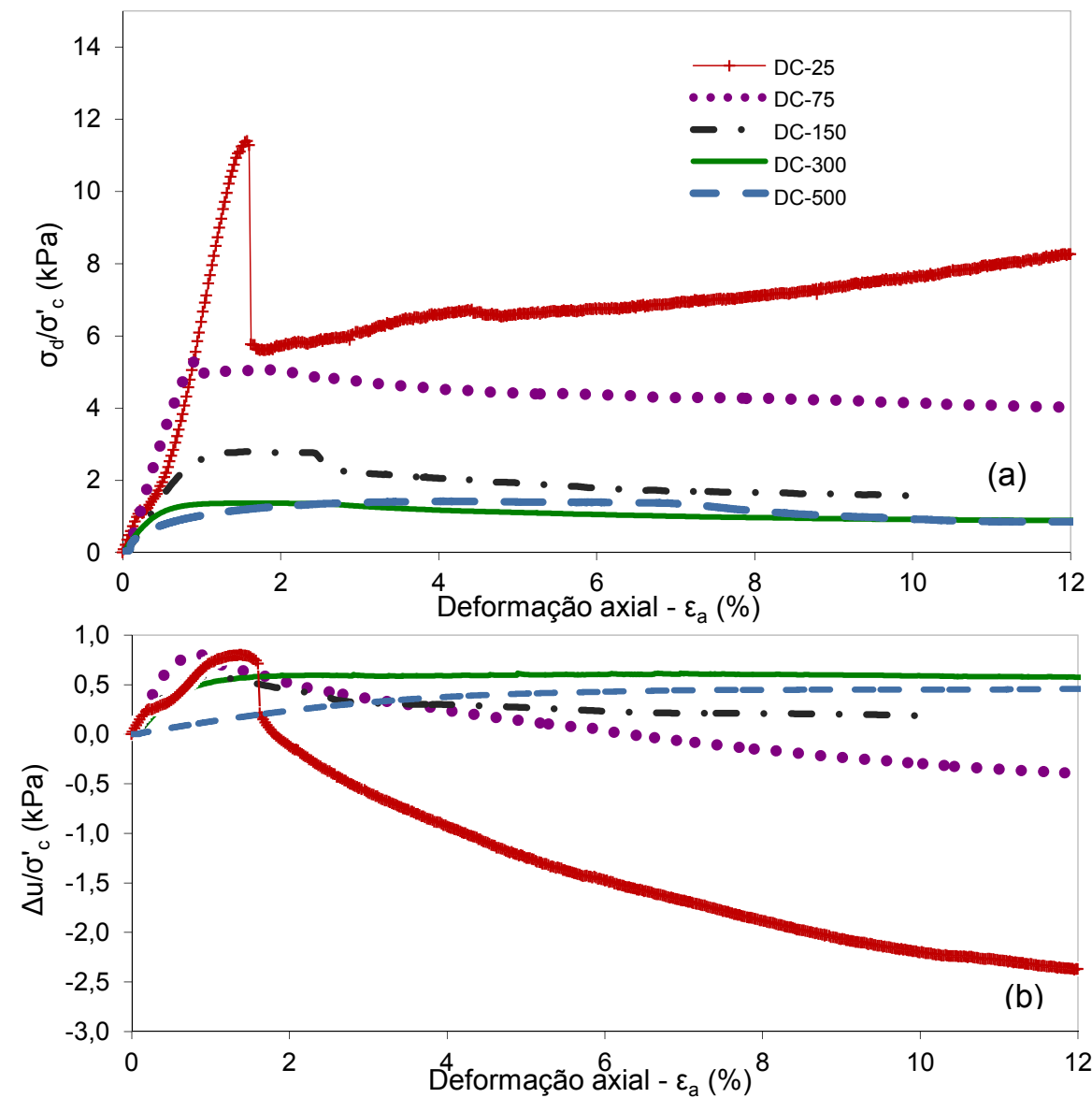

Figura 6.40 - Curvas $\sigma_{\mathrm{d}} / \sigma_{3}^{\prime}$ vs $\varepsilon_{\mathrm{a}}$ dos ensaios ClU do solo residual jovem de Duque de Caxias (Carvalho, 2012)

\section{Trajetórias de tensão e Parâmetros de Resistência}

As trajetórias de tensão são reunidas na Figura 6.41. O caráter não linear da envoltória de resistência para baixos valores de $\sigma_{c}^{\prime}$ devido à presença de cimentação fica evidente na figura.

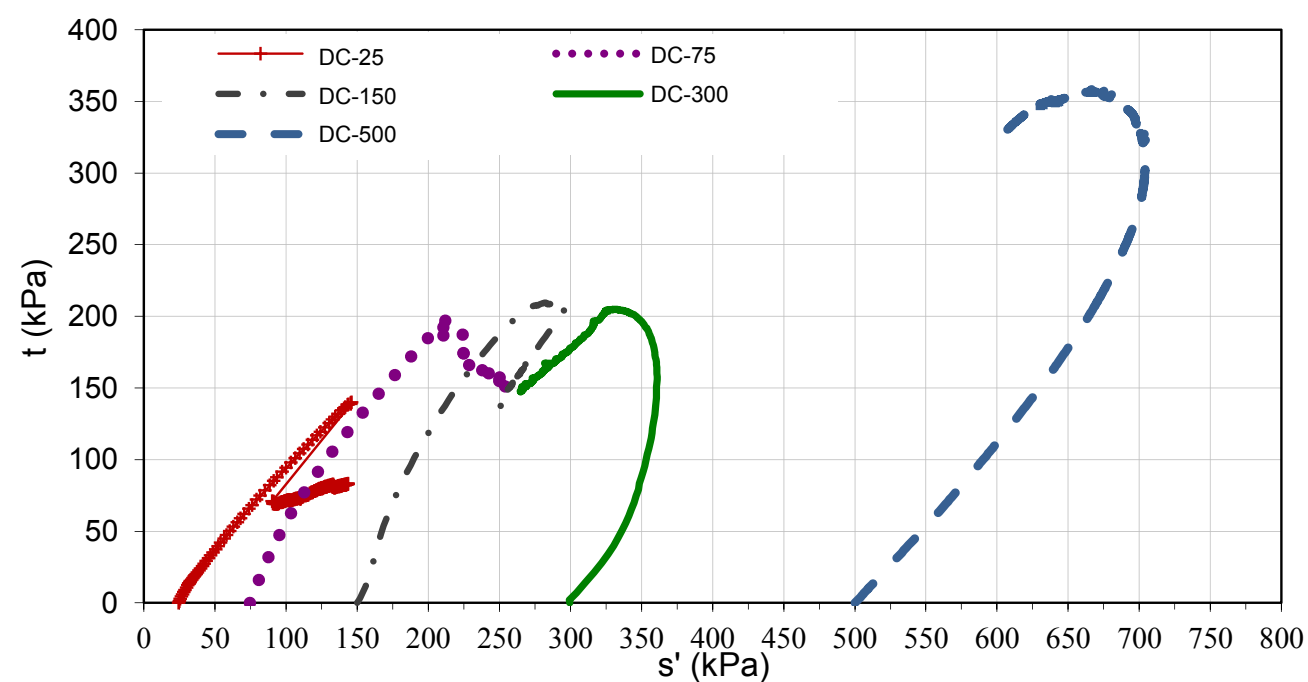

Figura 6.41 - Trajetórias de tensões dos ensaios CIU do solo residual jovem de Duque de Caxias (Carvalho, 2012) 
Na Figura 6.42 observam-se as curvas da razão das máximas tensões efetivas principais em função da deformação axial para a determinação da resistência ao cisalhamento na ruptura. Para a tensão efetiva de $25 \mathrm{kPa}$, a curva apresenta um pico intenso e bem definido. Com o aumento da tensão efetiva, os picos das curvas ficam menos intensos, até se apresentar suave no ensaio DC-300 e não ocorrer no ensaio DC-500. Nos ensaios executados com maior tensão efetiva, as curvas são bastante próximas. Segundo Carvalho (2012) nesta representação fica claro o aumento gradual da influência da tensão efetiva de adensamento no processo de desestruturação do solo.

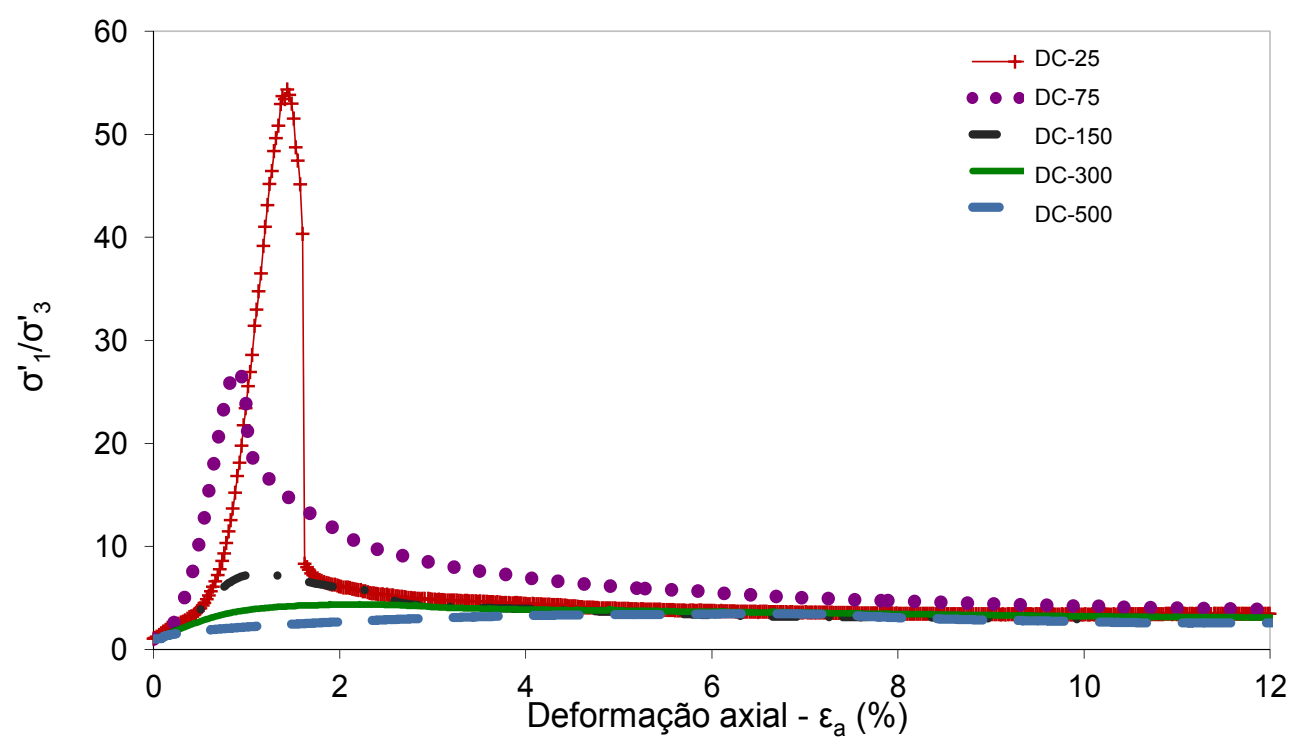

Figura 6.42 - Curvas $\sigma_{1}^{\prime} / \sigma_{3}^{\prime}$ vs $\varepsilon_{\mathrm{a}}$ dos ensaios $\mathrm{CIU}$ do solo residual jovem de Duque de Caxias (Carvalho, 2012)

Apesar da envoltória de resistência de ruptura para solos com estrutura cimentada ser curva para tensões inferiores à cedência, envoltórias lineares foram estimadas por Carvalho (2012), seguindo os critérios de ruptura $\sigma_{1} / \sigma_{3 \text { máx }}$

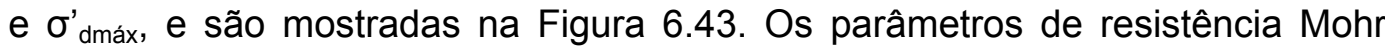
Coulomb obtidos constam na mesma figura.

Segundo Carvalho (2012) o alto valor de intercepto coesivo (105,8 kPa) e baixo ângulo de atrito $\left(21,5^{\circ}\right)$ da envoltória linear, refletem a forte influência da estrutura no comportamento do solo. Tal estrutura já havia sido identificada pela autora na microscopia eletrônica de varredura (MEV) e constatada em ensaios de adensamento edométrico, CRS e isotrópico. 


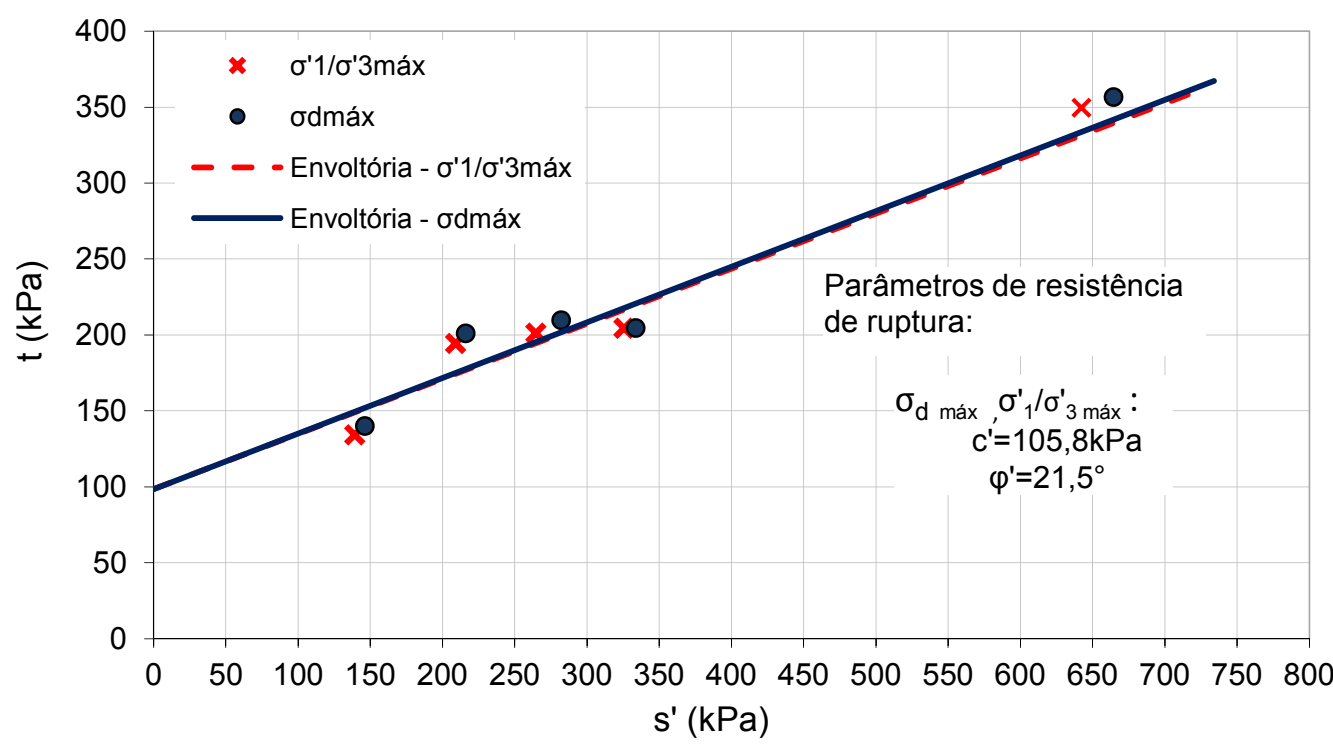

Figura 6.43 - Envoltórias de resistência de ruptura dos ensaios realizados por Carvalho (2012), no solo residual jovem de Duque de Caxias

\section{Parâmetros de Deformabilidade}

A Tabela 6.12 apresenta o módulo de Young secante correspondente a $50 \%$ da máxima tensão desviadora, obtidos a partir dos ensaios CIU no Solo de Duque de Caxias. Na Figura 6.44 é apresentada a variação de $E_{50}$ com a tensão efetiva de confinamento. Observa-se que os módulos tendem a aumentar com a tensão efetiva.

Tabela 6.12 - Módulo de deformabilidade $E_{50}$ obtidos nos ensaios triaxiais do solo residual de Duque de Caxias (Carvalho, 2012)

\begin{tabular}{c|c}
\hline Ensaio & $\mathrm{E}_{50}(\mathrm{Mpa})$ \\
\hline $\mathrm{DC}-25$ & 15,18 \\
\hline $\mathrm{DC}-75$ & 46,43 \\
\hline $\mathrm{DC}-150$ & 46,37 \\
\hline $\mathrm{DC}-300$ & 84,27 \\
\hline $\mathrm{DC}-500$ & 83,00 \\
\hline
\end{tabular}




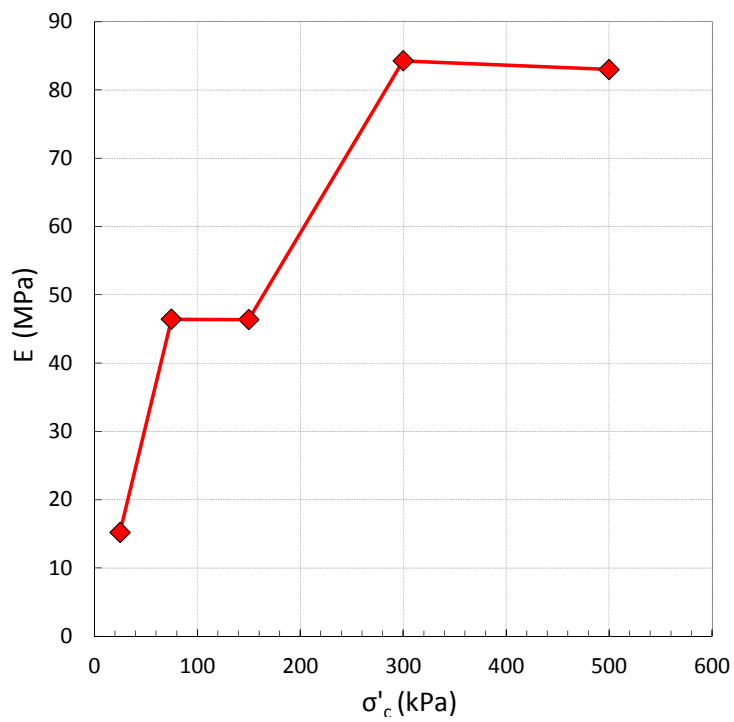

Figura 6.44 - Variação do módulo de Young secante correspondente a 50\% da máxima tensão desviadora para o solo residual jovem de Duque de Caxias

\section{Estado Crítico}

Carvalho (2012) determinou a linha de estado crítico ou de condição última seguindo os critérios seguintes: para os ensaios onde a curva tensãodeformação apresentou um pico bem definido, a resistência da condição última foi assumida como sendo a correspondente a cerca de $2 \%$ de deformação axial após a ruptura. De acordo com o observado por Leroueil e Hight (2003), o tipo de ruptura onde se apresenta uma queda abrupta de resistência após a ruptura, faz com que a resistência pós pico se aproxime ou coincida com o crítico. Nos ensaios de difícil identificação deste ponto, assim como nos que possuem um comportamento atípico, como ganho de resistência após uma queda ou estabilização da mesma após a ruptura, e que ainda podem estar associados ou não à não estabilização da resistência não drenada e do excesso de poropressão, adotou como critério a estabilização da razão entre as tensões efetivas principais.

Para a determinação da linha do estado crítico, a autora empregou, além de ensaios CIU, ensaios CID em amostras reconstituídas. A linha do estado crítico no espaço e vs $\mathrm{p}_{\mathrm{c}}^{\prime}$ e $\mathrm{p}_{\mathrm{c}}^{\prime}$ vs $\mathrm{q}_{\mathrm{c}}$ do solo são apresentados na Figura 6.45.

$\mathrm{O}$ valor médio do parâmetro $\mathrm{M}$ obtido no espaço $\mathrm{p}_{\mathrm{c}}^{\prime}$ vs $\mathrm{q}_{\mathrm{c}}$, é de 1,46 , correspondente a $\phi_{c}^{\prime}=36,1^{\circ}$. Os parâmetros $\Gamma$ e $\lambda$ que definem a linha dos estados críticos no espaço e vs $\mathrm{p}_{\mathrm{c}}$, obtidos através do ajuste de uma reta são, respectivamente, 3,28 e 0,179 . 


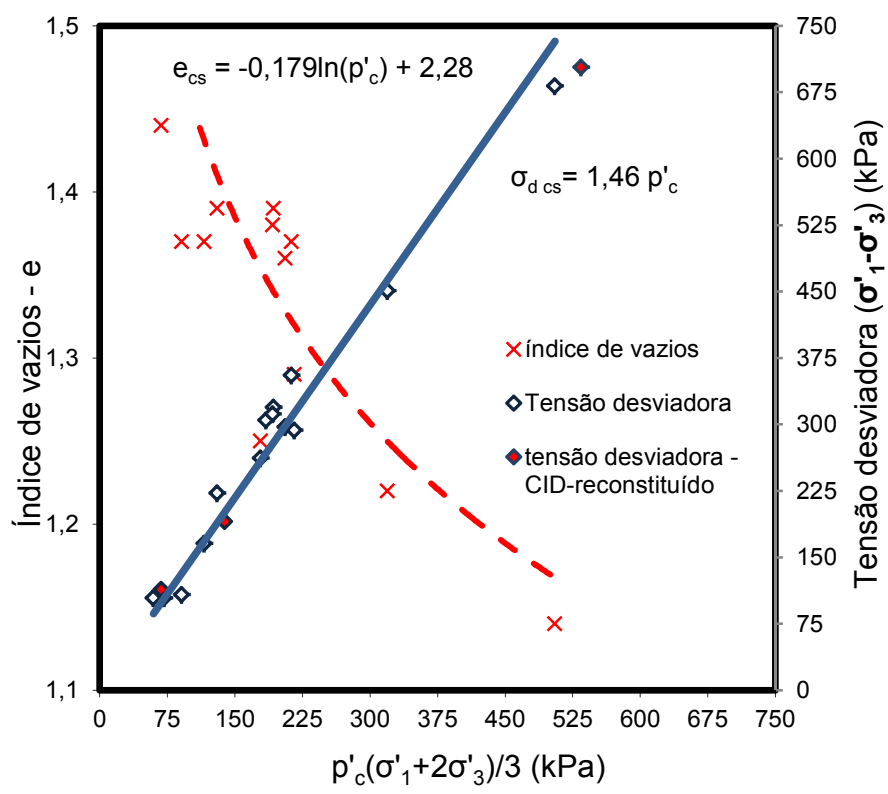

Figura 6.45 - Estimativa das linhas de estado crítico do solo residual de Duque de Caxias (Carvalho, 2012)

\section{Curva de Plastificação da Estrutura}

Um ponto de plastificação é identificado quando ocorre uma mudança significativa da rigidez na curva tensão-deformação. Em solos estruturados (cimentados) é possível identificar, também um ponto de plastificação na curva tensão-deformação associado à estrutura. Nestes solos, este ponto corresponde ao nível de tenso efetiva para o qual ocorrem danos na estrutura.

Uma vez definidos os pontos de plastificação do solo, suas posições em um gráfico p' vs q ou s' vs t permite caracterizar uma superfície ou curva de plastificação associada à estrutura. Esta superfície limita a região na qual a estrutura do solo é preservada. Nela, o solo apresenta menor deformabilidade para quaisquer trajetórias de tensão aplicada, porém se a trajetória de tensão aplicada ao solo atinge a mesma, grandes deformações passam a desenvolverse (Leroueil \& Vaughan, 1990; Leroueil \& Hight, 2003). Quando a trajetória de tensões atinge a superfície de plastificação da estrutura, o solo sofre uma desestruturação progressiva.

A partir dos ensaios CIU, Carvalho (2012), determinou a curva de plastificação no espaço s' vs t correspondente à região por cisalhamento, e é apresentada na Figura 6.46. Os pontos de escoamento destes ensaios foram determinados usando o critério sugerido por Graham et al. (1988), em escala aritmética, semilogaritmica e bi-logaritmica da curva $\sigma_{d}$ vs $\varepsilon_{a}$. Pode-se observar que a região da curva de plastificação da estrutura por cisalhamento, se situa acima da linha do estado crítico. 
Para uma melhor definição da curva de plastificação, Carvalho (2012) recomendou a execução de uma maior quantidade de ensaios CIU, CID e de s' constante, além de ensaios de adensamento isotrópico e anisotrópico, com tensões efetivas suficientemente elevadas para uma determinação adequada da tensão de cedência.

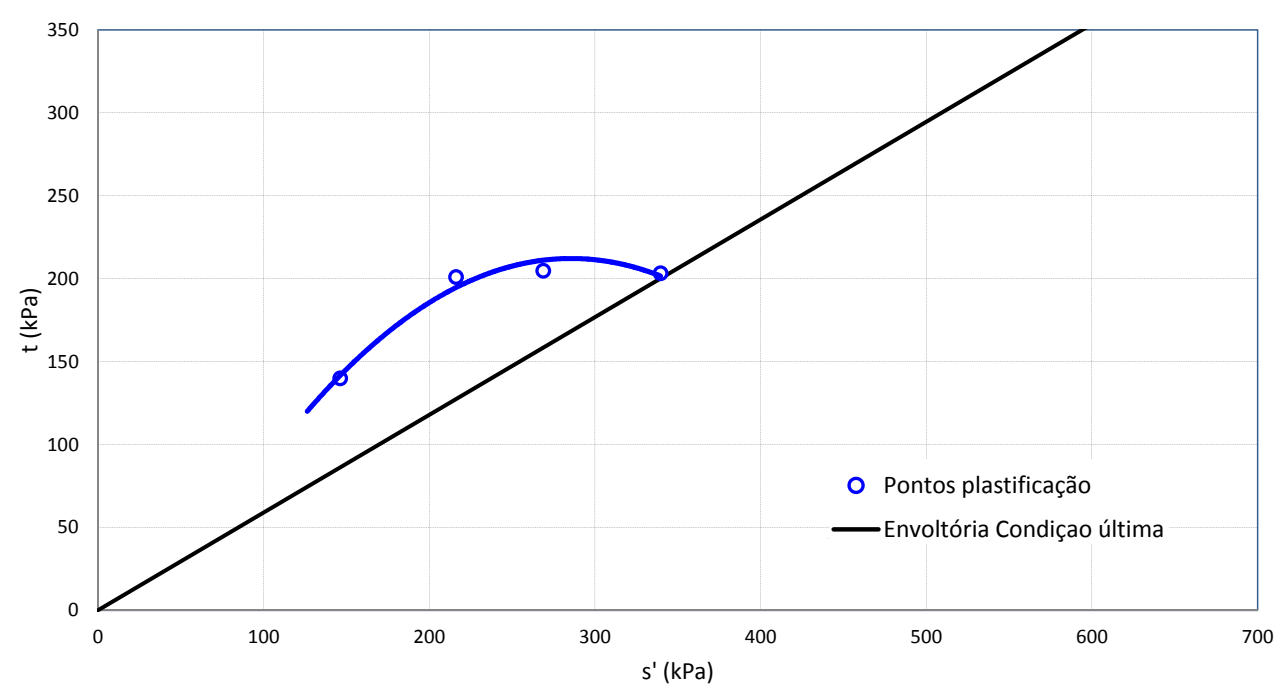

Figura 6.46 - Curva de plastificação correspondente à região de plastificação da estrutura por cisalhamento no solo residual jovem de Duque de Caxias (Carvalho, 2012)

\section{3. \\ Considerações finais dos ensaios de triaxiais convencionais e de cisalhamento direto com plano cortado e superfície polida}

Os ensaios apresentados e discutidos neste capítulo tiveram o objetivo de investigar as caraterísticas de resistência e o comportamento dos solos no seu estado crítico, de pico e residual. Mostraram-se resultados de ensaios triaxiais tipo CIU e CID realizados nesta tese nos solos coluvionares da PUC e Tinguá, bem como obtidos da literatura para o solo residual jovem de Duque de Caxias. Adicionalmente, apresentaram-se resultados de ensaios CKU realizados em corpos de prova do solo coluvionar de Tinguá. Ensaios de cisalhamento direto com plano cortado e superfície polida permitiram obter, além da resistência máxima, a resistência residual dos três solos estudados.

Nos ensaios de cisalhamento direto realizados sob condições inundadas, observou-se que, os solos coluvionares têm resistência ao cisalhamento semelhante, mas com caraterísticas particulares para cada solo. No solo coluvionar da PUC, a envoltória de resistência de pico é claramente curva para baixas tensões, seguida pela envoltória linear para tensões maiores. Já no solo coluvionar de Tinguá observou-se uma envoltória única levemente curva. Esta curvatura observada deve-se, provavelmente, à existência de cimentações 
ocasionadas pelo processo de laterização, reveladas nas comparações realizadas entre as análises granulométricas com e sem uso de defloculante. Os solos coluvionares, apesar de apresentarem altas porcentagens de argila, possuem ângulos de atrito residuais altos, possivelmente, também, pela sua estrutura agregada; de modo que não houve queda apreciável no valor de resistência, confundindo-se a envoltória de pico com a residual.

Para o solo residual de Duque de Caxias, o forte caráter não linear da envoltória de resistência de ruptura, para a faixa de tensões investigadas nos ensaios de cisalhamento direto, é um dos maiores reflexos da presença de cimentação. Tal estrutura já havia sido identificada na microscopia eletrônica de varredura (MEV). Por possuir partículas lamelares (mica) na sua fração areia e silte, apresentaram ângulo de atrito residual muito menor que o de pico.

Os efeitos da estrutura também foram observados nas envoltórias de resistência ao cisalhamento do solo, obtidas através dos ensaios triaxiais. A envoltória de resistência e a linha de estados críticos foram determinadas conjuntamente com os dados dos ensaios drenados e não drenados. Conforme já comentado, o trecho inicial da envoltória de resistência não é linear, e é mais acentuado no caso do solo residual jovem de Duque de Caxias. Esta não linearidade também foi encontrada na linha de estado crítico nos solos coluvionares. No caso do solo residual Duque de Caxias, Carvalho (2012) conseguiu determinar uma linha de estado último ou crítico, com intercepto nulo, empregando dados de ensaios executados com amostras reconstituídas.

Pelos resultados obtidos, verifica-se que a envoltória curva é uma excelente opção para a determinação da resistência ao cisalhamento dos solos coluvionares e residual.

$\mathrm{Na}$ tentativa de determinar parâmetros de resistência, obteve-se uma pequena parcela coesiva nos solos coluvionares, sendo esta um pouco maior no solo coluvionar da PUC. O alto valor de intercepto coesivo no solo residual de Duque de Caxias reflete a forte influência da estrutura no comportamento do solo.

As deformações volumétricas observadas durante a ruptura dos corpos de prova do solo residual de Duque de Caxias tem uma nítida tendência à expansão nos ensaios de cisalhamento direto com carregamentos menores que $150 \mathrm{kPa}$. Os solos coluvionares de Tinguá e da PUC tiveram comportamento de compressão independentemente da tensão normal aplicada. A mesma tendência foi observada nos ensaios triaxiais. 


\section{7 \\ Apresentação e avaliação dos resultados: Ensaios triaxiais com aumento de poropressão}

Este capítulo apresenta os resultados dos ensaios triaxiais com aumento de poropressão realizados nos três solos estudados, os quais serão analisados à medida que forem mostrados.

No total foram considerados como satisfatórios vinte e oito ensaios triaxiais de aumento de poropressão, aqui denominados de ensaios APP. Foram oito para o solo da PUC, oito para Tinguá e doze para o solo de Duque de Caxias.

\section{1.}

\section{Solo do Campo Experimental II PUC-Rio}

Neste item são apresentados e analisados os resultados dos ensaios triaxiais de aumento de poropressão, realizados em amostras saturadas do solo coluvionar do Campo Experimental II da PUC, adensadas anisotropicamente com relações de tensões principais, $\mathrm{K}_{\mathrm{c}}$, de 2,0 $\left(\mathrm{K}_{\mathrm{c}}=\sigma^{\prime}{ }_{1} / \sigma^{\prime}{ }_{3}\right)$

A Tabela 7.1 apresenta os índices físicos associados a cada uma das amostras ensaiadas, as tensões efetivas de adensamento que foram submetidas, assim como a denominação de cada um dos ensaios.

Tabela 7.1 - Índices físicos no início, após o adensamento e no final dos ensaios APP, dos corpos de prova do solo coluvionar da PUC

\begin{tabular}{|c|c|c|c|c|c|c|c|c|c|c|c|}
\hline \multirow[b]{2}{*}{ Ensaio } & \multirow{2}{*}{$\begin{array}{c}\mathrm{s}^{\prime} \\
(\mathrm{kPa}) \\
\frac{\sigma_{1}^{\prime}+\sigma_{3}^{\prime}}{2}\end{array}$} & \multirow{2}{*}{$\begin{array}{c}p^{\prime} \\
(\mathrm{kPa}) \\
\frac{\sigma_{1}^{\prime}+2 \sigma_{3}^{\prime}}{3}\end{array}$} & \multicolumn{6}{|c|}{ Índices físicos iniciais } & \multirow{2}{*}{\begin{tabular}{|c|}
$\begin{array}{c}\text { Após } \\
\text { adensamento }\end{array}$ \\
$\mathrm{e}_{\text {adens }}$ \\
\end{tabular}} & \multicolumn{2}{|c|}{ Finais } \\
\hline & & & $\begin{array}{l}w_{\circ} \\
(\%)\end{array}$ & $\begin{array}{c}\gamma_{\mathrm{n}} \\
\left(\mathrm{kN} / \mathrm{m}^{3}\right)\end{array}$ & $\begin{array}{c}\gamma_{\mathrm{d}} \\
\left(\mathrm{kN} / \mathrm{m}^{3}\right)\end{array}$ & $\mathrm{e}_{\mathrm{o}}$ & $\begin{array}{c}\mathrm{n} \\
(\%)\end{array}$ & $\begin{array}{c}S \\
(\%)\end{array}$ & & $e_{f}$ & $\begin{array}{l}w_{f} \\
(\%)\end{array}$ \\
\hline PUC25 & 25 & 22 & 26,90 & 17,84 & 14,05 & 0,949 & 48,69 & 77,66 & 0,953 & 0,980 & 35,21 \\
\hline PUC25II & 25 & 22 & 21,10 & 17,80 & 14,70 & 0,863 & 46,33 & 66,93 & 0,862 & 0,912 & 32,83 \\
\hline PUC50 & 50 & 44 & 24,32 & 17,94 & 14,43 & 0,898 & 47,31 & 74,18 & 0,880 & 1,001 & 34,92 \\
\hline PUC75 & 75 & 67 & 22,93 & 18,12 & 14,74 & 0,858 & 46,19 & 73,15 & 0,833 & 0,968 & 33,08 \\
\hline PUC100 & 100 & 89 & 23,65 & 17,98 & 14,54 & 0,884 & 46,91 & 73,31 & 0,726 & 0,775 & 32,29 \\
\hline PUC150 & 159 & 143 & 21,92 & 18,34 & 15,05 & 0,821 & 45,07 & 73,18 & 0,779 & 0,846 & 30,23 \\
\hline PUC220 & 220 & 196 & 24,22 & 18,34 & 14,77 & 0,855 & 46,09 & 77,60 & 0,776 & 0,813 & 30,69 \\
\hline PUC300 & 300 & 267 & 22,16 & 18,09 & 14,81 & 0,850 & 45,94 & 71,43 & 0,737 & 0,788 & 29,49 \\
\hline
\end{tabular}


A correção de área dos corpos de prova foi realizada utilizando a fórmula proposta por Bishop e Henkel (1962) para o tipo de ruptura observada nos ensaios, que neste caso foi de "embarrigamento". Não foram aplicadas correções de tensão devidas à influência da membrana de látex.

Na Figura 7.1 são apresentados três conjuntos de resultados dos ensaios de aumento de poropressão: trajetórias de tensão, curvas tensão-deformação axial e curvas tensão-deformação volumétrica. Devido à rápida ruptura do ensaio realizado com a menor tensão efetiva inicial (PUC25), executou-se um segundo ensaio com a mesma tensão (PUC25II - o número romano indica a ordem em que o ensaio foi realizado).

As tensões efetivas foram estimadas com os valores de poropressão registrados a meia altura do corpo de prova.

Neste trabalho, as deformações axiais foram determinadas por meio da medição externa dos deslocamentos com uso do LSCDT, e por meio da medição interna através dos resultados de dois eletroníveis. Para a apresentação dos resultados na Figura $7.1(\mathrm{~b})$, foram utilizados apenas os resultados obtidos com os eletroníveis.

Como o corpo de prova rompeu por "embarrigamento", os eletroníveis tenderam a apresentar resultados semelhantes entre si; sendo a deformação axial determinada através da média dos resultados de ambos.

Na Figura 7.1(c) é apresentada a deformação volumétrica obtida mediante o medidor de variação de volume.

Analisando a Figura 7.1(a), verifica-se que de acordo com as trajetórias de tensão, durante a etapa de aumento de poropressão, há uma diminuição da tensão média efetiva nas amostras. O início dos ensaios APP, ou fim de adensamento anisotrópico de cada ensaio, está representado por um losango. Como esperado, as trajetórias de tensão seguidas no espaço $p^{\prime}$ vs $q$ permaneceram essencialmente horizontais. No entanto, quando a ruptura foi iniciada, uma queda na tensão de cisalhamento ocorreu como resultado do aumento na área da secção transversal do corpo de prova. Na figura é mostrada, como referência, a linha que representa a condição $\sigma_{3}^{\prime}=0$ (as poropressões na amostra se igualam à tensão confinante aplicada na câmara triaxial, $\sigma_{3}=u$ ). 

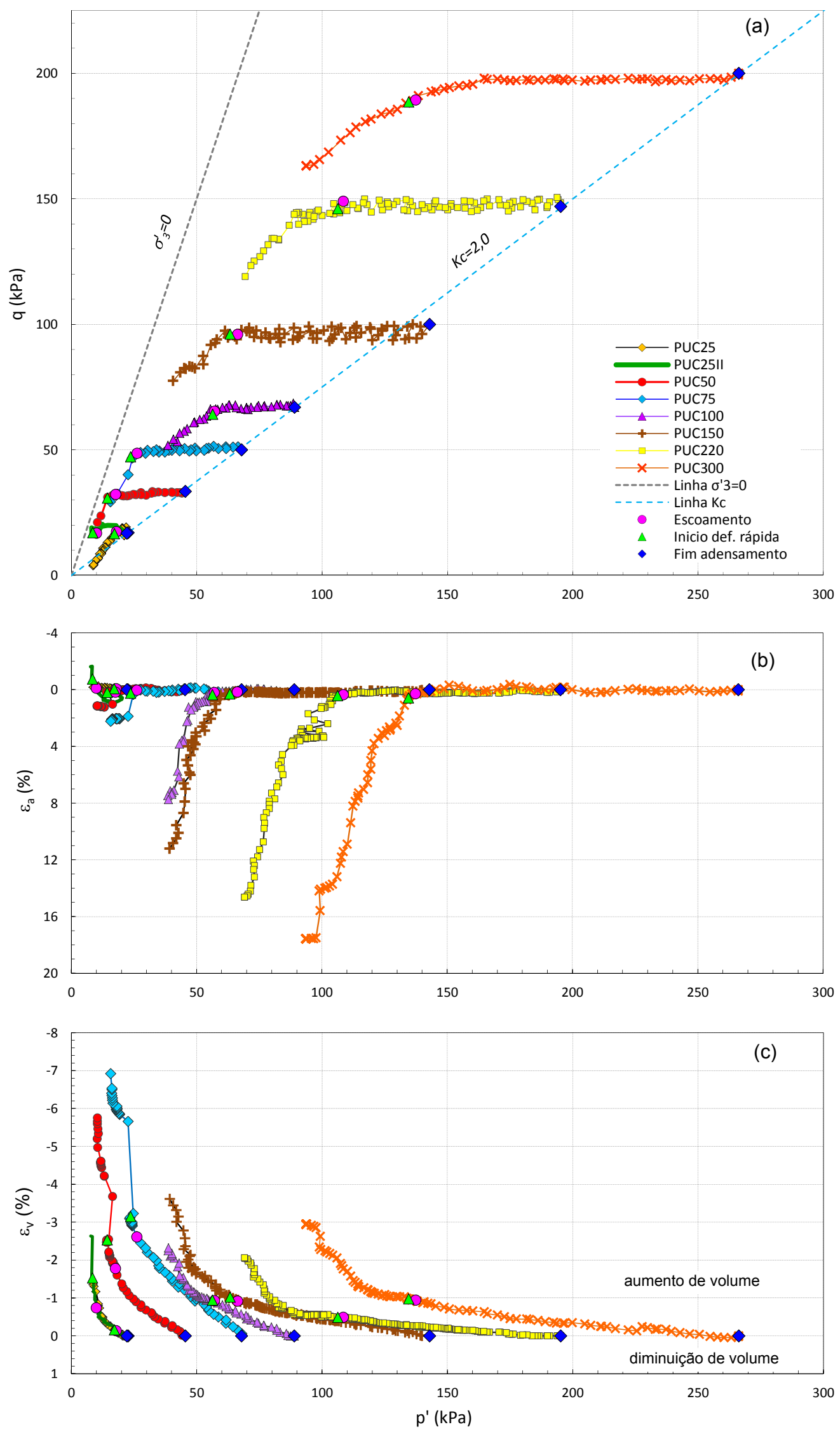

Figura 7.1 - Resultados dos ensaios APP no solo coluvionar da PUC: (a) Trajetórias de tensão vs tensão média efetiva, (b) Deformação axial vs tensão média efetiva, (c) Deformação volumétrica vs tensão média efetiva 
A relação tensão vs deformação axial mostrada na Figura 7.1(b) indica que, depois de decorrido algum tempo e ter sido gerada suficiente poropressão, a deformação axial aumentou primeiro gradualmente e posteriormente sofreu um rápido incremento que levou o corpo de prova até a ruptura. O ponto de início da ruptura ou de "início de deformação rápida" é designado na figura por um triângulo, e refere-se ao estado em que a taxa de deformação axial começa a aumentar rapidamente. Pode-se observar que o ensaio PUC25II, inicialmente apresentou deformação axial positiva e, em seguida, mudou de comportamento para deformação negativa (extensão axial), diferentemente dos outros ensaios.

A Figura 7.1(c) mostra a variação da deformação volumétrica vs a tensão média efetiva. As deformações de compressão são consideradas positivas, enquanto que as deformações de expansão são negativas.

$\mathrm{Na}$ fase inicial dos ensaios se observa uma leve deformação volumétrica devido à redução de tensão efetiva média, p'. A partir de certo valor de p', a taxa de deformação se incrementou significativamente, especialmente nos ensaios com menores tensões efetivas de confinamento.

Nas figuras também é mostrado o ponto de plastificação ou escoamento, representado por um círculo. O ponto de plastificação está associado com a mudança na rigidez volumétrica do solo, e é determinado com o comportamento volumétrico da amostra, que é a primeira resposta nos ensaios de aumento de poropressão. Nesta pesquisa, os pontos de plastificação foram obtidos apenas com o intuito de distinguir se os corpos de prova dilataram ou contraíram durante o ensaio de aumento de poropressão.

Segundo Junaideen (2005), a redução de p', sob uma condição de q constante, origina um aumento de volume do corpo de prova. Dentro da zona limite de plastificação, a resposta do solo é geralmente assumida elástica. A porção do ensaio localizado nesta zona poderia ser chamada de descarregamento elástico, e é linear no plano $\ln \left(p^{\prime}\right)$ vs $\varepsilon_{v}$ (vide Figura 7.2), onde o gradiente da linha é denotada como $k \varepsilon_{v}$. Nestes ensaios, o ponto de plastificação pode ser definido como o ponto onde a linha de descarregamento torna-se não linear no plano $\ln \left(p^{\prime}\right)$ vs $\varepsilon_{v}$. Para qualquer decréscimo de $p^{\prime}$ após o ponto de plastificação, $\left(p^{\prime} \Delta \varepsilon_{v} / \Delta p^{\prime}\right)>k \varepsilon_{v}$ indica uma resposta dilatante, e $\left(p^{\prime} \Delta \varepsilon v / \Delta p^{\prime}\right)<k \varepsilon_{v}$ indica uma resposta contrátil. O método usado para definir o ponto de plastificação encontra-se resumido na Figura 7.2. 


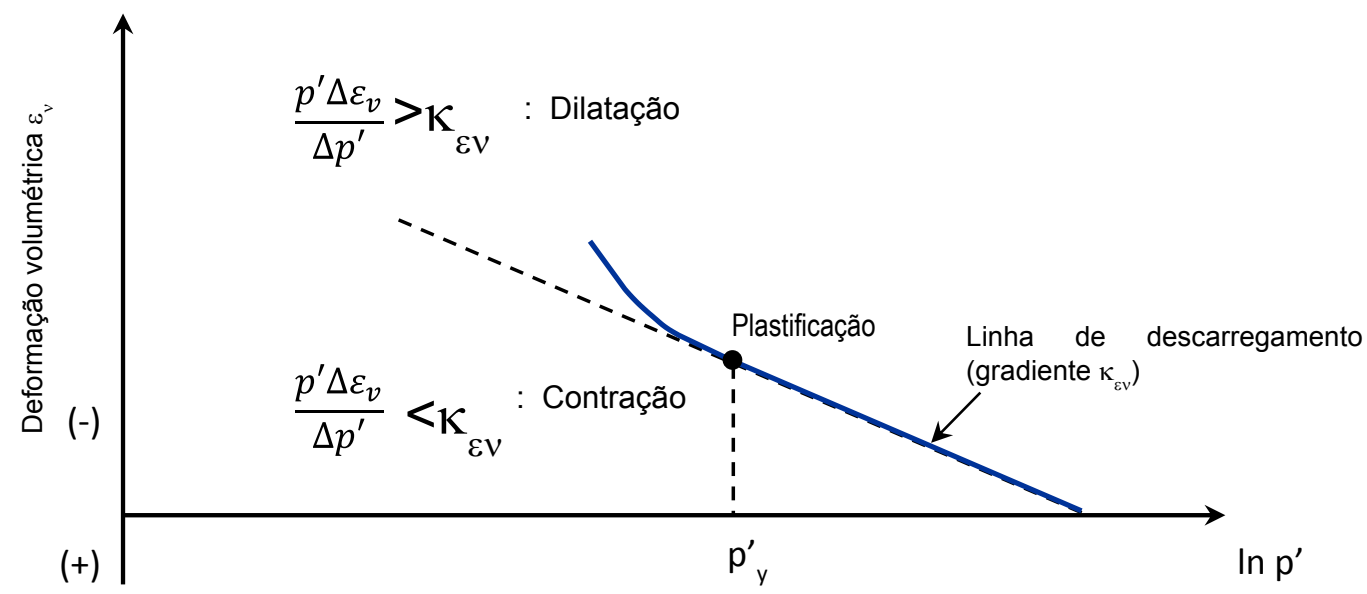

Figura 7.2 - Desenho esquemático do ponto de plastificação e mudança de volume em um ensaio de aumento de poropressão (adaptado de Junaideen et al., 2010)

A partir da definição do ponto de plastificação e da análise do comportamento de curvas de deformação volumétrica, considerando os critérios acima descritos, pôde-se determinar que todos os corpos de prova do solo coluvionar da PUC sofreram um aumento de volume depois de atingido o escoamento. Nota-se, também, que o início da ruptura encontra-se muito próximo ao ponto de plastificação.

\section{Comparação das deformações obtidas com instrumentação interna e externa}

Nas Figuras 7.3 e 7.5 são mostrados gráficos comparativos das deformações axial $\left(\varepsilon_{a}\right)$ e volumétrica $\left(\varepsilon_{v}\right)$, obtidas com a instrumentação interna (eletroníveis e transdutor de deslocamento radial) e externa (LSCDT e MVV). Nas ilustrações, $\varepsilon_{a}$ e $\varepsilon_{v}$ são representadas graficamente versus a tensão média efetiva. Todas as deformações mostradas foram induzidas unicamente pelo aumento da poropressão. Mostram-se demarcados, somente nas curvas obtidas com a instrumentação interna, os pontos correspondentes ao início do ensaio de APP (ou final do adensamento anisotrópico), início do escoamento e início da ruptura ou deformação rápida.

Na Figura 7.3 pode-se apreciar a diferença entre as deformações axiais obtidas com as diferentes metodologias de medição. 


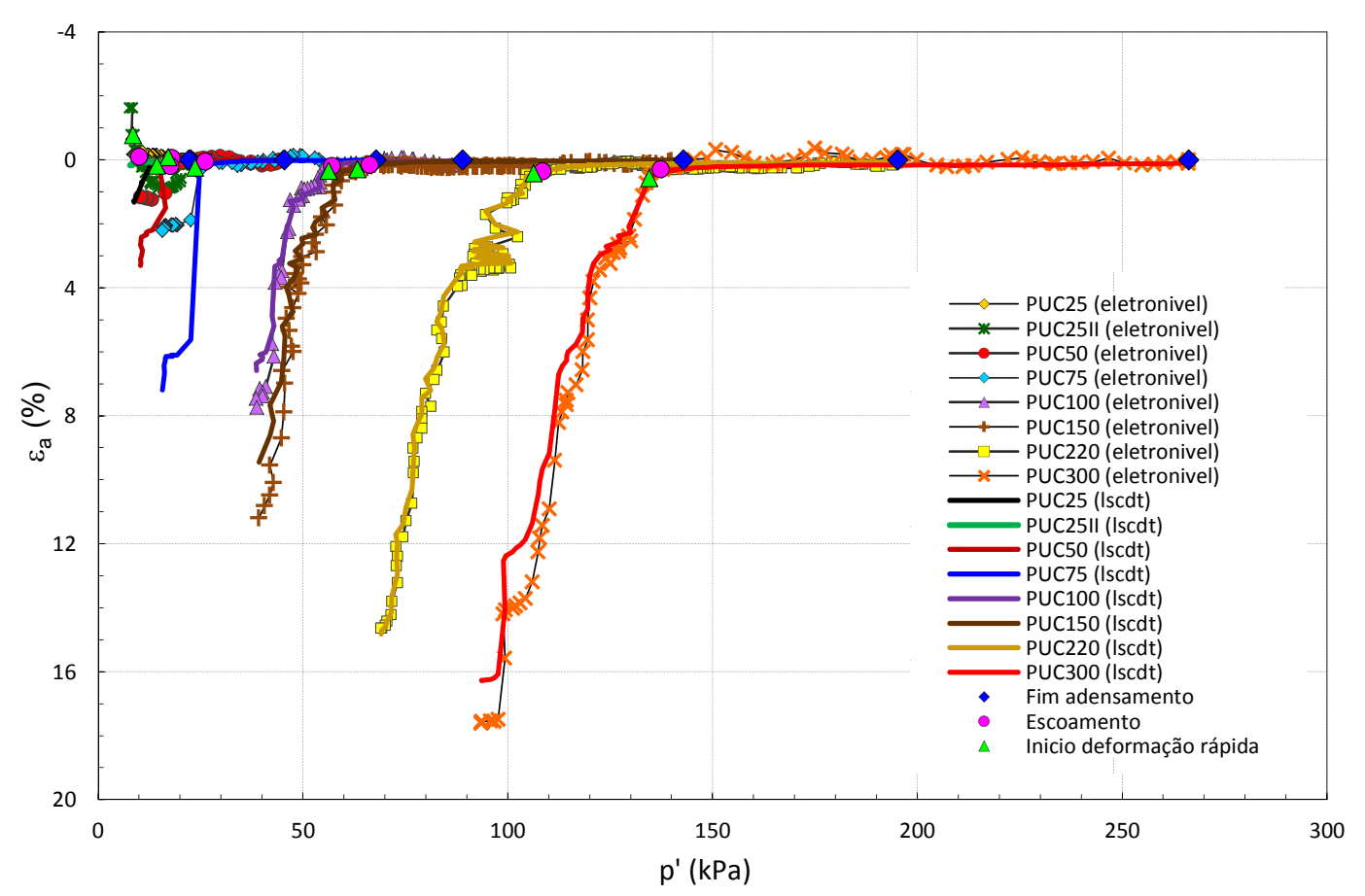

Figura 7.3 - Comparação entre as curvas de deformação axial obtidas com a instrumentação interna (eletroníveis) e instrumentação externa (LSCDT) nos ensaios APP do solo coluvionar da PUC

No início do ensaio há concordância entre as duas metodologias; porém, após o início da ruptura observa-se uma clara divergência, principalmente nos ensaios com menores tensões de confinamento. A deformação inicial positiva e posteriormente negativa (evidenciando expansão do corpo de prova), detectada pelos eletroníveis no ensaio PUC25II, não foi percebida com o LSCDT, que unicamente exibiu deformações de compressão.

As velocidades de deformação após o inicio da ruptura foram determinadas da inclinação das curvas de deformação axial vs tempo, tanto para as deformações obtidas com a instrumentação interna como com o transdutor de deslocamento externo. A Figura 7.4 mostra uma das curvas $\varepsilon_{\mathrm{a}}$ vs tempo do ensaio, traçada com as leituras registradas pelos eletroníveis. Como neste caso, a taxa de deformação após o início da ruptura não chegou a atingir um valor constante em alguns dos ensaios. O comportamento de aceleração foi perturbado por períodos ocasionais de desaceleração.

As velocidades de deformação, uma vez que a ruptura ocorreu, foram relativamente lentas, porém, maiores nos ensaios PUC50 e PUC75 (entre 0,14 a $0,23 \% /$ min para os eletroníveis e de 0,25 a $0,90 \% / m i n$ para o LSCDT). As menores velocidades ocorreram nos ensaios com maiores tensões efetivas de confinamento inicial $(0,0020 \% / m i n$ para o caso de leituras com eletroníveis e de $0,0025 \% /$ min para LSCDT). 


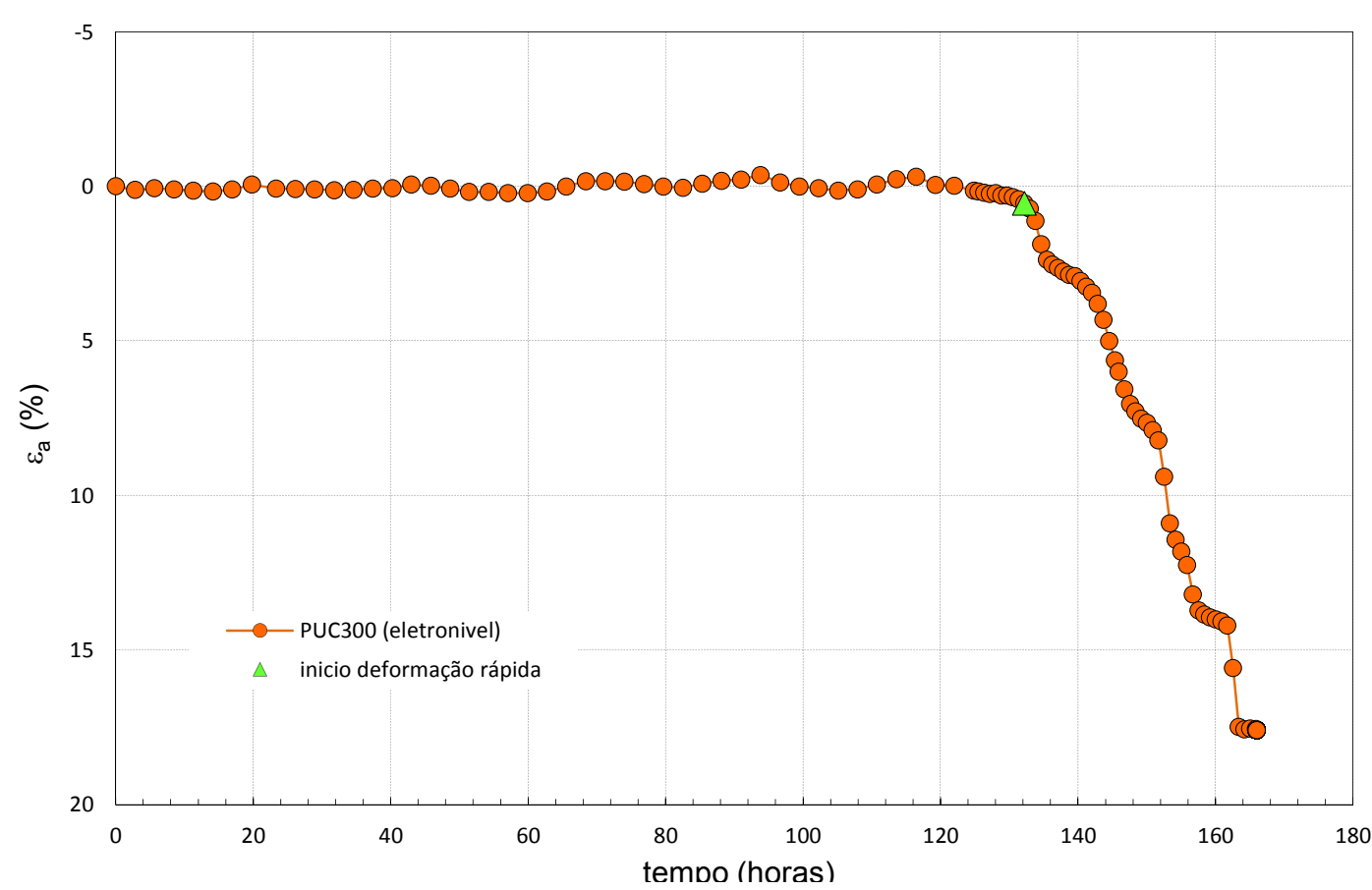

Figura 7.4 - Exemplo de curva $\varepsilon_{a}$ vs tempo utilizada no cálculo da velocidade de deformação axial após inicio da ruptura (ensaio PUC300)

Considera-se que a medição interna dos deslocamentos é menos afetada por erros inerentes às condições de contorno da amostra e representa razoavelmente bem as deformações desta, especialmente a baixos níveis de deformação. Não entanto em virtude da diminuição da tensão confinante efetiva, existe a possibilidade de um deslocamento relativo entre o solo e a membrana quando a tensão efetiva média é muito baixa, o que pode ter causado as principais diferenças encontradas entre ambas as metodologias de medição no final dos ensaios, principalmente nos de menores tensões confinantes.

A comparação entre as medidas de deformação volumétrica, $\varepsilon_{v}$, obtidas com o medidor de variação de volume tipo Imperial College (MVV) e com a instrumentação interna é ilustrada na Figura 7.5.

A deformação volumétrica estimada com o MVV foi calculada a partir do volume de água que entrou e saiu do corpo de prova. Por outro lado, a deformação volumétrica, obtida com os transdutores internos montados diretamente no corpo de prova, foi calculada da seguinte forma, considerando-se negativas as deformações expansivas,

$$
\varepsilon_{\mathrm{v}}=\varepsilon_{\mathrm{a}}+2 \varepsilon_{\mathrm{r}}
$$

Onde $\varepsilon_{\mathrm{a}}$ é a deformação axial determinada com os eletroníveis, e $\varepsilon_{\mathrm{r}}$ é a deformação radial obtida a partir da mudança do diâmetro medido no meio do corpo de prova. 


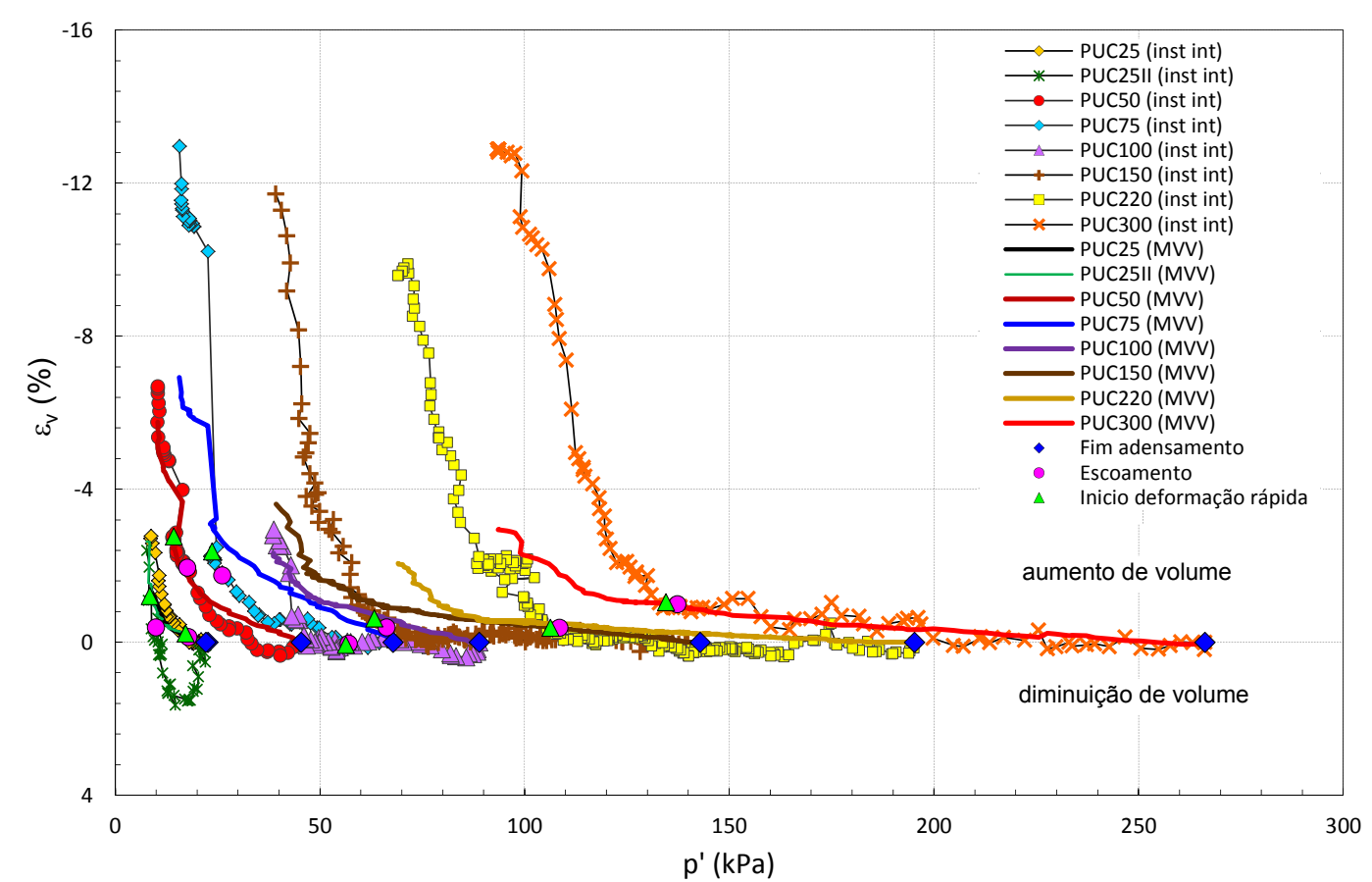

Figura 7.5 - Comparação entre as curvas de deformação volumétrica obtidas com a instrumentação interna (eletroníveis e transdutor de deslocamento radial) e o medidor de variação de volume tipo Imperial College (MVV) nos ensaios APP do solo coluvionar da PUC

A comparação entre os dois sistemas de obtenção de deformação volumétrica mostraram tendências não coincidentes, principalmente nos ensaios de menor tensão média efetiva, e depois do início da deformação rápida ou ruptura. Pode-se observar que a variação volumétrica deduzida pelo MVV é inferior à avaliada pela instrumentação interna, nos ensaios com tensão confinante inicial maior que $75 \mathrm{kPa}$. Na figura, percebe-se ainda um comportamento de diminuição de volume, seguido pelo aumento deste, experimentado pela amostra PUC25II; que foi registrado pela instrumentação interna, mas não pelo MVV.

As diferenças nas deformações, encontradas pelas duas metodologias, podem estar relacionadas ao fato de que o cálculo da variação volumétrica mediante a instrumentação interna assume que a amostra se deforma como um cilindro. No entanto, quando uma amostra tende a deformar por "embarrigamento" (originado pelas restrições nas extremidades do corpo de prova), a hipótese de deformação como cilindro torna-se progressivamente mais erronea. Apenas uma medida de deformação radial no centro do corpo de prova não seria representativa o bastante para ensaios que demandam alta acurácia. Adicionalmente, tal como no caso anterior, os efeitos de perda de confinamento e deslocamento da membrana influenciariam nas leituras da instrumentação interna, que se tornaria não confiável. 


\section{Trajetórias de deformação $\varepsilon_{v}$ vs $\varepsilon_{s}$}

Na Figura 7.6 são apresentadas as trajetórias de deformação $\varepsilon_{v} v s \varepsilon_{s}$, onde a deformação volumétrica foi determinada com o MVV, e a deformação de cisalhamento $\left(\varepsilon_{\mathrm{s}}\right)$ foi estimada das deformações axiais e radiais obtidas com a instrumentação interna, a partir de,

$$
\varepsilon_{\mathrm{s}}=2 / 3\left(\varepsilon_{\mathrm{a}}-\varepsilon_{\mathrm{r}}\right)
$$

Pode-se observar que o aumento da tensão confinante inicial faz com que o comportamento do solo seja menos dilatante.

A maioria das amostras apresentou inicialmente quase nenhuma mudança de volume. No entanto, uma vez que a ruptura foi iniciada, mostraram aumento de volume. Como nas figuras anteriores, pode-se perceber o comportamento diferenciado de uma das amostras com menor tensão média inicial (PUC25II).

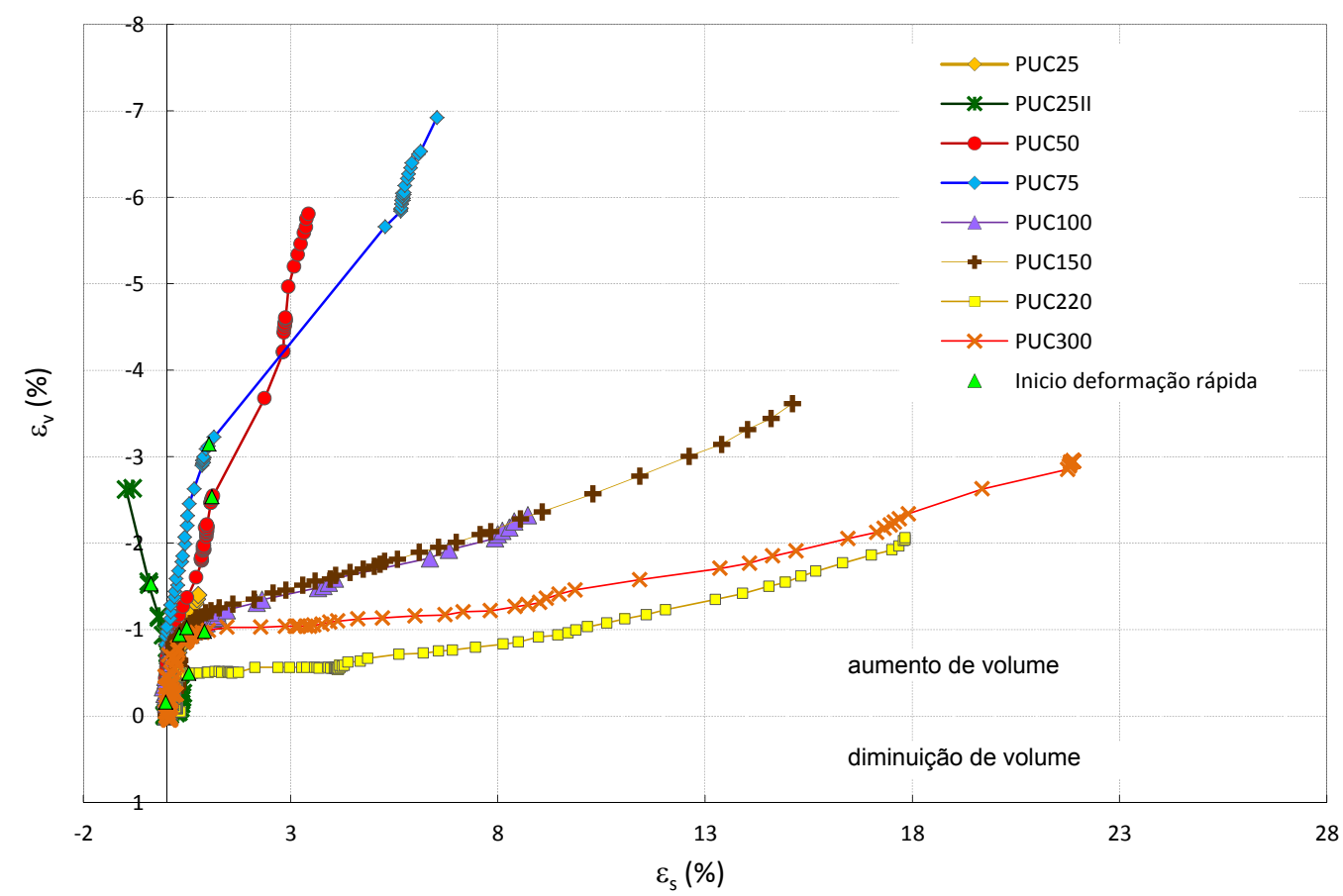

Figura 7.6 - Relação entre a deformação volumétrica e a deformação de cisalhamento nos ensaios APP do solo coluvionar da PUC

\section{Comportamento no espaço e vs $p^{\prime}$}

A Figura 7.7 mostra as mudanças da trajetória de tensão dos corpos de prova no espaço e vs p'. Na figura apresentam-se os índices de vazios calculados mediante o MVV, com a tensão efetiva média, p', representada em escala aritmética e logarítmica.

Na figura é mostrada, também, a linha de estado crítico obtida através de um ajuste linear na escala logarítmica, assumindo que as amostras estão na condição de estado crítico no final dos ensaios. Esta suposição é consistente 
com a realizada por vários autores (Andersom e Sitar, 1995; Zhu e Anderson, 1988, Orense et al., 2004).
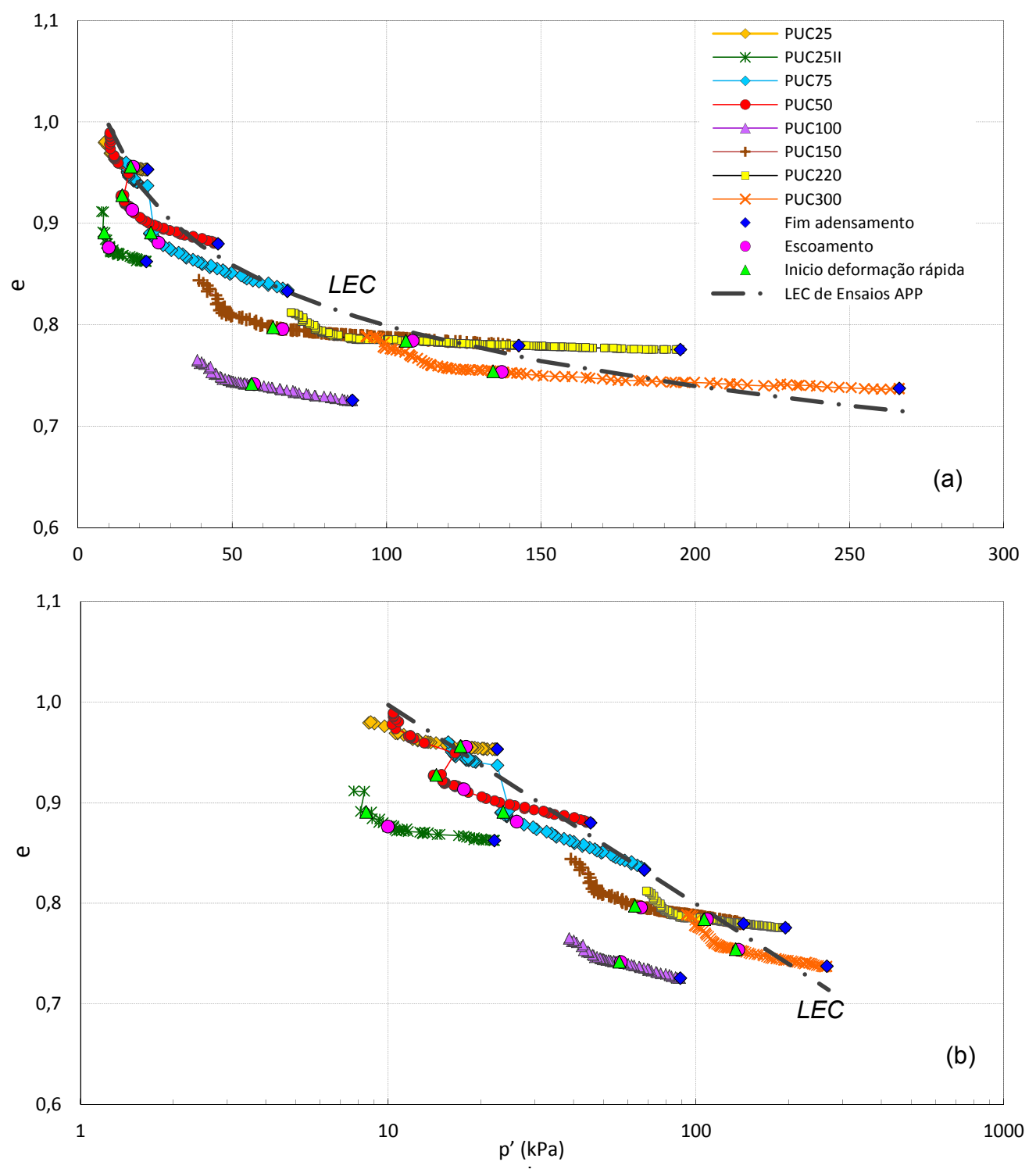

Figura 7.7 - Trajetórias de tensão dos ensaios APP do solo coluvionar da PUC no espaço e vs p', (a) p' em escala aritmética, (b) p' em escala logarítmica

As Figuras 7.7 (a) e (b) mostram que a maioria dos ensaios se inicia acima da linha de estado crítico, mas se desenvolvem abaixo dela. Pode-se notar que p' diminui com o aumento da poropressão e o índice de vazios inicialmente muda muito pouco. No entanto, quando $p^{\prime}$ atinge o início da ruptura $(\Delta)$ a maioria das curvas tende a continuar em direção à linha de estado crítico, aumentando o índice de vazios. Note-se que o corpo de prova PUC25 teve um excepcionalmente elevado índice de vazios, e, consequentemente, uma ruptura mais rápida. 
Conforme mencionado anteriormente, no item 2.4 do capítulo de revisão bibliográfica, a partir do índice de vazios e da tensão efetiva é possível determinar o parâmetro de estado do solo, $\psi$, e o parâmetro de estado modificado, $\bar{\psi}$. Segundo Leroueil (2001), este último caracteriza o comportamento do solo nos ensaios APP. Elementos de solo com condições de estado abaixo da LEC $(\bar{\psi}<0)$ são associados a um comportamento dilatante, enquanto elementos de solo com condições de estado acima da LEC $(\bar{\psi}>0)$ são associados a um comportamento contrátil.

Através da análise da figura, definiu-se o parâmetro de estado modificado, $\bar{\psi}$, proposto por Chu et al. (2003) como $\bar{\psi}=e_{y}-e_{s s}$, onde $e_{y}$ é o índice de vazios no ponto de escoamento, e e $e_{s s}$ é o índice de vazios no estado crítico sob a mesma tensão média efetiva. A diferença entre o parâmetro de estado modificado $(\bar{\psi})$ e o parâmetro de estado $(\psi)$ definido por Been e Jefferies (1985), é que $\bar{\psi}$ define o estado no escoamento, diferentemente do proposto por Been e Jefferies (1985) que seria no estado após o adensamento. A definição esquemática do parâmetro de estado é mostrada na Figura 2.14.

$\mathrm{Na}$ Tabela 7.2 são mostrados os parâmetros de estado modificado, $\bar{\psi}$, obtidos na Figura 7.7. São mostrados também, para fins de referência, os parâmetros de estado, $\psi$, definidos considerando o início do ensaio e a relação das tensões efetivas no escoamento, $n=q_{y} / p_{y}^{\prime}$. Pode-se observar que $\bar{\psi}$ varia de 0,12 a $0(\bar{\psi}<0)$, indicando o comportamento dilatante da maioria dos ensaios depois de alcançado o ponto de escoamento. Apenas o ensaio PUC25 apresentou o parâmetro de estado modificado próximo de zero.

Tabela 7.2 - Parâmetros de estado, $\psi$, e parâmetros de estado modificado, $\bar{\psi}$, obtidos das trajetórias de tensão no espaço e vs p' dos ensaios APP do solo coluvionar da PUC

\begin{tabular}{|c|c|c|c|c|c|}
\hline Ensaio & $\begin{array}{c}\mathrm{py}^{\prime} \\
(\mathrm{kPa})\end{array}$ & $\begin{array}{c}\mathrm{q}_{\mathrm{y}} \\
(\mathrm{kPa})\end{array}$ & $\eta=q_{y} / p_{y}{ }^{\prime}$ & $\psi$ & $\bar{\psi}$ \\
\hline PUC25 & 17,92 & 17,39 & 0,97 & 0,03 & $\approx 0$ \\
\hline PUC25II & 9,97 & 16,80 & 1,69 & $-0,07$ & $-0,12$ \\
\hline PUC50 & 17,61 & 32,29 & 1,83 & 0,01 & $-0,04$ \\
\hline PUC75 & 26,14 & 48,62 & 1,86 & 0 & $-0,03$ \\
\hline PUC100 & 57,07 & 65,43 & 1,15 & $-0,08$ & $-0,11$ \\
\hline PUC150 & 66,30 & 95,97 & 1,45 & 0,01 & $-0,04$ \\
\hline PUC220 & 108,49 & 149,11 & 1,37 & 0,03 & $-0,01$ \\
\hline PUC300 & 137,36 & 189,41 & 1,38 & 0,02 & $-0,02$ \\
\hline
\end{tabular}




\section{Comportamento da poropressão}

As figuras acima revelam que os corpos de prova do solo da PUC apresentaram comportamento volumétrico dilatante, uma vez que o ponto de escoamento foi atingido. Assim, a maioria das amostras sofreram deformações lentas, provavelmente devido a uma tendência de diminuição de poropressão, associada com o processo de cisalhamento. Porém, somente nos ensaios PUC50 e PUC75 foi observada uma leve diminuição do excesso de poropressão dentro do corpo de prova (gerada provavelmente pelo comportamento dilatante mencionado). Como indicado anteriormente, estes dois ensaios apresentaram as maiores taxas de deformação axial.

As Figuras 7.8 (a) e (b) mostram o comportamento da poropressão no decorrer do tempo desses ensaios, assim como, a deformação volumétrica e axial, determinadas a partir de medidas com o MVV e os eletroníveis, respectivamente. Também, são indicados por linhas tracejadas, os momentos de início do escoamento e da deformação rápida.
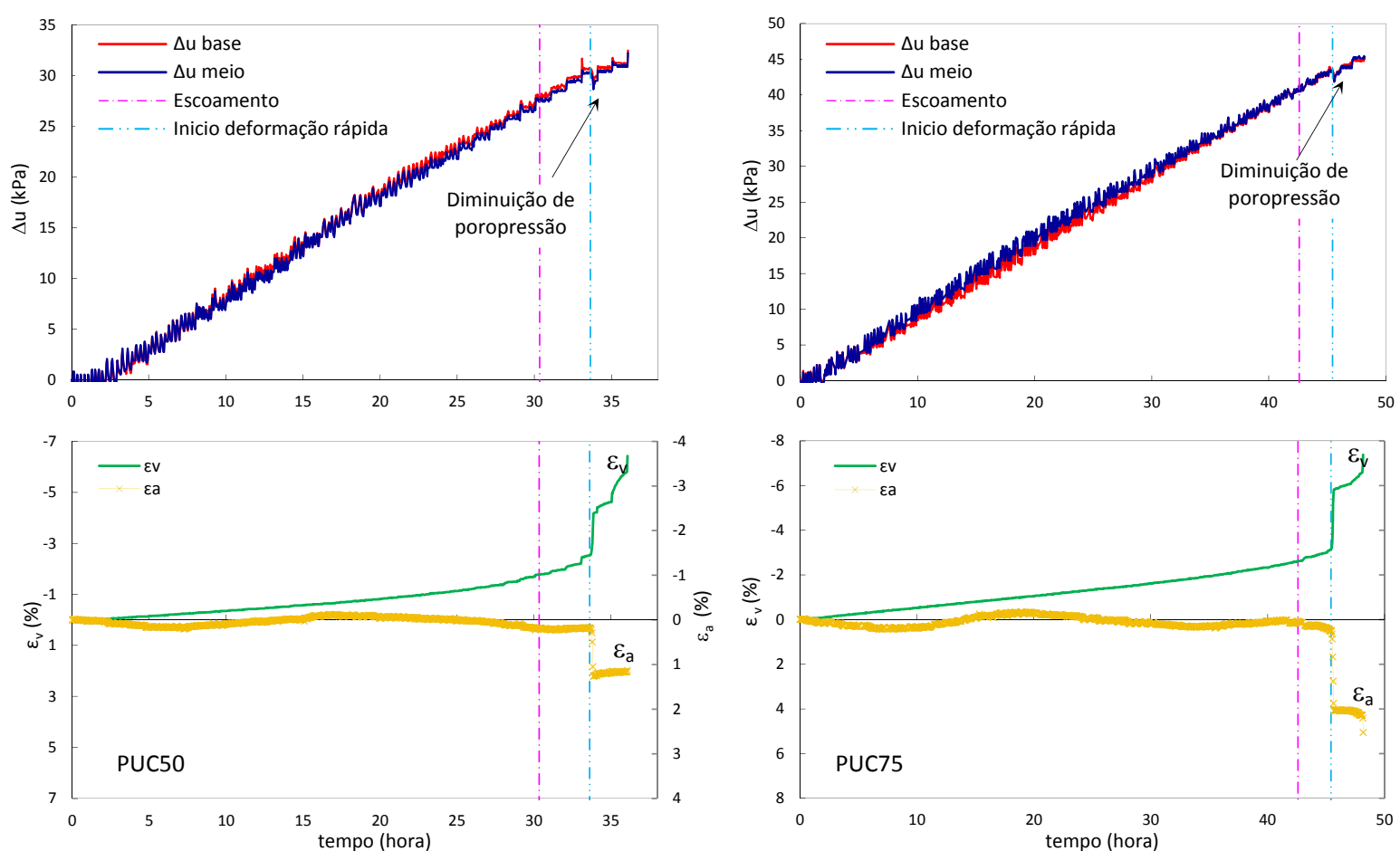

(a)

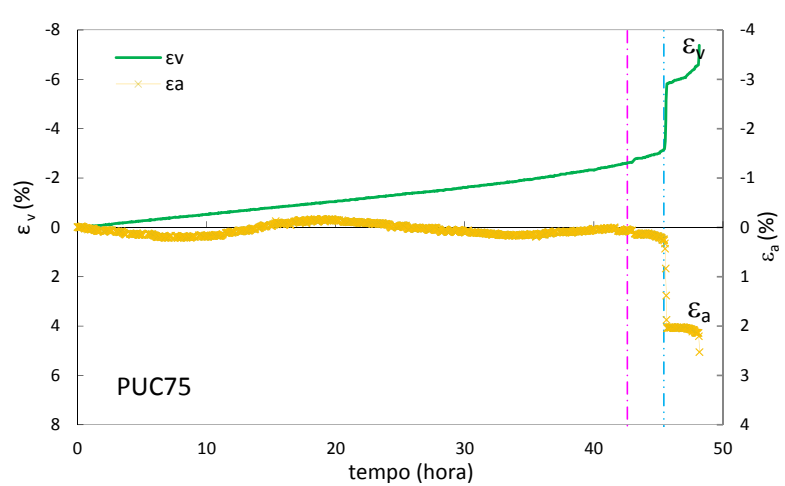

(b)

Figura 7.8 - Variação ao longo do tempo da poropressão a meia altura e na base do corpo de prova, da deformação axial e da deformação volumétrica dos ensaios : (a) PUC50 e (b) PUC75

$\mathrm{Na}$ Figura 7.8 pode-se observar o incremento da deformação axial, causada pelo aumento de volume durante a ruptura, e a consequente diminuição da poropressão. Esta diminuição de poropressão foi recuperada rapidamente, 
uma vez que o GDS continuou funcionando depois de atingida a ruptura, impondo a taxa especificada de aumento de poropressão.

As leituras de poropressão apresentadas nas figuras mostram que a variação da poropressão, medidas na parte do meio e inferior do corpo de prova, essencialmente é a mesma durante todo o ensaio. Isto é um indicativo de que a distribuição da pressão efetiva ao longo da altura da amostra foi uniforme para a taxa de aumento de poropressão utilizada.

\section{Envoltória dos ensaios de aumento de poropressão e linha de estado crítico no espaço $p$ ' vs $q$}

A linha de estado crítico e a envoltória definida com os pontos de início da deformação rápida dos ensaios APP são mostradas na Figura 7.9. As tendências das trajetórias mostradas na figura sugerem claramente a posição de uma linha de condição última ou de estado crítico.

$\mathrm{Na}$ figura verifica-se que as trajetórias de tensão e o ponto de escoamento dos ensaios PUC25II, PUC50 e PUC75 ultrapassaram a linha de estado crítico. Posteriormente, a tensão desviadora caiu quando o corpo de prova se deformou rapidamente, dado que o material já não pôde sustentar a tensão de cisalhamento que estava sendo aplicada, fazendo com que a trajetória se dirija em direção à linha de estado crítico. Coincidentemente, somente estes ensaios apresentaram diminuição da poropressão durante o início da ruptura. O ensaio PUC25 atingiu muito rápido o ponto de escoamento e a ruptura. $O$ ensaio PUC25II alcançou o ponto de escoamento na linha de estado crítico, perto da linha $\sigma_{3}^{\prime}=0$, e depois disso, a trajetória seguiu essa linha.

As amostras com maiores tensões médias efetivas atingiram o ponto de escoamento e romperam dirigindo-se em direção à linha de estado crítico para continuar posteriormente paralelas a ela.

Observa-se que a amostra PUC100, apesar de ter um índice de vazios menor no início da fase de aumento de poropressão (vide Figura 7.7), alcançou o ponto de escoamento e o início de ruptura antes que os outros ensaios. 


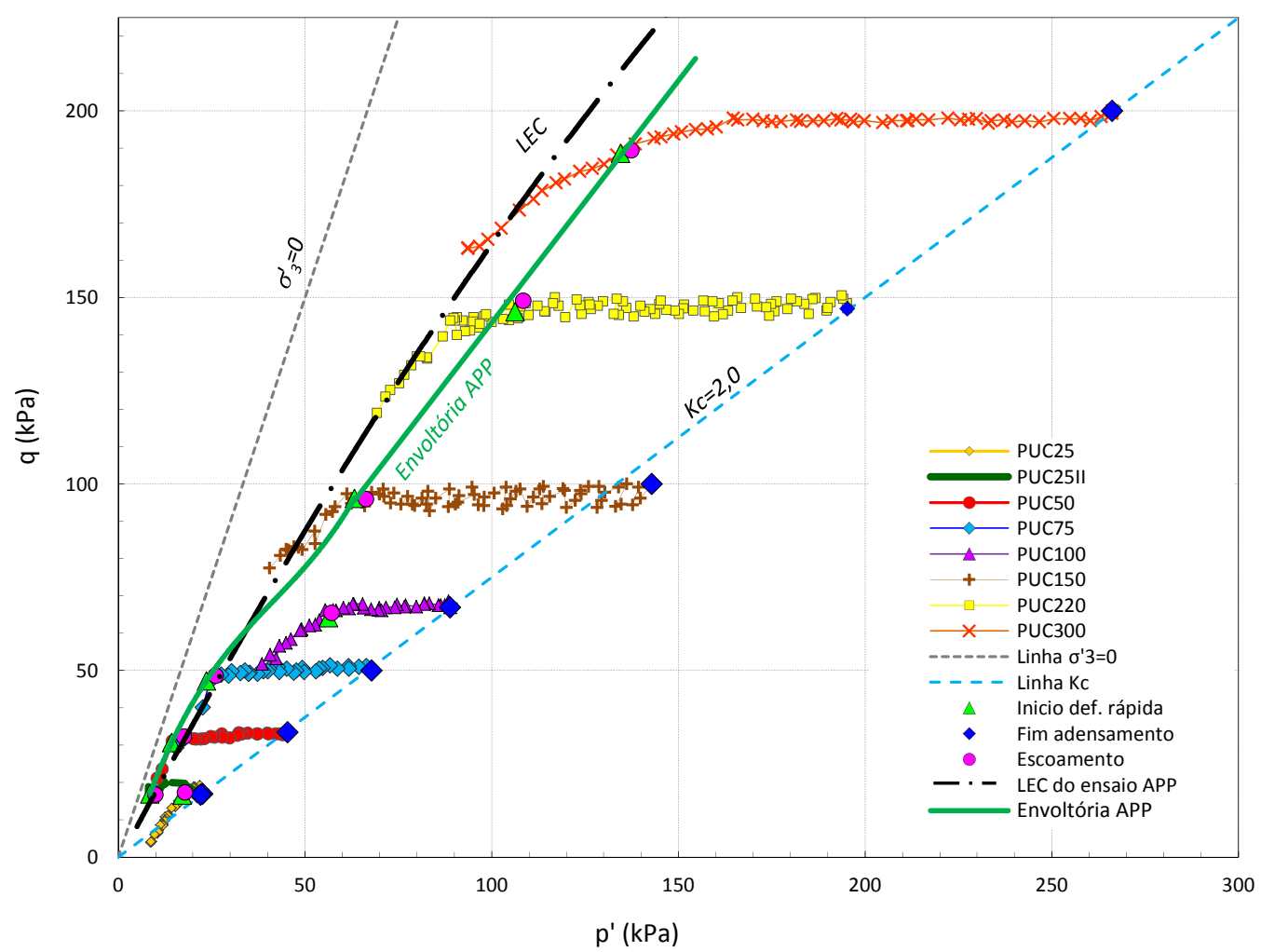

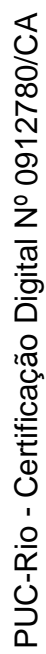

Figura 7.9 - Trajetórias de tensão dos ensaios APP do solo coluvionar da PUC, junto à linha de estado crítico e envoltória correspondente ao inicio da deformação rápida

O detalhe das trajetórias de tensão dos ensaios realizados com as menores tensões confinantes iniciais pode ser observado na Figura 7.10.

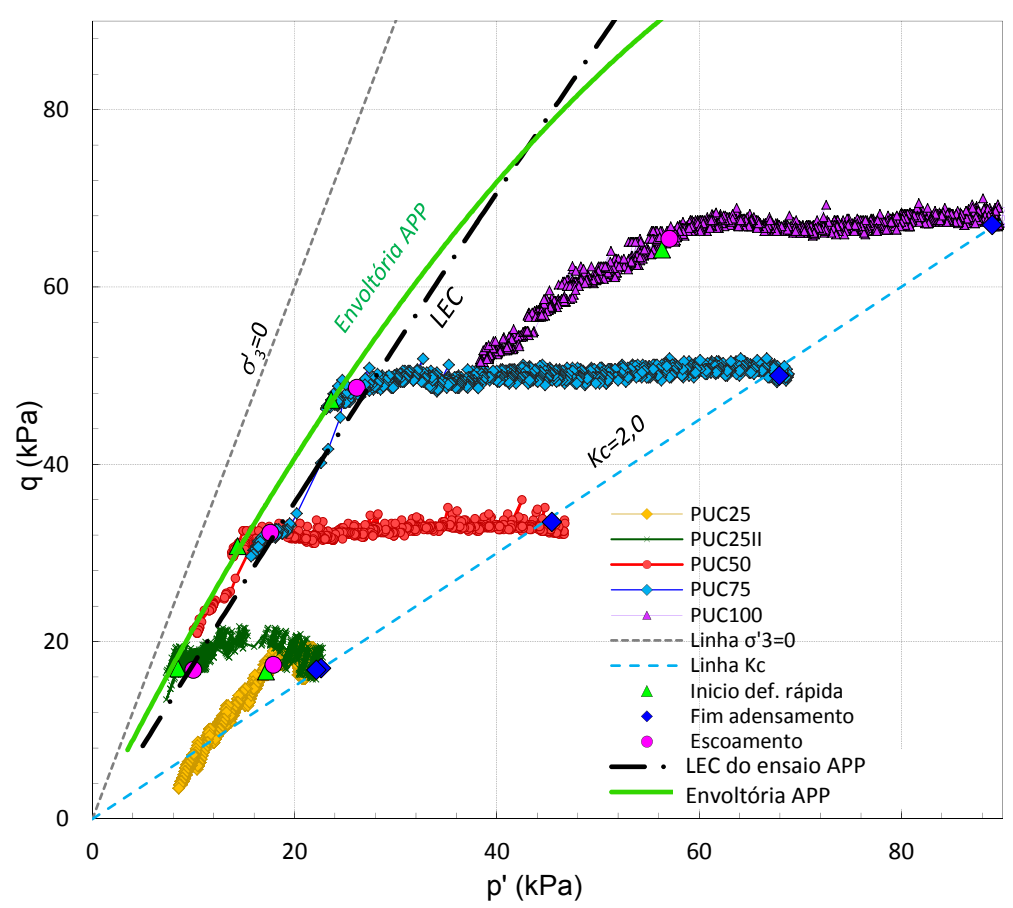

Figura 7.10 - Detalhe das trajetórias de tensão dos ensaios APP de menor tensão confinante inicial do solo coluvionar da PUC, junto à linha de estado crítico e envoltória correspondente ao inicio da deformação rápida 
Para a definição da envoltória correspondente ao inicio da deformação rápida ou ruptura dos ensaios $\mathrm{APP}$, não foram considerados os resultados dos ensaios PUC25 e PUC100. A envoltória definida é não linear, conforme mostrado pela linha de traço cheio. Pode-se observar nas Figuras 7.9 e 7.10 que para os ensaios com tensões médias maiores (PUC100, PUC150, PUC220 e PUC300) a envoltória APP está abaixo da linha de estado crítico (linha preta tracejada); porém, para os ensaios com tensões menores (PUC25II, PUC50 e PUC 75) a envoltória APP apresenta-se curva e levemente acima da LEC.

\section{2.}

\section{Solo do Campus Avançado da PUC em Tinguá}

Os resultados dos oito ensaios triaxiais de aumento de poropressão, realizados em amostras saturadas no solo coluvionar do Campus Avançado da PUC em Tinguá, são apresentados a seguir. A relação de tensões principais $K_{c}$ usada para o adensamento anisotrópico foi de 2,5.

A Tabela 7.3 apresenta as condições em que os ensaios foram realizados.

Tabela 7.3 - Índices físicos no início, após o adensamento e no final do ensaio APP, dos corpos de prova do solo coluvionar de Tinguá

\begin{tabular}{|c|c|c|c|c|c|c|c|c|c|c|c|}
\hline \multirow{2}{*}{ Ensaio } & \multirow{2}{*}{$\begin{array}{c}\mathrm{s}^{\prime} \\
(\mathrm{kPa}) \\
\frac{\sigma_{1}^{\prime}+\sigma_{3}^{\prime}}{2}\end{array}$} & \multirow{2}{*}{$\begin{array}{c}\begin{array}{c}p^{\prime} \\
(\mathrm{kPa})\end{array} \\
\frac{\sigma_{1}^{\prime}+2 \sigma_{3}^{\prime}}{3}\end{array}$} & \multicolumn{6}{|c|}{ Índices físicos iniciais } & \multirow{2}{*}{\begin{tabular}{|c|}
$\begin{array}{c}\text { Após o } \\
\text { adensamento }\end{array}$ \\
$\mathrm{e}_{\text {adens }}$
\end{tabular}} & \multicolumn{2}{|c|}{ Finais } \\
\hline & & & $\begin{array}{l}w_{o} \\
(\%)\end{array}$ & $\begin{array}{c}\gamma_{\mathrm{n}} \\
\mathrm{kN} / \mathrm{m}^{3} \\
\end{array}$ & $\begin{array}{c}\gamma_{\mathrm{d}} \\
\mathrm{kN} / \mathrm{m}^{3}\end{array}$ & $e_{0}$ & $\begin{array}{c}n \\
(\%) \\
\end{array}$ & $\begin{array}{c}S \\
(\%) \\
\end{array}$ & & $e_{f}$ & $\begin{array}{l}w_{f} \\
(\%)\end{array}$ \\
\hline TIN25 & 25 & 21 & 23,06 & 17,32 & 14,07 & 0,901 & 47,41 & 68,47 & 0,895 & 0,951 & 35,76 \\
\hline TIN25II & 25 & 21 & 24,82 & 17,15 & 13,74 & 0,948 & 48,67 & 70,05 & 0,945 & 1,014 & 38,17 \\
\hline TIN50 & 50 & 43 & 23,34 & 17,21 & 13,95 & 0,918 & 47,87 & 68,01 & 0,900 & 0,989 & 38,72 \\
\hline TIN75 & 75 & 64 & 26,24 & 16,95 & 13,42 & 0,994 & 49,84 & 70,67 & 0,952 & 1,044 & 37,10 \\
\hline TIN100 & 100 & 86 & 25,66 & 16,63 & 13,23 & 1,022 & 50,54 & 67,18 & 0,949 & 0,962 & 36,32 \\
\hline TIN150 & 150 & 129 & 25,18 & 17,53 & 14,00 & 0,911 & 47,68 & 73,94 & 0,845 & 0,879 & 33,51 \\
\hline TIN220 & 220 & 189 & 21,23 & 17,25 & 14,23 & 0,880 & 46,81 & 64,53 & 0,747 & 0,776 & 32,76 \\
\hline TIN300 & 300 & 257 & 21,42 & 17,85 & 14,70 & 0,820 & 45,07 & 69,87 & 0,732 & 0,750 & 29,91 \\
\hline
\end{tabular}

Para o cálculo da tensão desviadora foram usadas as mesmas correções de área empregadas no caso do solo coluvionar da PUC.

Resultados típicos dos ensaios de aumento de poropressão são mostrados na Figura 7.11, p' vs q, $\varepsilon_{\mathrm{a}}$ vs p', e, $\varepsilon_{v} v s$ p'. As deformações axiais e volumétricas apresentadas são as obtidas com os eletroníveis e o medidor de variação de volume, respectivamente. Os pontos de início do aumento de poropressão (ou 
fim de adensamento anisotrópico), escoamento e o início da deformação axial rápida são indicados também na figura. Além disso, é mostrada a linha correspondente $\mathrm{a}_{3}{ }_{3}=0$, como referência.

O padrão geral do processo de ruptura na maioria dos ensaios foi semelhante ao observado no caso do solo da PUC, isto é, p' decresceu como resultado do incremento de poropressão, permanecendo a trajetória de tensão essencialmente horizontal. Quando o início da ruptura foi atingido, aconteceu a diminuição da tensão de cisalhamento (vide a Figura 7.11 a).

$\mathrm{Na}$ fase inicial do aumento de poropressão foram detectadas deformações axiais muito pequenas ou insignificantes, com tendência à extensão axial $\left(\varepsilon_{\mathrm{a}}<0\right)$ nos ensaios de menor tensão efetiva (Figura 7.11 b). Também, detectou-se aumento de volume devido à redução de $\mathrm{p}^{\prime}$, desde o início dos ensaios. A quantidade de deformação volumétrica é detectada pela parte inicial inclinada da trajetória de tensão na Figura 7.11 (c).

Depois de decorrido certo tempo, a deformação axial começou a se desenvolver de repente em um valor específico de $p^{\prime}$, neste momento, a amostra atingiu o início da ruptura. Na Figura 7.11 (b) pode-se observar que a taxa de deformação axial não chegou a um valor estável, acelerando e desacelerando por intervalos; sendo estas mudanças mais acentuadas neste solo que no da PUC. O ensaio TIN25II apresentou somente deformação axial negativa (de expansão), ao contrário do resto dos ensaios.

Da análise da Figura 7.11 (c), observa-se que o aumento da deformação volumétrica após o ponto de escoamento, nos ensaios TIN25II, TIN50 e TIN75, foi uma forte indicação do comportamento dilatante das amostras. Nos ensaios de maior tensão média inicial (TIN100, TIN150, TIN220 e TIN300), a partir do ponto de escoamento, o volume da amostra se manteve constante em um trecho, o que reflete a natureza contrátil dos corpos de prova e a provável condição não drenada atingida. Pouco depois, a maioria das amostras contraiu e logo após aumentou de volume. A amostra TIN220, depois da não variação de volume, unicamente dilatou. O ensaio TIN75, comportou-se diferente dos outros, exibindo uma grande deformação volumétrica desde o início.

A definição do ponto de escoamento e a análise do comportamento de curvas de deformação volumétrica, a partir desse ponto, foram realizadas considerando os critérios recomendados por Junaideen (2005), mostrados na Figura 7.2. 

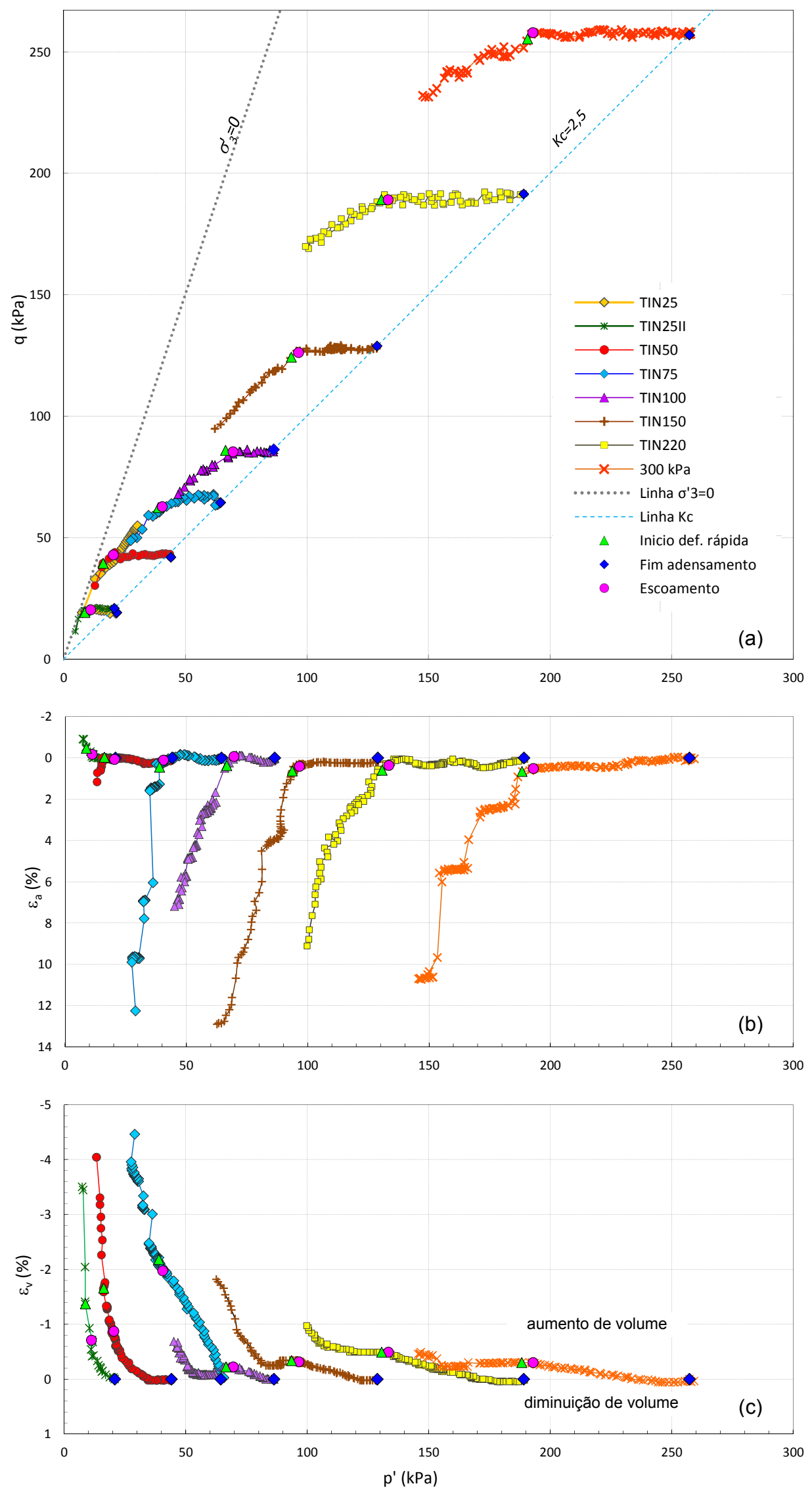

Figura 7.11 - Resultados dos ensaios APP no solo coluvionar de Tinguá: (a) Trajetórias de tensão vs tensão média efetiva, (b) Deformação axial vs tensão média efetiva, (c) Deformação volumétrica vs tensão média efetiva 
Note-se que, de todos os ensaios realizados, o ensaio TIN25 foi o único que não atingiu a ruptura com o aumento de poropressão, por esta razão, foi submetido a cisalhamento não drenado pouco antes de atingir $\sigma_{3}{ }_{3}=0$. A trajetória de tensão seguida pela amostra é mostrada na Figura 7.11 (a).

Em todas as tensões confinantes avaliadas, exceto para os ensaios TIN50 e TIN75, as velocidades de deformação axial após o início da ruptura foram superiores às registradas nos ensaios da PUC. Para este solo, as menores velocidades de deformação na ruptura ocorreram no ensaio TIN220 (0,005 $\% /$ min para o caso de leituras com eletroníveis e de $0,004 \% /$ min para LSCDT), enquanto a maior velocidade de deformação na ruptura aconteceu no ensaio $\operatorname{TIN75}$ (0,2\%/min para o caso de leituras com eletroníveis e de $0,165 \% / m i n$ para LSCDT).

\section{Trajetórias de deformação $\varepsilon_{v}$ vs $\varepsilon_{s}$}

A partir das trajetórias de deformação mostradas na Figura 7.12, pode-se observar que as amostras com maiores tensões confinantes apresentaram uma condição de volume quase constante, seguida de aumento de volume.

Observa-se que a maioria das amostras tendeu a apresentar uma taxa de dilatância menor com o aumento de tensão efetiva média inicial.

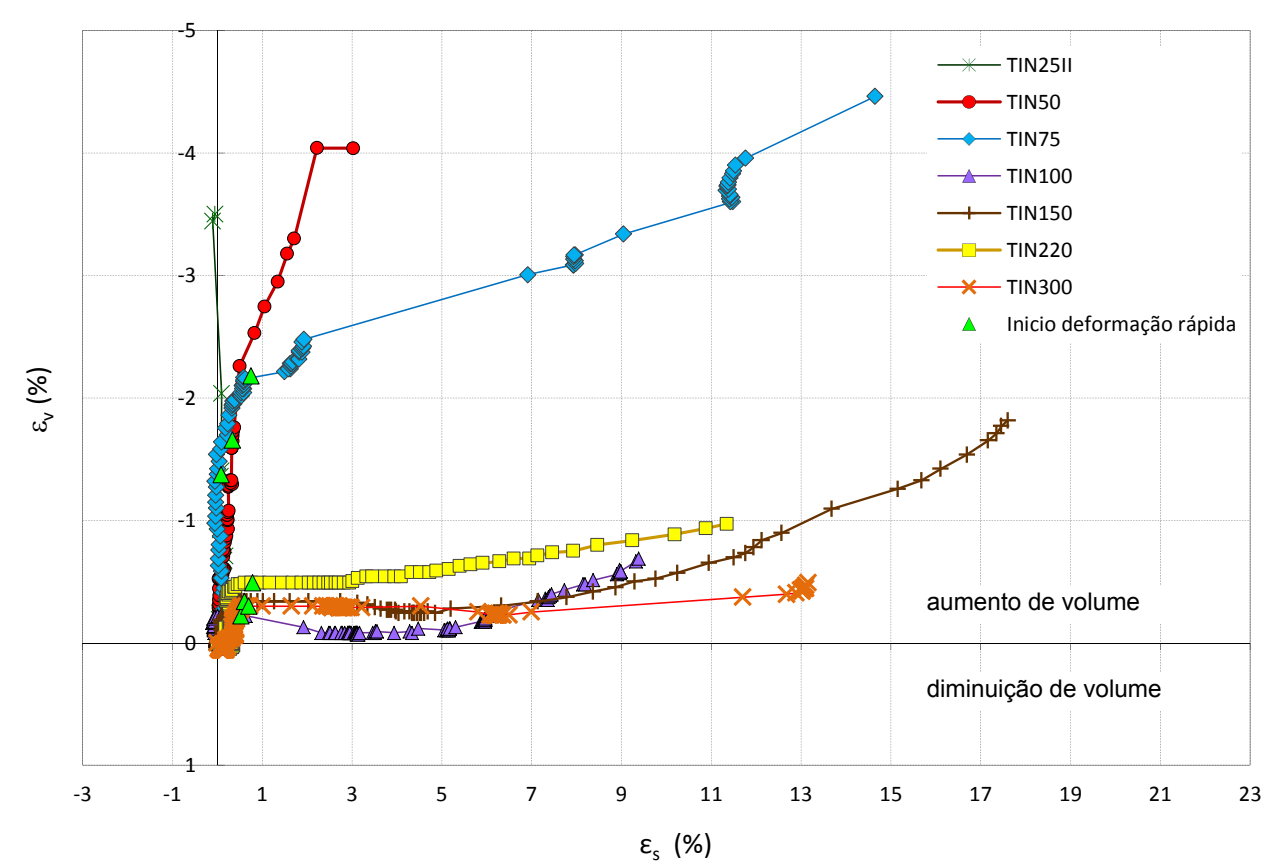

Figura 7.12 - Relação entre a deformação volumétrica e a deformação de cisalhamento nos ensaios APP do solo coluvionar de Tinguá 


\section{Comportamento no espaço e vs $p^{\prime}$}

A Figura 7.13 apresenta os resultados dos ensaios no plano e vs p'. O valor dos índices de vazios foi calculado com os dados registrados através do MVV. $\mathrm{Na}$ figura observa-se, ademais, o ajuste da linha de estado crítico determinada para este tipo de ensaios. Como no solo anterior, foi assumido que as amostras no final dos ensaios tendem à condição de estado crítico. Pode ser visto que, embora haja geralmente uma relação linear logarítmica, existe uma grande dispersão nos dados.
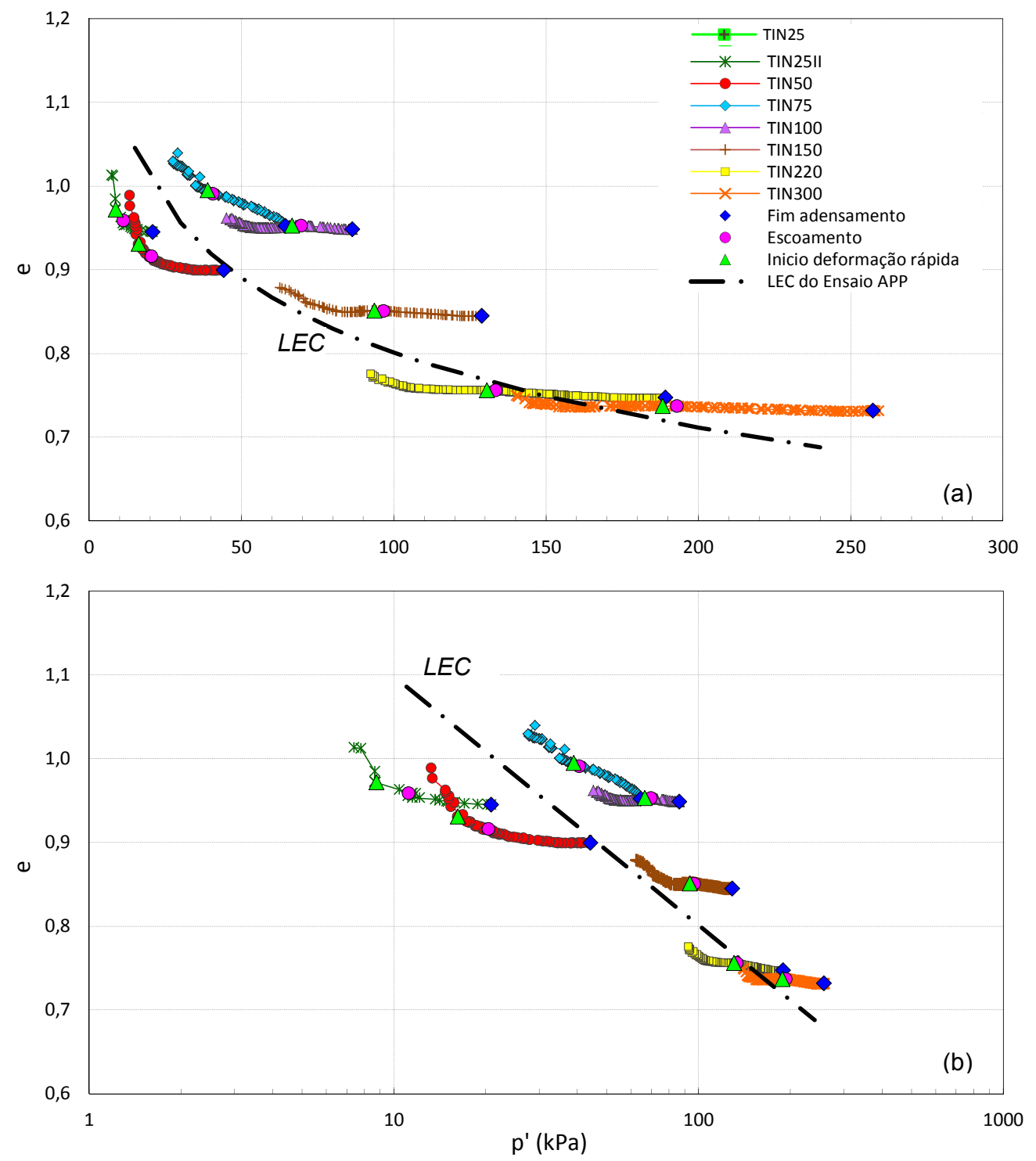

Figura 7.13 - Trajetórias de tensão dos ensaios APP do solo coluvionar de Tinguá no espaço e vs p', (a) p' em escala aritmética, (b) p' em escala logarítmica

Pode-se observar nas trajetórias da figura a leve mudança dos índices de vazios ao início dos ensaios; no entanto, quando $p^{\prime}$ atinge o início da ruptura $(\Delta)$ o índice de vazios se incrementa e a maioria das curvas tende a ir na direção da linha de estado crítico e continuar paralela a ela. 
Analisando a figura, percebe-se uma grande dispersão nos pontos de partida dos ensaios, os que correspondem aos estados finais do adensamento anisotrópico. Assim, depois do adensamento, dois corpos de prova ficaram embaixo da linha de estado crítico e o resto acima dela. No entanto, a subsequente diminuição da tensão média efetiva deslocou o estado do solo de mais dois ensaios abaixo desta linha.

Aquela dispersão pôde-se dever, provavelmente, à heterogeneidade natural do solo coluvionar ou às diferentes trajetórias de adensamento usadas para atingir a tensão desejada com uma relação $\mathrm{K}_{\mathrm{c}}=2,5\left(\mathrm{~K}_{\mathrm{c}}=\sigma^{\prime}{ }_{1} / \sigma^{\prime}{ }_{3}\right)$.

Os ensaios no solo coluvionar de Tinguá, realizados com tensões efetivas iniciais menores que $150 \mathrm{kPa}$, foram adensados anisotropicamente ao longo da linha $\mathrm{K}_{\mathrm{c}}=2,5$. Os ensaios de tensões efetivas maiores foram adensados mediante o "método simplificado", que consistiu na combinação de adensamento isotrópico e carregamento axial drenado até alcançar a relação $\mathrm{K}_{\mathrm{c}}$, dado que vários corpos de prova sofreram ruptura ao tentar ser adensados ao longo dessa linha. Os procedimentos usados na etapa de adensamento anisotrópico encontram-se resumidos no item 5.2.2.3 e na Figura 5.17. Aparentemente, as diversas trajetórias seguidas no adensamento anisotrópico não afetaram a variação do índice de vazios, como pode ser observado na comparação das curvas da Figura 7.14; porém, um estudo mais detalhado seria necessário para analisar essa influência.
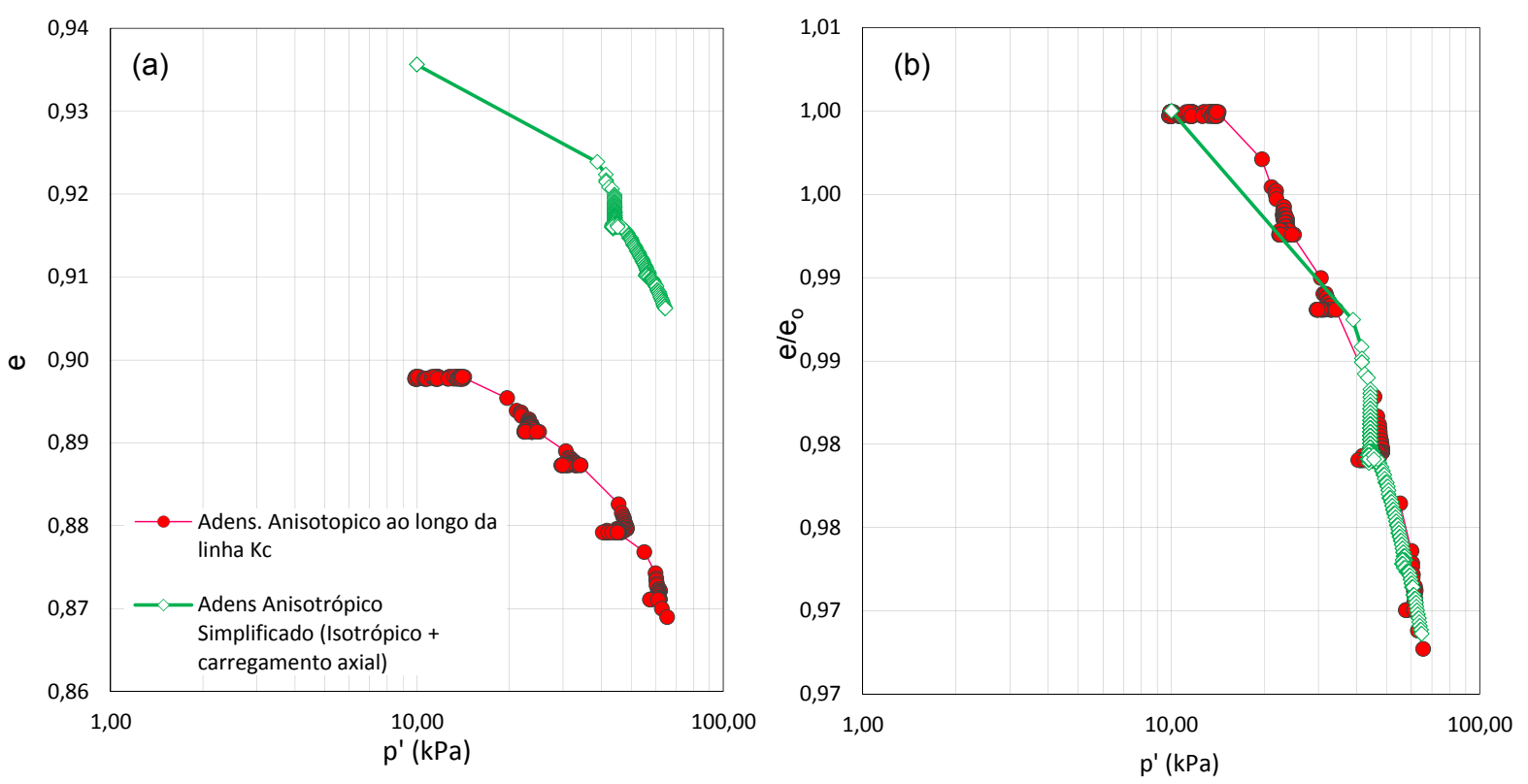

Figura 7.14 - Comparação entre as curvas obtidas no adensamento anisotrópico ao longo da linha $\mathrm{K}_{\mathrm{c}}$ e o adensamento anisotrópico simplificado (adensamento isotrópico + carregamento axial drenado) 
Na Figura 7.14 se apresentam o índice de vazios e a variação relativa dos índices de vazios $\left(e / e_{o}\right)$ relacionados com a tensão efetiva média, expressa em escala logarítmica, na fase de adensamento anisotrópico de duas amostras do solo coluvionar de Tinguá. Na figura, os corpos de prova foram adensados anisotropicamente até uma mesma tensão de adensamento, um ao longo da linha $\mathrm{K}_{\mathrm{c}}$ e o outro mediante o "método simplificado". Comparando os resultados, constata-se o paralelismo das curvas dos ensaios realizados (Figura 7.14 a) e a tendência dos dois ensaios de apresentar uma variação relativa dos índices de vazios bastante semelhante (Figura $7.14 \mathrm{~b}$ ).

O parâmetro de estado, $\psi$, tal como definido por Been e Jefferies (1985), o parâmetro de estado modificado, $\bar{\psi}$, definido por Chu et al. (2003), e a relação das tensões efetivas no escoamento, $\eta=q_{y} / p_{y}^{\prime}$, para cada um dos ensaios da Figura 7.13 são mostrados na Tabela 7.4 .

Tabela 7.4 - Parâmetros de estado, $\psi$, e parâmetros de estado modificado, $\bar{\psi}$, obtidos das trajetórias de tensão no espaço e vs p' dos ensaios APP do solo coluvionar de Tinguá

\begin{tabular}{c|c|c|c|c|c}
\hline Ensaio & $\begin{array}{c}\mathrm{p}_{\mathrm{y}}^{\prime} \\
(\mathrm{kPa})\end{array}$ & $\begin{array}{c}\mathrm{q}_{\mathrm{y}} \\
(\mathrm{kPa})\end{array}$ & $\eta=\mathrm{q}_{\mathrm{y}} / \mathrm{p}_{\mathrm{y}}{ }^{\prime}$ & $\psi$ & $\bar{\psi}$ \\
\hline TIN25II & 11,17 & 20,30 & 1,82 & $-0,06$ & $-0,12$ \\
\hline TIN50 & 20,41 & 42,88 & 2,10 & $\approx 0$ & $-0,09$ \\
\hline TIN75 & 40,57 & 62,77 & 1,55 & 0,09 & 0,07 \\
\hline TIN100 & 69,62 & 85,37 & 1,23 & 0,13 & 0,11 \\
\hline TIN150 & 96,57 & 126,19 & 1,31 & 0,08 & 0,05 \\
\hline TIN220 & 133,45 & 189,04 & 1,42 & 0,03 & $-0,01$ \\
\hline TIN300 & 192,95 & 257,88 & 1,34 & 0,05 & 0,02 \\
\hline
\end{tabular}

Os ensaios TIN25II e TIN50 apresentaram parâmetros de estado modificado negativos $(\bar{\psi}<0)$, indicando o comportamento dilatante das amostras após atingir o escoamento.

Os parâmetros de estado modificado positivos $(\bar{\psi} \geq 0)$, obtidos nos ensaios TIN75, TIN100, TIN150 e TIN300, seriam indicativo do comportamento de compressão (contrátil) das amostras depois de atingido o escoamento. No entanto, no ensaio TIN75 o comportamento contrátil não foi observado na curva 7.11 (c). As outras amostras que apresentaram certa estabilização volumétrica assim que atingiram o escoamento, sofreram contração no início da deformação rápida, e seguidamente aumentaram de volume; este último provavelmente pela 
influência do comportamento do GDS que tentou manter a taxa de aumento de poropressão dentro do corpo de prova.

A amostra TIN220, que teve seu ponto de escoamento perto da linha de estado crítico e o parâmetro de estado modificado próximo a zero, alcançou a estabilização volumétrica (que seria um indício de comportamento contrátil); porém, após atingir o início de deformação rápida experimentou aumento de volume.

\section{Comportamento da poropressão}

A partir dos resultados obtidos, pode-se observar que os ensaios APP apresentaram comportamentos diferenciados desde o ponto de escoamento, aumentando ou diminuindo de volume em alguns casos.

No entanto, as amostras que mostraram comportamento de mudança de volume dilatante, não apresentaram desenvolvimento adicional de poropressão durante a ruptura. Por outro lado, a maioria dos corpos de prova com comportamento contrátil, exibiu um excesso de poropressão positiva.

A Figura 7.15 mostra a variação da poropressão ao longo do tempo das amostras que exibiram o comportamento contrátil após atingir o ponto de escoamento: TIN100, TIN150, TIN220 e TIN300. As deformações axiais e volumétricas, mostradas paralelamente nesta figura, são as mesmas da Figura 7.11, obtidas mediante eletroníveis e o MVV. As medidas de poropressão correspondem às leituras na base e a meia altura do corpo de prova.

É interessante observar na Figura 7.15 que, embora os ensaios fossem realizados em condições drenadas, a condição de volume quase constante se manteve após o ponto de escoamento ser atingido; prevalecendo aparentemente o estado não drenado dentro dos corpos de prova, onde a deformação rápida teria ocorrido. Como resultado, um excesso de poropressão dentro do corpo de prova se gerou rapidamente durante a deformação.

As deformações volumétricas medidas indicariam a condição não drenada alcançada e a posterior diminuição de volume, seguida de um aumento deste, influenciado provavelmente pelo GDS. Nas curvas $\varepsilon_{a}$ vs tempo dos ensaios TIN100, TIN150 e TIN300 (não apresentadas aqui) verificou-se que as taxas de deformação após o início da ruptura foram mais elevadas do que as registradas no solo da PUC nessas tensões, provavelmente, por causa da resposta compressiva das amostras.

O aumento da poropressão foi maior nos casos TIN100 e TIN150. 
Note-se na Figura 7.15 (c) o comportamento diferente da amostra TIN220, que depois da deformação volumétrica constante, unicamente dilatou, ainda mais, não desenvolveu aumento de poropressão.
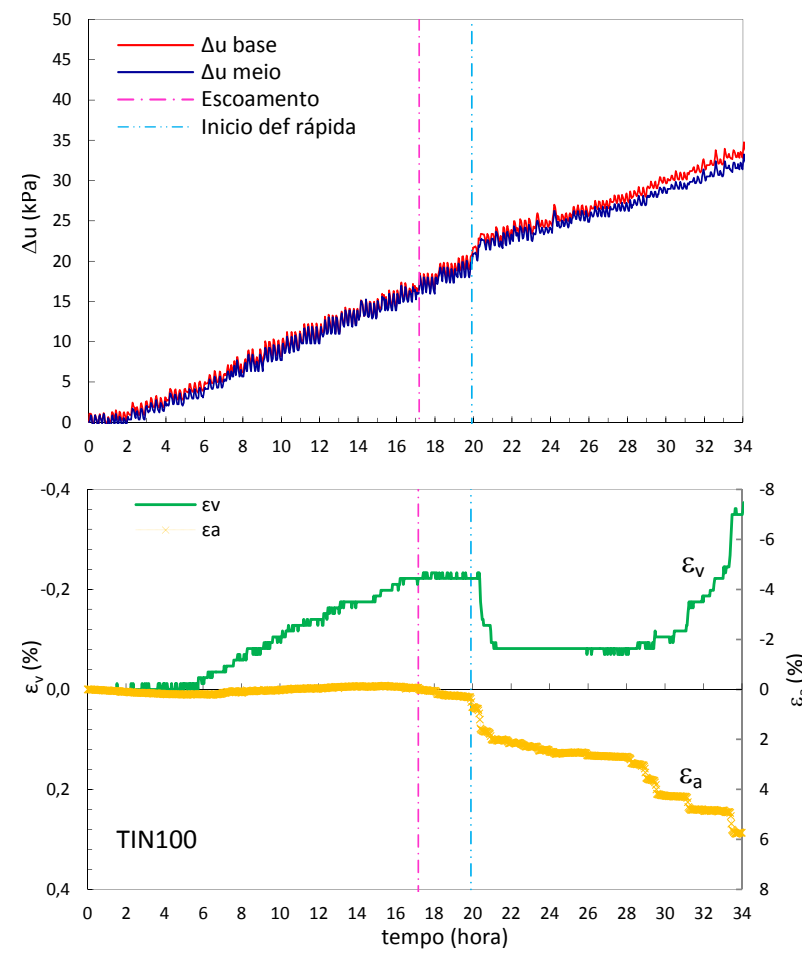

(a)
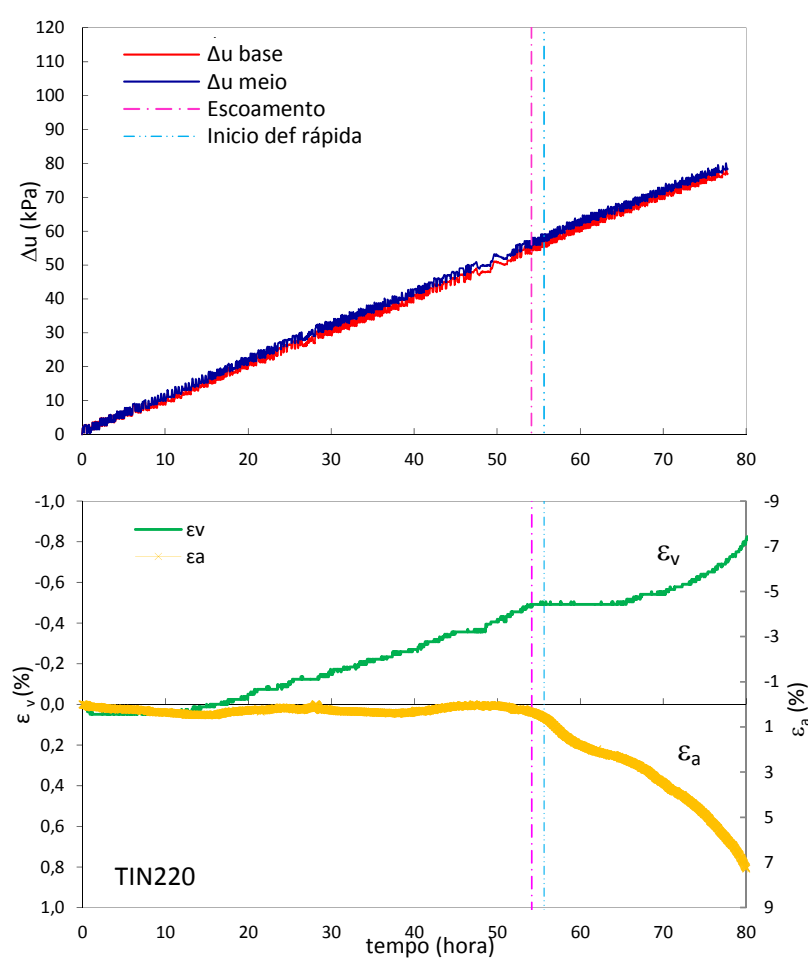

(c)
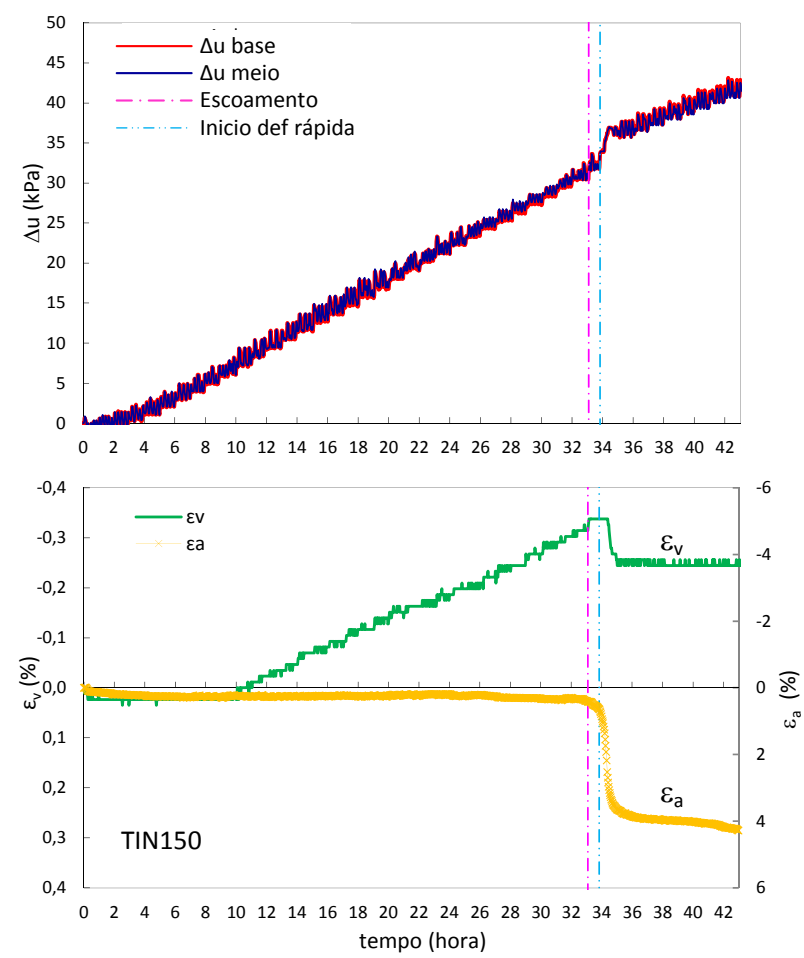

(b)
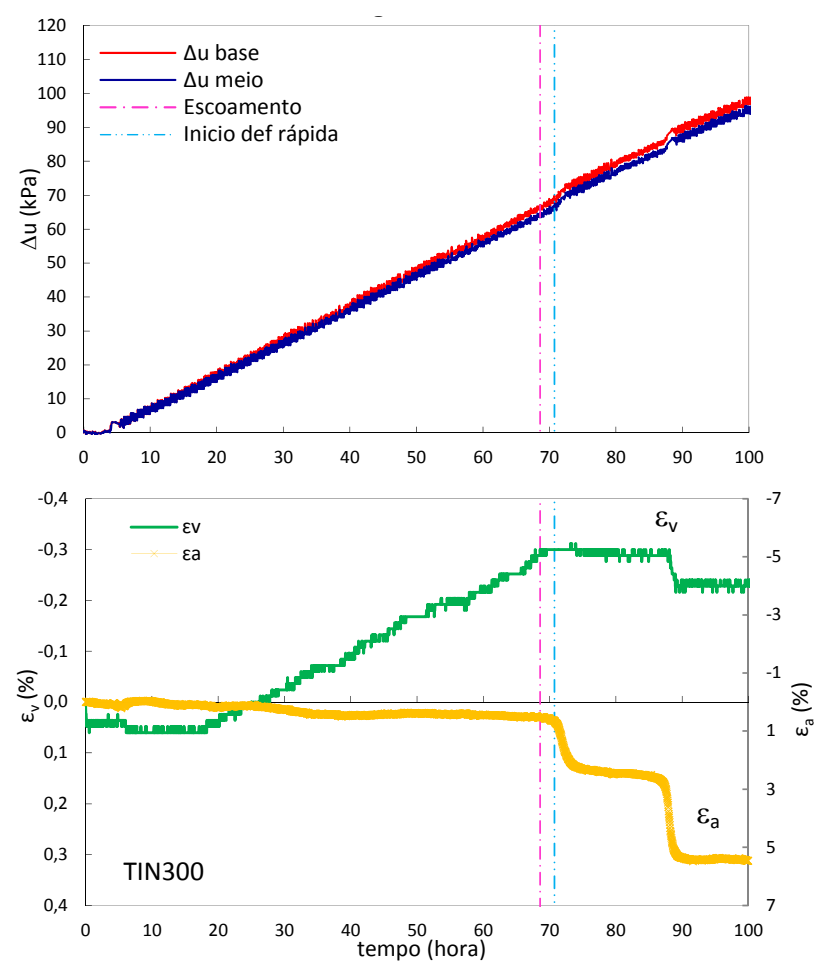

(d)

Figura 7.15 - Variação ao longo do tempo da poropressão a meia altura e na base do corpo de prova, da deformação axial e da deformação volumétrica dos ensaios: (a) TIN100, (b) TIN150, (c) TIN220, (d) TIN300 


\section{Envoltória dos ensaios de aumento de poropressão e linha de estado crítico no espaço p' vs $q$}

As trajetórias de tensão dos ensaios APP e a correspondente envoltória definida com os pontos de inicio de deformação rápida ou ruptura, assim como a linha de estado crítico determinada com a tendência das trajetórias de tensão são mostradas na Figura 7.16.

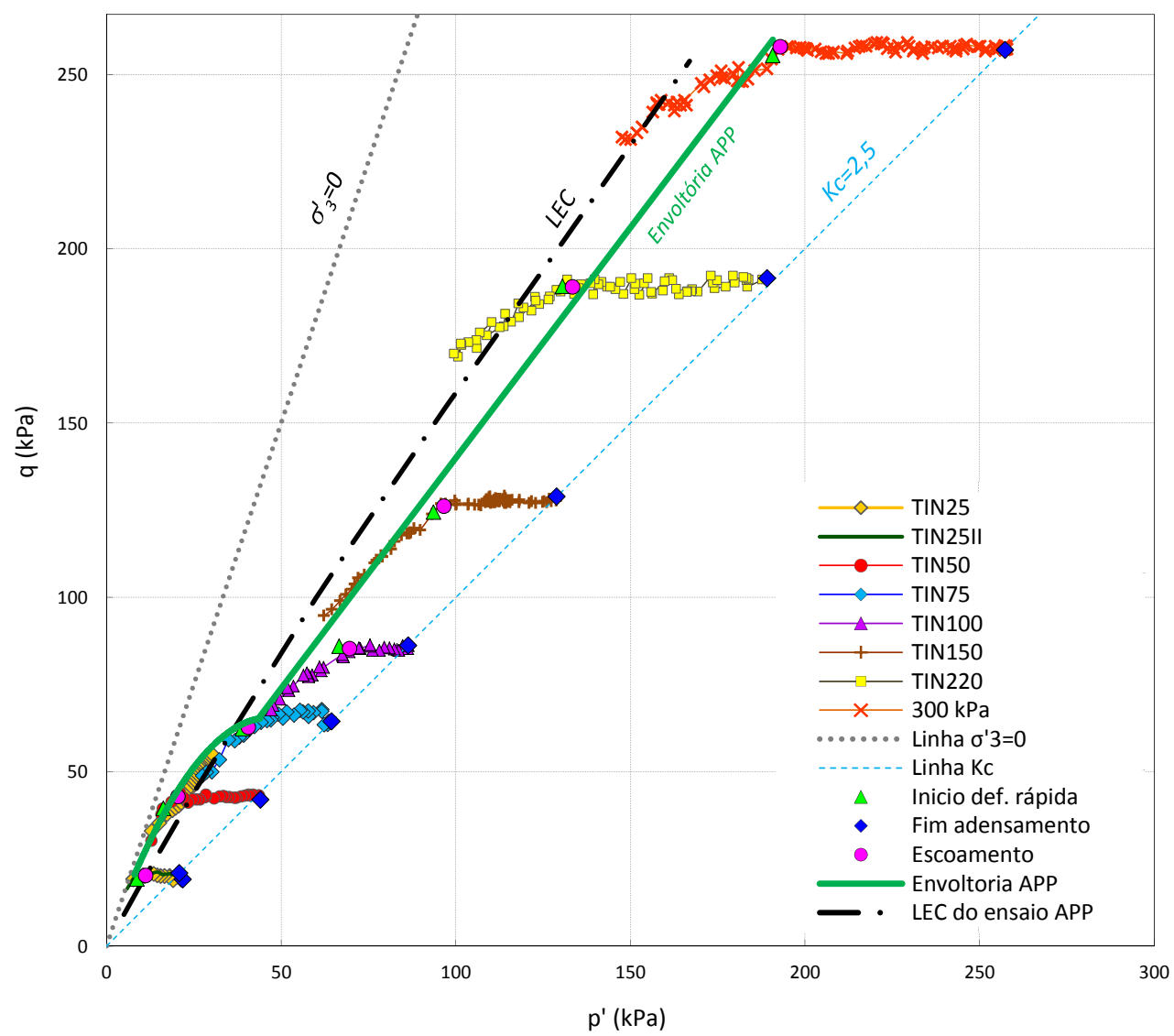

Figura 7.16 - Trajetórias de tensão dos ensaios APP do solo coluvionar de Tinguá, junto à linha de estado crítico e envoltória APP

$\mathrm{Na}$ figura pode-se observar que as trajetórias de tensão foram quase horizontais até atingir o ponto de escoamento; logo após, caíram abruptamente. No caso das amostras com menores tensões médias iniciais (TIN25II e TIN50), as trajetórias passaram a linha de estado crítico até alcançar o ponto de início de ruptura, o qual se situou próximo à linha correspondente $a \sigma_{3}=0$; caindo logo subitamente na direção da linha de estado crítico. As amostras com maiores tensões confinantes alcançaram o início da ruptura antes de atingir a linha de estado crítico e após a ruptura se dirigiram em direção a ela. O início de ruptura da amostra TIN100 foi atingido muito antes que as outras amostras.

Observa-se na Figura 7.17 o detalhe das trajetórias de tensão dos ensaios realizados com as menores tensões médias iniciais. Pode-se apreciar o 
comportamento do ensaio TIN25, que não alcançou a ruptura com o aumento da poropressão e foi submetido a cisalhamento não drenado. Note-se que a trajetória se dirige até a LEC e continua por ela. Deve-se indicar que após a conclusão do ensaio foi verificada a presença de finas raízes que possivelmente influenciaram no comportamento do corpo de prova.

A envoltória definida com os pontos de início de ruptura dos ensaios de aumento de poropressão é não linear para tensões médias menores, superando ligeiramente a linha de estado crítico, representada pela linha preta tracejada. Para tensões maiores a envoltória APP se localizou abaixo da linha de estado crítico.

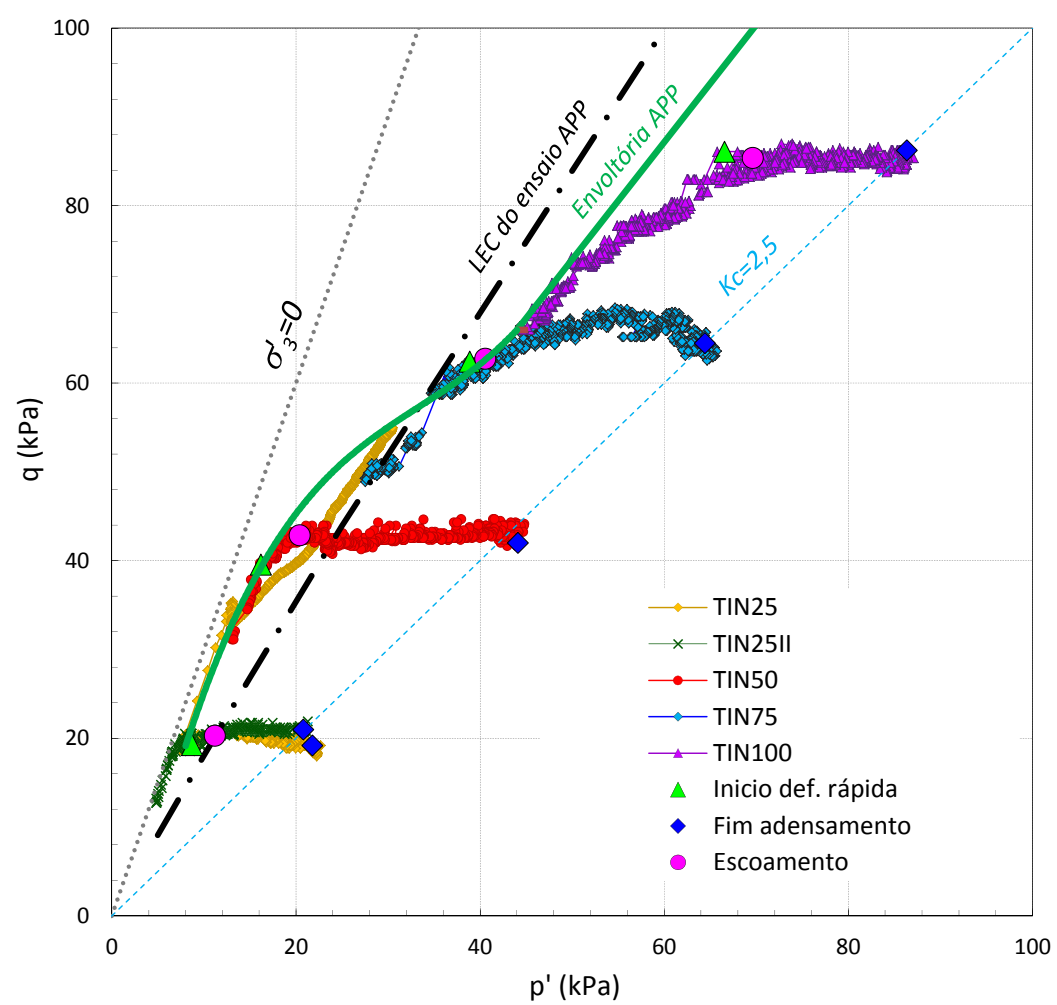

Figura 7.17 - Detalhe das trajetórias de tensão dos ensaios APP de menor tensão confinante no solo coluvionar de Tinguá, junto à linha de estado crítico e envoltória APP

\section{3.}

\section{Solo de Duque de Caxias}

São aqui apresentados resultados dos doze ensaios APP realizados em corpos de prova do solo residual jovem de Duque de Caxias. Esta série de ensaios foi executada com as mesmas tensões confinantes iniciais usadas nos outros solos estudados. O adensamento anisotrópico foi realizado com uma relação de tensões principais igual a $\mathrm{K}_{\mathrm{c}}=2,5$. 
A Tabela 7.5 apresenta os índices físicos das amostras ao início, após adensamento e finais dos ensaios, além das tensões de adensamento às que foram submetidos. Pode ser observado que alguns ensaios foram repetidos, a fim de verificar resultados ou para obter deformações medidas diretamente dos corpos de prova, uma vez que nos primeiros ensaios não se dispunha da instrumentação interna.

Tabela 7.5 - Índices físicos no início, após o adensamento e no final dos ensaios APP, dos corpos de prova do solo residual jovem de Duque de Caxias

\begin{tabular}{|c|c|c|c|c|c|c|c|c|c|c|c|}
\hline \multirow[b]{2}{*}{ Ensaio } & \multirow{2}{*}{$\begin{array}{c}\mathrm{s}^{\prime} \\
(\mathrm{kPa}) \\
\frac{\sigma_{1}^{\prime}+\sigma_{3}^{\prime}}{2} \\
\end{array}$} & \multirow{2}{*}{$\begin{array}{c}\mathrm{p}^{\prime} \\
(\mathrm{kPa}) \\
\frac{\sigma_{1}^{\prime}+2 \sigma_{3}^{\prime}}{3} \\
\end{array}$} & \multicolumn{6}{|c|}{ Índices físicos iniciais } & \multirow{2}{*}{\begin{tabular}{|c|}
$\begin{array}{c}\text { Após } \\
\text { adensamento }\end{array}$ \\
$\mathrm{e}_{\text {adens }}$ \\
\end{tabular}} & \multicolumn{2}{|c|}{ Finais } \\
\hline & & & $\begin{array}{l}w_{\circ} \\
(\%)\end{array}$ & $\begin{array}{c}\gamma_{\mathrm{n}} \\
\mathrm{kN} / \mathrm{m}^{3}\end{array}$ & $\begin{array}{c}\gamma_{\mathrm{d}} \\
\mathrm{kN} / \mathrm{m}^{3}\end{array}$ & $e_{o}$ & $\begin{array}{c}n \\
(\%) \\
\end{array}$ & $\begin{array}{c}S \\
(\%)\end{array}$ & & $e_{f}$ & $\begin{array}{l}w_{f} \\
(\%)\end{array}$ \\
\hline $\mathrm{DC} 25^{*}$ & 25 & 21 & 32,45 & 16,36 & 12,35 & 1,328 & 57,04 & 70,28 & 1,326 & 1,343 & 44,83 \\
\hline DC25II & 25 & 21 & 31,11 & 15,1 & 11,52 & 1,497 & 59,96 & 59,76 & 1,493 & 1,551 & 48,57 \\
\hline DC50 & 50 & 43 & 34,37 & 15,76 & 11,73 & 1,451 & 59,21 & 68,11 & 1,430 & 1,461 & 47,76 \\
\hline DC75* & 75 & 64 & 32,74 & 16,22 & 12,22 & 1,353 & 57,50 & 69,60 & 1,349 & 1,441 & 45,34 \\
\hline DC75II & 75 & 64 & 36,97 & 15,6 & 11,39 & 1,525 & 60,39 & 69,74 & 1,495 & 1,526 & 52,59 \\
\hline DC100 & 100 & 86 & 29,28 & 15,29 & 11,83 & 1,431 & 58,87 & 58,85 & 1,373 & 1,420 & 48,07 \\
\hline DC150 & 150 & 129 & 34,12 & 16,09 & 12,00 & 1,398 & 58,29 & 70,22 & 1,35 & 1,434 & 48,51 \\
\hline DC150II & 150 & 129 & 36,10 & 15,36 & 11,29 & 1,548 & 60,75 & 67,08 & 1,499 & 1,676 & 50,55 \\
\hline DC220* & 220 & 189 & 32,94 & 15,59 & 11,73 & 1,452 & 59,22 & 65,25 & 1,380 & 1,474 & 49,18 \\
\hline DC220II & 220 & 189 & 35,92 & 15,46 & 11,38 & 1,528 & 60,44 & 67,62 & 1,479 & 1,581 & 48,46 \\
\hline DC300* & 300 & 257 & 31,55 & 16,24 & 12,35 & 1,329 & 57,07 & 68,26 & 1,255 & 1,302 & 53,88 \\
\hline DC300II & 300 & 257 & 32,83 & 15,39 & 11,59 & 1,482 & 59,71 & 63,71 & 1,404 & 1,439 & 49,05 \\
\hline
\end{tabular}

* Não se utilizou instrumentação para medida de deformação interna

Os corpos de prova deste solo romperam formando plano de cisalhamento. A ruptura foi muita rápida, causando a separação das partes e seu deslocamento, impossibilitando fazer as medidas necessárias para as correções recomendas por Chandler (1966), para este tipo de ruptura. Carvalho (2012), também observou tais problemas nos ensaios triaxiais executados neste solo.

Em virtude disso, foi aplicada a correção de área cilíndrica dos corpos de prova proposta por Bishop e Henkel (1962) até antes da formação do plano de cisalhamento, a que foi mínima. A partir daí nenhuma correção foi feita.

A Figura 7.18 mostra as curvas p' vs q, $\varepsilon_{a}$ vs p', e $\varepsilon_{v} v s$ p' dos ensaios de aumento de poropressão. As tensões efetivas foram determinadas com os valores de poropressão registrados na parte central do corpo de prova, a exceção dos ensaios DC25II, DC100 e DC300II onde aconteceram problemas elétricos com o minitransdutor de poropressão. 

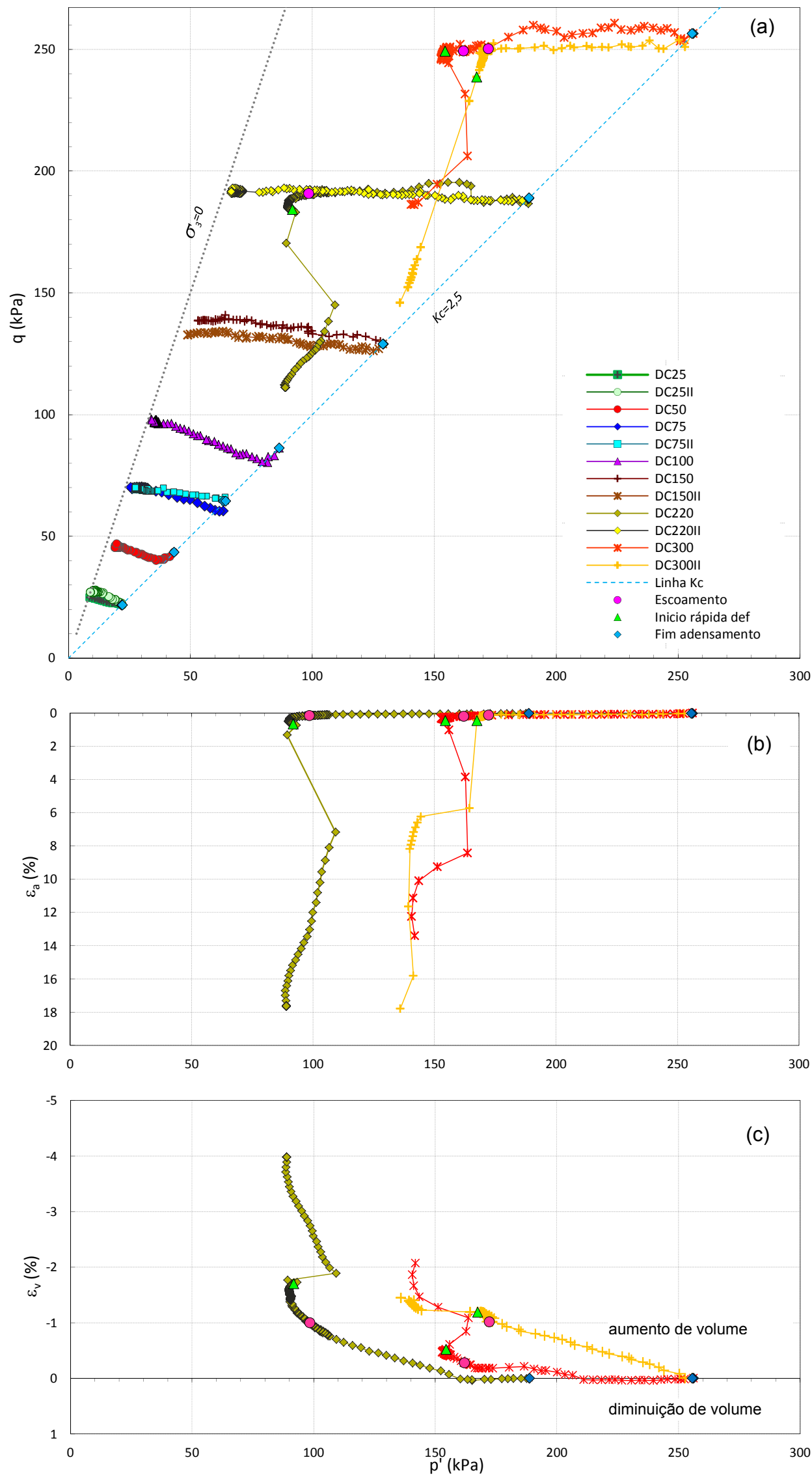

Figura 7.18 - Resultados dos ensaios APP no solo de Duque de Caxias, (a) Trajetórias de tensão vs tensão média efetiva, (b) e (c) Deformação axial e deformação volumétrica vs tensão média efetiva dos ensaios que romperam 
Analisando a figura, observa-se que dois tipos diferentes de resultados foram alcançados nos ensaios. Embora $\sigma_{3}^{\prime}$ foi reduzida a zero ou aproximadamente zero, apenas três dos ensaios realizados com as maiores tensões médias efetivas (DC220, DC300 e DC300II) atingiram a ruptura por aumento de poropressão. Este fato foi possivelmente causado por uma resistência não confinada da amostra, resultante da estrutura cimentante do solo.

Para as amostras que romperam, a trajetória de tensão foi quase horizontal até alcançar o ponto onde a ruptura aconteceu. Em seguida, a tensão desviadora caiu, enquanto a amostra se deformou rapidamente, colapsando devido, provavelmente, à quebra de ligações e ao fato que o solo já não podia suportar a tensão de cisalhamento aplicada.

A variação das deformações axiais e volumétricas são apresentadas apenas para as amostras que atingiram a ruptura (Figura 7.18 b e c). Os resultados apresentados na Figura 7.18 (b) mostram as deformações obtidas com o transdutor de deslocamento externo (LSCDT); uma vez que havendo formação de um plano de ruptura, o comportamento dos eletroníveis passou a ser função da sua localização, ocorrendo grandes divergências entre suas medições. A deformação volumétrica da Figura 7.18 (c) foi obtida com o MVV.

Para todos os casos, o aumento da poropressão durante a fase inicial do ensaio, não causou deformação axial significativa do corpo de prova. No entanto, nas amostras que romperam, a ruptura foi iniciada em um determinado valor de p' e a deformação axial se desenvolveu subitamente. A taxa de deformação axial após o início da ruptura para estas amostras foi muito alta, de 23 a $280 \% / \mathrm{min}$. Devido à alta velocidade da ruptura é complicado determinar o comportamento de deformação dos corpos de prova após o momento da ruptura. Mesmo assim, tentou-se estimar esta deformação com os poucos dados registrados.

Na Figura 7.18 (c) observa-se a variação de volume dilatante dos ensaios DC220 e DC300, enquanto o ensaio DC300II apresentou um pequeno aumento de volume, para depois passar a uma condição de volume constante que poderia indicar uma tendência à contração. O aumento de volume dos corpos de prova DC220 e DC300, após o início da ruptura, causou uma rápida diminuição de poropressão no interior da amostra. Este aspecto será discutido abaixo em maior detalhe.

Nas curvas dos ensaios que romperam são mostrados o ponto de fim de adensamento ou início do aumento de poropressão, o ponto de escoamento, e o ponto de início de ruptura ou da deformação rápida. 
As trajetórias dos três ensaios que romperam, no espaço e vs p', são mostradas na Figura 7.19 (a) e (b). Com a finalidade de avaliar o comportamento do solo mediante a determinação do parâmetro de estado modificado, colocouse na figura a possível linha de estado crítico determinada para este tipo de ensaio. Na Figura 7.19 (b), p' está representado em escala logarítmica, onde a LEC se apresenta como uma linha reta.
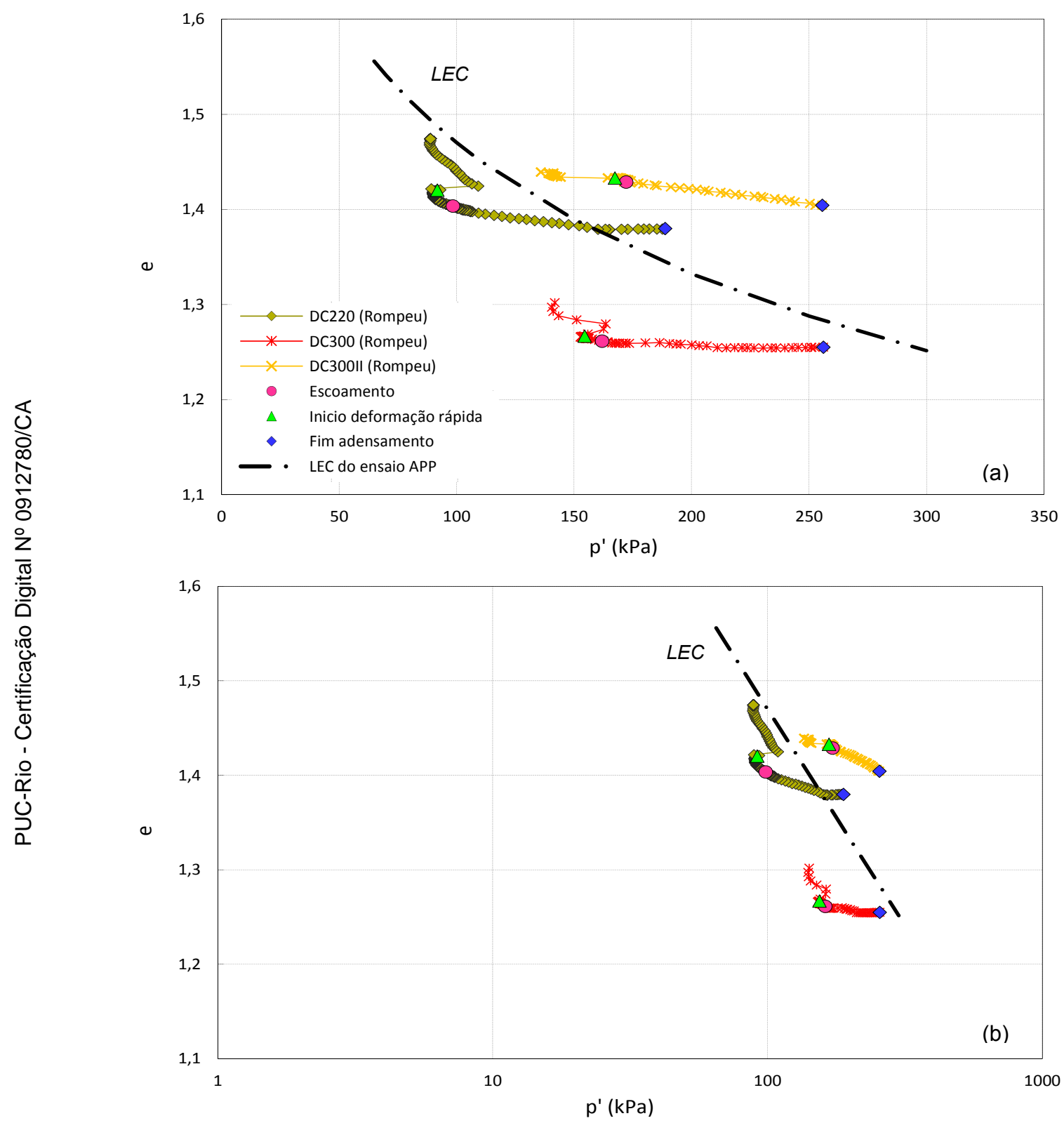

Figura 7.19 - Trajetórias de tensão dos ensaios APP no espaço e vs p', (a) Trajetórias com p' em escala aritmética, (b) Trajetórias com p' em escala logarítmica

Pode-se observar que depois do adensamento anisotrópico, dois ensaios ficaram acima da linha de estado crítico e um abaixo dela. Ainda, durante o ensaio, o estado de tensão de mais uma amostra se deslocou embaixo desta linha. O índice de vazios teve uma leve mudança no início do ensaio, mas, 
quando $p^{\prime}$ atingiu o início de ruptura, o índice de vazios aumentou principalmente nas amostras que alcançaram o escoamento debaixo da LEC, e as trajetórias tenderam a ir na direção desta linha. A amostra que alcançou o escoamento acima da LEC apresentou um ligeiro aumento do índice de vazios e em seguida se manteve constante, em direção a ela.

O parâmetro de estado, $\psi$, o parâmetro de estado modificado, $\bar{\psi}$, e a relação das tensões efetivas no escoamento, $\eta=q_{y} / p_{y}^{\prime}$, para cada um dos ensaios são mostrados na Tabela 7.6. Os ensaios DC220 e DC300 alcançaram um $\bar{\psi}<0$, o que revelaria um comportamento dilatante depois de ter atingido o ponto de escoamento; já o ensaio DC300Il alcançou um $\bar{\psi}>0$, sugerindo um comportamento contrátil.

Tabela 7.6 - Parâmetros de estado, $\psi$, e parâmetros de estado modificado, $\bar{\psi}$, obtidos das trajetórias de tensão no espaço e vs p' dos ensaios APP do solo residual jovem Duque de Caxias

\begin{tabular}{c|c|c|c|c|c}
\hline Ensaio & $\begin{array}{c}\mathrm{p}_{\mathrm{y}}{ }^{\prime} \\
(\mathrm{kPa})\end{array}$ & $\begin{array}{c}\mathrm{q}_{\mathrm{y}} \\
(\mathrm{kPa})\end{array}$ & ${\mathrm{n}=\mathrm{q}_{\mathrm{y}} / \mathrm{p}_{\mathrm{y}}^{\prime}}^{\prime}$ & $\psi$ & $\bar{\psi}$ \\
\hline DC220 & 98,44 & 190,80 & 1,94 & 0,04 & $-0,07$ \\
\hline DC300 & 162,01 & 249,34 & 1,54 & $-0,03$ & $-0,11$ \\
\hline DC300II & 172,20 & 250,29 & 1,45 & 0,12 & 0,07 \\
\hline
\end{tabular}

\section{Comportamento da poropressão}

Na Figura 7.20 se mostra o comportamento da poropressão na base e na parte central do corpo de prova, assim como a deformação axial e volumétrica no instante da ruptura dos três ensaios que romperam durante o aumento de poropressão.

A deformação volumétrica da figura corresponde à registrada com o MVV, enquanto a deformação axial é a obtida com o LSCDT. No ensaio DC300II não se mostra a medida do incremento de poropressão na parte central do corpo de prova, dado que o minitransdutor de poropressão parou de funcionar durante o ensaio. Pode-se observar que as amostras DC220 e DC300 apresentaram aumento de volume assim que a ruptura começou, provocando uma queda súbita na poropressão durante o estado pós-ruptura. A curvatura das trajetórias de tensão no espaço e vs p' da Figura 7.19 reflete claramente esta diminuição. $A$ taxa de deformação do solo foi tão rápida que o controlador de pressão e volume (GDS) não foi capaz de manter a taxa de incremento de poropressão. $O$ aumento da poropressão, registrado depois da queda observada, revelaria o comportamento do GDS tentando manter esse ritmo de incremento. 

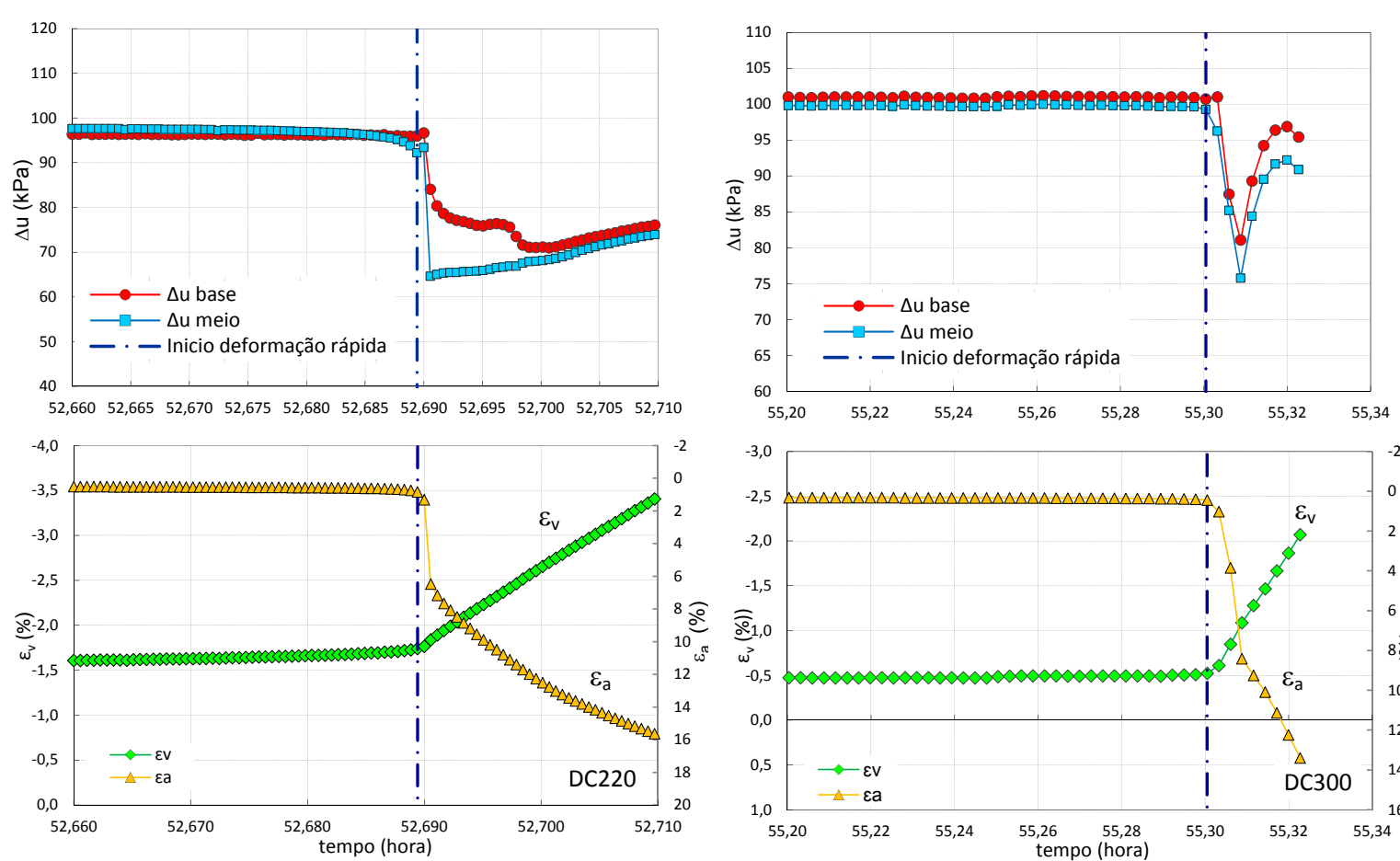

(a)

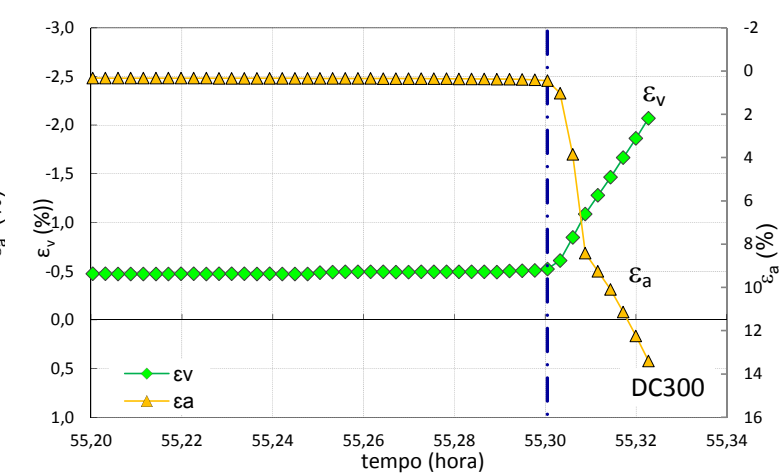

(b)
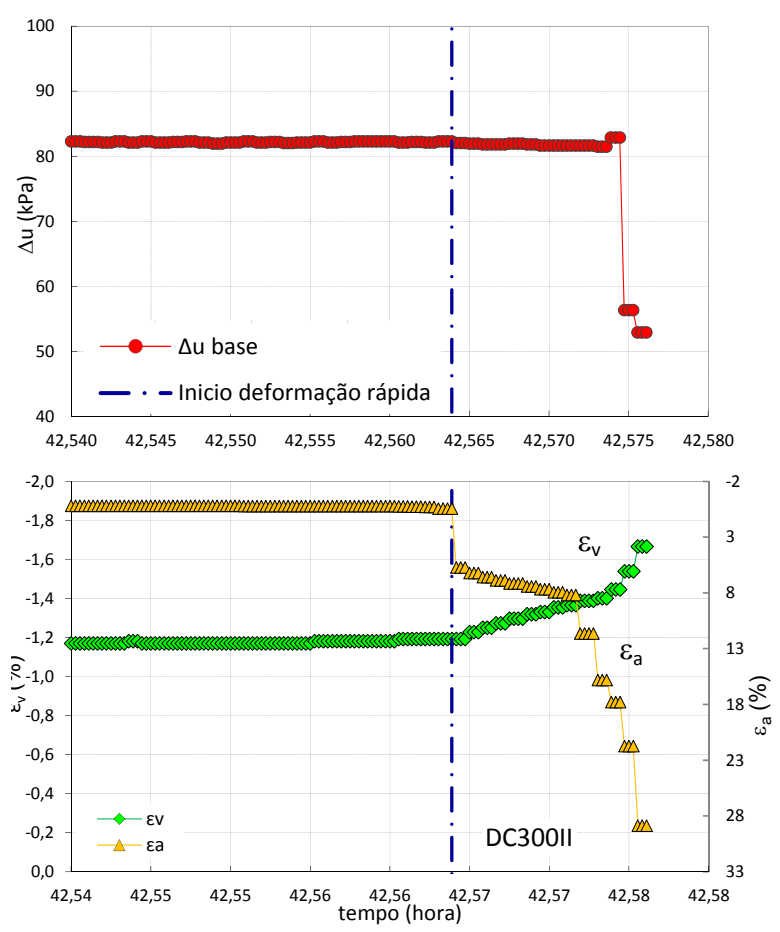

(c)

Figura 7.20 - Variação, ao longo do tempo, da poropressão, deformação axial e da deformação volumétrica dos ensaios: (a) DC220, (b) DC300, (c) DC300II

No ensaio DC300II, o transdutor localizado na base não registrou essa queda de poropressão no momento do início da deformação rápida (que foi a maior registrada, $280 \% / \mathrm{min}$ ), mas sim depois de alguns segundos quando o plano de cisalhamento já estava formado. Devido à falta da medida de 
poropressão a meia altura deste corpo de prova é difícil definir o comportamento da poropressão depois do momento da ruptura, uma vez que a variação volumétrica registrada, depois de atingir o ponto de início de deformação rápida, é baixa e negativa, o que indicaria expansão do corpo de prova. No entanto, segundo a avaliação com o parâmetro de estado modificado, uma vez que o ponto de escoamento foi alcançado, o solo mostrou comportamento de compressão (contrátil), de modo que o solo, provavelmente, poderia ter registrado um leve aumento de poropressão.

\section{Comportamento de amostras que não romperam durante o aumento de poropressão}

Com exceção do ensaio DC25, todos os demais corpos de prova que não romperam com o acréscimo de poropressão foram submetidos a carregamento axial não drenado antes de atingir $\sigma_{3}^{\prime}=0\left(\sigma^{\prime}{ }_{3} \approx 2 \mathrm{kPa}\right)$.

Esta fase de cisalhamento foi realizada sob deformação controlada, com a velocidade de deslocamento da prensa de $0,098 \mathrm{~mm} / \mathrm{min}$.

Na Figura 7.21 se apresentam as curvas tensão desviadora vs deformação axial, e variação de poropressão vs deformação axial, correspondentes à fase de carregamento axial não drenado. Pode-se observar que as curvas tensãodeformação formam pico de resistência ao cisalhamento, que ocorrem para deformações inferiores a 1,6\%. Foi observada a formação de um plano preferencial de ruptura, característico da ruptura frágil. Segundo Leroueil e Hight (2003), este tipo de ruptura faz com que a resistência pós-pico se aproxime ou coincida com o estado crítico.

O excesso de poropressão gerado durante o ensaio foi negativo, o que indicaria uma tendência de expansão do corpo de prova. Pode-se observar que para baixas tensões, a máxima taxa negativa de geração de poropressão não coincide com o pico de resistência, indicando que a resistência de pico é controlada pela estrutura e não pela densidade do material. Este fato coincide com caraterísticas mencionadas por Leroueil e Vaughan (1990) para solos com estrutura cimentada sob baixos níveis de tensão.

Nos ensaios com maiores tensões médias, por causa da baixa resistência dos corpos de prova no início do carregamento não drenado, ocorreu um deslocamento significativo da célula de carga junto ao embolo, fazendo com que o corpo de prova colapsasse e as deformações axiais aumentaram de forma brusca, pouco tempo depois de iniciado o carregamento. Com isto, não foi 
possível registrar uma grande quantidade de dados após a ocorrência da ruptura.

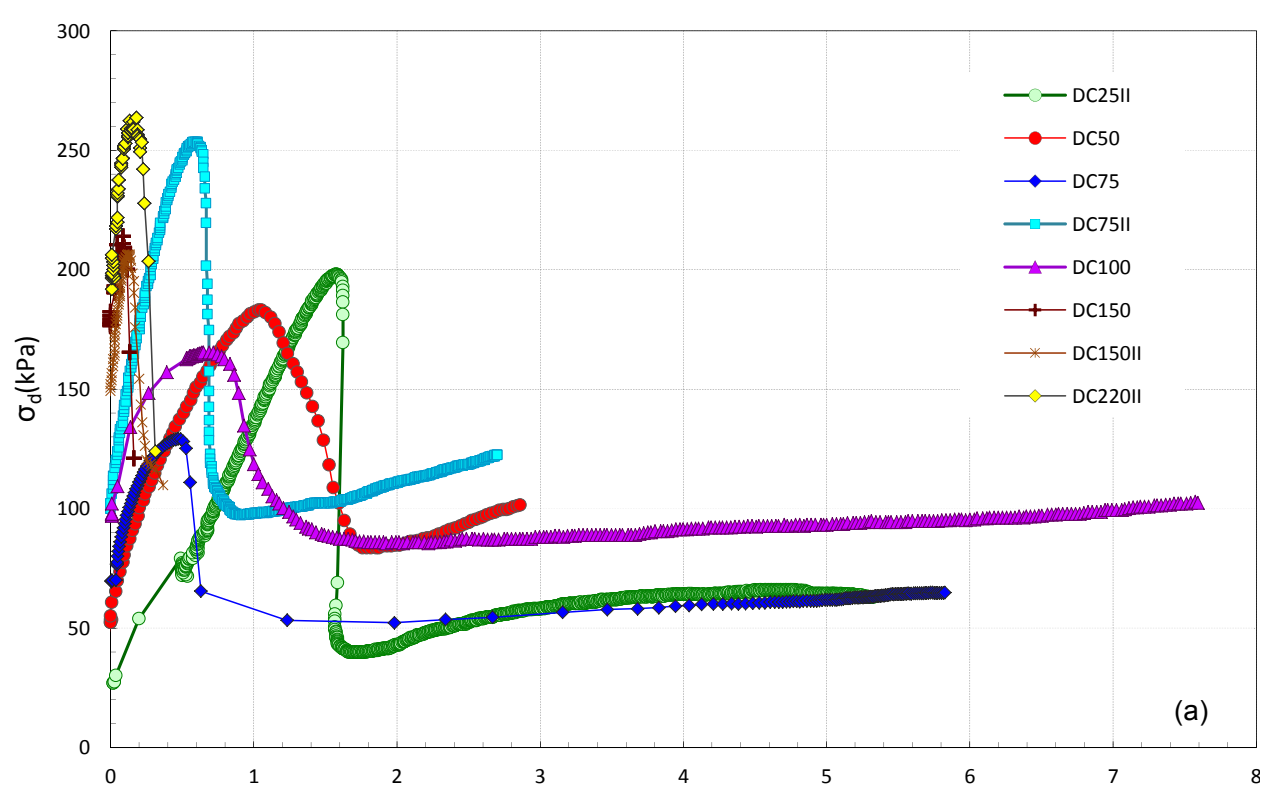

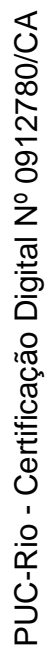

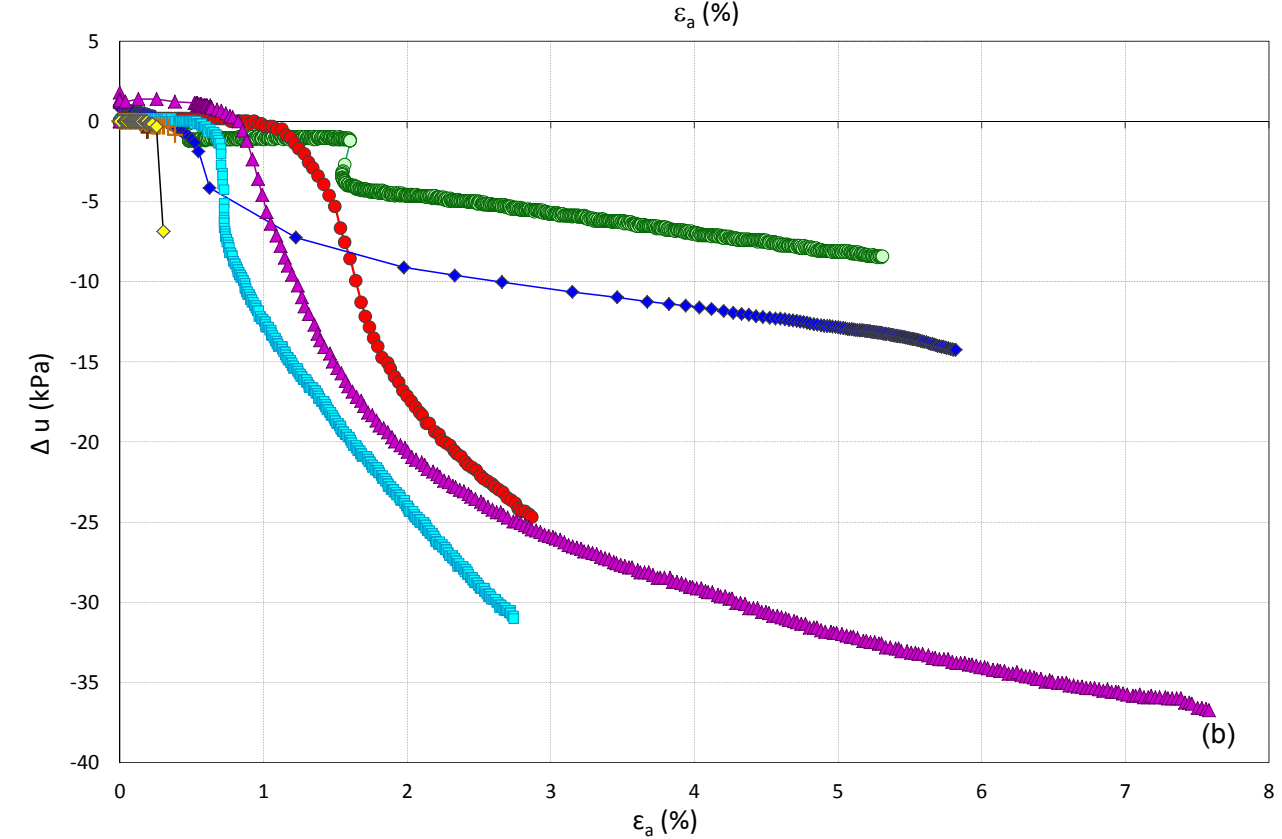

Figura 7.21 - Resultado do carregamento axial não drenado realizado em amostras que não romperam durante o ensaio APP, (a) Curva tensão desviadora vs deformação axial, (b) Variação da poropressão vs deformação axial

A Figura 7.22 mostra as trajetórias de tensão da fase de carregamento axial não drenado. Observa-se que as trajetórias de tensão se dirigiram para a direita até a máxima tensão desviadora para, então, apresentar uma queda abrupta nos valores de p' e q. Em seguida, as mesmas seguiram rumo à suposta envoltória de resistência última devido à geração negativa de poropressão. 


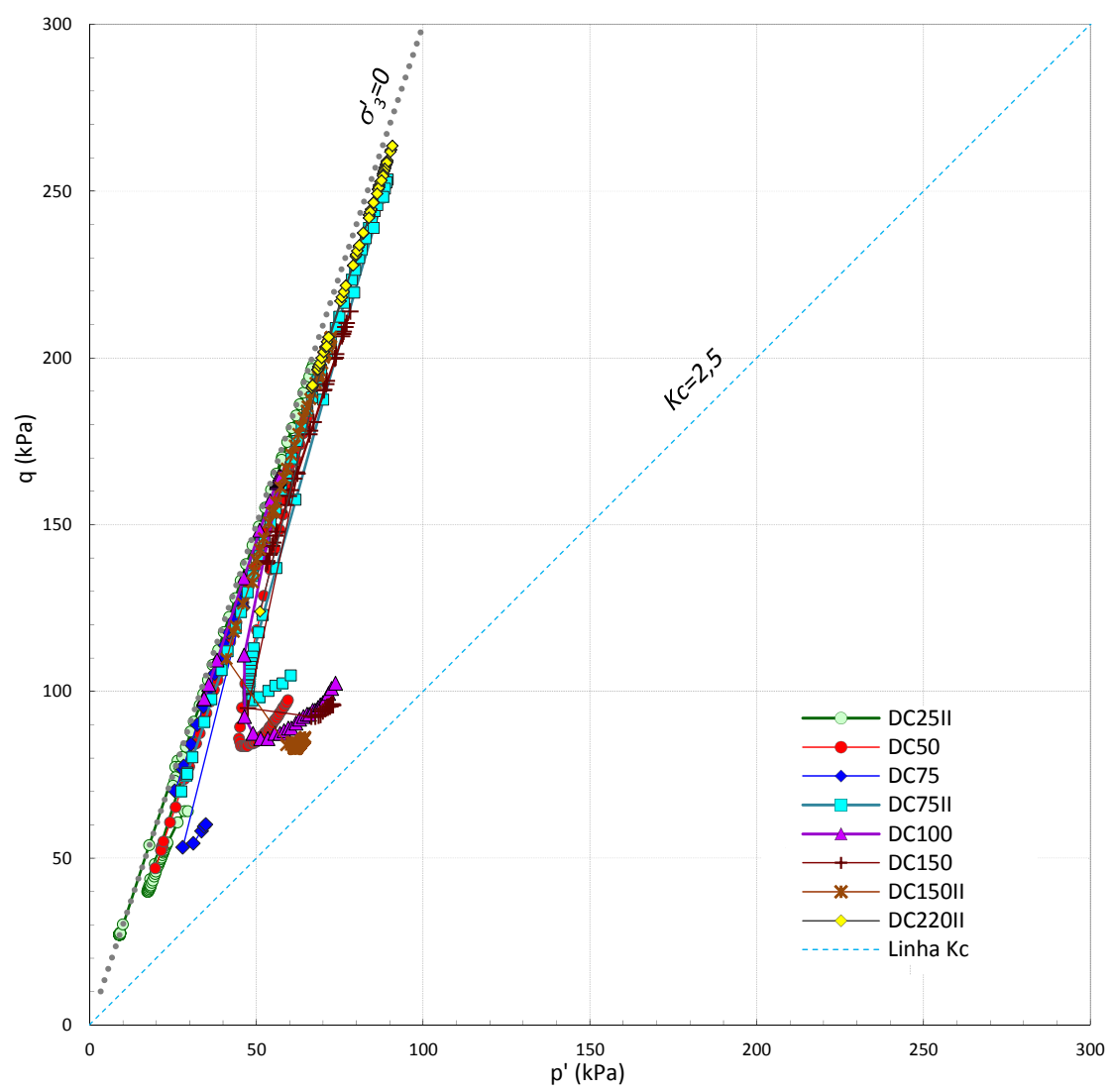

Figura 7.22 - Trajetórias de tensão do carregamento axial não drenado em amostras que não romperam durante os ensaios APP

Envoltória dos ensaios de aumento de poropressão e linha de estado crítico no espaço $p$ ' vs $q$

Na Figura 7.23 são apresentadas as trajetórias dos ensaios APP e de carregamento axial não drenado (para as amostras que não romperam durante o incremento de poropressão). Na mesma figura foram colocadas a linha de estado crítico definida para esses ensaios e a correspondente envoltória determinada com os pontos que representam o inicio de deformação rápida dos ensaios APP.

Analisando a Figura 7.23, verifica-se que durante a etapa de aumento de poropressão, as trajetórias de tensão foram quase horizontais. As trajetórias das amostras DC220 e DC300 passaram através da linha de estado crítico até alcançar o ponto de início de ruptura. Imediatamente após a ruptura, as trajetórias desceram atingindo a linha de estado crítico e a atravessaram novamente. A amostra DC300II alcançou o início de ruptura ao atingir a linha de estado crítico. 


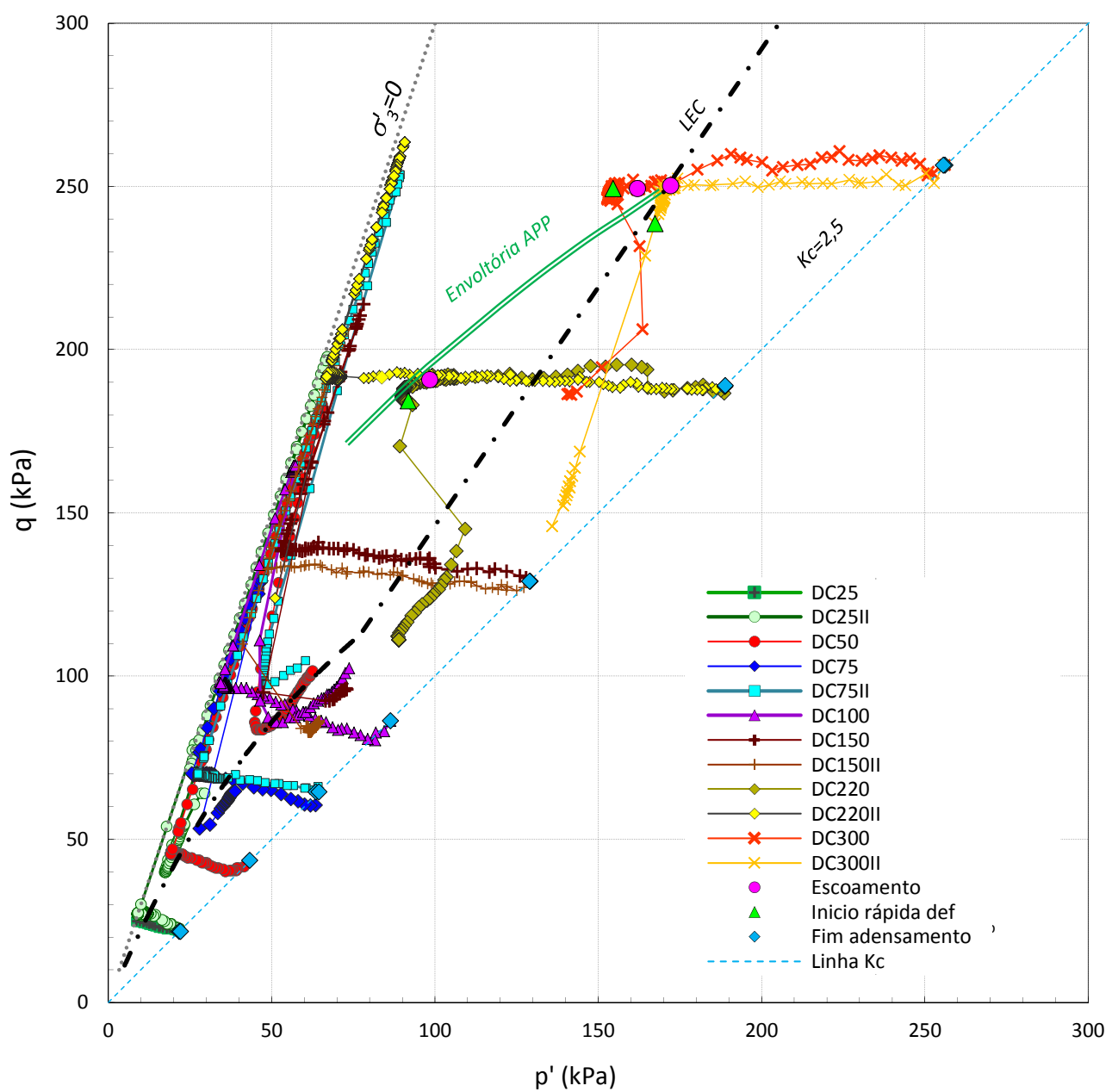

Figura 7.23 - Trajetórias de tensão dos ensaios APP e de carregamento axial não drenado do solo de Duque de Caxias, junto à linha de estado crítico e envoltória APP

Repara-se que a forma das trajetórias após a ruptura é meramente referencial, uma vez que, como indicado anteriormente, devido à alta velocidade da ruptura, só alguns pontos foram registrados. A formação de plano de cisalhamento permitiu usar apenas as leituras registradas pelo LSCDT para a obtenção da deformação axial.

Todas as amostras que não romperam durante o aumento de poropressão ultrapassaram a linha de estado crítico. A capacidade das amostras para sustentar uma tensão de cisalhamento acima desta linha, ainda mais, com $\sigma_{3}$ reduzida a zero ou aproximadamente zero, pode ser atribuída à estrutura cimentada do material. De acordo com Zhu e Andersom (1998), quando o solo alcança o ponto de escoamento, a estrutura cimentada é alterada e começa a ser destruída, conduzindo-se assim ao solo a uma resistência menor no estado de grandes deformações. Acredita-se que nas amostras que romperam durante o aumento de poropressão, a cimentação já teria sido rompida na fase de adensamento anisotrópico. 


\section{8 \\ Discussão final dos resultados}

No capítulo prévio, os resultados dos ensaios de aumento de poropressão realizados nos três solos estudados foram mostrados e analisados a detalhe. Neste capítulo é apresentada a discussão final desses resultados, considerando para isso os diferentes ensaios descritos nos capítulos precedentes. Adicionalmente, apresentam-se comparações com os resultados obtidos em outras pesquisas.

\section{1 \\ Solo do Campo Experimental II PUC-Rio}

Os ensaios realizados no solo coluvionar da PUC mostraram que a ruptura, resultante do aumento gradual da poropressão, deu-se com pequenas deformações axiais. Com relação às deformações volumétricas, as amostras exibiram comportamento dilatante. Em contraste, amostras desse solo apresentaram comportamento compressivo nos ensaios de cisalhamento direto e triaxiais convencionais, conforme pode ser visto nas Figuras 6.4 e 6.13, respectivamente.

Os resultados obtidos neste solo coluvionar, coincidem com vários dos estudos encontrados na literatura, onde os ensaios de aumento de poropressão mostraram aumento de volume durante o cisalhamento, mesmo que tenham mostrado tendência de compressão nos ensaios triaxiais convencionais. Anderson e Riemer (1995), Anderson e Sitar (1995) e Dai et al. (1999) observaram esse comportamento em amostras indeformadas de solos coluvionares, e Santos (1995) em amostras indeformadas de um solo residual.

A maioria das amostras ensaiadas do solo coluvionar da PUC sofreram deformações lentas uma vez de iniciada a ruptura, provavelmente devido a uma tendência de diminuição de poropressão, associada com o processo de cisalhamento. Entretanto, somente em dois dos ensaios realizados com tensões confinantes baixas (PUC50 e PUC75) foi registrada uma diminuição da poropressão (Figura 7.8). Coincidentemente estes ensaios apresentaram as 
maiores velocidades de deformação, que por sua vez podem estar relacionadas à presença da cimentação fraca ou ao arranjo dos grãos.

Segundo Anderson e Sitar (1995), na zona de cisalhamento, o excesso de poropressão negativa se desenvolve como resultado da dilatação; ademais, a tensão efetiva aumenta até que o excesso da poropressão negativa seja dissipado pela água que flui para o volume de vazios em expansão. Como o excesso de poropressão negativa leva a uma maior tensão efetiva, o solo endurece e se reforça até o equilíbrio ser atingido. Assim, a taxa de ruptura é controlada pela condutividade hidráulica do solo e a disponibilidade de água para equilibrar a perda da poropressão devido à dilatação. Isto sugere uma taxa de ruptura relativamente lenta ao longo da trajetória de tensão do ensaio APP. Esta presunção poderia explicar o fato que nos ensaios realizados a deformação não chegou atingir uma taxa constante, acelerando ao alcançar a ruptura, desacelerando devido ao próprio reforço do solo, e acelerando novamente diante um novo incremento da poropressão imposto pelo GDS, que equilibra a redução da poropressão causado pela dilatação.

Os resultados dos ensaios de aumento de poropressão foram interpretados utilizando os critérios de instabilidade propostos por Leroueil (2001), quem enfatizou que no contexto das encostas a possibilidade de liquefação está controlada pela posição relativa do ponto de escoamento com respeito à linha de estado crítico, ou parâmetro de estado modificado, $\bar{\psi}$.

Com base nos resultados dos ensaios apresentados no espaço e vs p', a linha de estado crítico seria útil na identificação do possível comportamento insitu, da mudança de volume do solo submetido a uma trajetória de tensão originada pelas chuvas intensas. Se o estado do solo no início da ruptura estiver acima da linha de estado crítico no espaço e vs p', o comportamento do solo seria de compressão e poderia dar origem ao desenvolvimento de poropressão durante a deformação, originando uma ruptura rápida. Por outro lado, se o estado do solo no início da ruptura estiver abaixo da linha de estado crítico, o comportamento volumétrico do solo será dilatante e sofreria movimentos lentos devido a uma diminuição de poropressão associada com o processo de cisalhamento (Orense et al., 2004).

O comportamento dilatante do solo coluvionar da PUC ficou evidente no espaço e vs p', na Figura 7.7, com as trajetórias dos ensaios se desenvolvendo abaixo da linha de estado crítico determinada para os ensaios APP e valores de parâmetros de estado modificado, $\bar{\psi}$, menores a zero. Isto indicaria que o solo 
desenvolveria movimentos lentos e não seria susceptível ao fenômeno de liquefação.

Com a finalidade de comparação, a linha de estado crítico determinada através dos ensaios triaxiais convencionais (Figura 6.19), foi traçada no espaço e vs p', junto às trajetórias e à linha de estado crítico dos ensaios APP da Figura 7.7. Na Figura 8.1, observa-se que ambos os tipos de ensaio definiram diferentes, mas, subparalelas linhas de estado crítico; ficando a linha obtida com os triaxiais convencionais acima da determinada com os ensaios APP. Observase que o estado do solo continua sendo dilatante.
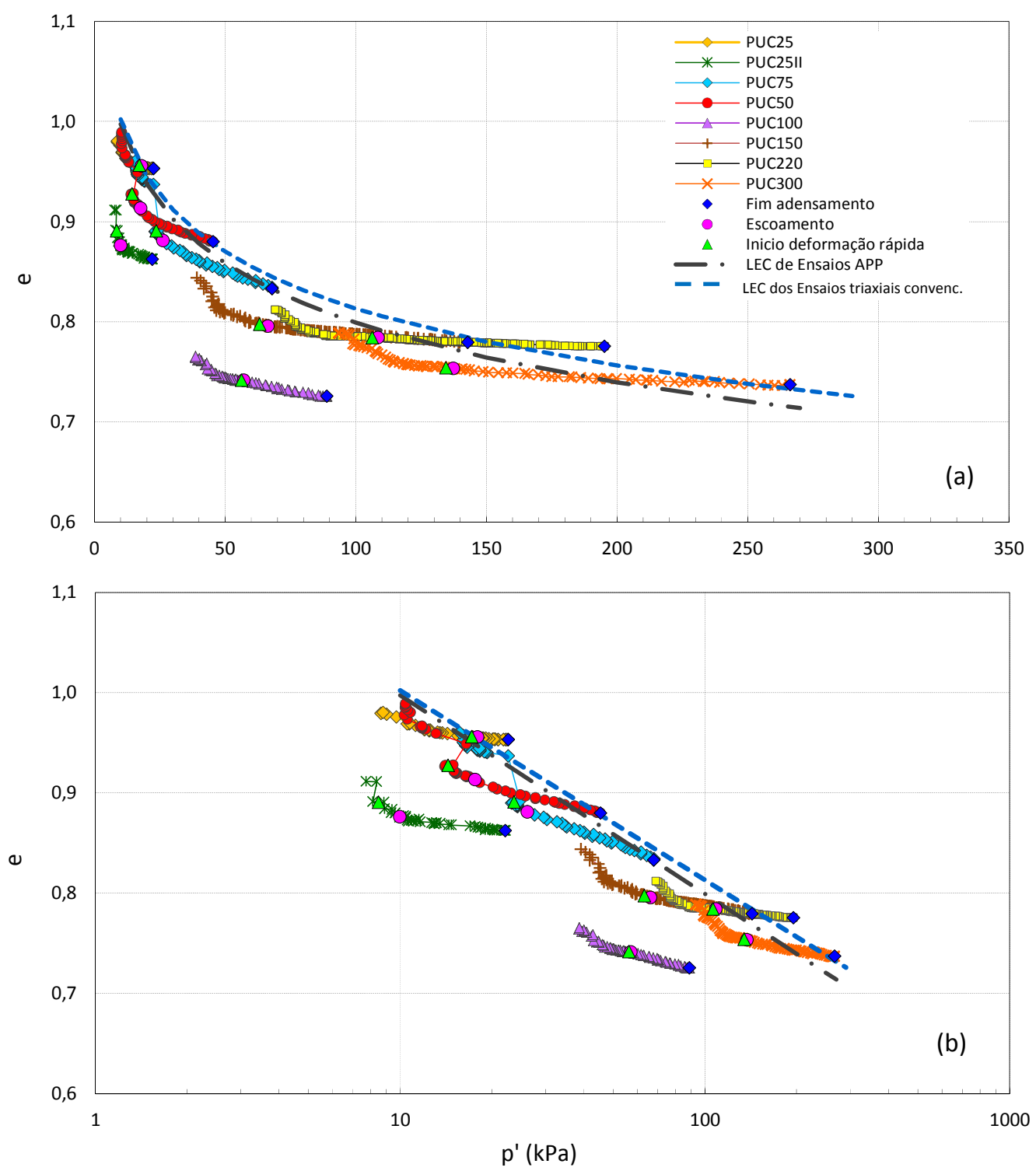

Figura 8.1 - Trajetórias de tensão no espaço e vs p' e linhas de estado crítico obtidas nos ensaios APP e ensaios triaxiais convencionais do solo coluvionar da PUC

$\mathrm{Na}$ Figura 8.2 mostra-se a relação entre as tensões efetivas no escoamento de cada ensaio, $n=q / p^{\prime}$, plotadas versus o valor correspondente $\bar{\psi}$. O valor de $\eta\left(\eta=q / p^{\prime}\right)$ no escoamento varia de 0,97 a 1,86 , para valores de $\bar{\psi}$ 
variando entre $-0,12$ e 0,01 . No mesmo gráfico colocou-se a linha correspondente ao valor do parâmetro $M=1,25$ (inclinação da linha do estado crítico no plano p' vs q, com intercepto na origem) obtido a partir dos ensaios triaxiais convencionais.

Note-se a diferença do posicionamento do valor de $\eta$ dos diferentes ensaios com respeito à linha de estado crítico obtida com um ajuste linear dos ensaios triaxiais convencionais, representada pelo parâmetro $M=1,25$. $\mathrm{Na}$ figura, várias amostras se localizaram acima da linha de estado crítico, já que alcançaram uma maior relação entre as tensões efetivas no escoamento. Enquanto nas Figuras 7.9 e 7.10, que considera a linha de estado crítico não linear obtida dos ensaios APP, apenas duas amostras ultrapassaram essa linha.

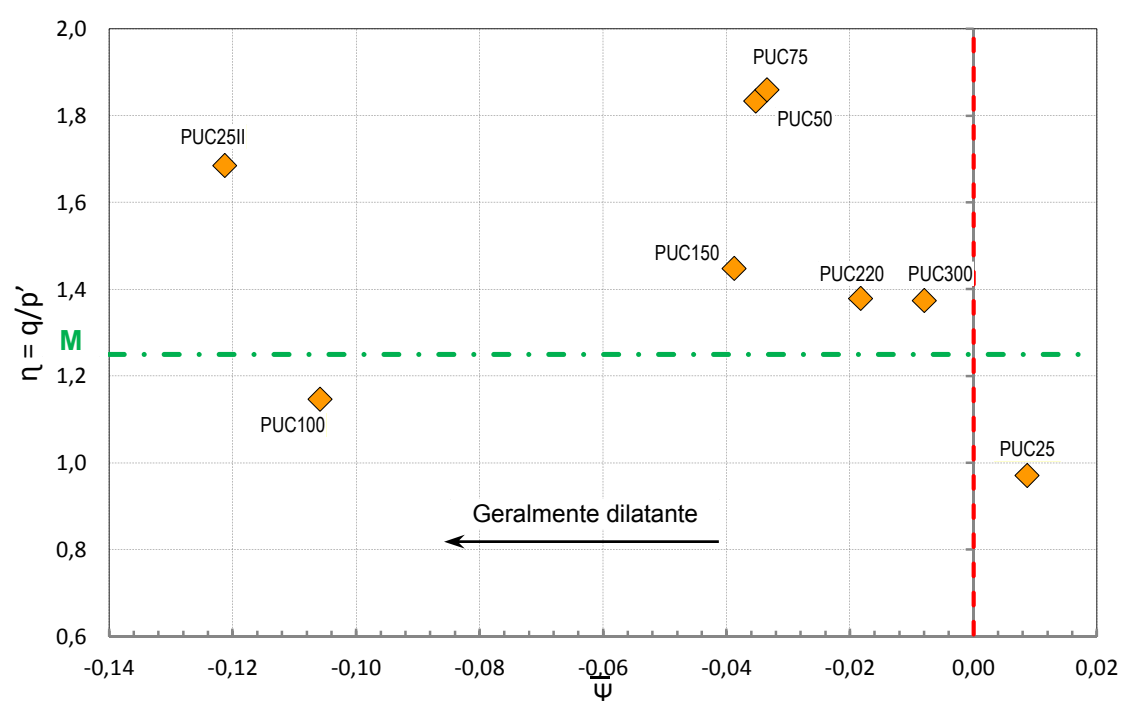

Figura 8.2 - Relação entre o parâmetro de estado modificado, $\bar{\psi}$, e a relação de tensões efetivas no escoamento, $\eta$, nos ensaios APP do solo coluvionar da PUC

Os ensaios de aumento de poropressão permitiram definir, no espaço p'vs q, uma envoltória com os pontos de início da deformação rápida, denominada aqui como "envoltória APP", e a linha de condição última ou de estado crítico, determinada com a tendência final das trajetórias de tensão. $O$ efeito de cimentação fraca neste solo foi evidente principalmente para baixos níveis de tensão confinante. O estado floculado e a presença de óxidos de ferro no solo, relatados no capítulo de caracterização dos solos, fazem com que a envoltória APP apresente a baixas tensões uma parcela adicional de resistência, como observado na Figura 7.9. As trajetórias dos ensaios realizados com baixas tensões ultrapassaram a linha de estado crítico, provocando que a envoltória APP se situe acima da linha de estado crítico para tensões menores que $50 \mathrm{kPa}$ e por abaixo para tensões maiores. Anderson e Sitar (1995) obtiveram, da 
mesma forma, uma envoltória não linear e mais inclinada em baixas tensões confinantes, em amostras inalteradas de um solo coluvionar do parque regional de Briones, na Califórnia; porém, a linha de estado crítico ficou muito próxima da envoltória APP.

Na Figura 8.3 são mostradas, no espaço p' vs q, a envoltória APP e a linha de estado crítico obtidas nos ensaios de aumento de poropressão, comparadas com a envoltória de resistência de pico e a linha de estado crítico, obtidas a partir dos ensaios triaxiais convencionais drenados e não drenados. Ademais, observa-se a envoltória de resistência residual, conseguida no ensaio de cisalhamento direto com plano cortado e superfície polida.

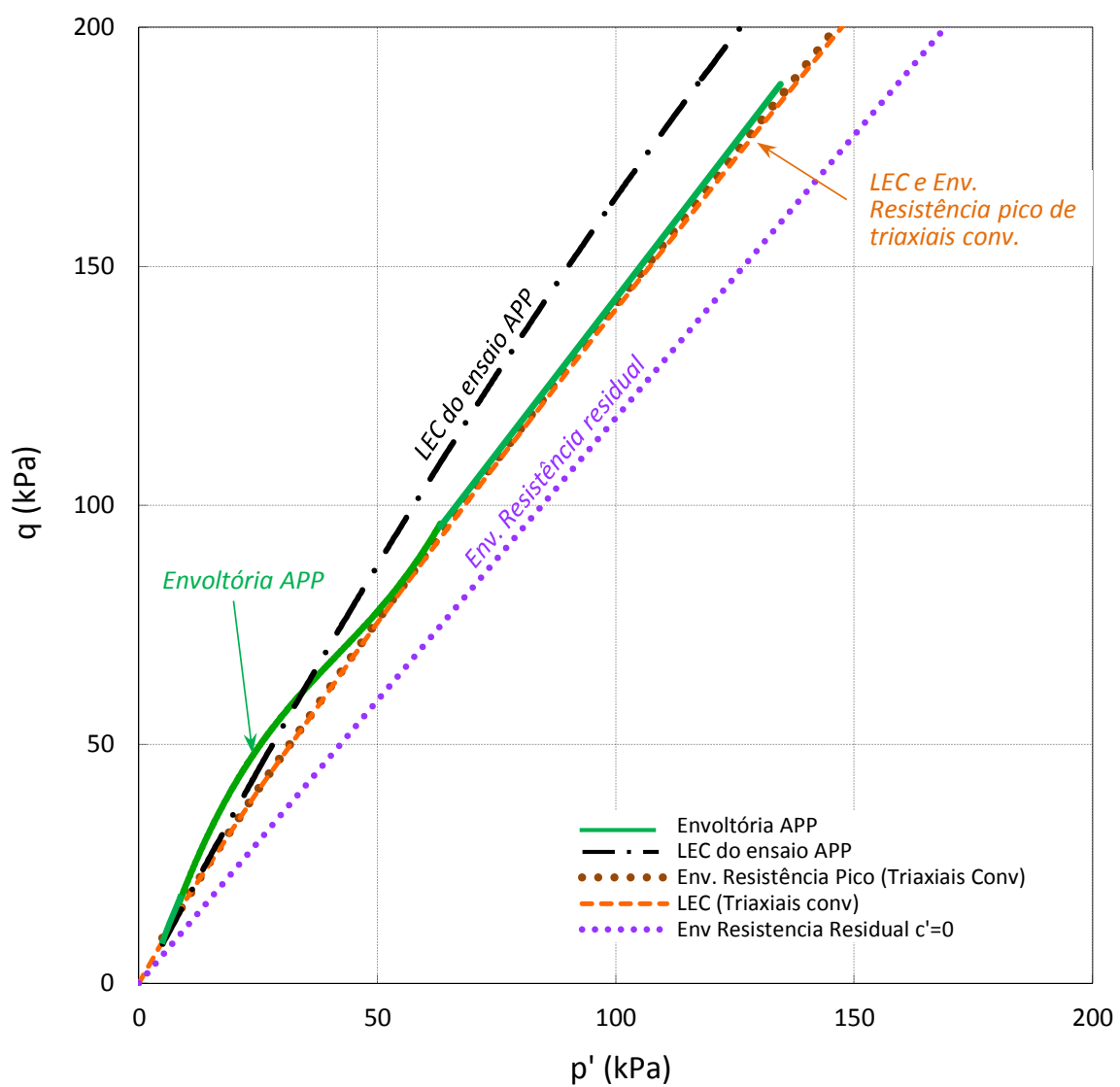

Figura 8.3 - Envoltórias obtidas a partir dos diferentes tipos de ensaios realizados no solo coluvionar da PUC

$\mathrm{Na}$ figura observa-se que para tensões maiores que $50 \mathrm{kPa}$, a envoltória definida com os pontos de inicio da deformação rápida nos ensaios APP coincide com a envoltória de resistência de pico e a linha de estado crítico dos ensaios triaxiais convencionais. Já, para tensões menores, a envoltória APP apresentase curva e por acima do resto das envoltórias. 
No que respeita às linhas de estado crítico, percebe-se a variação do posicionamento de ambas as linhas, situando-se a linha determinada pelos ensaios APP por acima e afastada da obtida nos ensaios triaxiais convencionais. Como neste caso, diferentes linhas de estado permanente ou crítico foram reportadas por Anderson e Sitar (1994) para um solo coluvionar submetido a ensaios APP e triaxiais não drenados, adensados anisotropicamente.

A envoltória de resistência residual encontra-se por abaixo do resto das envoltórias. As amostras PUC25 e PUC100 que romperam antes que os outros ensaios o fizeram ao alcançar esta envoltória.

Das comparações feitas, pode-se dizer que a avaliação da resistência para tensões menores que $50 \mathrm{kPa}$ seria conservadora ao realizar-se com resultados dos ensaios triaxiais convencionais. Para as tensões maiores não se observariam diferenças nas análises realizadas com os resultados obtidos nos ensaios APP ou nos triaxiais convencionais.

Da mesma maneira, com os resultados dos ensaios triaxiais convencionais, uma análise conservadora teria lugar na avaliação da resistência a grandes deformações.

\section{2 \\ Solo do Campus Avançado da PUC em Tinguá}

O comportamento do solo coluvionar de Tinguá, durante o aumento da poropressão, foi similar ao observado no solo da PUC, com pequenas deformações antes do inicio da ruptura rápida e aumento de volume inicial devido à redução de p'. Porém, observou-se que nas amostras com maiores tensão confinantes (TIN100, TIN150, TIN220 e TIN300), a partir do ponto de escoamento, a deformação volumétrica se manteve constante o que revelaria que provavelmente a condição não drenada prevaleceu dentro dos corpos de prova, devido à natureza compressiva do solo. A condição não drenada provocou a deformação axial rápida, que por sua vez gerou um excesso adicional de poropressão em três das amostras, Figura 7.15. Já nos ensaios triaxiais, para a maioria dos estados de tensão, o solo apresentou comportamento compressivo.

Estes resultados poderiam confirmar a hipótese feita por alguns pesquisadores (Anderson e Sitar, 1995; Tsukamoto et al., 1998), os quais indicaram que a ruptura rápida de um talude causada pela infiltração da água de chuva é o resultado de uma iniciação drenada e mobilização não drenada. De 
acordo com Orense et al., (2004), a ruptura ao longo da superfície potencial de ruptura em um talude sujeito a infiltração de chuvas é iniciada em condições drenadas. No entanto, se a tendência de alteração de volume do solo após a iniciação de ruptura for compressiva, um estado não drenado prevaleceria no interior da massa do solo, mesmo sob a condição drenada (ou seja, quando a válvula de drenagem está aberta), e isto poderia causar um aumento de poropressão durante o processo de cisalhamento que levaria ao solo a uma ruptura rápida. Contudo, este comportamento foi observado, somente, nos corpos de prova do solo de Tinguá, ensaiados com maiores tensões confinantes. Possivelmente, a cimentação fraca deste solo coluvionar contribuiu para que não se apresente em menores tensões confinantes.

No espaço e vs p' (Figura 7.13) as amostras TIN100, TIN150, e TIN300 apresentaram parâmetros de estado modificado, $\bar{\psi}$, positivos; por consequência, o comportamento do solo seria de compressão e propenso ao desenvolvimento de liquefação, de acordo aos critérios de instabilidade propostos por Leroueil (2001).

A presença de gibbsita (hidróxidos de alumínio) no solo laterítico de Tinguá, promove, possivelmente, a agregação de partículas argilosas, atribuindo-lhe uma estrutura mais porosa, influenciando diretamente na capacidade de retenção de água neste solo, o que lhe conferiria a possibilidade de desenvolver o fenômeno de liquefação.

A linha de estado crítico obtida com as trajetórias dos ensaios de aumento de poropressão no espaço e vs p' da Figura 7.13 é comparada com a obtida a partir de ensaios triaxiais convencionais da Figura 6.34. A Figura 8.4 mostra essa comparação; observa-se a pouca variação na disposição das linhas. 

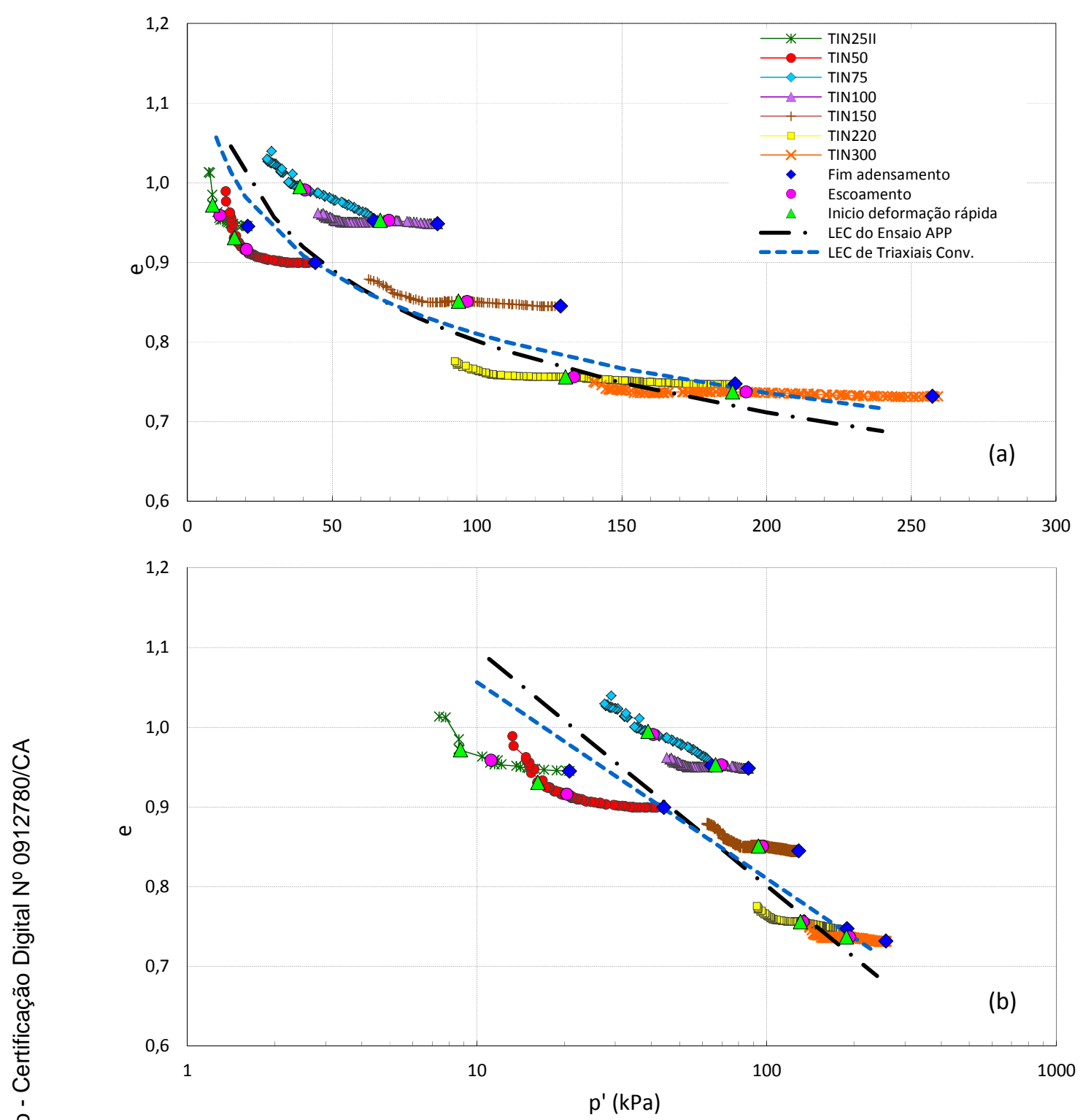

Figura 8.4 - Trajetórias de tensão no espaço e vs p' e linhas de estado crítico obtidas no ensaio APP e ensaios triaxiais convencionais do solo coluvionar de Tinguá

A Figura 8.5 mostra a relação entre as tensões efetivas no escoamento, $\eta=q / p^{\prime}$, versus o parâmetro de estado modificado $\bar{\psi}$. $O$ valor de $\eta$ no escoamento varia de 1,23 a 2,10, para valores de $\bar{\psi}$ variando entre $-0,12$ a 0,11 . Pode-se observar a linha correspondente ao valor do parâmetro $M$ do estado crítico $(1,36)$, obtido a partir dos ensaios triaxiais convencionais.

Na Figura 8.5 observa-se que para a maioria das amostras consideradas contrativas $(\bar{\psi}>0)$, a relação entre as tensões efetivas no escoamento, $\eta=q / p$, é menor que o parâmetro $\mathrm{M}$, ficando abaixo da linha de estado crítico linear; enquanto que para as amostras dilatantes $(\bar{\psi}<0)$, o valor de $\eta=q / p$ ' é maior a $M$. Percebe-se a diferença na posição do ponto de escoamento das diferentes amostras com respeito à linha de estado crítico não linear determinada com os 
ensaios APP (da Figura 7.16), onde unicamente o ponto de escoamento de duas amostras está acima da linha de estado crítico.

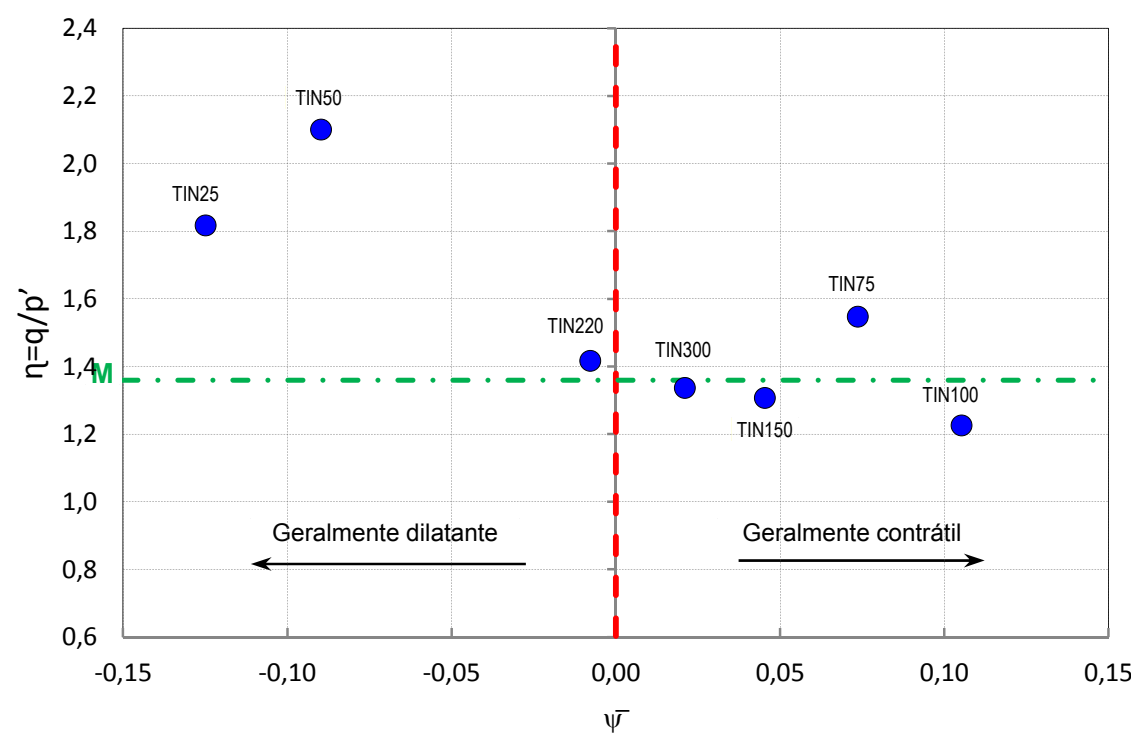

Figura 8.5 - Relação entre o parâmetro de estado modificado, $\bar{\psi}$, e a relação de tensões efetivas no escoamento, $\eta$, nos ensaios APP do solo coluvionar de Tinguá

Analisando a envoltória de inicio de deformação rápida obtida dos ensaios APP na Figura 7.16, fica claro que, como o solo coluvionar da PUC, o solo coluvionar de Tinguá sofre a influência de uma cimentação fraca nos níveis menores de tensão. Neste caso, também, a envoltória APP ficou acima da linha de estado crítico em baixas tensões e por abaixo nas maiores. Resultados semelhantes aos conseguidos para as tensões maiores foram obtidos por Junaideen et al. (2010) em amostras de solo residual compactado, definindo uma "linha de início de ruptura" embaixo da linha de estado crítico e fornecendo parâmetros de resistência menores que os atingidos com a envoltória última. Andersom e Riemer (1995), Tsukamoto et al. (1999) e Orense et al. (2004) encontraram resultados parecidos em amostras de areia preparadas com uma densidade baixa.

As envoltórias determinadas a partir dos diferentes tipos de ensaios são plotadas juntas na Figura 8.6. As envoltórias correspondentes aos ensaios triaxiais convencionais foram traçadas para o intervalo de tensões mostrado na figura, enquanto que na envoltória de resistência residual usou-se o valor do ângulo de atrito residual, $\phi_{\mathrm{r}}$, obtido por interpolação linear e intercepto coesivo nulo $\left(c_{r}^{\prime}=0\right)$ nos ensaios de cisalhamento direto com plano cortado e superfície polida. 


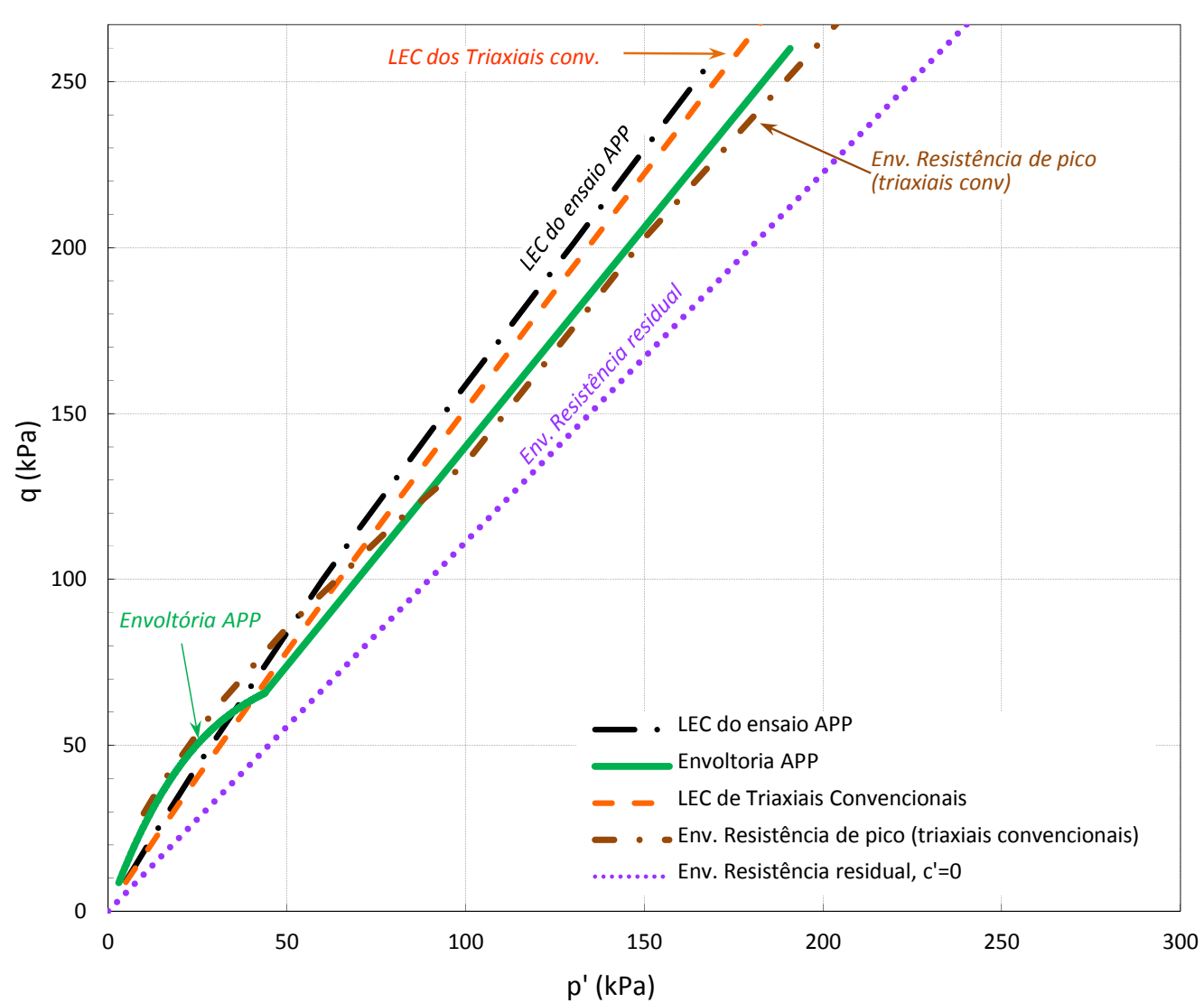

Figura 8.6 - Envoltórias obtidas a partir dos diferentes tipos de ensaios realizados no solo coluvionar de Tinguá

$\mathrm{Na}$ figura pode-se observar que para este caso a envoltória APP é praticamente coincidente com a envoltória de resistência de pico obtida dos triaxiais convencionais, apresentando curvaturas para baixas tensões. Porém, deve-se mencionar que os ensaios triaxiais convencionais foram executados para uma maior faixa de tensões, com tensões de ruptura entre 56 a $523 \mathrm{kPa}$, enquanto os ensaios de poropressão foram executados em uma faixa de tensões menor, com tensões na ruptura entre 9 a 190 kPa. Por consequência, a envoltória para baixas tensões estaria mais bem definida com os ensaios de aumento de poropressão.

As linhas de estado crítico, determinadas para ambos os tipos de ensaios, situam-se por debaixo da envoltória APP nas baixas tensões, já para tensões maiores se localizam acima. Pode-se apreciar que ambas as linhas são próximas. A envoltória de resistência residual encontra-se por abaixo do resto das envoltórias; a que por sua vez representaria a resistência de pico obtida nos ensaios de cisalhamento direto.

A tendência geral sugerida pelas envoltórias conseguidas dos ensaios é que não se observariam diferenças na avaliação da resistência com os resultados dos ensaios triaxiais convencionais e com os de aumento de 
poropressão. Na avaliação da resistência a grandes deformações as diferenças seriam mínimas.

De forma semelhante, Santos et al., (2004) reportaram parâmetros de resistência obtidos a partir de ensaios de aumento de poropressão idênticos àqueles obtidos em ensaios de compressão triaxial convencional CID e CIU em um solo residual da encosta de Soberbo, Alto de Boa Vista, Rio de Janeiro.

\section{3}

\section{Solo de Duque de Caxias}

A não ruptura dos corpos de prova do solo residual de Duque de Caxias com tensões confinantes menores que $220 \mathrm{kPa}$, submetidos ao aumento de poropressão, é um dos maiores reflexos da presença da cimentação no solo, proporcionada pelo oxi-hidróxido de ferro e o material fino (principalmente a goethita). As amostras que romperam durante o aumento da poropressão, poderiam ter sofrido ruptura da cimentação durante o processo de adensamento anisotrópico.

Resultados semelhantes aos encontrados neste solo foram achados por Zhu e Anderson (1998) em um solo residual de basalto procedente de uma encosta no Honolulu, Havaí; onde algumas das amostras ensaiadas com tensões efetivas muito baixas não romperam $\left(p^{\prime}<34 \mathrm{kPa}\right)$, embora as poropressões na amostra se igualaram à tensão confinante aplicada na câmara triaxial, reduzindo $\sigma_{3}{ }_{3}$ a zero. Segundo os autores, isto aconteceu devido a certa resistência não confinada da amostra, que foi atribuída à estrutura cimentante do solo ou ao reforço de raízes, o que provocou que algumas amostras com elevado índice de vazios dilataram, enquanto que algumas amostras com baixo índice de vazios contraíram. De acordo com Zhu e Anderson, a cimentação fraca tende a ser alterada após o estado de escoamento, o que pode provocar um aumento ou uma diminuição do volume da amostra, dependendo do movimento das partículas cimentadas.

Na Figura 8.7 são mostradas, no plano p' vs q, as envoltórias obtidas a partir dos diferentes tipos de ensaios realizados no solo residual jovem de Duque de Caxias, junto às trajetórias dos ensaios APP e de carregamento axial não drenado realizados no presente trabalho. Observa-se a envoltória de inicio de ruptura e a linha de estado crítico determinadas com os ensaios APP. Na mesma figura foi colocada a curva de plastificação determinada por Carvalho (2012). Adicionalmente, traçou-se a envoltória não linear de resistência de pico, obtida de contornar as trajetórias dos ensaios triaxiais realizados por Carvalho neste 
solo. A envoltória de resistência residual, apresentada também na figura, foi obtida dos ensaios de cisalhamento direto com plano cortado e superfície polida feitos no presente estudo. Com a finalidade de ajudar nas comparações, como no solo coluvionar de Tinguá, usou-se o valor do ângulo de atrito residual, $\phi$ ', obtido por interpolação linear na Figura 6.11(a) e intercepto coesivo nulo $\left(c^{\prime}=0\right)$.

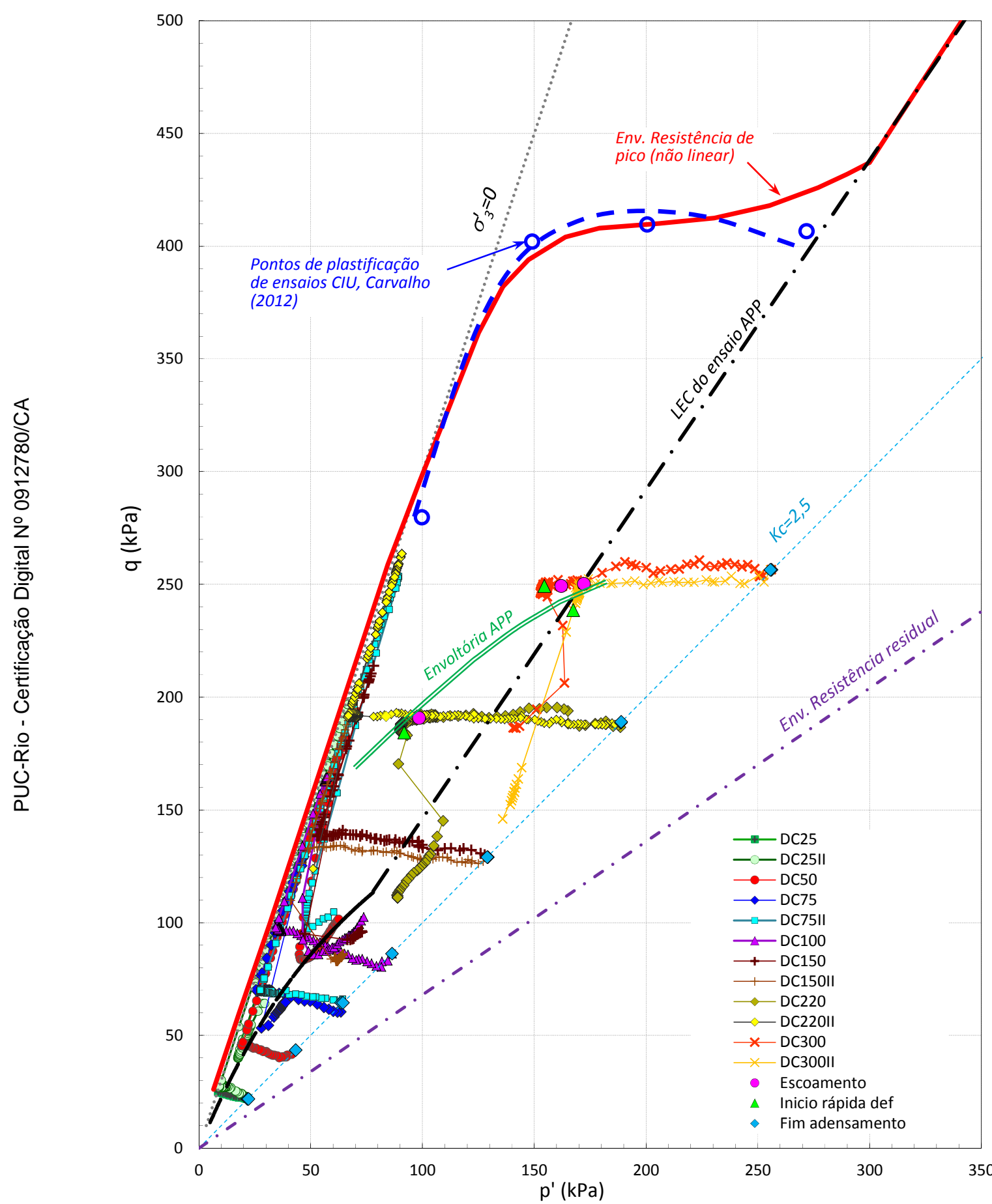

Figura 8.7 - Trajetórias de tensão dos ensaios APP do solo residual jovem de Duque de Caxias, junto à linha de estado crítico, envoltórias de resistência de pico e residual, curva de plastificação e envoltória APP 
A forte influência da estrutura cimentada no comportamento do solo residual jovem de Duque de Caxias ficou também evidente na envoltória de resistência de pico curva, obtida dos ensaios triaxiais CIU realizados por Carvalho (2012), e constatada nos ensaios de cisalhamento direto realizados no presente trabalho.

Analisando a figura é possível notar que a envoltória de resistência de pico não linear coincide com a linha que representa $\sigma_{3}=0$ até a tensão média de 100 $\mathrm{kPa}$ aproximadamente. Além disso, observa-se o bom ajuste, debaixo desta envoltória, das diferentes trajetórias de tensão traçadas.

Por outro lado, note-se que as trajetórias do carregamento axial não drenado complementam a envoltória de plastificação (linha tracejada) definida por Carvalho (2012).

Como pode ser visto, a envoltória de resistência residual é notavelmente diferente das outras envoltórias, ficando bem abaixo delas. A presença da mica na composição da fração areia e silte explicaria a causa do valor de ângulo de atrito residual mais baixo.

A envoltória dos ensaios APP foi traçada para os ensaios que romperam, ficando por acima da linha de estado crítico.

A linha de estado crítico definida para os ensaios APP praticamente coincidiu com a linha determinada por Carvalho (2012), exceto pela curvatura encontrada para baixas tensões efetivas, como pode ser observado na Figura 8.8. Ainda assim, na Figura $8.9, \eta=q / p^{\prime}$ vs $\bar{\psi}$, observa-se uma boa concordância das relações entre as tensões efetivas no escoamento e o parâmetro $M=1,46$ obtido por Carvalho (2012); onde duas amostras ficaram acima da linha de estado crítico (representada pelo valor de M), como no caso da Figura 8.7, onde os pontos de escoamento de duas amostras ultrapassaram a linha de estado crítico não linear. 


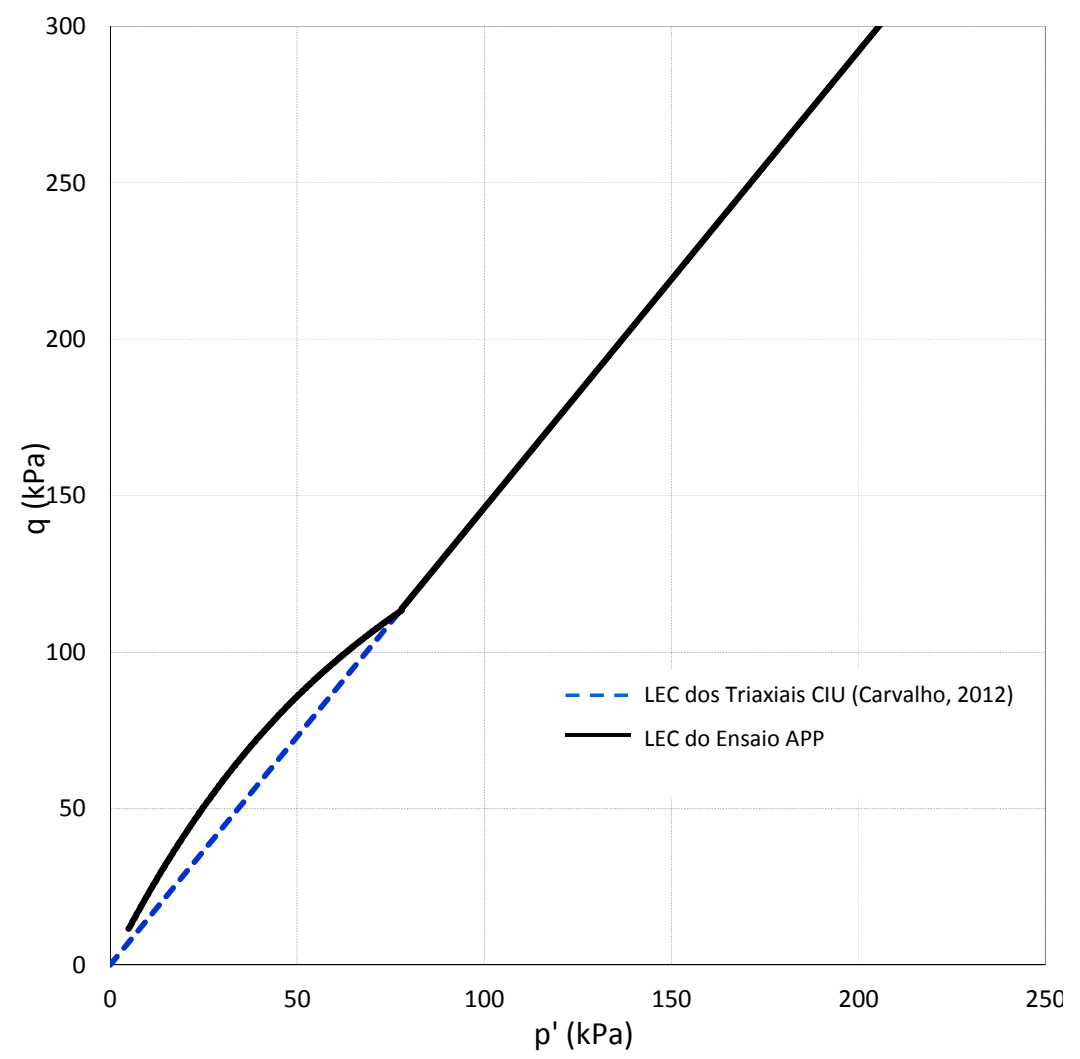

Figura 8.8 - Comparação no plano p' vs q da linha de estado crítico determinada nos ensaios APP com a linha estabelecida por Carvalho (2012) no solo residual jovem de Duque de Caxias

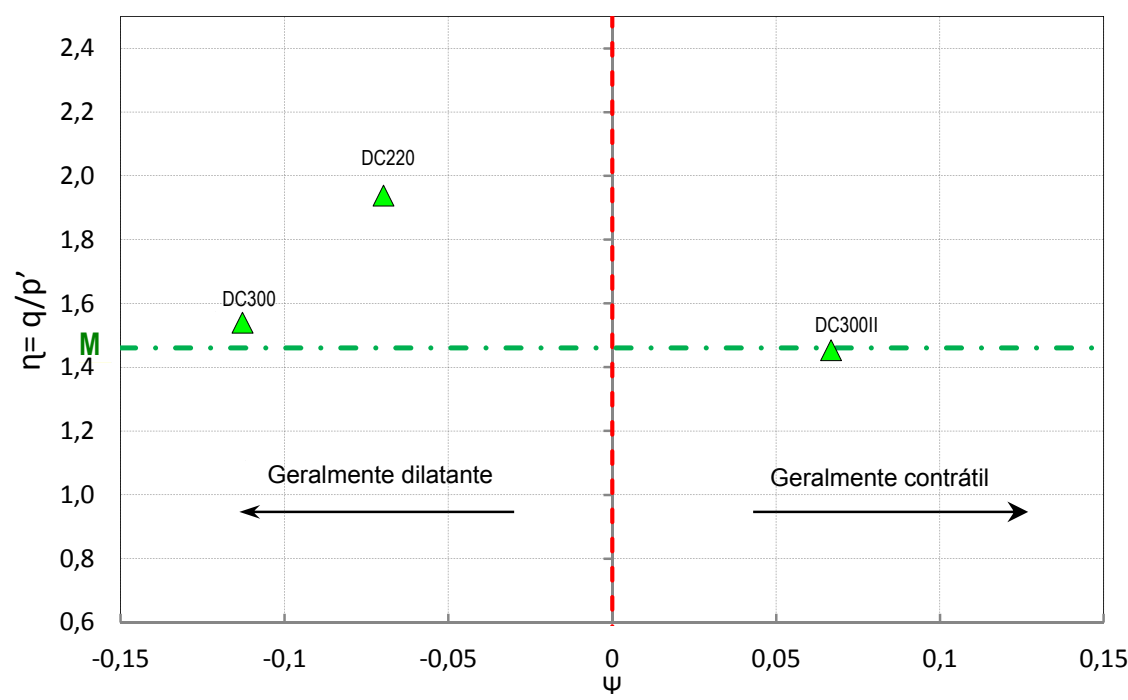

Figura 8.9 - Relação entre o parâmetro de estado modificado, $\bar{\psi}$, e a relação de tensões efetivas no escoamento, $\eta=q / p^{\prime}$, nos ensaios APP do solo residual jovem de Duque de Caxias

A linha de estado crítico obtida por Carvalho no espaço e' vs p foi traçada junto aos resultados obtidos no presente trabalho na Figura 8.10. Observa-se a pouca variação no posicionamento de ambas as linhas. 

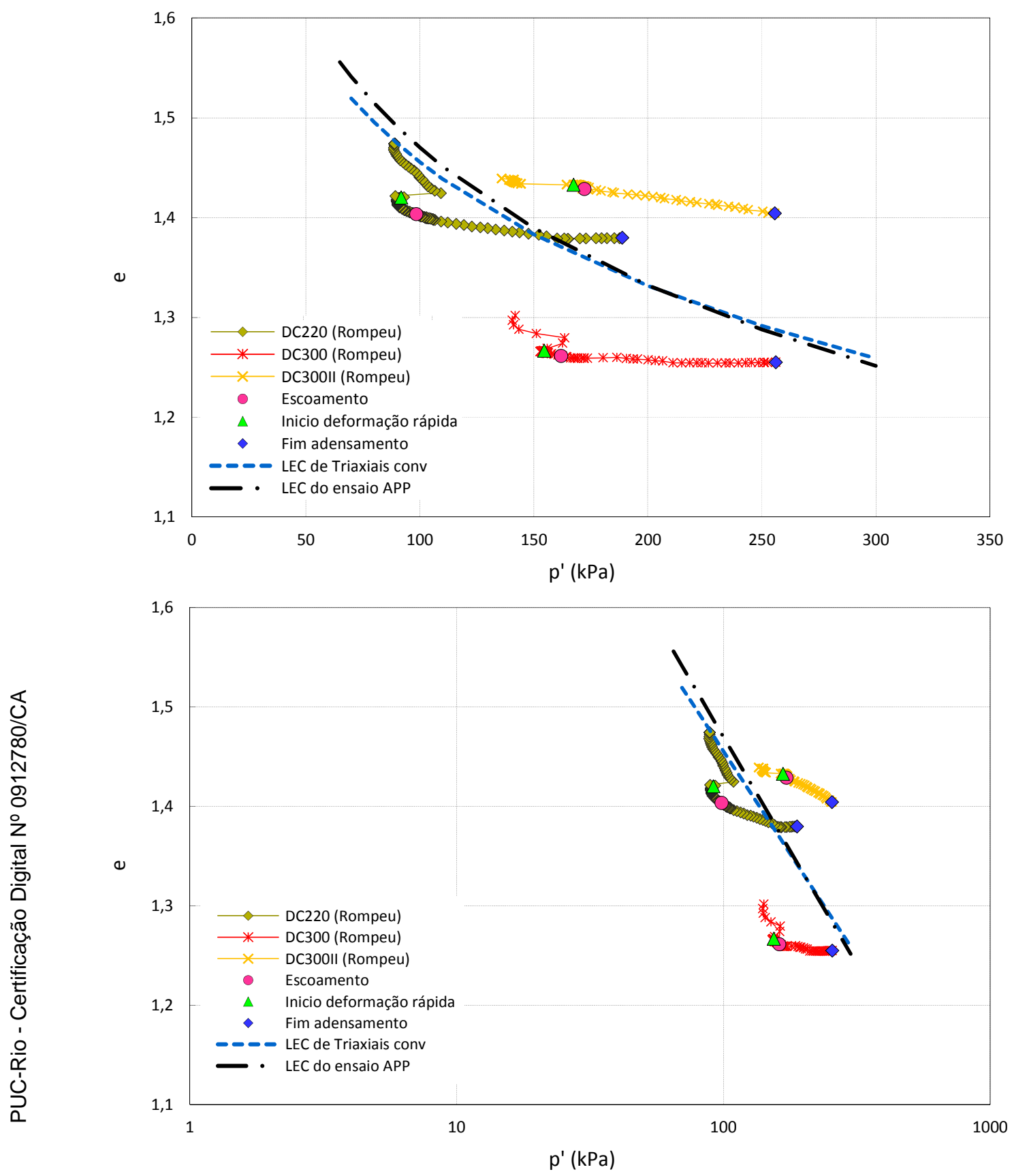

Figura 8.10 - Trajetórias de tensão no espaço e vs p' e linhas de estado crítico obtidas no ensaio APP e ensaios triaxiais CIU realizados por Carvalho (2012), no solo residual jovem de Duque de Caxias 


\section{9 \\ Conclusões e sugestões para trabalhos futuros}

O presente trabalho consistiu na avaliação do efeito do aumento de poropressão nas caraterísticas de resistência de três solos tropicais. Para tal fim, foram selecionados dois solos coluvionares e um solo residual jovem, provenientes de encostas localizadas em diferentes áreas do Estado de Rio de Janeiro. Estes solos foram devidamente caracterizados e submetidos a ensaios de aumento de poropressão (ensaios APP), além de ensaios de cisalhamento direto com plano cortado e superfície polida e ensaios triaxiais convencionais. Neste capítulo são apresentadas as conclusões e sugestões, baseadas nas informações obtidas durante a realização do estudo.

\section{1}

\section{Conclusões}

\section{Referentes aos solos coluvionares}

- Os solos coluvionares estudados são considerados lateríticos, sendo que o solo coluvionar de Tinguá está em estado mais avançado de laterização. Os processos de laterização conferem à estrutura aberta destes solos a formação de microagregados que podem se ligar a outros por contato entre eles ou por algum cimento, que embora fraco, pode atribuir ao solo efeitos de um pseudo sobreadensamento.

- $\quad$ Os efeitos da estrutura agregada dos solos coluvionares foram observados nas curvaturas das envoltórias de resistência ao cisalhamento, obtidas a partir dos ensaios de cisalhamento direto e triaxiais convencionais. Da mesma forma, a linha de estado crítico foi achada não linear para ambos os solos.

- Os ensaios de cisalhamento direto com plano cortado e superfície polida foram usados como uma alternativa para estimar a resistência residual dos solos. Os solos coluvionares, apesar de contar com elevadas porcentagens de argila, apresentaram ângulos de atrito residuais altos, possivelmente, por causa de sua estrutura agregada. Não houve queda 
apreciável no valor de resistência, confundindo-se a envoltória de pico com a residual.

- A ruptura nos ensaios APP aconteceu com pequenas deformações axiais. Com relação às deformações volumétricas, a maioria das amostras apresentou comportamento dilatante, uma vez que a ruptura foi iniciada. Apenas quatro amostras do solo coluvionar de Tinguá, adensadas acima de tensões efetivas na ordem de $p^{\prime}=86 \mathrm{kPa}$, apresentaram comportamento contrátil. Em contraste, a maioria das amostras de ambos os solos coluvionares exibiram comportamento compressivo nos ensaios de cisalhamento direto e triaxiais convencionais.

- $\quad$ Nos ensaios APP, para tensões confinantes menores (PUC25II e TIN25II) foi observada, por meio dos eletroníveis, uma tendência à extensão axial $\left(\varepsilon_{\mathrm{a}}<0\right)$, verificando-se o comportamento dilatante causado pela perda de confinamento e presença de cimentação.

- As deformações axiais e volumétricas determinadas através dos eletroníveis e do MVV, respectivamente, consideraram-se as mais apropriadas, principalmente a baixos níveis de deformação. Devido à possibilidade do deslocamento relativo entre o solo e a membrana, quando a tensão efetiva é muito baixa as deformações obtidas se tornariam não confiáveis.

- Uma vez atingida a ruptura nos ensaios APP, as amostras que apresentaram comportamento dilatante sofreram deformações lentas, geradas provavelmente por este comportamento. As amostras adensadas abaixo de tensões efetivas na ordem de p'=67 kPa, desenvolveram velocidades de deformação mais elevadas do que as amostras adensadas com tensões maiores. Estas velocidades foram levemente superiores nos ensaios do solo da PUC, PUC50 e PUC75, onde foi observada a diminuição do excesso de poropressão dentro dos corpos de prova, que por sua vez pode estar relacionada à presença da cimentação fraca e ao arranjo dos grãos.

- Nas amostras do solo coluvionar de Tinguá adensadas acima de tensões efetivas na ordem de $p^{\prime}=86 \mathrm{kPa}$, a deformação volumétrica se manteve constante a partir do ponto de escoamento, o que refletiria a natureza compressiva do solo e a aparente condição não drenada alcançada. A condição não drenada teria causado a deformação axial rápida, que por sua vez gerou um excesso adicional de poropressão. 
- As trajetórias dos ensaios APP do solo coluvionar da PUC, no espaço e vs $\mathrm{p}^{\prime}$, desenvolveram-se debaixo da linha de estado crítico determinada para este tipo de ensaios, obtendo-se parâmetros de estado modificado negativos $(\bar{\psi}<0)$. $O$ parâmetro de estado negativo definiria 0 comportamento dilatante do solo e a sua tendência de desenvolver movimentos lentos e não ser susceptível a liquefação.

- No espaço e vs p', três das amostras do solo coluvionar de Tinguá (TIN100, TIN150 e TIN300) apresentaram parâmetros de estado modificado positivos $(\bar{\psi}>0)$, o que definiria o comportamento de compressão e a sua predisposição ao desenvolvimento de liquefação. Possivelmente, a cimentação fraca deste solo coluvionar contribuiu para que esse comportamento não se apresente em menores tensões confinantes.

- Estudos efetuados em laboratório indicam que os solos susceptíveis ao desenvolvimento do fenômeno de liquefação são principalmente os que apresentam granulometria uniforme, sendo constituídos basicamente por areia fina. A presença de gibbsita (hidróxidos de alumínio) no solo laterítico de Tinguá promoveria, possivelmente, a agregação de partículas argilosas, atribuindo-lhe uma estrutura porosa, com menor capacidade de retenção de água, fazendo com que este solo se comporte na prática como silte ou até mesmo como areia fina, o que the conferiria uma maior possibilidade de desenvolver esse tipo de fenômeno.

- No espaço $p$ vs q' definiu-se a "envoltória APP" com os pontos de inicio de deformação rápida de cada um dos ensaios APP. Além disso, com a tendência final das trajetórias de tensão determinou-se a linha de condição última ou de estado crítico. Por causa da resistência conferida pela cimentação fraca ou a estrutura agregada nos solos coluvionares, a envoltória dos ensaios APP para pequenas tensões efetivas (menores que $50 \mathrm{kPa}$ ), apresentou-se marcadamente curva e acima da linha de estado crítico. Para tensões maiores, a envoltória APP ficou abaixo dessa linha.

- No solo coluvionar da PUC, para tensões maiores que $50 \mathrm{kPa}$, a envoltória APP coincide com a envoltória de resistência de pico e a linha de estado crítico obtidas nos ensaios triaxiais convencionais. Porém, para tensões de ruptura menores, a envoltória APP apresenta-se curva e por acima do resto das envoltórias. 
- No solo coluvionar de Tinguá, a envoltória APP é praticamente coincidente com a envoltória de resistência de pico obtida dos triaxiais convencionais, apresentando ambas as curvaturas para baixas tensões. Contudo, devido às menores tensões de ruptura nos ensaios APP, a envoltória para baixas tensões estaria mais bem definida com este tipo de ensaios.

- Das comparações feitas no solo coluvionar da PUC, pode-se dizer que a avaliação da resistência para tensões menores que $50 \mathrm{kPa}$ seria conservadora ao realizar-se com resultados dos ensaios triaxiais convencionais. Para as tensões maiores não se observariam diferenças nas análises realizadas com os resultados obtidos nos ensaios APP ou com os triaxiais convencionais.

- A tendência geral, sugerida pelas envoltórias conseguidas dos ensaios no solo coluvionar de Tinguá, é que não se observariam diferenças na avaliação da resistência com os resultados dos ensaios triaxiais convencionais e com os de aumento de poropressão.

- Os ensaios APP e os triaxiais convencionais, definiram diferentes linhas de estado crítico nos espaços p' vs q e e vs p', encontrando-se variabilidade na sua posição, principalmente nos solos coluvionares.

\section{Referentes ao solo residual jovem}

- O solo residual jovem ou saprolítico de Duque de Caxias está constituído principalmente por biotita intemperizada com presença de concreções de manganês (óxi-hidróxido de ferro precipitado), sendo o ferro liberado depositado nos vazios do solo. O óxi-hidróxido de ferro juntamente com o material fino (silte e argila - principalmente a goethita) atuam como cimento que pode contribuir com o aumento da resistência ao cisalhamento do solo, em termos de coesão aparente.

- $\quad$ O forte caráter não linear da envoltória de resistência de ruptura obtida nos ensaios de cisalhamento direto e triaxiais CIU, realizados neste trabalho e por Carvalho (2012), é um dos maiores reflexos da presença de cimentação no solo residual jovem de Duque de Caxias.

- Por possuir partículas lamelares (mica) na sua fração areia e silte, as amostras ensaiadas do solo residual jovem de Duque de Caxias apresentaram resistência residual muito menor que a de pico.

- A não ruptura dos corpos de prova do solo residual de Duque de Caxias com tensões confinantes iniciais menores que $220 \mathrm{kPa}$, submetidos ao aumento de poropressão, seria decorrente da presença da cimentação no 
solo. As amostras que romperam durante o aumento da poropressão, teriam sofrido, possivelmente, a alteração da cimentação durante o processo de adensamento anisotrópico e sofreram uma deformação axial súbita no momento da ruptura. Devido à alta velocidade de ruptura é complicado determinar o comportamento de deformação dos corpos de prova após o inicio desta.

- A envoltória APP, definida na faixa de tensões que romperam pelo aumento de poropressão, localizou-se acima da linha de estado crítico.

- $\quad$ Analisando os resultados dos ensaios APP do solo Duque de Caxias, junto com a envoltória de resistência pico não linear obtida por Carvalho (2012), é possível notar que esta coincide com a linha que representa $\sigma_{3}^{\prime}=0$ até a tensão média de $100 \mathrm{kPa}$ aproximadamente. Ainda, observa-se o bom ajuste, abaixo desta linha, das diferentes trajetórias de tensão traçadas.

\section{Conclusões Gerais}

- O aumento da poropressão é um fator causal importante da maioria dos movimentos gravitacionais de massa, principalmente em regiões com climas tropicais, como o Brasil. Daí, a importância da simulação no laboratório de este fenômeno.

- Os ensaios de aumento de poropressão, executados neste trabalho, permitiram representar no laboratório as trajetórias de tensão seguida pelos solos no campo durante chuvas intensas. Os resultados, obtidos mediante uma adequada instrumentação interna, proporcionaram um melhor entendimento dos distintos mecanismos gerados pelo aumento da poropressão antes e durante o desenvolvimento da ruptura, e da influência das trajetórias nas características de resistência dos solos estudados. Além disso, observou-se que sob o efeito do aumento de poropressão cada solo apresentou um comportamento distinto, o que se atribui principalmente ao grau de intemperismo e a suas diferentes características estruturais.

\section{2}

\section{Sugestões}

As seguintes recomendações podem ser feitas para futuras pesquisas:

- Avaliar o efeito de mudanças e perda de sucção pelo aumento de poropressão em solos não saturados, mediante a infiltração de água pela base dos corpos de prova e saída pelo topo (aberto para a atmosfera). 
- Para verificar o comportamento metaestável ou susceptível a liquefação do solo de Tinguá, recomenda-se fazer ensaios triaxiais não drenados com diferentes velocidades de cisalhamento, com medição de poropressão na meia altura do corpo de prova, e obter a trajetória de mudança de estado.

- Estimar a influência da variação de Kc na etapa de adensamento anisotrópico, definindo como afeta na compressibilidade do material.

- $\quad$ Em ordem de investigar o efeito do ângulo de inclinação do talude no desenvolvimento da ruptura causada pela infiltração de água de chuva nas encostas, sugere-se realizar ensaios de aumento de poropressão com diferentes valores de Kc iniciais.

- Examinar o comportamento do solo quando submetido a diferentes velocidades de aumento de poropressão, e avaliar sua influência nos mecanismos de desenvolvimento de deslizamentos de terra.

- As diferenças entre dois solos coluvionares em relação à distribuição granulométrica, composição mineralógica e microestrutura, influenciam diretamente na sua capacidade de retenção de água pelo que se sugere a elaboração das curvas características e de retenção de água para uma correta avaliação. 


\section{Referências bibliográficas}

ABNT - ASSOCIAÇÃO BRASILEIRA DE NORMAS TÉCNICAS. Amostra de Solos - Preparação para ensaios de compactação e caracterização. NBR6457, 1986.

ABNT - ASSOCIAÇÃO BRASILEIRA DE NORMAS TÉCNICAS. Solo - Análise granulométrica - NBR-7181, 1984a.

ABNT - ASSOCIAÇÃO BRASILEIRA DE NORMAS TÉCNICAS. Solo Determinação do limite de liquidez -NBR-6459, 1984b.

ABNT - ASSOCIAÇÃO BRASILEIRA DE NORMAS TÉCNICAS. Solo Determinação do limite de plasticidade - NBR-7180, 1984c.

ABNT - ASSOCIAÇÃO BRASILEIRA DE NORMAS TÉCNICAS. Grãos de solos que passam na peneira de $\mathbf{4 , 8} \mathrm{mm}$ - Determinação da massa específica NBR-6508, 1984d.

AGNELLI, N.; ALBIERO, J. Aspectos físicos, químicos e mecânicos de um solo colapsível, inundado com diferentes líquidos. Solos e Rochas, Revista Brasileira de Geotecnia, v. 18, n. 1, p. 77-95, 1997.

ALARCON-GUZMAN, A.; LEONARDS, G. A.; CHAMEAU, J. L. Undrained monotonic and cyclic strength of sands. Journal of Geotechnical Engineering, ASCE, v. 114, n. 10, p. 1089-1109, 1988.

ALONSO, E.; GENS, A.; LLORET, A.; DELAHAYE, C. Effect of rain infiltration on the stability of slopes. In: Proc. of the First International Conference on Unsaturated Soils, UNSAT'95, Paris, France, v. 1, p. 241-249, 1995.

ANDERSON, S. A. The role of hydrologic response and soil behavior in the initiation of rainfall-induced debris flows. Ph.D. Thesis. University of California at Berkeley, 1992, 220p.

ANDERSON, S. A.; SITAR, N. Procedures for the analysis of the mobilization of debris flows. In: Proc. 13th International Conference on Soil Mechanics and Foundation Engineering, New Delhi, India, v. 1, p. 255-258, 1994.

ANDERSON, S. A.; RIEMER, M. F. Collapse of saturated soil due to reduction in confinement. Journal of Geotechnical Engineering, ASCE, v. 121, n. 2, p. 216220, 1995.

ANDERSON, S. A.; SITAR, N. Analysis of rainfall-induced debris flows. Journal of Geotechnical Engineering, ASCE, v. 121, n. 7, p. 544-552, 1995.

ANDERSON, S. A.; SITAR, N. Shear strength and slope stability in a shallow clayed soil regolith. In: Clay and Shale Slope Instability. Geological Society of 
America Reviews in Engineering Geology. Boulder, Colorado, v. X, p. 1-11, 1995b.

ANDERSON, S. P.; DIETRICH, W. E.; MONTGOMERY, D. R. Subsurface flow paths in a steep, unchanneled catchment. Water Resources Research, v. 33, n. 12, p. 2637-2653, 1997.

ANDRADE, S. A. Estudo da estabilidade da encosta próxima à torre esquerda da igreja do Carmo-Olinda/PE. Dissertação de mestrado, PUC-Rio, Rio de Janeiro, 1988.

ANDRADE, M. H. N.; DE CAMPOS, T. M. P.; VARGAS, E. A. Retroanálise do escorregamento da encosta do Cactáreo. In: 1ra Conferência Brasileira de Estabilidade de Encostas, ABMS/ABGE, Rio de Janeiro, v. 1, p. 161-172, 1992.

ANTUNES, F. S. Comunicação pessoal, 2015.

ANTUNES, F.S.; BARRETO, W. O. Contribuição ao estudo químico e mineralógico das frações silte e argila de latossolos desenvolvidos de rochas básicas do Sul de Matogrosso. Centro Tecnológico do Instituto Militar de Engenharia, 1982.

ANTUNES, F.S.; POLIVANOV, H.; PORTOCARRERO, H.; DE CAMPOS, T.M.P. Solos : Subsídio para estudos de geologia de engenharia. Anuário do Instituto de Geociências - UFRJ, v. 38, p. 180-198, Rio de Janeiro, 2015.

ARAÚJO, A. P. Estudo de campo para a determinação da relação fossapoço em uma área intensamente urbanizada no município de Nova Iguaçu. Universidade Federal Rural do Rio de Janeiro, 2008, 44p.

ATKINSON J. H.; FARRAR D. M. Stress path tests to measure soil strength parameters for shallow landslips. In: Proc. 11th International Conference on Soil Mechanics and Foundation Engineering, San Francisco, California, v. 2, p. 983-986, 1985.

AUGUSTO FILHO, L. M. O. Caracterização geológico-geotécnica voltada à estabilização de encostas: uma proposta metodológica. In: $1^{\text {a }}$ Conferência Brasileira de Estabilidade de Encostas, ABMS/ABGE, v. 2, p. 721-733, Rio de Janeiro, 1992.

AUGUSTO FILHO, L. M. O.; VIRGILI, J. C. Estabilidade de Taludes. Geologia de Engenharia. São Paulo: Associação Brasileira de Geologia de Engenharia, cap. 15 , p. 243-269, 1998.

BALDI, G.; HIGHT, D. W.; THOMAS, G. E. A reevaluation of conventional triaxial test methods. In: Advanced triaxial testing of soil and rock, ASTM STP 977, (eds. Donaghe, R.; Chaney, R.; Silver, M.), Philadelphia, p. 219-263, 1988.

BARATA, F. E. Landslides in the tropical region of Rio de Janeiro. In: Proc. 7th International conference on soil mechanic and foundation engineering, Mexico, v. 2, p. 507-516, 1969.

BEEN, K.; JEFFERIES, M. G. A state parameter for sands. Géotechnique, v. 35, n. 2, p. 99-112, 1985. 
BEEN, K.; JEFFERIES, M. G.; HACHEY, J. The critical state of sands. Géotechnique, v. 41, n. 3, p. 365-381, 1991.

BENEVELI, R. M. Estudo dos efeitos de umedecimento e secagem na resistência ao cisalhamento de um solo compactado em laboratório. Dissertação de mestrado, PUC-Rio, Rio de Janeiro, 2002, 182p.

BISHOP, A. W.; HENKEL, D. J. The measurement of soil properties in triaxial tests. Edward Arnold ed., London, 1962.

BRAND, E. W. Some thoughts on rain-induced slope failures. In: Proc. 10th International Conference on Soil Mechanics and Foundation Engineering, Stockholm, v. 3, p. 373-376, 1981.

BRAND, E. W.; PREMCHIT, J.; PHILLIPSON, H. B. Relationship between rainfall and landslides in Hong Kong. In: Proc. 4th International Symposium on Landslides, Toronto, p. 377-384, 1984.

BRENNER, R. P.; TAM, H. K.; BRAND, E. W. Field stress path simulation of rain induced slope failure. In: Proc. 11th International Conference on Soil Mechanics and Foundation Engineering, San Francisco, v. 2, p. 991-996, 1985.

BRESSANI, L. A.; VAUGHAN, P. R. Damage to soil structure during triaxial testing. In: Proc. 12th International Conference on Soil Mechanics and Foundation Engineering, Rio de Janeiro, v. 1, p. 17-20, 1989.

BRITO, A. T. A. Estudo químico e mineralógico de um perfil de alteração de gnaisse migmatítico do campo experimental II da PUC-RJ, Gávea, Rio de Janeiro. Dissertação de mestrado, PUC-Rio, Rio de Janeiro, 1981, 312 p.

BURLAND, J. B.; SYMES, M. A simple axial displacement gauge for use in the triaxial apparatus. Géotechnique, v. 32, n. 1, p. 62-65, 1982.

CAMAPUM DE CARVALHO, J. Propriedades e comportamento de solos tropicais não-saturados. In: $5^{\circ}$ Simpósio Brasileiro de Solos Não Saturados, São Carlos/SP, p. 597-616, 2004.

CAPRA, L.; LUGO-HUBP, J.; BORSELLI, L. Mass movements in tropical volcanic terrains: the case of Teziùtlan (Mexico). Engineering Geology, v. 69, p. 359379, 2003.

CAREY, J. M. The progressive development and post-failure behaviour of deep-seated landslide complexes. Ph.D. Thesis, University of Durham, 2011, 396p.

CARVALHO, T. M. O. Desenvolvimento de um sistema de medição de variação de volume total de amostras não saturadas em ensaios triaxiais e avaliação da influência da técnica de saturação no comportamento tensão deformação- resistência de solos residuais. Tese de doutorado, PUC-Rio, Rio de Janeiro, 2012, 401p.

CASAGRANDE, A. Liquefaction and cyclic deformation of sands, a critical review. In: Proc. 5th Panamerican Conference on Soil Mechanics and Foundation Engineering, Buenos Aires, v. 5, p. 79-133, 1975. 
CASCINI, L. The flowslides of May 1998 in the Campania region, Italy: the scientific emergency management. Italian Geotechnical Journal, v. 2, p. 11-44, 2004.

CASCINI, L.; CUOMO, S.; PASTOR, M.; SORBINO, G. Modeling of rainfallinduced shallow landslides of the flow-type. Journal of Geotechnical and Geoenvironmental Engineering, v. 136, n. 1, p. 85-98, 2010.

CASTRO, G. Liquefaction of sands. Ph.D thesis, Harvard University, Cambridge, MA. Harvard Soil Mechanics Series, No. 81, 1969.

CASTRO, G.; ENOS, J.L.; FRANCE, J.W.; POLOUS, S.J. Liquefaction induced by cyclic loading. National Science Foundation Report NSF/CEE-82018, 1982.

CHANDLER, R.J. The measurement of residual strength in triaxial compression. Géotechnique, v. 16, n. 3, p. 181-186, 1966.

CHEN, H.; LEE, C. F.; SHEN, J. M. Mechanisms of rainfall-induced landslides in Hong Kong. In: Proc. $2^{\text {nd }}$ International Conference on Debris Flows, Debrisflow hazards mitigation: mechanics, prediction, and assessment, (eds. Wieczorek, G.; Naeser, D.), Taipei, Taiwan, p. 53-60, 2000.

CHEN, H.; LEE, C. F.; LAW, K. T. Causative mechanisms of rainfall-induced fill slope failures. Journal of Geotechnical and Geoenvironmental Engineering, ASCE, p. 593-602, June 2004.

CHU, J.; LEROUEIL, S.; LEONG, W. K. Unstable behaviour of sand and its implication for slope instability. Canadian Geotechnical Journal, v. 40, n. 5, p. 873-885, 2003.

CHU, J.; LEONG W. K.; LOKE, W. L.; WANATOWSKI, D. Instability of loose sand under drained conditions. Journal of Geotechnical and Geoenvironmental Engineering, ASCE, v.138, p. 207-216, 2012.

COLLINS, K. Towards characterization of tropical soil microstructure. In: Proc. 1st Conference on Geomechanics in Tropical Lateritic and Saprolitic Soils,Brasília, v. 1, p. 85-96, 1985.

COSTA NUNES, A. J. Landslides in soil of decomposed rock due intense rainstorms. In: 7th International Conference of Soil Mechanics and Foundation Engineering. México, n. 2, p. 547-554, 1969.

COUTINHO, R. Q.; SEVERO , R. N. F. Investigação geotécnica para estabilidade de encosta. In: V Conferência Brasileira de Estabilidade de Encostas, ABMS, São Paulo, p. 19-74, 2009.

CRUDEN, D. M.; KRAUTER, E.; BELTRAM, L.; LEFEBVRE, G.; TERSTEPANIAN, G. I.; ZHANG, Z. Y. Describing landslides in several languages: the multilingual landslide glossary. In: 7th International Congress Association of Engineering Geology, Lisboa, Portugal, v. 3, p. 1325-1333, 1994.

CRUDEN, D. M.; VARNES, D. J. Landslide types and processes. In: Landslides Investigation and Mitigation. Transportation Research Board Special 
Report 247, Washington DC: National Research Council, (eds. Turner, A.K. and Schuster, R.L.), p. 36-75, 1996.

DAI, F.; LEE, C. F.; WANG, S. Analysis of rainstorm-induced slide-debris flows on natural terrain of Lantau Island, Hong Kong. Engineering Geology, v. 51, n. 4, p. 279-290, 1999.

DAYLAC, R. Desenvolvimento e utilização de uma célula para medição de Ko com controle de sucção. Dissertação de mestrado, PUC-Rio, Rio de Janeiro, 1994, 180p.

DE CAMPOS, T. M. P. Two low plasticity clays under cyclic and transient loading. Ph.D. Thesis, University of London, London, 1984, 728p.

DE CAMPOS, T. M. P. Características de Projeto e Dimensionamento de um Transdutor de Variação de Volume. Departamento de Engenharia Civil PUC/RJ. Relatório Interno, RI 07/85, 1985.

DE CAMPOS, T. M. P. Relatório técnico do projeto Tinguá. 113p, 2012.

DE CAMPOS, T.M.P, MARINHO, F.A.M. Influencia do Sistema de medição de deformações nas características tensão-deformação de um solo residual parcialmente saturado. In: $8^{\circ}$ Congresso de Mecânica de Solos e Engenharia de Fundações. São Paulo, v.1, p. 173-181, 1986.

DE CAMPOS, T.M.P, CARRILLO, C.W. Direct Shear Testing on an Unsaturated Soil from Rio de Janeiro. Unsaturated Soils, Alonso \& Delage (eds), p. 31-38, 1995.

DUARTE, A. P. L. Avaliação das propriedades termo-hidráulicas de solos requeridas na aplicação da técnica de dessorção térmica. Tese de doutorado, PUC-Rio, Rio de Janeiro, 2004, 290p.

DUARTE, A. P. L.; DE CAMPOS, T. M. P.; ROCHA, F. P.; VARGAS, E. A. Avaliação dos fatores de segurança e mecanismos de ruptura através de soluções analíticas. In: V Conferência Brasileira de Estabilidade de Encostas, ABMS, São Paulo, p. 531-540, 2005.

ECKERSLEY, J. D. Instrumented laboratory flowslides. Géotechnique, v. 40, n. 3, p. 489-502, 1990.

EKANAYAKE, J. C.; PHILIPPS, C. J. Slope stability thresholds for vegetated hillslopes: a composite model. Canadian Geotechnical Journal, v. 39, p. 849862, 2002.

EMBRAPA - Manual de métodos de análise de solos, Centro Nacional de Pesquisa de Solos, Rio de Janeiro, 2da Ed., 1997.

EMBRAPA - Sistema Brasileiro de classificação de solos, Centro Nacional de Pesquisa de Solos, Rio de Janeiro, 3ra. Ed., 2013.

FAROOQ, K.; ORENSE, R.; TOWHATA, I. Response of unsaturated sandy soils under constant shear stress drained condition. Soils and Foundations, v. 44, n. 2, p. 1-13, 2004. 
FELL, R.; HUNGR, O.; LEROUEIL, S.; RIEMAR, W. Keynote lecture Geotechnical engineering of the stability of natural slopes and cuts and fills in soil. In: International Conference on geotechnical e geological engineering, Melbourne, v. 1, p. 21-120, 2000.

FRANCH, F. A. J.; FUTAI , M. M. Influência da variação sazonal das pressões de água na estabilidade de talude não-saturado. In: V Conferência Brasileira de Estabilidade de Encostas, São Paulo, ABMS, v. 1, p. 141-148, 2009.

FUCHU, D.; LEE, C. F.; SIJING, W. Analysis of rain storm induced slide-debris flows on natural terrain of Lantau Island, Hong Kong. Engineering Geology, v. 51, p. 279-290, 1999.

FUTAI, M. M. Estudo teórico-experimental do comportamento de solos tropicais não-saturados: aplicação a um caso de voçorocamento. UFRJ, Rio de Janeiro, 2002, Tese de doutorado, 559p.

FUTAI, M. M. Efeito da infiltração na elevação de nível freático nas encostas. Inc: Tópicos sobre infiltração: teoria e prática aplicadas a solos tropicais, Brasília, 2012.

FUTAI, M. M.; ALMEIDA, M. S. S.; LACERDA, W. A. Yield, Strength, and critical state behavior of a tropical saturated soil. Journal of geotechnical and geoenvironmental engineering, ASCE, v. 130. p. 1169-1179, 2004.

GALINDO, M. S. V. Desenvolvimento de uma metodologia para determinação da viscosidade de solos. Dissertação de mestrado, PUC-Rio, Rio de Janeiro, 2013, 122p.

GEOTECHNICAL CONTROL OFFICE (GCO). Mid-levels study: report on geology, hydrology and soil properties, Government printer, Hong Kong, 1982, 264p.

GEOTECHNICAL ENGINEERING OFFICE (GEO), Report on the Kwun Lung Lau landslide of 23 July 1994, Vol 2: Findings of the Landslide Investigation, Hong Kong, 1994, 379p.

GERSCOVICH, D. M. S.; VARGAS, E. A.; DE CAMPOS, T. M. P. On the evaluation of unsaturated flow in a natural slope in Rio de Janeiro, Brazil. Engineering Geology, v. 88, p. 23-40, 2006.

GIBSON, R. E.; HENKEL, D. J. Influence of duration of tests at constant rate of strain on measured "Drained" strength. Géotechnique, v. 4, n. 1, p. 6-15, 1954.

GRAHAM, J.; CROOKS, J. H.; LAU, S. L. Yield envelop: Identification and geometric properties. Géotechnique, v. 38, n. 1, p. 125-134, 1988.

HEAD, K. H. Manual of soil laboratory testing: Testing effective stress tests. $2 a$ ed., London, v. 3, 1998, 425p.

HEILBRON, M.; VALERIANO, C. M.; VALLADARES, C. S.; MACHADO, N. A orogênese brasiliana no segmento central da Faixa Ribeira, Brasil. Rev. Brasileira de Geociências, v. 25, p. 245-266, 1995. 
HIGHT, D. W. A simple piezometer probe for the routine measurement of pore pressure in triaxial tests on saturated soils. Géotechnique, v. 32, n. 4, p. 396401, 1982.

HUNGR, O. Flow slides and flows in granular soils. In: Proc. Int. Workshop Flows 2003 - Occurrence and Mechanisms of Flows in Natural Slopes and Earthfill, L. (ed. Picarelli), Sorrento, Italy, 2003.

HUNGR, O.; EVANS, S. G.; BOVIS, M. J.; HUTCHINSON, J. N. A review of the classification of landslides of the flow type. Environmental \& Engineering Geoscience, v. 7, n. 3, p. 221-238, 2001.

HURTADO ESPINOZA, L. O. Avaliação do potencial de liquefação de solos coluvionares do Rio de Janeiro. Dissertação de mestrado, PUC-Rio, 2010, 146p.

HUTCHINSON, J. N. General report: morphological and geotechnical parameters of landslides in relation to geology and hidrology. In: 5th International Symposium On Landslides, Lausanne, Switzerland, v. 1, p. 3-35, 1988.

IUPAC: União Internacional de Química Pura e Aplicada. Reporting Physisoption data for gás/solid systems, v. 54, p. 2201-2218, 1982.

IVERSON, R. M.; REID, M. E.; LAHUSEN, R. G. Debris flow mobilization from landslides. Annual Review of Earth and Planetary Sciences, v. 25, p. 85-138, 1997.

JARDINE, R. J.; SYMES, M. J.; BURLAND, J. B. The measurement of soil stiffness in the triaxial apparatus. Géotechnique, v. 34, n. 3, p. 323-340, 1984.

JOHNSON, K. A.; SITAR, N. Hydrologic conditions leading to debris-flow initiation. Canadian Geotechnical Journal, v. 27, p. 789-801, 1990.

JUNAIDDEN, S. M. Failure of saturated sandy soils due to increase in pore water pressure, Ph.D. Thesis, University of Hong Kong, 2005, 244p.

JUNAIDEEN, S. M.; THAM, L. G.; LAW, K. T.; DAI, F. C.; LEE, C. F. Behaviour of recompacted residual soils in a constant shear stress path. Canadian Geotechnical Journal, v. 47, p. 648-661, 2010.

KRAMER, S. L. Triggering of liquefaction flow slides in coastal soil deposits. Engineering Geology, v. 26, p. 17-31, 1988.

KUWANO, R.; CONNOLLY, T. M.; JARDINE, R. J. Anisotropic stiffness measurements in a stress-path triaxial cell. Geotechnical Testing Journal, v. 23, n. 2, p. 141-157, 2000.

LACERDA, W. A. Stability of natural slopes along the tropical coast of Brazil. In: Proc. of the Int. Symp. On Recent Developments in Soil and Pavement Mechanics, Rio de Janeiro, p. 17-40, 1997.

LACERDA, W. A. Fatigue of residual soils due to cyclic pore pressure variations. In: 12th International Conference on Soil Mechanics and Foundations Engineering, Rio de Janeiro, p. 3085-3087, 1989. 
LACERDA , W. A. Comportamento geotécnico de massas coluvionares. GEOSUL. Anais do III Simpósio de Prática de Engenharia Geotécnica da Região Sul, Joenvile, p. 219-231, 2002

LACERDA, W. A. The behaviour of colluvial slopes in a tropical environment. In: Proc. 9th International Symposium On Landslides: Landslides, evaluation \& stabilization, (eds. Lacerda, W.; Ehrlich, M.; Fontoura, S.; Sayao, A.), Rio de Janeiro, v. 2, p. 1315-1342, 2004.

LACERDA, W. A.; SANTOS, O. F.; ERHLICH, M. Efeitos das variações de poropressão sobre a estabilidade de encostas em solos residuais. In: 2nd Panamerican Symposium on Landslides, Rio de Janeiro, p. 381-388, 1997.

LEE, H. J.; ELLEN, S. D.; KAYEN, R. E. Predicting transformation of shallow landslides into high-speed debris flows. In: Proc. 5th International Symposium on Landslides, Lausanne, Switzerland, v. 1, p. 713-718, 1988.

LEROUEIL, S. Natural slopes and cuts: movement and failure mechanisms. Géotechnique, v. 51, n. 3, p. 197-243, 2001.

LEROUEIL, S. Geotechnics of slopes before failure. In: Proc. 9th International Symposium on Landslides: Landslides, evaluation \& stabilization, (eds. Lacerda, W.; Ehrlich, M.; Fontoura, S.; Sayao, A.), Rio de Janeiro, v. 2, p. 863884, 2004.

LEROUEIL, S; HIGHT, D. W. Behaviour and properties of natural soils and soft rocks. In: Proc. Characterization and Engineering Properties of Natural Soils, p. 29-254, 2003.

LEROUEIL, S.; LOCAT, J.; SĖVE, G.; PICARELLI, L. \& FAURE, R. M. Slopes and mass movements. Geotechnical and geoenvironmental engineering handbook. Part III. Slope, embankment and wall stability and soil improvement. (ed. Rowe, K.), Ontario, Canada, p. 397-428, 2001.

LEROUEIL, S.; VAUGHAN, P. R. The general and congruent effects of structure in natural clays and weak rocks. Géotechnique, v. 40, n. 3, p. 467-488, 1990.

LEROUEIL, S.; VAUNAT, J.; PICARELLI, L.; LOCAT, J.; FAURE, R.; LEE, H. A geotechnical characterization of slope movements. In: Proc. 7th International Symposium On Landslides: Landslides - Glissement de Terrain, (ed. Senneset, K.) Trondheim, Normay, v. 1, p. 53-74, 1996.

LIN, H. D.; KUNG, J. H. S. Rainfall-induced slope failures in Taiwan. In: Proc. First Asian Conference on Unsaturated Soil, (eds. Rahardjo, H.; Toll, D.; Leong, E.), Singapore, p. 801-806, 2000

LINS, H. A. P. Resistência e poro-pressões desenvolvidas em um solo compactado não saturado em laboratório. Tese de doutorado, Universidade Federal do Rio de Janeiro, UFRJ, Rio de Janeiro, 1991, 363p.

LOPES, M.B.L. Influência da sucção na resistência ao cisalhamento de um solo residual de filito de Belo Horizonte, MG. Dissertação de mestrado, PUCRio, Rio de Janeiro, 2006, 175p. 
LOURENÇO, S.; SASSA, K.; FUKUOKA, H. Failure process and hydrologic response of a two layer physical model: Implications for rainfall-induced landslides. Geomorphology, v. 73, n. 1-2, p. 115-130, 2006.

LOURENÇO, S.; WANG, G.; CHU, J. Aspects of sand behavior by modified constant shear drained tests. Environ Earth Sci, v. 62, p. 865-870, 2011.

LOWE, J. Stability analysis of embankments. Journal of the Soil Mechanics and Foundations Division, ASCE, SM4, v. 93, n. SM4, p. 1-33, 1967.

LUMB, P. Slope failures in Hong Kong. Quarterly Journal of Engineering Geology, v. 8, p. 31-65, 1975.

MARINHO, F. A. M. Características de deformabilidade do solo residual do campo experimental II da PUC/RJ obtidas a partir de ensaios triaxiais axissimétricos. Dissertação de mestrado, PUC-Rio, Rio de Janeiro, 1986, 192p.

MARTINS, F. B. Investigação do comportamento mecânico de um solo naturalmente estruturado. Tese doutorado, UFRGS, Porto Alegre, 2001, 303p.

MARTINS, F.; BRESSANI, L.; BICA, A.; FERREIRA, P. Mecanismos de ruptura de um talude em solo residual de arenito Botucatu. In: 3a Conferência Brasileira sobre Estabilidade de Encostas - COBRAE, Rio de Janeiro, v. 1, p. 279-286, 2001.

MENACHO CASO, J. E. Características de resistência não saturada de um solo coluvionar e um solo saprolítico de Tinguá, RJ, Dissertação de mestrado, PUC-Rio, Rio de Janeiro, 2014, 177p.

MONTGOMERY, D. R.; DIETRICH, W. E.; TORRES, R.; ANDERSON, S. P.; HEFFNER, J. T.; LOAGUE, K. Piezometric response of a steep unchanneled valley to natural and applied rainfall. Water Resources Research, v. 33, p. 91109, 1997.

MURALEETHARAN, K. K.; GRANGER, K. K. The use of miniature pore pressure transducers in measuring matric suction in unsaturated soils. Geotechnical Testing Journal, v. 22, n. 3, p. 226-234, 1999.

NG, K. Y. Mechanism of shallow rainfall-induced landslides in residual soils in humid tropical enviroments, Ph.D. thesis, University of Durham, 2007, 269p.

NG, K. Y.; PETLEY D. N. The use of pore pressure reinflation testing in landslide management in Hong Kong. Quarterly Journal of Engineering Geology and Hydrogeology, v. 42, n. 4, p. 487-498, 2009.

ORENSE, R.; FAROOQ, K.; TOWHATA, I. Deformation behavior of sandy slopes during rainwater infiltration. Soils and Foundations, v. 44, n. 2, p.15-30, 2004.

PENHA, H. M.; FERRARI, A. L.; JUNHO, M. C. B.; SOUZA, S. L. A.; BRENNER, T. L. Relatório Final - Folha Itaipava - Projeto Carta Geológica do Estado do Rio de Janeiro. Departamento de Recursos Minerais/ Departamento de Geologia (UFRJ). Niterói, 1981. 
PETLEY, D. N.; ALLISON, R. J. On the movement of landslides. In: Proc. International Conference on Slopes, Malaysia, Special lecture, p. 115-137, 2006.

PETLEY, D. N.; BULMER, M. H.; MURPHY, W. Patterns of movement in rotational and translational landslides. Geology, v. 30, n. 8, p. 719-722, 2002.

PETLEY, D. N.; HIGUCHI, T.; BULMER, M. H.; CAREY, J. Development of progressive landslide failure in cohesive materials. Geology, v. 33, n. 3, p. 201204, 2005a.

PETLEY, D. N.; HIGUCHI, T.; DUNNING, S.; ROSSER, N. J. A new model for the development of movement in progressive landslides, Inc: International Conference of Landslide Risk Management (ed. Hungr, O; Fell, R.; Couture, R; Eberhardt, E.), Vancouver, p. 201-204, 2005b.

POLIVANOV. H. Caracterização química, mineralógica, física e geotécnica de perfis de alteração desenvolvidos de gnaisse. Tese de doutorado, UFRJ, Rio de Janeiro, 1998, 387p.

POOROOSHASB, H.B.; CONSOLI,N.C. The ultimate state, Proc. IX Panamerican Conference on Soil Mechanics and Foundation Engineering, Viña del Mar, Chile, v. 3, p. 1083-1089, 1991.

POULOS, S.J. The steady state of deformation. Journal of the Geotechnical Engineering Division, ASCE, v. 107, n. 5, p. 553-562, may 1981.

RIGO, M.L.; PINHEIRO R.J.B.; BRESSANI,L.A.; BICA,A.V.D.B; SILVEIRA,R.M. The residual shear strength of tropical soils. Canadian Geotechnical Journal, v. 43, n. 4, p. 431-447, 2006.

ROSCOE, K. H.; SCHOFIELD, A. N.; WROTH, C. P. On the yielding of soils. Géotechnique, v. 8, n. 1, p. 22-53, 1958.

SAITO, M. Forecasting the time of occurrence of a slope failure. In: Proc. 6th International Conference on Soil Mechanics and Foundation Engineering, Montreal, Canada, p. 537-541, 1965.

SANTOS, P. S. Tecnologia de argilas aplicada às argilas brasileiras. Editora da Universidade de São Paulo, volume I, 340p, 1975.

SANTOS, O. F. Estudo experimental do comportamento de um solo residual submetido a variações cíclicas de poropressão. Tese doutorado, UFRJ, Rio de Janeiro, 1996, 215p.

SANTOS, O. F.; LACERDA, W. A.; ERHLICH, M. Discussion of: Collapse of saturated soil due to reduction in confinement. Journal of Geotechnical Engineering, ASCE, v. 122, n. 6, p. 505-506, 1996.

SANTOS, O. F.; LACERDA, W. A.; ERHLICH, M. Comportamento do solo residual da encosta do soberbo (Rio de Janeiro) em ensaios triaxiais com variações monotônica e cíclica de poro-pressão. Solos e Rochas, v. 27, n. 2, p.117-130, 2004. 
SASITHARAN, S.; ROBERTSON, P. K.; SEGO, D. C.; MORGENSTERN, N.R. Collapse behaviour of sand. Canadian Geotechnical Journal, v. 30, n. 4, p. 569-577, 1993.

SASSA, K. The geotechnical classification of landslides. In: Proc 4th International Conference and Field Workshop on Landslides, Tokyo, p. 3145, 1985.

SERTÃ, H. B. C. Aspectos geológicos e geotécnicos do solo residual do campo experimental II da PUC-RJ. Dissertação de mestrado, PUC-Rio, Rio de Janeiro, 1986, 185p.

SHARPE, C.F.S. Landslide and related phenomena: A study of massmovements of soil and rock. New York, Columbia University Press, 1938, $137 p$.

SILVEIRA, R. M. Comportamento geotécnico de um solo coluvionar da São Vendelino (RS). Tese de doutorado, UFRGS, Porto Alegre, 2008, 301p.

SITAR, N.; ANDERSON, S. A.; JOHNSON, K. A. Conditions for Initiation of rainfall-induced debris flows. In: Geotechnical Special Publication (GSP) No 31: Stability and Performance of Slopes and Embankments II, ASCE, New York, N.Y., v. 1, p. 834-839, 1992.

SKEMPTON, A. W.; HUCTHINSON, J. N. Stability of natural slopes and embankment foundations. Inc: 7th International Conference on Soil Mechanics and Foundation Engineering, State-of-the-art Report, Mexico, p. 291-339, 1969.

SLADEN, J. A.; D'HOLLANDER, R. D.; KRAHN, J. The liquefaction of sands, a collapse surface approach. Canadian Geotechnical Journal, v. 22, n. 4, p. 564578, 1985.

SLONGO, G. R. Desenvolvimento de um sistema triaxial servo-controlado e avaliação do comportamento mecânico de um solo residual de biotita gnaisse. Dissertação de mestrado, PUC-Rio, Rio de Janeiro, 2008, 142p.

SOARES, R.M. Resistência ao cisalhamento de um solo coluvionar não saturado do Rio de Janeiro. Dissertação de mestrado, PUC-Rio, Rio de Janeiro, 2005, 196p.

SOUZA, V. A. D. Estudo de mecanismos de ruptura na encosta do Morro de Santos Rodrigues (Querosene) - RJ. Dissertação de mestrado, PUC-Rio, Rio de Janeiro, 1985, 167p.

SPRINGMAN, S. M.; JOMMI, C.; TEYSSEIRE, P. Instabilities on moraine slopes induced by loss of suction: a case history. Géotechnique, v. 53, n. 1, p. 3-10, 2003.

SYMES, M. J. Rotation of principal stresses in sand. Ph.D. Thesis, Imperial College, University of London, 1983, 560p.

SYMES, M. J.; BURLAND, J. B. Determination of local displacements on soil samples. Geotechnical Testing Journal, v. 7, n. 2, p. 49-59, 1984. 
TAKE, W. A.; BOLTON, M. D.; WONG, P. C. P.; YEUNG, F. J. Evaluation of landslide triggering mechanisms in model fill slopes. Landslides, v. 1, n. 3, p. 173-184, 2004.

TERZAGHI, K. Mechanisms of Landslides. In: Geological Society of America, Engineering Geology (Berkey Volume), p. 83-123, 1950.

TIBANA, S. Desenvolvimento de uma célula triaxial cúbica servo controlada e estudo da susceptibilidade à liquefação de um resíduo da lavra de mineração de ferro. Tese de doutorado, PUC-RIO, Rio de Janeiro, 1997, 256p.

TSUKAMOTO, Y.; ISHIHARA, K.; NOSAKA, Y. On the initiation of rainfall induced soil failure. In: Proc. 11th Danube European Conference Soil Mechanics and Geotechnical Engineering, Geotechnical Hazards (eds. B. Maric, Z. Lisac \& A. Szavits-Nossan), Porec, p. 883-890, 1998.

VAID, Y. P.; ELIADORANI, A. Instability and liquefaction of granular soils under undrained and partially drained states. Canadian Geotechnical Journal, v. 35, n. 6, p. 1053-1062, 1998.

VARGAS, M. The concept of tropical soils. In: Proc 1st International Conference on Geomechanics in Tropical Lateritic and Saprolitic Soils, Brasília, Brasil, v. 3, p. 101-134, feb 1985.

VARGAS, M. Revisão histórico-conceitual dos escorregamentos da Serra do Mar. Solos e Rochas, v. 22, p. 53-83, 1999.

VARNES, D. J. Landslides types and processes. In: Landslides and engineering practice, Special Report 29, (ed. Eckel, E.B.), HRB, National Reserch Council, Washington D.C., p. 20-47, 1958.

VARNES, D. J. Slope movements, types and processes. In: Landslides Analysis and Control, Special report 176. (ed. Schuster, R.) National Academy of Sciences, Washington, D.C., p.11-33, 1978.

VAUGHAN, P. R.; KWAN, C. W. Weathering, structure and in-situ stress in residual soils. Géotechnique, v. 34, n. 1, p. 43-59, 1984.

VAUGHAN, P.R. Mechanical and hydraulic properties of tropical lateritic and saprolitic soils, particulary as related to their structure and mineral components. In: 1st. International Conference in Tropical Lateritic and Saprolitic Soils, Brasilia, 1985.

VAUNAT, J.; LEROUEIL, S.; FAURE, R. Slope movements: a geotechnical perspective. In: 7th International Congress Association of Engineering Geology, Lisboa, Portugal, p. 1637-1646, 1994.

WANG, F. W.; SASSA, K.; WANG, G. Mechanism of a long run out landslide triggered by the august 1998 heavy rainfall in Fukushima Prefecture, Japan. Engineering Geology, v. 63, p. 169-185, 2002.

WOLLE, C. M. Mecanismos de Instabilização de Encostas na Serra do Mar. Encontro Técnico: Estabilidade de Encostas, ABMS, 1988, p. 16-40. 
WOLLE, C.M.; CARVALHO, C.S. Deslizamentos em encostas na Serra do MarBrasil. Solos e Rochas, v. 12, p. 27-36, 1989.

ZHU, J. H.; ANDERSON, S. A. Determination of shear strength of Hawaiian residual soil subjected to rainfall-induced landslides. Géotechnique, v. 48, n. 1, p. 73-82, 1998. 


\section{Apêndice A}

\section{Calibração dos instrumentos eletrônicos de medição}

Para as medições realizadas nos ensaios de aumento de poropressão foram usados dez instrumentos eletrônicos, sendo duas células de carga, dois transdutores de pressão, um minitransdutor de poropressão, um medidor de variação volumétrica, um transdutor de deslocamento (LSCDT), um medidor de deslocamento radial e dois eletroníveis.

As principais características desses instrumentos estão mostradas na Tabela A.1

A calibração das células de carga foi feita com o auxilio do pendural de carga e braço de alavanca do equipamento de cisalhamento direto, através da colocação de pesos conhecidos.

Os transdutores de pressão foram calibrados com o auxilio do equipamento Bundenberg, aplicando-se valores conhecidos de pressão.

O medidor de variação volumétrica foi calibrado usando uma bureta graduada, onde a entrada e saída da agua era medida pela posição da anilina dentro da mesma.

Para a calibração do transdutor de deslocamento (LSCDT), transdutor de deslocamento radial e eletroníveis foi utilizado um micrômetro de precisão, sendo impostos deslocamentos de 1,27 mm, tanto para compressão como para extensão. Os eletroníveis foram calibrados simultaneamente acoplados ao micrometro por meio de duas peças de alumínio, utilizando-se para a calibração a mesma distância entre sapatas utilizada nos ensaios.

A metodologia utilizada foi praticamente a mesma em todas as operações, foram aplicados ciclos de carga e descarga para cada instrumento, com um numero mínimo de três conjuntos de ciclos para uma maior confiabilidade nos resultados. As curvas e suas respectivas equações de calibração obtidas de ajustes lineares são apresentadas nas Figuras A.1 a A.9. 


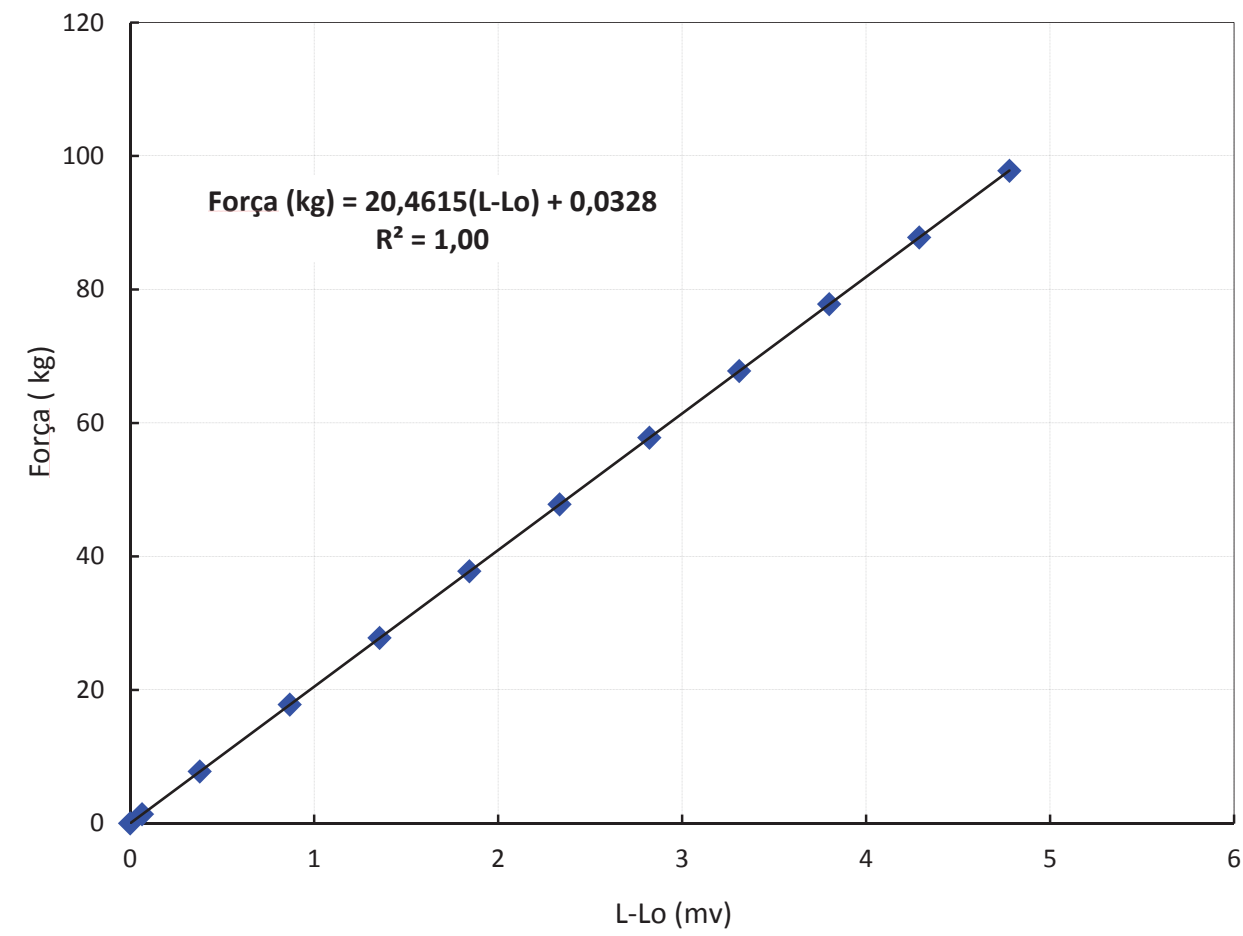

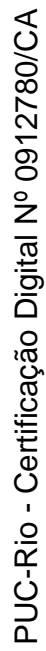

Figura A.1 : Curva de calibração da célula de carga EL-27 (5 kN)

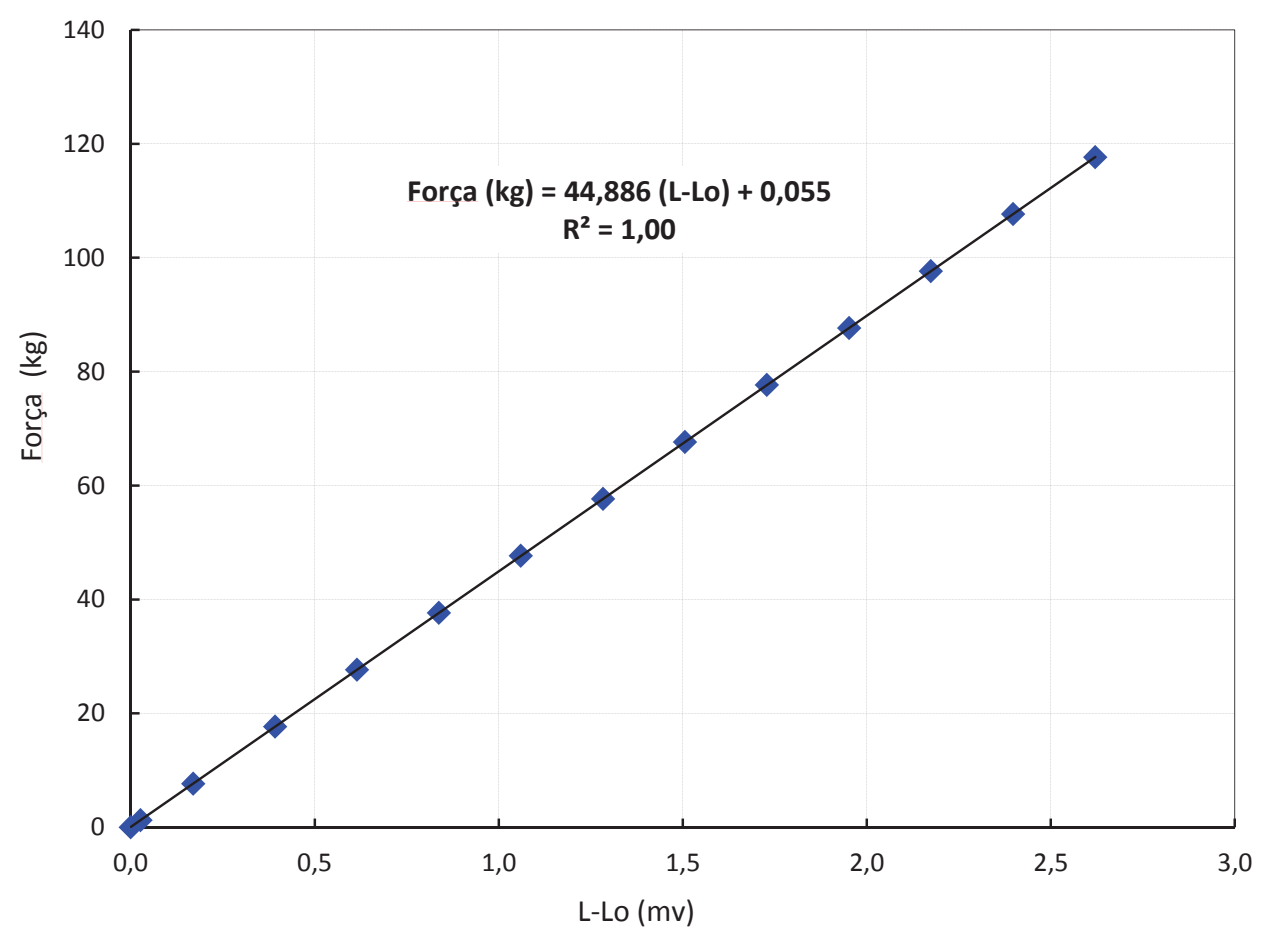

Figura A.2 : Curva de calibração da célula de carga 28-WF (1 kN) 


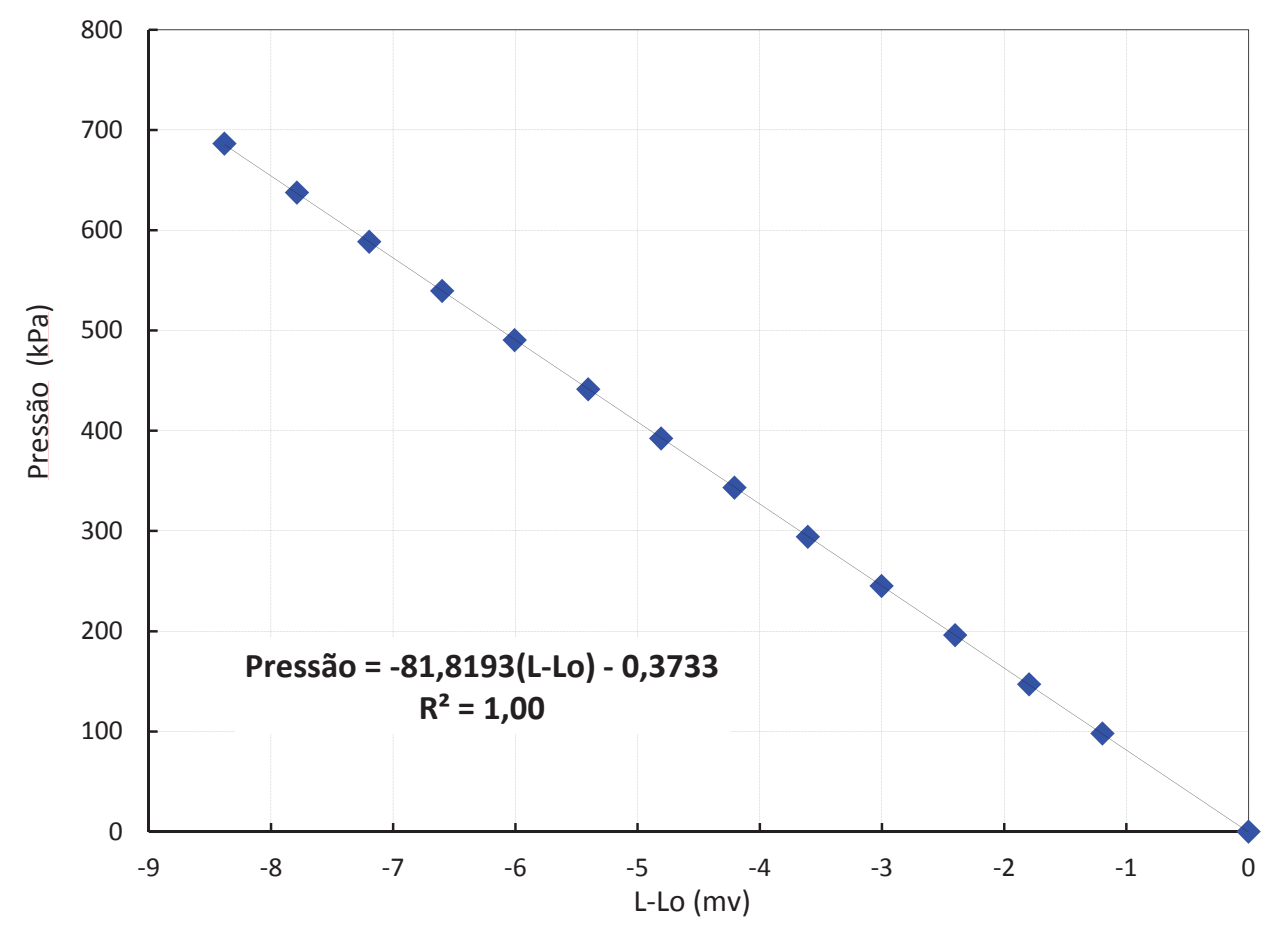

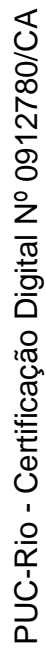

Figura A.3 : Curva de calibração do Transdutor de pressão P723

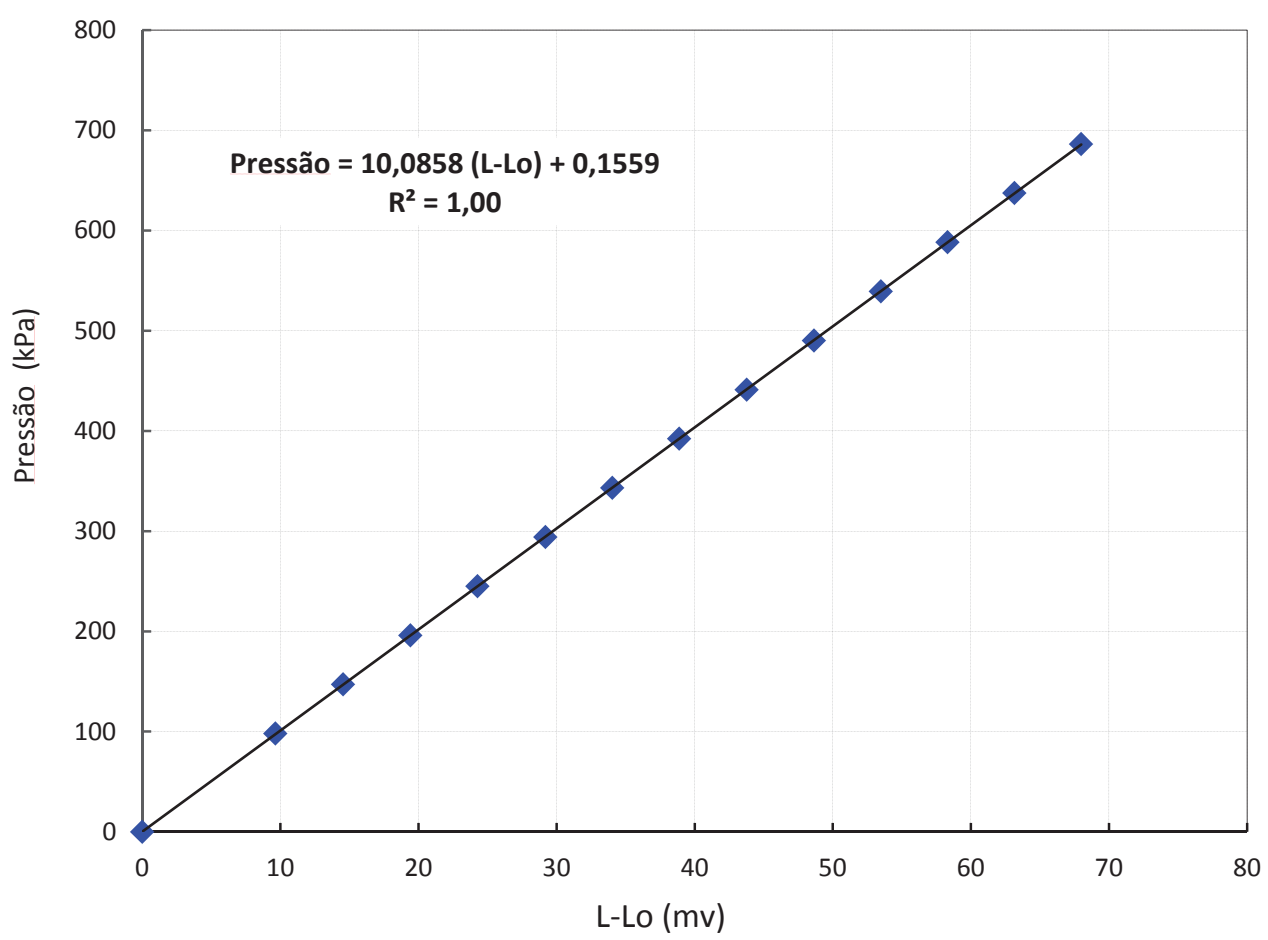

Figura A.4 : Curva de calibração do Transmissor de pressão TRP-42 


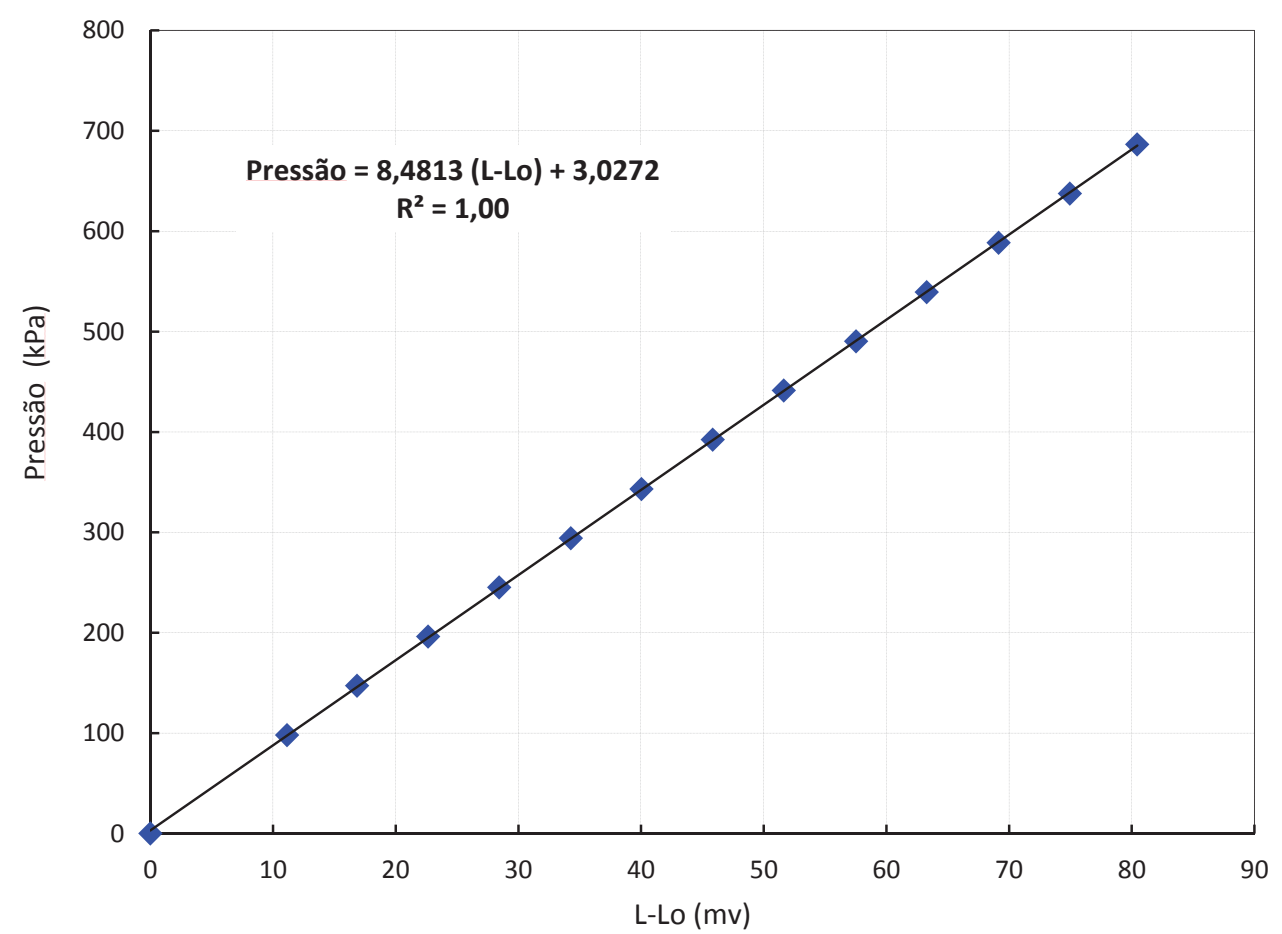

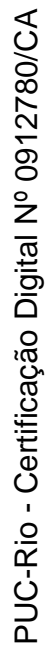

Figura A.5 : Curva de calibração do Minitransdutor de poropressão PDCR 81

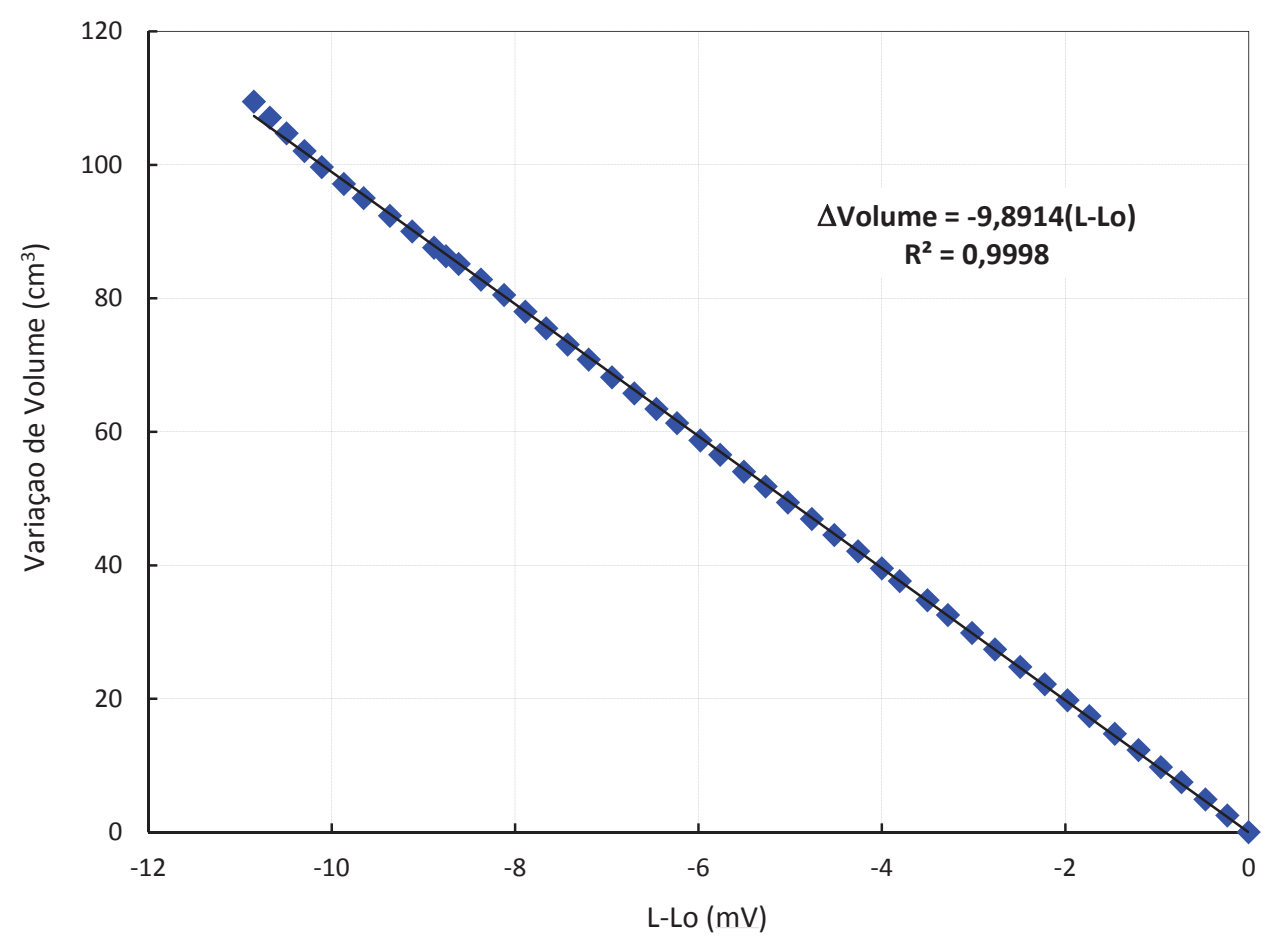

Figura A.6 : Curva de calibração do medidor de variação de volume 


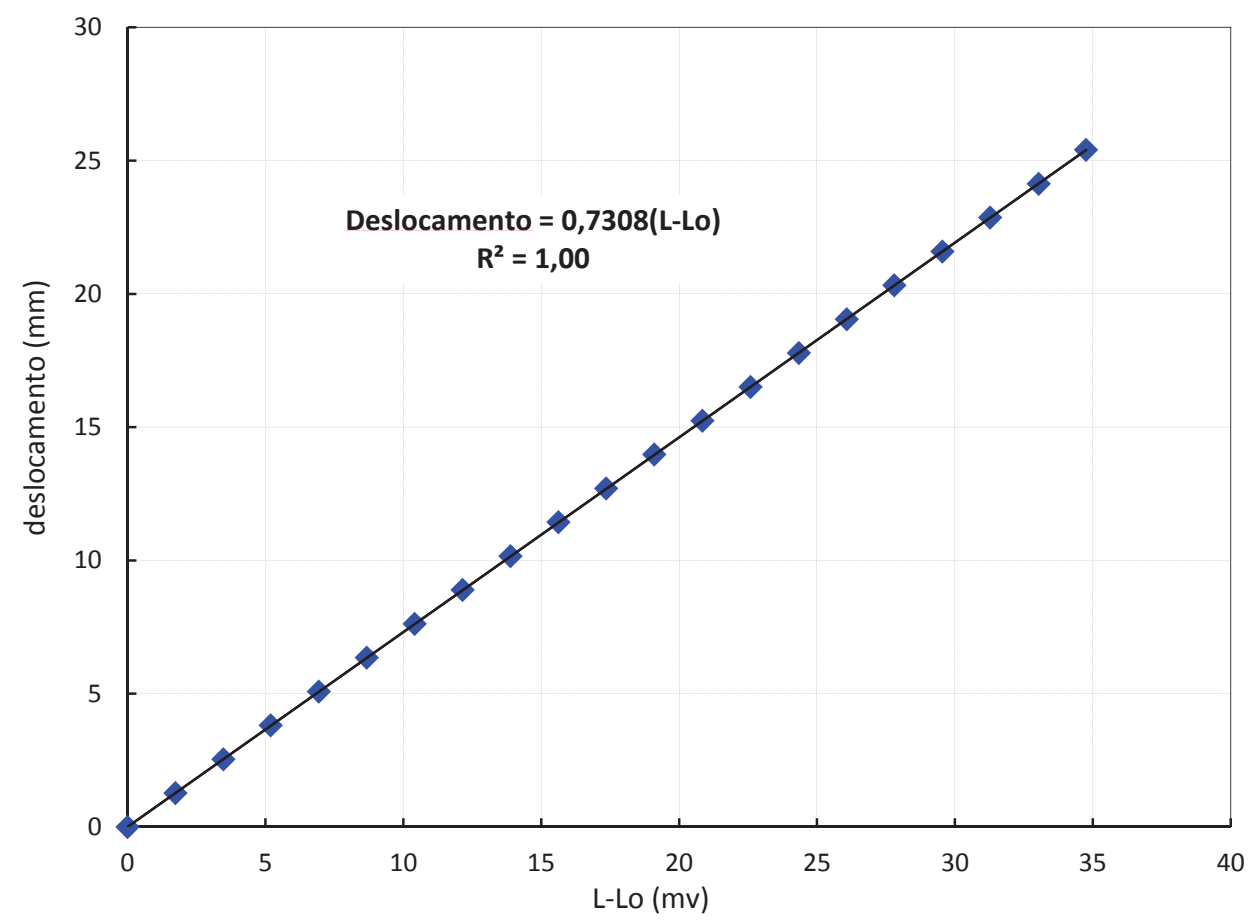

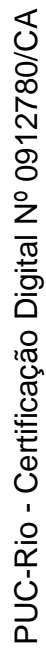

Figura A.7 : Curva de calibração do Transdutor de deslocamento HS25

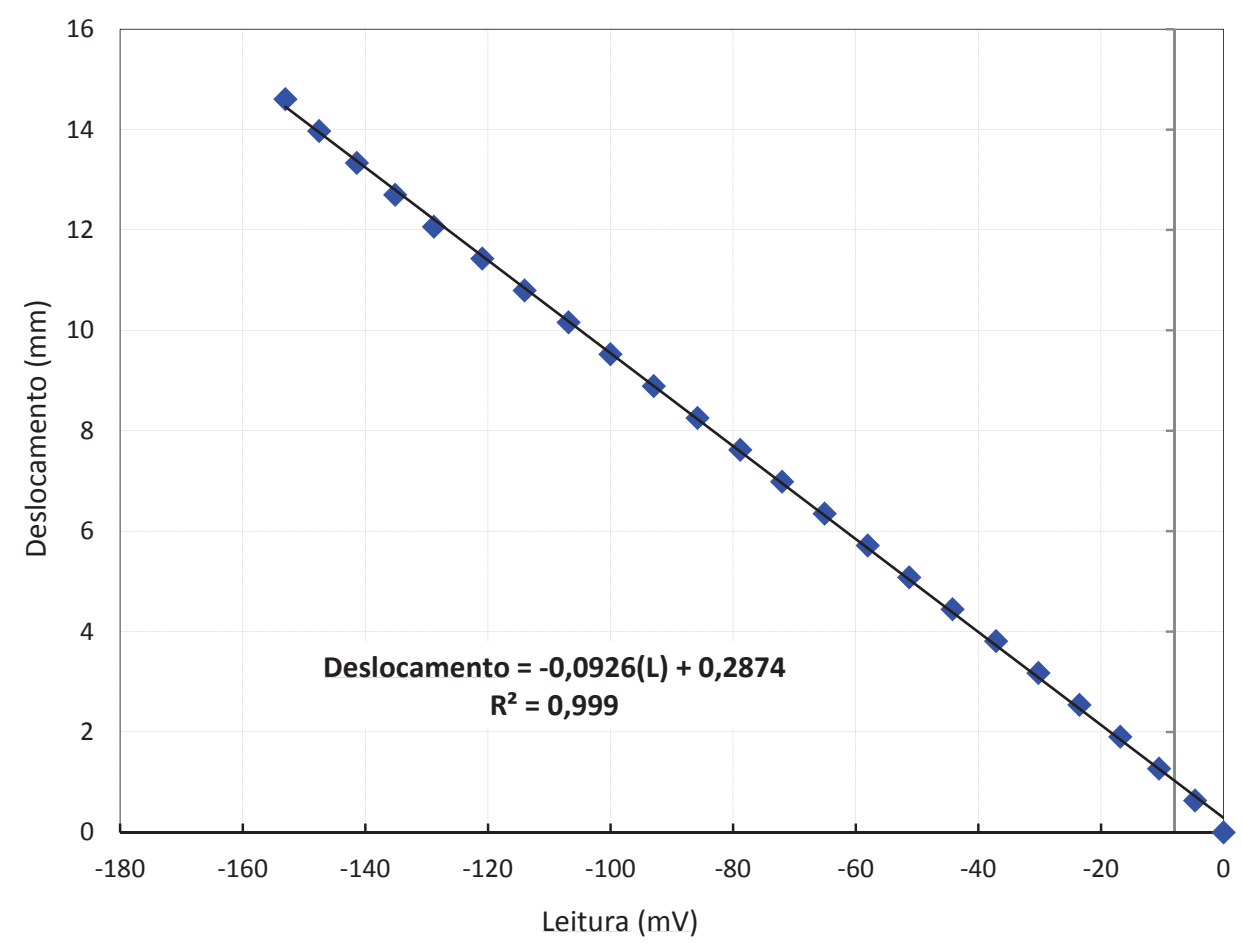

Figura A.8: Curva de calibração do Transdutor de deslocamento radial 


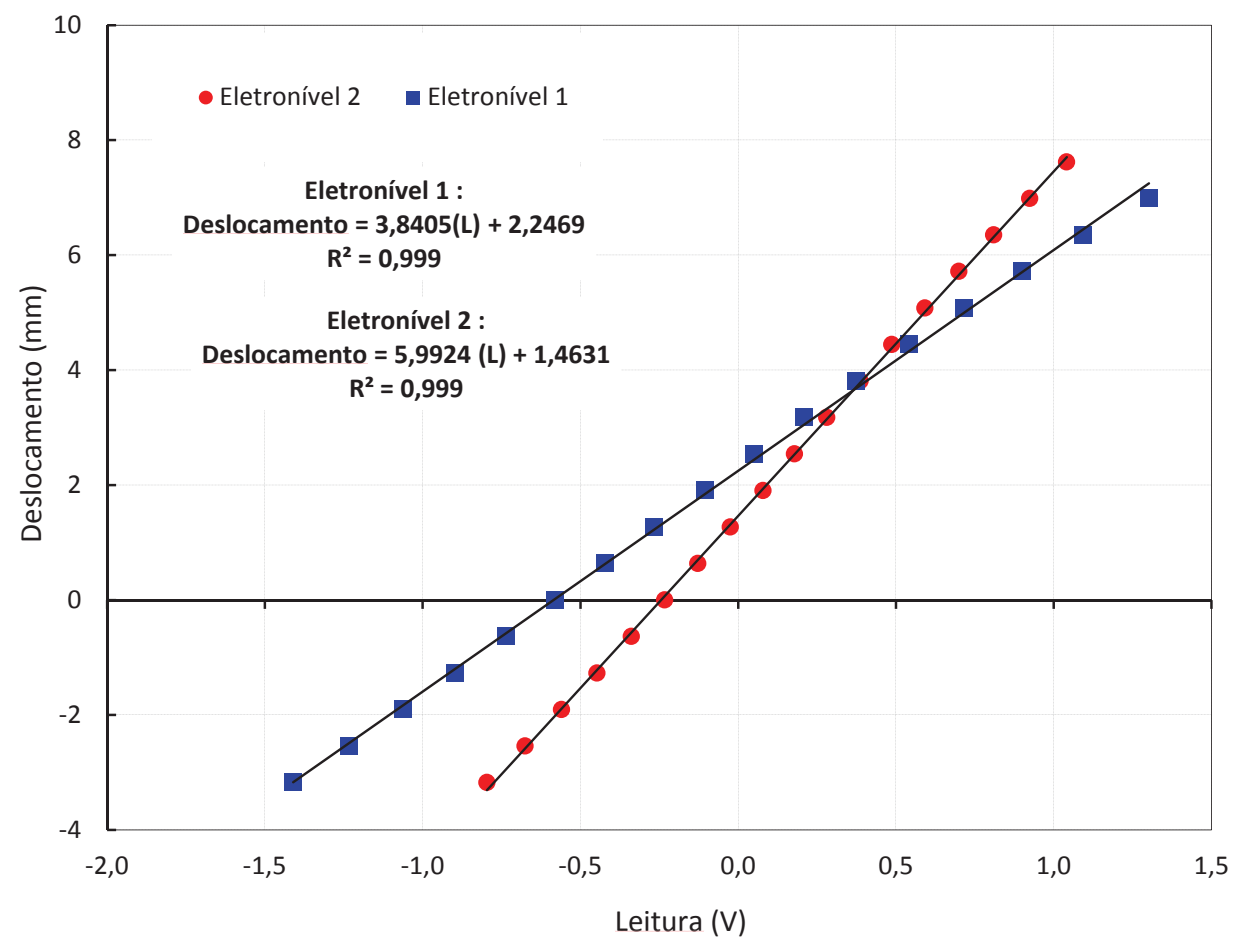

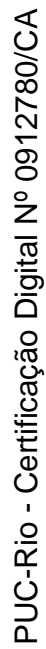

Figura A.9 : Curva de calibração dos eletroníveis 


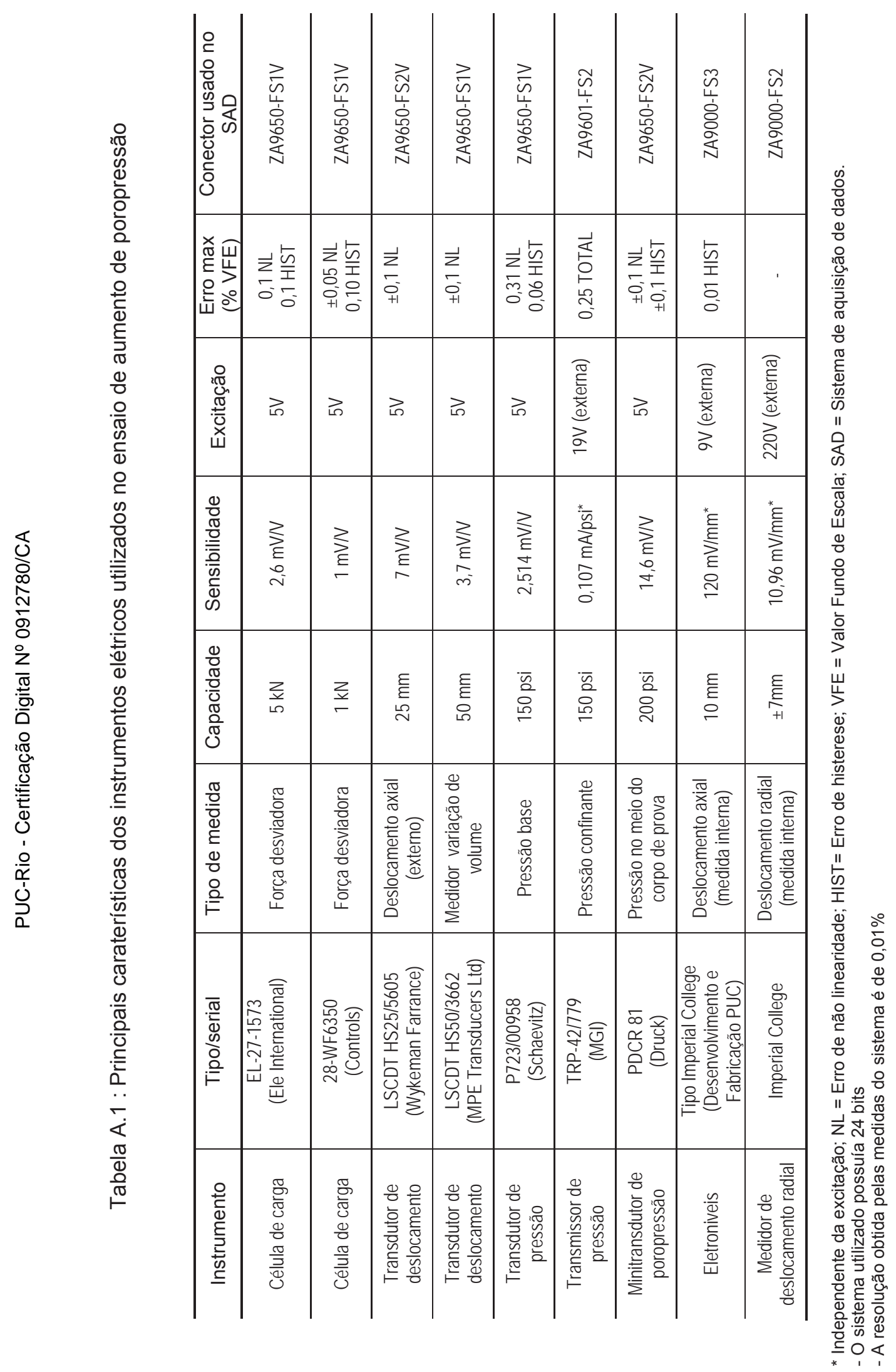




\section{Apêndice B}

Fotografias dos corpos de prova ao final dos ensaios de aumento de poropressão

Nesta seção, é mostrada a condição dos corpos de prova ao final dos ensaios de Aumento de Poropressão. Devido à formação do plano de ruptura e à impossibilidade de manter a forma durante a desmontagem e/ou retirada da membrana, as imagens das amostras de Duque de Caxias correspondem ao momento do fim de ensaio.
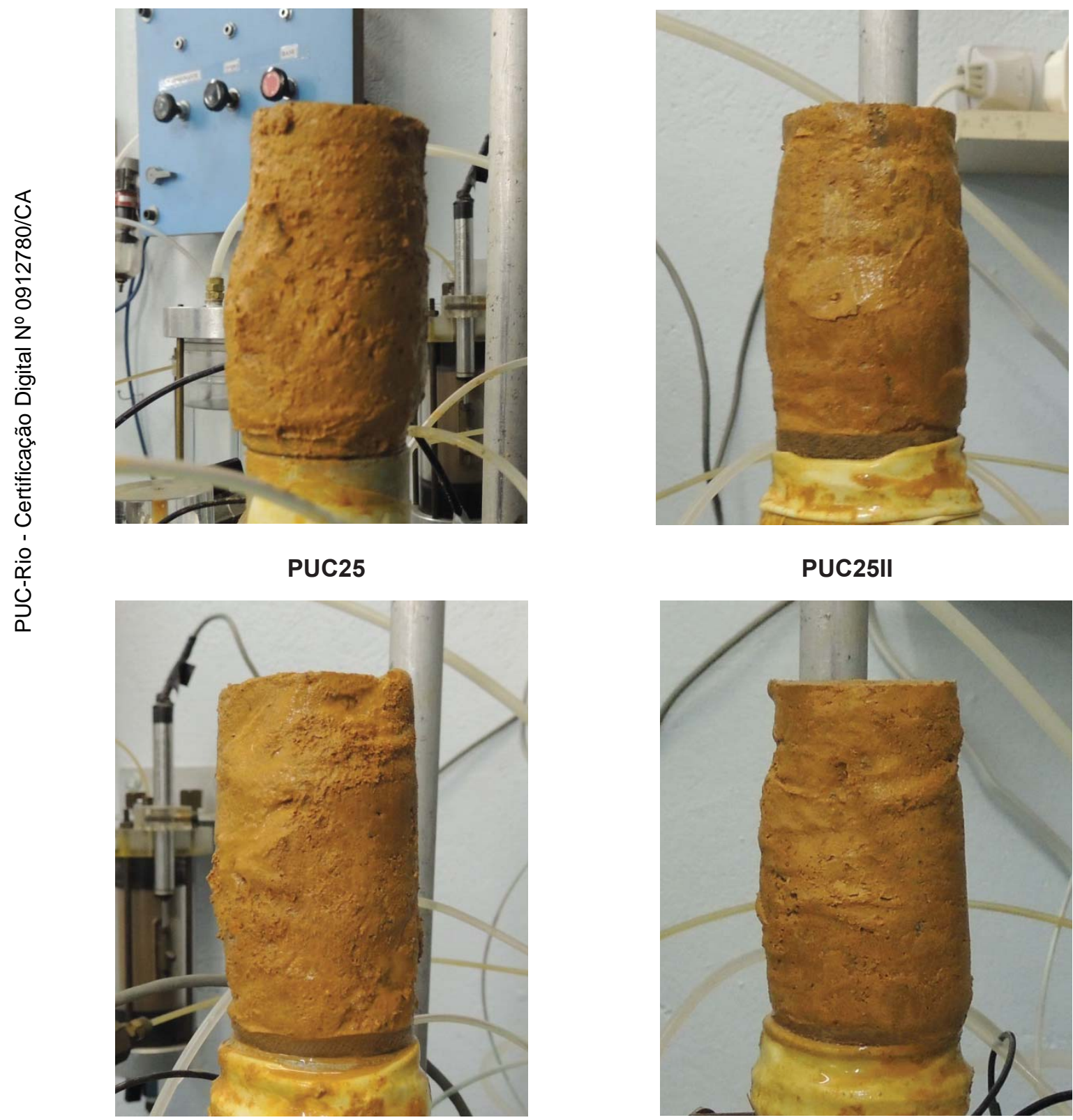

PUC50

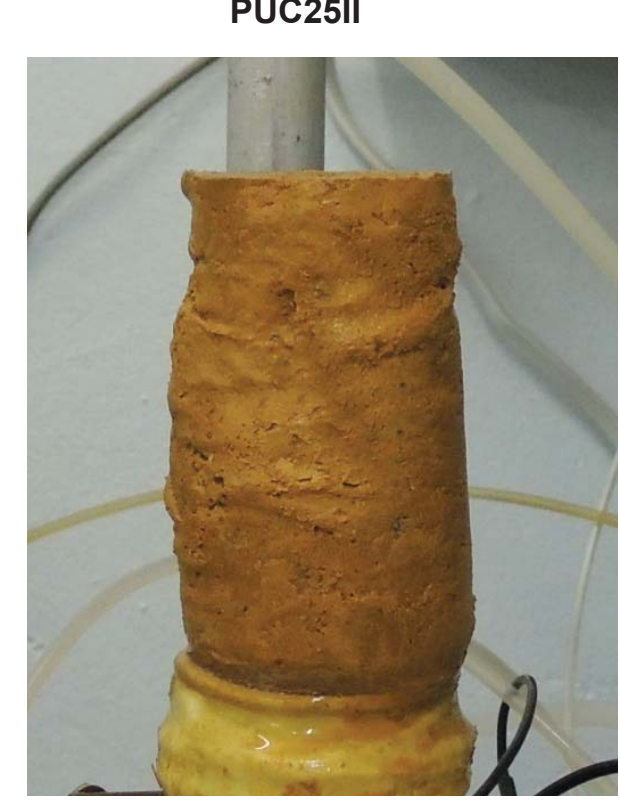

PUC75 


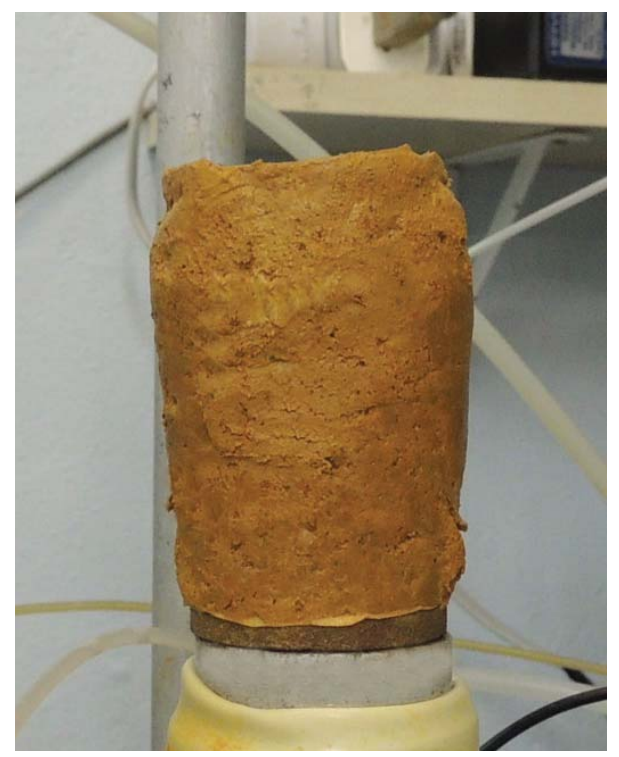

PUC100

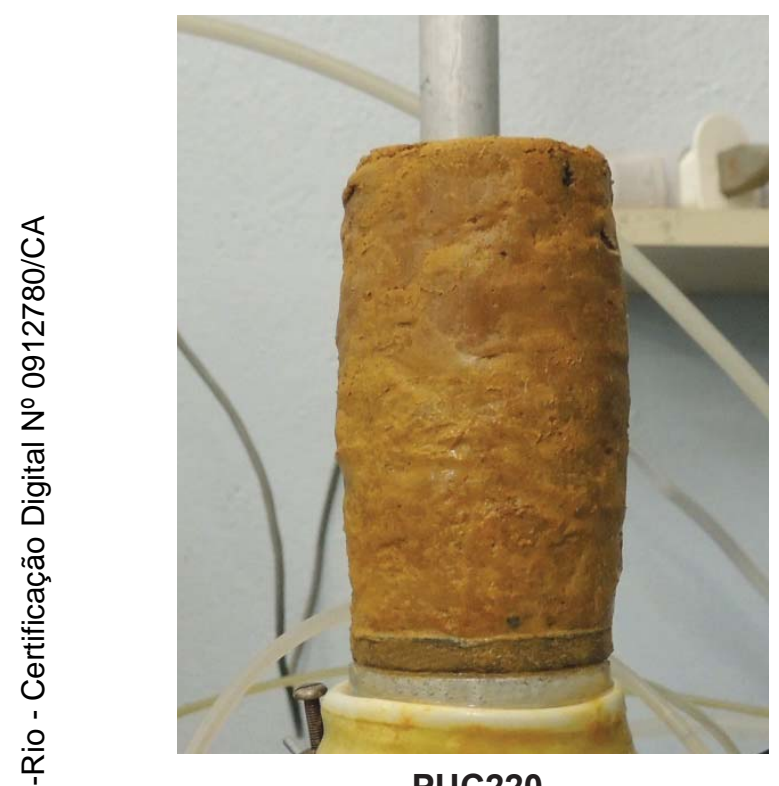

仓ํㅁㅁ

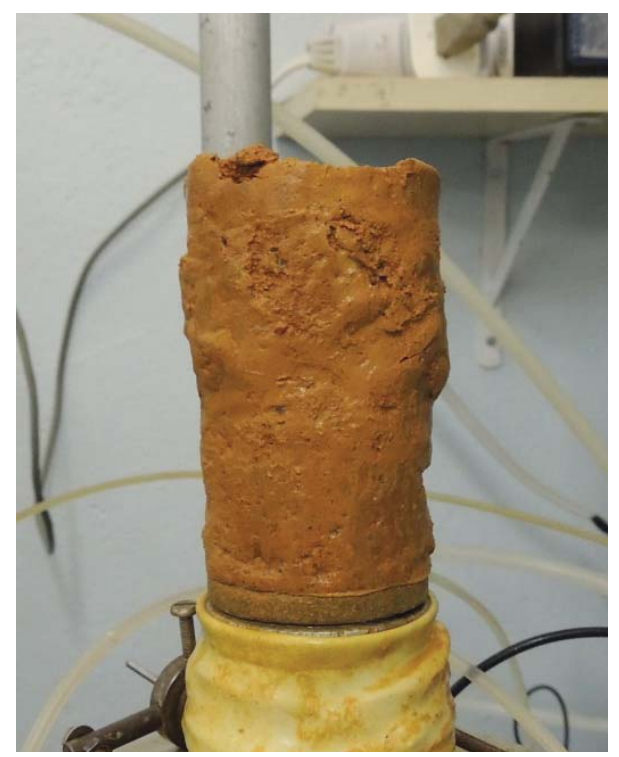

TIN25
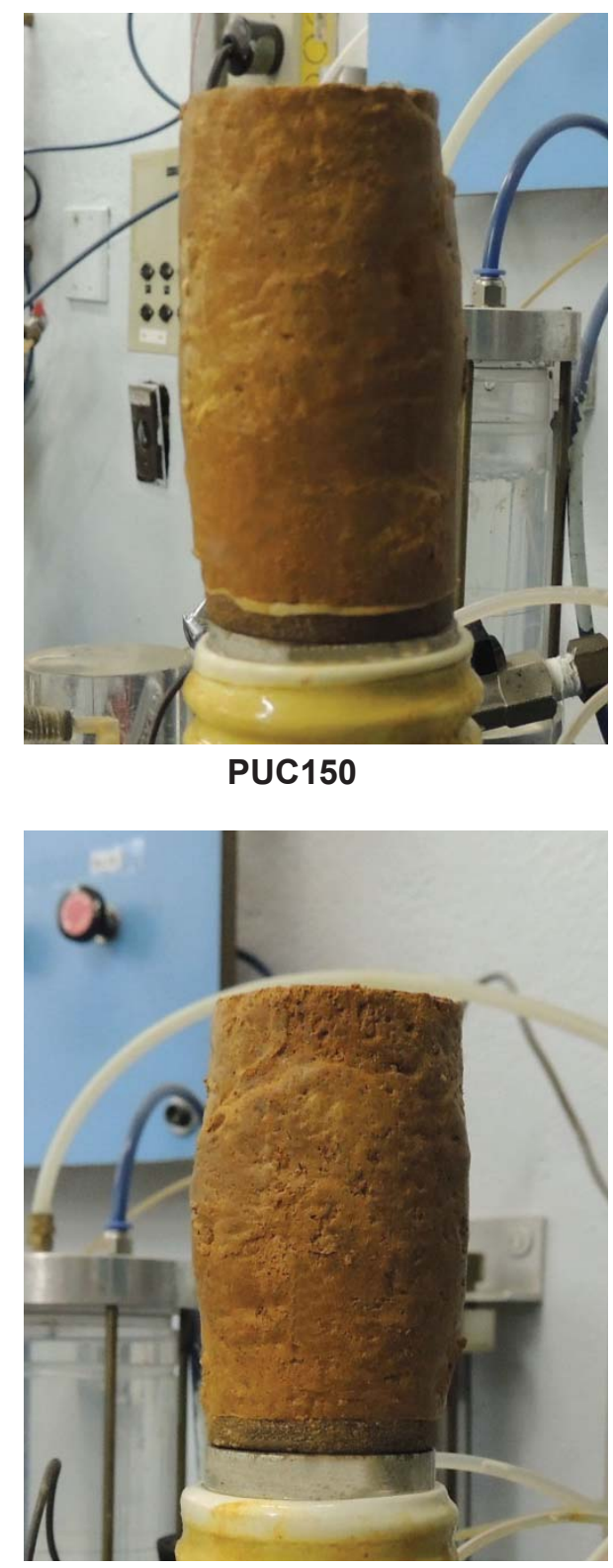

PUC300

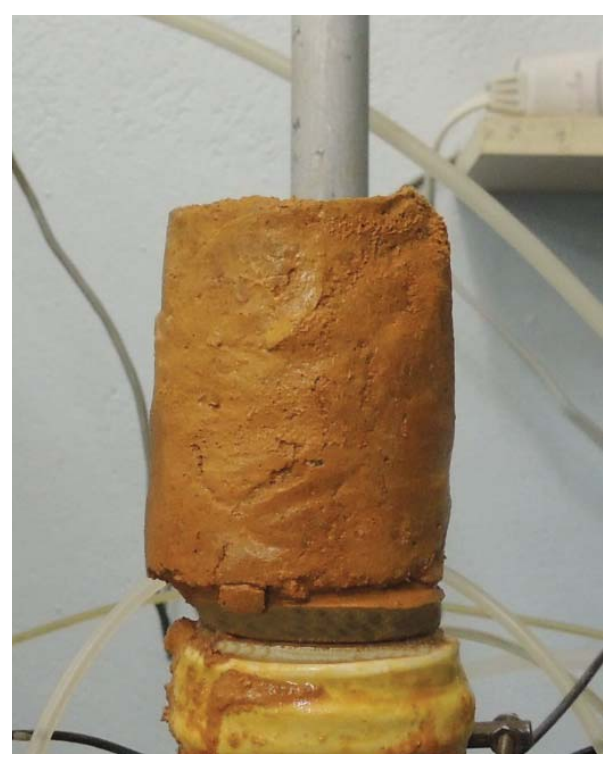

TIN25II 

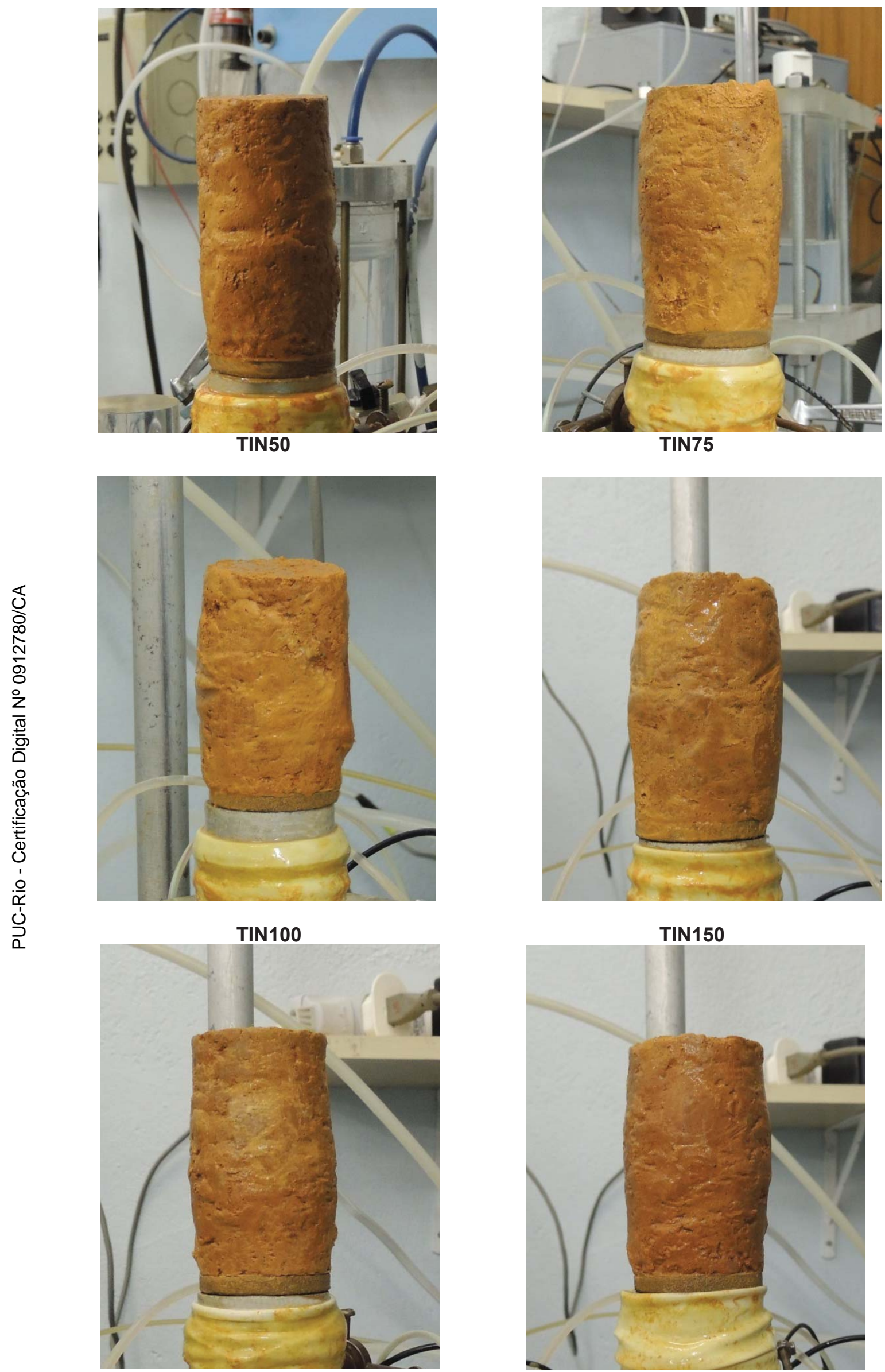

TIN220

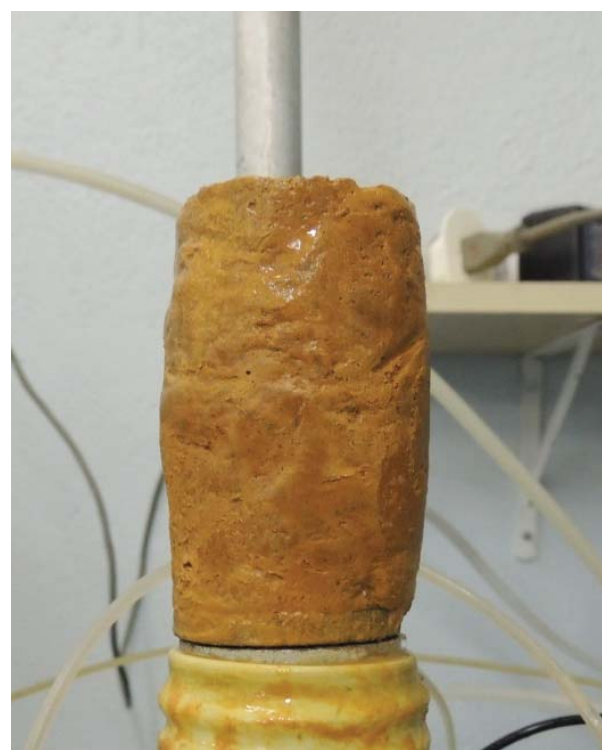

TIN150

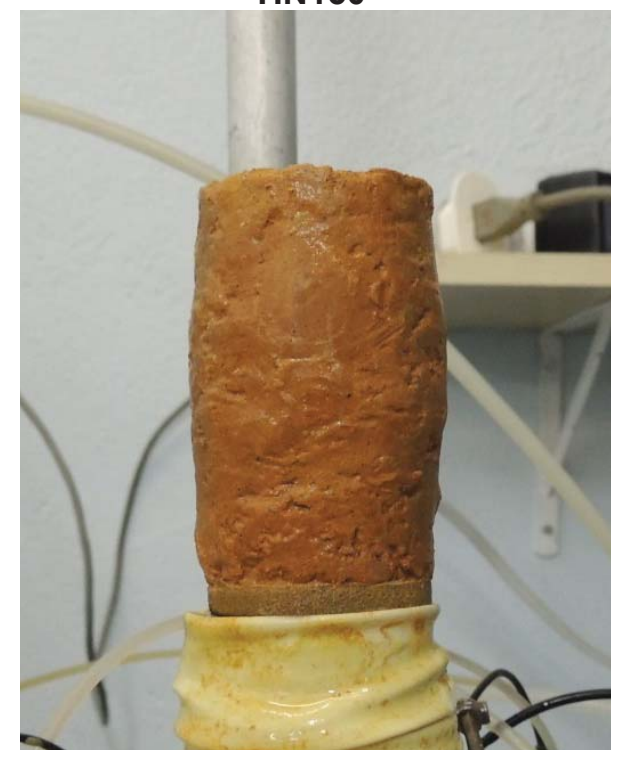

TIN300 


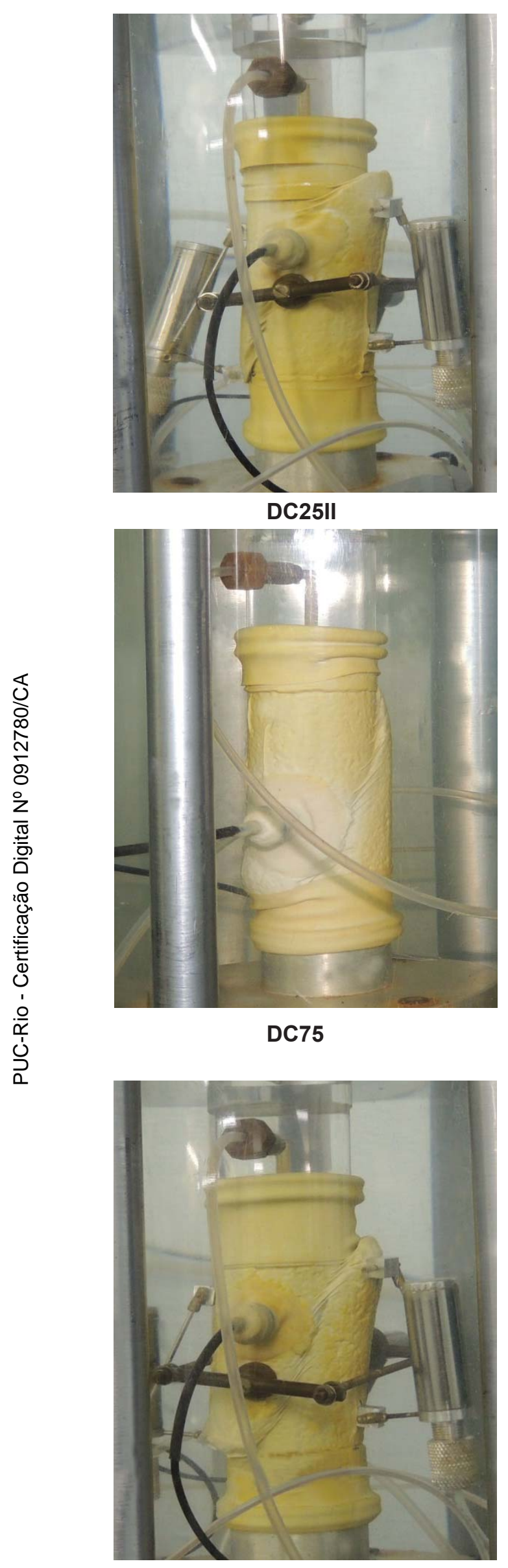

DC100
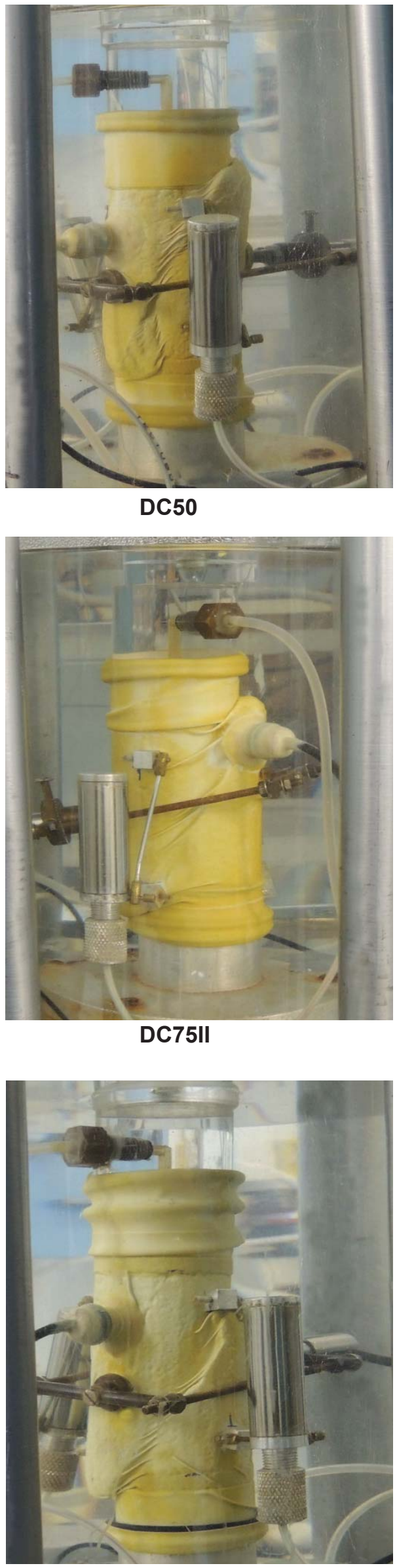

DC150 

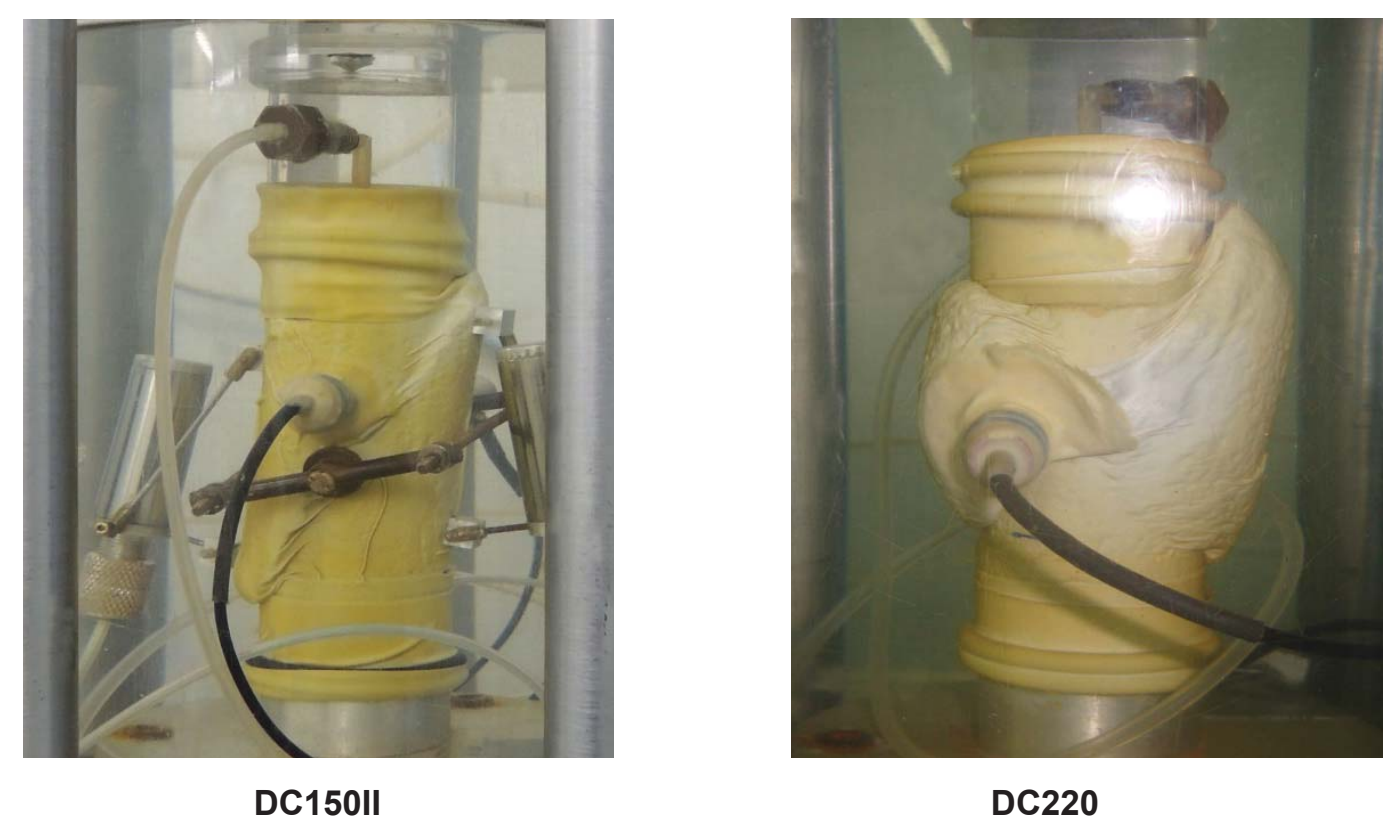

$$
\text { DC220 }
$$

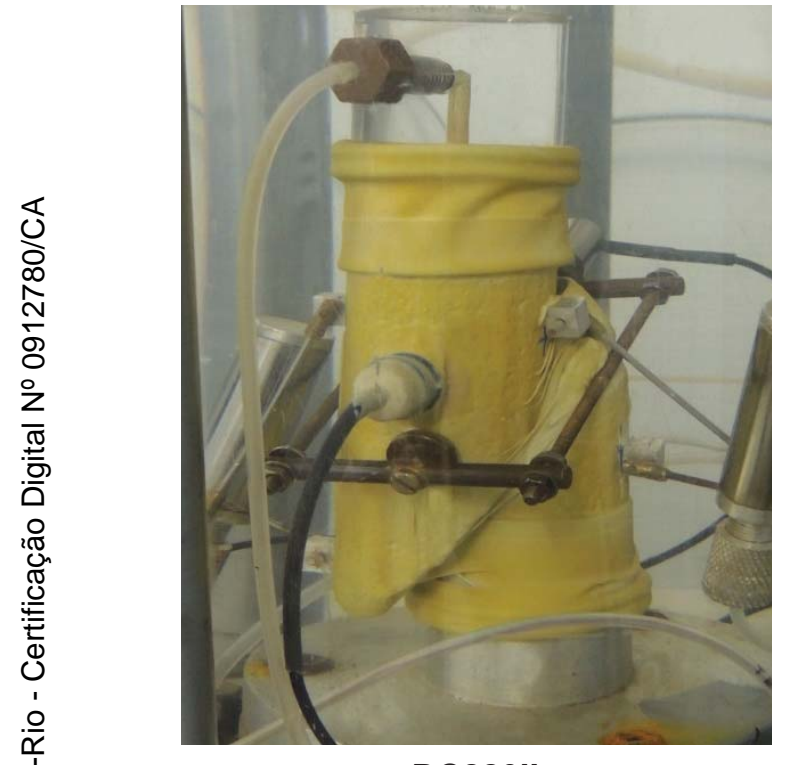

仓

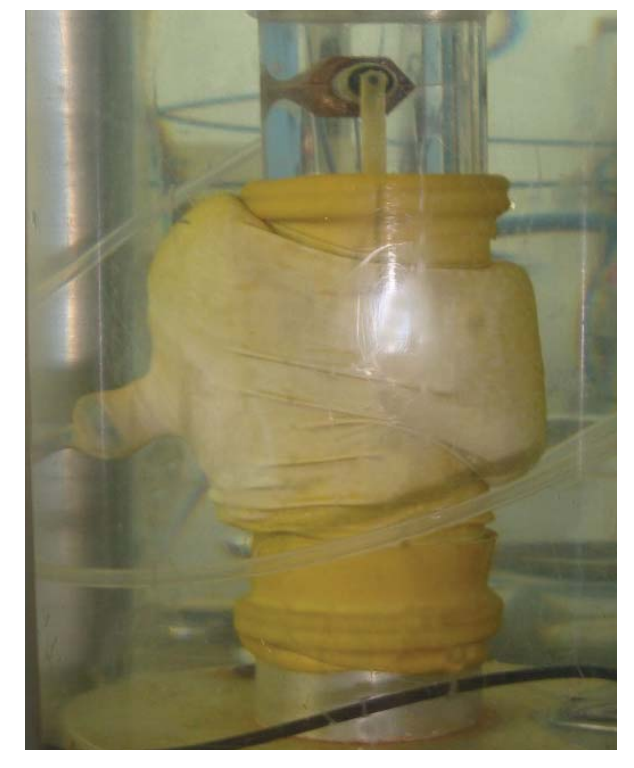

DC300

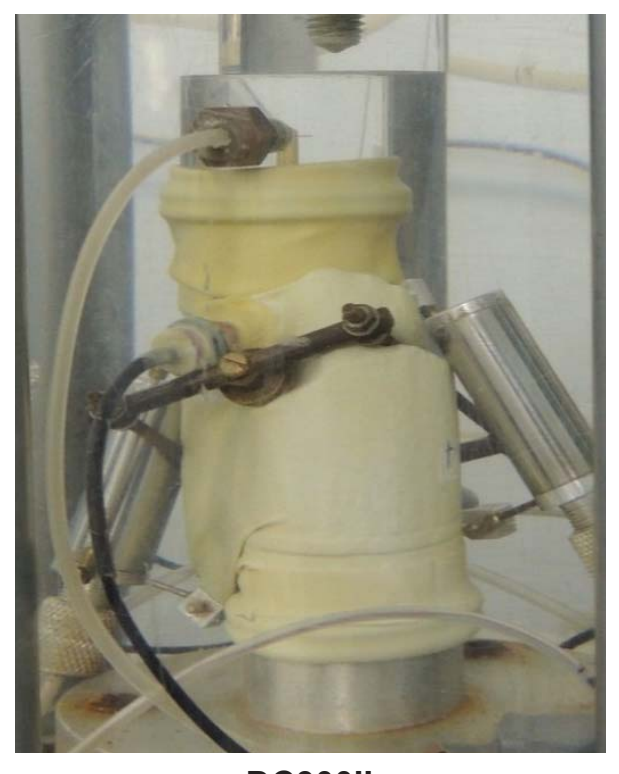

DC300II 